\title{
Petroleum Supply Monthly
}

\section{October 1991}

\author{
Energy Iniormation Administration \\ Office of Oil and Gas \\ U.S. Department of Energy \\ Washington, DC 20585
}

This report was prepared by the Energy Information Administration, the independent statistical and analytical agency within the Department of Energy. The information contained herein should not be construed as advocating or reflecting any policy position of the Department of Energy or any other organization. 


\title{
Electronic Publishing System (EPUB)
}

\author{
User Instructions
}

EPUB is an electronic publishing system maintained by the Energy Information Administration of the U.S. Department of Energy. EPUB allows the general public to electronically access selected energy data from many of EIA's statistical reports. The system is a menu-driven, bulletin board type system with extensive online help capabilities that can be accessed free of charge 24 hours a day by using a terminal or PC with an asynchronous modem. (EPUB will be taken down briefly at midnight for backup.)

\section{CONFIGURING YOUR PC SOFTWARE}

PC users must provide the following information to their communications software in order to successfully access the EPUB system. Consult your communications software documentation for information on how to correctly configure your software.

Communication Parameters:

BAUD RATE: 300 - 2400 bps

DATA BITS: 8

STOP BITS: 1

PARITY: NONE

DUPLEX: FULL

TERMINAL TYPE: examples: ANSI, ANSI-BBS, VT100

\section{ACCESS PHONE NUMBER}

Once your communications software and/or hardware has been configured, you can access EPUB by dialing (202) 586-2557.

\section{USING EPUB}

When a connection to the system has been made, some users may find that the menu-driven instructions and the online help capabilities will provide enough information to effectively use EPUB. If needed, more extensive information may be found in the EPUB Users Guide, which is available online from the EPUB system or from:

National Energy Information Centır, EI-231

Energy Information Administration

Forrestal Building, Room 1F-048

Washington, DC 20585

(202) 586-8800

Hours: 8:00 a.m. to 5:00 p.m. Eastern Time, Monday through Friday

\section{EPUB ASSISTANCE}

For communications or technical assistance, call (202) 586-8959, 8:00 a.m. to 5:00 p.m. Eastern Time, Monday through Friday.

For questions about the content of EPUB reports, call (202) 586-8800, 8:00 a.m. to 5:00 p.m. Eastern Time, Monday through Friday.

\section{EPUB PROVIDES SELECTED DATA FROM THE FOLLOWING EIA PUBLICATIONS:}

Weekly Petroleum Status Report, updated on Wednesdays (Thursday in event of a holiday) at 5:00 p.m.

Petroleum Supply Monthly, updated on the 20th of the inonth

Petroleum Marketing Monthly, updated on the 20th of the inonth

Winter Fuels Report, updated on Thursdays (Friday in event of a holiday) at 5:00 p.m.

Natural Gas Monthly, updated on the 20th of the month

Weekly Coal Production, updated on Fridays at 5:00 p.m.

Quarterly Coal Report, updated 60 days after the end of the quarter

Electric Power Monthly, updated on the Ist of the month

Monthly Energy Review, updated the last week of the month

Short Term Energy Outlook, updated 60 days after the end of the quarter. 


\section{EIA Petroleum Data Available in Machine-Readable Files}

Petroleum supply statistics are available on five magnetic tapes. One tape contains final 1983 through 1990 petroleum supply statistics by month, taken from the Petroleum Supply Annual; the second contains preliminary 1991 statistics to date by month, from the Petroleum Supply Monthly. Three additional tapes contain current and historical statistics on imports of crude oil and petroleum products into the United States and Puerto Rico. The current import tape contains preliminary 1991 statistics to date by month. The two historical import tapes contain final statistics by month. One tape contains statistics for the years 1977 through 1985; the second contains 1986 through 1990 statistics. The current tapes are updated each month. All tapes are fully documented.

Tapes are sold for $\$ 200$ each and should be referenced by the titles listed below:

Petroleum Supply Annual - 1983-1990

Petroleum Supply Monthly - Preliminary (1991)

Oil Imports into the United States and Puerto Rico, Annual - 1977-1985

Oil Imports into the United States and Puerto Rico, Annual - 1986-1990

Oil Imports into the United States and Puerto Rico, Monthly — Preliminary (1991)

To order, contact:

National Technical Information Service (NTIS)

Office of Data Base Services

U.S. Department of Commerce

5285 Port Royal Road

Springfield, Virginia 22161

(703) $487-4650$

Further information as to content may be obtained from the National Energy Information Center (NEIC), telephone (202) 586-8800. The current tapes are also available on a subscription basis. All files available on magnetic tape can be converted into diskette files. (Please contact NTIS for current prices.) Ordering information may be obtained by calling (703) 487-4807. 


\section{Contacts}

The Petroleum Supply Monthly is prepared by the Petroleum Supply Division of the Oiffice of Oil and Gas, Energy Information Administration, under the direction of Charles C. Heath (202) 586-6860.

Questions and comments concerning the sontents of the Petroleum Supply Monthly may be referred to Ronald W. O'Neill (202) 586-9884, Chief of the Industry Analysis Branch, or the following specialists:

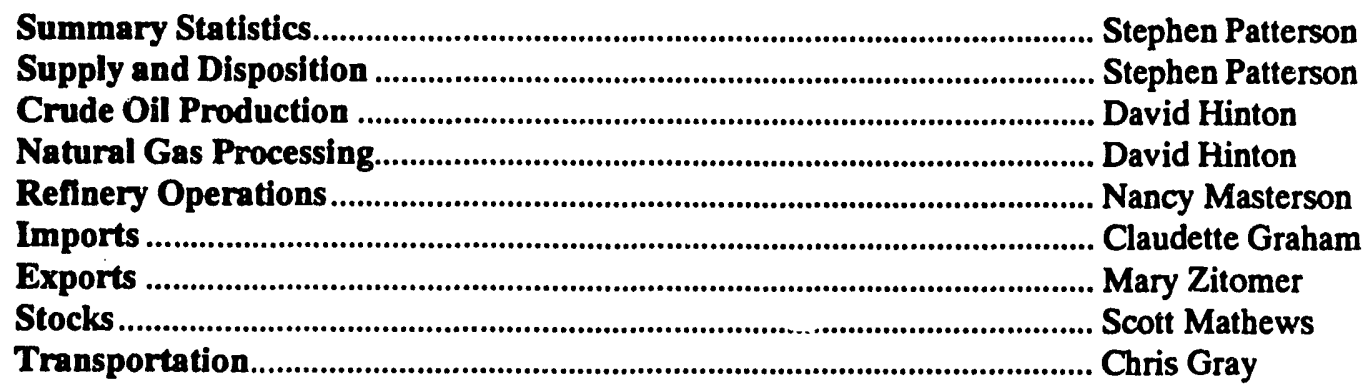

(202) 586-5994

(202) 586-5994

(202) 586-2990

(202) 586-2990

(202) 586-8393

(202) 586-9649

(202) $586-8380$

(202) $586-1266$

(202) 586-8995

Additional information on all energy statistics available from the Energy Information Administration may be obtained from the National Energy Information Center (202) 586-8800. 


\section{Preface}

The Petroleum Supply Monthly (PSM) is one of a family of three publications produced by the Petroleum Supply Division within the Energy Information Administration (EIA) reflecting different levels of data timeliness and completeness. The other two publications are the Weekly Petroleum Status Report (WPSR) and the Petroleum Supply Annual (PSA).

Data presented in the PSM describe the supply and disposition of petroleum products in the United States and major U.S. geographic regions. The data series describe production, imports and exports, inter-Petroleum Administration for Defense (PAD) District movements, and inventories by the primary suppliers of petroleum products in the United States (50 States and the District of Columbia). The reporting universe includes those petroleum sectors in Primary Supply. Included are: petroleum refiners, motor gasoline blenders, operators of natural gas processing plants and fractionators, inter-PAD transporters, importers, and major inventory holders of petroleum products and crude oil. When aggregated, the data reported by these sectors approximately represent the consumption of petroleum products in the United States.

Data presented in the PSM are divided into two sections (1) the Summary Statistics and (2) the Detailed Statistics.

\section{Summary Statistics}

The tables and figures in the Summary Statistics section of the PSM present a time series of selected petroleum data on a U.S. level. Most time series include preliminary estimates for one month based on the Weekly Petroleum Supply Reporting System (WPSRS); statistics based on the most recent data from the Monthly Petroleum Supply Reporting System (MPSRS); and statistics published in prior issues of the PSM and PSA.

\section{Detailed Statistics}

The Detailed Statistics tables of the PSM present statistics for the most current month available as well as year-to-date. In most cases, the statistics are presented for several geographic areas - - the United States (50 States and the District of Columbia), five PAD Districts, and 12 Refining Districts. At the U.S. and PAD District level, the total volume and the daily rate of activities are presented. The statistics are developed from monthly survey forms submitted by respondents to the EIA and from data provided from ciner sources.

\section{Appendices}

Explanatory Notes present information describing data collection, sources, estimation methodology, data quality control procedures, modifications to reporting requirements and interpretation of tables. Industry terminology and product definitions are listed alphabetically in the Glossary. Final statistics for the data series published in the PSM, as well as additional data from an annual refinery survey are published in the PSA. During the processing year, a summary of the impact of resubmissions (corrections) on major series is provided in Appendix C. The PSA is published approximately five months after the end of the report year. 


\section{Contents}

Feature Article.

Highlights

Tables

Summary Statistics

S1. Crude Oil and Petroleum Products Overview, 1973-Present

S2. Crude Oil Supply and Disposition, 1973-Present.

S3. Crude Oil and Petroleum Product Imports, 1973-Present

S4. Finished Motor Gasoline Supply and Disposition, 1973-Present ...............................................................................

S5. Distillate Fuel Oil Supply and Disposition, 1973-Present.

S5. Residual Fuel Oil Supply and Disposition, 1973-Present

S7. Jet Fuel Supply and Disposition, 1973-Present

S8. Liquefied Petroleum Gases Supply and Disposition, 1973-Present

S9. Other Petroleum Products Supply and Disposition, 1973-Present

Summary Statistics Table and Figure Sources

Summary Statistics Explanatory Notes.

\section{Detailed Statistics}

\section{National Statistics}

1. U.S. Petroleum Balance

2. U.S. Supply, Disposition, and Ending Stocks of Crude Oil and Petroleum Products ................................................

3. U.S. Year-to-Date Supply, Disposition, and Ending Stocks of Crude Oil and Petroleum Products ............................. 35

4. U.S. Daily Average Supply and Disposition of Crude Oil and Petroleum Products ....................................................

5. U.S. Year-to-Date Daily Average Supply and Disposition of Crude Oil and Petroleum Products.

Supply and Disposition of Crude Oil and Petroleum Products

6. PAD District I

7. Year-to-Date PAD District I

8. Daily Average PAD District I.

9. Year-to-Date Daily Average PAD District I

10. PAD District II

11. Year-to-Date PAD District II.

12. Daily Average PAD District II .

13. Year-to-Date Daily Average PAD District II

14. PAD District III

15. Year-to-Date PAD District III

16. Daily Average PAD District III

17. Year-to-Date Daily Average PAD District III.

18. PAD District IV.

19. Year-to-Date PAD District IV..

20. Daily Average PAD District IV.

21. Year-to-Date Daily Average PAD District IV

22. PAD District $V$.

23. Year-to-Date PAD District V.

24. Daily Average PAD District $V$.

25. Year-to-Date Daily Average PAD District V

Production of Crude Oil

26. Production of Crude Oil by PAD District and State

Natural Gas Processing

27. Natural Gas Plant Net Production and Stocks of Petroleum Products by PAD and Refining Districts

Refinery Operations

28. Refinery Input of Crude Oil and Petroleum Products by PAD and Refining Districts

29. Refinery Net Production of Finished Petroleum Products by PAD and Refining Districts 
30. Refinery Stocks of Crude Oil and Petroleum Products by PAD and Refining Districts ............................................. 64

31. Percent Refinery Yield of Petroleum Products by PAD and Refining Districts......................................................... 66

Imports of Crude Oil and Petroleum Products

State of Entry

32. Imports of Residual Fuel Oil by Sulfur Content

PAD District

33. Imports of Crude Oil and Petroleum Products

34. Year-to-Date Imports of Crude Oil and Petroleum Products

Country of Origin

35. United States

36. PAD District I.

37. PAD District II

38. PAD District III

39. PAD Districts IV and V

40. Year-to-Date United States

41. Year-to-Date PAD District I

42. Year-to-Date PAD District II

43. Year-to-Date PAD District III

44. Year-to-Date PAD Districts IV and V

Exports of Crude Oil and Petroleum Products

45. Exports of Crude Oil and Petroleum Products by PAD District.

46. Year-to-Date Exports of Crude Oil and Petroleum Products by PAD District

47. Exports of Crude Oil and Petroleum Products by Destination .

48. Year-to-Date Exports of Crude Oil and Petroleum Products by Destination

\section{Net Imports}

49. Net Imports of Crude Oil and Petroleum Products into the United States by Country ................................................. 96

50. Year-to-Date Net Imports of Crude Oil and Petroleum Products into the United States by Country

Stocks

51. Stocks of Crude Oil and Petroleum Products by PAD District

52. Refinery, Bulk Terminal, and Natural Gas Plant Stocks of Selected Petroleum Products by PAD District and State

Movements of Crude Oil and Petroleum Products

53. Movements of Crude Oil and Petroleum Products by Pipeline, Tanker, and Barge Between PAD Districts.

54. Movements of Crude Oil and Petroleum Products by Pipeline Between PAD Districts

55. Movements of Crude Oil and Petroleum Products by Tanker and Barge Between PAD Districts.

56. Net Movements of Crude Oil and Petroleum Products by Pipeline, Tanker, and Barge Between PAD Districts

\section{Illustrations}

S1. Petroleum Overview, August 1990-Present.

S2. Petroleum Products Supplied, August 1990-Present

S3. Crude Oil Supply and Disposition, August 1990-Present

S4. Crude Oil Ending Stocks, August 1990-Present.

S5. Finished Motor Gasoline Supply and Disposition, August 1990-Present

S6. Motor Gasoline Ending Stocks, August 1990-Present

S7. Distillate Fuel Oil Supply and Disposition, August 1990-Present .

S8. Distillate Fuel Oil Ending Stocks, August 1990-Present.

S9. Residual Fuel Oil Supply and Disposition, August 1990-riresent

S10. Residual Fuel Oil Ending Stocks, August 1990-Present

S11. Jet Fuel Supply and Disposition, August 1990-Present.

S12. Jet Fuel Ending Stocks, August 1990-Present

S13. Liquefied Petroleum Gases Supply and Disposition, July 1990-Present

S14. Liquefied Petroleum Gases Ending Stocks, July 1990-Present. Appendices

A. District Descriptions and Maps

B. Detailed Statistics Explanatory Notes

C. Impact of Resubmissions on Major Series, 1991

Glossary

Definitions of Petroleum Products and Other Terms. 


\section{Articles}

Feature articles on energy-related subjects are frequently included in this publication. The following articles have appeared in previous issues.

Trends in Petroleum Product Consumption

January 1986

Western Countries Lead U.S. Petroleum Import Sources

U.S. Petroleum Exports Show Slight Upturn

Motor Gasoline Trends

Oil Imports from Saudi Arabia

Refinery Capacity Trends and Outlook

Timeliness and Accuracy of Petroleum Supply Data

Midyear Petroleum Review

Winter 1986-1987 Distillate Fuel Outlook

Recent Trends for Middle Distillates

Comparison of Independent Statistics on Petroleum Supply

U.S. Petroleum Developments: 1986

U.S. Petroleum Imports, 1986 Regional Highlights

Leading Petroleum Importers, 1986

U.S. Exports of Petroleum Products Reach Record High

Trends in Petroleum Product Consumption

Refinery Capacity: 1987

Motor Gasoline Outlook for Summer 1987

Motor Gasoline Trends Through 1986

Timeliness and Accuracy of Petroleum Supply Data

Midyear Petroleum Review

Petroleum Heating Fuels

Distillate Fuel Oil Outlook for Winter 1987/1988

Petroleum Exports

EIA Releases Annual Reserves Summary.

Comparisons of Independent Statistics on Petroleum Supply

The Northeast-Distillate Fuel Oil Supply

U.S. Petroleum Developments: 1987

U.S. Petroleum Import/Export Trends Through 1987

Motor Gasoline Trends Through 1987

Distillate Fuel Oil Outlook: Winter 1988/1989

Comparison of Independent Statistics on Petroleum Supply

U.S. Petroleum Developments: 1988

U.S. Petroleum Trade Trends: 1988

Timeliness and Accuracy of Petroleum Supply Data

Distillate Fuel Oil Outlook: Winter 1989/1990.

Comparisons of Independent Statistics on Petroleum Supply

U.S. Petroleum Developments: 1989

U.S. Petroleum Trade Trends: 1989

Motor Gasoline Outlook: 1990

Timeliness and Accuracy of Petroleum Supply Data

Heating Fuel Outlook: Winter 1990-91

Comp. urisons of Independent Statistics on Petroleum Supply

U.S. Petroleum Developments: 1990

U.S. Petroleum Trade 1990

Effects of the Clean Air Act's Highway Diesel Fuel Oil Provisions

Timeliness and Accuracy of Petroleum Supply Data

Regulation of Underground Petroleum Storage

January 1986

January 1986

February 1986

February 1986

March 1986

April 1986

May 1986

July 1986

July 1986

September 1986

November 1986

December 1986

December 1986

December 1986

February 1987

March 1987

March 1987

March 1987

April 1987

May 1987

July 1987

July 1987

August 1987

August 1987

September 1987

November 1987

December 1987

January 1988

February 1988

July 1988

September 1988

December 1988

January 1989

July 1989

July 1989

September 1989

December 1989

January 1990

February 1990

April 1990

July 1990

September 1990

February 1991

March 1991

June 1991

June 1991

August 1991 
Feature Article

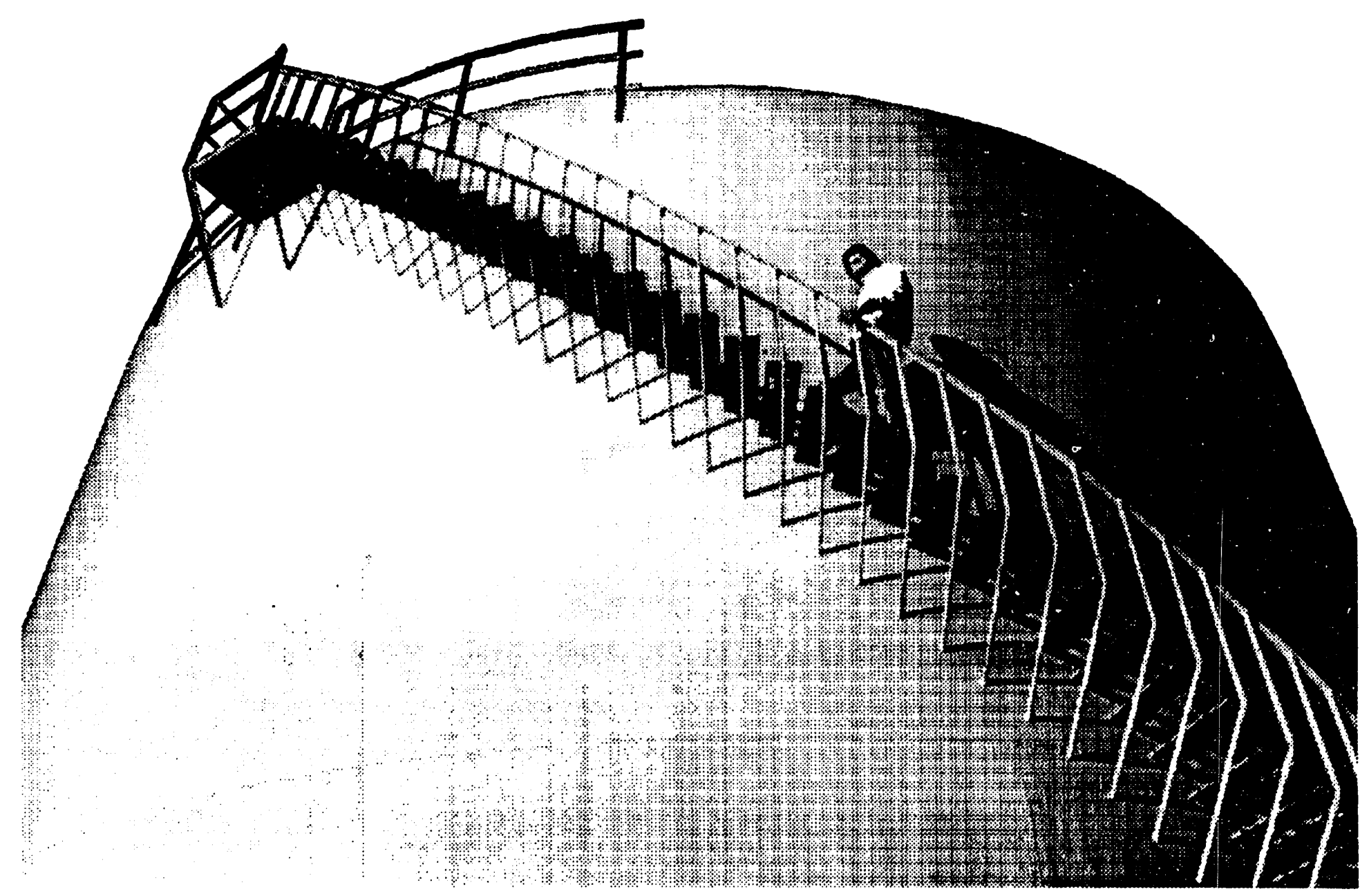




\title{
Alternative Transportation Fuels
}

\author{
by Mary E. Joyce
}

Growing concerns about the effects of fossil fuel use on the environment and about the Nation's high level of dependence en foreign oil are providing the impetus for the development of new transportation fuels. Ongoing research, evaluation, and legislative efforts are aimed at cleaning up traditional fuels through reformulation and at developing substitutes, or alternatives, for traditional fuels. These efforts are rapidly changing the outlook for transportation fuels and will impact analyses of transportation fuel supplies. This article focuses on the current usage of alternative fuels in motor vehicles and on legislation and other factors affecting the demand and supply for alternative fuels.

Energy use in the transportation sector includes fuels for motor vehicles - automobiles, trucks, buses, and motorcycles - and for trains, aircraft, ships, and barges. In the United States, petroleum provides nearly all the energy used to fill transportation demand. In 1990, 10.76 million barrels per day of petroleum products were consumed in the transportation sector. Transportation demand accourted for 63 percent of total U.S. petroleum demand.

Motor gasoline and distillaie fuel oil (primarily diesel fuel) accounted for over 75 percent of transportation demand in 1990. These are the traditional fuels for motor vehicles. Emissions from the evaporation and combustion of these fuels in vehicles are known contributors to ground-level ozone (the major component of smog) and carbon monoxide pollution. From 1987 to 1989,96 metropolitan areas across the United States exceeded the Environmental Protection Agency's (EPA) allowable level for ozone. During 1988 and 1989, 41 cities did not attain the air quality standard for carbon monoxide and 18 cities were in nonattainment status for both carbon monoxide and ozone. ${ }^{1}$ Motor vehicle fuels have been the primary focus of transportation fuel legislation.

Net petroleum imports (imports less exports) provided 42 percent of the petroleum products supplied in all sectors in 1990. The potential for political disturbances in foreign oil-producing regions, that could result in oil price increases and supply shortages, increase concerns about high import dependence. Some of the potential alternative fuels will draw on domestic energy resources, while others are likely to be imported, but from more diversified sources.

Transportation consumption of energy is expected to grow at an average rate of 1 to 2 percent annually over the next 20 years. ${ }^{2}$ Although petroleum is expected to remain the leader in the transportation energy market, alternative fuels will play an increasing role, especially in some States and among certain vehicle groups, such as commercial fleets and urban buses.
The role of alternative fuels could grow even faster if there are increases in the price of oil that make the alternatives more economically competitive.

\section{Potential Alternative Fuels}

Known potential alternative energy sources for motor vehicles are natural gas, liquefied petroleum gases (LPG's), alcohols such as ethanol and methanol, electricity, solar energy, and hydrogen. Some of these alternatives - natural gas, methanol, and LPG's - are fossil fuels or derivatives of fossil fuels. Electricity is primarily generated from fossil fuels, especially coal. Other alternatives, such as solar energy and ethanol, are produced from renewable energy resources. Some renewable fuels are derived from biomass - organic material such as agricultural crops, wood, or waste. Ethanol is an example of a fuel that is usually biomass-derived.

Each of the potential alternative fuels has different associated costs and benefits. Cost considerations include fuel and vehicle production costs, fuel distribution costs, and vehicle operation and maintenance costs. In general, alternative fuels are expected to produce fewer, or less harmful, air emissions than gasoline and diesel fuel. However, comprehensive definitive tests have not been completed. Some alternatives have proven effective at reducing certain emissions while they tended to increase other pollutants. Testing and evaluation to

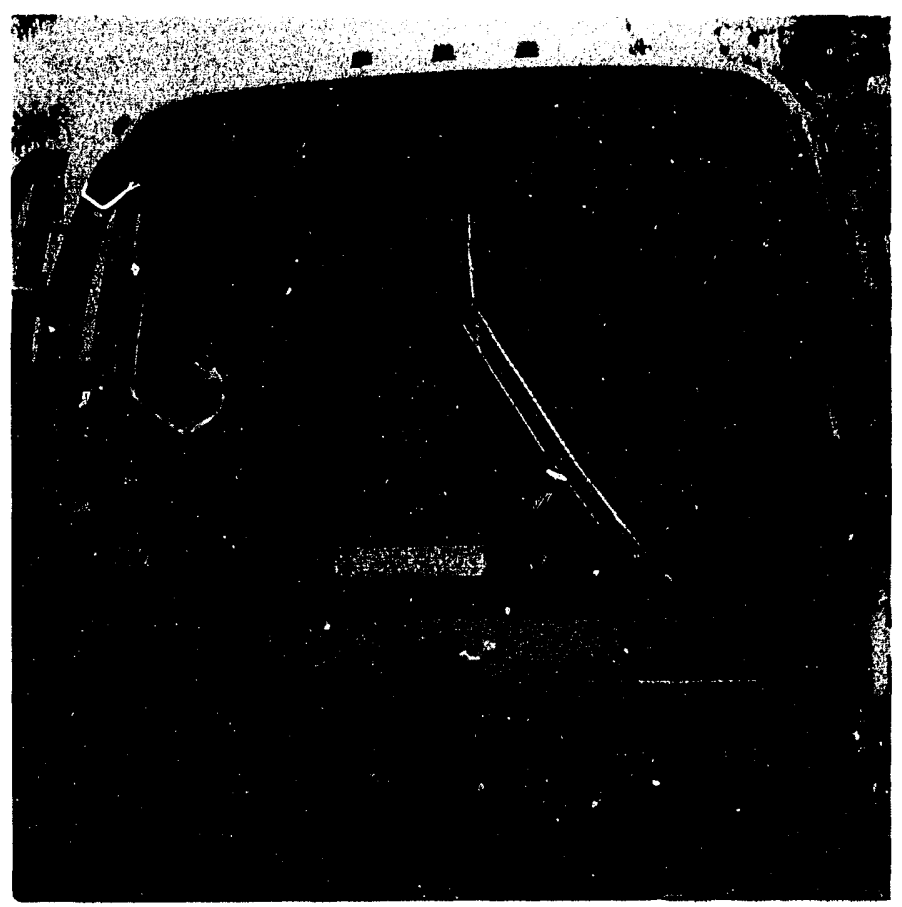

A methanol bus operating in Southern California. 
determine the environmental benefits of alternative fuels is increasing, but it is important to note that many questions remain unanswered.

\section{Legislative Activities}

Lawmakers at all levels of government have initiated new laws leading to rules and regulations that require changes in the composition of diesel fuel and gasoline and promote the use of alternative transportation fuels in the future.

\section{Federal}

The Alternative Motor Fuels Act of 1988 directs Federal Government agencies to administer several programs designed to foster the commercial development of alternative fuels and to encourage the production of vehicles capable of operating on the new fuels. This Act requires the completion of specified research and analytical studies, the establishment of an Interagency Commission on Alternative Motor Fuels to coordinate agency activities, and the execution of designated programs for light-duty vehicles, trucks, and buses. The Department of Energy is charged with ensuring that the "maximum practicable number" of new light-duty vehicles purchased by the Federal Government are alternative-fuel vehicles and with conducting at least one commercial program for alternative-fuel trucks or heavy-duty vehicles. The Federal Government is also required to assist local agencies in testing alcohol and natural gas buses in urban areas. In response to the law, 65 alternative-fuel Federal fleet vehicles were purchased in 1990 and more purchases have been initiated. The Interagency Commission on Alternative Motor Fuels and its advisory group, the U.S. Alternative Fuels Council, were

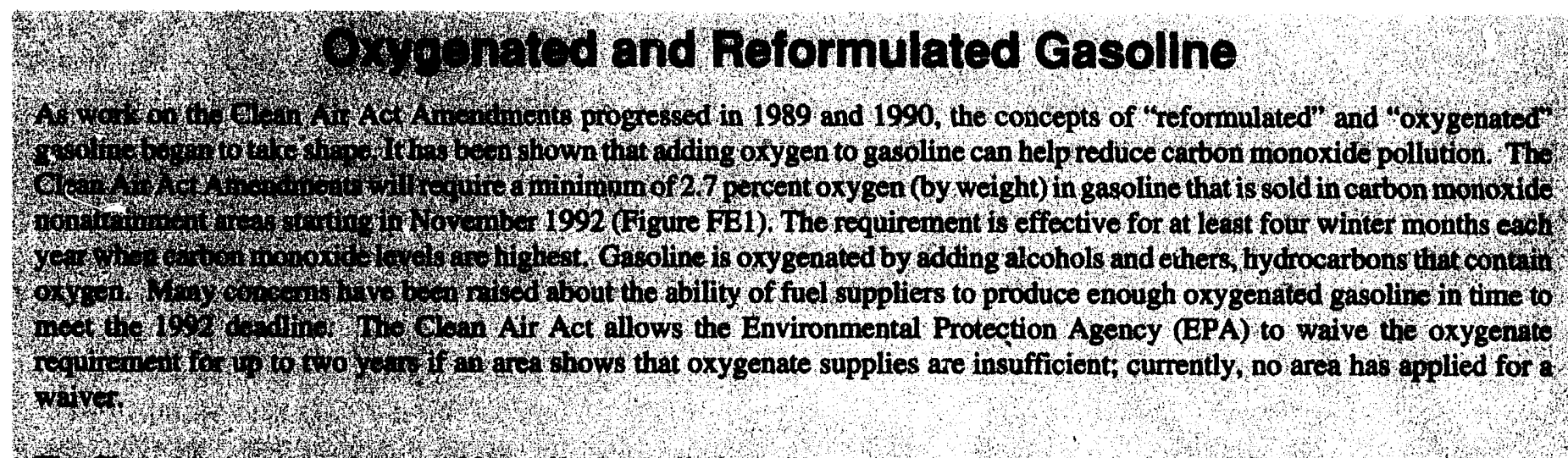

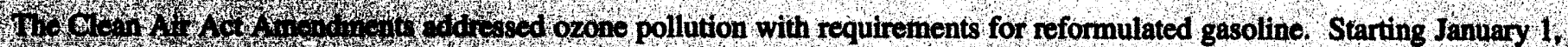

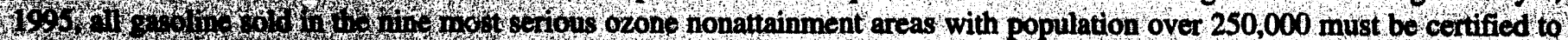
comity

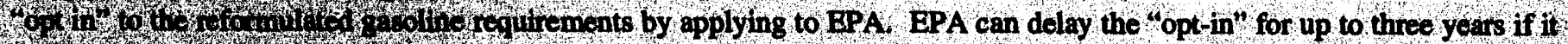

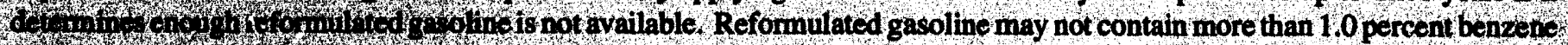

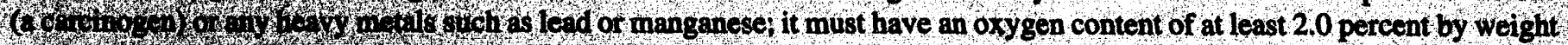

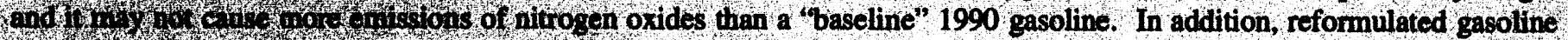

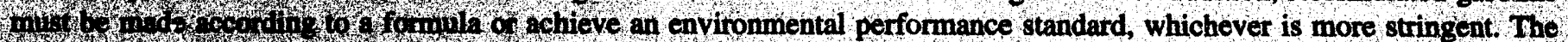
forivil.

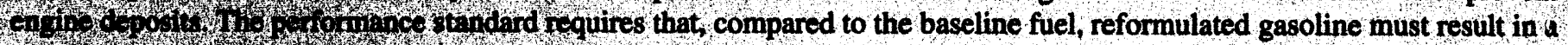

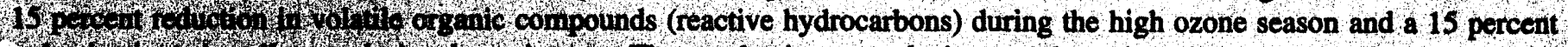

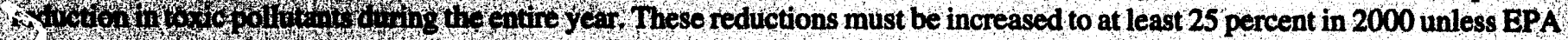

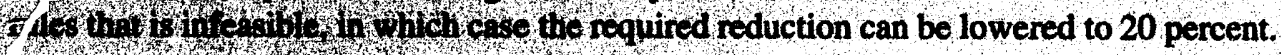

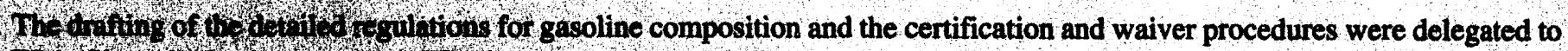

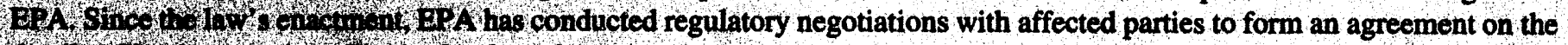

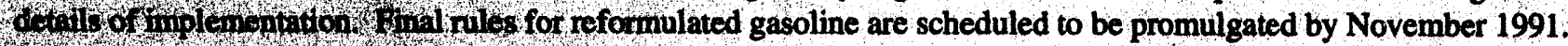

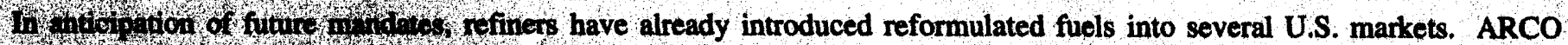

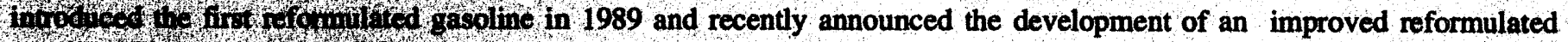

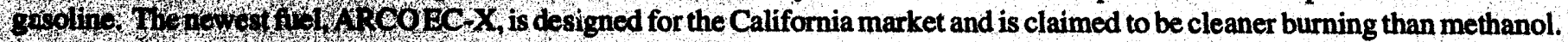

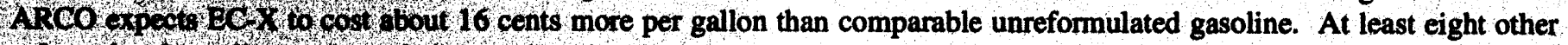

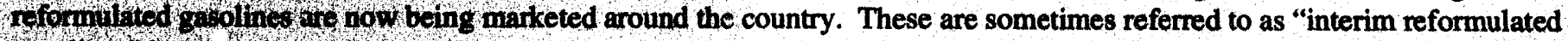
ga. olings b.

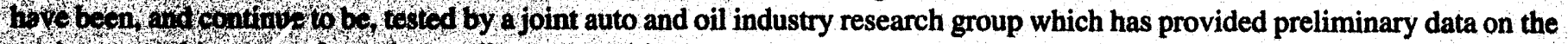
chvironinenthi impars of certain gasoline compositions. 
formed. Their first report to Congress was completed in September 1990 . Under a program directed by the Urban Mass Transportation Administration (UMTA), 65 alternative-fuel buses were in service during 1990. UMTA is evaluating these for emissions, safety, performance, etc.

In November 1990, the Clean Air Act Amendments of 1990 became law. A principal goal of this law is to reduce motor vehicle related pollution by requiring the use of cleaner fuels. The Amendments require oxygenation of gasoline in carbon monoxide nonattainment areas starting in November 1992. More extensive gasoline reformulation for nine of the worst ozone nonattainment areas of the United States is required beginning in 1995 (see page xiv). The Clean Air Act Amendments also set new specifications for diesel fuel effective in 1993, similar to an earlier EPA ruling. The Clean Air Act Amendments stimulate the introduction of alternative fuels by requiring the use of "clean fuels" for certain groups of motor vehicles. The strict emissions standards set for clean fuels are expected to be met by alternative fuels. However, the law allows gasoline and diesel fuel to fulfill the "clean fuel" requirements if they can be reformulated to meet the standards.
In 22 cities (determined by population and severity of pollution), most new light- and heavy-duty fleet vehicles must run exclusively on clean fuels by the year 2000 . With a few exceptions, fleets include all groups of 10 or more vehicles which are owned by one party and are fueled and maintained at a central facility. Purchase requirements begin in 1998, when 30 percent of new light-duty vehicle purchases and 50 percent of new heavy-duty truck purchases must be clean-fuel vehicles. Light-duty requirements increase to 70 percent in 2000 . The Clean Air Act Amendments also require a pilot program in California. Beginning in 1996, 150,000 light-duty vehicles that run on clean fuels must be produced and sold in the State annually. In 1999 and thereafter, 300,000 such vehicles will have to be produced and sold each year. California is required to develop a plan that assures the availability of fuel for the program.

The Clean Air Act Amendments also set new pollution reduction requirements for urban buses. If it is found these standards cannot be maintained with improved diesel fuel or advanced diesel engine systems, the EPA must require buses operating in designated metropolitan areas to operate

\section{Figure FE1. Areas Subject to Clean Ali Act Gasoline Requirements}

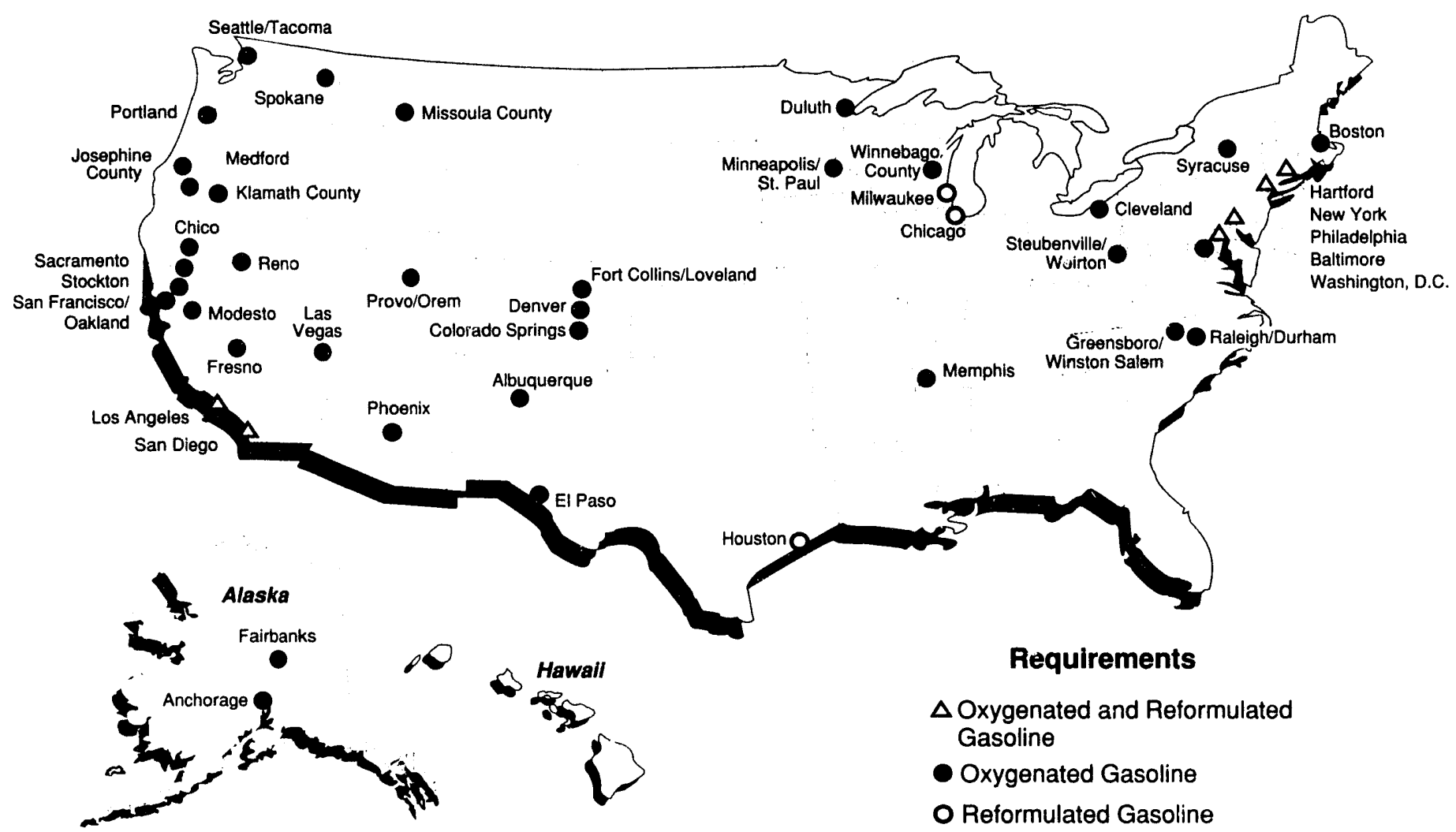

Source: Environmental Protection Agency, Office of Air Quality Planning and Standards, Ozone and Carbon Monoxide Areas Violating the National Ambient Air Quality Standards And Status of 1988 \& 1989 Calls For State Implementation Plan Revisions (September 12, 1990). 
exclusively on low polluting fuels such as ethanol, methanol, propane, or natural gas.

In early 1991, the Administration proposed a National Energy Strategy (NES). Several bills that would implement NES proposals have been introduced in Congress and are in various stages of the legislative process. Some of these bills incorporate proposals similar to NES that mandate the introduction of alternative-fuel vehicles into specified fleets. NES specifies that, starting in 1995, 10 percent of the new fleet vehicles in the areas covered by th: fleet provisions of the Clean Air Act Amendments would be alternatively fueled. By 2000, 90 perient of the'se purchases would be alternatively fueled. The NES :ules would expand coverage to all urban areas with a population of at least 250,000 but, in those areas not covered by the Clean Air Act Amendments, only fleets of 20 or more would be subject to the requirements. Alternative fuel purchase requirem nts for operators of bus fleets would begin to take effect in $2000 .^{3}$ The NES fleet rules could not be satisfied by cleaner versions of traditional fuels. As an incentive for manufacturers to produce flexible- or dual-fuel vehicles, NES prcposes a lifting of the cap on corporate average fuel econorry (CAFE) credits available to these vehicles. NES also includes provisions for the Federal Government to buy more alternative-fuel vehicles, and for the funding of more research and development for biomass alcohol fuels.

\section{State and Local}

State and local alternative fuel use laws usually fall into one of the following categories: demonstration/research programs; monetary incentives; government and commercial fleet mandates; and the California low-emissions vehicle phase-in. A State may provide funds for demonstrations of alternative-fuel vehicles and for fuel research. Wisconsin, for example, recently passed a law that provides funds for a State demonstration and assists local governments with their own programs. Monetary incentives include tax credits and rebates for purchases of new vehicles or conversion of existing vehicles. Oklahoma, for example, allows a State tax credit for a portion of costs incurred to convert or purchase new vehicles that operate on natural gas or propane. Colorado offers a small rebate to private owners who convert to alternative fuels. The most popular forms of State and local laws are fleet mandates. Texas and Louisiana have laws requiring that certain State vehicles purchased starting in September 1991 be capable of operating on alternative fuels and that, starting in 1994, an increasing portion of these vehicles must operate on alternative fuels. Several other States are considering fleet mandates and at least three cities - New York City, Denver, and Washington, DC - have enacted alternative fuel requirements for city-operated vehicles.

Probably the most widely known program is the plan to be enforced by the California Air Resources Board. The program begins in 1994 and will require a phase-in of successively lower emission vehicles: transitional low-emission vehicles, low-emission vehicles, ultralow emission vehicles, and zero-emission vehicles. Electric vehicles are the only ones expected to qualify as zero-emission vehicles. By 1998, 2 percent of the vehicles sold in California must be zero-emission vehicles. The percentage increases to 10 percent in 2003. Several States, especially those in the Northeast, have announced their intentions to adopt the California plan.

\section{Current Alternative Fuel Use}

Technology for using alternative fuels in vehicles has been developed. Research is increasing and fuel tests and demonstrations are being conducted. Vehicle and engine manufacturers, including the major auto companies and other smaller companies, are now working to make more and better alternative-fuel vehicles available. Many small scale projects in this country and around the world are designed to evaluate such things as performance, environmental impact, and the economic feasibility of using alternative fuels.

There are estimated to be about 700,000 natural gas vehicles currently operating worldwide. The largest programs are in Italy (300,000 vehicles), the Soviet Union (about 200,000 vehicles), and New Zealand (125,000 vehicles). ${ }^{4}$ There are about 3.5 million LPG vehicles in the world. ${ }^{5}$ Italy (almost 1 million vehicles), the Netherlands (about 600,000 vehicles), and Japan have large LPG vehicle programs. There are methanol programs in the Netherlands, Australia, and Canada (less than 500 vehicles each). ${ }^{6}$ The number of electric vehicles in the world is unknown. The Griffon Van program, begun in England, is probably the most successful electric vehicle program to date. The Griffon Van and its successor, the G-Van, are battery-powered vans used mostly by fleets as delivery vans.

Brazil has conducted the largest single demonstration of an alternative fuel. In 1975, Brazil began to encourage the use of ethanol, produced from its abundant sugar cane crop, in motor vehicles. By the late 1980 's, there were about 4 million altomobiles in Brazil operating on ethanol. ${ }^{7}$ In addition, gasoline powered cars were running on blends of 22 percent ethanol and 78 percent gasoline. Brazil's ethanol program has not been completely successful. It has required large government subsidies and, in 1989, a rise in sugar prices increased competition for the sugar cane crop and led to ethanol price increases and shortages. As shortages continued, the country was forced to reduce the amount of ethanol blended with gasoline, and some ethanol was imported from the United States. Shortages caused long waiting lines for fuel and a large number of conversions back to gasoline. However, in 1990, there was again a surplus and the amount of ethanol blended in gasoline increased.

Only a very small portion of the 187 million $^{8}$ motor vehicles registered in the United States are alternative-fuel vehicles: 30,000 are fueled by natural gas; 350,000 are LPG vehicles; 
and between 1,000 and 1,500 are methanol-fueled vehicles. ${ }^{9}$ There are also estimated to be between 1,400 and 2,100 electric vehicles $^{10}$ and a very small number of ethanol vehicles. Most of the alternative-fuel vehicles are operated under special fleet programs which range in size from 1 or 2 vehicles to several hundred vehicles. All kinds of vehicles are used in these programs, including automobiles, buses, and light- and heavy-duty trucks. Alternative fuel demonstration programs are currently being conducted by groups such as commercial fleet owners, local governments, and urban transit associations.

California, which contains the most seriously polluted urban area (Los Angcles) and has almost 22 million registered vehicles, has been a leader in exploring alternative fuel potential. The California Energy Commission, the California Air Resources Board, and the South Coast Air Quality Management District actively promote the use of alternative fuels. The California Energy Commission began testing methanol vehicles in the early 1980 's and continues to work with local governments, utilities, and other groups in programs using methanol and other alternative fuels. The Southern California Rapid Transit District operates 47 alternative-fuel buses, 30 of them on methanol. Large utilities such as Pacific Gas and Electric, which operates 100 natural gas vehicles, and Southern California Edison, which owns and operates 15 electric G-Vans, have been leaders in demonstrating the use of their products as alternative fuels.

Utilities that provide natural gas and electric service to consumers are also prime sponsors of alternative-fuel vehicle programs elsewhere. Two of the largest fleets of natural gas vehicles are operated by East Ohio Gas ( 795 vehicles in 1989)

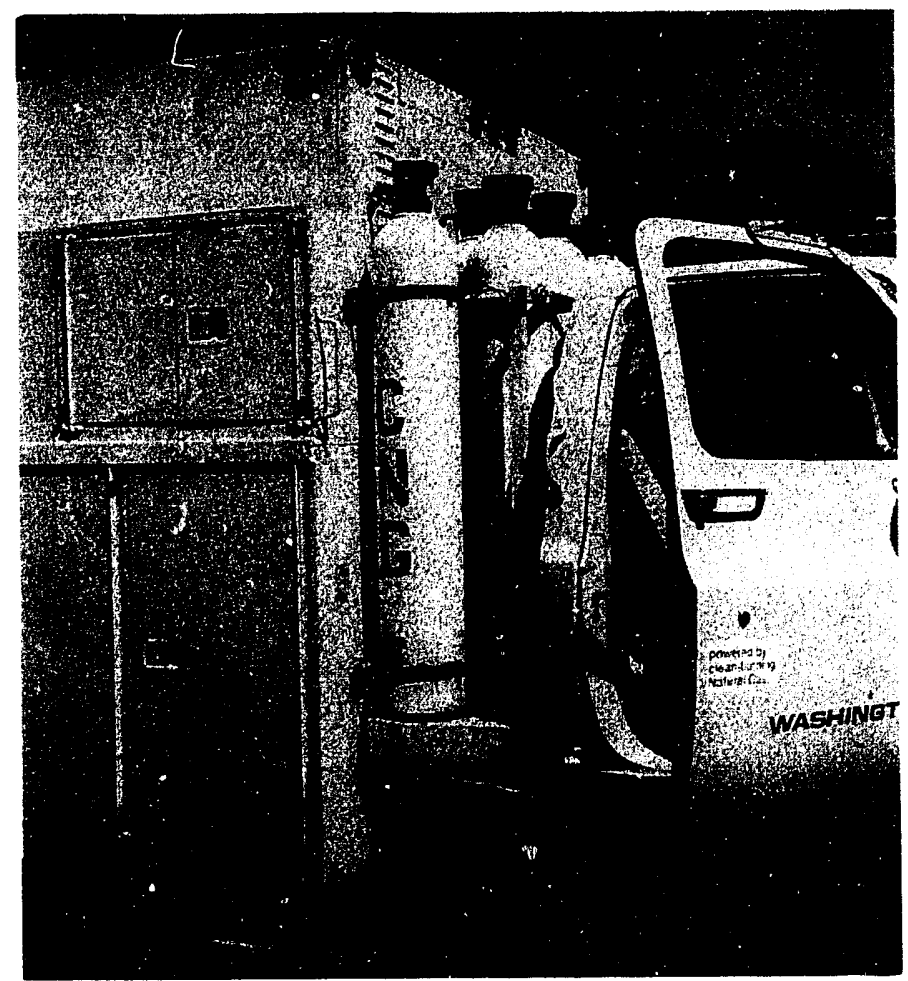

Utility truck operating on natural gas. and the Northern Indiana Public Service Company (703 vehicles in 1989). An American Gas Association Survey found that, in 1989, 7.6 percent of gas utility fleets were natural gas vehicles and this percentage was expected to be higher in $19900^{11}$

There are other programs involving commercial fleets, local governments, and transit associations scattered throughout the Nation. For example, Duluth, Minnesota, operates about 300 of its city vehicles on LPG's and the Sheriff's Office in Sarasota County, Florida, operates about 200 vehicles including many patrol cars on LPG's. In Hudson, Ohio, and Garland, Texas, about 100 school buses operate on compressed natural gas. The Houston Metropolitan Transit Authority is testing a few liquefied natural gas buses. Buses in Cedar Rapids and Des Moines, Iowa, use an ethanol/diesel system that combines 20 percent ethanol and 80 percent diesel fuel. These are just a few examples of the programs currently underway in the United States.

\section{Supply Issues for Alternative Fuels}

Several barriers must be overcome for widescale commercialization of alternative transportation fuels to occur. In addition to their environmental and energy security benefits, the new fuels and the vehicles designed to use them must be able to compete with gasoline- and diesel-powered vehicles in order to increase demand. Some demand will be created as new laws and regulations require a shift from traditional fuels to the alternatives. Cost, safety, performance, and availability of the vehicles and fuels will also be important factors in stimulating demand. Supply availability is hindered by the "chicken and egg" problem. Vehicle manufacturers, unable to foresee a market for alternative-fuel vehicles until the fuels are broadly available, are reluctant to begin vehicle production. Fuel producers, unable to see a market for fuels without the vehicles available, are reluctant to invest in new fuel production and delivery capacity.

Alternative-fuel vehicles can be produced by converting existing vehicles or by producing new "original equipment manufacturer" (OEM) vehicles. Alternative-fuel vehicles can be "dedicated," "flexible-fuel," "dual-fuel," or "hybrid." Flexible-fuel vehicles are designed to run on two separate fuels alternately or on a combination of two fuels (usually gasoline and alcohol). Dual-fuel vehicles are also capable of operating on two fuels, but the fuels are used alternately. A switch allows the driver to change from one fuel to another (usually natural gas and gasoline). Dedicated vehicles are built to run exclusively on one fuel. A hybrid vehicle is an electric vehicle that contains a small gasoline or diesel engine for recharging the battery. Most of today's alternative-fuel vehicles are conversions because there are few commercial manufacturers. Many are flexible- or dual-fuel because the fuel distribution infrastructure is not widely developed yet. Conversions and 
flexible- or dual-fueled systems are expected to be the key to overcoming the "chicken and egg" problem.

The availability of fuel supplies is as important as the availability of vehicles. Some alternative fuels are being produced domestically, today. $\mathrm{Na}$ ural gas, electricity, and LPG's have been produced for man y years for uses outside the transportation sector. For sone fuels, however, the construction of new production cap acity will be required. Raw materials or feedstocks needed to f roduce the fuels must also be available. Production capacily and feedstock supply situations around the world may give imports an advantage over domestic production for some alternative fuels.

Another hurdle for alternative fuel supplies is the need for a distribution infrastructure that includes transportation and storage systems and sales outlets. Some fuels, such as natural gas and LPG's, have transportation systems in place while others will require new types of systems. Some fuels will be able to use today's sales outlets with some modifications, while others may require a very different type of system. The building of new infrastructure is costly and operating and construction permits may be difficult to obtain for environmental reasons. Fuels which can adapt easily to the current structure have an advantage.

Each potential alternative fuel presents different supply difficulties. These are discussed below.

\section{Natural Gas}

Natural gas, consisting primarily of the hydrocarbon methane and consumed by millions of households and businesses in the United States, is also a potential alternative vehicle fuel. To facilitate storage in vehicles, natural gas delivered from a pipeline is usually compressed to about 3000 pounds per square inch. Compressed natural gas (CNG) is stored and used in the gaseous state. It is returned to near atmospheric pressure before it is used in the engine. Most of the natural gas vehicles operating today use CNG and it is likely to remain the most common form of natural gas for vehicles. However, interest in using liquefied natural gas (LNG) as a vehicle fuel (especially for heavy-duty vehicles) is growing. LNG is produced by cooling natural gas to a liquid state for storage.

The energy content of compressed natural gas is substantially less than an equivalent volume of gasoline or diesel fuel. The lower energy content decreases the distance a vehicle can travel before refueling. The growing interest in LNG is due, in part, to its higher energy content.

Adapting vehicles for CNG use requires the installation of heavy, thick-walled tanks or cylinders for storing the fuel. Other equipment needed for CNG-fueled vehicles include new tubing, a pressure regulator, a recalibrated fuel gauge, and a gas/air mixer. The additional weight of CNG tanks affects fuel efficiency, so efforts to develop tanks from new, lighter

\section{Alternative Fuel Data Sources}

The Energy Information Administration (BLA) maintains a comprehensivo datacollocton program for traditional transportation

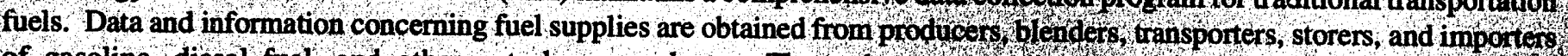
of gasoline, diesel fuel, and other petroleum products. These data are pubilihed in the Petroleum Supply Monthif (DOE/ELA-0109) and Petroleum Supply Annual (DOE/EIA-0340). Price information for petroleum fuels is published in the

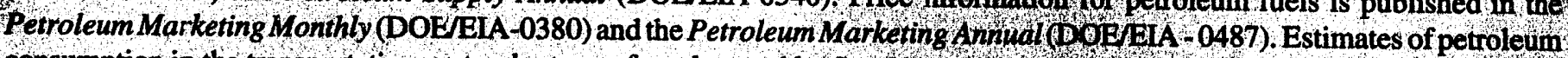
consumption in the transportation sector, by type of product and by State is publishod annually in the State Energy Data Report (DOE/EIA-0214), Forecasts of energy consumption and energy prices in the transportaton sector can be found in the Annual Energy Outlook (DOE/EIA-0383).

In light of expected changes in the supply system for motor fuels, EIA is assessing new data requirements. A one-time "oxygenates" survey is being conducted to identify a potential respondent frame and helpatalyze some of the new requirements for motor gasoline.

The data available at this time to analyze alternative fuels are limited. Data collection programs for alternative transportation fuels are difficult to design because of present uncertainty about the types of fucls which will be developed. Each fuel option presents unique data collection problems because suppliers are very different depending on type of fuel. Some scattered data are currently available from government sources. Data on LPG consumption for transportation fuels are published in EIA's State Energy Data Report. These estimates are based on information from the American Petroleum Institute, the National Propane Gas Association, and the Gas Processors Association. The Annual Report on Alcohol fuel Use issued by DOE's Office of Alcohol Fuels provides information and data on production, production capacity, and consumption of fuel ethanol and sales of methanol. The Intemational Trade Commission, in its Report on U.S. Production of Selected Synthetic Organic Chemicals publishes production data for methanol. The Census Bureau's Truck Inventory and Use Survey provides data on private and commercial trucks, with a special category for "LPG and other" engine types. Data include such items as number of trucks operating in the United States, average mileage, major uses, etc. The Federal Highway Administration collects data on sales of gasohol. 
materials are underway. LNG tanks are lighter weight but must be heavily insulated. Estimates of the cost of converting a gasoline powered auto to $\mathrm{CNG}$ range from about $\$ 1,500$ to $\$ 3,000$. Production of an original equipment manufacture $C N G$ vehicle, however, is expected to cost considerably less, in the range of $\$ 400$ to $\$ 1,000$ more than a comparable gasoline powered car. Diesel engine conversions are much more difficult. The cost of converting a diesel bus to $\mathrm{CNG}$ is estimated to be about $\$ 3,000$ to $\$ 6,000$ for engine conversion plus up to $\$ 10,000$ for fuel storage tanks. ${ }^{12}$ The EPA estimates, however, that the cost of an original equipment manufacture heavy-duty vehicle will only modestly exceed the cost of a conventional diesel vehicle. ${ }^{13}$

Natural gas has the advantage of not requiring new production and transportation systems because vehicles will draw on the same supplies as other natural gas consumers. Natural gas already has a very large and developed production and distribution infrastructure. In 1990, 17.6 trillion cubic feet of dry natural gas was produced in the United States. Consumers used 18.8 trillion cubic feet of natural gas that was delivered via an extensive pipeline transmission network that stretches across the Nation. Although it is possible to compress natural gas at one of several points in the distribution system, compression most likely will occur at the outlet where CNG vehicles are fueled. In some cases, pipelines rnust be extended to reach these outlets. Fuel for LNG vehicles 、 ould be liquefied at the sales site using a small liquefaction plant or it could be delivered to the sales location by truck from an offsite liquefaction plant.

Two methods for fueling a CNG vehicle have been developed - slow-fill and fast-fill. During slow filling, gas is compressed as it is fed into the vehicle's tank. It takes several hours and is most suitable for fleet facilities where vehicles can be assembled and filled overnight. Fast filling takes only a few

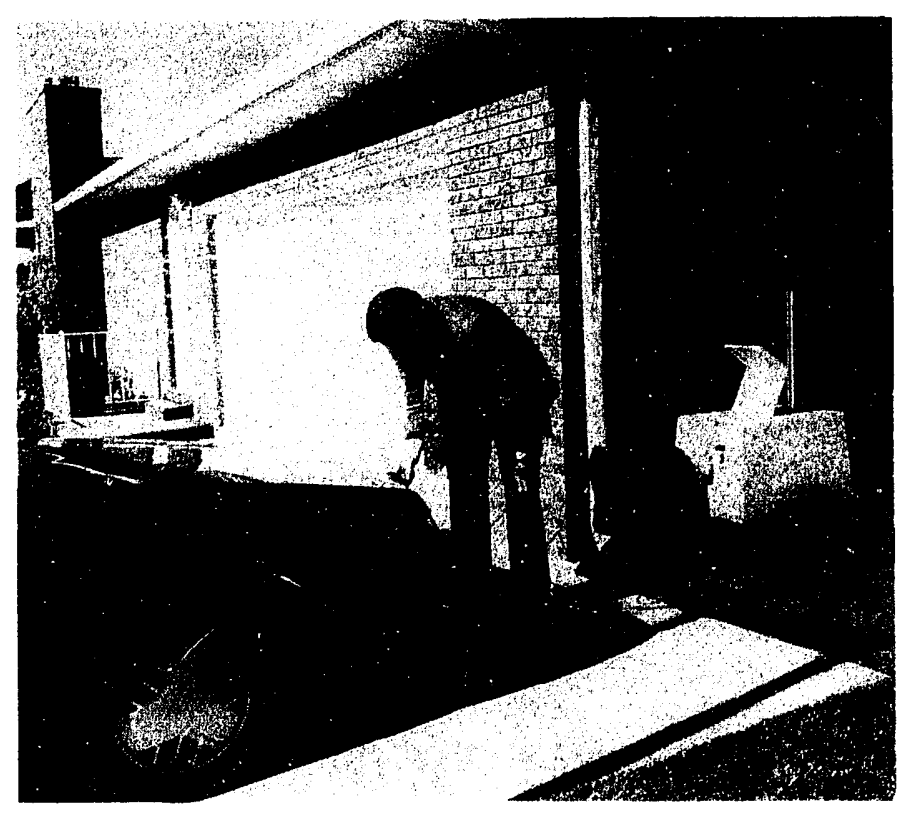

CNG fueling system designed for home use. minutes because previously compressed gas is obtained from storage tanks which are kept filled continuously by the compressor. Because the time needed for refueling is comparable to gasoline refueling, the fast-fill system was designed for public refueling stations. Fast-fill fueling systems are more expensive than slow-fill. Systems have also been designed that enaole homeowners to refuel their own vehicles by drawing on the natural gas delivered to their homes. Home compressors have bien commercially built in Canada and cost about $\$ 3,000$. These home systems would decrease the expansion needed in the delivery infrastructure for CNG. Consumers, however, will still need somewhere to refuel when away from home. The cost of adding CNG fast-fill capability to a traditional gasoline station is estimated to be $\$ 225,000$ to $\$ 395,000$. Most of this cost is for the addition of a compressor (estimated to cost $\$ 100,000$ to $\$ 200,000$ ) and for storage facilities (estimated to cost $\$ 26,000$ to $\$ 99,000$ ). ${ }^{14}$ LNG fueling is faster than $\mathrm{CNG}$ and would be less expensive because there is no compressor involved. However, LNG plants, as well as shipping and storage, are much more expensive than CNG. Today, there are about 300 natural gas refueling places in the United States, but most are run by utilities and only a few are open to the public. In 1990, some public natural gas refueling stations opened. The first one, at the Denver airport, was opened by Natural Fuels Corporation on June 4, 1990. Another public station opened later that year in Port Arthur, Texas.

Several estimates have been made comparing the expected price of natural gas to an equivalent volume of gasoline or diesel fuel. These estimates generally show that natural gas (excluding vehicle conversion and compression costs) has a price advantage over gasoline. The EPA estimated that CNG prices will range from much less to slightly more than gasoline, but that CNG suffers a disadvantage compared to diesel fuel. ${ }^{15}$ Natural gas prices at the pump are subject to some regulation. Several proposals have been made to remove regulations on natural gas used as vehicle fuel.

\section{LPG'S}

LPG's include a number of light hydrocarbon compounds that have a variety of applications as fuels and chemicals. Propane is the most widely used LPG and the one most often used as an alternative motor fuel. In 1989, almost 100 percent of the LPG sold for motor fuel in the United States was propane; less than .1 percent was butane. ${ }^{16}$ LPG's are separated from natural gas at gas processing plants or produced from crude oil as byproducts during refinery processing. Of the approximately 880,000 barrels per day of propane produced in the United States in 1990, 54 percent was produced in gas processing plants and 46 percent was derived from crude oil at refineries. As with natural gas, the production and transportation infrastructure for LPG's is already substantially developed. There are thousands of miles of long-distance LPG pipelines in the United States and an extensive system of rail cars and tank trucks for transportation. Expansion needed to meet increasing vehicle demand would not be as difficult as for some 


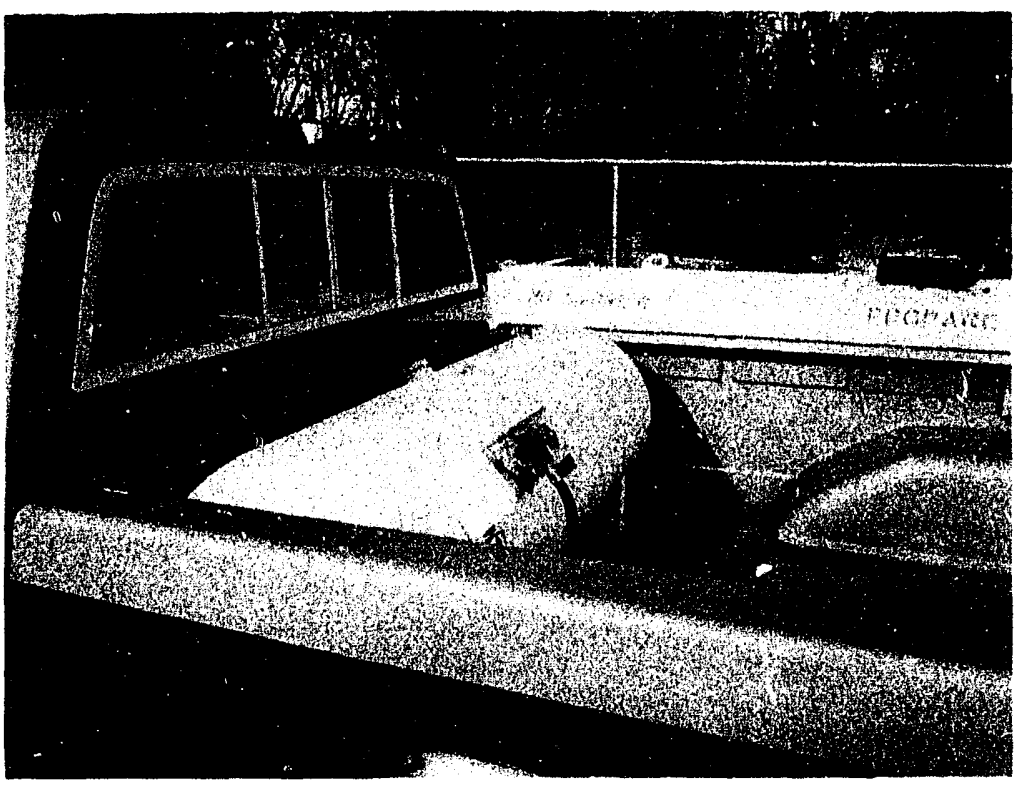

Fuel tank is located in the bed of this LPG-powered pickup truck.

other alternative fuels. Propane consumption for motor fuel was about 45,000 barrels per day in 1989. Demand was greatest in California, Texas, Ohio, Michigan, and Illinois. ${ }^{17}$

Some changes are needed to make vehicles compatible with propane, including the installation of special tanks and fuel lines, a convertor to vaporize the fuel, and an air/fuel mixer. In a vehicle, propane is stored as a liquid but is vaporized to a gas before use. It must be stored under slight pressure (100 to 300 psi) to keep it liquid at normal temperatures. Propane provides about 20 to 25 percent less energy than the same volume of gasoline. Thus, larger fuel tanks or more frequent fill-ups will be needed to get an equivalent range. The conversion cost for a propane automobile is estimated to be about $\$ 1,000$ per vehicle. $^{18}$

The fueling equipment needed for propane is similar to gasoline, but it would require some modification to accommodate the pressure. Most of today's propane vehicles are fueled at fleet fueling sites or propane retail outlets (such as campgrounds, truck stops and lumber yards). About 10,000 propane retail outlets around the country have facilities for vehicle fueling. ${ }^{19}$ Some commercial fueling stations have recently added propane capacity. In 1990 and 1991, Phillips Petroleum Co. opened vehicle conversion and fueling facilities in Colorado and Wyoming. Conoco Inc. recently announced plans to sell propane at two gasoline stations in Colorado. An increase in propane vehicles would require the addition of new, more accessible, fueling outlets. New storage facilities must be added at some sites.

Propane is usually more expensive than natural gas but slightly less expensive than gasoline. The price of propane, however, is affected by several factors. Unusually cold weather at the end of 1989 increased demand for propane as a heating fuel. Prices increased sharply in early 1990 as supplies became tight.
Above average petrochemical demand is a contributing factor to low propane stock levels in the fall of 1991. Low stock levels raise concerns about winter propane supplies. Propane for motor fuel will have to compete with demands from the industrial and residential sectors that will affect its competitiveness with traditional motor fuels.

\section{Alcohols}

The alcohols with greatest motor fuel potential are methanol (also known as "methyl" or "wood" alcohol) and ethanol ("ethyl" or "grain" alcohol). These alcohols already contribute to the Nation's transportation fuel supplies. Since 1979, ethanol has been blended into a portion of the U.S. gasoline pool to produce gasohol (10 percent ethanol and 90 percent gasoline) for sale to consumers. Ethanol consumption, virtually all of which was consumed as gasohol, reached about 750 million gallons in 1989. Methanol is a raw material for the production of methyl tertiary butyl ether (MTBE), a gasoline component for which demand has grown dramatically in recent years. Fuel methanol consumption was 463 million gallons in 1989. Ninety-eight percent was converted into MTBE and blended with gasoline. The remaining 2 percent was used as "neat" fuel and for other uses. 20

The term "neat" refers to fuels which are 100 percent alcohol. These fuels are also known as M100 (methanol) or E100 (ethanol).The physical properties of alcohols make engine starting difficult in cold weather. A small amount of gasoline is often added to alcohol fuels to overcome this problem. Mixtures of 85 percent ethanol or methanol and gasoline are called M85 or E85 and may be referred to as "neat" or "near neat." M85, E85, M100, and E100 are considered to be alternative fuels.

Ethanol and methanol, with slightly different chemical formulas, differ in how they are made and in how they are used. Ethanol is similar to beverage alcohol, while methanol is primarily used as a chemical. Alcohol fuels are much more corrosive than other liquid fuels and they have a tendency to absorb water, so special handling is required during transportation and distribution.

Alcohol-compatible vehicles need special lines, hoses, valves, etc., that can resist corrosion. Alcohol fuels contain about one-third to one-half less energy per volume than traditional fuels, so fuel tanks must be larger or the range of the vehicle is reduced. The cost to convert a car to run on methanol is estimated to be about $\$ 1,000$. However, EPA estimates that an original equipment manufacturer flexible-fueled methanol car will cost an additional $\$ 300$ and a new "dedicated" methanol auto will be comparable in cost to a gasoline auto (assuming large scale production). ${ }^{21}$ EPA concludes that the cost comparisons are about the same for ethanol cars. ${ }^{22}$ 
Ethanol is produced by the fermentation of sugars that are derived from biomass feedstocks. The fermentation process produces an ethanol and water mix, which is then distilled to obtain fuel-grade ethanol. The most widely used feedstocks for ethanol are agricultural products. Nearly all the ethanol produced in the United States today uses corn as a feedstock. Additional feedstocks include grains other than corn, brewery waste, cheese whey, and other waste streams. Production of ethanol from biomass feedstocks is expensive. According to the U.S. Department of Agriculture, based on corn prices of $\$ 2$ per bushel and today's technology, ethanol is not competitive with gasoline unless oil prices reach $\$ 40$ per barrel. ${ }^{23}$ However, the Federal Governme.lt grants an : xcise tax exemption of 5.4 cents per gallon for gasohol sales or a tax credit of 54 cents for each gallon of biomass-derived ethanol added by blenders to gasoline. There is also a Federal credit of 10 cents per gallon available to small producers (those with production capacity below 30 million gallons a year) and several State tax exemptions. With these subsidies, ethanol prices are more comparable to gasoline prices. It is possible to produce ethanol from ethylene that is derived from fossil fuels, but this is not being done now because it does not receive subsidies. Research is now underway to develop new technology that will lower the cost of producing ethanol from corn and other biomass feedstocks.

Methanol is produced by reacting a synthesis gas, derived from fossil fuel or biomass feedstocks, in the presence of a catalyst. There are several processes that can be used to produce the synthesis gas and the choice of process affects cost. Most of the methanol produced in the world today uses natural gas as a feedstock. Other feedstocks include heavy hydrocarbon liquids, light hydrocarbon gases, and coal. Methanol can also be produced from renewable biomass feedstocks such as wood and municipal wastes. When natural gas is used as a feedstock, methanol can be competitive with today's gasoline prices. ${ }^{24}$ The cost of producing methanol from other feedstocks is higher. A few test programs are underway that may someday improve the technology enough to make biomass and coal methanol cost competitive with natural gas derived methanol.

Alcohol production capacity is expected to grow in the near future as demand increases to meet the requirements for the oxygenated and reformulated mandates in the Clean Air Act Amendments of 1990 . Increased demand for alternative fuel and gasoline use will require a significant and costly increase in production capacity. Methanol production capacity, in particular, is growing outside the United States. Areas such as Venezuela, Ecuador, North Africa, and the Middle East, which have abundant natural gas supplies, are finding that methanol may be a profitable way to export natural gas. The Interagency Alternative Fuels Commission believes overseas natural gas will provide the least expensive methanol in the near future. ${ }^{25}$

The corrosiveness of alcoho! fuels and their water absorption properties makes shipment through the existing pipeline system difficult. Today, alcohols depend on rail, water, and highway transportation. Building a sufficient transportation system is a costly obstacle in the way of introducing alcohol fuels in the transportation sector on a large scale. In addition to transportation systems, some changes to fueling facilities are needed to accommodate these more corrosive fuels. New storage tanks (perhaps with special liners), noncorrosive lines, and replacements for metal, rubber, and plastic parts in dispensing pumps would be required. The cost to convert a gasoline station for methanol sales is estimated to be $\$ 35,000$ to $\$ 46,000{ }^{26}$ In 1990 , a methanol pump was operating at a Washington, DC, service station and methanol fueling capability was available at a few California stations. More fuel outlets are planned and may be open soon.

In addition to the cost of expanding production capacity and changing feedstock prices, future ethanol costs will reflect byproduct prices. The production of ethanol from corn results in several byproducts, such as corn gluten and animal feed. Higher prices obtained for these byproducts increase the cost competitiveness of ethanol. Future methanol prices will also reflect the cost of feedstocks and capital investment in plants, but will also likely reflect the cost of shipping methanol from overseas producers.

\section{Electricity}

Electric vehicles are unique in that they have a motor, not an engine, like other vehicles. They store and use electricity that is generated remotely from a variety of energy sources such as

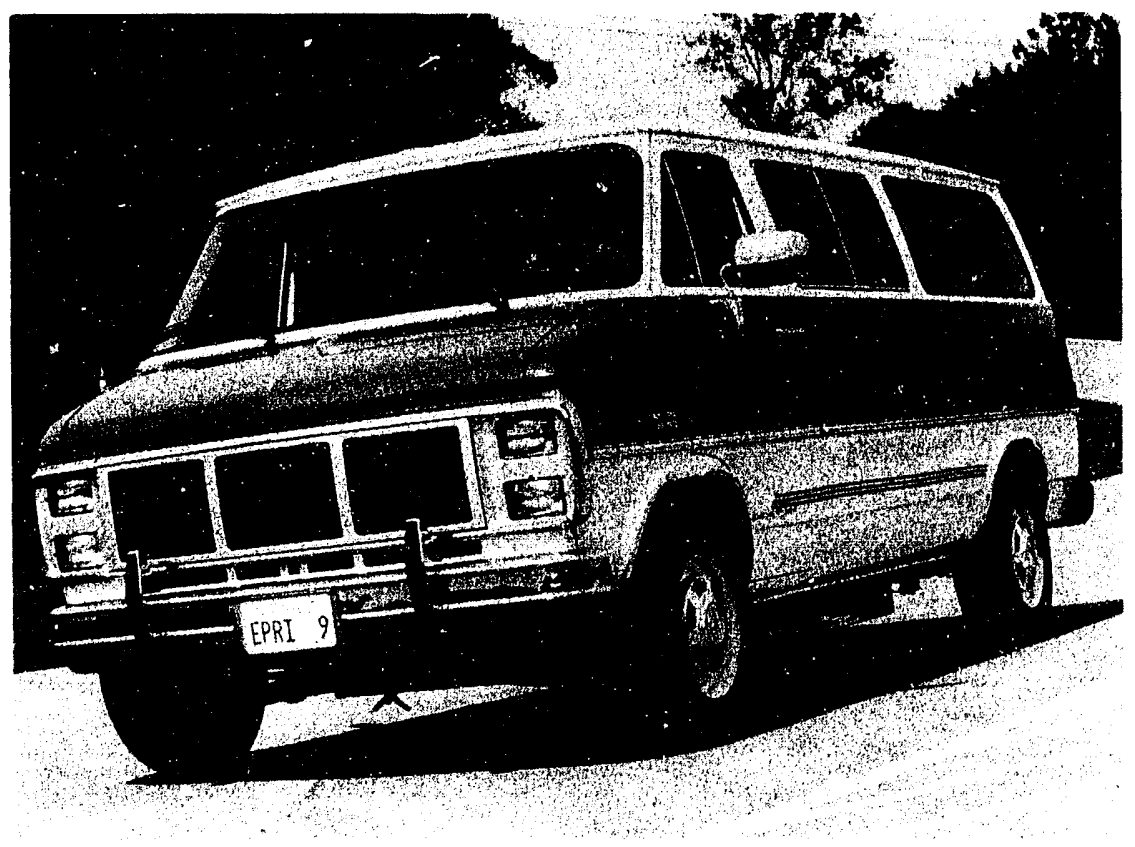

The electric G-Van. 
coal, natural gas, and hydropower. Although the vehicles, themselves, do not emit pollutants, the use of fuels to generate electricity usually has some negative environmental impact.

The biggest obstacle for electric vehicles, so far, has teen the inability to produce vehicles which exhibit satisfactory performance for many users. Battery technology is advancing rapidly, but cars that can travel more than 60 to 100 miles before recharging are still extremely difficult to produce. The G-Van, for example, has only a 60 -mile range. The recharging process is time consuming, usually requiring overnight fueling. Short range and long refueling time me'se electric vehicles impractical for many consumers. Sc 'ie manufacturers are attempting to develop "hybrid vehicles" to help extend the range of electric vehicles. Most of today's electric vehicles are used by commercial fleets that have well-established daily routes and can be recharged at a central facility at night; for example, delivery vans.

Some advantages of electric vehicles are the existing fully developed production and transportation infrastructure for electricity and the relative ease of recharging these vehicles. Most refueling could be done wherever the vehicle is garaged, so a much smaller refueling infrastructure is required. Household vehicles could be charged at ordinary household outlets. Fleet vehicles could be charged by plugging into electrical outlets at central fleet fueling facilities. A few ideas for refueling away from a vehicle's home base have surfaced. For example, public lots where one would plug their car into a coin-operated device similar to a parking meter could be built. Other facilities that have been proposed are "electrified roads" where cars would receive electricity from a grid under the road.

Generally, the cost of electricity is lower than an equivalent amount of gasoline. However, when the cost of vehicle production and battery replacement are included, electric cars are today far from economically competitive with gasoline powered cars. Most of today's electric vehicles need about 30 batteries and these batteries must be replaced after a few years. With traditional batteries costing $\$ 75$ to $\$ 250$ each and newer technology batteries even more, it makes the battery cost significant. General Motors has estimated that the total energy cost to run its IMPACT (a prototype electric vehicle developed in 1990), including battery replacement, would be about twice the cost of gasoline. ${ }^{27}$ Electricity rates are regulated. It is possible that special rates for vehicle charging will be offered, especially if charging is done during off-peak hours.

\section{Other Alternatives}

A few other alternative transportation fuels are in the research stage but, for the most part, they are still far from commercialization. However, two types in particular have received support primarily because of their potential advantages in terms of environment and energy security. These are solar power and hydrogen. Energy from the sun can be converted to electricity using photovoltaic solar cells. This energy can be stored in batteries and used to run motors in vehicles. The experimentai solar cars produced so far have had difficulty storing enough energy for long-range and high-speed driving.

Research on hydrogen vehicles is currently focusing on fuel cells which will chemically convert hydrogen into electricity to run cars. (Fuel cells can also use alcohol fuels.) BMW and Mercedes have built experimental hydrogen cars and, in California, Riverside Community College is experimenting with hydrogen vehicles. Hydrogen can be produced in several ways, including at refineries, but hydrogen storage and vehicle fueling is difficult. Hydrogen vehicles also raise safety concerns.

\section{Conclusion}

The future for transportation fuels is still unfolding. On almost a daily basis, technology in production of fuels and vehicles is changing, new laws and regulations are being proposed and taking effect, and new knowledge about the environmental impact of changing transportation fuels is becoming available. At the same time, changes in the supply and demand situation for fossil fuels and other energy sources are determining the economic impacts of motor fuel changes.

Legislation passed to date should allow gasoline and diesel fuel to continue to dominate the motor fuels market for many years. However, the composition of those products will have to change to meet stricter environmental requirements. At the same time, alternative motor fuels should continue to penetrate the market, but it is difficult to predict the rate of penetration. It is unknown which of the supply problems will be solved first and which fuels will solve the environmental and energy security problems sufficiently to successfully compete with traditional transportation fuels. 


\section{NOTES}

${ }^{1}$ Environmental Protection Agency, Office of Air Quality Planning and Standards, Ozone and Carbon Monoxide Areas Violating the National Ambient Air Quality Standards And Status of 1988 \& 1989 Calls for State Implementation Plan Revisions, (Research Triangle Park, NC, September 1990).

2 Energy Information Administration, Annual Energy Outlook 1991, DOE/EIA-0383 (91) (Washington, DC, March 1991), Tables A2, B2, C2, D2.

${ }^{3}$ National Energy Strategy: Powerful Ideas for America, 1st ed. (Washington, DC, February 1991), p. 68.

${ }^{4}$ American Gas Association, Natural Gas Vehicles, 2nd ed. (1990), p. 1.

5 National Propane Gas Association, LP-Gas is Moving America's Fleets, (Lisle, IL, 1991).

6 J.E. Sinor Consultants, Inc., The Clean Fuels Report, Vol. 2 No. 4 (Niwot, CO, September 1990), pp. 76-78.

${ }^{7}$ Alternative Transportation Fuels: An Environmental and Energy Solution, ed. D. Sperling (New York: Quorum Books, 1989), p. 163.

8 U.S. Department of Transportation, Federal Highway Administration, Highway Statistics 1989 (Washington, DC, September 1990), Table MV-1.

9 "Webb Report Adds Support for Choosing LPG as a Motor Fuel," Butane-Propane News (January 1990), p. 20, and National Propane Gas Association, LP-Gas is Moving America's Fleets.

${ }^{10}$ U.S. Department of Energy, Conservation and Renewable Energy Inquiry and Referral Service, Electric Vehicles, DOE/CE-0289P (Washington, DC, March 1990).

${ }^{11}$ American Gas Association, Natural Gas as an Alternative Transportation Fuel: Clean Air Strategy for State and Local Officials, Issue Brief 1990-14 (October 29, 1990), p. 14.

${ }^{12}$ Environmental Protection Agency, Office of Mobile Sources, Analysis of the Economic and Environmental Effects of Compressed Natural Gas as a Vehicle Fuel, Vol II, Special Report (April 1990), p. 4-20 - 4-23.

${ }^{13}$ Environmental Protection Agency, Analysis of the Economic and Environmental Effects of Compressed Natural Gas as a Vehicle Fuel, p. 4-20.

${ }^{14}$ Interagency Commission on Alternative Motor Fuels, First Interim Report of the Interagency Commission on Alternative Fuels (September 30, 1990), p. 4-9.

${ }^{15}$ Environmental Protection Agency, Analysis of the Economic and Environmental Effects of Compressed Natural Gas as a Vehicle Fuel, p. 4-8.

${ }^{16}$ American Petroleum Institute, National Propane Gas Association, and Gas Processors Association, Sales of Natural Gas Liquids and Liquefied Refinery Gases (Washington, DC, September 1990), Tables 3, 4, 5.

${ }^{17}$ American Petroleum Institute, National Propane Gas Association, and Gas Processors Association, Sales of Natural Gas Liquids, Table 4.

${ }^{18}$ National Propane Gas Association, Using LP-Gas as an Alternative Fuel, NPGA Fact Sheet (Lisle, IL, 1990), p. 3.

${ }^{19}$ National Propane Gas Association, LP-Gas is Moving America's Fleets.

${ }^{20}$ U.S. Department of Energy, Office of Alcohol Fuels, Eleventh Annual Report on the Use of Alcohol Fuels (Washington, DC, June 1990), p. 4. 
${ }^{21}$ Environmental Protection Agency, Office of Mobile Sources, Analysis of the Economic and Environmental Effects of Methanol as an Automotive Fuel, Special Report (September 1989), pp. 13-14.

${ }^{22}$ Environmental Protection Agency, Office of Mobile Sources, Analysis of the Economic and Environmental Effects of Ethunol as an Automotive Fuel, Special Report (April 1990), pp. 34-35.

${ }^{23}$ U.S. Department of A griculture, Economics of Ethanol Production in the United States, Agricultural Economic Report Number 607 (Washington, DC, March 1989), p. v.

${ }^{24}$ Environmental Protection Agency, Analysis of the Economic and Environmental Effects of Methanol as an Automotive Fuel, $\mathrm{p}$. 1 .

${ }^{25}$ Interagency Commission on Alternative Motor Fuels, First Interim Report of the Interagency Commission on Alternative Motor Fuels, p. 3-15.

26 “Methanol Sales Seen Tightening Marketers' Margins," The Oil Daily (November 7, 1989), p. 1.

27 "How clean is the plug-in car?" The Economist (October 13. 1990), p. 76.

xxiv 


\section{Highlights}

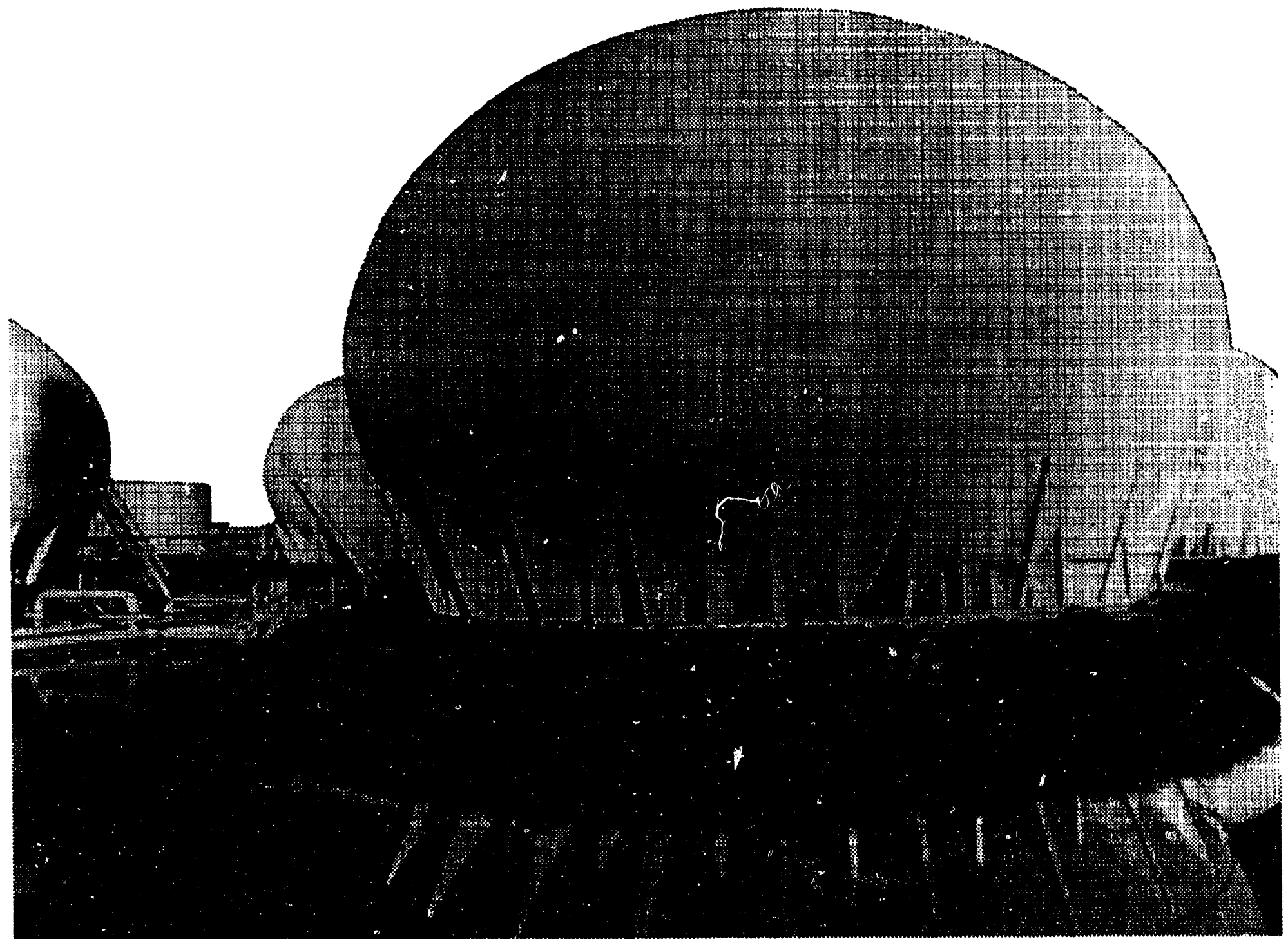




\section{Highlights}

The slowly recovering economy, warmer-than-normal temperatures, the attempted Soviet coup in mid-month, and the threat of an oil workers' strike in Brazil were the major factors affecting U.S. petroleum supply and demand in August. Total demand for petroleum products (measured as product supplied) increased slightly to 17.1 million barrels per day (Table H1), the highest monthly level this year. Demand was substantially below the August 1990 level, however, when demand for some products escalated as a result of events associated with Iraq's invasion of Kuwait a year ago.

Exports of motor gasoline and distillate fuel oil remained relatively high in August, partly because the attempted Soviet coup caused concern about possible disruption of distillate fuel oil supplies in Europe. In addition, an increase in exports to South America was related to the Brazilian government's increased oil needs in order to build up supplies as t.ee threat of an oil workers' strike loomed. Motor gasoline exports to Mexico continued to escalate in August, to accommodate increased demand in areas close to the U.S. border and to replace supplies lost through Mexican refinery shutdowns this year.

Information about the latest OPEC meeting and the end of the Brazilian oil workers' strike begin on page xxx.

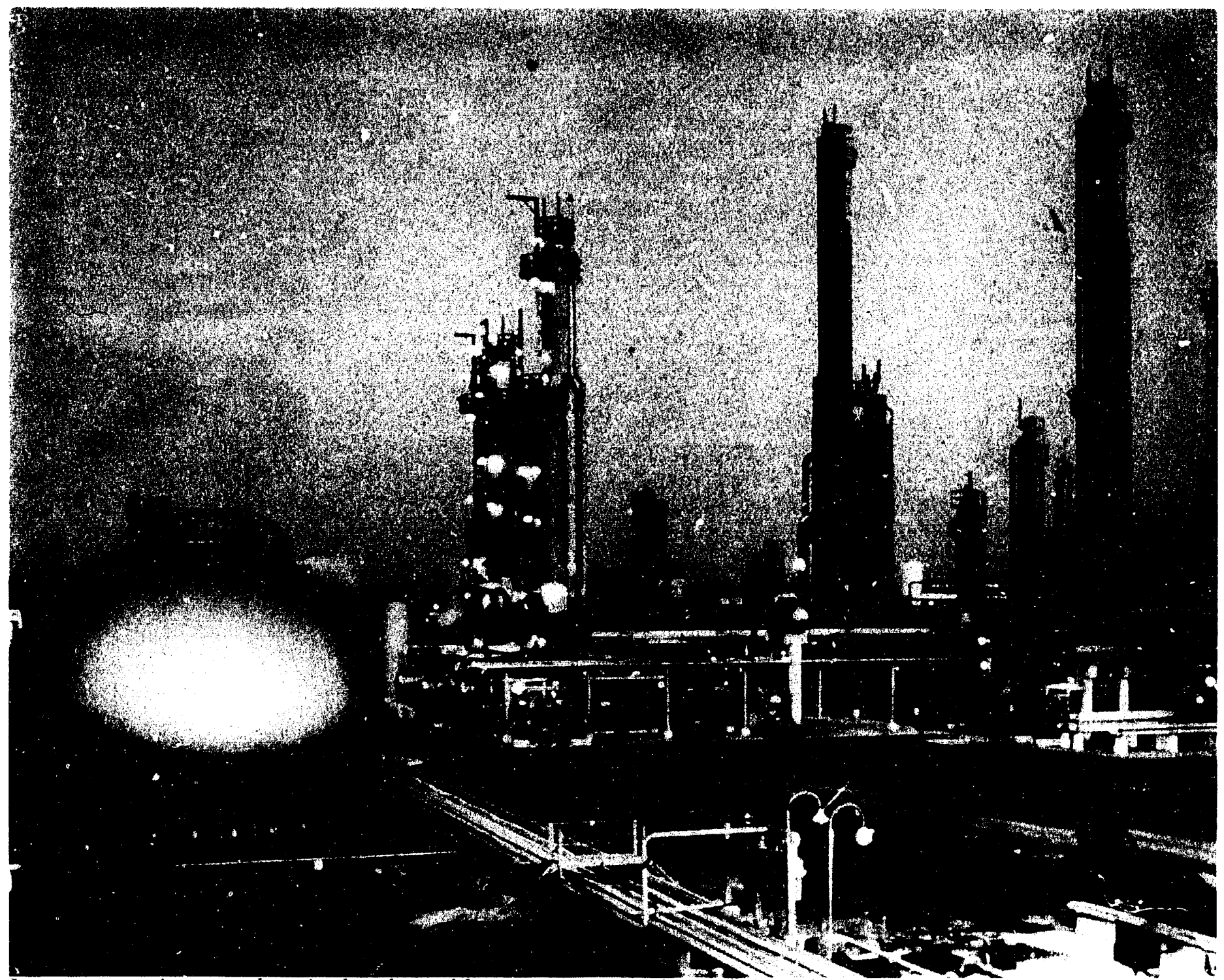

Low propane prices served to stimulate demand for propane at petrochemical plants this summer, which contributed to unusually low primary stocks at the end of August. 
Table H1. Petroleum Supply Summary

(Million Barrels per Day, Except Where Noted)

\begin{tabular}{|c|c|c|c|c|c|c|}
\hline \multirow{2}{*}{ Category } & \multicolumn{3}{|c|}{1991} & \multirow{2}{*}{1980} & \multicolumn{2}{|c|}{ January - August } \\
\hline & August & July & Difference ${ }^{a}$ & & 1991 & 1990 \\
\hline $\begin{array}{l}\text { Producte Supplled } \\
\text { Finished Motor Gasoline } \\
\text { Distillate Fuel Oil } \\
\text { Residual Fuel Oil } \\
\text { Liquefied Petroleum Gases } \\
\text { Other Petroleum Products } \\
\text { Crude Oil }\end{array}$ & $\begin{array}{r}17.1 \\
7.6 \\
2.8 \\
1.2 \\
1.6 \\
4.0 \\
\text { (s) }\end{array}$ & $\begin{array}{r}16.9 \\
7.6 \\
2.6 \\
1.1 \\
1.5 \\
4.0 \\
(\mathrm{~s})\end{array}$ & $\begin{array}{l}0.2 \\
\text { (s) } \\
0.1 \\
0.1 \\
(\mathrm{~s}) \\
(\mathrm{s}) \\
\text { (s) }\end{array}$ & $\begin{array}{r}18.1 \\
7.8 \\
3.2 \\
1.2 \\
1.5 \\
4.3 \\
\text { (s) }\end{array}$ & $\begin{array}{r}16.5 \\
7.2 \\
2.9 \\
1.2 \\
1.6 \\
3.6 \\
\text { (s) }\end{array}$ & $\begin{array}{r}17.2 \\
7.3 \\
3.1 \\
1.3 \\
1.5 \\
4.0 \\
\text { (s) }\end{array}$ \\
\hline Crude Oll Inputs & 13.8 & 13.7 & 0.1 & 14.1 & 13.3 & 13.5 \\
\hline Operating Cttllization Rete (percent) & 91.9 & 91.7 & 0.2 & $\mathbf{9 4 . 3}$ & 89.5 & 91.7 \\
\hline $\begin{array}{l}\text { Imports } \\
\text { Crude Oll } \\
\text { Strategic Petroleum Reserve } \\
\text { Other } \\
\text { Products } \\
\text { Finished Motor Gasoline } \\
\text { Distillate Fuel Oil } \\
\text { Residual Fuel Oil } \\
\text { Liquefied Petroleum Gases } \\
\text { Other Petroleum Products" }\end{array}$ & $\begin{array}{l}8.6 \\
6.7 \\
0.0 \\
6.7 \\
2.0 \\
0.4 \\
0.2 \\
0.6 \\
0.1 \\
0.7\end{array}$ & $\begin{array}{l}7.7 \\
5.9 \\
0.0 \\
5.9 \\
1.8 \\
0.2 \\
0.2 \\
0.4 \\
0.1 \\
0.8\end{array}$ & $\begin{array}{r}0.9 \\
0.7 \\
C .0 \\
0.7 \\
0.2 \\
0.2 \\
(s) \\
0.1 \\
(s) \\
-0.1\end{array}$ & $\begin{array}{l}8.6 \\
6.5 \\
0.1 \\
6.4 \\
2.2 \\
0.3 \\
0.3 \\
0.6 \\
0.3 \\
0.8\end{array}$ & $\begin{array}{l}7.6 \\
5.9 \\
0.0 \\
5.9 \\
1.8 \\
0.3 \\
0.2 \\
0.4 \\
0.1 \\
0.7\end{array}$ & $\begin{array}{l}8.6 \\
6.3 \\
(s) \\
6.2 \\
2.3 \\
0.4 \\
0.3 \\
0.6 \\
0.2 \\
0.8\end{array}$ \\
\hline $\begin{array}{l}\text { Exports } \\
\text { Crude Oil } \\
\text { Products }\end{array}$ & $\begin{array}{l}0.8 \\
0.1 \\
0.8\end{array}$ & $\begin{array}{l}1.0 \\
0.1 \\
0.8\end{array}$ & $\begin{array}{r}-0.1 \\
-0.1 \\
(\mathrm{~s})\end{array}$ & $\begin{array}{l}0.8 \\
0.1 \\
0.8\end{array}$ & $\begin{array}{l}1.0 \\
0.1 \\
0.9\end{array}$ & $\begin{array}{l}0.8 \\
0.1 \\
0.7\end{array}$ \\
\hline Total Not Imports & 7.8 & 6.8 & 1.0 & 7.8 & 6.6 & 7.8 \\
\hline $\begin{array}{l}\text { Stock Changec } \\
\text { Crude Oil } \\
\text { Products }\end{array}$ & $\begin{array}{l}0.4 \\
0.1 \\
0.3\end{array}$ & $\begin{array}{r}(8) \\
-0.2 \\
0.2\end{array}$ & $\begin{array}{l}0.3 \\
0.3 \\
0.1\end{array}$ & $\begin{array}{l}-0.3 \\
-0.2 \\
-0.1\end{array}$ & $\begin{array}{l}0.1 \\
(s) \\
0.1\end{array}$ & $\begin{array}{l}0.5 \\
0.2 \\
0.3\end{array}$ \\
\hline $\begin{array}{l}\text { Total Stocks at End of Perlod } \\
\text { (million barrels) }\end{array}$ & 1,645 & 1,634 & 11 & 1,699 & - & 一 \\
\hline $\begin{array}{l}\text { Crude Oll } \\
\text { Strategic Petroleum Reserve } \\
\text { Other }\end{array}$ & $\begin{array}{l}914 \\
569 \\
345\end{array}$ & $\begin{array}{l}911 \\
569 \\
343\end{array}$ & $\begin{array}{r}3 \\
(\mathbf{s}) \\
3\end{array}$ & $\begin{array}{l}959 \\
590 \\
370\end{array}$ & $\overline{-}$ & - \\
\hline $\begin{array}{l}\text { Products } \\
\text { Finished Motor Gasoline } \\
\text { Distillate Fuel Oil } \\
\text { Residual Fuel Oil } \\
\text { Liquefied Petroleum Gases } \\
\text { Other Petroleum Products }\end{array}$ & $\begin{array}{r}731 \\
171 \\
131 \\
46 \\
116 \\
268\end{array}$ & $\begin{array}{r}723 \\
171 \\
124 \\
43 \\
112 \\
272\end{array}$ & $\begin{array}{r}8 \\
(s) \\
6 \\
2 \\
5 \\
.5\end{array}$ & $\begin{array}{r}739 \\
172 \\
130 \\
49 \\
125 \\
264\end{array}$ & $\begin{array}{l}- \\
z \\
-\end{array}$ & $\begin{array}{l}- \\
\overline{-} \\
-\end{array}$ \\
\hline
\end{tabular}

Difference is equal to volume for current month minus volume for previous month.

Includes pentanes plus, other hydrocarbons and alcohol, unfinished oils, gasoline blending components, and all finished petroleum products except finished motor gasoline, distillate fuel oil, residual fuel oil, and liquefied petroleum gases.

c A negative number indicates a decrease in stocks and a positive number indicates an increase.

$(s)=$ Less than 0.05 miltion barrels per day, or less than 0.05 percent, or less than 0.5 million barrels.

Note: Totals may not equal sum of components due to independent rounding.

Source: Energy Information Administration, appropriate issues of Petroleum Supply Monthly, see Explanatory Note 5. 
Other August 1991 highlights include the following:

- Motor gasoline demand was unchanged, but lagged behind the comparable August 1990 and 1989 levels, affected by the continued slow economic recovery. Stocks of finished motor gasoline were also unchanged from the July level, and were below normal for August. Exports remained higher than normal.

- Effects of the attempted Soviet coup stimulated exports of distillate fuel oil, while imports remained low. Demand increased slightly, but was the lowest for August since 1987. The stock buildup continued, reaching the highest level for August since 1986.

- Residual fuel oil demand increased and was close to the year-earlier level for only the second time this year, as abnormally hot weather and continued improvement in industrial production stimulated demand.

- Stocks of liquefied petroleum gases (LPG's) increased at about half the normal rate for August. The summer buildup of propane stocks was unusually flat, leaving stocks even lower than in August 1990.

- The continuation of the relatively low world price of crude oil sent impcits, excluding the Strategic Petroleum Reserve (SPR), to the highest level since July 1990, the month before the Iraqi invasion of Kuwait.

- Refinery utilization increased slightly, but remained lower than the average rate for August in recent years.

\section{Motor Gasoline}

Motor gasoline demand of 7.6 million barrels per day was about the same as in July, but lagged behind the August 1990 and 1989 levels. During the last year monthly highway travel was either stagnant, growing less than 1 percent each month compared with the same month of the previous year, or it declined. ${ }^{1}$ Before the Persian Gulf crisis began last August, highway travel had grown at an average rate of 3 percent for several years. The economic recession that has prevailed since the third quarter of 1990 was an additional force that served to curb driving during this period.

Stocins of finished motor gasoline were unchanged in August at 171 million barrels. This was slightly below the year-earlier level, and well below the average for this time of year.

Exports of motor gasoline declined from the record high level recorded in July, but remained higher than normal. Exports to Mexico have increased significantly this year, and this trend continued in August. Refinery shutdowns in Mexico have reduced indigenous supplies of motor gasoline, and economic development in areas bordering the United States have increased Mexico's reliance on U.S. supplies.

\section{Distillate Fuel Oil}

Demand for distillate fuel oil increased slightly in August to 2.8 million barrels per day, but was at the lowest level for August since 1987, primarily due to the slow recovery in the industrial sector of the economy.

Imports continued to be low while exports were unusually high, as had been the trend for most of the last year. The attempted Soviet coup in August caused prices in Europe to escalate over concern that supplies from the Soviet Union would be disrupted. As a result, the comparatively low New York spot prici stimulated exports. Exports to Brazil also increased, as the Brazilian national oil company, Petrobras, built up supplies in anticipation of the oil workers' strike that began on September 11, 1991.

Despite continued high exports, stocks remained strong as the buildup for the winter heating season continued. The moderate increase to 131 million barrels brought stocks slightly higher than at the end of August 1990, and to the highest level for the end of August since 1986.

\section{Residual Fuel Oil}

The continuation of the slow improvement in industrial production and the persistence of warmer-than-normal temperatures in August provided the impetus for a moderate increase in demand for residual fuel oil. Demand increased to 1.2 million barrels per day and was about the same as in August 1990. The index of industrial production increased for the fifth consecutive month, although it was still 2 percent below the year-earlier level. August weather was considerably warmer than normal, especially in the East where most of the residual fuel oil electric generation capacity is located. Despite the positive impact of the improving economy and hot weather, more favorable natural gas prices continued to dampen residual fuel oil use at dual-fuel industrial plants and utilities.

\section{Liquefied Petroleum Gases}

Stocks of LPG's at the end of August increased at about half the normal rate for this time of year. Stocks reached 116 million barrels, well below the year-earlier level. Propane stocks are of special concern because the summer buildup in preparation for the winter heating season flattened out in July and August. The slight buildup from the previous month left propane stocks at the end of August even lower than during the same period of 1990 . The combination of relatively low imports in recent months and the collapse of natural gas prices contributed to the low propane stocks. The natural gas price collapse depressed propane prices as well, which stimulated demand for propane. Propane demand was higher this summer,

\footnotetext{
${ }^{1}$ U.S. Department of Transportation, Traffic Volume Trends, December 1990 and July 1991 issues, Table 1.
} 
primarily due to increased use as a petrochemical feedstock because of its attractive price relative to that of other feedstocks.

Approximately 90 percent of U.S. propane stocks are held in PAD Districts II and III. In August 1991, supplies were abundant in PAD District II but very low in PAD District III (Figure H1) where petrochemical plants are plentiful.

\section{Crude Oil}

Gross imports of crude oil (excluding the SPR) of 6.7 million barrels per day in August were the highest since July 1990, the month before the invasion of Kuwait. Import levels were at an 11 -year high last July because the world price of crude oil had fallen to about $\$ 13$ per barrel in June of that year. Although the world price this year was higher than in June 1990 , the relatively low price of about $\$ 17$ per barrel between Februpry and August revitalized imports in recent months.

\section{Refinery Utilization}

The operating utilization rate edged upward to 91.9 percent in August, which was well below the August level of recent years. Gross inputs (crude and other oils) to atmospheric crude oil distillation units also increased slightly to 14.0 million barrels per day. The operable utilization rate (which reflects the utilization rate if all idle capacity is included) increased slightly to 88.8 percent (Table H2).

\section{News Highlights}

\section{OPEC Agreement Sanctions Previous Production Levels}

At a meeting on September 24 and 25, 1991, in Geneva, Switzerland, oil ministers of the 13 Organization of Petroleum Exporting Countries (OPEC) agreed to increase their production ceiling to 23.65 million barrels per day during the fourth quarter of 1991, when oil use usually escalates. The new ceiling is an unofficial guideline rather than a formal production quota, with no limits set for individual members. The new production ceiling is more than 1 million barrels per
August Ending Stocks of Propane in Selected

Areas

(Million Barrels)

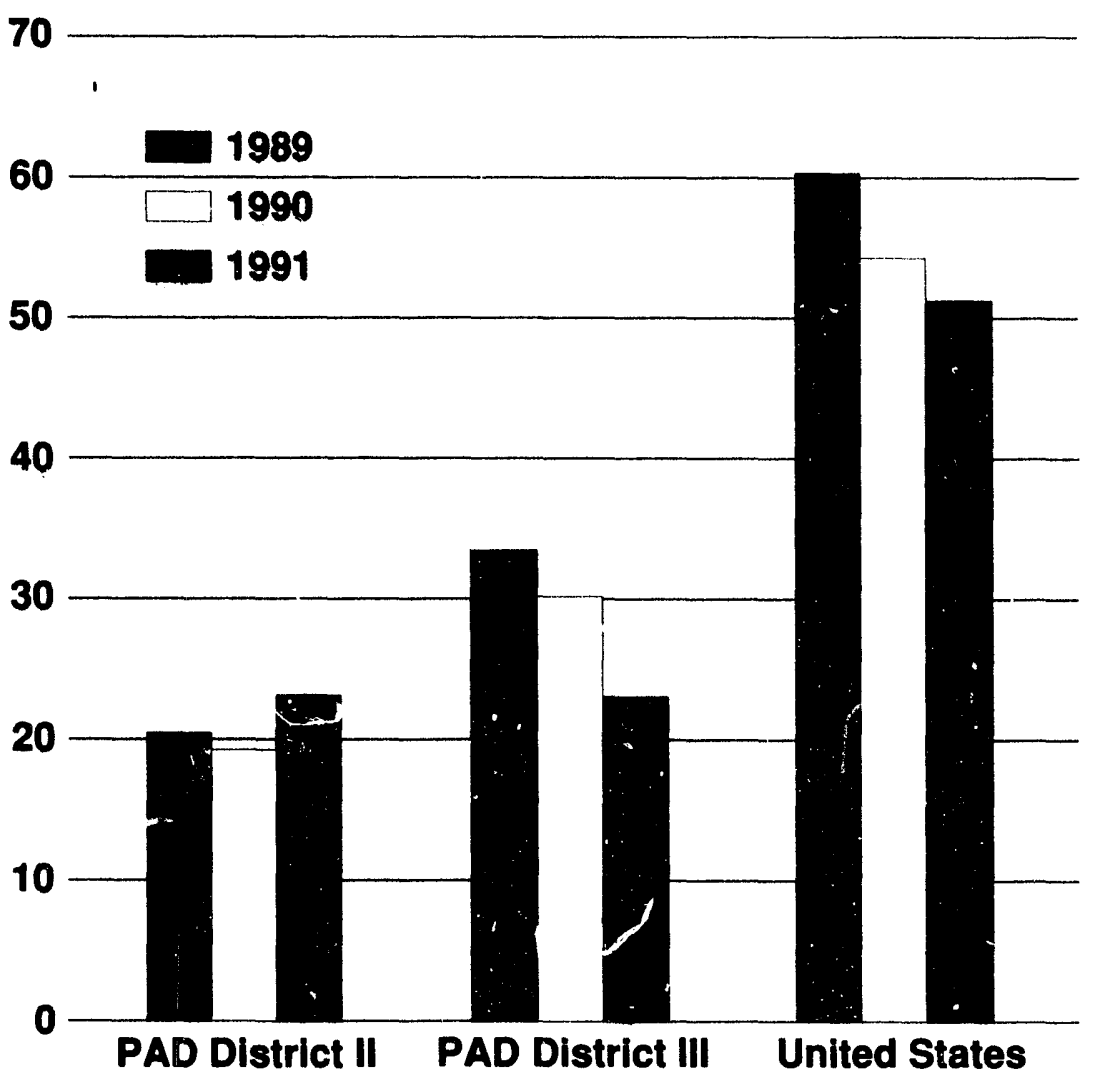

Source: Energy Infornation Administration, Petroleum Supply Annual, Volume 2, 1989 and 1990, Tables 2, 6, and 8; Petroleum Supply Monthly, August 1991 data issue, Tables 2, 10, and 14.

day higher than the ceiling under the latest official quota, which was established in July 1990 . The quota of 22.49 million barrels per day was temporarily set aside last August after the United Nations imposed an embargo on all oil originating in Iraq or Kuwait. The embargo is still in effect, with a large portion of the 4.3 million-barrel-per-day shortfall replaced by production from other OPEC members.

The new production ceiling is about equivalent to OPEC production levels in September 1991, and is intended to move the price of OPEC's "basket of seven reference crude oils"weighted average price-toward $\$ 21$ per barrel during the fourth quarter. The average price before the Geneva meeting was around $\$ 19$ per barrel.

When Iraq and Kuwait resume full-scale exports, OPEC expects to reinstate the July 1990 official production quota, apportioning production restraints among its members. Iraq is producing about 300,000 barrels per day but is capable of immediately producing 500,000 barrels per day and Kuwait, currently producing 250,000 barrels per day, is expected to 
Table H2. U.S. Refinery Inputs, Capacities and Utilization Rates: 1990-1991

(Thousand Barrels per Day, Except Where Noted)

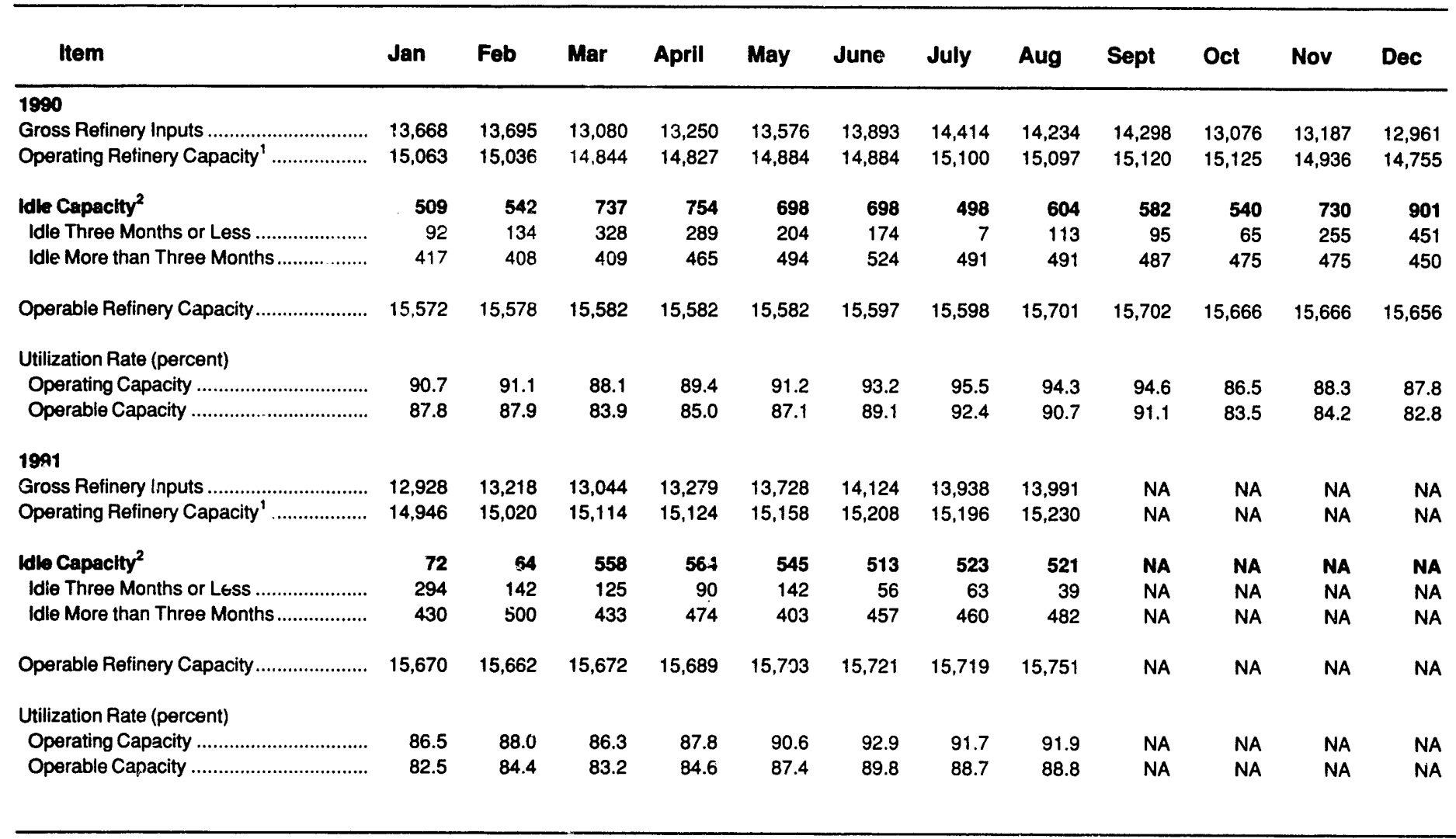

\footnotetext{
${ }^{1}$ Operating capacity equals the operable capacity less the total idle capacity.

${ }^{2}$ Idle capacity is the component of operable capacity that is not in operation and not under active repair, but is capable of being placed in operation within 30 days; and capacity not in operation tut is under active repair that can be completed within 90 days.

$\mathrm{NA}=$ Not Available.

Sources: Energy information Administration, Petroleum Supply Monthly, 1991 data issues, Table 28: Petroleum Supply Annual, Volume 2, 1990, Table 16; Form ElA. 810, "Monthly Refinery Report."
}

double production by the end of the year. ${ }^{2}$ Most of the current production from these two countries is needed domestically. Iraq and Kuwait together were producing 5 million barrels per day and were exporting about 4.3 million barrels per day before Iraq invaded Kuwait on August 2, 1990. At present, Iraq has not accepted the United Nations terms for resuming exports, and Kuwait is still repairing war damage to its oii production facilities. ${ }^{3}$

The next scheduled meeting of the OPEC ministers is the winter conference on November 26, 1991, in Geneva, Switzerland.

\section{Brazil Oil Workers' Strike Erıds}

The Brazilian oil workers' strike that began on September 11, 1991, came to an end after strike leaders recommended on
September 22 that they return to work. The workers had demanded a 370-percent pay increase to help counteract inflation, while Petrobras, the national oil company that oversees all petroleuin operations in Brazil, had offered an 80 -percent increase. The workers will get an average 100 -percent increase.

Exports of petroleum products were expected to resume within a week after the end of the strike. Brazil has traditionally exported motor gasoline and residual fuel oil to the United States.

Petrobras had stockpiled at least 2 weeks' supply of motor gasoline, distillate fuel oil, jet fuel, propane, and naphtha, ${ }^{5}$ and imported additional supplies during the strike to avoid shortages. ${ }^{6}$

\footnotetext{
2 "OPEC Agrees to Continue High Output Through End of Year," The Washington Post, September 26, 1991, p. A.25.

3 "OPEC Ceiling of 23.65 Million B/D Sanctions Current Output," The Oil Daily, Seriember 26, 1991, p. 8.

4 "Labor Walkout Comes to an End in Brazil," Oil and Gas Journal, September 30, 1991, p. 112.

${ }_{6}^{5}$ Bloomberg Oil Buyers' Guide, September 16, 1991, p. 5.

6 "Brazil Oil Products Slated for Export in Wake of Strike," The Oil Daily, September 25, 1991, p. 3.
} 


\section{Summary Statistics}

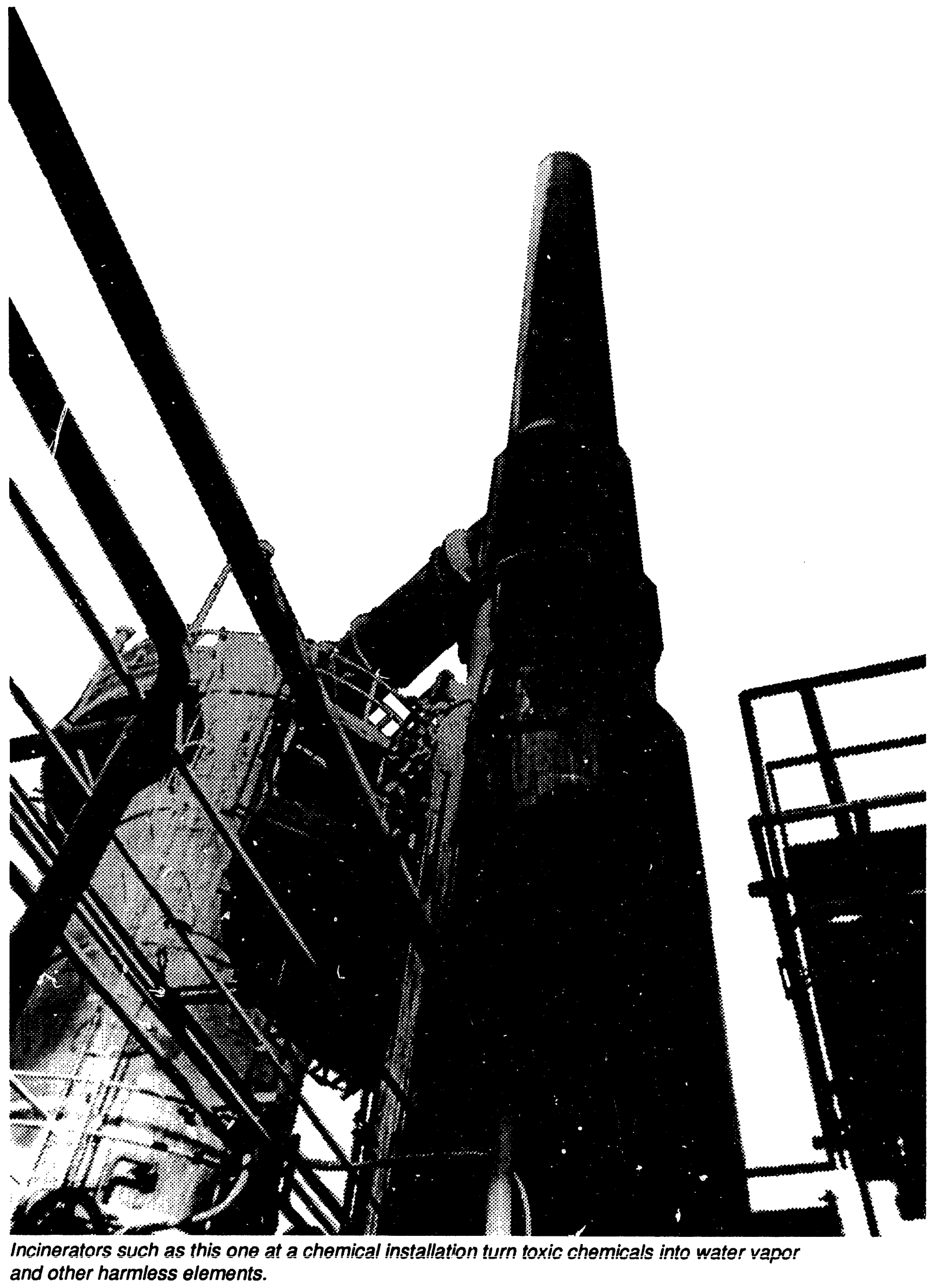


Table S1. Crude Oil ${ }^{\mathrm{a}}$ and Petroleum Products Overview, 1973 - Present

\begin{tabular}{|c|c|c|c|c|c|c|c|c|}
\hline & \multirow{3}{*}{ Year/Month } & \multicolumn{3}{|c|}{ Fleld Production } & \multicolumn{2}{|c|}{ Stock Change ${ }^{b}$} & \multirow[b]{2}{*}{$\begin{array}{l}\text { Petroloum } \\
\text { Products } \\
\text { Supplied }\end{array}$} & \multirow{2}{*}{$\begin{array}{c}\text { Ending Stocks }{ }^{\mathrm{c}} \\
\text { Crude Oil }{ }^{\mathrm{e}} \text { and } \\
\text { Petroleum } \\
\text { Products }\end{array}$} \\
\hline & & $\begin{array}{c}\text { Total } \\
\text { Domestlc }\end{array}$ & $\begin{array}{c}\text { Crude } \\
\text { Oll }\end{array}$ & $\begin{array}{l}\text { Natural } \\
\text { Gas Plant } \\
\text { Liquids }\end{array}$ & $\begin{array}{c}\text { Crude } \\
\text { OlI }^{\Theta}\end{array}$ & $\begin{array}{l}\text { Petroleum } \\
\text { Products }\end{array}$ & & \\
\hline & & \multicolumn{6}{|c|}{ Thousand Barrels per Day } & Million Barrels \\
\hline $\begin{array}{l}1973 \\
1974 \\
1975 \\
1976 \\
1977 \\
1978 \\
1979 \\
1980 \\
1981 \\
1982 \\
1983 \\
1984 \\
1985 \\
1986 \\
1987 \\
1988\end{array}$ & $\begin{array}{l}\text { Average } \\
\text { Average } \\
\text { Average }\end{array}$.................... & $\begin{array}{r}10,975 \\
10,498 \\
10,045 \\
9,774 \\
9,913 \\
10,328 \\
10,179 \\
10,214 \\
10,230 \\
10,252 \\
10,299 \\
10,554 \\
10,636 \\
10,289 \\
10,008 \\
9,818\end{array}$ & $\begin{array}{l}9,208 \\
8,774 \\
8,375 \\
8,132 \\
8,245 \\
8,707 \\
8,552 \\
8,597 \\
8,572 \\
8,649 \\
8,688 \\
8,879 \\
8,971 \\
8,680 \\
8,349 \\
8,140\end{array}$ & $\begin{array}{l}1,738 \\
1,688 \\
1,633 \\
1,603 \\
1,618 \\
1,567 \\
1,584 \\
1,573 \\
1,609 \\
1,550 \\
1,559 \\
1,630 \\
1,609 \\
1,551 \\
1,595 \\
1,625\end{array}$ & $\begin{array}{r}-11 \\
62 \\
\mathrm{~h} \\
17 \\
39 \\
170 \\
78 \\
148 \\
98 \\
\mathrm{~h} \\
290 \\
136 \\
\mathrm{~h} \\
214 \\
199 \\
50 \\
78 \\
128 \\
1\end{array}$ & $\begin{array}{r}146 \\
117 \\
h \\
15 \\
-96 \\
378 \\
-172 \\
25 \\
42 \\
h-130 \\
-283 \\
h-234 \\
81 \\
-153 \\
124 \\
-87 \\
-29\end{array}$ & $\begin{array}{l}17,308 \\
16,653 \\
16,322 \\
17,461 \\
18,431 \\
18,847 \\
18,513 \\
17,056 \\
16,058 \\
15,296 \\
15,231 \\
15,726 \\
15,726 \\
16,281 \\
16,665 \\
17,283\end{array}$ & 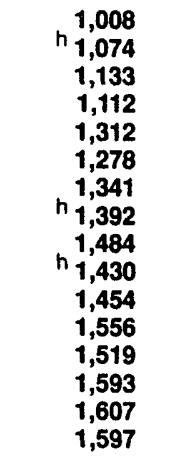 \\
\hline \multicolumn{2}{|c|}{ 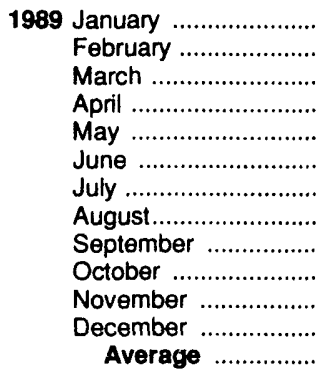 } & $\begin{array}{l}9,678 \\
9,441 \\
9,284 \\
9,501 \\
9,498 \\
9,188 \\
9,055 \\
9,106 \\
9,096 \\
8,983 \\
9,084 \\
8,734 \\
9,219\end{array}$ & $\begin{array}{l}7,937 \\
7,788 \\
7,575 \\
7,772 \\
7,816 \\
7,624 \\
7,444 \\
7,544 \\
7,548 \\
7,453 \\
7,536 \\
7,337 \\
7,613\end{array}$ & $\begin{array}{l}1,664 \\
1,607 \\
1,650 \\
1,674 \\
1,620 \\
1,507 \\
1,541 \\
1,504 \\
1,480 \\
1,478 \\
1,483 \\
1,343 \\
1,546\end{array}$ & $\begin{array}{r}179 \\
47 \\
-127 \\
494 \\
271 \\
-434 \\
148 \\
283 \\
-144 \\
73 \\
541 \\
-302 \\
86\end{array}$ & $\begin{array}{r}563 \\
-733 \\
-924 \\
413 \\
598 \\
-64 \\
1,182 \\
-104 \\
577 \\
-378 \\
-367 \\
-2,335 \\
-129\end{array}$ & $\begin{array}{l}17,269 \\
17,920 \\
17,989 \\
16,624 \\
16,546 \\
17,497 \\
16,453 \\
17,360 \\
16,795 \\
17,304 \\
17,311 \\
18,858 \\
17,325\end{array}$ & $\begin{array}{r}1,620 \\
1,601 \\
1,568 \\
1,596 \\
1,623 \\
1,608 \\
1,649 \\
1,654 \\
1,667 \\
1,658 \\
1,663 \\
1,581 \\
-\end{array}$ \\
\hline \multicolumn{2}{|c|}{ 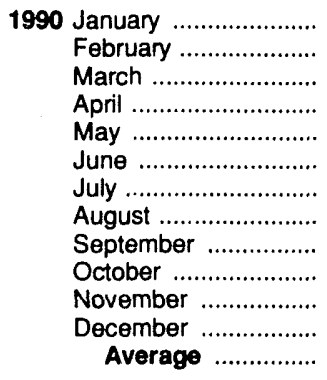 } & $\begin{array}{l}9,178 \\
9,147 \\
9,034 \\
8,979 \\
8,923 \\
8,645 \\
8,735 \\
8,931 \\
8,891 \\
9,301 \\
9,155 \\
9,019 \\
\mathbf{8 , 9 9 4}\end{array}$ & $\begin{array}{l}7,546 \\
7,497 \\
7,433 \\
7,407 \\
7,328 \\
7,106 \\
7,173 \\
7,287 \\
7,224 \\
7,542 \\
7,387 \\
7,338 \\
7,355\end{array}$ & $\begin{array}{l}1,541 \\
1,570 \\
1,526 \\
1,493 \\
1,502 \\
1,458 \\
1,484 \\
1,575 \\
1,597 \\
1,667 \\
1,690 \\
1,604 \\
1,559\end{array}$ & $\begin{array}{r}273 \\
-330 \\
1,057 \\
26 \\
479 \\
72 \\
-154 \\
-227 \\
-896 \\
111 \\
-364 \\
-528 \\
-35\end{array}$ & $\begin{array}{r}1,284 \\
507 \\
-823 \\
-83 \\
532 \\
378 \\
929 \\
-113 \\
887 \\
-879 \\
-322 \\
-544 \\
142\end{array}$ & $\begin{array}{l}16,964 \\
17,175 \\
17,087 \\
16,778 \\
16,915 \\
17,165 \\
17,084 \\
18,050 \\
16,512 \\
16,934 \\
16,695 \\
16,494 \\
16,988\end{array}$ & $\begin{array}{r}1,630 \\
1,635 \\
1,642 \\
1,640 \\
1,672 \\
1,685 \\
1,709 \\
1,699 \\
1,698 \\
1,674 \\
1,654 \\
1,621 \\
-\end{array}$ \\
\hline \multicolumn{2}{|c|}{ 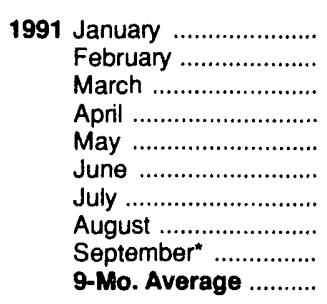 } & $\begin{array}{r}E_{9,135} \\
E_{9,334} \\
E_{9,225} \\
E_{9,206} \\
E_{9,116} \\
E_{9,976} \\
R E_{8,972} \\
P E_{8,993} \\
P E_{9,106}\end{array}$ & $\begin{array}{r}\text { E } 7,418 \\
\text { E } 7,548 \\
\text { E } 7,481 \\
\text { E } 7,467 \\
\text { E } 7,368 \\
\text { E } 7,282 \\
\text { E } 7,326 \\
\text { RE } 7,272 \\
\text { PE } 7,301 \\
\text { PE } 7,383\end{array}$ & $\begin{array}{r}1,635 \\
1,690 \\
1,670 \\
1,656 \\
1,647 \\
1,616 \\
1,608 \\
R_{1,617} \\
E_{1,613} \\
E_{1,639}\end{array}$ & $\begin{array}{r}-94 \\
250 \\
-242 \\
65 \\
638 \\
-364 \\
-163 \\
R_{91} \\
E_{-313} \\
E_{-15}\end{array}$ & $\begin{array}{r}-1,094 \\
-688 \\
-261 \\
560 \\
986 \\
551 \\
174 \\
R_{265} \\
E_{406} \\
E_{104}\end{array}$ & $\begin{array}{r}16,882 \\
16,284 \\
16,100 \\
16,103 \\
16,098 \\
16,764 \\
16,910 \\
R_{17,133} \\
E_{16,906} \\
16,579\end{array}$ & $\begin{array}{r}1,587 \\
1,574 \\
1,559 \\
1,578 \\
1,628 \\
1,634 \\
1,634 \\
\text { E } 1,645 \\
1,666 \\
-\end{array}$ \\
\hline \multicolumn{2}{|c|}{$\begin{array}{l}1990 \text { 9-Mo. Average ........... } \\
1989 \text { 9-Mo. Average .......... }\end{array}$} & $\begin{array}{l}8,939 \\
9,316\end{array}$ & $\begin{array}{l}7,333 \\
7,671\end{array}$ & $\begin{array}{l}1,527 \\
1,583\end{array}$ & $\begin{array}{l}41 \\
81\end{array}$ & $\begin{array}{l}387 \\
176\end{array}$ & $\begin{array}{l}17,083 \\
17,155\end{array}$ & - \\
\hline
\end{tabular}

a Includes lease condensate.

b A negative number indicates a decrease in stocks and a positive number indicates an increase.

c Stocks are totals as of end of period.

I Inciudes crude oil, natural gas plant liquids, other hydrocarbons, and alcohol.

- Includes stocks located in the Strategic Petroleum Reserve.

Includes crude oil for storage in the Strategic Petroleum Reserve.

9 Net Imports equal Imports minus Exports.

h in January 1975,1981 , and 1983 , numerous respondents were added to surveys affecting stocks reported and stock change calculations.

See Summary Statistics Explanatory Note 4.

Footnotes continued on following page. 
Table S1. Crude Oil ${ }^{\mathrm{a}}$ and Petroleum Products Overview, 1973 - Present (Continued)

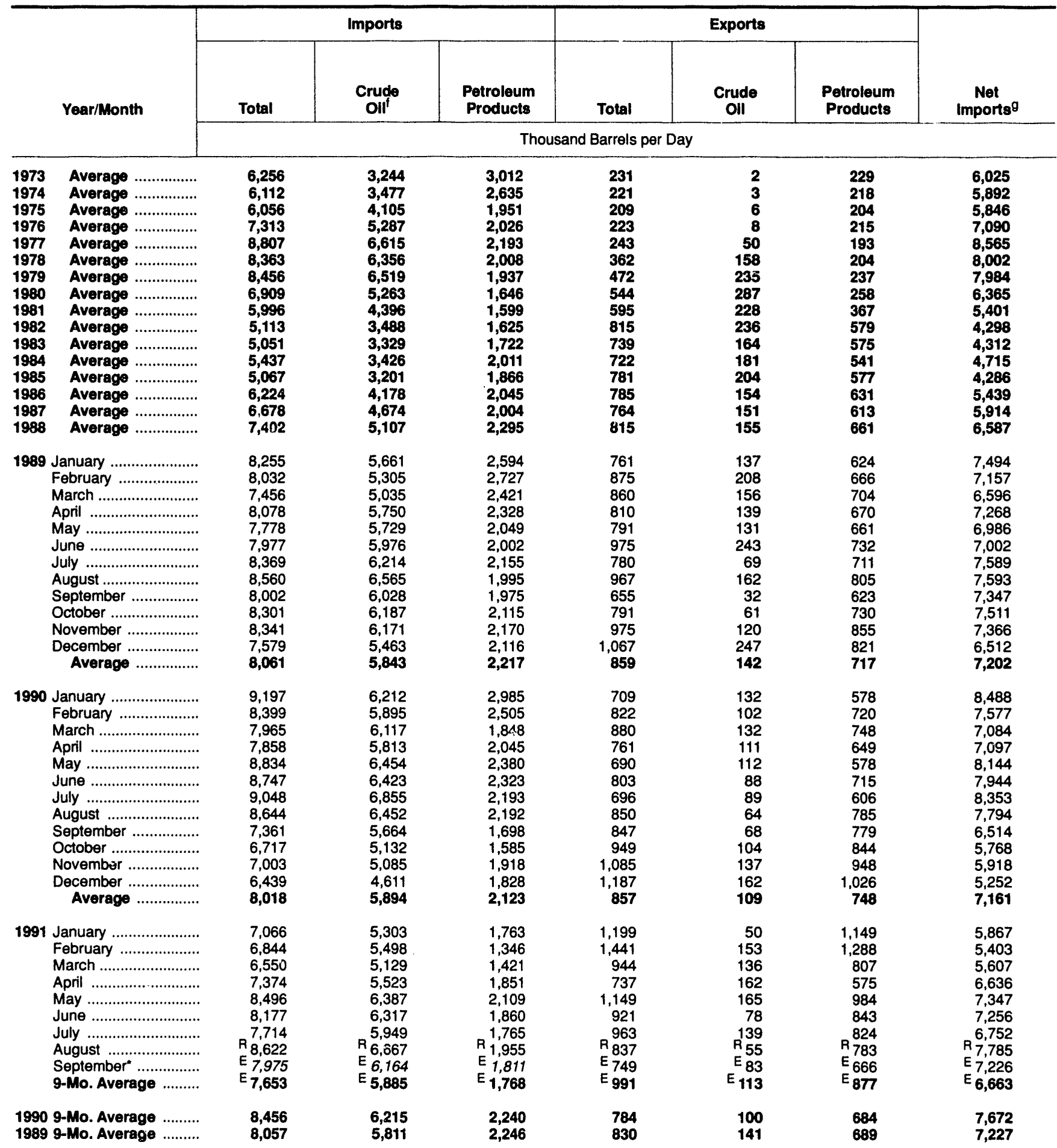

Footnotes continued.

$R=$ Revised data. $E=$ Estimated. $P E=$ Preliminary estimate. $R E=$ Revised estimate.

- See Summary Statistics Explanatory Note 1.

Notes: - Italics denote estimates based upon preliminary data. - Geographic coverage is the 50 States and the District of Columbia. - Totals may not equal sum of components due to independent rounding.

Source: See Summary Statistics Table and Figure Sources. 
25,000

Net Petroleum Products Imports

${ }^{0}$ Aug Sep $\begin{gathered}\text { Oct } \\ 1990\end{gathered}$ Nov Dec Jan Feb Mar Apr $\underset{1991}{\text { May Jun Jul Aug Sep }}{ }^{0}$

Source: Energy Information Administration, Petroleum Supply Monthly, Table S1. See Summary Statistics Table and Figure Sources.

Figure S2. Petroleum Products Supplied, August 1990 - Present

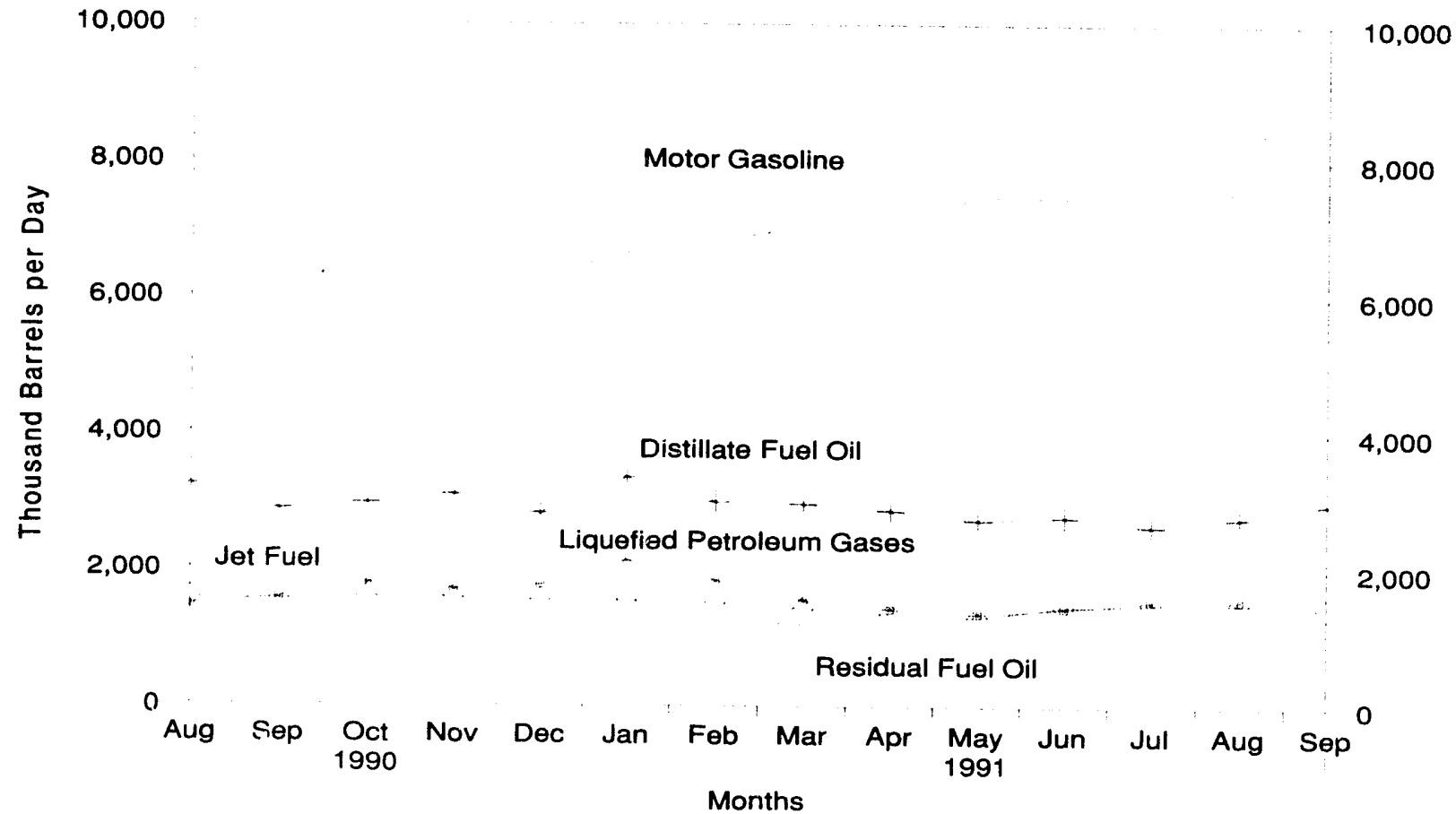

Source: Energy Information Administration, Petroleum Supply Monthly, Tables S4-S8. See Summary Statistics Table and Figure Sources. 
Figure S3. Crude OIl Supply and Disposition, August 1990 - Present

17,500

17,500

15,000

Refinery Inputs

15,000

12,500

12,500

10,000

10,000

Domestic Crude Oil Production

Net Imports (excludes SPR)

2,500

O

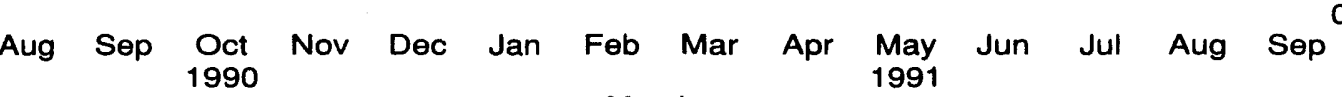

Months

Source: Energy Information Administration, Petroleum Supply Monthly, Table S2. See Summary Statistics Table and Figure Sources.

Figure S4. Crude Oil Ending Stocks', August 1990 - Present

450

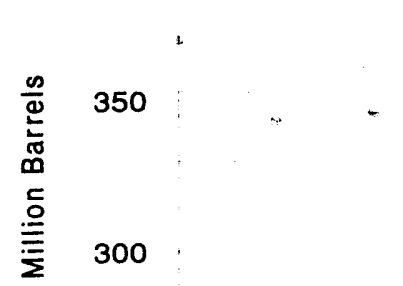

Average Stock Range (excludes SPR)

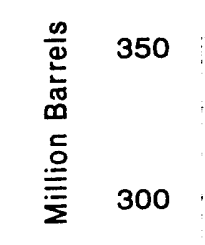
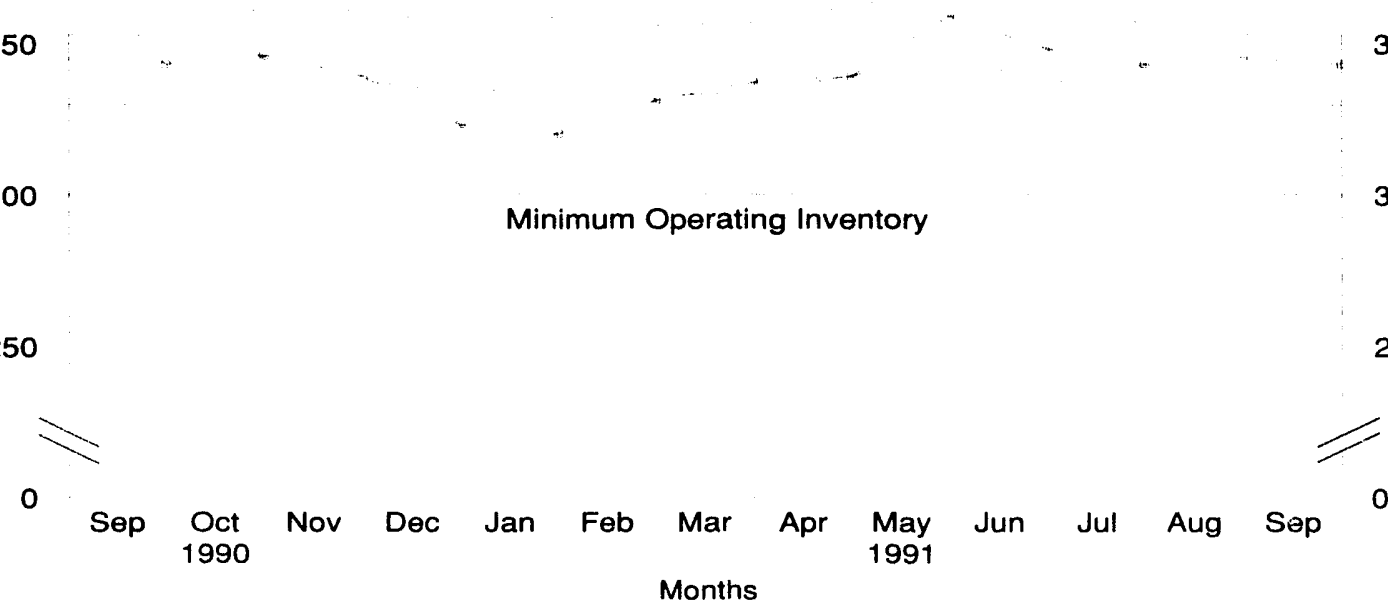

${ }^{1}$ Excludes stocks held in the Strategic Petroleum Reserve (SPR).

Note: The National Petroleum Council (NPC) defines the Minimum Operating Inventory as the inventory level below which operating problems and shortages vould begin to appear in a defined distribution system. In its 1988 study, the NPC estimated this inventory level for crude oil to be 300 million barrels.

Source: Energy Information Administration, Petroleum Supply Monthly, Table S2. See Summary Statistics Table and Figure Sources. 
Table S2. Crude OII ${ }^{\mathrm{a}}$ Supply and Disposition, 1973 - Present

\begin{tabular}{|c|c|c|c|c|c|c|c|c|c|}
\hline & \multirow{4}{*}{ Year/Month } & \multicolumn{7}{|c|}{ Supply } & \multirow{3}{*}{$\begin{array}{c}\text { Disposition } \\
\text { Crude } \\
\text { Losses }\end{array}$} \\
\hline & & \multicolumn{2}{|c|}{ Fleld Production } & \multicolumn{3}{|c|}{ Imports } & \multirow[b]{2}{*}{$\begin{array}{l}\text { Unaccounted } \\
\text { for Crude } \\
\text { olld }\end{array}$} & \multirow[b]{2}{*}{$\begin{array}{c}\text { Crude } \\
\text { Used } \\
\text { Directlyo }\end{array}$} & \\
\hline & & $\begin{array}{c}\text { Total } \\
\text { Domestic }\end{array}$ & Alaskan & Total & SPA & Other & & & \\
\hline & & \multicolumn{8}{|c|}{ Thousand Barrels per Day } \\
\hline $\begin{array}{l}1973 \\
1974 \\
1975 \\
1976 \\
1977 \\
1978 \\
1979 \\
1980 \\
1981 \\
1982 \\
1983 \\
1984 \\
1985 \\
1986 \\
1987 \\
1988\end{array}$ & $\begin{array}{c}\text { Average } \\
\text { Average }\end{array}$............... & $\begin{array}{l}9,208 \\
8,774 \\
8,375 \\
8,132 \\
8,245 \\
8,707 \\
8,552 \\
8,597 \\
8,572 \\
8,649 \\
8,688 \\
8,879 \\
8,971 \\
8,680 \\
8,349 \\
8,140\end{array}$ & $\begin{array}{r}198 \\
193 \\
191 \\
173 \\
464 \\
1,229 \\
1,401 \\
1,617 \\
1,609 \\
1,696 \\
1,714 \\
1,722 \\
1,825 \\
1,867 \\
1,962 \\
2,017 \\
\end{array}$ & $\begin{array}{l}3,244 \\
3,477 \\
4,105 \\
\mathbf{5 , 2 8 7} \\
\mathbf{6 , 6 1 5} \\
\mathbf{6 , 3 5 6} \\
\mathbf{6 , 5 1 9} \\
\mathbf{5 , 2 6 3} \\
\mathbf{4 , 3 9 6} \\
\mathbf{3 , 4 8 8} \\
\mathbf{3 , 3 2 9} \\
\mathbf{3 , 4 2 6} \\
\mathbf{3 , 2 0 1} \\
\mathbf{4 , 1 7 8} \\
\mathbf{4 , 6 7 4} \\
\mathbf{5 , 1 0 7}\end{array}$ & $\begin{array}{r}\bar{Z} \\
\bar{z} \\
21 \\
162 \\
67 \\
44 \\
256 \\
165 \\
234 \\
197 \\
118 \\
48 \\
73 \\
51\end{array}$ & $\begin{array}{l}3,244 \\
3,477 \\
4,105 \\
5,287 \\
6,594 \\
6,195 \\
6,452 \\
5,219 \\
4,141 \\
3,323 \\
3,096 \\
3,229 \\
3,083 \\
4,130 \\
4,601 \\
5,055\end{array}$ & $\begin{array}{r}3 \\
-25 \\
17 \\
77 \\
-6 \\
-57 \\
-11 \\
34 \\
83 \\
71 \\
114 \\
185 \\
145 \\
139 \\
145 \\
196\end{array}$ & $\begin{array}{l}-19 \\
-15 \\
-17 \\
-18 \\
-14 \\
-14 \\
-13 \\
-13 \\
-58 \\
-59 \\
= \\
= \\
= \\
=\end{array}$ & $\begin{array}{r}13 \\
13 \\
13 \\
15 \\
16 \\
16 \\
16 \\
15 \\
5 \\
3 \\
2 \\
2 \\
1 \\
(8) \\
(8) \\
(8)\end{array}$ \\
\hline 1989 & 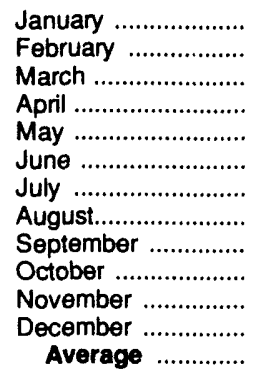 & $\begin{array}{l}7,937 \\
7,788 \\
7,575 \\
7,772 \\
7,816 \\
7,624 \\
7,444 \\
7,544 \\
7,548 \\
7,453 \\
7,536 \\
7,337 \\
7,613\end{array}$ & $\begin{array}{l}1,958 \\
1,962 \\
1,686 \\
1,890 \\
1,973 \\
1,861 \\
1,725 \\
1,870 \\
1,875 \\
1,877 \\
1,915 \\
1,904 \\
1,874\end{array}$ & $\begin{array}{l}\mathbf{5 , 6 6 1} \\
\mathbf{5 , 3 0 5} \\
\mathbf{5 , 0 3 5} \\
\mathbf{5 , 7 5 0} \\
\mathbf{5 , 7 2 9} \\
\mathbf{5 , 9 7 6} \\
\mathbf{6 , 2 1 4} \\
\mathbf{6 , 5 6 5} \\
\mathbf{6 , 0 2 8} \\
\mathbf{6 , 1 8 7} \\
\mathbf{6 , 1 7 1} \\
\mathbf{5 , 4 6 3} \\
\mathbf{5 , 8 4 3}\end{array}$ & $\begin{array}{l}65 \\
84 \\
75 \\
59 \\
77 \\
55 \\
75 \\
32 \\
59 \\
37 \\
41 \\
12 \\
56\end{array}$ & $\begin{array}{l}\mathbf{5 , 5 9 6} \\
\mathbf{5 , 2 2 1} \\
4,960 \\
\mathbf{5 , 6 9 0} \\
\mathbf{5 , 6 5 2} \\
\mathbf{5 , 9 2 0} \\
\mathbf{6 , 1 3 9} \\
\mathbf{6 , 5 3 3} \\
\mathbf{5 , 9 6 9} \\
\mathbf{6 , 1 4 9} \\
\mathbf{6 , 1 3 1} \\
\mathbf{5 , 4 5 2} \\
\mathbf{5 , 7 8 7}\end{array}$ & $\begin{array}{r}94 \\
-26 \\
426 \\
91 \\
280 \\
135 \\
426 \\
213 \\
121 \\
-125 \\
397 \\
343 \\
200\end{array}$ & $\begin{array}{l}\bar{z} \\
\bar{z} \\
\bar{z} \\
\bar{z} \\
\bar{z} \\
\bar{z}\end{array}$ & $\begin{array}{l}\text { (s) } \\
\text { (s) } \\
\text { (s) } \\
(\mathbf{s}) \\
(\mathbf{s}) \\
(\mathbf{s}) \\
(\mathbf{s}) \\
(\mathbf{s}) \\
1 \\
0 \\
(\mathbf{s}) \\
(\mathbf{s}) \\
\text { (8) }\end{array}$ \\
\hline 1990 & 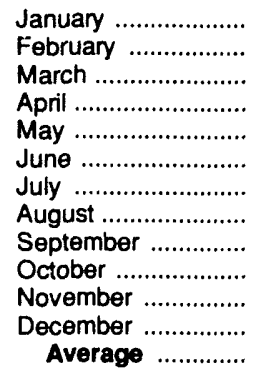 & $\begin{array}{l}7,546 \\
7,497 \\
7,433 \\
7,407 \\
7,328 \\
7,106 \\
7,173 \\
7,287 \\
7,224 \\
7,542 \\
7,387 \\
7,338 \\
7,355\end{array}$ & $\begin{array}{l}1,864 \\
1,834 \\
1,819 \\
1,802 \\
1,765 \\
1,612 \\
1,687 \\
1,727 \\
1,702 \\
1,884 \\
1,746 \\
1,838 \\
1,773\end{array}$ & $\begin{array}{l}6,212 \\
5,895 \\
6,117 \\
5,813 \\
6,454 \\
6,423 \\
6,855 \\
6,452 \\
5,664 \\
5,132 \\
5,085 \\
4,611 \\
\mathbf{5 , 8 9 4}\end{array}$ & $\begin{array}{r}24 \\
12 \\
44 \\
38 \\
89 \\
17 \\
0 \\
95 \\
0 \\
0 \\
0 \\
0 \\
27\end{array}$ & $\begin{array}{l}6,188 \\
5,883 \\
6,073 \\
5,775 \\
6,365 \\
6,407 \\
6,855 \\
6,357 \\
5,664 \\
5,132 \\
5,085 \\
4,611 \\
5,867\end{array}$ & $\begin{array}{r}178 \\
-98 \\
540 \\
-9 \\
225 \\
349 \\
150 \\
259 \\
402 \\
382 \\
269 \\
409 \\
258\end{array}$ & $\begin{array}{l}\bar{z} \\
\bar{z} \\
\bar{z} \\
\bar{z} \\
\bar{z} \\
\bar{z} \\
=\end{array}$ & $\begin{array}{r}\text { (s) } \\
0 \\
0 \\
(s) \\
0 \\
(s) \\
0 \\
(s) \\
(s) \\
(s) \\
(s) \\
(s) \\
(s)\end{array}$ \\
\hline 1991 & 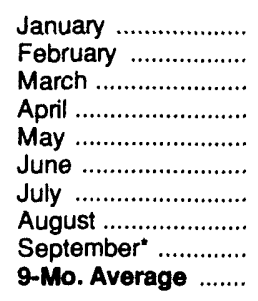 & $\begin{array}{r}E_{7,418} \\
E_{7,548} \\
E_{7,481} \\
E_{7,467} \\
E_{7,368} \\
E_{7,282} \\
E_{7,326} \\
\text { RE } 7,272 \\
P E_{7,301} \\
P E_{7,383}\end{array}$ & $\begin{array}{r}E_{1,848} \\
E_{1,908} \\
E_{1,887} \\
E_{1,798} \\
E_{1,771} \\
E_{1,757} \\
E_{1,775} \\
R E_{1,731} \\
P E_{1,783} \\
P E_{1,805}\end{array}$ & $\begin{array}{r}\mathbf{5 , 3 0 3} \\
\mathbf{5 , 4 9 8} \\
\mathbf{5 , 1 2 9} \\
\mathbf{5 , 5 2 3} \\
\mathbf{6 , 3 8 7} \\
\mathbf{6 , 3 1 7} \\
\mathbf{5 , 9 4 9} \\
\mathrm{A}_{6,667} \\
\mathrm{E}_{6,164} \\
\mathrm{E} \mathbf{5 , 8 8 5}\end{array}$ & $\begin{array}{l}0 \\
0 \\
0 \\
0 \\
0 \\
0 \\
0 \\
0 \\
\mathrm{E}_{0}^{0} \\
\mathrm{E}_{0}\end{array}$ & $\begin{array}{r}5,303 \\
5,498 \\
5,129 \\
5,523 \\
6,387 \\
6,317 \\
5,949 \\
R_{6,667} \\
E_{6,164} \\
E_{5,885}\end{array}$ & $\begin{array}{r}-14 \\
424 \\
134 \\
294 \\
596 \\
47 \\
418 \\
R_{8} \\
E_{105} \\
E_{222}\end{array}$ & $\begin{array}{l}\bar{z} \\
\bar{z} \\
\bar{z} \\
\bar{z} \\
-\end{array}$ & $\begin{array}{r}0 \\
0 \\
(\mathbf{s}) \\
(\mathbf{s}) \\
(\mathbf{s}) \\
(\mathbf{s}) \\
0 \\
\mathrm{R}_{0} \\
\mathrm{E}_{(\mathbf{s})} \\
\mathrm{E}(\mathbf{s )}\end{array}$ \\
\hline $\begin{array}{l}1990 \\
1989\end{array}$ & $\begin{array}{l}\text { 9-Mo. Average ....... } \\
\text { 9-Mo. Average ....... }\end{array}$ & $\begin{array}{l}7,333 \\
7,671\end{array}$ & $\begin{array}{l}1,757 \\
1,866\end{array}$ & $\begin{array}{l}6,215 \\
5,811\end{array}$ & $\begin{array}{l}36 \\
65\end{array}$ & $\begin{array}{l}6,180 \\
5,747\end{array}$ & $\begin{array}{l}225 \\
199\end{array}$ & - & $\begin{array}{l}\text { (s) } \\
\text { (s) }\end{array}$ \\
\hline
\end{tabular}

a Includes lease condensate.

b Stocks are totals as of end of period.

c A negative number indicates a decrease in stocks and a positive number indicates an increase.

d Unaccounted for crude oil represents the difference between the supply and disposition of crude oil. Preliminary estimates of crude oil imports at the National level have historically understated final values by approximately 50 thousand barrels per day. This causes the preliminary values of unaccounted for crude oil to overstate the final values by the same amount.

Beginning in January 1983, crude oil used directly as fuel is shown as product supplied.

Stocks of Alaskan crude oil in transit were included beginning in January 1981. Stock changes are calculated using new basis stock levels. See Summary Statistics Explanatory Note 4.

Footnotes continued on following page. 
Table S2. Crude OII ${ }^{\mathrm{a}}$ Supply and Disposition, 1973 - Present (Continued)

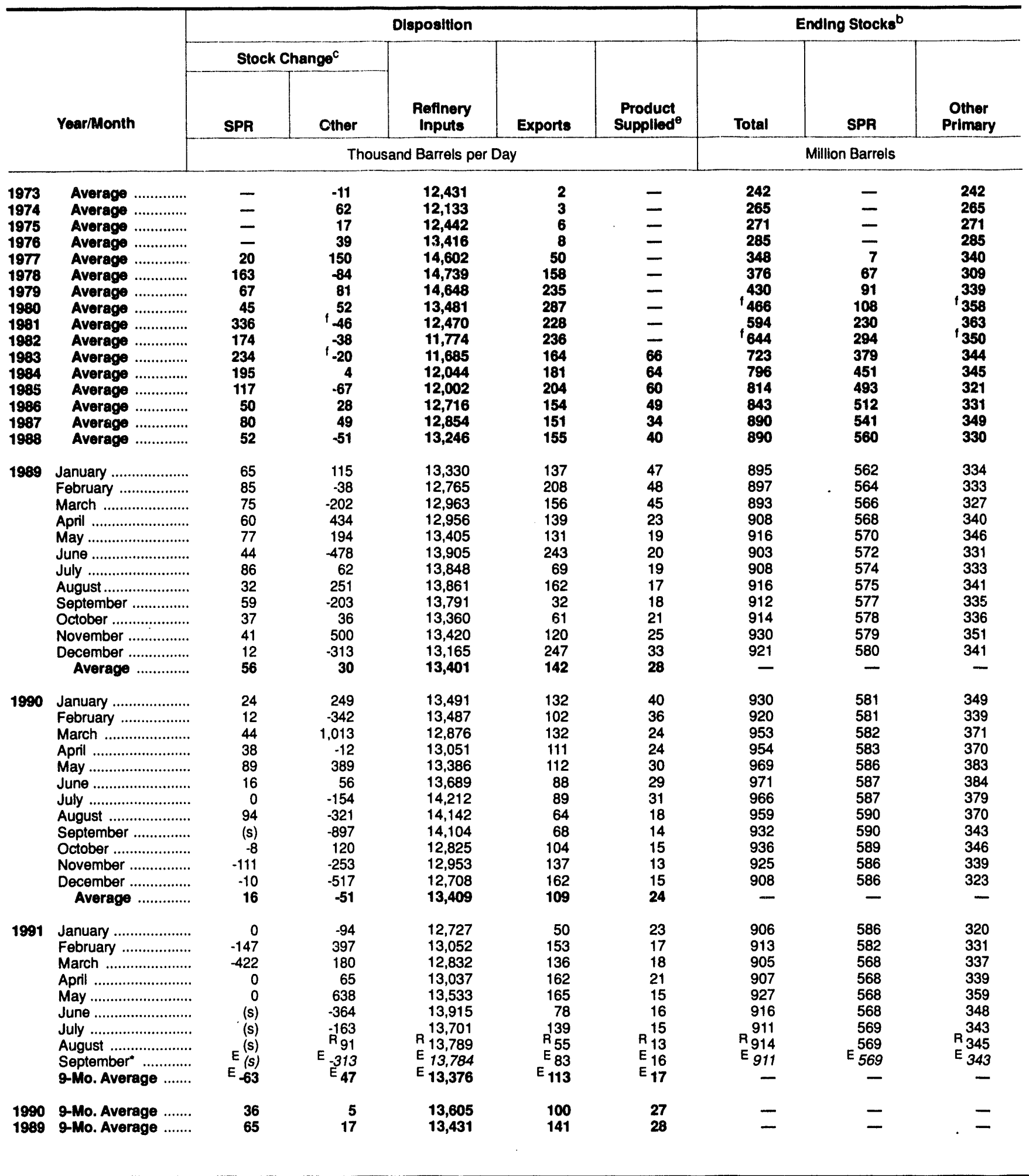

Footnotes continued.

$R=$ Revised data. $(s)=$ Less than 500 barrels per day. $E=$ Estimated. $P E=$ Preliminary estimate. RE $=$ Revised estimate.

SPR = Strategic Petroleum Reserve.

- See Summary Statistics Explanatory Note 1.

Notes: - Italics denote estimates based upon preliminary data. - Geographic coverage is the 50 States and the District of Columbia. - Totals may not equal sum of components due to independent rounding.

Source: See Summary Statistics Table and Figure Sources. 
Table S3. Crude Oll and Petroleum Product Imports, 1973 - Present

\begin{tabular}{|c|c|c|c|c|c|c|c|c|c|}
\hline & \multirow{4}{*}{ Year/Month } & \multicolumn{8}{|c|}{ Imports from Arab-OPEC Sources } \\
\hline & & \multicolumn{2}{|c|}{ Algeria } & \multicolumn{2}{|c|}{ Iraq } & \multicolumn{2}{|c|}{ Kuwait } & \multicolumn{2}{|c|}{ Libya } \\
\hline & & Total & Crude OII & Total & Crude OII & Total & Crude OII & Total & Crude OII \\
\hline & & \multicolumn{8}{|c|}{ Thousand Barrels per Day } \\
\hline $\begin{array}{l}1973 \\
1974 \\
1975 \\
1976 \\
1977 \\
1978 \\
1979 \\
1980 \\
1981 \\
1982 \\
1983 \\
1984 \\
1985 \\
1986 \\
1987 \\
1988\end{array}$ & $\begin{array}{l}\text { Average } \\
\text { Average }\end{array}$........... & $\begin{array}{l}136 \\
190 \\
282 \\
432 \\
559 \\
649 \\
636 \\
488 \\
311 \\
170 \\
240 \\
323 \\
187 \\
271 \\
295 \\
300\end{array}$ & $\begin{array}{r}120 \\
180 \\
264 \\
408 \\
544 \\
634 \\
608 \\
456 \\
261 \\
90 \\
176 \\
194 \\
84 \\
78 \\
115 \\
58\end{array}$ & $\begin{array}{r}4 \\
0 \\
2 \\
26 \\
74 \\
62 \\
88 \\
28 \\
(8) \\
3 \\
10 \\
12 \\
46 \\
81 \\
83 \\
345\end{array}$ & $\begin{array}{r}4 \\
0 \\
2 \\
26 \\
74 \\
62 \\
88 \\
28 \\
0 \\
3 \\
10 \\
12 \\
46 \\
81 \\
82 \\
343\end{array}$ & $\begin{array}{r}47 \\
5 \\
16 \\
5 \\
48 \\
6 \\
8 \\
27 \\
0 \\
5 \\
14 \\
36 \\
21 \\
68 \\
84 \\
92\end{array}$ & $\begin{array}{r}42 \\
5 \\
4 \\
1 \\
42 \\
5 \\
5 \\
27 \\
0 \\
2 \\
7 \\
24 \\
4 \\
28 \\
70 \\
80\end{array}$ & $\begin{array}{r}164 \\
4 \\
232 \\
453 \\
723 \\
654 \\
658 \\
554 \\
319 \\
26 \\
0 \\
1 \\
4 \\
0 \\
0 \\
0\end{array}$ & $\begin{array}{r}133 \\
4 \\
223 \\
444 \\
704 \\
638 \\
642 \\
548 \\
317 \\
23 \\
0 \\
0 \\
0 \\
0 \\
0 \\
0\end{array}$ \\
\hline 1989 & 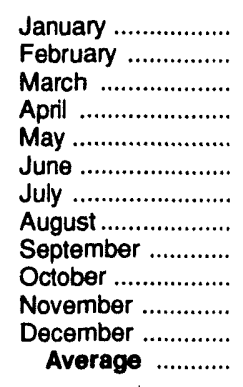 & $\begin{array}{l}335 \\
310 \\
272 \\
235 \\
272 \\
205 \\
263 \\
216 \\
256 \\
250 \\
323 \\
288 \\
269\end{array}$ & $\begin{array}{l}93 \\
62 \\
40 \\
75 \\
34 \\
30 \\
43 \\
77 \\
58 \\
74 \\
71 \\
60 \\
60\end{array}$ & $\begin{array}{l}345 \\
430 \\
361 \\
555 \\
424 \\
384 \\
530 \\
528 \\
513 \\
509 \\
443 \\
372 \\
449\end{array}$ & $\begin{array}{l}345 \\
430 \\
361 \\
526 \\
402 \\
384 \\
530 \\
517 \\
498 \\
495 \\
442 \\
367 \\
441\end{array}$ & $\begin{array}{r}32 \\
79 \\
0 \\
0 \\
64 \\
309 \\
334 \\
348 \\
271 \\
191 \\
148 \\
105 \\
157\end{array}$ & $\begin{array}{r}32 \\
79 \\
0 \\
0 \\
64 \\
303 \\
314 \\
348 \\
271 \\
191 \\
148 \\
105 \\
155\end{array}$ & $\begin{array}{l}0 \\
0 \\
0 \\
0 \\
0 \\
0 \\
0 \\
0 \\
0 \\
0 \\
0 \\
0 \\
0\end{array}$ & $\begin{array}{l}0 \\
0 \\
0 \\
0 \\
0 \\
0 \\
0 \\
0 \\
0 \\
0 \\
0 \\
0 \\
0\end{array}$ \\
\hline 1990 & 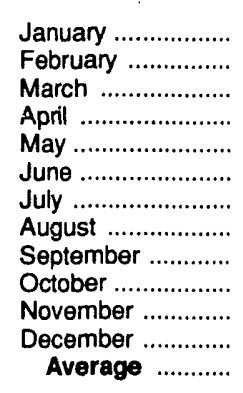 & $\begin{array}{l}413 \\
282 \\
301 \\
234 \\
259 \\
333 \\
308 \\
360 \\
279 \\
173 \\
177 \\
242 \\
\mathbf{2 8 0}\end{array}$ & $\begin{array}{l}97 \\
47 \\
67 \\
62 \\
38 \\
72 \\
70 \\
80 \\
69 \\
15 \\
46 \\
92 \\
63\end{array}$ & $\begin{array}{r}690 \\
500 \\
585 \\
588 \\
727 \\
708 \\
1,120 \\
966 \\
318 \\
0 \\
0 \\
0 \\
\mathbf{5 1 8}\end{array}$ & $\begin{array}{r}657 \\
488 \\
580 \\
588 \\
724 \\
708 \\
1,120 \\
966 \\
318 \\
0 \\
0 \\
0 \\
514\end{array}$ & $\begin{array}{r}250 \\
150 \\
100 \\
50 \\
64 \\
105 \\
43 \\
243 \\
33 \\
0 \\
0 \\
0 \\
86\end{array}$ & $\begin{array}{r}250 \\
140 \\
82 \\
50 \\
64 \\
94 \\
33 \\
207 \\
33 \\
0 \\
0 \\
0 \\
79\end{array}$ & $\begin{array}{l}0 \\
0 \\
0 \\
0 \\
0 \\
0 \\
0 \\
0 \\
0 \\
0 \\
0 \\
0 \\
0\end{array}$ & $\begin{array}{l}0 \\
0 \\
0 \\
0 \\
0 \\
0 \\
0 \\
0 \\
0 \\
0 \\
0 \\
0 \\
0\end{array}$ \\
\hline 1991 & 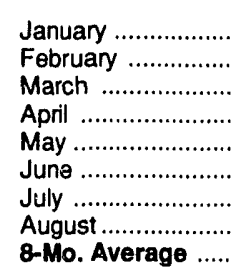 & $\begin{array}{l}327 \\
246 \\
222 \\
282 \\
308 \\
304 \\
202 \\
182 \\
259\end{array}$ & $\begin{array}{l}63 \\
38 \\
76 \\
90 \\
87 \\
70 \\
44 \\
16 \\
60\end{array}$ & $\begin{array}{l}0 \\
0 \\
0 \\
0 \\
0 \\
0 \\
0 \\
0 \\
0\end{array}$ & $\begin{array}{l}0 \\
0 \\
0 \\
0 \\
0 \\
0 \\
0 \\
0 \\
0\end{array}$ & $\begin{array}{l}0 \\
0 \\
0 \\
0 \\
0 \\
0 \\
0 \\
0 \\
0\end{array}$ & $\begin{array}{l}0 \\
0 \\
0 \\
0 \\
0 \\
0 \\
0 \\
0 \\
0\end{array}$ & $\begin{array}{l}0 \\
0 \\
0 \\
0 \\
0 \\
0 \\
0 \\
0 \\
0\end{array}$ & $\begin{array}{l}0 \\
0 \\
0 \\
0 \\
0 \\
0 \\
0 \\
0 \\
0\end{array}$ \\
\hline $\begin{array}{l}1990 \\
1989\end{array}$ & $\begin{array}{l}\text { 8-Mo. Average .... } \\
\text { 8-Mo. Average ..... }\end{array}$ & $\begin{array}{l}312 \\
263\end{array}$ & $\begin{array}{l}67 \\
57\end{array}$ & $\begin{array}{l}739 \\
445\end{array}$ & $\begin{array}{l}732 \\
437\end{array}$ & $\begin{array}{l}126 \\
146\end{array}$ & $\begin{array}{l}115 \\
143\end{array}$ & $\begin{array}{l}0 \\
0\end{array}$ & $\begin{array}{l}0 \\
0\end{array}$ \\
\hline
\end{tabular}

See footnotes at end of table. 
Table S3. Crude Oll and Petroleum Product Imports, 1973 - Present (Continued)

\begin{tabular}{|c|c|c|c|c|c|c|c|c|c|}
\hline & \multirow{4}{*}{ Year/Month } & \multicolumn{8}{|c|}{ Imports from Arab-OPEC Sources } \\
\hline & & \multicolumn{2}{|c|}{ Qatar } & \multicolumn{2}{|c|}{$\begin{array}{l}\text { Saudl } \\
\text { Arablab }\end{array}$} & \multicolumn{2}{|c|}{$\begin{array}{c}\text { United } \\
\text { Arab } \\
\text { Emirates }\end{array}$} & \multicolumn{2}{|c|}{$\begin{array}{c}\text { Total } \\
\text { Arab } \\
\text { OPEC }\end{array}$} \\
\hline & & Total & Crude Oll & Total & Crude OII & Total & Crude OII & Total & Crude Oll \\
\hline & & \multicolumn{8}{|c|}{ Thousand Barrels per Day } \\
\hline 1989 & 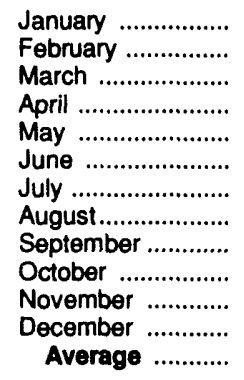 & $\begin{array}{r}0 \\
0 \\
0 \\
0 \\
0 \\
0 \\
0 \\
0 \\
26 \\
0 \\
0 \\
U \\
2\end{array}$ & $\begin{array}{r}0 \\
0 \\
0 \\
0 \\
0 \\
0 \\
0 \\
0 \\
26 \\
0 \\
0 \\
0 \\
2\end{array}$ & $\begin{array}{l}1,449 \\
1,290 \\
1,108 \\
1,226 \\
1,155 \\
1,249 \\
1,182 \\
1,316 \\
1,109 \\
1,158 \\
1,342 \\
1,115 \\
1,224\end{array}$ & $\begin{array}{l}1,335 \\
1,177 \\
1,025 \\
1,074 \\
1,056 \\
1,147 \\
1,096 \\
1,159 \\
1,021 \\
1,047 \\
1,230 \\
1,029 \\
1,116\end{array}$ & $\begin{array}{r}59 \\
17 \\
64 \\
14 \\
61 \\
17 \\
0 \\
44 \\
20 \\
14 \\
0 \\
26 \\
28\end{array}$ & $\begin{array}{r}59 \\
17 \\
64 \\
14 \\
61 \\
17 \\
0 \\
0 \\
0 \\
14 \\
0 \\
0 \\
21\end{array}$ & $\begin{array}{l}2,219 \\
2,126 \\
1,805 \\
2,030 \\
1,977 \\
2,164 \\
2,308 \\
2,453 \\
2,195 \\
2,122 \\
2,257 \\
1,905 \\
2,130\end{array}$ & $\begin{array}{l}1,863 \\
1,765 \\
1,490 \\
1,689 \\
1,617 \\
1,881 \\
1,982 \\
2,101 \\
1,874 \\
1,819 \\
1,891 \\
1,561 \\
1,794\end{array}$ \\
\hline 1991 & 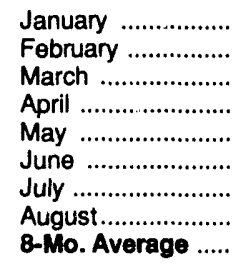 & $\begin{array}{l}0 \\
0 \\
0 \\
0 \\
0 \\
0 \\
0 \\
0 \\
0\end{array}$ & $\begin{array}{l}0 \\
0 \\
0 \\
0 \\
0 \\
0 \\
0 \\
0 \\
0\end{array}$ & $\begin{array}{l}1,934 \\
1,566 \\
1,623 \\
1,764 \\
2,258 \\
1,841 \\
1,725 \\
2,019 \\
1,845\end{array}$ & $\begin{array}{l}1,782 \\
1,538 \\
1,586 \\
1,702 \\
2,053 \\
1,795 \\
1,641 \\
1,964 \\
1,761\end{array}$ & $\begin{array}{l}0 \\
0 \\
0 \\
0 \\
0 \\
0 \\
0 \\
7 \\
1\end{array}$ & $\begin{array}{l}0 \\
0 \\
0 \\
0 \\
0 \\
0 \\
0 \\
0 \\
0\end{array}$ & $\begin{array}{l}2,261 \\
1,812 \\
1,845 \\
2,046 \\
2,566 \\
2,145 \\
1,928 \\
2,208 \\
2,105\end{array}$ & $\begin{array}{l}1,846 \\
1,576 \\
1,662 \\
1,792 \\
2,140 \\
1,865 \\
1,685 \\
1,980 \\
1,821\end{array}$ \\
\hline $\begin{array}{l}1990 \\
1989\end{array}$ & $\begin{array}{l}\text { 8-Mo. Average ..... } \\
\text { 8-Mo. Avergge ..... }\end{array}$ & $\begin{array}{l}5 \\
0\end{array}$ & $\begin{array}{l}\mathbf{5} \\
\mathbf{0}\end{array}$ & $\begin{array}{l}1,249 \\
1,246\end{array}$ & $\begin{array}{l}1,104 \\
1,133\end{array}$ & $\begin{array}{l}24 \\
35\end{array}$ & $\begin{array}{l}14 \\
29\end{array}$ & $\begin{array}{l}2,454 \\
2,136\end{array}$ & $\begin{array}{l}2,037 \\
1,799\end{array}$ \\
\hline
\end{tabular}

See footnotes at end of table. 
Table S3. Crude OII and Petroleum Product Imports, 1973 - Present (Continued)

\begin{tabular}{|c|c|c|c|c|c|c|c|c|c|}
\hline & \multirow{4}{*}{ Yoar/Month } & \multicolumn{8}{|c|}{ Imports from Other-OPEC Sources } \\
\hline & & \multicolumn{2}{|c|}{ Ecuador } & \multicolumn{2}{|c|}{ Gabon } & \multicolumn{2}{|c|}{ Indonesia } & \multicolumn{2}{|c|}{ Iran } \\
\hline & & Total & Crude Oll & Total & Crude Oll & Total & Crude OII & Total & Crude OII \\
\hline & & \multicolumn{8}{|c|}{ Thousand Barrels per Day } \\
\hline $\begin{array}{l}1973 \\
1974 \\
1975 \\
1976 \\
1977 \\
1978 \\
1979 \\
1980 \\
1981 \\
1982 \\
1983 \\
1984 \\
1985 \\
1986 \\
1987 \\
1988\end{array}$ & 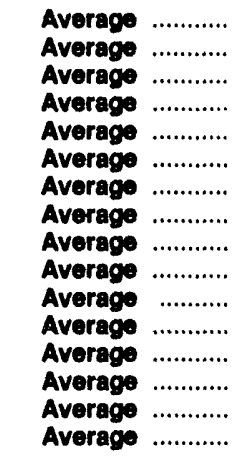 & $\begin{array}{l}48 \\
42 \\
57 \\
51 \\
57 \\
54 \\
42 \\
27 \\
48 \\
42 \\
61 \\
55 \\
67 \\
77 \\
29 \\
47\end{array}$ & $\begin{array}{l}47 \\
42 \\
57 \\
51 \\
55 \\
38 \\
30 \\
17 \\
38 \\
32 \\
56 \\
47 \\
56 \\
64 \\
23 \\
33\end{array}$ & $\begin{array}{l}0 \\
23 \\
27 \\
28 \\
42 \\
41 \\
42 \\
26 \\
35 \\
40 \\
59 \\
58 \\
52 \\
26 \\
35 \\
16\end{array}$ & $\begin{array}{l}0 \\
23 \\
27 \\
26 \\
35 \\
38 \\
42 \\
25 \\
35 \\
40 \\
59 \\
57 \\
51 \\
25 \\
35 \\
15\end{array}$ & $\begin{array}{l}213 \\
300 \\
390 \\
539 \\
541 \\
573 \\
420 \\
348 \\
366 \\
248 \\
338 \\
343 \\
314 \\
318 \\
285 \\
205\end{array}$ & $\begin{array}{l}200 \\
284 \\
379 \\
537 \\
507 \\
533 \\
380 \\
314 \\
318 \\
226 \\
315 \\
304 \\
292 \\
297 \\
262 \\
186\end{array}$ & $\begin{array}{r}223 \\
469 \\
280 \\
298 \\
535 \\
555 \\
304 \\
9 \\
0 \\
35 \\
48 \\
10 \\
27 \\
19 \\
98 \\
d(8)\end{array}$ & $\begin{array}{r}216 \\
\mathbf{4 6 3} \\
278 \\
298 \\
530 \\
554 \\
297 \\
8 \\
0 \\
35 \\
48 \\
10 \\
27 \\
19 \\
98 \\
9 \\
\text { d } \\
\mathbf{9})\end{array}$ \\
\hline 1989 & 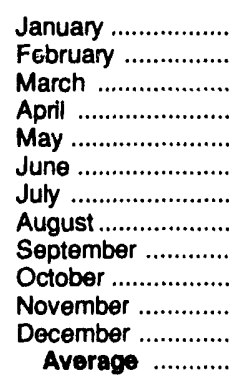 & $\begin{array}{r}52 \\
74 \\
100 \\
116 \\
123 \\
75 \\
86 \\
97 \\
115 \\
122 \\
71 \\
41 \\
89\end{array}$ & $\begin{array}{r}46 \\
67 \\
85 \\
111 \\
112 \\
75 \\
86 \\
79 \\
109 \\
105 \\
62 \\
23 \\
80\end{array}$ & $\begin{array}{l}0 \\
11 \\
10 \\
72 \\
19 \\
88 \\
42 \\
87 \\
32 \\
50 \\
99 \\
85 \\
50\end{array}$ & $\begin{array}{r}0 \\
11 \\
10 \\
72 \\
12 \\
88 \\
37 \\
87 \\
32 \\
50 \\
99 \\
85 \\
49\end{array}$ & $\begin{array}{l}218 \\
292 \\
167 \\
128 \\
264 \\
138 \\
113 \\
115 \\
113 \\
167 \\
231 \\
263 \\
183\end{array}$ & $\begin{array}{r}201 \\
244 \\
107 \\
97 \\
264 \\
129 \\
108 \\
100 \\
91 \\
130 \\
208 \\
222 \\
158\end{array}$ & $\begin{array}{l}0 \\
0 \\
0 \\
0 \\
0 \\
0 \\
0 \\
0 \\
0 \\
0 \\
0 \\
0 \\
0\end{array}$ & $\begin{array}{l}0 \\
0 \\
0 \\
0 \\
0 \\
0 \\
0 \\
0 \\
0 \\
0 \\
0 \\
0 \\
0\end{array}$ \\
\hline 1990 & 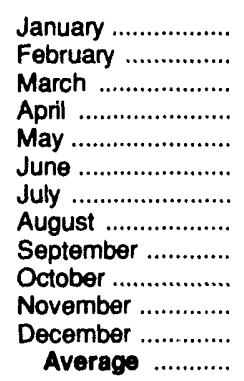 & $\begin{array}{l}48 \\
60 \\
49 \\
31 \\
17 \\
98 \\
60 \\
81 \\
43 \\
49 \\
13 \\
35 \\
49\end{array}$ & $\begin{array}{l}35 \\
40 \\
38 \\
29 \\
12 \\
86 \\
43 \\
69 \\
37 \\
43 \\
13 \\
12 \\
38\end{array}$ & $\begin{array}{r}75 \\
43 \\
134 \\
32 \\
27 \\
59 \\
69 \\
119 \\
59 \\
50 \\
71 \\
30 \\
64\end{array}$ & $\begin{array}{r}75 \\
43 \\
134 \\
28 \\
27 \\
59 \\
69 \\
119 \\
59 \\
50 \\
71 \\
30 \\
64\end{array}$ & $\begin{array}{r}153 \\
254 \\
138 \\
88 \\
85 \\
138 \\
143 \\
69 \\
111 \\
88 \\
72 \\
45 \\
114\end{array}$ & $\begin{array}{r}118 \\
189 \\
97 \\
80 \\
77 \\
129 \\
137 \\
55 \\
111 \\
88 \\
72 \\
36 \\
98\end{array}$ & $\begin{array}{l}0 \\
0 \\
0 \\
0 \\
0 \\
0 \\
0 \\
0 \\
0 \\
0 \\
0 \\
0 \\
0\end{array}$ & $\begin{array}{l}0 \\
0 \\
0 \\
0 \\
0 \\
0 \\
0 \\
0 \\
0 \\
0 \\
0 \\
0 \\
0\end{array}$ \\
\hline 1991 & 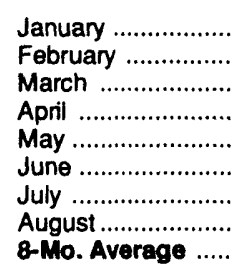 & $\begin{array}{r}12 \\
66 \\
67 \\
35 \\
109 \\
129 \\
62 \\
112 \\
74\end{array}$ & $\begin{array}{r}6 \\
55 \\
58 \\
24 \\
103 \\
126 \\
47 \\
93 \\
64\end{array}$ & $\begin{array}{r}41 \\
95 \\
29 \\
72 \\
96 \\
70 \\
137 \\
56 \\
74\end{array}$ & $\begin{array}{r}41 \\
95 \\
29 \\
72 \\
96 \\
70 \\
137 \\
56 \\
74\end{array}$ & $\begin{array}{r}61 \\
162 \\
93 \\
61 \\
111 \\
187 \\
88 \\
93 \\
106\end{array}$ & $\begin{array}{r}61 \\
153 \\
93 \\
61 \\
111 \\
187 \\
88 \\
87 \\
104\end{array}$ & $\begin{array}{r}0 \\
0 \\
0 \\
0 \\
0 \\
0 \\
81 \\
48 \\
16\end{array}$ & $\begin{array}{r}0 \\
0 \\
0 \\
0 \\
0 \\
0 \\
81 \\
48 \\
16\end{array}$ \\
\hline $\begin{array}{l}1990 \\
1989\end{array}$ & $\begin{array}{l}\text { 8-Mo. Average ..... } \\
\text { 8-Mo. Average ..... }\end{array}$ & $\begin{array}{l}55 \\
90\end{array}$ & $\begin{array}{l}44 \\
83\end{array}$ & $\begin{array}{l}70 \\
41\end{array}$ & $\begin{array}{l}70 \\
40\end{array}$ & $\begin{array}{l}132 \\
178\end{array}$ & $\begin{array}{l}109 \\
156\end{array}$ & $\begin{array}{l}0 \\
0\end{array}$ & $\begin{array}{l}0 \\
0\end{array}$ \\
\hline
\end{tabular}

See footnotes at end of table. 
Table S3. Crude Oll and Petroleum Product Imports, 1973 - Present (Continued)

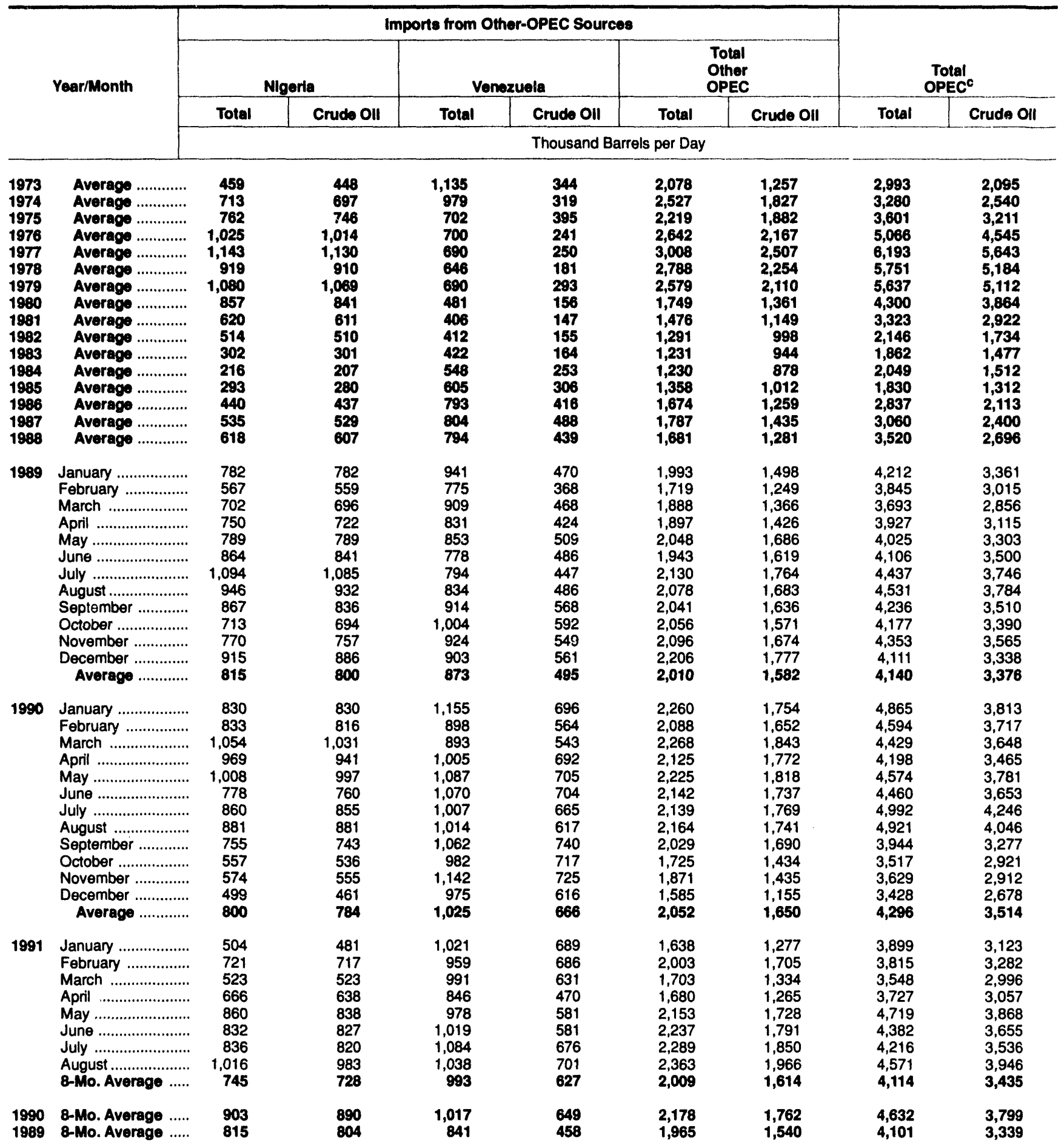

See footnotes at end of table. 
Table S3. Crude Oll and Petroleum Product Imports, 1973 - Present (Continued)

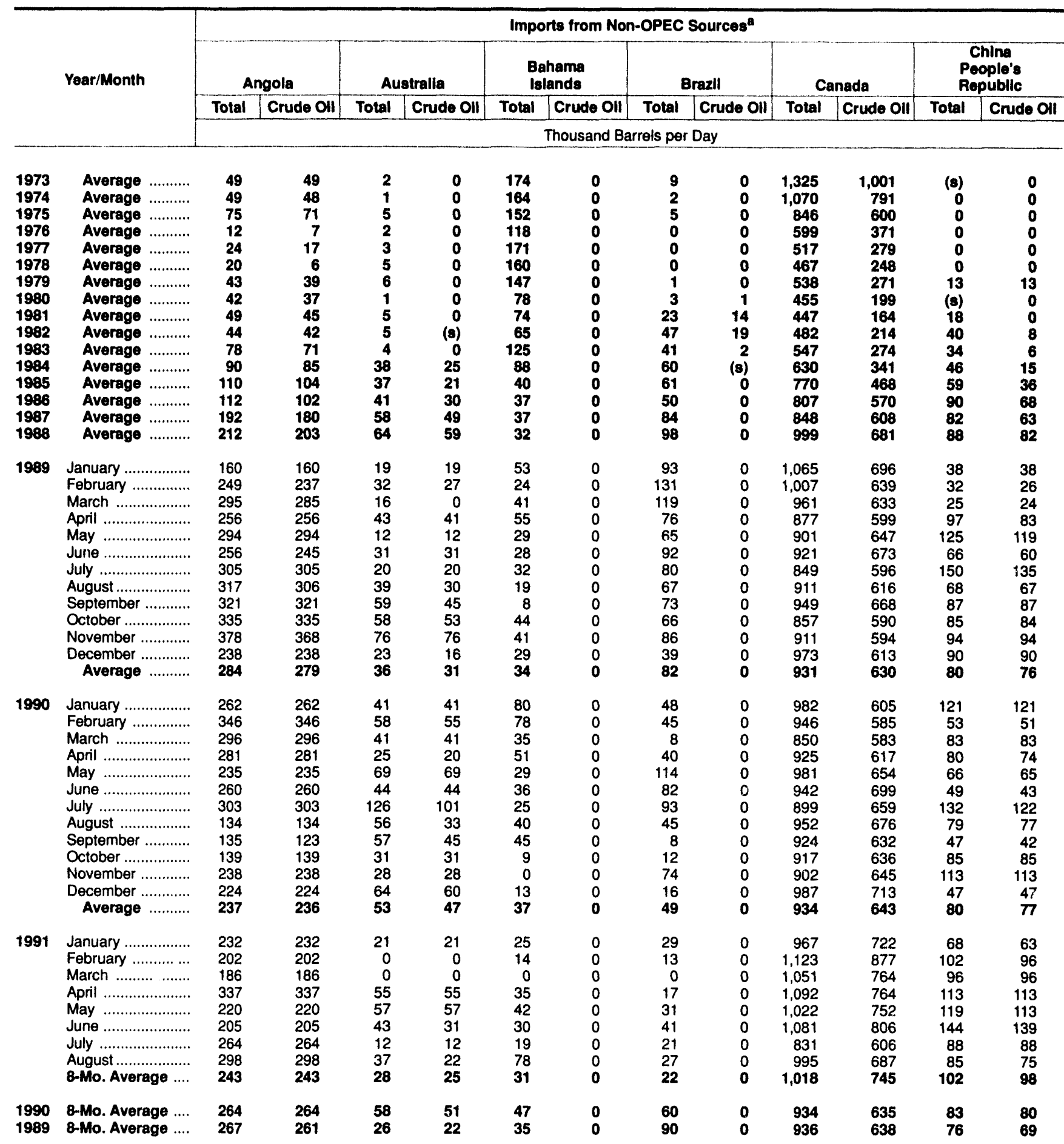

See footnotes at end of table. 
Table S3. Crude OII and Petroleum Product Imports, 1973 - Present (Continued)

\begin{tabular}{|c|c|c|c|c|c|c|c|c|c|c|c|}
\hline & \multirow{4}{*}{ Year/Month } & \multicolumn{10}{|c|}{ Imports from Non-OPEC Sources } \\
\hline & & \multicolumn{2}{|c|}{ Colombla } & \multicolumn{2}{|c|}{ Haly } & \multicolumn{2}{|c|}{ Malaysla } & \multicolumn{2}{|c|}{ Mexico } & \multicolumn{2}{|c|}{ Notherlands } \\
\hline & & Total & Crude OII & Total & Crude OII & Total & Crude OII & Total & Crude OII & Total & Crude OII \\
\hline & & \multicolumn{10}{|c|}{ Thousand Barrels per Day } \\
\hline $\begin{array}{l}1973 \\
1974 \\
1975 \\
1976 \\
1977 \\
1978 \\
1979 \\
1980 \\
1981 \\
1982 \\
1993 \\
1984 \\
1985 \\
1986 \\
1987 \\
1988\end{array}$ & $\begin{array}{l}\text { Average .......... } \\
\text { Average .......... } \\
\text { Average ......... } \\
\text { Average .......... } \\
\text { Average .......... } \\
\text { Average .......... } \\
\text { Average .......... } \\
\text { Average .......... } \\
\text { Average }\end{array}$ & $\begin{array}{r}9 \\
5 \\
9 \\
21 \\
17 \\
20 \\
18 \\
4 \\
1 \\
5 \\
10 \\
8 \\
23 \\
87 \\
148 \\
134\end{array}$ & $\begin{array}{r}2 \\
0 \\
0 \\
6 \\
0 \\
0 \\
0 \\
0 \\
0 \\
0 \\
0 \\
0 \\
0 \\
57 \\
115 \\
106\end{array}$ & $\begin{array}{r}125 \\
74 \\
27 \\
39 \\
51 \\
38 \\
30 \\
4 \\
11 \\
18 \\
18 \\
45 \\
60 \\
76 \\
54 \\
65\end{array}$ & $\begin{array}{r}0 \\
0 \\
0 \\
0 \\
0 \\
0 \\
0 \\
0 \\
0 \\
(8) \\
(8) \\
(8) \\
(8) \\
0 \\
1 \\
5\end{array}$ & $\begin{array}{r}12 \\
12 \\
8 \\
18 \\
66 \\
42 \\
66 \\
70 \\
36 \\
20 \\
4 \\
1 \\
3 \\
12 \\
13 \\
19\end{array}$ & $\begin{array}{r}1 \\
1 \\
5 \\
16 \\
55 \\
37 \\
52 \\
61 \\
33 \\
18 \\
3 \\
0 \\
1 \\
11 \\
12 \\
19\end{array}$ & $\begin{array}{r}16 \\
8 \\
71 \\
87 \\
179 \\
318 \\
439 \\
533 \\
522 \\
685 \\
826 \\
748 \\
816 \\
699 \\
655 \\
747\end{array}$ & $\begin{array}{r}1 \\
2 \\
70 \\
87 \\
87 \\
177 \\
316 \\
437 \\
507 \\
469 \\
645 \\
766 \\
659 \\
715 \\
621 \\
602 \\
674\end{array}$ & $\begin{array}{r}53 \\
43 \\
19 \\
8 \\
31 \\
5 \\
23 \\
2 \\
30 \\
35 \\
65 \\
65 \\
58 \\
54 \\
60 \\
61\end{array}$ & $\begin{array}{l}0 \\
0 \\
4 \\
0 \\
4 \\
2 \\
7 \\
(8) \\
(8) \\
(8) \\
3 \\
3 \\
0 \\
0 \\
0 \\
0\end{array}$ \\
\hline 1989 & 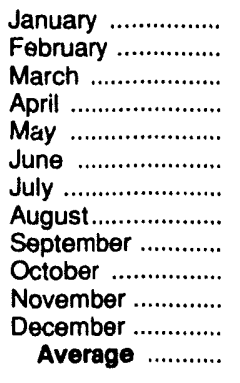 & $\begin{array}{l}261 \\
146 \\
185 \\
168 \\
122 \\
139 \\
108 \\
191 \\
163 \\
147 \\
227 \\
199 \\
172\end{array}$ & $\begin{array}{r}204 \\
105 \\
146 \\
140 \\
68 \\
113 \\
71 \\
71 \\
159 \\
146 \\
116 \\
188 \\
173 \\
136 \\
136\end{array}$ & $\begin{array}{r}19 \\
77 \\
59 \\
9 \\
26 \\
33 \\
1 \\
30 \\
22 \\
74 \\
42 \\
19 \\
34\end{array}$ & $\begin{array}{r}0 \\
12 \\
0 \\
0 \\
10 \\
0 \\
0 \\
14 \\
0 \\
0 \\
0 \\
0 \\
3\end{array}$ & $\begin{array}{r}62 \\
10 \\
15 \\
47 \\
22 \\
110 \\
16 \\
13 \\
10 \\
28 \\
97 \\
33 \\
39\end{array}$ & $\begin{array}{r}62 \\
10 \\
15 \\
47 \\
22 \\
110 \\
16 \\
13 \\
10 \\
28 \\
97 \\
33 \\
39\end{array}$ & $\begin{array}{r}809 \\
756 \\
667 \\
1,002 \\
808 \\
688 \\
758 \\
806 \\
721 \\
837 \\
743 \\
610 \\
767\end{array}$ & $\begin{array}{l}748 \\
706 \\
621 \\
941 \\
764 \\
639 \\
708 \\
765 \\
659 \\
760 \\
715 \\
566 \\
716\end{array}$ & $\begin{array}{r}57 \\
153 \\
30 \\
48 \\
31 \\
46 \\
34 \\
32 \\
54 \\
43 \\
33 \\
37 \\
49\end{array}$ & $\begin{array}{l}0 \\
0 \\
0 \\
0 \\
0 \\
0 \\
0 \\
0 \\
0 \\
0 \\
0 \\
0 \\
0\end{array}$ \\
\hline 1990 & 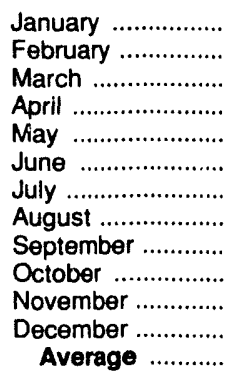 & $\begin{array}{r}188 \\
203 \\
177 \\
198 \\
220 \\
180 \\
169 \\
203 \\
97 \\
183 \\
209 \\
161 \\
182\end{array}$ & $\begin{array}{r}146 \\
168 \\
146 \\
143 \\
175 \\
117 \\
111 \\
132 \\
84 \\
159 \\
177 \\
121 \\
140\end{array}$ & $\begin{array}{r}124 \\
76 \\
47 \\
53 \\
101 \\
95 \\
56 \\
43 \\
38 \\
21 \\
32 \\
13 \\
58\end{array}$ & $\begin{array}{r}0 \\
0 \\
0 \\
0 \\
10 \\
0 \\
11 \\
0 \\
0 \\
0 \\
0 \\
0 \\
2\end{array}$ & $\begin{array}{r}14 \\
42 \\
28 \\
38 \\
0 \\
9 \\
20 \\
142 \\
105 \\
78 \\
8 \\
6 \\
41\end{array}$ & $\begin{array}{r}14 \\
38 \\
28 \\
38 \\
0 \\
9 \\
20 \\
142 \\
105 \\
78 \\
8 \\
6 \\
40\end{array}$ & $\begin{array}{l}776 \\
725 \\
815 \\
466 \\
788 \\
912 \\
706 \\
773 \\
871 \\
828 \\
761 \\
637 \\
755\end{array}$ & $\begin{array}{l}691 \\
669 \\
757 \\
414 \\
688 \\
815 \\
651 \\
676 \\
807 \\
793 \\
706 \\
595 \\
689\end{array}$ & $\begin{array}{r}129 \\
80 \\
21 \\
47 \\
63 \\
92 \\
54 \\
39 \\
20 \\
37 \\
49 \\
28 \\
55\end{array}$ & $\begin{array}{l}0 \\
0 \\
0 \\
0 \\
0 \\
0 \\
0 \\
0 \\
0 \\
0 \\
0 \\
0 \\
0\end{array}$ \\
\hline 1991 & 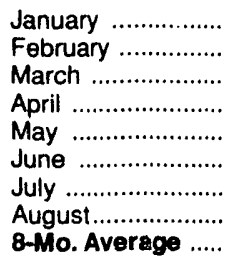 & $\begin{array}{l}194 \\
151 \\
157 \\
163 \\
163 \\
169 \\
163 \\
219 \\
173\end{array}$ & $\begin{array}{r}174 \\
98 \\
127 \\
131 \\
112 \\
124 \\
111 \\
179 \\
133\end{array}$ & $\begin{array}{l}25 \\
42 \\
29 \\
41 \\
60 \\
46 \\
54 \\
57 \\
44\end{array}$ & $\begin{array}{r}0 \\
13 \\
0 \\
12 \\
0 \\
0 \\
0 \\
11 \\
4\end{array}$ & $\begin{array}{r}0 \\
9 \\
21 \\
0 \\
66 \\
49 \\
9 \\
14 \\
21\end{array}$ & $\begin{array}{r}0 \\
9 \\
21 \\
0 \\
66 \\
49 \\
9 \\
14 \\
21\end{array}$ & $\begin{array}{l}779 \\
742 \\
791 \\
889 \\
757 \\
919 \\
835 \\
878 \\
824\end{array}$ & $\begin{array}{l}759 \\
693 \\
772 \\
819 \\
736 \\
872 \\
748 \\
797 \\
775\end{array}$ & $\begin{array}{r}6 \\
8 \\
33 \\
35 \\
45 \\
49 \\
47 \\
30 \\
32\end{array}$ & $\begin{array}{l}0 \\
0 \\
0 \\
0 \\
0 \\
0 \\
0 \\
0 \\
0\end{array}$ \\
\hline $\begin{array}{l}1990 \\
1989\end{array}$ & $\begin{array}{l}\text { 8-Mo. Average ..... } \\
\text { 8-Mo. Average ...... }\end{array}$ & $\begin{array}{l}192 \\
165\end{array}$ & $\begin{array}{l}142 \\
126\end{array}$ & $\begin{array}{l}74 \\
31\end{array}$ & $\begin{array}{l}3 \\
4\end{array}$ & $\begin{array}{l}37 \\
37\end{array}$ & $\begin{array}{l}36 \\
37\end{array}$ & $\begin{array}{l}746 \\
787\end{array}$ & $\begin{array}{l}670 \\
736\end{array}$ & $\begin{array}{l}65 \\
53\end{array}$ & $\begin{array}{l}0 \\
0\end{array}$ \\
\hline
\end{tabular}

See footnotes at end of table. 
Table S3. Crude Oil and Petroleum Product Imports, 1973 - Present (Continued)

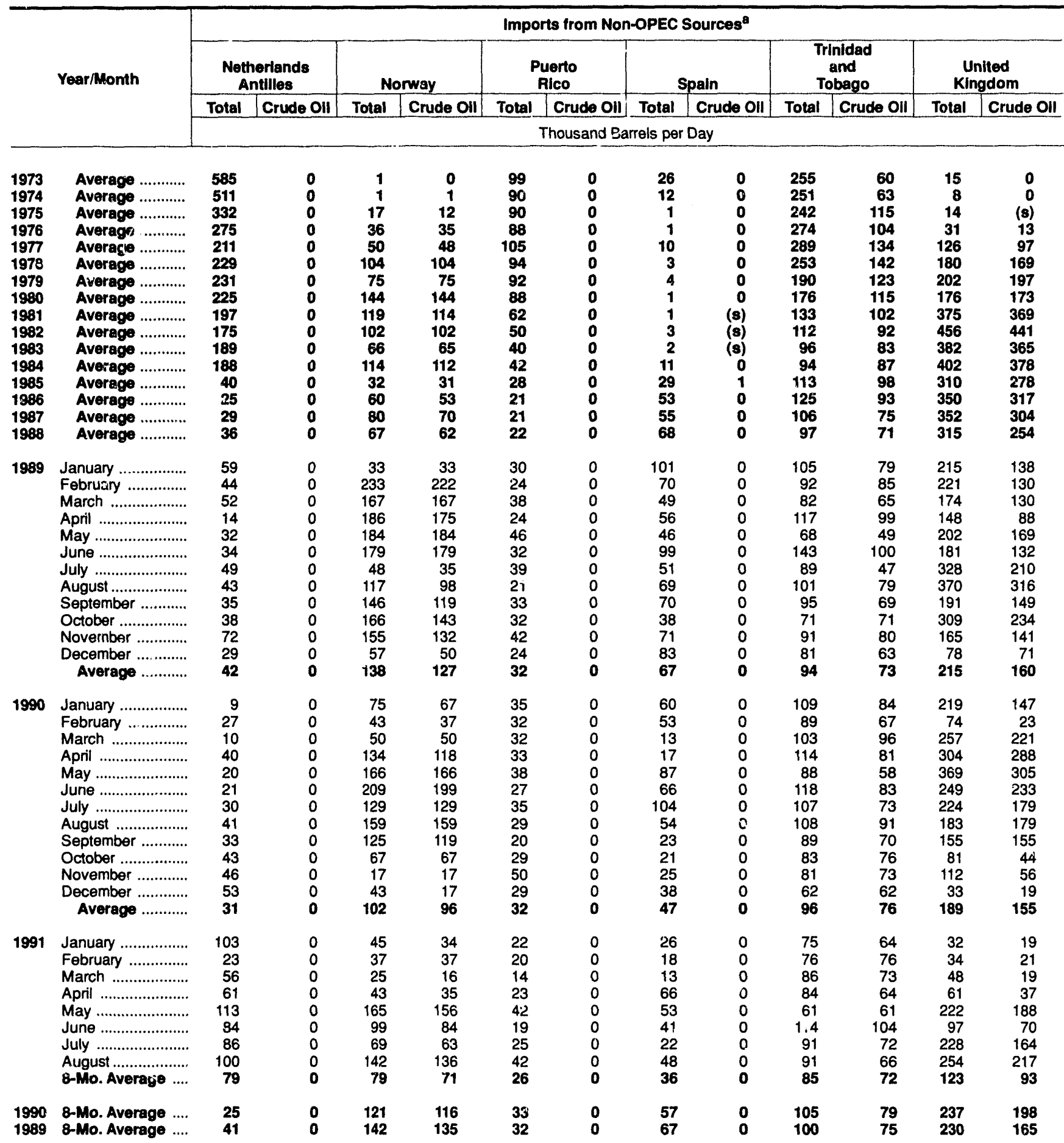

See footnotes at end of table. 
Table S3. Crude Oil and Petroleum Product Imports, 1973 - Present (Continued)

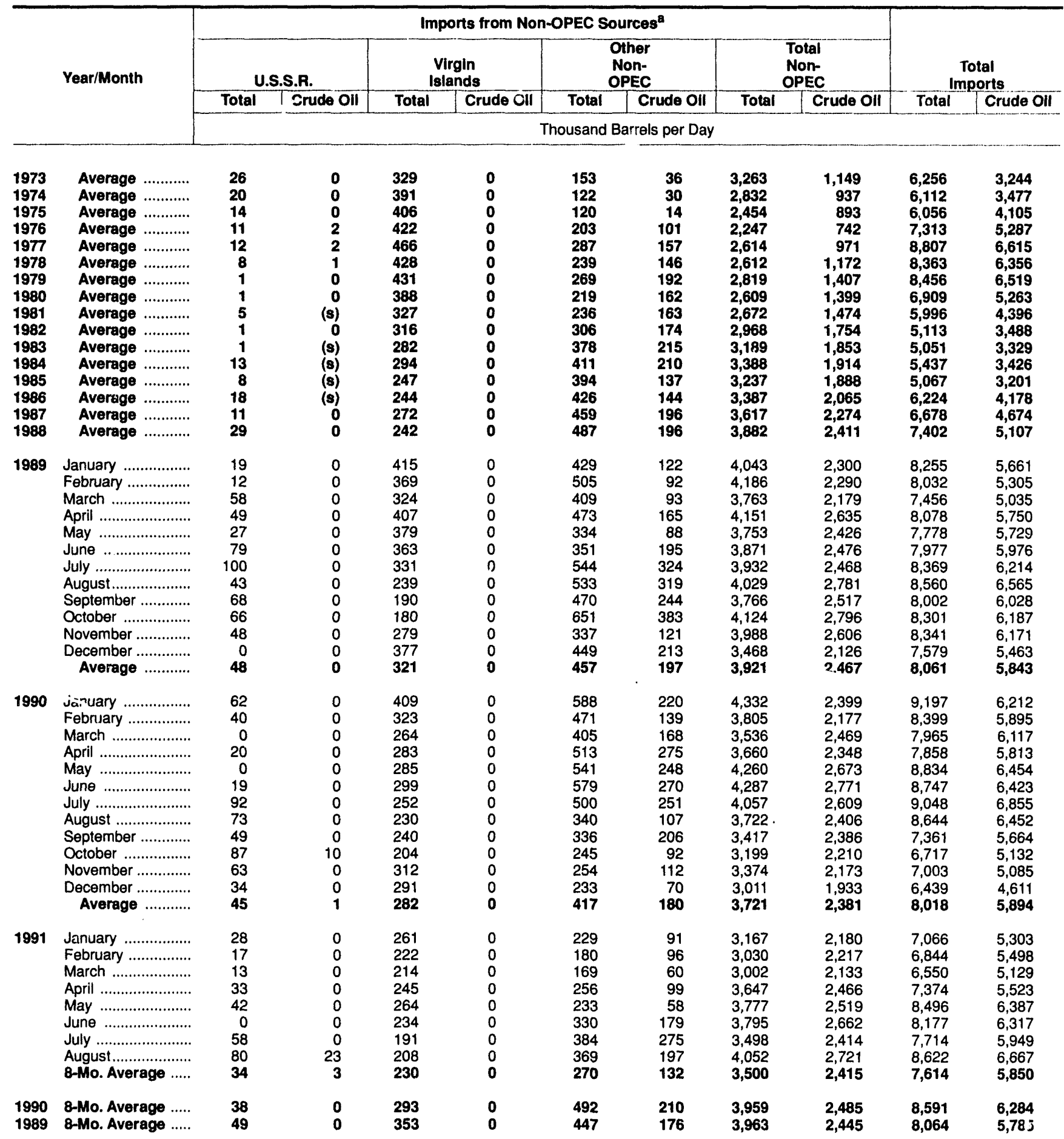

${ }^{a}$ Includes petroleum imported into the United States indiractly from members of the Organization of Petroleum Exporting Countries (UPEC) primarily from Caribbean and West European areas as petroleum products that were refined from crude oil produced by OPEC.

Imports from the Neutral Zone between Kuwait and Saudi Arabia are included in imports from Saudi Arabia.

${ }^{c}$ Excludes petroleum imported into the United States indirectly from members on the Organization of Petroleum Exporting Countries (OPEC), primarily from Caribbean and West European areas, as petroleum products that were refined from crude oil produced by OPEC.

A small amount of Iranian crude oil entered the United States in January 1988 from the Virgin Islands. "his oil originated in Iran and was exported to the Virgin Islands prior to the signing of Executive Order 12613 on October 29, 1987.

$(s)=$ Less than 500 barrels per day. $R=$ Revised data.

Notes: - Beginning in October 1977. Strategic Petroleum Reserve imports are included. - Geographic coverage is the 50 States and the District of

Columbia. - Totals may not equal sum of components due to independent rounding.

Source: See Summary Statistics Table and Figure Sources. 
Figure S5. Finished Motor Gasoline Supply and Disposition, August 1990 - Present

10,000

10,000

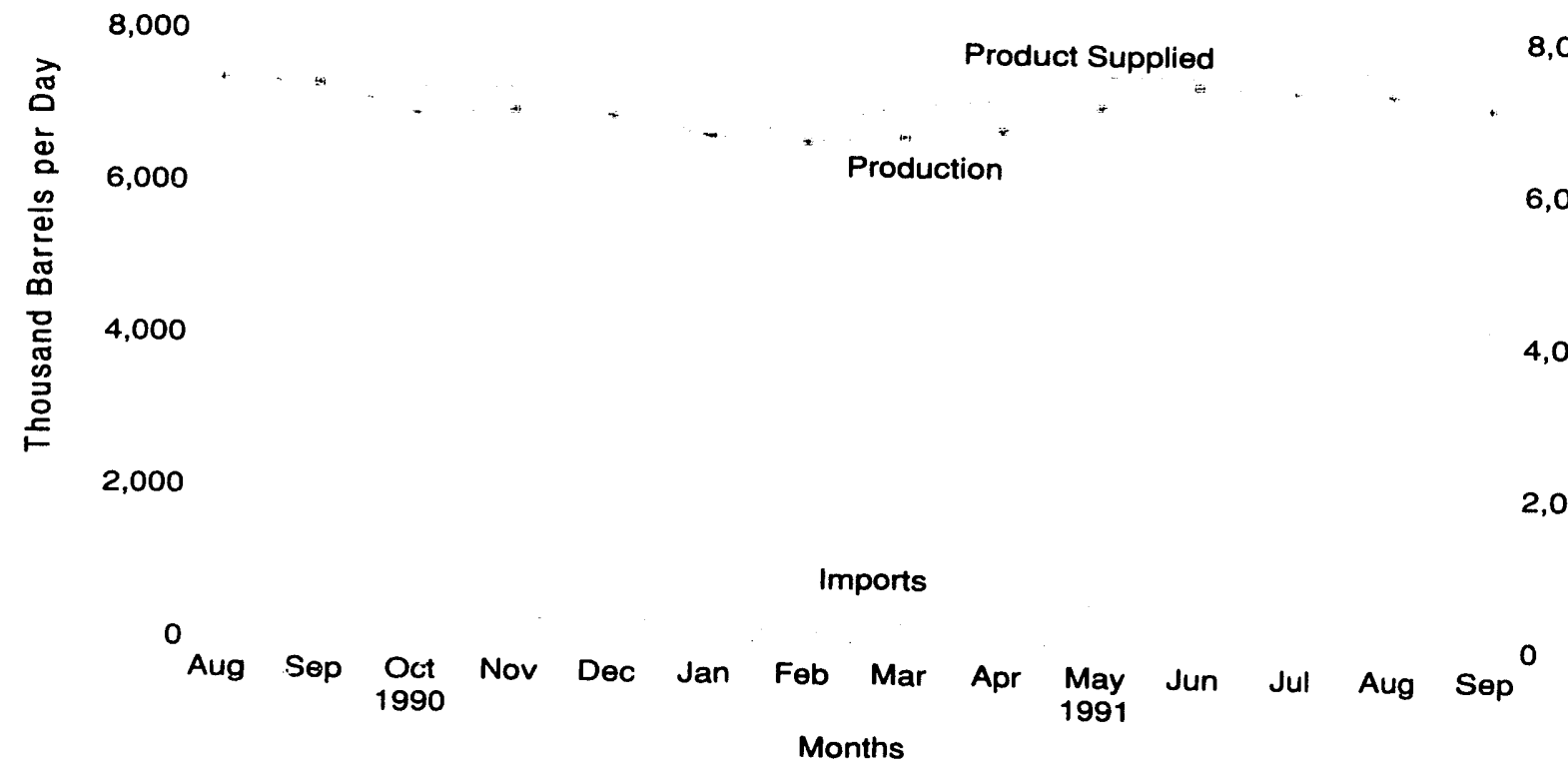

Source: Energy Information Administration, Petroleum Supply Monthly, Table S4. See Summary Statistics Table and Figure Sources.

Figure S6. Motor Gasoline Ending Stocks, August 1990 - Present

300

250

Average Stock Range for Total Motor Gasoline

250

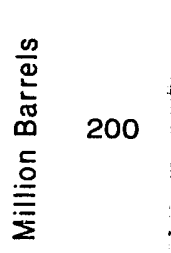

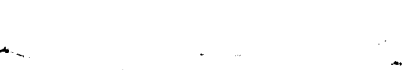

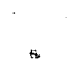

Total Motor Gaso
Minimum Operating Inventory

Finished Motor Gasoline

150

150

0

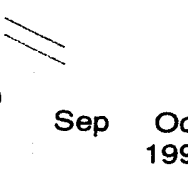
Oct
1990

Nov Dec Jan

Feb

Mar

Months

Note: - Total motor gasoline includes motor gasoline blending components and finished motor gasoline. - The National Petroleum Council (NPC) defines the Minimum Operating Inventory as the inventory level below which operating problems and shortages would begin to appear incil defined distribution system. In its 1988 study, the NPC estimated this inventory level for total motor gasoline to be 205 million barrels.

Source: Energy Information Administration, Petroleum Supply Monthly, Table S4. See Summary Statistics Table and Figure Sources. 
Table S4. Finished Motor Gasoline Supply and Disposition, 1973 - Present



a Stocks are totals as of end of period.

b Beginning in 1981, excludes blending components.

c A negative number indicates a decrease in stocks and a positive number indicates an increase.

d Includes gasohol.

$\theta$ Includes motor gasoline blending components.

In January 1975,1981 , and 1983, numerous respondents were added to surveys affecting stocks reported and stock change calculations. See Summary Statistics Explanatory Note 4.

geginning in January 1981, survey forms were modified. See Summary Statistics Explanatory Note 4

$R=$ Revised data. $(s)=$ Less than 500 barrels per day. $E=$ Estimated.

- See Summary Statistics Explanatory Note 1.

Notes: - Italics denote estimates based upon preliminary data. - Geographic coverage is the 50 States and the District of Columbia. - Totals may not equal sum of components due to independent rounding.

Source: See Summary Statistics Table and Figure Sources. 
Figure S7. Distillate Fuel Oil Supply and Disposition, August 1990 - Present

5,000

4,000

4,000

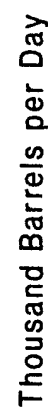

Product Supplied

3,000

Production

2,000

2,000

1,000

Imports

${ }^{0}$ Aug Sep $\begin{gathered}\text { Oct } \\ 1990\end{gathered}$ Nov Dec Jan Feb Mar Apr $\underset{1991}{\operatorname{May}}$ Jun Jul Aug Sep Months

Source: Energy Information Administration, Petroleum Supply Monthly, Table S5. See Summary Statistics Table and Figure Sources.

\section{Figure S8. Distillate Fuel Oil Ending Stocks, August 1990 - Present}

200

150

Average Stock Range

150

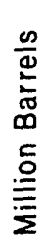

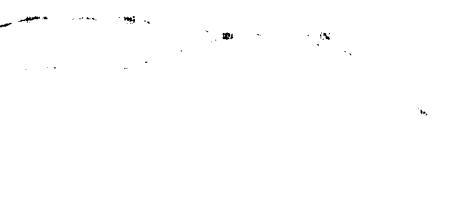

Minimum Operating Inventory

0

$$
\begin{gathered}
\text { Sep Oct Nov Dec Jan Feb Mar Apr } \begin{array}{c}
\text { May Jun Jul Aug Sep } \\
1990
\end{array} \\
\text { Months }
\end{gathered}
$$

Note: The National Petroleum Council (NPC) defines the Minimum Operating Inventory as the inventory level below which operating problems and shortages would begin to appear in a defined distribution system. In its 1988 study, the NPC estimated this inventory level for distillate fuel oil to be 85 million barrels.

Source: Energy Information Administration, Petroleum Supply Monthly, Table S5. See Summary Statistics Table and Figure Sources. 
Table S5. Distillate Fuel OII Supply and Disposition, 1973 - Present

\begin{tabular}{|c|c|c|c|c|c|c|c|c|}
\hline & \multirow{3}{*}{ Year/Month } & \multicolumn{3}{|c|}{ Supply } & \multicolumn{3}{|c|}{ Disposition } & \multirow{3}{*}{$\begin{array}{c}\begin{array}{c}\text { Ending } \\
\text { Stocks }\end{array} \\
\text { Million Barrels }\end{array}$} \\
\hline & & $\begin{array}{c}\text { Total } \\
\text { Production }\end{array}$ & Imports & $\begin{array}{c}\text { Crude } \\
\text { Used } \\
\text { Directlya }\end{array}$ & $\begin{array}{c}\text { Stock } \\
\text { Changeb }\end{array}$ & Exports & $\begin{array}{c}\text { Product } \\
\text { Supplied }^{a}\end{array}$ & \\
\hline & & \multicolumn{6}{|c|}{ Thousand Barrels per Day } & \\
\hline $\begin{array}{l}1973 \\
1974 \\
1975 \\
1976 \\
1977 \\
1978 \\
1979 \\
1980 \\
1981 \\
1982 \\
1983 \\
1984 \\
1985 \\
1986 \\
1987 \\
1988\end{array}$ & 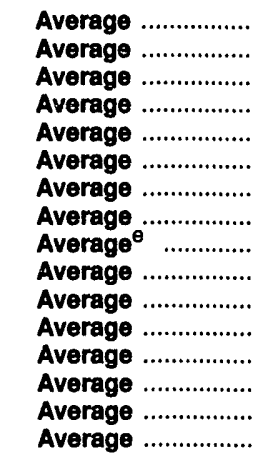 & $\begin{array}{l}2,822 \\
2,669 \\
2,654 \\
2,924 \\
3,278 \\
3,167 \\
3,153 \\
2,662 \\
2,613 \\
2,606 \\
2,456 \\
2,681 \\
2,687 \\
2,798 \\
2,731 \\
2,859\end{array}$ & $\begin{array}{r}392 \\
289 \\
155 \\
146 \\
250 \\
173 \\
193 \\
142 \\
173 \\
93 \\
174 \\
272 \\
200 \\
247 \\
255 \\
302\end{array}$ & $\begin{array}{r}2 \\
2 \\
2 \\
1 \\
1 \\
1 \\
1 \\
1 \\
10 \\
10 \\
- \\
- \\
- \\
-\end{array}$ & $\begin{array}{r}115 \\
9 \\
d-40 \\
-62 \\
176 \\
-93 \\
34 \\
-64 \\
\mathrm{~d}-38 \\
-35 \\
\mathrm{~d}-124 \\
57 \\
-48 \\
31 \\
-56 \\
-30\end{array}$ & $\begin{array}{r}9 \\
2 \\
1 \\
1 \\
1 \\
3 \\
3 \\
3 \\
5 \\
74 \\
64 \\
51 \\
67 \\
100 \\
66 \\
69\end{array}$ & $\begin{array}{l}3,092 \\
2,948 \\
2,851 \\
3,133 \\
3,352 \\
3,432 \\
3,311 \\
2,866 \\
2,829 \\
2,671 \\
2,690 \\
2,845 \\
2,868 \\
2,914 \\
2,976 \\
3,122 \\
\end{array}$ & $\begin{array}{r}196 \\
d 200 \\
209 \\
186 \\
250 \\
216 \\
229 \\
d 205 \\
192 \\
d 179 \\
140 \\
161 \\
144 \\
155 \\
134 \\
124\end{array}$ \\
\hline 1989 & 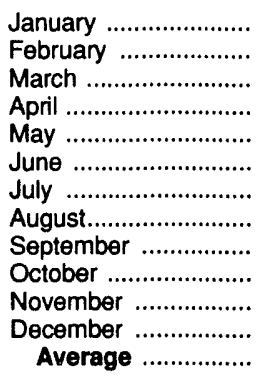 & $\begin{array}{l}2,974 \\
2,797 \\
2,713 \\
2,789 \\
2,750 \\
2,809 \\
2,848 \\
2,907 \\
2,952 \\
2,906 \\
3,063 \\
3,266 \\
2,899\end{array}$ & $\begin{array}{l}346 \\
331 \\
439 \\
301 \\
290 \\
233 \\
334 \\
254 \\
249 \\
261 \\
307 \\
324 \\
306\end{array}$ & $\begin{array}{l}- \\
- \\
- \\
- \\
- \\
- \\
-\end{array}$ & $\begin{array}{r}-93 \\
-463 \\
-352 \\
60 \\
35 \\
(s) \\
498 \\
41 \\
231 \\
-50 \\
-64 \\
-454 \\
-49\end{array}$ & $\begin{array}{r}110 \\
164 \\
76 \\
56 \\
51 \\
39 \\
89 \\
154 \\
81 \\
90 \\
123 \\
130 \\
97\end{array}$ & $\begin{array}{l}3,303 \\
3,427 \\
3,428 \\
2,975 \\
2,954 \\
3,002 \\
2,596 \\
2,966 \\
2,889 \\
3,127 \\
3,311 \\
3,914 \\
3,157\end{array}$ & $\begin{array}{r}121 \\
108 \\
97 \\
99 \\
100 \\
100 \\
115 \\
116 \\
123 \\
122 \\
120 \\
106 \\
-\end{array}$ \\
\hline 1990 & 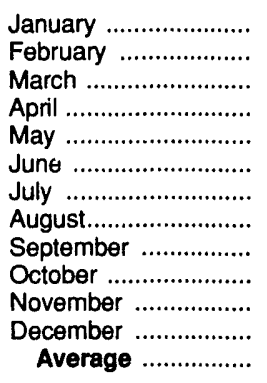 & $\begin{array}{l}3,130 \\
2,753 \\
2,657 \\
2,803 \\
2,874 \\
2,996 \\
3,008 \\
3,131 \\
2,968 \\
2,928 \\
2,915 \\
2,917 \\
2,925\end{array}$ & $\begin{array}{l}505 \\
357 \\
281 \\
308 \\
209 \\
257 \\
236 \\
293 \\
226 \\
190 \\
238 \\
239 \\
278\end{array}$ & $\begin{array}{l}- \\
- \\
- \\
z \\
z \\
- \\
- \\
- \\
-\end{array}$ & $\begin{array}{r}388 \\
-215 \\
-415 \\
9 \\
108 \\
246 \\
487 \\
156 \\
207 \\
8 \\
-129 \\
-7 \\
73\end{array}$ & $\begin{array}{r}62 \\
65 \\
75 \\
59 \\
75 \\
84 \\
30 \\
51 \\
123 \\
150 \\
188 \\
347 \\
109\end{array}$ & $\begin{array}{l}3,185 \\
3,260 \\
3,277 \\
3,043 \\
2,900 \\
2,923 \\
2,726 \\
3,218 \\
2,864 \\
2,960 \\
3,094 \\
2,816 \\
3,021\end{array}$ & $\begin{array}{r}118 \\
112 \\
99 \\
99 \\
103 \\
110 \\
125 \\
130 \\
136 \\
136 \\
132 \\
132 \\
-\end{array}$ \\
\hline 1991 & 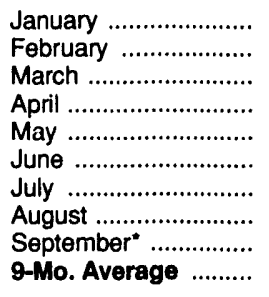 & $\begin{array}{r}2,851 \\
2,867 \\
2,862 \\
2,822 \\
2,924 \\
2,940 \\
2,992 \\
R_{2,959} \\
E_{3,120} \\
E_{2,927}\end{array}$ & $\begin{array}{r}190 \\
138 \\
206 \\
258 \\
185 \\
209 \\
153 \\
R 167 \\
E 263 \\
E 197\end{array}$ & $\begin{array}{l}- \\
z \\
z \\
z \\
-\end{array}$ & $\begin{array}{r}-648 \\
-388 \\
-96 \\
130 \\
156 \\
216 \\
348 \\
R_{203} \\
E_{302} \\
E_{27}\end{array}$ & $\begin{array}{r}332 \\
393 \\
198 \\
81 \\
218 \\
150 \\
149 \\
R_{144} \\
E_{95} \\
E_{194}\end{array}$ & $\begin{array}{r}3,356 \\
3,000 \\
2,966 \\
2,869 \\
2,735 \\
2,783 \\
2,649 \\
R_{2,779} \\
E_{2,987} \\
E_{2,902}\end{array}$ & $\begin{array}{r}112 \\
101 \\
98 \\
102 \\
107 \\
113 \\
124 \\
131 \\
\text { E } 140 \\
-\end{array}$ \\
\hline $\begin{array}{l}1990 \\
1989\end{array}$ & $\begin{array}{l}\text { 9-Mo. Average ......... } \\
\text { 9-Mo. Average ......... }\end{array}$ & $\begin{array}{l}2,926 \\
2,838\end{array}$ & $\begin{array}{l}297 \\
309\end{array}$ & - & $\begin{array}{r}111 \\
-1\end{array}$ & $\begin{array}{l}69 \\
91\end{array}$ & $\begin{array}{l}3,043 \\
3,057\end{array}$ & - \\
\hline
\end{tabular}

\footnotetext{
a Beginning in January 1983, product supplied for distillate fuel oil does not include crude oil used directly.

b A negative number indicates a decrease in stocks and a positive number indicates an increase.

c Stocks are totals as of end of period.

I In January 1975,1981, and 1983, numerous respondents were added to surveys affecting stocks reported and stock change calculations. See Summary Statistics Explanatory Note 4.

Beginning in January 1981, survey forms were modified. See Summary Statistics Explanatory Note 4.

$R=$ Revised data. $(s)=$ Less than 500 barrels per day. $E=$ Estimated.

- See Summary Statistics Explanatory Note 1.

Notes: - Italics denote estimates based upon preliminary data. - Goographic coverage is the 50 States and the District of Columbia. - Totals may not equal sum of components due to independent rounding.

Source: See Summary Statistics Table and Figure Sources.
} 
Figure S9. Residual Fuel Oll Supply and Disposition, August 1990 - Present

2,500

2,500

2,000

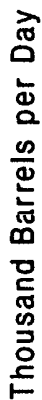

1,500

Product Supplied

1,500

1,000

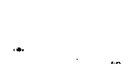

1,000

Production

500

500

${ }^{\circ}$ Aug Sep $\begin{gathered}\text { Imports } \\ 1990\end{gathered}$ Nov Dec Jan Feb Mar Apr $\begin{gathered}\text { May Jun Jul Aug Sep } \\ \text { Months }\end{gathered}$

Source: Energy Information Administration, Petroleum Supply Monthly, Table S6. See Summary Statistics Table and Figure Sources.

\section{Figure S10. Residual Fuel Oil Ending Stocks, August 1990 - Present}

100

80

80

$\begin{array}{ll}\frac{\infty}{2} & 60 \\ \frac{\infty}{\infty} & \\ \frac{5}{\Sigma} & \\ \sum & 40\end{array}$

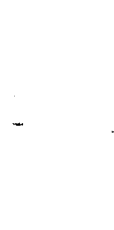

Average Stock Range

60

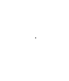

Minimum Operating Inventory

20

Sep Oct
1990 Nov Dec Jan Feb Mar Apr $\underset{1991}{\text { May Jun Jul Aug Sep }}$ Months

Note: The National Petroleum Council (NPC) defines the Minimum Operating Inventory as the inventory level below which operating problems and shortages would begin to appear in a defined distribution system. In its 1988 study, the NPC estimated this inventory level for residual fuel oil to be $\mathbf{3 0}$ million barrels.

Source: Energy Information Administration, Petroleum Supply Monthly, Table S6. See Summary Statistics Table and Figure Sources. 
Table S6. Residual Fuel OII Supply and Disposition, 1973 - Present

\begin{tabular}{|c|c|c|c|c|c|c|c|c|}
\hline & \multirow{3}{*}{ Year/Month } & \multicolumn{3}{|c|}{ Supply } & \multicolumn{3}{|c|}{ Disposition } & \multirow{3}{*}{$\begin{array}{c}\begin{array}{c}\text { Ending } \\
\text { Stocks }\end{array} \\
\text { Mittion Barrels }\end{array}$} \\
\hline & & $\begin{array}{c}\text { Total } \\
\text { Production }\end{array}$ & Imports & $\begin{array}{c}\text { Crude } \\
\text { Used } \\
\text { Directlya }\end{array}$ & $\begin{array}{c}\text { Stock } \\
\text { Changeb }\end{array}$ & Exports & $\begin{array}{l}\text { Product } \\
\text { Supplied }\end{array}$ & \\
\hline & & \multicolumn{6}{|c|}{ Thousand Barrels per Day } & \\
\hline $\begin{array}{l}1973 \\
1974 \\
1975 \\
1976 \\
1977 \\
1978 \\
1979 \\
1980 \\
1981 \\
1982 \\
1983 \\
1984 \\
1985 \\
1986 \\
1987 \\
1988\end{array}$ & $\begin{array}{l}\text { Average } \\
\text { Average }\end{array}$................. & $\begin{array}{r}971 \\
1,070 \\
1,235 \\
1,377 \\
1,754 \\
1,667 \\
1,687 \\
1,580 \\
1,321 \\
1,070 \\
852 \\
891 \\
882 \\
889 \\
885 \\
926\end{array}$ & $\begin{array}{r}1,853 \\
1,587 \\
1,223 \\
1,413 \\
1,359 \\
1,355 \\
1,151 \\
939 \\
800 \\
776 \\
699 \\
681 \\
510 \\
669 \\
565 \\
644\end{array}$ & $\begin{array}{l}17 \\
13 \\
15 \\
17 \\
13 \\
13 \\
12 \\
12 \\
48 \\
48 \\
- \\
- \\
- \\
-\end{array}$ & $\begin{array}{r}-5 \\
17 \\
d-2 \\
-5 \\
48 \\
1 \\
15 \\
-10 \\
d-37 \\
-32 \\
d-55 \\
12 \\
-7 \\
-8 \\
(8) \\
-8\end{array}$ & $\begin{array}{r}23 \\
14 \\
15 \\
12 \\
6 \\
13 \\
9 \\
33 \\
118 \\
209 \\
185 \\
190 \\
197 \\
147 \\
186 j \\
200\end{array}$ & $\begin{array}{l}2,822 \\
2,639 \\
2,462 \\
2,801 \\
3,071 \\
3,023 \\
2,826 \\
2,508 \\
2,088 \\
1,716 \\
1,421 \\
1,369 \\
1,202 \\
1,418 \\
1,264 \\
1,378\end{array}$ & $\begin{array}{r}53 \\
\text { d } 60 \\
74 \\
72 \\
90 \\
90 \\
96 \\
\text { d } 92 \\
78 \\
\text { d } 66 \\
49 \\
53 \\
50 \\
47 \\
47 \\
45\end{array}$ \\
\hline 1989 & 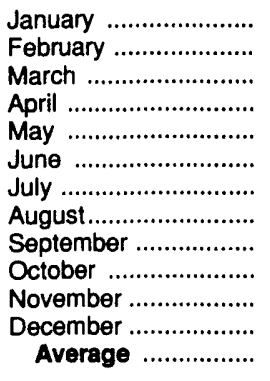 & $\begin{array}{r}949 \\
930 \\
937 \\
904 \\
934 \\
953 \\
862 \\
903 \\
856 \\
1,001 \\
1,075 \\
1,140 \\
954\end{array}$ & $\begin{array}{l}909 \\
877 \\
706 \\
681 \\
538 \\
533 \\
556 \\
501 \\
454 \\
583 \\
543 \\
680 \\
629\end{array}$ & $\begin{array}{l}- \\
- \\
z \\
z \\
z \\
- \\
-\end{array}$ & $\begin{array}{r}84 \\
-58 \\
-128 \\
-52 \\
77 \\
54 \\
-44 \\
58 \\
162 \\
50 \\
48 \\
-275 \\
-2\end{array}$ & $\begin{array}{l}151 \\
146 \\
220 \\
236 \\
276 \\
208 \\
176 \\
225 \\
137 \\
243 \\
330 \\
226 \\
215\end{array}$ & $\begin{array}{l}1,623 \\
1,719 \\
1,551 \\
1,401 \\
1,119 \\
1,223 \\
1,286 \\
1,121 \\
1,010 \\
1,292 \\
1,240 \\
1,870 \\
1,370\end{array}$ & $\begin{array}{l}47 \\
46 \\
42 \\
40 \\
42 \\
44 \\
43 \\
45 \\
49 \\
51 \\
52 \\
44 \\
-\end{array}$ \\
\hline 1990 & $\begin{array}{l}\text { January } \\
\text { February ........... } \\
\text { March ................. } \\
\text { April . } \\
\text { May } \\
\text { June }\end{array}$ & $\begin{array}{r}1,163 \\
1,060 \\
976 \\
882 \\
884 \\
926 \\
987 \\
944 \\
909 \\
799 \\
846 \\
1,021 \\
950\end{array}$ & $\begin{array}{l}825 \\
663 \\
335 \\
559 \\
507 \\
485 \\
536 \\
574 \\
313 \\
383 \\
387 \\
484 \\
504\end{array}$ & $\begin{array}{l}- \\
- \\
- \\
- \\
- \\
- \\
- \\
- \\
- \\
-\end{array}$ & $\begin{array}{r}205 \\
36 \\
-158 \\
90 \\
22 \\
-98 \\
72 \\
-1 \\
15 \\
-3 \\
25 \\
-50 \\
13\end{array}$ & $\begin{array}{l}186 \\
214 \\
277 \\
200 \\
141 \\
207 \\
171 \\
280 \\
200 \\
160 \\
243 \\
259 \\
211\end{array}$ & $\begin{array}{r}1,597 \\
1,474 \\
1,192 \\
1,151 \\
1,227 \\
1,302 \\
1,280 \\
1,238 \\
1,007 \\
1,026 \\
965 \\
1,296 \\
1,229\end{array}$ & $\begin{array}{l}50 \\
51 \\
46 \\
49 \\
50 \\
47 \\
49 \\
49 \\
49 \\
49 \\
50 \\
49 \\
-\end{array}$ \\
\hline 1991 & 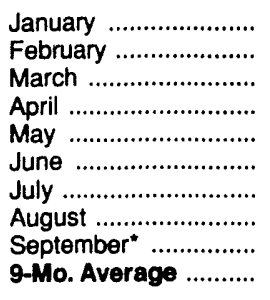 & $\begin{array}{r}1,000 \\
1,049 \\
997 \\
915 \\
926 \\
933 \\
870 \\
R_{925} \\
E_{878} \\
E_{943}\end{array}$ & $\begin{array}{r}422 \\
384 \\
331 \\
416 \\
420 \\
499 \\
419 \\
R_{568} \\
E_{408} \\
E_{430}\end{array}$ & $\begin{array}{l}- \\
- \\
- \\
- \\
- \\
-\end{array}$ & $\begin{array}{r}-32 \\
-106 \\
-55 \\
58 \\
36 \\
-78 \\
-4 \\
R_{72} \\
E_{40} \\
E_{-7}\end{array}$ & $\begin{array}{r}320 \\
299 \\
178 \\
145 \\
300 \\
245 \\
176 \\
R_{216} \\
E_{154} \\
E_{226}\end{array}$ & $\begin{array}{l}1,133 \\
1,239 \\
1,206 \\
1,128 \\
1,010 \\
1,265 \\
1,118 \\
R_{1,205} \\
E_{1,092} \\
E_{1,154}\end{array}$ & $\begin{array}{r}48 \\
45 \\
43 \\
45 \\
46 \\
43 \\
43 \\
46 \\
\mathrm{E} 48 \\
\end{array}$ \\
\hline $\begin{array}{l}1990 \\
1989\end{array}$ & $\begin{array}{l}\text { 9-Mo. Average ........... } \\
\text { 9-Mo. Average .......... }\end{array}$ & $\begin{array}{l}970 \\
914\end{array}$ & $\begin{array}{l}532 \\
638\end{array}$ & - & $\begin{array}{l}21 \\
18\end{array}$ & $\begin{array}{l}208 \\
198\end{array}$ & $\begin{array}{l}1,273 \\
1,336\end{array}$ & $\overline{-}$ \\
\hline
\end{tabular}

a Beginning in January 1983, product supplied for residual fuel oil does not include crude oll usea directly.

b A negative number indicates a decrease in stocks and a positive number indicates an increase.

c Stocks are totals as of end of period.

d In January 1975, 1981, and 1983, numerous respondents were added to surveys affecting stocks reported and stock change calculations. See Summary Statistics Explanatory Note 4.

$\theta$ Beginning in January 1981, survey forms were modified. See Summary Statistics Explanatory Note 4.

$\mathrm{R}=$ Revised data. $(\mathrm{s})=$ Less than 500 barrels per day. $\mathrm{E}=$ Estimated.

- See Summary Statistics Explanatory Note 1.

Notes: - Italics denote estimates based upon preliminary data. - Geographic coverage is the 50 States and the District of Columbla. - Totals may not equal sum of components due to independent rounding.

Source: See Summary Statistics Table and Figure Sources. 
Figure S11. Jet Fuel Supply and Disposition, August 1990 - Present

2,100

2,100

1,800

1,800

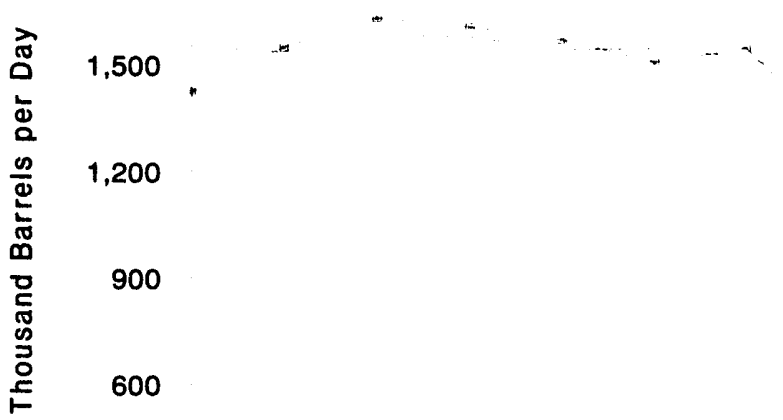

1,500

Total Production

1,200

900

600

300

Imports

300

${ }^{0}$ Aug Sep $\begin{gathered}\text { Oct } \\ 1990\end{gathered}$ Nov Dec Jan Feb Mar Apr $\begin{gathered}\text { May Jun Jul Aug Sep } \\ 1991\end{gathered}$ Months

Source: Energy Information Administration, Petroleum Supply Monthly, Table S7. See Summary Statistics Table and Figure Sources.

\section{Figure S12. Jet Fuel Ending Stocks, August 1990 - Present}

100

80

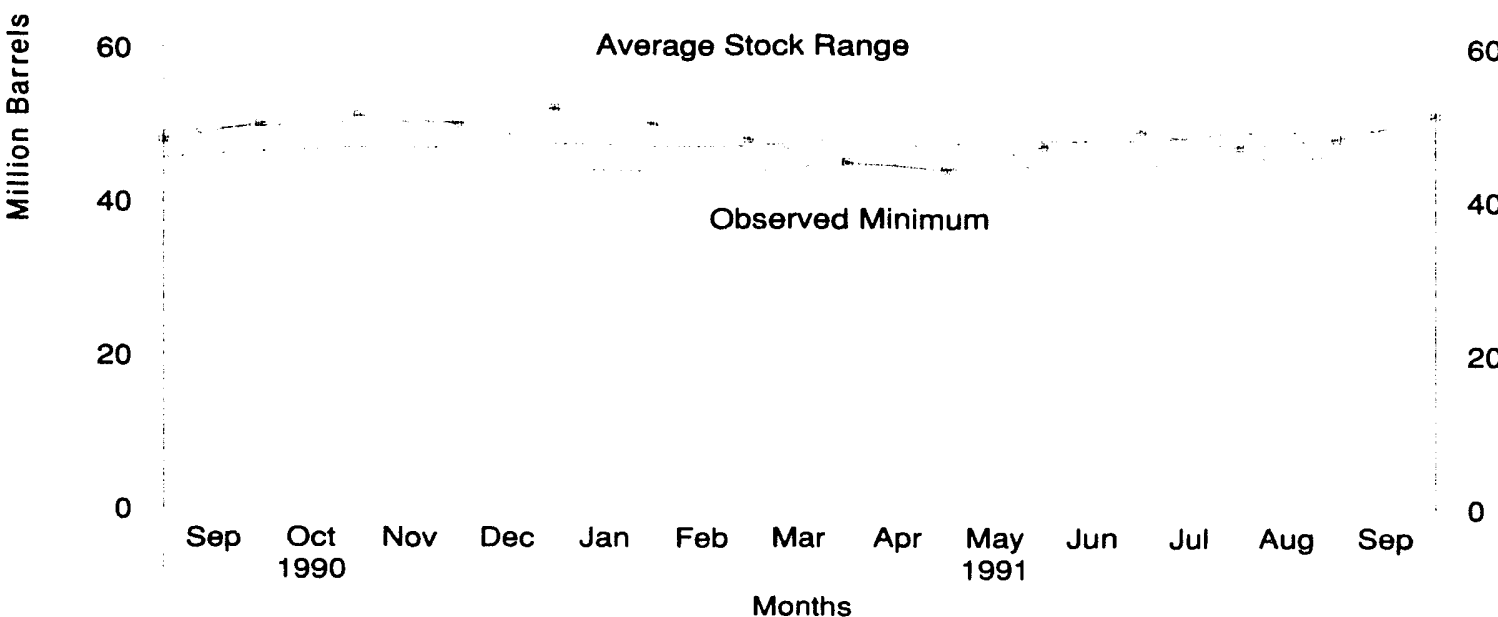

Note: The observed minimum for total stocks in the last 36-month period was 40.9 million barrels, occuring in December 1989.

Source: Energy Information Administration, Petroleum Supply Monthly, Table S7. See Summary Statistics Table and Figure Sources. 
Table S7. Jet Fuel Supply and Disposition, 1973 - Present

\begin{tabular}{|c|c|c|c|c|c|c|c|c|c|c|}
\hline & \multirow{4}{*}{ Year/Month } & \multicolumn{3}{|c|}{ Supply } & \multicolumn{4}{|c|}{ Disposition } & \multicolumn{2}{|c|}{ Ending Stocks ${ }^{a}$} \\
\hline & & \multicolumn{2}{|c|}{ Production } & \multirow[b]{2}{*}{ Imports } & \multirow[b]{2}{*}{$\begin{array}{c}\text { Stock } \\
\text { Changeb }\end{array}$} & \multirow[b]{2}{*}{ Exports } & \multicolumn{2}{|c|}{ Product Supplled } & \multirow[b]{2}{*}{ Total } & \multirow{2}{*}{$\begin{array}{c}\text { Kerosene } \\
\text { Type }\end{array}$} \\
\hline & & Total & Kerosene-Type & & & & Total & Kerosene-Type & & \\
\hline & & \multicolumn{7}{|c|}{ Thousand Barrels per Day } & \multicolumn{2}{|c|}{ Million Barrels } \\
\hline $\begin{array}{l}1973 \\
1974 \\
1975 \\
1976 \\
1977 \\
1978 \\
1979 \\
1980 \\
1981 \\
1982 \\
1983 \\
1984 \\
1985 \\
1986 \\
1987 \\
1988\end{array}$ & 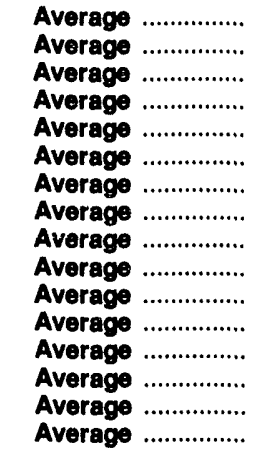 & $\begin{array}{r}859 \\
836 \\
871 \\
918 \\
973 \\
970 \\
1,012 \\
999 \\
968 \\
978 \\
1,022 \\
1,132 \\
1,189 \\
1,293 \\
1,343 \\
1,370\end{array}$ & $\begin{array}{r}679 \\
641 \\
691 \\
731 \\
787 \\
791 \\
835 \\
811 \\
775 \\
778 \\
817 \\
919 \\
983 \\
1,097 \\
1,138 \\
1,164\end{array}$ & $\begin{array}{r}212 \\
163 \\
133 \\
76 \\
75 \\
86 \\
78 \\
80 \\
38 \\
29 \\
29 \\
62 \\
39 \\
57 \\
67 \\
90\end{array}$ & $\begin{array}{r}8 \\
2 \\
c_{2} \\
5 \\
7 \\
-2 \\
13 \\
10 \\
c^{-4} \\
-12 \\
c^{c}(8) \\
9 \\
-4 \\
25 \\
(8) \\
-17\end{array}$ & $\begin{array}{r}4 \\
3 \\
2 \\
2 \\
2 \\
1 \\
1 \\
1 \\
2 \\
6 \\
6 \\
9 \\
13 \\
18 \\
24 \\
28\end{array}$ & $\begin{array}{r}1,059 \\
993 \\
1,001 \\
987 \\
1,039 \\
1,057 \\
1,076 \\
1,068 \\
1,007 \\
1,013 \\
1,046 \\
1,175 \\
1,218 \\
1,307 \\
1,385 \\
1,449\end{array}$ & $\begin{array}{r}842 \\
771 \\
791 \\
789 \\
831 \\
858 \\
876 \\
851 \\
809 \\
804 \\
839 \\
953 \\
1,005 \\
1,105 \\
1,181 \\
1,236\end{array}$ & $\begin{array}{r}29 \\
c_{29} \\
30 \\
32 \\
35 \\
34 \\
39 \\
c^{4} 42 \\
41 \\
c^{4} 37 \\
39 \\
42 \\
40 \\
50 \\
50 \\
44\end{array}$ & $\begin{array}{r}23 \\
c_{24} \\
25 \\
26 \\
28 \\
28 \\
33 \\
c_{36} \\
34 \\
c^{31} \\
32 \\
35 \\
34 \\
43 \\
42 \\
38\end{array}$ \\
\hline 1989 & 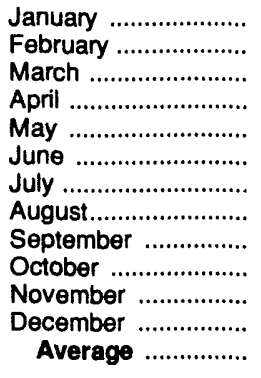 & $\begin{array}{l}1,503 \\
1,404 \\
1,396 \\
1,270 \\
1,249 \\
1,350 \\
1,410 \\
1,437 \\
1,442 \\
1,504 \\
1,514 \\
1,354 \\
1,403\end{array}$ & $\begin{array}{l}1,312 \\
1,214 \\
1,188 \\
1,074 \\
1,031 \\
1,139 \\
1,194 \\
1,237 \\
1,218 \\
1,300 \\
1,305 \\
1,149 \\
1,197\end{array}$ & $\begin{array}{r}101 \\
120 \\
101 \\
127 \\
120 \\
124 \\
113 \\
90 \\
95 \\
74 \\
91 \\
115 \\
106\end{array}$ & $\begin{array}{r}21 \\
-40 \\
-2 \\
31 \\
40 \\
-27 \\
90 \\
28 \\
-13 \\
74 \\
34 \\
-335 \\
-8\end{array}$ & $\begin{array}{r}75 \\
21 \\
11 \\
16 \\
1 \\
1 \\
11 \\
15 \\
34 \\
30 \\
52 \\
59 \\
27\end{array}$ & $\begin{array}{l}1,508 \\
1,542 \\
1,488 \\
1,351 \\
1,328 \\
1,500 \\
1,422 \\
1,484 \\
1,516 \\
1,474 \\
1,519 \\
1,745 \\
1,489\end{array}$ & $\begin{array}{l}1,334 \\
1,342 \\
1,277 \\
1,150 \\
1,103 \\
1,286 \\
1,219 \\
1,260 \\
1,316 \\
1,252 \\
1,337 \\
1,541 \\
1,284\end{array}$ & $\begin{array}{l}44 \\
43 \\
43 \\
44 \\
45 \\
45 \\
47 \\
48 \\
48 \\
50 \\
51 \\
41 \\
-\end{array}$ & $\begin{array}{l}38 \\
37 \\
37 \\
38 \\
39 \\
38 \\
41 \\
42 \\
41 \\
44 \\
44 \\
34 \\
-\end{array}$ \\
\hline 1990 & 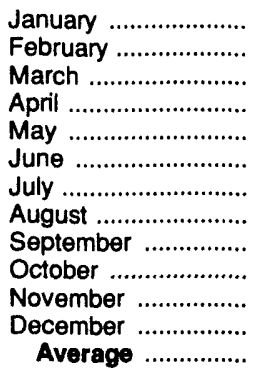 & $\begin{array}{l}1,527 \\
1,530 \\
1,457 \\
1,357 \\
1,392 \\
1,388 \\
1,434 \\
1,424 \\
1,548 \\
1,630 \\
1,606 \\
1,570 \\
1,488\end{array}$ & $\begin{array}{r}1,340 \\
1,330 \\
1,256 \\
1,179 \\
1,194 \\
1,214 \\
1,307 \\
1,250 \\
1,339 \\
1,463 \\
1,445 \\
1,411 \\
1,311\end{array}$ & $\begin{array}{r}163 \\
158 \\
120 \\
103 \\
119 \\
125 \\
99 \\
83 \\
81 \\
71 \\
93 \\
82 \\
108\end{array}$ & $\begin{array}{r}76 \\
120 \\
92 \\
-91 \\
8 \\
13 \\
117 \\
-82 \\
48 \\
39 \\
-19 \\
51 \\
31\end{array}$ & $\begin{array}{r}30 \\
50 \\
30 \\
19 \\
8 \\
10 \\
10 \\
37 \\
47 \\
77 \\
141 \\
60 \\
43\end{array}$ & $\begin{array}{l}1,584 \\
1,519 \\
1,455 \\
1,531 \\
1,495 \\
1,490 \\
1,406 \\
1,552 \\
1,534 \\
1,585 \\
1,578 \\
1,541 \\
1,522\end{array}$ & $\begin{array}{l}1,404 \\
1,316 \\
1,289 \\
1,335 \\
1,313 \\
1,320 \\
1,259 \\
1,363 \\
1,329 \\
1,406 \\
1,369 \\
1,378 \\
1,340\end{array}$ & $\begin{array}{l}43 \\
47 \\
49 \\
47 \\
47 \\
47 \\
51 \\
48 \\
50 \\
51 \\
50 \\
52 \\
-\end{array}$ & $\begin{array}{l}37 \\
40 \\
42 \\
40 \\
40 \\
40 \\
45 \\
43 \\
44 \\
45 \\
45 \\
46 \\
-\end{array}$ \\
\hline 1991 & 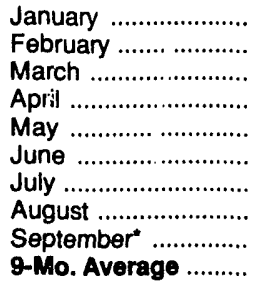 & $\begin{array}{r}1,508 \\
1,548 \\
1,299 \\
1,286 \\
1,365 \\
1,473 \\
1,426 \\
R 1,486 \\
E_{1,510} \\
E_{1,432}\end{array}$ & $\begin{array}{r}1,353 \\
1,384 \\
1,157 \\
1,135 \\
1,190 \\
1,300 \\
1,255 \\
1,316 \\
1,344 \\
E_{1,269}\end{array}$ & $\begin{array}{r}67 \\
44 \\
65 \\
73 \\
87 \\
64 \\
67 \\
\text { R } 72 \\
\text { E } 79 \\
E_{69}\end{array}$ & $\begin{array}{r}-46 \\
-91 \\
-109 \\
-29 \\
104 \\
56 \\
-49 \\
\mathrm{R}_{20} \\
\mathrm{E}_{95} \\
\mathrm{E}_{-5}\end{array}$ & $\begin{array}{r}73 \\
159 \\
40 \\
38 \\
35 \\
13 \\
31 \\
R_{11} \\
E_{33} \\
E_{47}\end{array}$ & $\begin{array}{r}1,548 \\
1,523 \\
1,433 \\
1,350 \\
1,314 \\
1,468 \\
1,511 \\
R_{1,527} \\
E_{1,461} \\
E_{1,459}\end{array}$ & $\begin{array}{r}1,367 \\
1,342 \\
1,279 \\
1,195 \\
1,123 \\
1,282 \\
1,344 \\
R_{1,328} \\
\text { E } 1,285 \\
\text { E } 1,283\end{array}$ & $\begin{array}{r}50 \\
48 \\
45 \\
44 \\
47 \\
49 \\
47 \\
48 \\
\text { E } 51 \\
-\end{array}$ & $\begin{array}{r}44 \\
42 \\
39 \\
38 \\
41 \\
43 \\
41 \\
\mathrm{R}_{42} \\
\mathrm{E}_{46} \\
\end{array}$ \\
\hline $\begin{array}{l}1990 \\
1989\end{array}$ & $\begin{array}{l}\text { 9-Mo. Average ......... } \\
\text { 9-Mo. Average ......... }\end{array}$ & $\begin{array}{l}1,450 \\
1,385\end{array}$ & $\begin{array}{l}1,267 \\
1,179\end{array}$ & $\begin{array}{l}117 \\
110\end{array}$ & $\begin{array}{l}33 \\
15\end{array}$ & $\begin{array}{l}27 \\
21\end{array}$ & $\begin{array}{l}1,507 \\
1,459\end{array}$ & $\begin{array}{l}1,325 \\
1,253\end{array}$ & - & - \\
\hline
\end{tabular}

a Stocks are totals as of end of period.

b A negative number indicates a decrease in stocks and a positive number indicates an increase.

c In January 1975,1981,1983, and 1984, a new stock basis was established affecting stocks reported and stock change calculations.

See Summary Statistics Explanatory Note 4

$(s)=$ Less than 500 barrels per day. $E=$ Estimated.

" See Summary Statistics Explanatory Note 1.

Notes: - italics denote estimates based upon preliminary data. Geographic coverage is the 50 States and the District of Columbia. - Totals may not equal sum of compr nents due to independent rounding.

Source' See Summary Statistics Table and Figure Sources. 
Figure S13. Liquefied Petroleum Gases Supply and Disposition, July 1990 - Present
2,500
2,500

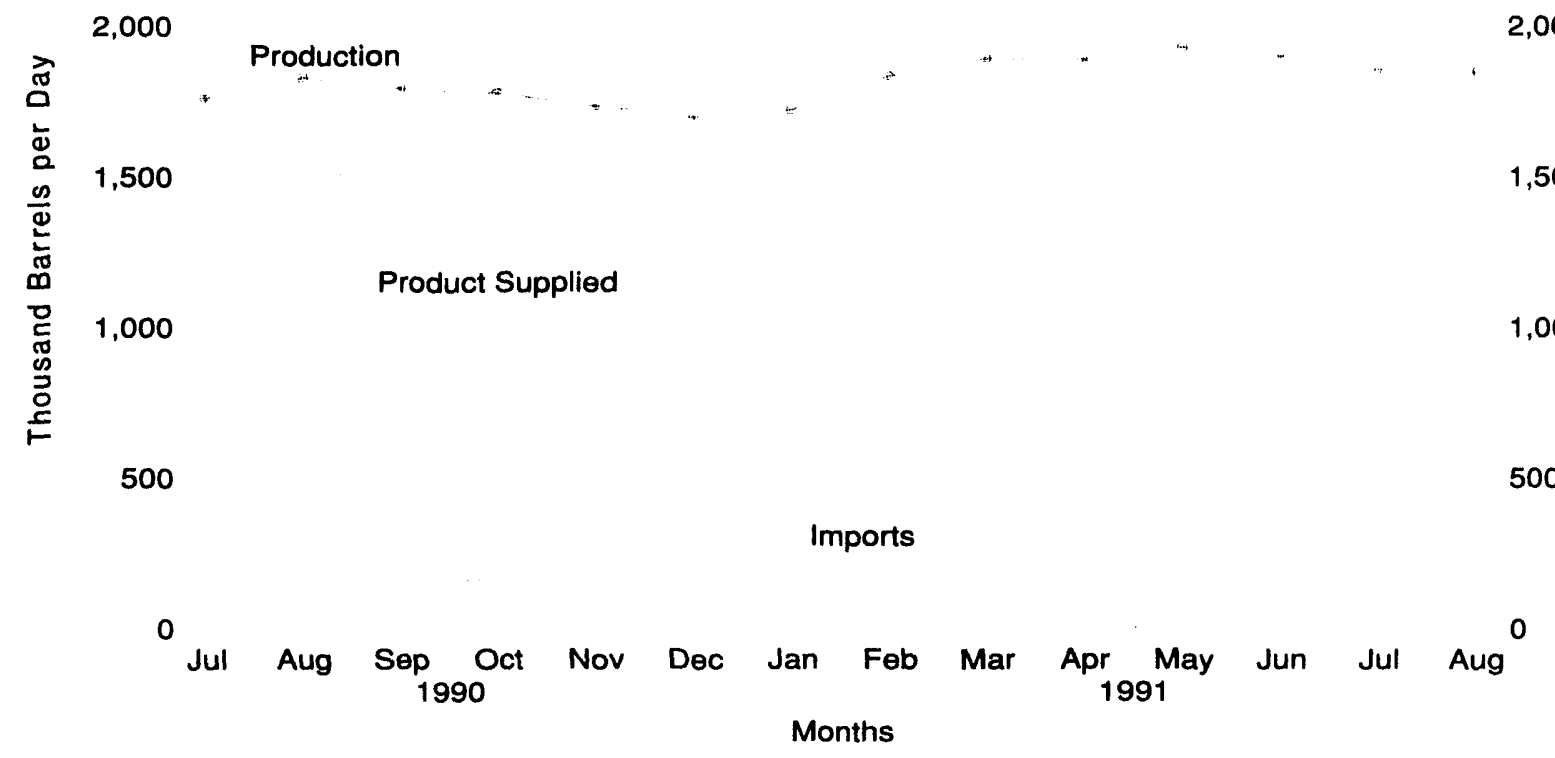

Source: Energy Information Administration, Petroleum Supply Monthly, Table S8. See Summary Statistics Table and Figure Sources.

Figure S14. Liquefied Petroleum Gases Ending Stocks, July 1990 - Present

200

150

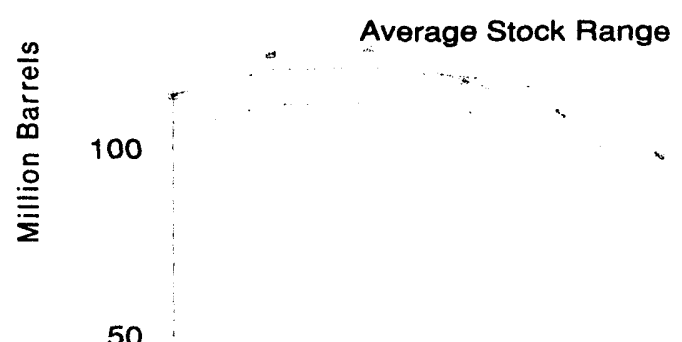

0

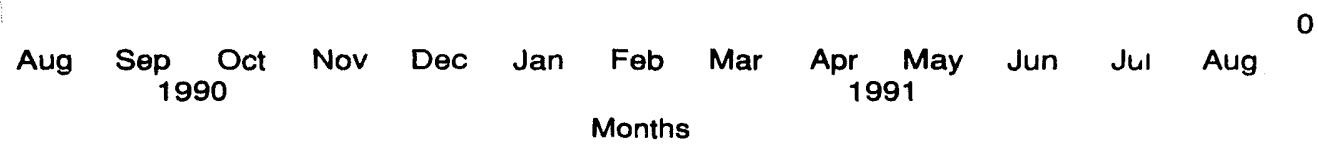

Source: Energy Information Administration, Petroleum Supply Monthly, Table S8. See Summary Statistics Table and Figure Sources. 
Table S8. Liquefied Petroleum Gases ${ }^{a}$ Supply and Dispozition, 1973 - Present

\begin{tabular}{|c|c|c|c|c|c|c|c|c|}
\hline & \multirow{3}{*}{ Year/Month } & \multicolumn{2}{|c|}{ Supply } & \multicolumn{4}{|c|}{ Disposition } & \multirow{3}{*}{$\frac{\begin{array}{c}\text { Ending } \\
\text { Stocks }\end{array}}{\text { Million Barrels }}$} \\
\hline & & $\begin{array}{c}\text { Total } \\
\text { Production }\end{array}$ & Imports & $\begin{array}{c}\text { Stock } \\
\text { Changeb }\end{array}$ & $\begin{array}{c}\text { Refinery } \\
\text { Inputs }\end{array}$ & Exports & $\begin{array}{l}\text { Product } \\
\text { Supplied }\end{array}$ & \\
\hline & & \multicolumn{6}{|c|}{ Thousand Barrels per Day } & \\
\hline $\begin{array}{l}1973 \\
1974 \\
1975 \\
1976 \\
1977 \\
1978 \\
1979 \\
1980 \\
1981 \\
1982 \\
1983 \\
1994 \\
1985 \\
1986 \\
1987 \\
1988\end{array}$ & $\begin{array}{l}\text { Average } \\
\text { Average } \\
\text { Average } \\
\text { Average } \\
\text { Average } \\
\text { Avera } \\
\text { Average } \\
\text { Average } \\
\text { Average } \\
\text { Average }\end{array}$ & $\begin{array}{l}1,600 \\
1,565 \\
1,527 \\
1,535 \\
1,566 \\
1,537 \\
1,556 \\
1,535 \\
1,571 \\
1,528 \\
1,642 \\
1,697 \\
1,704 \\
1,695 \\
1,748 \\
1,817\end{array}$ & $\begin{array}{l}132 \\
123 \\
112 \\
130 \\
161 \\
123 \\
217 \\
216 \\
244 \\
226 \\
190 \\
195 \\
187 \\
242 \\
190 \\
209\end{array}$ & $\begin{array}{r}35 \\
38 \\
d 35 \\
-24 \\
55 \\
-12 \\
-70 \\
27 \\
d 18 \\
-111 \\
-11 \\
d-4 \\
d-19 \\
-75 \\
80 \\
-15 \\
1\end{array}$ & $\begin{array}{l}220 \\
220 \\
246 \\
260 \\
233 \\
239 \\
236 \\
233 \\
289 \\
300 \\
253 \\
291 \\
304 \\
302 \\
304 \\
321\end{array}$ & $\begin{array}{l}27 \\
25 \\
26 \\
25 \\
18 \\
20 \\
15 \\
21 \\
42 \\
65 \\
73 \\
48 \\
62 \\
42 \\
38 \\
49\end{array}$ & $\begin{array}{l}1,449 \\
1,406 \\
1,333 \\
1,404 \\
1,422 \\
1,413 \\
1,592 \\
1,469 \\
1,466 \\
1,499 \\
1,509 \\
1,572 \\
1,599 \\
1,512 \\
1,612 \\
1,656\end{array}$ & $\begin{array}{r}99 \\
d 113 \\
125 \\
116 \\
136 \\
132 \\
111 \\
d 120 \\
135 \\
d 94 \\
d 101 \\
101 \\
74 \\
103 \\
97 \\
97\end{array}$ \\
\hline 1989 & 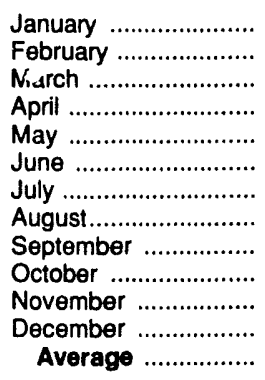 & $\begin{array}{l}1,885 \\
1,798 \\
1,909 \\
1,950 \\
1,943 \\
1,824 \\
1,850 \\
1,787 \\
1,737 \\
1,679 \\
1,643 \\
1,483 \\
1,791\end{array}$ & $\begin{array}{l}239 \\
260 \\
150 \\
121 \\
110 \\
155 \\
192 \\
202 \\
182 \\
176 \\
179 \\
205 \\
181\end{array}$ & $\begin{array}{r}-335 \\
-333 \\
-85 \\
294 \\
428 \\
269 \\
407 \\
272 \\
-46 \\
-313 \\
-389 \\
-749 \\
-47\end{array}$ & $\begin{array}{l}422 \\
328 \\
274 \\
242 \\
226 \\
254 \\
247 \\
245 \\
303 \\
371 \\
446 \\
424 \\
315\end{array}$ & $\begin{array}{l}19 \\
31 \\
43 \\
27 \\
43 \\
35 \\
45 \\
40 \\
31 \\
31 \\
33 \\
37 \\
35\end{array}$ & $\begin{array}{l}2,018 \\
2,032 \\
1,827 \\
1,507 \\
1,357 \\
1,422 \\
1,343 \\
1,433 \\
1,631 \\
1,766 \\
1,732 \\
1,975 \\
1,668\end{array}$ & $\begin{array}{r}87 \\
78 \\
75 \\
84 \\
97 \\
105 \\
118 \\
126 \\
125 \\
115 \\
103 \\
80 \\
-\end{array}$ \\
\hline 1990 & $\begin{array}{l}\text { January } \\
\text { February } \\
\text { March } \\
\text { April } \\
\text { May } \\
\text { June } \\
\text { July } \\
\text { August } \\
\text { September } \\
\text { October } \\
\text { November } \\
\text { December } \\
\text { Average }\end{array}$ & $\begin{array}{l}1,684 \\
1,743 \\
1,763 \\
1,751 \\
1,761 \\
1,719 \\
1,756 \\
1,825 \\
1,789 \\
1,773 \\
1,731 \\
1,692 \\
1,749\end{array}$ & $\begin{array}{l}261 \\
235 \\
155 \\
150 \\
204 \\
202 \\
157 \\
256 \\
149 \\
159 \\
140 \\
184 \\
188\end{array}$ & $\begin{array}{r}-92 \\
11 \\
80 \\
91 \\
287 \\
469 \\
268 \\
339 \\
37 \\
-243 \\
-296 \\
-370 \\
48\end{array}$ & $\begin{array}{l}414 \\
339 \\
199 \\
195 \\
209 \\
212 \\
217 \\
236 \\
293 \\
348 \\
427 \\
427 \\
293\end{array}$ & $\begin{array}{l}44 \\
42 \\
44 \\
25 \\
36 \\
28 \\
36 \\
43 \\
41 \\
38 \\
39 \\
58 \\
40\end{array}$ & $\begin{array}{l}1,580 \\
1,587 \\
1,595 \\
1,589 \\
1,433 \\
1,211 \\
1,392 \\
1,463 \\
1,567 \\
1,790 \\
1,702 \\
1,762 \\
1,556\end{array}$ & $\begin{array}{r}77 \\
78 \\
80 \\
83 \\
92 \\
106 \\
114 \\
125 \\
126 \\
118 \\
109 \\
98 \\
-\end{array}$ \\
\hline 1991 & 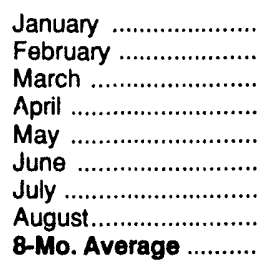 & $\begin{array}{l}1,716 \\
1,829 \\
1,887 \\
1,881 \\
1,924 \\
1,894 \\
1,851 \\
1,844 \\
1,853\end{array}$ & $\begin{array}{r}137 \\
119 \\
81 \\
149 \\
127 \\
143 \\
146 \\
137 \\
130\end{array}$ & $\begin{array}{r}-700 \\
-267 \\
121 \\
353 \\
425 \\
324 \\
181 \\
153 \\
76\end{array}$ & $\begin{array}{l}359 \\
304 \\
234 \\
224 \\
221 \\
238 \\
244 \\
244 \\
258\end{array}$ & $\begin{array}{l}56 \\
60 \\
56 \\
31 \\
45 \\
32 \\
24 \\
18 \\
40\end{array}$ & $\begin{array}{l}2,139 \\
1,850 \\
1,556 \\
1,423 \\
1,360 \\
1,443 \\
1,548 \\
1,566 \\
1,609\end{array}$ & $\begin{array}{r}76 \\
69 \\
73 \\
83 \\
96 \\
106 \\
112 \\
116 \\
-\end{array}$ \\
\hline $\begin{array}{l}1990 \\
1989\end{array}$ & 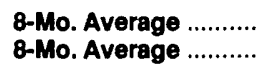 & $\begin{array}{l}1,750 \\
1,869\end{array}$ & $\begin{array}{l}202 \\
178\end{array}$ & $\begin{array}{l}183 \\
119\end{array}$ & $\begin{array}{l}252 \\
279\end{array}$ & $\begin{array}{l}37 \\
35\end{array}$ & $\begin{array}{l}1,481 \\
1,613\end{array}$ & $\overline{-}$ \\
\hline
\end{tabular}

a Includes ethane, propane, normal butane, and isobutalı. Beginning in January 1984, unfractionated stream is reported by individual product.

b A negative number indicates a decrease in stocks and a positive number indicates an increase.

c Stocks are totals as of end of period.

d In January 1975,1981,1983, and 1984, a new stock basis was established affecting stocks reported and stock change calculations.

See Summary Statistics Explanatory Note 4.

Notes: - Geographic coverage is the 50 States and the District of Columbia. - Totals may not equal sum of components due to independent rounding

Source: See Summary Statistics Table and Figure Sources. 
Table S9. Other Petroleum Products ${ }^{\mathrm{a}}$ Supply and Disposition, 1973 - Present

\begin{tabular}{|c|c|c|c|c|c|c|c|c|}
\hline & \multirow{3}{*}{ Yoar/Month } & \multicolumn{2}{|c|}{ Supply } & \multicolumn{4}{|c|}{ Diaposttion } & \multirow{3}{*}{$\frac{\begin{array}{c}\text { Ending } \\
\text { Stocks }\end{array}}{\text { Million Barrels }}$} \\
\hline & & $\begin{array}{c}\text { Total } \\
\text { Production }\end{array}$ & Imports & $\begin{array}{c}\text { Stock } \\
\text { Changeb }\end{array}$ & $\begin{array}{l}\text { Refinery } \\
\text { Inputs }\end{array}$ & Exports & $\begin{array}{l}\text { Products } \\
\text { Supplled }\end{array}$ & \\
\hline & & \multicolumn{6}{|c|}{ Thcusand Barrels per Day } & \\
\hline $\begin{array}{l}1973 \\
1974 \\
1975 \\
1976 \\
1977 \\
1978 \\
1979 \\
1890 \\
1981 \\
1892 \\
1883 \\
1984 \\
1985 \\
1986 \\
1987 \\
1888\end{array}$ & 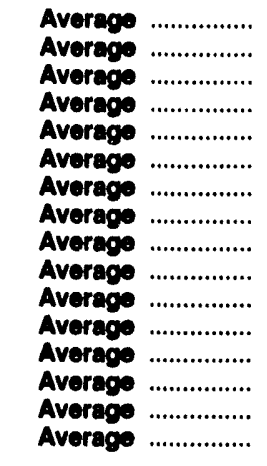 & $\begin{array}{l}2,833 \\
2,722 \\
2,547 \\
2,725 \\
2,939 \\
3,076 \\
3,141 \\
2,957 \\
2,771 \\
2,475 \\
2,437 \\
2,500 \\
2,532 \\
2,704 \\
2,737 \\
2,773\end{array}$ & $\begin{array}{r}290 \\
269 \\
144 \\
129 \\
130 \\
80 \\
116 \\
130 \\
188 \\
305 \\
382 \\
503 \\
550 \\
504 \\
543 \\
645\end{array}$ & $\begin{array}{r}1 \\
d^{25} \\
(8) \\
20 \\
-12 \\
24 \\
15 \\
d-42 \\
d^{-68} \\
d_{-3}^{-32} \\
22 \\
-15 \\
-1 \\
22\end{array}$ & $\begin{array}{l}751 \\
685 \\
537 \\
524 \\
514 \\
492 \\
352 \\
310 \\
723 \\
787 \\
712 \\
791 \\
886 \\
888 \\
829 \\
799\end{array}$ & $\begin{array}{l}162 \\
172 \\
158 \\
172 \\
164 \\
165 \\
208 \\
197 \\
197 \\
205 \\
236 \\
238 \\
227 \\
291 \\
264 \\
294\end{array}$ & $\begin{array}{l}2,211 \\
2,129 \\
2,001 \\
2,158 \\
2,371 \\
2,511 \\
2,673 \\
2,566 \\
2,081 \\
1,856 \\
1,877 \\
2,007 \\
1,947 \\
2,045 \\
2,187 \\
2,303\end{array}$ & $\begin{array}{r}179 \\
d 188 \\
188 \\
188 \\
195 \\
191 \\
200 \\
d 205 \\
205 \\
d 21 \\
d 216 \\
217 \\
198 \\
208 \\
201 \\
200 \\
208\end{array}$ \\
\hline 1889 & 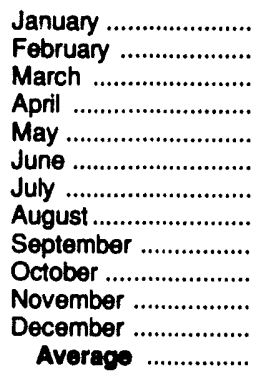 & $\begin{array}{l}2,696 \\
2,553 \\
2,671 \\
2,683 \\
2,882 \\
3,025 \\
3,044 \\
2,998 \\
2,986 \\
2,687 \\
2,608 \\
2,409 \\
2,771\end{array}$ & $\begin{array}{l}646 \\
717 \\
644 \\
727 \\
635 \\
571 \\
576 \\
587 \\
675 \\
632 \\
645 \\
486 \\
627\end{array}$ & $\begin{array}{r}375 \\
231 \\
114 \\
102 \\
181 \\
-179 \\
-159 \\
-244 \\
125 \\
-42 \\
-77 \\
-266 \\
12\end{array}$ & $\begin{array}{l}706 \\
726 \\
660 \\
808 \\
688 \\
838 \\
955 \\
893 \\
737 \\
730 \\
900 \\
918 \\
797\end{array}$ & $\begin{array}{l}236 \\
281 \\
311 \\
290 \\
258 \\
388 \\
333 \\
313 \\
309 \\
308 \\
299 \\
332 \\
305\end{array}$ & $\begin{array}{l}2,024 \\
2,032 \\
2,230 \\
2,210 \\
2,391 \\
2,549 \\
2,491 \\
2,623 \\
2,490 \\
2,323 \\
2,131 \\
1,910 \\
2,285\end{array}$ & $\begin{array}{l}220 \\
226 \\
230 \\
233 \\
239 \\
233 \\
228 \\
221 \\
224 \\
223 \\
221 \\
213 \\
-\end{array}$ \\
\hline 1980 & 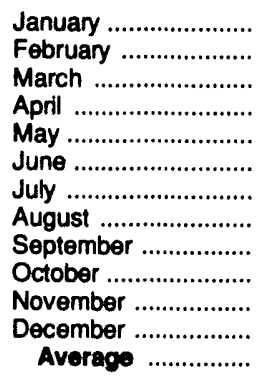 & $\begin{array}{l}2,567 \\
2,781 \\
2,670 \\
2,774 \\
2,847 \\
2,907 \\
3,146 \\
3,097 \\
3,029 \\
2,848 \\
2,788 \\
2,644 \\
2,842 \\
\end{array}$ & $\begin{array}{l}814 \\
680 \\
687 \\
596 \\
756 \\
879 \\
732 \\
673 \\
674 \\
590 \\
800 \\
575 \\
705\end{array}$ & $\begin{array}{r}86 \\
387 \\
78 \\
-138 \\
295 \\
-160 \\
-148 \\
-291 \\
68 \\
-436 \\
206 \\
-288 \\
-32\end{array}$ & $\begin{array}{r}735 \\
654 \\
795 \\
869 \\
544 \\
919 \\
958 \\
998 \\
760 \\
1,211 \\
1,010 \\
1,172 \\
887\end{array}$ & $\begin{array}{l}225 \\
298 \\
276 \\
318 \\
292 \\
334 \\
317 \\
297 \\
265 \\
329 \\
270 \\
249 \\
289\end{array}$ & $\begin{array}{l}2,335 \\
2,122 \\
2,207 \\
2,320 \\
2,471 \\
2,692 \\
2,752 \\
2,766 \\
2,611 \\
2,334 \\
2,102 \\
2,087 \\
2,402\end{array}$ & $\begin{array}{l}215 \\
226 \\
229 \\
224 \\
234 \\
229 \\
224 \\
215 \\
217 \\
204 \\
210 \\
201 \\
-\end{array}$ \\
\hline 1991 & 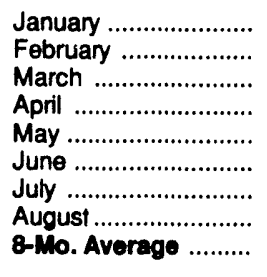 & $\begin{array}{l}2,640 \\
2,683 \\
2,585 \\
2,735 \\
2,884 \\
3,032 \\
3,036 \\
3,005 \\
2,826\end{array}$ & $\begin{array}{l}720 \\
555 \\
504 \\
584 \\
762 \\
574 \\
747 \\
625 \\
635\end{array}$ & $\begin{array}{r}167 \\
391 \\
145 \\
125 \\
209 \\
-125 \\
-129 \\
-173 \\
73\end{array}$ & $\begin{array}{r}835 \\
723 \\
832 \\
790 \\
921 \\
1,102 \\
1,082 \\
1,019 \\
915\end{array}$ & $\begin{array}{l}317 \\
275 \\
239 \\
228 \\
327 \\
304 \\
321 \\
296 \\
289\end{array}$ & $\begin{array}{l}2,041 \\
1,849 \\
1,873 \\
2,176 \\
2,190 \\
2,325 \\
2,508 \\
2,489 \\
2,185\end{array}$ & $\begin{array}{r}207 \\
218 \\
223 \\
226 \\
233 \\
229 \\
225 \\
220 \\
-\end{array}$ \\
\hline $\begin{array}{l}1990 \\
1989\end{array}$ & $\begin{array}{l}\text { 8-Mo. Average ......... } \\
\text { 8-Mo. Average ......... }\end{array}$ & $\begin{array}{l}2,849 \\
2,822\end{array}$ & $\begin{array}{l}728 \\
637\end{array}$ & $\begin{array}{l}10 \\
51\end{array}$ & $\begin{array}{l}810 \\
785\end{array}$ & $\begin{array}{l}294 \\
301\end{array}$ & $\begin{array}{l}2,462 \\
2,322\end{array}$ & - \\
\hline
\end{tabular}

a Includes pentanes plus, other hydrocarbons and aicohol, unfinished oils, gasoline blending components and all finished petroleum products except finished motor gasoline, distillate fuel oil, residual fuel oil, jet fuel, and liquefied petroleum gases.

A negative number indicates a decrease in stocks and a positive number indicates an increase.

c Stocks are totals as of end of period.

d In January 1975, 1981, 1983, and 1984, a new stock basis was established affecting stocks reported and stock change calculations.

See Summary Statistics Explanatory Note 4.

Notes: - Geographic coverage is the 50 States and the District of Columbia. - Totals may not equal sum of components due to independent rounding.

Source: See Summary Statistics Table and Figure Sources. 


\section{Summary Statistics Table and Figure Sources}

Information about petroleum supply and disposition at the National level are presented in the Summary Statistics tables. Industry terminology and product definitions are listed alphabetically in the Glossary.

The data presented in these tables are from several sources and represent different levels of timeliness and data finality.

- U.S. Department of the Interior, Bureau of Mines, Mineral Industry Surveys, Petroleum Statement, Annual and PAD Districts Supply/Demand, Annual (1973 through 1976).

- U.S. Department of Energy, Energy Information Administration (EIA), Energy Data Reports, Petroleum Statement, Annual, PAD Districts Supply/Demand, Annual, and unleaded gasoline data from Monthly Petroleum Statistics Report (1977 through 1980).
- EIA, Petroleum Supply Annual (1981 through 1990).

- EIA, Petroleum Supply Monthly (January 1991 through August 1991).

- EIA, Weekly Petroleum Supply Reporting System (except domestic crude oil production) (September 1991). A more detailed explanation is provided in Summary Statistics Explanatory Note 1.

Domestic crude oil production estimate is based on historical statistics from State conservation agencies and the Minerals Management Service of the U.S. Department of the Interior. (January 1991 through September 1991). Refer ,to Summary Statistics Explanatory Note 2 for a more detailed explanation. 


\section{Summary Statistics Explanatory Notes}

The following notes are provided to assist in understanding and interpreting the data.

\section{Note 1. Preliminary Monthly Statistics Derivation}

Data collected from the Weekly Petroleum Supply Reporting System (WPSRS) are used to develop estimates of the most current monthly quantities. The forms that comprise the WPSRS are:

$\begin{array}{cl}\text { Eorm Number } & \text { Name } \\ \text { EIA-800 } & \text { "Weekly Refinery Report" } \\ \text { EIA-801 } & \text { "Weekly Bulk Terminal Report" } \\ \text { EIA-802 } & \text { "Weekly Product Pipeline Report" } \\ \text { EIA-803 } & \text { "Weekly Crude Oil Stocks Report" } \\ \text { EIA-804 } & \text { "Weekly Imports Report" }\end{array}$

A sample of all petroleum companies report weekly data to the Energy Information Administration (EIA) on crude oil and petroleum products stocks, refinery inputs and production, and crude oil and petroleum product imports. The sample of companies that report weekly is selected from the iniverse of companies that report on the comparable monthly surveys.

The sampling procedure used for the weekly system is the cut-off method. In the cut-off method, companies are ranked from largest to smallest on the basis of the quantities reported during a 12-month period. Companies are chosen for the sample beginning with the largest companies with additional companies added until the total sample coverage represents a minimum of 90 percent of each item by geographic region being measured. All monthly-from-weekly estimates are shown in italics.

In calculating monthly estimates based upon weekly submissions, an interpolation process is used to make the weekly figures comparable to the monthly. The interpolation process is designed to resolve the timing differences bet ween the weekly and the monthly systems - . the time-of-day of reporting periods and the day-of-month of reporting periods. The end of the weekly reporting period (exactly 1 week long) is 7 a.m. Friday. The end of the monthly reporting period (one calendar month long) is 12 midnight on the last day of the month. To resolve the difference in the time-of-day of the weekly and monthly reporting periods, it is assumed that there is no activity during the period 12 midnight Thursday through 7 a.m. Friday. Thus, for the purposes of interpolation, the weekly system reporting period is assumed to end at 12 midnight on Thursday. The resolution of the day-of-month differences depends on whether the series is a cumulative one (such as production and imports) or a value at a fixed point-in-time (i.e., stocks).

For cumulative items (all items except stocks) the following method is used to calculate a monthly-from-weekly figure for a given month. First, a weight is assigned to each week in the month based on the number of days in that week that asc in the month. (All intermediate weeks in a month will have a weight of seven; the beginning and ending weeks in the month may have a weight of less than seven, according to the number of days of the week that are in the month.) The weight for each week is then multiplied by the average daily volume for that week. To arrive at the monthly-from-weekly figure, a sum is taken of these weighted weekly volumes. The daily average for the monthly-from-weekly figure is calculated by dividing the total monthly-from-weekly figure by the number of days in the month.

Stock figures are not cumulative but represent inventories as of the last day of the reporting period. When the reporting week does not coincide with the end of a reporting month, an interpolation is necessary to derive a monthly-from-weekly figure for end-of-month stocks.

To derive the monthly-from-weekly stock figures, the two weekly reports that bracket the end of the month are used. Average daily stock change and the number of interpolated days are determined. The average daily stock change is defined as one-seventh of the difference between the stock level at the end of the last full week of the month and the stock level at the end of the week containing the last day of the month. The number of interpolation days is defined as the number of days between the end of the preceding weekly reporting period (midnight Thursday) and the end of the monthly reporting period. The end-of-month stock levels are then estimated as the sum of (a) the stock level reported the last full week of the month, plus (b) the number of interpolation days multiplied by the average daily stock change for the week.

The monthly-from-weekly export data are derived by using the most recen data published in the Weekly Petroleum Status Report. Preliminary monthly export and net import estimates are displayed in Table E1. EIA recommends a careful review of the preceding methodology when utilizing these preliminary estimates. 
Table E1. Preliminary Export and Net Import Estimates, September 1991 (Thousand Barrels per Day)

\begin{tabular}{|c|c|c|c|}
\hline Commodity & Quantity & Commodity & Quantity \\
\hline Crude Oil Exports & 83 & Finished Motor Gasoline Exports . & 54 \\
\hline Petroleum Products Exports & 666 & Distillate Fuel Oil Exports ........................ & 95 \\
\hline 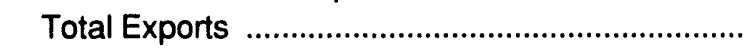 & 749 & 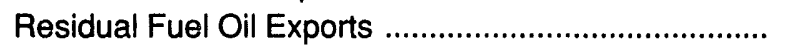 & 154 \\
\hline Net Imports & ... 7,226 & Jet Fuel Exports & 33 \\
\hline
\end{tabular}

\section{Note 2. Domestic Crude Oil Production}

The Energy Information Administration (EIA) collects monthly crude oil production data on an ongoing basis. Data on crude oil production for States are reported to the EIA by State government agencies. Data on crude oil production for Federal offshore areas are reported to the EIA by the Minerals Management Service of the U.S. Department of the Interior and the Conservation Committee of California Oil Producers.

Currently, all except four crude oil producing States (Michigan, New York, Ohio, and Pennsylvania) report production on a monthly basis. These four States report crude oil production on an annual basis. Estimates of monthly crude oil production for these four States are made by the EIA using data reported on Form EIA-182, "Domestic Crude Oil First Purchase Report." After the end of each calendar year, the monthly crude oil production estimates are updated using annual reports from various State agencies, the Minerals Management Service, and the Conservation Committee of California Oil Producers. The final estimate is published in the Petroleum Supply Annual (PSA). There is a time lag of approximately 4 months between the end of the production month and the time when most monthly State crude oil production data become available.

In order to present more timely crude oil production estimates, the EIA prepares an original, forecast estimate on the first day of the production month. Approximately 75 days later, this original estimate of monthly crude oil production is replaced by State-level interim estimates. The State-level interim estimates are based on: (a) data reported by the States (e.g., production data for Alaska are typically reported to the EIA before the interim estimate is made); (b) first purchase data reported on Form EIA-182, "Domestic Crude Oil First Purchase Report;" (c) exponential or hyperbolic curve fitted projections based on recent State data; or (d) constant level projections based on the average production rate during a recent time period.

\section{Note 3. Figures}

Figures associated with the Summary Statistics tables are provided which depict the balance between supply, disposition, and ending stocks for various commodities.
The national inventory (stocks) graphs (Figures S4, S6, S8, S10, S12 and S14) for crude oil, finished motor gasoline, distillate fuel oil, residual fuel oil, jet fuel and liquefied petroleum gases, in this publication include features to assist in comparing current inventory levels with past inventory levels and minimum operating levels. These features are described below.

The graphs displaying inventory levels provide the reader with actual inventory data compared to an average range from the most recent 3-year period running from January through December or from July through June. The ranges are updated every 6 months in April and October. The 3-year period is adjusted by dropping the oldest 6 months and including the most recent 6 months. The ranges also reflect seasonal variation determined from a 7 -year period. The seasonal factors, which determine the shape of the upper and lower curves, are updated annually in October, using the most recent year's final monthly data.

The monthly seasonal factors are estimated by means of a seasonal adjustment technique developed at the U.S. Bureau of the Census (Census X-11). The seasonal factors are assumed to be stable (i.e., unchanging from year to year) and additive (i.e., the series is deseasonalized by subtracting the seasonal factor for the appropriate month from the reported inventory levels). The intent of deseasonalization is to remove only variation from the data. Thus, a deseasonalized series would contain the same trends, cyclical components, and irregularities as the original data.

After seasonal factors are derived, data from the most recent 3-year period (January through December or July through June) are deseasonalized. The average of the deseasonalized 36-month series determines the midpoint of the deseasonalized average band. The standard deviation of the deseasonalized 36 months is calculated adjusting for extreme data points. The upper curve of the average range is defined as the average plus the standard deviation. The lower curve is defined as the average plus the seasonal factors minus the standard deviation. Thus, the width of the average range is twice the standard deviation.

The lines labeled "Minimum Operating Inventory" (MOI) on the stocks graphs for crude oil, finished motor gasoline, distillate fuel oil, and residual fuel oil represent estimates of those inventory levels made by the National Petroleum 
Council (NPC) and published in April 1989 in a report of the NPC's Committee on Petroleum Storage \& Transportation. The NPC defines the MOI as the inventory level below which operating problems and shortages would begin to appear in a defined distribution system. The NPC report presents the findings of a study which was directed by the NPC Committee. MOI estimates presented in the report were developed by consensus through a decision-making process that relied on the judgement of Committee members based on their operating experience, on historical inventory trends, and on the results of an NPC survey of companies that provide primary inventory data to the EIA. The estimated MOI values are: Crude oil - 300 million barrels; finished motor gasoline - 205 million barrels; distillate fuel oil -85 million barrels; and residual fuel oil -30 million barrels.

The NPC did not develop a minimum operating inventory level for jet fuel stocks. The line labeled "observed minimum" on the "Jet Fuel Ending Stocks" graph is the lowest inventory level observed during the most recent 36-month period as published in the Petroleum Supply Monthly.

\section{Note 4. Frames Maintenance}

In January 1975, 1981, 1983, and 1984, numerous respondents were added to bulk terminal and pipeline surveys affecting subsequent stocks reported and stock change calculations. Using the expanded coverage (new basis), the end-of-year stocks, in million barrels, would have been as listed below.

- Crude Oil: 1980-488 (Total) and 380 (Other Primary); 1982-645 (Total) and 351 (Other Primary).
- Crude Oil and Petroleum Products: 1974-1,121; 1980-1,425; and 1982-1,461.

- Motor Gasoline: 1974-225 (Total); 1980-263 (Total) and 214 (Finished); 1982-244 (Total) and 202 (Finished).

- Distillate Fuel Oil: 1974-224; 1980-205; and 1982-186.

- $\quad$ Residual Fuel Oil: 1974-75; 1980-91; and 1982-69.

- Jet Fuel: 1974-30 (Total) and 24 (Kerosene-type); 1980-42 (Total) and 36 (Kerosene-type); and 1982-39 (Total) and 32 (Kerosene-type).

- Liquefied Petroleum Gases: 1974-113; 1980-128; 1982-102; and 1983-108.

- Other Petroleum Products: 1974-190; 1980-207; 1982-219; and 1983-210.

- Stock change calculations beginning in 1975, 1981, and 1983 were made using new basis stock levels.

Stocks of Alaskan crude oil in-transit were included for the first time in January 1981. The major impact of this change is on the reporting of stock change calculations. Using the expanded coverage (new basis), 1980 end-of-year crude oil stocks would have been 488 million barrels for Total and 380 million barrels for Other Primary.

Beginning with January 1984, natural gas liquids supply and disposition data were collected on a component basis rather than a product basis. This change affected stocks reported and stock change calculations. Under the new basis, end-of-year 1983 stocks would have been 108 million barrels for Liquefied Petroleum Gases and 248 million barrels for Other Petroleum Products. 


\section{Detailed Statistics}

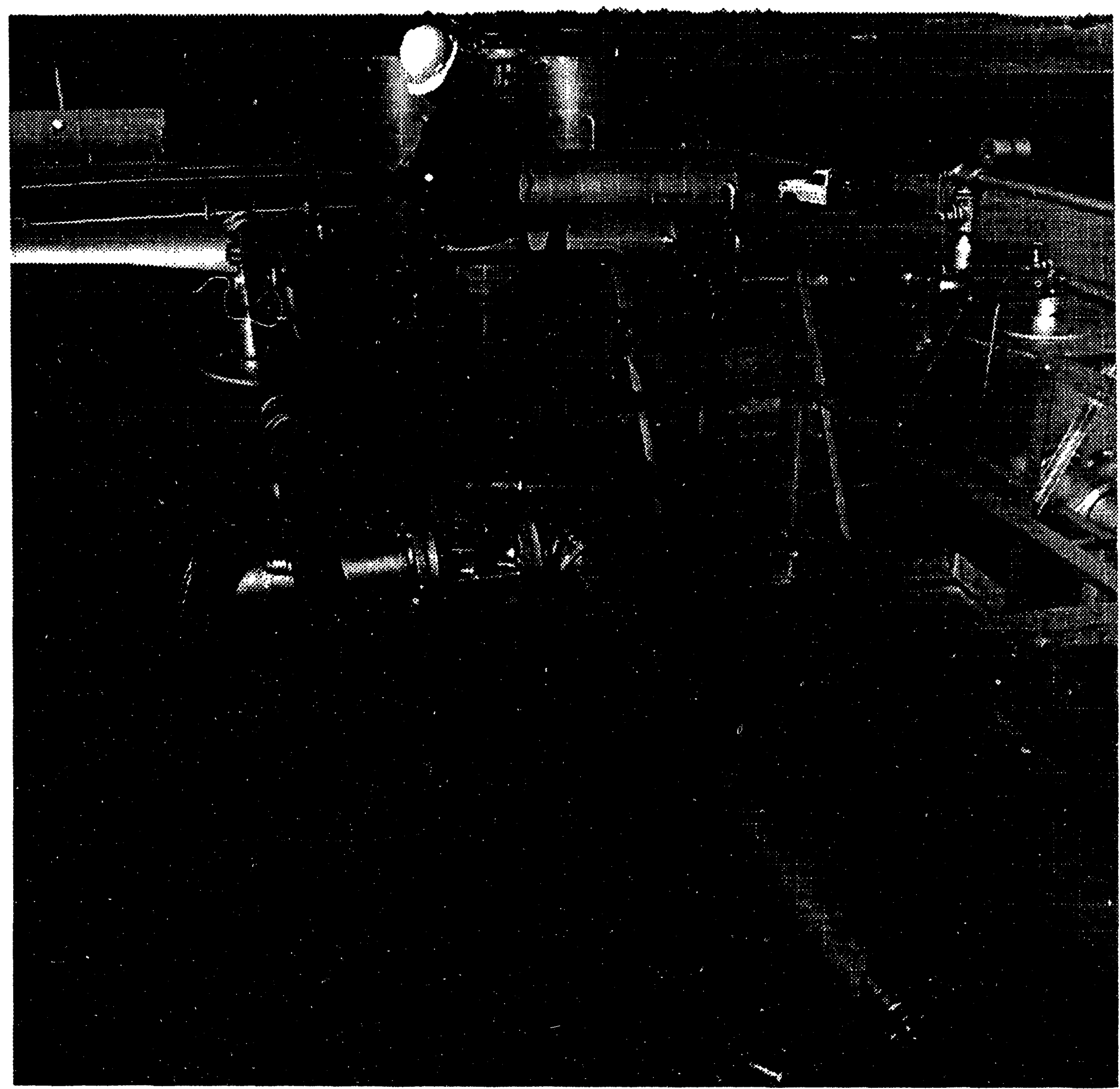




\begin{tabular}{|c|c|c|c|c|c|}
\hline \multirow{2}{*}{\multicolumn{2}{|c|}{ Commodity }} & \multicolumn{2}{|c|}{ Current Month } & \multicolumn{2}{|c|}{ Year to Date } \\
\hline & & $\begin{array}{l}\text { Thousand } \\
\text { Barrels }\end{array}$ & $\begin{array}{c}\text { Thousand Barrels } \\
\text { per Day }\end{array}$ & $\begin{array}{l}\text { Thousand } \\
\text { Barrels }\end{array}$ & $\begin{array}{c}\text { Thousand Barrele } \\
\text { per Day }\end{array}$ \\
\hline $\begin{array}{l}(1) \\
(2) \\
(3)\end{array}$ & 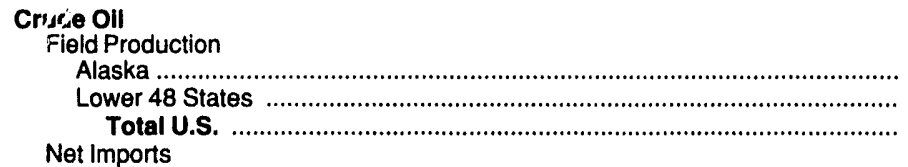 & $\begin{array}{r}E_{53,657} \\
E_{171,780} \\
E_{225,437}\end{array}$ & $\begin{array}{l}E_{1,731} \\
E_{5,541} \\
E_{7,272}\end{array}$ & $\begin{array}{r}E_{439,407} \\
E_{1,357,258} \\
E_{1,796,665}\end{array}$ & $\begin{array}{l}E_{1,808} \\
E_{5,585} \\
E_{7,384}\end{array}$ \\
\hline $\begin{array}{l}(4) \\
(5) \\
(6) \\
(7)\end{array}$ & 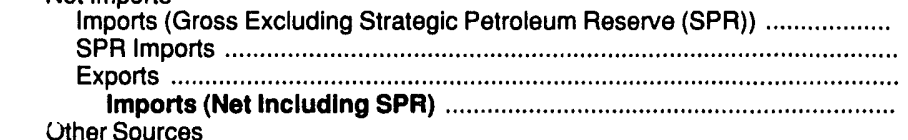 & $\begin{array}{r}206,675 \\
0 \\
1,699 \\
204,976\end{array}$ & $\begin{array}{r}6,667 \\
0 \\
55 \\
6,612\end{array}$ & $\begin{array}{r}1,421,642 \\
0 \\
28,394 \\
1,393,248\end{array}$ & $\begin{array}{r}5,850 \\
0 \\
117 \\
5,734\end{array}$ \\
\hline $\begin{array}{r}(8) \\
(9) \\
(10) \\
(11) \\
(12) \\
(13)\end{array}$ & $\begin{array}{l}\text { SPR Stock Change (Withdrawal }(+) \text {, Addition }(-)) \\
\text { Other Stock Change (Withdrawal }(+) \text {, Addition }(-)) \\
\text { Product Supplied and Losses } \\
\text { Unaccounted for } \\
\text { Total Other Sources } \\
\text { Crude Input to Refineries } \\
(13)=(3)+(7)+(12)\end{array}$ & $\begin{array}{r}-1 \\
-2,813 \\
-402 \\
251 \\
-2,965 \\
427,449\end{array}$ & $\begin{array}{r}(s) \\
-91 \\
-13 \\
8 \\
-96 \\
13,789\end{array}$ & $\begin{array}{r}17,189 \\
-22,363 \\
-4,185 \\
57,489 \\
48,130 \\
3,238,043\end{array}$ & $\begin{array}{r}71 \\
-92 \\
-17 \\
237 \\
198 \\
13,325\end{array}$ \\
\hline $\begin{array}{l}(14) \\
(15) \\
(16) \\
(17)\end{array}$ & 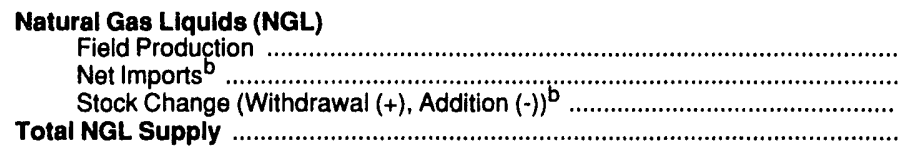 & $\begin{array}{r}50,135 \\
146 \\
-622 \\
49,659\end{array}$ & $\begin{array}{r}1,617 \\
5 \\
-20 \\
1,602\end{array}$ & $\begin{array}{r}398,971 \\
1,564 \\
-3,135 \\
397,400\end{array}$ & $\begin{array}{r}1,642 \\
6 \\
.13 \\
1,635\end{array}$ \\
\hline $\begin{array}{l}(18) \\
(19) \\
(20) \\
(21) \\
(22) \\
(23)\end{array}$ & 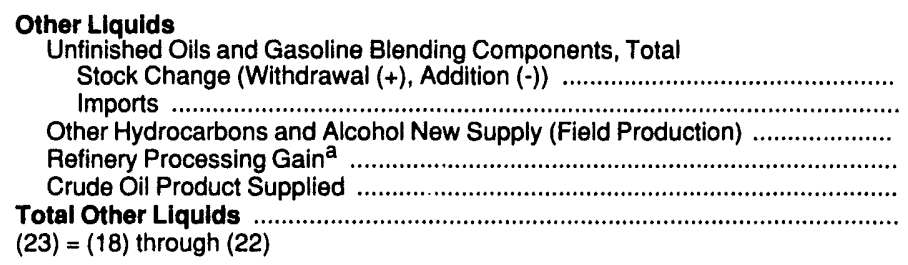 & $\begin{array}{r}1,546 \\
13,568 \\
2,557 \\
22,459 \\
402 \\
40,532\end{array}$ & $\begin{array}{r}50 \\
438 \\
82 \\
724 \\
13 \\
1,307\end{array}$ & $\begin{array}{r}-9,095 \\
105,116 \\
20,639 \\
164,333 \\
4,174 \\
285,167\end{array}$ & $\begin{array}{r}-37 \\
433 \\
85 \\
676 \\
17 \\
1,174\end{array}$ \\
\hline (24) & $\begin{array}{l}\text { Total Production of Products } \\
(24)=(13)+(17)+(23)\end{array}$ & 517,640 & 16,698 & $3,920,610$ & 16,134 \\
\hline $\begin{array}{l}(25) \\
(26) \\
(27)\end{array}$ & $\begin{array}{l}\text { Net Imports of Refined Products } \\
\text { Imports (Gross) } \\
\text { Exports }\end{array}$ & $\begin{array}{l}46,898 \\
24,257 \\
22,641\end{array}$ & $\begin{array}{r}1,513 \\
782 \\
730\end{array}$ & $\begin{array}{l}321,585 \\
219,399 \\
102,186\end{array}$ & $\begin{array}{r}1,323 \\
903 \\
421\end{array}$ \\
\hline (28) & $\begin{array}{l}\text { Total Now Supply of Products } \\
(28)=(24)+(27)\end{array}$ & 540,281 & $17,42.8$ & $4,022,796$ & 16,555 \\
\hline (29) & 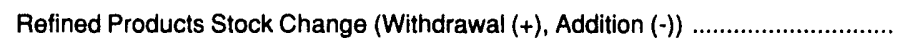 & $-9,143$ & -295 & $-4,011$ & -17 \\
\hline (30) & 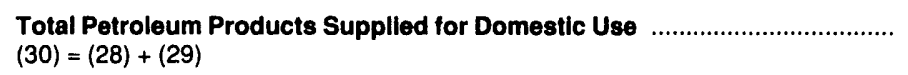 & 531,138 & 17,133 & $4,018,785$ & 16,538 \\
\hline $\begin{array}{l}(31) \\
(32) \\
(33) \\
(34) \\
(35) \\
(36) \\
(37) \\
(38)\end{array}$ & 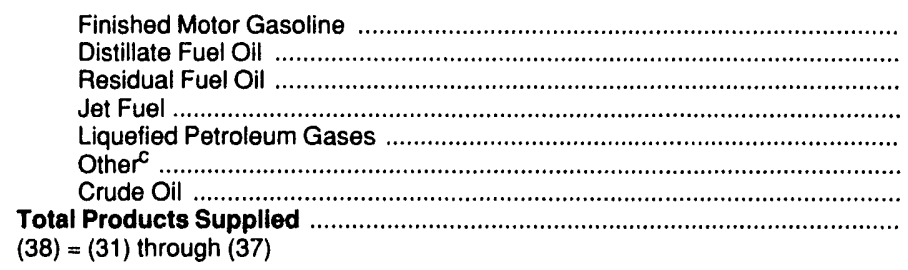 & $\begin{array}{r}234,201 \\
86,153 \\
37,359 \\
47,326 \\
48,536 \\
77,162 \\
402 \\
531,138\end{array}$ & $\begin{array}{r}7,555 \\
2,779 \\
1,205 \\
1,527 \\
1,566 \\
2,489 \\
13 \\
17,133\end{array}$ & $\begin{array}{r}1,753,291 \\
702,573 \\
282,302 \\
354,493 \\
391,031 \\
530,922 \\
4,174 \\
4,018,785\end{array}$ & $\begin{array}{r}7,215 \\
2,891 \\
1,162 \\
1,459 \\
1,609 \\
2,185 \\
17 \\
16,538\end{array}$ \\
\hline $\begin{array}{l}(39) \\
(40) \\
(41) \\
(42) \\
(43) \\
(44) \\
(45) \\
(46) \\
(47)\end{array}$ & $\begin{array}{l}\text { Ending Stocks, All Olis } \\
\text { Crude Oil (Excluding SPR) } \\
\text { Strategic Petroleum Reserve } \\
\text { Finished Motor Gasoline } \\
\text { Distillate Fuel Oil } \\
\text { Residual Fuel Oil } \\
\text { Jet Fuel }\end{array}$ & $\begin{array}{r}345,342 \\
568,503 \\
171,086 \\
130,550 \\
45,595 \\
47,713 \\
116,375 \\
219,818 \\
1,644,982\end{array}$ & $\begin{array}{l}- \\
- \\
- \\
- \\
- \\
-\end{array}$ & $\begin{array}{r}345,342 \\
568,503 \\
171,086 \\
130,550 \\
45,595 \\
47,713 \\
116,375 \\
219,818 \\
1,644,982\end{array}$ & $\begin{array}{l}- \\
- \\
- \\
- \\
-\end{array}$ \\
\hline
\end{tabular}

a Unaccounted for crude oil represents the difference between the supply and disposition of crude oil. Refinery processing gain represents the volumetric amount by which total output is greater than input for a given period of time. Preliminary estimates of crude oil imports at the National level have historically understated final values by approximately 50 thousand barrels per day. This causes the preliminary values of unaccounted for crude oil to overstate the final values by the same amount.

includes products in the pentanes plus category only.

c Includes pentanes plus, other liquids, and all finished petroleum products except finished motor gasoline, distillate fuel oil, residual fuel oil, jet fuel, and liquefied petroleum gases.

$(s)=$ Less than 500 barrels per day. $E=$ Estimated.

Note: Totals may not equal sum of components due to independent rounding.

Sources: - Energy Intormation Administration \{E!A), Menthly Potroloum Supply Poporting Systam. = Domestic crude oil production astimates based on historical statistics from State conservation agencies and the Minerals Management Service of the U.S. Department of the Interior. - Export data from the Bureau of the Census and Form EIA-810, "Monthly Refinery Report." 
Table 2. U.S. Supply, Disposition, and Ending Stocks of Crude Oll and Petroleum Products, August 1991 (Thousand Barrels)

\begin{tabular}{|c|c|c|c|c|c|c|c|c|c|c|}
\hline \multirow[b]{2}{*}{ Commodity } & \multicolumn{4}{|c|}{ Supply } & \multicolumn{5}{|c|}{ Disposition } & \multirow[b]{2}{*}{$\begin{array}{l}\text { Ending } \\
\text { Stocks }\end{array}$} \\
\hline & $\begin{array}{c}\text { Field } \\
\text { Production }\end{array}$ & $\begin{array}{c}\text { Refinery } \\
\text { Production }\end{array}$ & Imports & $\begin{array}{c}\text { Unaccounted } \\
\text { For Crude } \\
\text { Oll }^{\mathrm{a}}\end{array}$ & $\begin{array}{c}\text { Stock } \\
\text { Change } b\end{array}$ & $\begin{array}{c}\text { Crude } \\
\text { Losses }\end{array}$ & $\begin{array}{l}\text { Refinery } \\
\text { Inputs }\end{array}$ & Exports & $\begin{array}{l}\text { Products } \\
\text { Supplied }\end{array}$ & \\
\hline 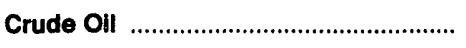 & $E_{225,437}$ & - & 206,675 & 251 & 2,814 & 0 & 427,449 & 1,699 & 402 & 913,845 \\
\hline 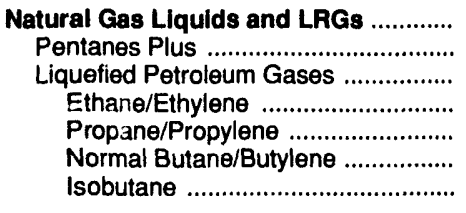 & $\begin{array}{r}50,135 \\
10,259 \\
39,876 \\
15,798 \\
14,523 \\
4,014 \\
5,541\end{array}$ & $\begin{array}{r}17,291 \\
17,291 \\
391 \\
12,671 \\
3,839 \\
390\end{array}$ & $\begin{array}{r}4,405 \\
148 \\
4,257 \\
233 \\
2,153 \\
1,271 \\
600\end{array}$ & $\begin{array}{l}- \\
- \\
- \\
-\end{array}$ & $\begin{array}{r}5,373 \\
622 \\
4,751 \\
-2,192 \\
1,117 \\
4,905 \\
921\end{array}$ & $\begin{array}{l}- \\
- \\
- \\
-\end{array}$ & $\begin{array}{r}13,045 \\
5,467 \\
7,578 \\
0 \\
0 \\
2,253 \\
5,325\end{array}$ & $\begin{array}{r}561 \\
2 \\
559 \\
0 \\
410 \\
149 \\
0\end{array}$ & $\begin{array}{r}\mathbf{5 2 , 8 5 2} \\
4,316 \\
48,536 \\
18,614 \\
27,820 \\
1,817 \\
285\end{array}$ & $\begin{array}{r}125,668 \\
9,293 \\
116,375 \\
18,631 \\
51,551 \\
36,261 \\
9,932\end{array}$ \\
\hline 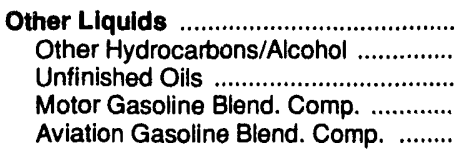 & $\begin{array}{r}2,557 \\
2,557 \\
- \\
-\end{array}$ & $\frac{-}{-}$ & $\begin{array}{r}13,568 \\
0 \\
12,489 \\
1,079 \\
0\end{array}$ & $\begin{array}{l}- \\
- \\
-\end{array}$ & $\begin{array}{r}-1,546 \\
-36 \\
-2,282 \\
788 \\
-16\end{array}$ & $\begin{array}{l}- \\
- \\
-\end{array}$ & $\begin{array}{r}26,120 \\
2,593 \\
20,460 \\
3,036 \\
31\end{array}$ & $\begin{array}{l}0 \\
0 \\
0 \\
0 \\
0\end{array}$ & $\begin{array}{r}-8,449 \\
0 \\
-5,689 \\
-2,745 \\
-15\end{array}$ & $\begin{array}{r}149,018 \\
3,232 \\
107,656 \\
38,063 \\
67\end{array}$ \\
\hline 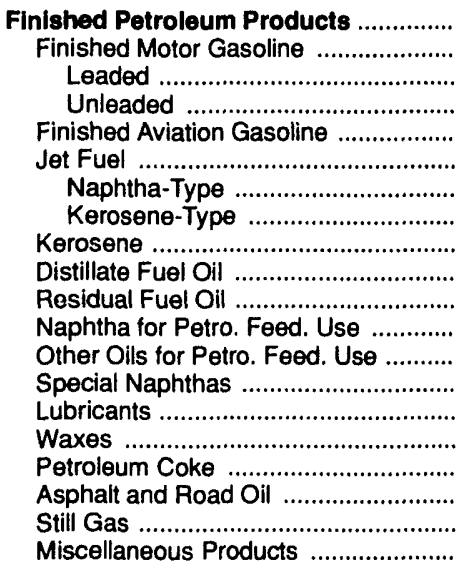 & $\begin{array}{l}- \\
- \\
= \\
- \\
- \\
- \\
- \\
- \\
- \\
- \\
-\end{array}$ & $\begin{array}{r}471,782 \\
224,967 \\
8,143 \\
216,824 \\
773 \\
46,068 \\
5,268 \\
40,800 \\
437 \\
91,741 \\
28,664 \\
4,666 \\
8,468 \\
1,487 \\
4,700 \\
620 \\
17,877 \\
17,624 \\
21,557 \\
2,133\end{array}$ & $\begin{array}{r}42,641 \\
11,948 \\
10 \\
11,938 \\
0 \\
2,219 \\
445 \\
1,774 \\
21 \\
5,185 \\
17,622 \\
692 \\
3,328 \\
439 \\
218 \\
24 \\
13 \\
885 \\
0 \\
47\end{array}$ & $\begin{array}{l}- \\
- \\
- \\
- \\
- \\
- \\
- \\
- \\
- \\
- \\
- \\
- \\
-\end{array}$ & $\begin{array}{r}4,392 \\
-325 \\
-801 \\
476 \\
-455 \\
635 \\
-442 \\
1,077 \\
-123 \\
6,294 \\
2,238 \\
21 \\
-477 \\
-201 \\
48 \\
-51 \\
-211 \\
-3,227 \\
0 \\
226\end{array}$ & $\begin{array}{l}- \\
- \\
- \\
- \\
- \\
- \\
- \\
- \\
- \\
- \\
- \\
- \\
- \\
-\end{array}$ & $\begin{array}{l}- \\
- \\
- \\
- \\
- \\
- \\
- \\
- \\
- \\
- \\
- \\
- \\
-\end{array}$ & $\begin{array}{r}23,698 \\
3,039 \\
167 \\
2,872 \\
0 \\
326 \\
1 \\
326 \\
18 \\
4,479 \\
6,689 \\
0 \\
0 \\
94 \\
594 \\
73 \\
8,221 \\
149 \\
0 \\
13\end{array}$ & $\begin{array}{r}486,333 \\
234,201 \\
8,787 \\
225,414 \\
1,228 \\
47,326 \\
6,154 \\
41,171 \\
563 \\
86,153 \\
37,359 \\
5,337 \\
12,273 \\
2,033 \\
4,276 \\
622 \\
9,880 \\
21,587 \\
21,557 \\
1,941\end{array}$ & $\begin{array}{r}456,451 \\
171,086 \\
6,484 \\
164,602 \\
1,670 \\
47,713 \\
5,286 \\
42,427 \\
4,936 \\
130,550 \\
45,595 \\
1,417 \\
1,899 \\
2,120 \\
12,673 \\
1,047 \\
8,189 \\
24,902 \\
0 \\
2,654\end{array}$ \\
\hline Total & 278,129 & 489,073 & 267,289 & 251 & 11,033 & 0 & 466,614 & 25,957 & 531,138 & $1,644,982$ \\
\hline
\end{tabular}

a Unaccounted for crude oil represents the difference between the supply and disposition of crude oil. Preliminary estimates of crude oil imports at the National level have historically understated final values by approximately 50,000 barrels per day. This causes the preliminary values of unaccounted for crude oil to overstate the final values by the same amount.

b A negative number indicates a decrease in stocks and a positive number indicates an increase in stocks.

c Products supplied is equal to field production, plus refinery production, plus imports, plus unaccounted for crude oil, minus stock change, minus crude losses, minus refinery inputs, minus exports.

(s) $=$ Less than 500 barrels.

$E=$ Estimated.

LRG = Liquefied Refinery Gas.

Note: Totals may not equal sum of components due to independent rounding.

Sources: - Energy Information Administration (EIA) Forms EIA-810, "Monthly Refinery Report," EIA-811, "Monthly Bulk Terminal Report," EIA-812, "Monthly Product Pipeline Report," EIA-813, "Monthly Crude Oil Report," EIA-814, "Monthly Imports Report," EIA-816, "Monthly Natural Gas Liquids Report," and EIA-817, "Monthly Tanker and Barge Movement Report." - Domestic crude oil production estimates based on historical statistics from State conservation agencies and the Minerals Management Service of the U.S. Department of the Interior. - Export data from the Bureau of the Census and Form EIA-810, "Monthly Refinery Report." 
Table 3. U.S. Year-to-Date Supply, Disposition, and Ending Stocks of Crude Oil and Petroleum Products, January-August 1991 (Thousand Barrels)

\begin{tabular}{|c|c|c|c|c|c|c|c|c|c|c|}
\hline \multirow[b]{2}{*}{ Commodity } & \multicolumn{4}{|c|}{ Supply } & \multicolumn{5}{|c|}{ Disposition } & \multirow[b]{2}{*}{$\begin{array}{l}\text { Ending } \\
\text { Stocks }\end{array}$} \\
\hline & $\begin{array}{c}\text { Field } \\
\text { Production }\end{array}$ & $\begin{array}{c}\text { Refinery } \\
\text { Production }\end{array}$ & Imports & $\begin{array}{c}\text { Unaccounted } \\
\text { For Crude } \\
\text { Oll }^{\mathrm{a}}\end{array}$ & $\begin{array}{l}\text { Stock } \\
\text { Changeb }\end{array}$ & $\begin{array}{c}\text { Crude } \\
\text { Losses }\end{array}$ & $\begin{array}{l}\text { Refinery } \\
\text { Inputs }\end{array}$ & Exports & $\begin{array}{l}\text { Products } \\
\text { Supplied }^{\mathrm{C}}\end{array}$ & \\
\hline 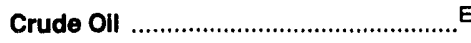 & $E_{1,796,665}$ & - & $1,421,642$ & 57,489 & 5,174 & 11 & $3,238,043$ & 28,394 & 4,174 & 913,845 \\
\hline 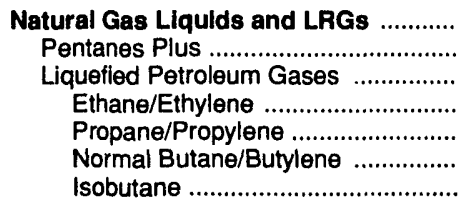 & $\begin{array}{r}398,971 \\
78,219 \\
320,752 \\
128,020 \\
117,285 \\
36,334 \\
39,113\end{array}$ & $\begin{array}{r}129,606 \\
129,606 \\
3,575 \\
100,722 \\
22,977 \\
2,332\end{array}$ & $\begin{array}{r}33,367 \\
1,740 \\
31,627 \\
2,083 \\
20,163 \\
6,505 \\
2,876\end{array}$ & $\begin{array}{l}- \\
- \\
- \\
-\end{array}$ & $\begin{array}{r}21,557 \\
3,135 \\
18,422 \\
-1,415 \\
3,035 \\
16,695 \\
107\end{array}$ & $\begin{array}{l}- \\
- \\
- \\
-\end{array}$ & $\begin{array}{r}104,529 \\
41,760 \\
62,769 \\
0 \\
9 \\
24,441 \\
38,319\end{array}$ & $\begin{array}{r}9,940 \\
176 \\
9,763 \\
0 \\
7,355 \\
2,408 \\
0\end{array}$ & $\begin{array}{r}425,918 \\
34,888 \\
391,031 \\
135,093 \\
227,771 \\
22,272 \\
5,895\end{array}$ & $\begin{array}{r}125,668 \\
9,293 \\
116,375 \\
18,631 \\
51,551 \\
36,261 \\
9,932\end{array}$ \\
\hline $\begin{array}{l}\text { Other Liquids ...................................... } \\
\text { Other Hydrocarbons/Alcohol ............... } \\
\text { Unfinished Oils .................................. } \\
\text { Motor Gasoline Blend. Comp. ............. } \\
\text { Aviation Gasoline Blend. Comp. ......... }\end{array}$ & $\begin{array}{r}20,639 \\
20,639 \\
- \\
-\end{array}$ & $\overline{-}$ & $\begin{array}{r}105,116 \\
600 \\
94,026 \\
10,490 \\
0\end{array}$ & $\begin{array}{l}- \\
- \\
-\end{array}$ & $\begin{array}{r}9,095 \\
1,995 \\
8,382 \\
-1,194 \\
-88\end{array}$ & $\begin{array}{c}- \\
- \\
-\end{array}$ & $\begin{array}{r}180,596 \\
19,244 \\
142,479 \\
18,772 \\
101\end{array}$ & $\begin{array}{l}0 \\
0 \\
0 \\
0 \\
0\end{array}$ & $\begin{array}{r}-63,936 \\
0 \\
-56,835 \\
-7,088 \\
-13\end{array}$ & $\begin{array}{r}149,018 \\
3,232 \\
107,656 \\
38,063 \\
67\end{array}$ \\
\hline 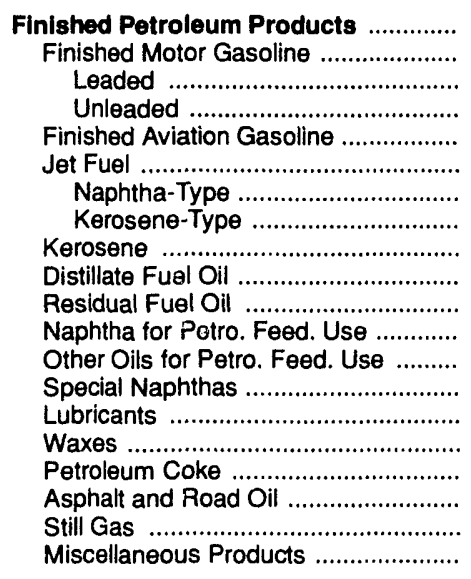 & $\begin{array}{l}- \\
- \\
- \\
- \\
- \\
- \\
- \\
- \\
- \\
- \\
-\end{array}$ & $\begin{array}{r}3,557,895 \\
1,687,791 \\
65,035 \\
1,622,756 \\
5,680 \\
345,735 \\
39,573 \\
306,162 \\
8,622 \\
705,377 \\
231,073 \\
35,669 \\
64,265 \\
12,640 \\
38,627 \\
4,472 \\
135,987 \\
105,760 \\
159,374 \\
16,823\end{array}$ & $\begin{array}{r}289,958 \\
75,055 \\
28 \\
75,027 \\
55 \\
16,450 \\
3,131 \\
13,319 \\
1,063 \\
45,782 \\
105,169 \\
6,398 \\
29,058 \\
2,021 \\
1,686 \\
350 \\
418 \\
5,919 \\
0 \\
534\end{array}$ & $\begin{array}{l}- \\
- \\
- \\
- \\
- \\
- \\
- \\
- \\
- \\
- \\
- \\
- \\
- \\
-\end{array}$ & $\begin{array}{r}-14,411 \\
-11,072 \\
-3,503 \\
-7,569 \\
-79 \\
-4,192 \\
-879 \\
-3,313 \\
-980 \\
-1,637 \\
-2,999 \\
-44 \\
-154 \\
-889 \\
300 \\
70 \\
793 \\
6,170 \\
0 \\
302\end{array}$ & $\begin{array}{l}- \\
- \\
- \\
- \\
- \\
- \\
- \\
- \\
- \\
- \\
- \\
- \\
-\end{array}$ & $\begin{array}{l}- \\
- \\
- \\
- \\
- \\
- \\
- \\
- \\
- \\
- \\
-\end{array}$ & $\begin{array}{r}209,635 \\
20,627 \\
1,310 \\
19,317 \\
0 \\
11,884 \\
667 \\
11,217 \\
1,091 \\
50,223 \\
56,939 \\
0 \\
0 \\
4,055 \\
4,311 \\
429 \\
59,364 \\
657 \\
0 \\
56\end{array}$ & $\begin{array}{r}3,652,629 \\
1,753,291 \\
67,256 \\
1,686,035 \\
5,814 \\
354,493 \\
42,916 \\
311,577 \\
9,574 \\
702,573 \\
282,302 \\
42,111 \\
93,477 \\
11,495 \\
35,702 \\
4,323 \\
76,248 \\
104,852 \\
159,374 \\
16,999\end{array}$ & $\begin{array}{r}456,451 \\
171,086 \\
6,484 \\
164,602 \\
1,670 \\
47,713 \\
5,286 \\
42,427 \\
4,936 \\
130,550 \\
45,595 \\
1,417 \\
1,899 \\
2,120 \\
12,673 \\
1,047 \\
8,189 \\
24,902 \\
0 \\
2,654\end{array}$ \\
\hline 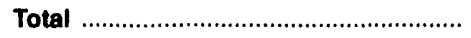 & $2,216,275$ & $3,687,501$ & $1,850,083$ & 57,489 & 21,415 & 11 & $3,523,168$ & 247,969 & $4,018,785$ & $1,644,982$ \\
\hline
\end{tabular}

a Unaccounted for crude oil represents the difference between the supply and disposition of crude oil. Preliminary estimates of crude oil imports at the National level have historically understated final values by approximately 50,000 barrels per day. This causes the preliminary values of unaccounted for crude oil to overstate the final values by the same amount.

c A negative number indicates a decrease in stocks and a positive number indicates an increase in stocks. refinery inputs, minus exports.

(s) $=$ Less than 500 barrels.

$E$ = Estimated.

LRG = Liquefied Refinery Gas.

Note: Totals may not equal sum of components due to independent rounding

Sources: - Energy Information Administration (EIA) Forms EIA-810, "Monthly Refinery Report," EIA-811, "Monthly Bulk Terminal Report," EIA-812, "Monthly Product Pipeline Report," EIA-813, "Monthly Crude Oil Report," ElA-814, "Monthly Imports Report," ElA-816, "Monthly Natural Gas Liquids Report," and ElA-817, "Monthly Tanker and Barge Movement Report." - Domestic crude oil production estimates based on historical statistics from State conservation agencies and the Minerals Management Service of the U.S. Department of the Interior. - Export data from the Bureau of the Census and Form ElA-810, "Monthly Refinery Report." 
Table 4. U.S. Daily Average Supply and Disposition of Crude Oil and Petroleum Products, August 1991

(Thousand Barrels per Day)

\begin{tabular}{|c|c|c|c|c|c|c|c|c|c|}
\hline \multirow[b]{2}{*}{ Commodity } & \multicolumn{4}{|c|}{ Supply } & \multicolumn{5}{|c|}{ Disposition } \\
\hline & $\begin{array}{c}\text { Fleid } \\
\text { Production }\end{array}$ & $\begin{array}{c}\text { Refinery } \\
\text { Production }\end{array}$ & Imports & $\begin{array}{c}\text { Unaccounted } \\
\text { For Crude } \\
\text { Oll }^{\mathrm{a}}\end{array}$ & $\begin{array}{c}\text { Stock } \\
\text { Change }\end{array}$ & $\begin{array}{l}\text { Crude } \\
\text { Losses }\end{array}$ & $\begin{array}{l}\text { Refinery } \\
\text { Inputs }\end{array}$ & Exports & $\begin{array}{l}\text { Products } \\
\text { Supplied }^{\mathrm{C}}\end{array}$ \\
\hline 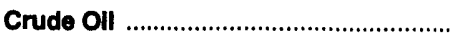 & $E_{7,272}$ & - & 6,667 & 8 & 91 & 0 & 13,789 & 55 & 13 \\
\hline 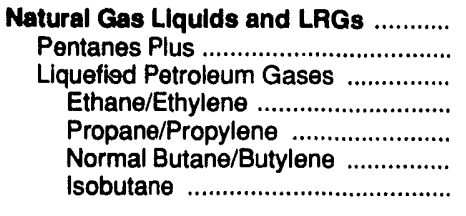 & $\begin{array}{r}1,617 \\
331 \\
1,286 \\
510 \\
468 \\
129 \\
179\end{array}$ & $\begin{array}{r}558 \\
558 \\
13 \\
409 \\
124 \\
13\end{array}$ & $\begin{array}{r}142 \\
5 \\
137 \\
8 \\
69 \\
41 \\
19\end{array}$ & $\begin{array}{l}- \\
- \\
- \\
-\end{array}$ & $\begin{array}{r}173 \\
20 \\
153 \\
-71 \\
36 \\
158 \\
30\end{array}$ & $\begin{array}{l}- \\
- \\
- \\
-\end{array}$ & $\begin{array}{r}421 \\
176 \\
244 \\
0 \\
0 \\
73 \\
172\end{array}$ & $\begin{array}{r}18 \\
(s) \\
18 \\
0 \\
13 \\
5 \\
0\end{array}$ & $\begin{array}{r}1,705 \\
139 \\
1,566 \\
600 \\
897 \\
59 \\
9\end{array}$ \\
\hline $\begin{array}{l}\text { Other Liquids ...................................... } \\
\text { Other Hydrocarbons/Alcohol ............. } \\
\text { Unfinished Oils .................................... } \\
\text { Motor Gasoline Blend. Comp. ........... } \\
\text { Aviation Gasoline Blend. Comp. ......... }\end{array}$ & $\begin{array}{l}82 \\
82 \\
- \\
-\end{array}$ & $\begin{array}{c}- \\
- \\
-\end{array}$ & $\begin{array}{r}438 \\
0 \\
403 \\
35 \\
0\end{array}$ & $\begin{array}{l}- \\
- \\
-\end{array}$ & $\begin{array}{r}-50 \\
-1 \\
-74 \\
25 \\
-1\end{array}$ & $\begin{array}{c}- \\
- \\
-\end{array}$ & $\begin{array}{r}843 \\
84 \\
660 \\
98 \\
1\end{array}$ & $\begin{array}{l}0 \\
0 \\
0 \\
0 \\
0\end{array}$ & $\begin{array}{r}-273 \\
0 \\
-184 \\
-89 \\
(s)\end{array}$ \\
\hline 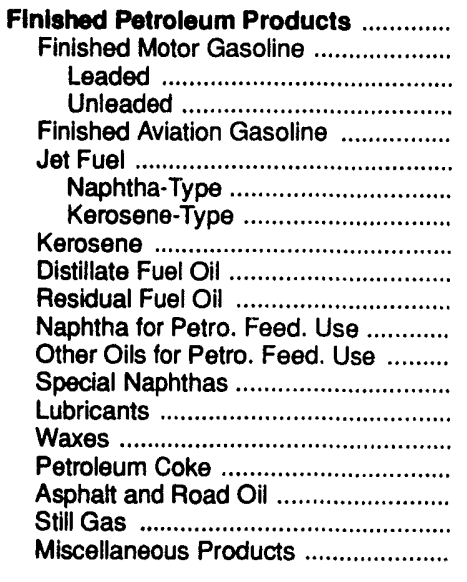 & $\begin{array}{l}- \\
- \\
- \\
- \\
- \\
- \\
- \\
- \\
- \\
- \\
-\end{array}$ & $\begin{array}{r}15,219 \\
7,257 \\
263 \\
6,994 \\
25 \\
1,486 \\
170 \\
1,316 \\
14 \\
2,959 \\
925 \\
151 \\
273 \\
48 \\
152 \\
20 \\
577 \\
569 \\
695 \\
69\end{array}$ & $\begin{array}{r}1,376 \\
385 \\
(s) \\
385 \\
0 \\
72 \\
14 \\
57 \\
1 \\
167 \\
568 \\
22 \\
107 \\
14 \\
7 \\
1 \\
(s) \\
29 \\
0 \\
2\end{array}$ & $\begin{array}{l}- \\
- \\
- \\
- \\
- \\
- \\
- \\
- \\
- \\
- \\
- \\
- \\
-\end{array}$ & $\begin{array}{r}142 \\
-10 \\
-26 \\
15 \\
-15 \\
20 \\
-14 \\
35 \\
-4 \\
203 \\
72 \\
1 \\
-15 \\
-6 \\
2 \\
-2 \\
-7 \\
-104 \\
0 \\
7\end{array}$ & $\begin{array}{l}- \\
- \\
- \\
- \\
- \\
- \\
- \\
- \\
- \\
- \\
- \\
- \\
-\end{array}$ & $\begin{array}{l}- \\
- \\
- \\
- \\
- \\
- \\
- \\
- \\
- \\
- \\
- \\
- \\
-\end{array}$ & $\begin{array}{r}764 \\
98 \\
5 \\
93 \\
0 \\
11 \\
(s) \\
11 \\
1 \\
144 \\
216 \\
0 \\
0 \\
3 \\
19 \\
2 \\
265 \\
5 \\
0 \\
(s)\end{array}$ & $\begin{array}{r}15,688 \\
7,555 \\
283 \\
7,271 \\
40 \\
1,527 \\
199 \\
1,328 \\
18 \\
2,779 \\
1,205 \\
172 \\
396 \\
66 \\
138 \\
20 \\
319 \\
696 \\
695 \\
63\end{array}$ \\
\hline 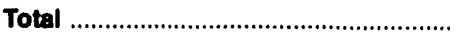 & 8,972 & 15,777 & 8,622 & 8 & 356 & 0 & 15,052 & 837 & 17,133 \\
\hline
\end{tabular}

a Unaccounted for crude oil represents the difference between the supply and disposition of crude oil. Preliminary estimates oí crude oil imports at the National level have historically understated final values by approximately 50,000 barrels per day. This causes the preliminary values of unaccounted for crude oil to overstate the final values by the same amount.

b A negative number indicates a decrease in stocks and a positive number indicates an increase in stocks.

c Products supplied is equal to field production, plus refinery production, plus imports, plus unaccounted for crude oil, minus stock change, minus crude losses, minus refinery inputs, minus exports.

$(s)=$ Less than 500 barrels per day.

$\mathrm{E}=$ Estimated.

LRG = Liquefied Refinery Gas.

Note: Totals may not equal sum of components due to independent rounding.

Sources: • Energy Information Administration (EIA) Forms EIA-810, "Monthly Refinery Report," EIA-811, "Monthly Bulk Terminal Report," EIA-812, "Monthly Product Pipeline Report," ElA-813, "Monthly Crude Oil Report," EIA-814, "Monthly Imports Report," ElA-816, "Monthly Natural Gas Liquids Report," and EIA-817, "Monthly Tanker and Barge Movement Report." - Domestic crude oil production estimates based on historical statistics from State conservation agencies and the Minerals Management Service of the U.S. Department of the Interior. Export data from the Bureau of the Census and Form EIA-810, "Monthly Refinery Report." 
Table 5. U.S. Year-to-Date Daily Average Supply and Disposition of Crude Oil and Petroleum Products, January-August 1991 (Thousand Barrels per Day)

\begin{tabular}{|c|c|c|c|c|c|c|c|c|c|}
\hline \multirow[b]{2}{*}{ Commodity } & \multicolumn{4}{|c|}{ Supply } & \multicolumn{5}{|c|}{ Disposition } \\
\hline & $\begin{array}{c}\text { Fleld } \\
\text { Production }\end{array}$ & \begin{tabular}{|c|} 
Refinery \\
Production
\end{tabular} & Imports & $\begin{array}{c}\text { Unaccounted } \\
\text { For Crude } \\
\text { Oll }^{\mathrm{a}}\end{array}$ & $\underset{\text { Change }}{\text { Stock }}$ & $\begin{array}{l}\text { Crude } \\
\text { Losses }\end{array}$ & $\begin{array}{c}\text { Refinery } \\
\text { Inputs }\end{array}$ & Exports & $\begin{array}{l}\text { Products } \\
\text { Supplled }\end{array}$ \\
\hline 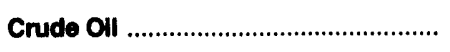 & $E_{7,394}$ & - & 5,850 & 237 & 21 & (8) & 13,325 & 117 & 17 \\
\hline 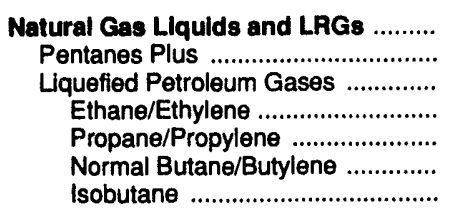 & $\begin{array}{r}1,642 \\
322 \\
1,320 \\
527 \\
483 \\
150 \\
161\end{array}$ & $\begin{array}{r}533 \\
533 \\
15 \\
414 \\
95 \\
10\end{array}$ & $\begin{array}{r}137 \\
7 \\
130 \\
9 \\
83 \\
27 \\
12\end{array}$ & $\begin{array}{l}\bar{z} \\
\bar{z} \\
\bar{z}\end{array}$ & $\begin{array}{l}89 \\
13 \\
76 \\
-6 \\
12 \\
69 \\
\text { (s) }\end{array}$ & $\begin{array}{l}\bar{z} \\
\bar{z} \\
\overline{-}\end{array}$ & $\begin{array}{r}430 \\
172 \\
258 \\
0 \\
(s) \\
101 \\
158\end{array}$ & $\begin{array}{r}41 \\
1 \\
40 \\
0 \\
30 \\
10 \\
10\end{array}$ & $\begin{array}{r}1,753 \\
144 \\
1,609 \\
556 \\
937 \\
92 \\
24\end{array}$ \\
\hline $\begin{array}{l}\text { Other Llquids . . } \\
\text { Other Hydrocarbons/Aicohol .............. } \\
\text { Unfinished Oils .......................... } \\
\text { Motor Gasoline Blend. Comp. ........ } \\
\text { Aviation Gasoline Blend. Comp. ....... }\end{array}$ & $\begin{array}{l}85 \\
85 \\
= \\
-\end{array}$ & $\begin{array}{l}\bar{z} \\
\bar{z}\end{array}$ & $\begin{array}{r}433 \\
2 \\
387 \\
43 \\
0\end{array}$ & $\begin{array}{l}\bar{z} \\
\bar{z}\end{array}$ & $\begin{array}{r}37 \\
8 \\
34 \\
-5 \\
(\mathbf{s})\end{array}$ & $\begin{array}{l}\bar{z} \\
\bar{z}\end{array}$ & $\begin{array}{r}743 \\
79 \\
586 \\
77 \\
(s)\end{array}$ & $\begin{array}{l}0 \\
0 \\
0 \\
0 \\
0\end{array}$ & $\begin{array}{r}-263 \\
0 \\
-234 \\
-29 \\
(s)\end{array}$ \\
\hline 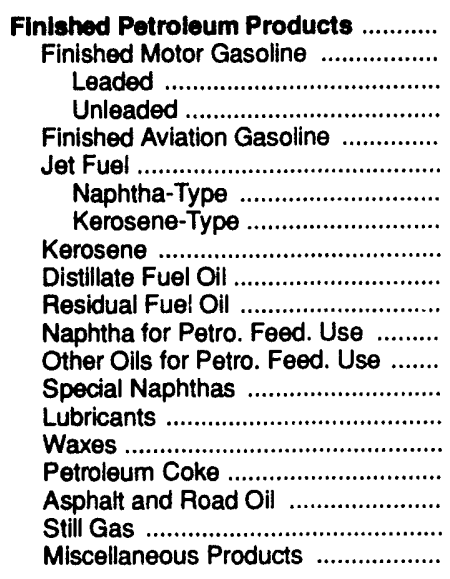 & $\begin{array}{l}= \\
= \\
= \\
= \\
= \\
= \\
= \\
= \\
= \\
= \\
=\end{array}$ & $\begin{array}{r}14,642 \\
6,946 \\
268 \\
6,678 \\
23 \\
1,423 \\
163 \\
1,260 \\
35 \\
2,903 \\
951 \\
147 \\
264 \\
52 \\
159 \\
18 \\
560 \\
435 \\
656 \\
69\end{array}$ & $\begin{array}{r}1,193 \\
309 \\
(\mathrm{~s}) \\
309 \\
(\mathrm{~s}) \\
68 \\
13 \\
55 \\
4 \\
188 \\
433 \\
26 \\
120 \\
8 \\
7 \\
1 \\
2 \\
24 \\
0 \\
2\end{array}$ & $\begin{array}{l}= \\
= \\
= \\
= \\
= \\
= \\
= \\
= \\
= \\
= \\
=\end{array}$ & $\begin{array}{r}-59 \\
-46 \\
-14 \\
-31 \\
(s) \\
-17 \\
-4 \\
-14 \\
-4 \\
-7 \\
-12 \\
(s) \\
-1 \\
-4 \\
1 \\
(s) \\
3 \\
25 \\
0 \\
1\end{array}$ & $\begin{array}{l}= \\
= \\
= \\
= \\
= \\
= \\
= \\
= \\
= \\
= \\
=\end{array}$ & $\begin{array}{l}\bar{z} \\
\bar{z} \\
\bar{z} \\
\bar{z} \\
\bar{z} \\
= \\
= \\
= \\
\bar{z} \\
= \\
=\end{array}$ & $\begin{array}{r}863 \\
85 \\
5 \\
79 \\
0 \\
49 \\
3 \\
46 \\
4 \\
207 \\
234 \\
0 \\
0 \\
17 \\
18 \\
2 \\
244 \\
3 \\
0 \\
(\mathrm{~s})\end{array}$ & $\begin{array}{r}15,031 \\
7,215 \\
277 \\
6,938 \\
24 \\
1,459 \\
177 \\
1,282 \\
39 \\
2,891 \\
1,162 \\
173 \\
385 \\
47 \\
147 \\
18 \\
314 \\
431 \\
656 \\
70\end{array}$ \\
\hline Total & 9,120 & 15,175 & 7,614 & 237 & 88 & (s) & 14,499 & 1,020 & 16,538 \\
\hline
\end{tabular}

a Unaccounted for crude oil represents the difference between the supply and disposition of crude oil. Preliminary estimates of crude oil imports at the National leve! have historically understated final values by approximately 50,000 barrels per day. This causes the preliminary values of unaccounted for crude oil to overstate the final values by the same amount.

b A negative number indicates a decrease in stocks and a positive number indicates an increase in stocks.

c Products supplied is equal to field production, plus refinery production, plus imports, plus unaccounted for crude oil, minus stock change, minus crude losses, minus refinery inputs, minus exports.

(s) = Less than 500 barrels per day.

$E=$ Estimated.

LRG = Liquefied Refinery Gas.

Note: Totals may not equal sum of components due to independent rounding.

Sources: • Energy Information Administration (EIA) Forms EIA-810, "Monthly Refinery Report," EIA-811, "Monthly Bulk Terminal Report," EIA-812, "Monthly Product Pipeline Report," EIA-813, "Monthly Crude Oil Report," EIA-814, "Monthly Imports Report," EIA-816, "Monthly Natural Gas Liquids Report," and EIA-817, "Monthly Tanker and Barge Movement Report." - Domestic crude oil production estimates based on historical statistics from State conservation agencies and the Minerals Management Service of the U.S. Department of the Interior. - Export data from the Bureau of the Census and Form EIA-810, "Monthly Refinery Report." 
Table 6. PAD District —-Supply, Disposition, and Ending Stocks of Crude Oll and Petroleum Products, August 1991 (Thousand Barrels)

\begin{tabular}{|c|c|c|c|c|c|c|c|c|c|c|c|}
\hline \multirow[b]{2}{*}{ Commodity } & \multicolumn{5}{|c|}{ Supply } & \multicolumn{5}{|c|}{ Disposition } & \multirow[b]{2}{*}{$\begin{array}{l}\text { Ending } \\
\text { Stocks }\end{array}$} \\
\hline & $\begin{array}{c}\text { Fleld } \\
\text { Production }\end{array}$ & $\begin{array}{c}\text { Refinery } \\
\text { Production }\end{array}$ & $\begin{array}{c}\text { Imports by } \\
\text { PAD } \\
\text { Dlstrlct } \\
\text { of Entry }\end{array}$ & $\begin{array}{c}\text { Unac- } \\
\text { counted } \\
\text { For } \\
\text { Crude Oll }\end{array}$ & $\begin{array}{c}\text { Not } \\
\text { Recelpts }\end{array}$ & \begin{tabular}{c|} 
Stock \\
Changec
\end{tabular} & $\begin{array}{c}\text { Crude } \\
\text { Losses }\end{array}$ & $\begin{array}{c}\text { Refinery } \\
\text { Inputs }\end{array}$ & Exports & $\begin{array}{l}\text { Products } \\
\text { Supplled }\end{array}$ & \\
\hline 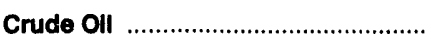 & $E_{736}$ & - & 42,392 & $-3,679$ & -33 & $-1,548$ & $\mathbf{0}$ & 40,964 & 0 & 0 & 15,711 \\
\hline $\begin{array}{l}\text { Natural Gas Llquids and LRGs ......... } \\
\text { Pentanes Plus ................................. } \\
\text { Liquefied Petroleum Gases ............ } \\
\text { Ethane/Ethylene ......................... } \\
\text { Propane/Propylene ................... } \\
\text { Normal Butane/Butylene ............ } \\
\text { Isobutane }\end{array}$ & $\begin{array}{r}728 \\
98 \\
630 \\
208 \\
285 \\
98 \\
39\end{array}$ & $\begin{array}{r}1,624 \\
1,624 \\
0 \\
1,186 \\
455 \\
-17\end{array}$ & $\begin{array}{r}181 \\
0 \\
181 \\
0 \\
132 \\
29 \\
20\end{array}$ & $\begin{array}{l}- \\
- \\
- \\
-\end{array}$ & $\begin{array}{r}2,361 \\
0 \\
2,361 \\
0 \\
2,200 \\
82 \\
79\end{array}$ & $\begin{array}{r}-86 \\
-19 \\
-67 \\
1 \\
-657 \\
565 \\
24\end{array}$ & $\begin{array}{l}- \\
- \\
- \\
-\end{array}$ & $\begin{array}{r}73 \\
14 \\
59 \\
0 \\
0 \\
21 \\
38\end{array}$ & $\begin{array}{r}61 \\
0 \\
61 \\
0 \\
31 \\
31 \\
0\end{array}$ & $\begin{array}{r}4,846 \\
103 \\
4,743 \\
207 \\
4,429 \\
47 \\
59\end{array}$ & $\begin{array}{r}6,052 \\
30 \\
6,022 \\
2 \\
3,276 \\
2,513 \\
231\end{array}$ \\
\hline $\begin{array}{l}\text { Other Liquids ................................. } \\
\text { Other Hydrocartons/Alcohol .......... } \\
\text { Unfinished Oils ................................ } \\
\text { Motor Gasoline Blend. Comp. ......... } \\
\text { Aviation Gasoline Blend. Comp. ..... }\end{array}$ & $\begin{array}{r}253 \\
253 \\
- \\
-\end{array}$ & $\frac{-}{-}$ & $\begin{array}{r}7,168 \\
0 \\
6,283 \\
885 \\
0\end{array}$ & $\begin{array}{l}- \\
- \\
-\end{array}$ & $\begin{array}{r}285 \\
0 \\
151 \\
134 \\
0\end{array}$ & $\begin{array}{r}232 \\
-66 \\
-290 \\
588 \\
0\end{array}$ & $\begin{array}{l}- \\
- \\
-\end{array}$ & $\begin{array}{r}7,865 \\
319 \\
6,003 \\
1,543 \\
0\end{array}$ & $\begin{array}{l}0 \\
0 \\
0 \\
0 \\
0\end{array}$ & $\begin{array}{r}-391 \\
0 \\
721 \\
-1,112 \\
0\end{array}$ & $\begin{array}{r}19,343 \\
366 \\
13,858 \\
5,119 \\
0\end{array}$ \\
\hline 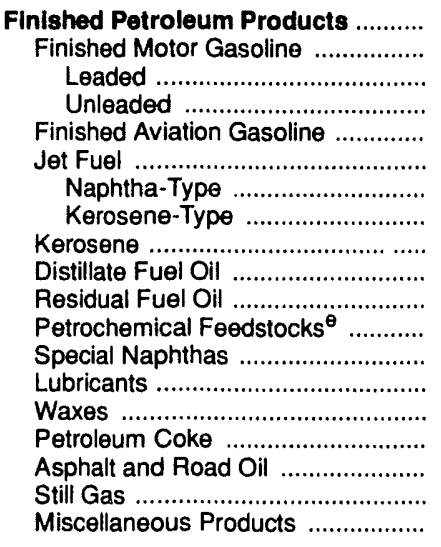 & $\begin{array}{l}- \\
- \\
- \\
- \\
- \\
- \\
- \\
- \\
- \\
-\end{array}$ & $\begin{array}{r}49,333 \\
22,734 \\
400 \\
22,334 \\
-4 \\
3,075 \\
97 \\
2,978 \\
-7 \\
11,129 \\
3,704 \\
420 \\
84 \\
519 \\
74 \\
1,360 \\
3,744 \\
2,172 \\
329\end{array}$ & $\begin{array}{r}32,695 \\
10,855 \\
0 \\
10,855 \\
0 \\
1,938 \\
418 \\
1,520 \\
21 \\
4,725 \\
13,693 \\
315 \\
240 \\
196 \\
13 \\
0 \\
658 \\
0 \\
41\end{array}$ & $\begin{array}{l}- \\
- \\
- \\
- \\
- \\
- \\
- \\
- \\
- \\
- \\
- \\
- \\
-\end{array}$ & $\begin{array}{r}69,033 \\
40,591 \\
0 \\
40,591 \\
117 \\
10,198 \\
99 \\
10,099 \\
116 \\
16,238 \\
548 \\
-58 \\
140 \\
543 \\
0 \\
0 \\
543 \\
0 \\
57\end{array}$ & $\begin{array}{r}5,414 \\
-552 \\
0 \\
-552 \\
25 \\
219 \\
-39 \\
258 \\
94 \\
5,464 \\
721 \\
-1 \\
59 \\
32 \\
-4 \\
92 \\
-782 \\
0 \\
47\end{array}$ & $\begin{array}{l}- \\
- \\
- \\
- \\
- \\
- \\
- \\
- \\
- \\
- \\
- \\
- \\
-\end{array}$ & $\begin{array}{l}- \\
- \\
- \\
- \\
- \\
- \\
- \\
- \\
- \\
- \\
- \\
- \\
-\end{array}$ & $\begin{array}{r}1,197 \\
55 \\
2 \\
53 \\
0 \\
40 \\
(s) \\
40 \\
1 \\
160 \\
553 \\
0 \\
26 \\
166 \\
8 \\
144 \\
30 \\
0 \\
13\end{array}$ & $\begin{array}{r}144,450 \\
74,677 \\
398 \\
74,279 \\
88 \\
14,952 \\
653 \\
14,299 \\
35 \\
26,468 \\
16,671 \\
678 \\
379 \\
1,060 \\
83 \\
1,124 \\
5,697 \\
2,172 \\
367\end{array}$ & $\begin{array}{r}147,682 \\
49,317 \\
106 \\
49,211 \\
212 \\
10,742 \\
461 \\
10,281 \\
2,243 \\
56,050 \\
18,018 \\
125 \\
604 \\
2,509 \\
158 \\
825 \\
5,933 \\
0 \\
946\end{array}$ \\
\hline . & 1,717 & 50,957 & 82,436 & $-3,679$ & 71,646 & 4,012 & $\mathbf{0}$ & 48,902 & 1,258 & 148,905 & 188,788 \\
\hline
\end{tabular}

a Represents the PAD District in which the material entered the United States and not necessarily where the crude oil or product is processed and/or consumed.

Unaccounted for crude oil represents the difference between the supply and disposition of crude oil.

c A negative number indicates a decrease in stocks and a positive number indicates an increase in stocks.

d Products supplied is equal to field production, plus refinery production, plus imports, plus unaccounted for crude oil, plus net receipts, minus stock change, minus crude losses, minus refinery inputs, minus exports.

Includes naphtha less than $401^{\circ} \mathrm{F}$ endpoint and other oils equal to or greater than $401^{\circ} \mathrm{F}$ endpoint.

(s) $=$ Less than 500 barrels.

$E=$ Estimated.

LRG $=$ Liquefied Refinery Gas.

Note: Totals may not equal sum of components due to independent rounding.

Sources: - Energy Information Administration (EIA) Forms EIA-810, "Monthly Refinery Report," EIA-811, "Monthly Bulk Terminal Report," ElA-812, "Monthly Product Pipeline Report," EIA-813, "Monthly Crude Oil Report," EIA-814, "Monthly Imports Report," EIA-816, "Monthly Natural Gas Liquids Report," and EIA-817, "Monthly Tanker

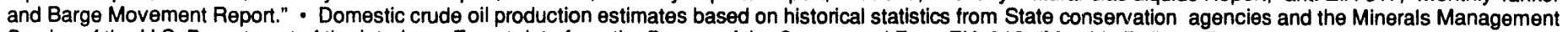
Service of the U.S. Department of the Interior. - Export data from the Bureau of the Census and Form EIA-810, "Monthly Refinery Report." 
Table 7. PAD District —Year-to-Date Supply, Disposition, and Ending Stocks of Crude Oil and Petroleum Products, January-August 1991

(Thousand Barrels)

\begin{tabular}{|c|c|c|c|c|c|c|c|c|c|c|c|}
\hline \multirow[b]{2}{*}{ Commodity } & \multicolumn{5}{|c|}{ Supply } & \multicolumn{5}{|c|}{ Disposition } & \multirow[b]{2}{*}{$\begin{array}{l}\text { Ending } \\
\text { Stocks }\end{array}$} \\
\hline & $\begin{array}{c}\text { Fleld } \\
\text { Production }\end{array}$ & $\begin{array}{c}\text { Refinery } \\
\text { Production }\end{array}$ & $\begin{array}{c}\text { Imports by } \\
\text { PAD } \\
\text { District } \\
\text { of Entry }\end{array}$ & $\begin{array}{c}\text { Unac- } \\
\text { counted } \\
\text { For } \\
\text { Crude Oli }\end{array}$ & $\begin{array}{c}\text { Not } \\
\text { Recelpts }\end{array}$ & $\begin{array}{c}\text { Stock } \\
\text { Changec }\end{array}$ & $\begin{array}{c}\text { Crude } \\
\text { Losses }\end{array}$ & $\begin{array}{c}\text { Refinery } \\
\text { Innuts }\end{array}$ & Exports & {$\left[\begin{array}{l}\text { Products } \\
\text { Supplled }\end{array}\right]$} & \\
\hline 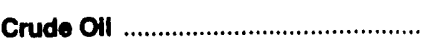 & $E_{6,023}$ & 一 & 300,333 & 1,030 & 611 & 1,191 & 0 & 306,535 & 272 & 0 & 15,711 \\
\hline 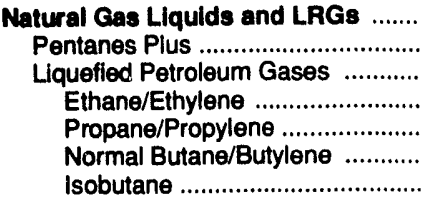 & $\begin{array}{r}5,630 \\
745 \\
4,885 \\
1,554 \\
2,249 \\
787 \\
295\end{array}$ & $\begin{array}{r}12,008 \\
- \\
12,008 \\
154 \\
10,357 \\
1,908 \\
-411\end{array}$ & $\begin{array}{r}4,282 \\
890 \\
3,392 \\
0 \\
3,100 \\
117 \\
175\end{array}$ & $\begin{array}{l}- \\
- \\
- \\
-\end{array}$ & $\begin{array}{r}18,586 \\
0 \\
18,586 \\
0 \\
18,063 \\
256 \\
267\end{array}$ & $\begin{array}{r}-389 \\
-15 \\
-374 \\
-14 \\
-1,713 \\
1,348 \\
5\end{array}$ & $\begin{array}{l}- \\
- \\
- \\
-\end{array}$ & $\begin{array}{r}414 \\
14 \\
400 \\
0 \\
0 \\
143 \\
257\end{array}$ & $\begin{array}{r}715 \\
12 \\
703 \\
0 \\
465 \\
238 \\
0\end{array}$ & $\begin{array}{r}39,766 \\
1,624 \\
38,142 \\
1,722 \\
35,017 \\
1,339 \\
64\end{array}$ & $\begin{array}{r}6,052 \\
30 \\
6,022 \\
2 \\
2 \\
3,276 \\
2,513 \\
231\end{array}$ \\
\hline $\begin{array}{l}\text { Other Llquids .............................. } \\
\text { Other Hydrocarbons/Alcohol ........... } \\
\text { Unfinished Oils ............................. } \\
\text { Motor Gasoline Blend. Comp. ......... } \\
\text { Aviation Gasoline Blend. Comp. ..... }\end{array}$ & $\begin{array}{r}1,824 \\
1,824 \\
= \\
-\end{array}$ & $\begin{array}{l}- \\
- \\
-\end{array}$ & $\begin{array}{r}43,834 \\
264 \\
35,334 \\
8,236 \\
0\end{array}$ & $\begin{array}{l}- \\
- \\
-\end{array}$ & $\begin{array}{r}3,678 \\
0 \\
1,322 \\
2,356 \\
0\end{array}$ & $\begin{array}{r}2,941 \\
66 \\
1,990 \\
885 \\
0\end{array}$ & $\begin{array}{l}- \\
- \\
-\end{array}$ & $\begin{array}{r}52,061 \\
2,022 \\
43,644 \\
6,395 \\
0\end{array}$ & $\begin{array}{l}0 \\
0 \\
0 \\
0 \\
0\end{array}$ & $\begin{array}{r}-5,666 \\
0 \\
-8,978 \\
3,312 \\
0\end{array}$ & $\begin{array}{r}19,343 \\
366 \\
13,858 \\
5,119 \\
0\end{array}$ \\
\hline 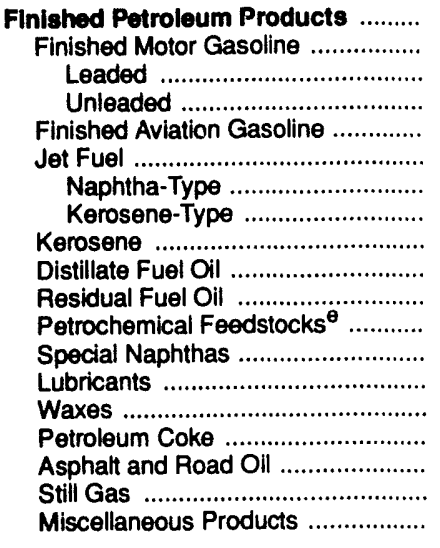 & $\begin{array}{l}- \\
- \\
- \\
- \\
= \\
- \\
= \\
- \\
- \\
-\end{array}$ & $\begin{array}{r}362,799 \\
164,518 \\
1,445 \\
163,073 \\
115 \\
19,874 \\
1,415 \\
18,459 \\
970 \\
84,773 \\
34,270 \\
2,852 \\
1,178 \\
4,218 \\
671 \\
10,562 \\
21,235 \\
15,101 \\
2,462\end{array}$ & $\begin{array}{r}223,155 \\
69,204 \\
0 \\
69,204 \\
11 \\
14,879 \\
2,791 \\
12,088 \\
976 \\
41,692 \\
86,876 \\
2,096 \\
537 \\
1,528 \\
296 \\
0 \\
4,787 \\
0 \\
273\end{array}$ & $\begin{array}{l}- \\
- \\
- \\
- \\
- \\
- \\
- \\
- \\
- \\
- \\
- \\
-\end{array}$ & $\begin{array}{r}559,000 \\
334,108 \\
-177 \\
334,285 \\
722 \\
81,651 \\
1,700 \\
79,951 \\
1,728 \\
126,228 \\
6,235 \\
-544 \\
1,365 \\
3,887 \\
26 \\
0 \\
3,029 \\
0 \\
565\end{array}$ & $\begin{array}{r}-13,601 \\
-6,716 \\
6 \\
-6,722 \\
6 \\
-2,850 \\
-67 \\
-2,783 \\
-669 \\
459 \\
-5,256 \\
46 \\
-3 \\
-500 \\
103 \\
76 \\
1,442 \\
0 \\
261\end{array}$ & $\begin{array}{l}- \\
- \\
- \\
- \\
- \\
- \\
- \\
- \\
- \\
- \\
- \\
-\end{array}$ & $\begin{array}{l}- \\
- \\
- \\
- \\
- \\
- \\
- \\
- \\
- \\
- \\
- \\
-\end{array}$ & $\begin{array}{r}11,255 \\
694 \\
21 \\
673 \\
0 \\
991 \\
15 \\
976 \\
472 \\
3,167 \\
2,634 \\
0 \\
430 \\
1,346 \\
69 \\
1,268 \\
132 \\
0 \\
53\end{array}$ & $\begin{array}{r}1,147,300 \\
573,852 \\
1,241 \\
572,611 \\
842 \\
118,263 \\
5,958 \\
112,305 \\
3,871 \\
249,067 \\
130,003 \\
4,358 \\
2,653 \\
8,787 \\
821 \\
9,218 \\
27,477 \\
15,101 \\
2,986\end{array}$ & $\begin{array}{r}147,682 \\
49,317 \\
106 \\
49,211 \\
212 \\
10,742 \\
461 \\
10,281 \\
2,243 \\
56,050 \\
18,018 \\
125 \\
604 \\
2,509 \\
158 \\
825 \\
5,933 \\
0 \\
946\end{array}$ \\
\hline Total & 13,477 & 374,807 & 571,604 & 1,030 & 581,875 & $-9,858$ & 0 & 359,010 & 12,242 & $1,181,399$ & 188,788 \\
\hline
\end{tabular}

a Represents the PAD District in which the material entered the United States and not necessarily where the crude oil or product is processed and/or consumed.

b Unaccounted for crude oil represents the difference between the supply and disposition of crude oil.

c A negative number indicates a decrease in stocks and a positive number indicates an increase in stocks.

d Prociucts supplied is equal to field production, plus refinery production, plus imports, plus unaccounted for crude oil, plus net receipts, minus stock change, minus crude losses, minus refinery inputs, minus exports.

Includes naphtha less than $401^{\circ} \mathrm{F}$ endpoint and other oils equal to or greater than $401^{\circ} \mathrm{F}$ endpoint.

(s) = Less than 500 barrels.

$E=$ Estimated.

LAG = Liquefied Refinery Gas.

Note: Totals may not equal sum of components due to independent rounding.

Sources: - Energy Information Administration (EIA) Forms EIA-810, "Monthly Refinery Report," EIA-811, "Monthly Bulk Terminal Report," EIA-812, "Monthly Product Pipeline Report," EIA-813, "Monthly Crude Oil Report," EIA-814, "Monthly Imports Report," EIA-816, "Monthly Natural Gas Liquids Report," and EIA-817, "Monthly Tanker and Barge Movement Report." - Domestic crude oil production estimates based on historical statistics from State conservation agencies and the Minerals Management Service of the U.S. Department of the Interior. - Export data from the Bureau of the Census and Form EIA-810, "Monthly Refinery Report." 
Table 8. PAD District —Daily Average Supply and Disposition of Crude Oil and Petroleum Products, August 1991 (Thousand Barrels per Day)

\begin{tabular}{|c|c|c|c|c|c|c|c|c|c|c|}
\hline \multirow[b]{2}{*}{ Commodity } & \multicolumn{5}{|c|}{ Supply } & \multicolumn{5}{|c|}{ Disposition } \\
\hline & $\begin{array}{c}\text { Field } \\
\text { Production }\end{array}$ & $\begin{array}{c}\text { Refinery } \\
\text { Production }\end{array}$ & $\begin{array}{c}\text { Imports by } \\
\text { PAD } \\
\text { District } \\
\text { of Entry }\end{array}$ & $\begin{array}{c}\text { Unac- } \\
\text { counted } \\
\text { For } \\
\text { Crude Oll } \\
\end{array}$ & $\begin{array}{c}\text { Net } \\
\text { Recelpts }\end{array}$ & $\begin{array}{c}\text { Stock } \\
\text { Changec }\end{array}$ & $\begin{array}{c}\text { Crude } \\
\text { Losses }\end{array}$ & $\begin{array}{c}\text { Refinery } \\
\text { Inputs }\end{array}$ & Exports & $\begin{array}{l}\text { Products } \\
\text { Supplled }\end{array}$ \\
\hline 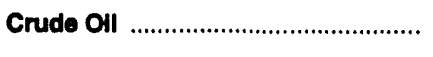 & $E_{24}$ & 一 & 1,367 & -119 & -1 & -50 & 0 & 1,321 & 0 & 0 \\
\hline 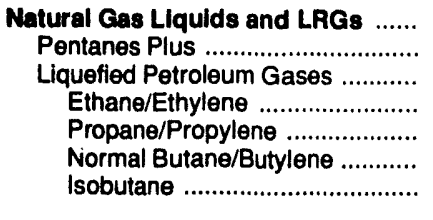 & $\begin{array}{r}23 \\
3 \\
20 \\
7 \\
9 \\
3 \\
1\end{array}$ & $\begin{array}{r}52 \\
52 \\
0 \\
38 \\
15 \\
-1\end{array}$ & $\begin{array}{l}6 \\
0 \\
6 \\
0 \\
4 \\
1 \\
1\end{array}$ & $\begin{array}{l}- \\
z \\
z \\
-\end{array}$ & $\begin{array}{r}76 \\
0 \\
76 \\
0 \\
71 \\
3 \\
3\end{array}$ & $\begin{array}{r}-3 \\
-1 \\
-2 \\
(s) \\
-21 \\
18 \\
1\end{array}$ & $\begin{array}{l}- \\
- \\
z \\
-\end{array}$ & $\begin{array}{r}2 \\
(s) \\
2 \\
0 \\
0 \\
1 \\
1\end{array}$ & $\begin{array}{l}2 \\
0 \\
2 \\
0 \\
1 \\
1 \\
0\end{array}$ & $\begin{array}{r}156 \\
3 \\
153 \\
7 \\
143 \\
2 \\
2\end{array}$ \\
\hline $\begin{array}{l}\text { Other Llquids .............................. } \\
\text { Other Hydrocarbons/Alcohol .......... } \\
\text { Unfinished Oils ........................... } \\
\text { Motor Gasoline Blend. Comp. ....... } \\
\text { Aviation Gasoline Blend. Comp. ... }\end{array}$ & $\begin{array}{l}8 \\
8 \\
- \\
-\end{array}$ & $\begin{array}{l}- \\
- \\
-\end{array}$ & $\begin{array}{r}231 \\
0 \\
203 \\
29 \\
0\end{array}$ & $\begin{array}{l}- \\
\overline{-} \\
-\end{array}$ & $\begin{array}{l}9 \\
0 \\
5 \\
4 \\
0\end{array}$ & $\begin{array}{r}7 \\
-2 \\
-9 \\
19 \\
0\end{array}$ & $\begin{array}{l}- \\
- \\
-\end{array}$ & $\begin{array}{r}254 \\
10 \\
194 \\
50 \\
0\end{array}$ & $\begin{array}{l}0 \\
0 \\
0 \\
0 \\
0\end{array}$ & $\begin{array}{r}-13 \\
0 \\
23 \\
-36 \\
0\end{array}$ \\
\hline 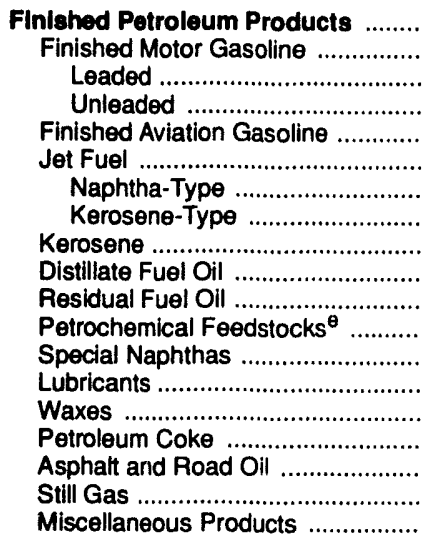 & 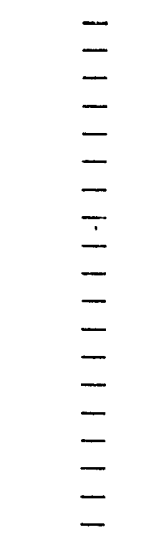 & $\begin{array}{r}1,591 \\
733 \\
13 \\
720 \\
(s) \\
99 \\
3 \\
96 \\
(s) \\
359 \\
119 \\
14 \\
3 \\
17 \\
2 \\
44 \\
121 \\
70 \\
11\end{array}$ & $\begin{array}{r}1,055 \\
350 \\
0 \\
350 \\
0 \\
63 \\
13 \\
49 \\
1 \\
152 \\
442 \\
10 \\
8 \\
6 \\
(s) \\
0 \\
21 \\
0 \\
1\end{array}$ & $\begin{array}{l}- \\
- \\
- \\
- \\
- \\
- \\
- \\
- \\
- \\
- \\
- \\
- \\
- \\
-\end{array}$ & $\begin{array}{r}2,227 \\
1,309 \\
0 \\
1,309 \\
4 \\
329 \\
3 \\
326 \\
4 \\
524 \\
18 \\
-2 \\
5 \\
18 \\
0 \\
0 \\
18 \\
0 \\
2\end{array}$ & $\begin{array}{r}175 \\
-18 \\
0 \\
-18 \\
1 \\
7 \\
-1 \\
8 \\
3 \\
176 \\
23 \\
(s) \\
2 \\
1 \\
(s) \\
3 \\
-25 \\
0 \\
2\end{array}$ & $\begin{array}{l}- \\
- \\
- \\
- \\
z \\
- \\
- \\
- \\
- \\
- \\
- \\
- \\
- \\
-\end{array}$ & $\begin{array}{l}- \\
- \\
- \\
- \\
- \\
- \\
- \\
- \\
- \\
- \\
- \\
- \\
- \\
-\end{array}$ & $\begin{array}{r}39 \\
2 \\
(\mathrm{~s}) \\
2 \\
0 \\
1 \\
(\mathrm{~s}) \\
1 \\
(\mathrm{~s}) \\
5 \\
18 \\
0 \\
1 \\
5 \\
(\mathrm{~s}) \\
5 \\
1 \\
0 \\
(\mathrm{~s})\end{array}$ & $\begin{array}{r}4,660 \\
2,409 \\
13 \\
2,396 \\
3 \\
482 \\
21 \\
461 \\
1 \\
854 \\
538 \\
22 \\
12 \\
34 \\
3 \\
36 \\
184 \\
70 \\
12\end{array}$ \\
\hline 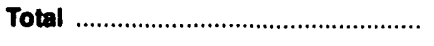 & 55 & 1,644 & 2,659 & -119 & 2,311 & 129 & $\mathbf{0}$ & 1,577 & 41 & 4,803 \\
\hline
\end{tabular}

\footnotetext{
a Represents the PAD District in which the material entered the United States and not necessarily where the crude oil or product is processed and/or consumed.

b Unaccounted for crude oil represents the difference between the supply and disposition of crude oil.

c A negative number indicates a decrease in stocks and a positive number indicates an increase in stocks.

d Products supplied is equal to field production, plus refinery production, plus imports, plus unaccounted for crude oil, plus net receipts, minus stock change, minus crude losses, minus refinery inputs, minus exports.

- Includes naphtha less than $401^{\circ} \mathrm{F}$ endpoint and other oils equal to or greater than $401^{\circ} \mathrm{F}$ endpoint.

(s) = Less than 500 barrels per day.

$E$ = Estimated.

LRG = Liquefied Refinery Gas.

Note: Totals may not equal sum of components due to independent rounding.

Sources: - Energy Information Administration (EIA) Forms EIA-810, "Monthly Refinery Report," EIA-811, "Monthly Bulk Terminal Report," EIA-812, "Monthly Product Pipeline Report," EIA-813, "Monthly Crude Oil Report," EIA-814, "Monthly Imports Report," EIA-816, "Monthly Natural Gas Liquids Report," and ElA-817, "Monthly Tanker and Barge Movement Report." - Domestic crude oil production estimates based on historical statistics from State conservation agencies and the Minerals Management Service of the U.S. Department of the Interior. - Export data from the Bureau of the Census and Form EIA-810, "Monthly Refinery Report."
} 
Table 9. PAD District —Year-to-Date Dally Average Supply and Disposition of Crude Oll and Petroleum Products, January-August 1991 (Thousand Barrels per Day)

\begin{tabular}{|c|c|c|c|c|c|c|c|c|c|c|}
\hline \multirow[b]{2}{*}{ Commodity } & \multicolumn{5}{|c|}{ Supply } & \multicolumn{5}{|c|}{ Dlsposition } \\
\hline & $\begin{array}{c}\text { Fleld } \\
\text { Production } \\
\end{array}$ & $\begin{array}{c}\text { Pefinery } \\
\text { Production }\end{array}$ & $\begin{array}{c}\text { Imports by } \\
\text { PAD } \\
\text { District } \\
\text { of Entry }\end{array}$ & $\begin{array}{c}\text { Unac- } \\
\text { counted } \\
\text { For } \\
\text { Crude OII }\end{array}$ & $\begin{array}{c}\text { Net } \\
\text { Recelpts }\end{array}$ & $\begin{array}{c}\text { Stock } \\
\text { Changec }\end{array}$ & $\begin{array}{c}\text { Crude } \\
\text { Losses }\end{array}$ & $\begin{array}{c}\text { Refinery } \\
\text { Inputs }\end{array}$ & Exports & $\begin{array}{l}\text { Products } \\
\text { Supplled }\end{array}$ \\
\hline 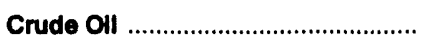 & $E_{25}$ & - & 1,236 & 4 & 3 & 5 & 0 & 1,261 & 1 & 0 \\
\hline $\begin{array}{l}\text { Natural Gas Llquids and LRGs ...... } \\
\text { Pentanes Plus .............................. } \\
\text { Liquefied Petroleum Gases .......... } \\
\text { Ethane/Ethylene ........................ } \\
\text { Propane/Propylene ................. } \\
\text { Normal Butane/Butylene .......... } \\
\text { Isobutane ................................ }\end{array}$ & $\begin{array}{r}23 \\
3 \\
20 \\
6 \\
9 \\
3 \\
1\end{array}$ & $\begin{array}{r}49 \\
49 \\
1 \\
43 \\
8 \\
-2\end{array}$ & $\begin{array}{r}18 \\
4 \\
14 \\
0 \\
13 \\
(s) \\
1\end{array}$ & $\begin{array}{l}- \\
- \\
- \\
-\end{array}$ & $\begin{array}{r}76 \\
0 \\
76 \\
0 \\
74 \\
1 \\
1\end{array}$ & $\begin{array}{r}-2 \\
(s) \\
-2 \\
(s) \\
-7 \\
6 \\
(s)\end{array}$ & $\begin{array}{l}- \\
- \\
- \\
-\end{array}$ & $\begin{array}{r}2 \\
(s) \\
2 \\
0 \\
0 \\
1 \\
1\end{array}$ & $\begin{array}{r}3 \\
\text { (s) } \\
3 \\
0 \\
2 \\
1 \\
0\end{array}$ & $\begin{array}{r}164 \\
7 \\
157 \\
7 \\
144 \\
6 \\
(s)\end{array}$ \\
\hline $\begin{array}{l}\text { Other Liquids ................................ } \\
\text { Other Hydrocarbons/Alcohol ........ } \\
\text { Unfinished Oils ............................. } \\
\text { Motor Gasoline Blend. Comp. ....... } \\
\text { Aviation Gasoline Blend. Comp. ... }\end{array}$ & $\begin{array}{l}8 \\
8 \\
- \\
-\end{array}$ & $\begin{array}{l}- \\
- \\
-\end{array}$ & $\begin{array}{r}180 \\
1 \\
145 \\
34 \\
0\end{array}$ & $\begin{array}{l}- \\
- \\
-\end{array}$ & $\begin{array}{r}15 \\
0 \\
5 \\
10 \\
0\end{array}$ & $\begin{array}{r}12 \\
\text { (s) } \\
8 \\
4 \\
0\end{array}$ & $\begin{array}{l}- \\
- \\
-\end{array}$ & $\begin{array}{r}214 \\
8 \\
180 \\
26 \\
0\end{array}$ & $\begin{array}{l}0 \\
0 \\
0 \\
0 \\
0\end{array}$ & $\begin{array}{r}-23 \\
0 \\
-37 \\
14 \\
0\end{array}$ \\
\hline 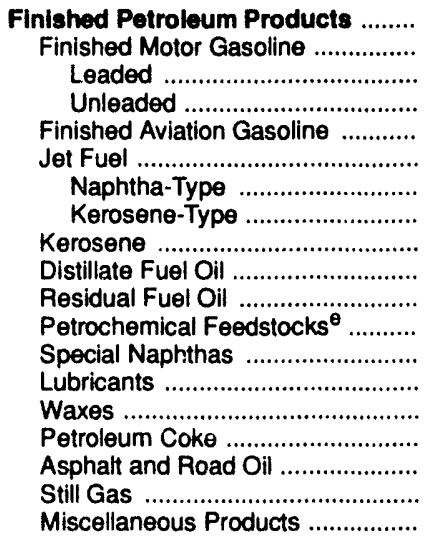 & $\begin{array}{l}- \\
- \\
- \\
- \\
- \\
- \\
- \\
- \\
- \\
- \\
-\end{array}$ & $\begin{array}{r}1,493 \\
677 \\
6 \\
671 \\
(s) \\
82 \\
6 \\
76 \\
4 \\
349 \\
141 \\
12 \\
5 \\
17 \\
3 \\
43 \\
87 \\
62 \\
10\end{array}$ & $\begin{array}{r}918 \\
285 \\
0 \\
285 \\
(\mathbf{s}) \\
61 \\
11 \\
50 \\
4 \\
172 \\
358 \\
9 \\
2 \\
6 \\
1 \\
0 \\
20 \\
0 \\
1\end{array}$ & $\begin{array}{l}- \\
- \\
- \\
- \\
- \\
- \\
- \\
- \\
- \\
- \\
- \\
- \\
- \\
-\end{array}$ & $\begin{array}{r}2,300 \\
1,375 \\
-1 \\
1,376 \\
3 \\
336 \\
7 \\
329 \\
7 \\
519 \\
26 \\
-2 \\
6 \\
16 \\
(s) \\
0 \\
12 \\
0 \\
2\end{array}$ & $\begin{array}{r}-56 \\
-28 \\
(s) \\
-28 \\
(s) \\
-12 \\
(s) \\
-11 \\
-3 \\
2 \\
-22 \\
(s) \\
(s) \\
-2 \\
(s) \\
(s) \\
6 \\
0 \\
1\end{array}$ & $\begin{array}{l}- \\
- \\
- \\
- \\
- \\
- \\
- \\
- \\
- \\
- \\
- \\
- \\
- \\
-\end{array}$ & $\begin{array}{l}- \\
- \\
- \\
- \\
- \\
- \\
- \\
- \\
- \\
- \\
- \\
- \\
- \\
-\end{array}$ & $\begin{array}{r}46 \\
3 \\
(s) \\
3 \\
0 \\
4 \\
(s) \\
4 \\
2 \\
13 \\
11 \\
0 \\
2 \\
6 \\
(s) \\
5 \\
1 \\
0 \\
(s)\end{array}$ & $\begin{array}{r}4,721 \\
2,362 \\
5 \\
2,356 \\
3 \\
487 \\
25 \\
462 \\
16 \\
1,025 \\
535 \\
18 \\
11 \\
36 \\
3 \\
38 \\
113 \\
62 \\
12\end{array}$ \\
\hline 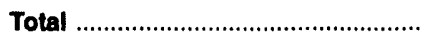 & 55 & 1,542 & 2,352 & 4 & 2,395 & -41 & 0 & 1,477 & 50 & 4,862 \\
\hline
\end{tabular}

a Represents the PAD District in which the material entered the United States and not necessarily where ?he crude oil or product is processed and/or consumed. b Unaccounted for crude oil represents the difference between the supply and disposition of crude oil.

c A negative number indicates a decrease in stocks and a positive number indicates an increase in stocks.

d Products supplied is equal to field production, plus refinery production, plus imports, plus unaccounted for crude oil, plus net receipts, minus stock change, minus crude losses, minus refinery inputs, minus exports.

$\theta$ Includes naphtha less than $401^{\circ} \mathrm{F}$ endpoint and other oils equal to ur greater than $401^{\circ} \mathrm{F}$ endpoint

(s) = Less than 500 barrels per day.

$E=$ Estimated.

LRG = Liquefied Refinery Gas.

Note: Totals may not equal sum of components due to independent rounding.

Sources: - Energy Information Administration (EIA) Forms EIA-810, "Monthly Refinery Report," EIA-811, "Monthly Bulk Terminal Report," EIA-812, "Monthly Product Pipeline Report," ElA-813, "Monthly Crude Oil Report," ElA-814, "Monthly Imports Report," ElA-816, "Monthly Natural Gas Liquids Report," and ElA-817, "Monthly Tanker and Barge Movement Report." - Domestic crude oll production estimates based on historical statistics from State conservation agencies and the Minerals Management Service of the U.S. Depr-ment of the Interior. - Export data from the Bureau of the Census and Form ElA-810. "Monthly Refinery Report." 
Table 10. PAD District II-Supply, Disposition, and Ending Stocks of Crude OII and Petroleum Products, August 1991 (Thousand Barrels)

\begin{tabular}{|c|c|c|c|c|c|c|c|c|c|c|c|}
\hline \multirow[b]{2}{*}{ Commodity } & \multicolumn{5}{|c|}{ Supply } & \multicolumn{5}{|c|}{ Disposition } & \multirow[b]{2}{*}{$\begin{array}{l}\text { Ending } \\
\text { Stocks }\end{array}$} \\
\hline & $\begin{array}{c}\text { Fleld } \\
\text { Production }\end{array}$ & $\begin{array}{c}\text { Refinery } \\
\text { Production }\end{array}$ & $\begin{array}{c}\text { Imports by } \\
\text { PAD } \\
\text { District } \\
\text { of Entry }\end{array}$ & $\begin{array}{l}\text { Unac- } \\
\text { counted } \\
\text { For } \\
\text { Crude Oll }\end{array}$ & $\begin{array}{c}\text { Not } \\
\text { Recelpts }\end{array}$ & $\begin{array}{c}\text { Stock } \\
\text { Change }\end{array}$ & $\begin{array}{l}\text { Crude } \\
\text { Losses }\end{array}$ & $\begin{array}{c}\text { Refinery } \\
\text { Inputs }\end{array}$ & Exports & $\begin{array}{l}\text { Producte } \\
\text { Supplled }^{\mathrm{d}}\end{array}$ & \\
\hline Crude Oil .................. & $E_{22,023}$ & - & 16,447 & 1,043 & 58,661 & 1,636 & 0 & 96,506 & 32 & $\mathbf{0}$ & 70,916 \\
\hline 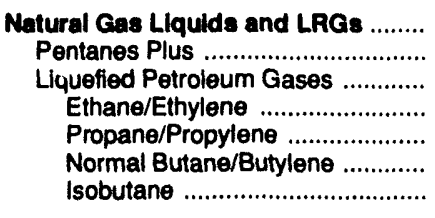 & $\begin{array}{r}9,248 \\
1,474 \\
7,774 \\
2,763 \\
3,244 \\
1,074 \\
693\end{array}$ & $\begin{array}{r}3,573 \\
3,573 \\
0 \\
3,149 \\
523 \\
-99\end{array}$ & $\begin{array}{r}1,783 \\
38 \\
1,745 \\
0 \\
1,414 \\
330 \\
1\end{array}$ & $\begin{array}{l}- \\
- \\
- \\
-\end{array}$ & $\begin{array}{r}426 \\
701 \\
-275 \\
-1,813 \\
518 \\
284 \\
736\end{array}$ & $\begin{array}{r}3,239 \\
616 \\
2,623 \\
13 \\
1,377 \\
1,261 \\
-28\end{array}$ & $\begin{array}{l}- \\
z \\
z\end{array}$ & $\begin{array}{r}3,178 \\
1,302 \\
1,876 \\
0 \\
0 \\
262 \\
1,614\end{array}$ & $\begin{array}{r}110 \\
0 \\
110 \\
0 \\
92 \\
18 \\
0\end{array}$ & $\begin{array}{r}8,503 \\
295 \\
8,208 \\
937 \\
6,856 \\
670 \\
-255\end{array}$ & $\begin{array}{r}44,646 \\
3,464 \\
41,182 \\
6,059 \\
23,048 \\
9,749 \\
2,326\end{array}$ \\
\hline $\begin{array}{l}\text { Cther Llquids ............................... } \\
\text { Other Hydrocarbons/Alcohol ........... } \\
\text { Unfinished Oils ............................. } \\
\text { Motor Gasoline Blend. Comp. ......... } \\
\text { Aviation Gasoline Blend. Comp. .... }\end{array}$ & $\begin{array}{l}83 \\
83 \\
- \\
-\end{array}$ & $\begin{array}{l}- \\
- \\
-\end{array}$ & $\begin{array}{r}193 \\
0 \\
0 \\
193 \\
0\end{array}$ & $\frac{-}{-}$ & $\begin{array}{r}202 \\
0 \\
172 \\
30 \\
0\end{array}$ & $\begin{array}{r}-1,782 \\
-20 \\
-2,009 \\
245 \\
2\end{array}$ & $\frac{-}{-}$ & $\begin{array}{r}4,268 \\
103 \\
3,506 \\
661 \\
-2\end{array}$ & $\begin{array}{l}0 \\
0 \\
0 \\
0 \\
0\end{array}$ & $\begin{array}{r}-2,008 \\
0 \\
-1,325 \\
683 \\
0\end{array}$ & $\begin{array}{r}23,650 \\
244 \\
15,926 \\
7,448 \\
32\end{array}$ \\
\hline 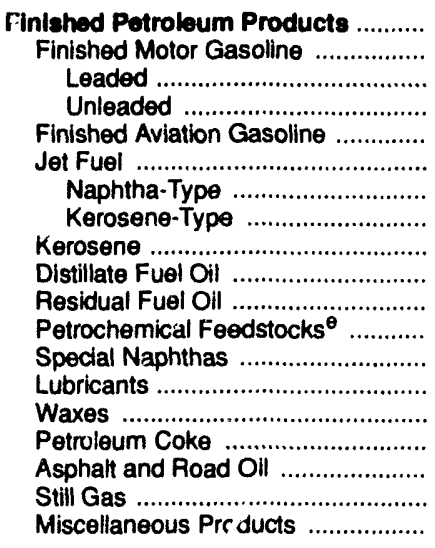 & $\begin{array}{l}- \\
- \\
- \\
z \\
- \\
z \\
z \\
- \\
- \\
-\end{array}$ & $\begin{array}{r}104,601 \\
56,137 \\
366 \\
55,771 \\
127 \\
6,528 \\
766 \\
5,762 \\
-22 \\
22,038 \\
2,450 \\
1,269 \\
494 \\
718 \\
78 \\
3,958 \\
6,001 \\
4,556 \\
269\end{array}$ & $\begin{array}{r}743 \\
302 \\
0 \\
302 \\
0 \\
27 \\
27 \\
0 \\
0 \\
183 \\
71 \\
9 \\
82 \\
22 \\
3 \\
0 \\
38 \\
0 \\
6\end{array}$ & $\begin{array}{l}- \\
- \\
- \\
- \\
- \\
- \\
- \\
- \\
- \\
- \\
-\end{array}$ & $\begin{array}{r}22,879 \\
15,796 \\
74 \\
15,722 \\
102 \\
2,736 \\
-8 \\
2,744 \\
21 \\
4,469 \\
-763 \\
58 \\
33 \\
224 \\
0 \\
0 \\
214 \\
0 \\
-11\end{array}$ & $\begin{array}{r}741 \\
2,965 \\
-105 \\
3,070 \\
-43 \\
114 \\
137 \\
-23 \\
-190 \\
-45 \\
32 \\
86 \\
-26 \\
44 \\
-7 \\
-47 \\
-2,075 \\
0 \\
-67\end{array}$ & $\begin{array}{l}- \\
- \\
- \\
- \\
- \\
- \\
- \\
- \\
- \\
- \\
- \\
-\end{array}$ & $\begin{array}{l}- \\
- \\
- \\
- \\
\overline{-} \\
\overline{-} \\
\overline{-} \\
\overline{-} \\
\overline{-} \\
\overline{-} \\
\overline{-}\end{array}$ & $\begin{array}{r}738 \\
303 \\
0 \\
303 \\
0 \\
36 \\
(s) \\
35 \\
16 \\
10 \\
0 \\
0 \\
2 \\
32 \\
8 \\
269 \\
61 \\
0 \\
0\end{array}$ & $\begin{array}{r}126,744 \\
68,967 \\
545 \\
68,422 \\
272 \\
9,141 \\
648 \\
8,494 \\
173 \\
26,725 \\
1,726 \\
1,250 \\
633 \\
888 \\
80 \\
3,-36 \\
8,267 \\
4,556 \\
331\end{array}$ & $\begin{array}{r}116,053 \\
52,165 \\
926 \\
51,239 \\
483 \\
10,297 \\
1,106 \\
9,191 \\
1,435 \\
33,133 \\
3,924 \\
367 \\
362 \\
1,806 \\
127 \\
1,766 \\
9,923 \\
0 \\
265\end{array}$ \\
\hline Total & 31,354 & 108,174 & 19,166 & 1,043 & 82,168 & 3,834 & $\mathbf{0}$ & 103,952 & 880 & 133,239 & 255,285 \\
\hline
\end{tabular}

a Represents the PAD District in which the material entered the United States and not necessarily where the crude oil or product is processed and/or consumed.

Unaccounted for crude oil represents the difference between the supply and disposition of crude oil.

c A negative number indicates a decrease in stocks and a positive number indicates an increase in stocks.

d Products supplied is equal to field production, plus refinery production, plus imports, plus unaccounted for crude oil, plus net receipts, minus stock change, minus crude losses, minus refinery inputs, minus exports.

$\theta$ Includes naphtha less than $401^{\circ} \mathrm{F}$ endpoint and other oils equal to or greater than $401^{\circ} \mathrm{F}$ endpoint.

(s) = Less than 500 barrels.

E is Estimated.

LRG = Liquefied Refinery Gas.

Note: Totals may not equal sum of components due to independemi rounding

Sources: - Energy Information Administration (EIA) Forms ElA-810, "Monthly Refinery Report," ElA-811, "Monthly Bulk Terminal Report," ElA-812, "Monthly Product Pipeline Report," EIA-813, "Monthly Crude Oil Report," ElA-814, "Monthly Imports Report, "ElA-816, "Monthly Natural Gas Liquids Report," and ElA-817, "Monthly Tanker and Barge Movement Peport." - Domestic crude oil production estimates based on historical statistics from State conservation agencies and the Minerals Management Service of the U.S. Department of the Interior. - Export data from the Bureau of the Census and Form EIA-810, "Monthly Refinery Report." 
Table 11. PAD District I-Year-to-Date Supply, Dlsposition, and Ending Stocks of Crude Oil and Petroleum Products, January-August 1991 (Thousand Barrels)

\begin{tabular}{|c|c|c|c|c|c|c|c|c|c|c|c|}
\hline \multirow[b]{2}{*}{ Commodity } & \multicolumn{5}{|c|}{ Supply } & \multicolumn{5}{|c|}{ Disposition } & \multirow[b]{2}{*}{$\begin{array}{l}\text { Ending } \\
\text { Stocks }\end{array}$} \\
\hline & $\begin{array}{c}\text { Fleld } \\
\text { Production }\end{array}$ & $\begin{array}{c}\text { Refinery } \\
\text { Production }\end{array}$ & $\begin{array}{c}\text { Imports by } \\
\text { PAD } \\
\text { District } \\
\text { of Entry }\end{array}$ & $\begin{array}{c}\text { Unac- } \\
\text { counted } \\
\text { For } \\
\text { Crude Ollb }\end{array}$ & $\begin{array}{c}\text { Net } \\
\text { Recelpts }\end{array}$ & $\begin{array}{c}\text { Stock } \\
\text { Changec }\end{array}$ & $\begin{array}{l}\text { Crude } \\
\text { Losses } \\
\end{array}$ & $\begin{array}{c}\text { Refinery } \\
\text { Inputs }\end{array}$ & Exports & $\begin{array}{l}\text { Products } \\
\text { Supplied }\end{array}$ & \\
\hline 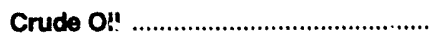 & $E_{177,416}$ & - & 145,502 & 3,157 & 418,428 & 2,546 & 1 & 741,905 & 51 & 0 & 70,916 \\
\hline 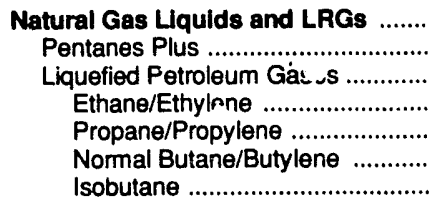 & $\begin{array}{r}75,771 \\
11,350 \\
64,421 \\
22,725 \\
27,130 \\
8,890 \\
5,676\end{array}$ & $\begin{array}{r}26,404 \\
26,404 \\
83 \\
24,568 \\
2,084 \\
-331\end{array}$ & $\begin{array}{r}15,468 \\
315 \\
15,153 \\
1,850 \\
10,603 \\
2,209 \\
491\end{array}$ & $\begin{array}{l}- \\
- \\
- \\
-\end{array}$ & $\begin{array}{r}5,289 \\
3,754 \\
1,535 \\
-9,221 \\
4,484 \\
1,603 \\
4,669\end{array}$ & $\begin{array}{r}11,318 \\
1,314 \\
10,004 \\
432 \\
5,169 \\
4,574 \\
-171\end{array}$ & $\begin{array}{l}- \\
- \\
- \\
-\end{array}$ & $\begin{array}{r}25,621 \\
8,110 \\
17,511 \\
0 \\
0 \\
5,745 \\
11,766\end{array}$ & $\begin{array}{r}1,260 \\
0 \\
1,260 \\
0 \\
988 \\
272 \\
0\end{array}$ & $\begin{array}{r}84,733 \\
5,995 \\
78,738 \\
15,005 \\
60,628 \\
4,195 \\
-1,090\end{array}$ & $\begin{array}{r}44,646 \\
3,464 \\
41,182 \\
6,059 \\
23,048 \\
9,749 \\
2,326\end{array}$ \\
\hline $\begin{array}{l}\text { Other Liquids ............................... } \\
\text { Other Hydrocarbons/Alcohol .......... } \\
\text { Unfinished Oils ............................... } \\
\text { Motor Gasoline Blend. Comp. ........ } \\
\text { Aviation Gasoline Blend. Comp. ..... }\end{array}$ & $\begin{array}{r}1,059 \\
1,059 \\
- \\
-\end{array}$ & $\begin{array}{l}- \\
- \\
-\end{array}$ & $\begin{array}{r}561 \\
0 \\
0 \\
561 \\
0\end{array}$ & $\begin{array}{l}- \\
- \\
-\end{array}$ & $\begin{array}{r}1,241 \\
0 \\
1,353 \\
-112 \\
0\end{array}$ & $\begin{array}{r}1,200 \\
57 \\
1,387 \\
-191 \\
-53\end{array}$ & $\begin{array}{l}- \\
- \\
-\end{array}$ & $\begin{array}{r}13,080 \\
1,002 \\
4,969 \\
7,056 \\
53\end{array}$ & $\begin{array}{l}0 \\
0 \\
0 \\
0 \\
0\end{array}$ & $\begin{array}{r}-11,419 \\
0 \\
-5,003 \\
-6,416 \\
0\end{array}$ & $\begin{array}{r}23,650 \\
244 \\
15,926 \\
7,448 \\
32\end{array}$ \\
\hline 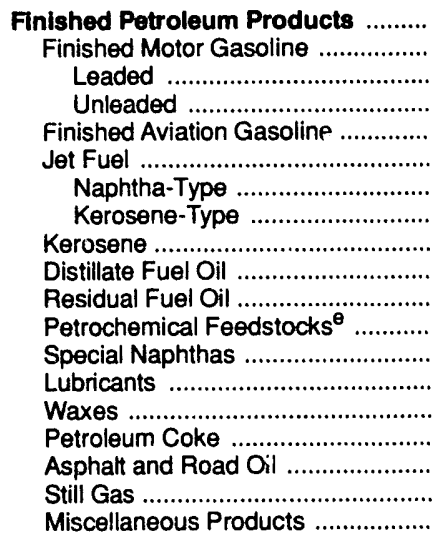 & $\begin{array}{l}- \\
- \\
z \\
z \\
z \\
z \\
z \\
- \\
- \\
-\end{array}$ & $\begin{array}{r}785,590 \\
420,999 \\
4,060 \\
416,939 \\
784 \\
48,261 \\
4,655 \\
43,606 \\
2,863 \\
171,394 \\
18,50 \\
9, \\
3,50 \\
5,674 \\
478 \\
29,352 \\
38,340 \\
33,510 \\
2,708\end{array}$ & $\begin{array}{r}7,385 \\
2,321 \\
0 \\
2,321 \\
11 \\
322 \\
322 \\
0 \\
0 \\
2,736 \\
649 \\
239 \\
796 \\
158 \\
17 \\
0 \\
90 \\
0 \\
46\end{array}$ & $\begin{array}{l}- \\
- \\
- \\
- \\
- \\
- \\
- \\
- \\
- \\
- \\
- \\
- \\
-\end{array}$ & $\begin{array}{r}147,697 \\
100,985 \\
466 \\
100,510 \\
597 \\
18,738 \\
403 \\
18,335 \\
-31 \\
30,489 \\
-5,996 \\
341 \\
205 \\
1,715 \\
0 \\
0 \\
760 \\
0 \\
-106\end{array}$ & $\begin{array}{r}8,248 \\
4,113 \\
-1,474 \\
5,587 \\
-74 \\
-435 \\
122 \\
-557 \\
-135 \\
426 \\
609 \\
69 \\
-122 \\
48 \\
-15 \\
752 \\
3,064 \\
0 \\
-52\end{array}$ & $\begin{array}{l}- \\
- \\
- \\
- \\
- \\
- \\
- \\
- \\
- \\
- \\
- \\
-\end{array}$ & $\begin{array}{l}- \\
- \\
- \\
- \\
- \\
- \\
- \\
- \\
- \\
- \\
- \\
-\end{array}$ & $\begin{array}{r}3,383 \\
670 \\
4 \\
665 \\
0 \\
297 \\
1 \\
296 \\
123 \\
173 \\
226 \\
0 \\
288 \\
225 \\
39 \\
1,078 \\
264 \\
0 \\
(s)\end{array}$ & $\begin{array}{r}929,041 \\
519,522 \\
5,996 \\
513,527 \\
1,466 \\
67,459 \\
5,257 \\
62,202 \\
2,844 \\
204,020 \\
12,321 \\
9,646 \\
4,424 \\
7,274 \\
471 \\
27,522 \\
35,862 \\
33,510 \\
2,700\end{array}$ & $\begin{array}{r}116,053 \\
52,165 \\
926 \\
51,239 \\
483 \\
10,297 \\
1,106 \\
9,191 \\
1,435 \\
33,133 \\
3,924 \\
367 \\
362 \\
1,806 \\
127 \\
1,766 \\
9,923 \\
0 \\
265\end{array}$ \\
\hline Total & 254,246 & 811,994 & 168,916 & 3,157 & $\mathbf{5 7 2 , 6 5 5}$ & 23,312 & 1 & 780,606 & 4,695 & $1,002,355$ & 255,265 \\
\hline
\end{tabular}

a Represents the PAD District in which th material entered the United States and not necessarily where the crude oil or product is processed and/or consumed.

b Unaccounted for crude oil represents the difference between the supply and disposition of crude oil.

c A negative number indicates a decrease in stocks and a positive number indicates an increase in stocks.

d Products supplied is equal to field production, plus refinery production, plus imports, plus unaccounted for crude oil, plus net receipts, minus stock change, minus crude losses, minus refinery inputs, minus exports.

$\theta$ Includes naphtha less than $401^{\circ} \mathrm{F}$ endpoint and other oils equal 30 or greater than $401^{\circ} \mathrm{F}$ endpoint.

(s) = Less than 500 barrels.

$\mathrm{E}=$ Estimated.

LRG = Liquefied Refinery Gas.

Note: Totals may not equal sum of components due to independent rounding.

Sources: - Energy Information Administration (EIA) Forms EIA-810, "Monthly Refinery Report," EIA-811, "Monthly Bulk Terminal Report," EIA-812, "Monthly Product Pipeline Report," EIA-813, "Monthly Crude Oil Report," EIA-814, "Monthly Imports Report," EIA-816, "Monthly Natural Gas Liquids Report," and ElA-817, "Monthly Tanker and Barge Movement Report." - Domestic crude oil production estimates based on historical statistics from State conservation agencies and the Minerals Manageınent Senvice of the U.S. Department of the Interior. - Export data from the Bureau of the Census and Form ElA-810, "Monthly Refinery Report." 
Table 12. PAD District II-Daily Average Supply and Dispositlon of Crude OII and Petroleum Products, August 1991

(Thousand Barrels per Day)

\begin{tabular}{|c|c|c|c|c|c|c|c|c|c|c|}
\hline \multirow[b]{2}{*}{ Commodity } & \multicolumn{5}{|c|}{ Supply } & \multicolumn{5}{|c|}{ Disposition } \\
\hline & $\begin{array}{c}\text { Field } \\
\text { Production }\end{array}$ & $\begin{array}{c}\text { Refinery } \\
\text { Production }\end{array}$ & $\begin{array}{c}\text { Imports by } \\
\text { PAD } \\
\text { District } \\
\text { of Entry }\end{array}$ & $\begin{array}{c}\text { Unac- } \\
\text { counted } \\
\text { For } \\
\text { Crude Oll }\end{array}$ & $\begin{array}{c}\text { Net } \\
\text { Recelpts }\end{array}$ & $\begin{array}{c}\text { Stock } \\
\text { Changec }\end{array}$ & $\begin{array}{c}\text { Crude } \\
\text { Losses }\end{array}$ & $\begin{array}{l}\text { Refinery } \\
\text { Inputs }\end{array}$ & Exports & $\begin{array}{l}\text { Products } \\
\text { Supplled }^{d}\end{array}$ \\
\hline 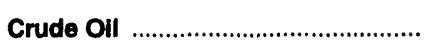 & $E_{710}$ & 一 & 531 & 34 & 1,892 & 53 & 0 & 3,113 & 1 & 0 \\
\hline 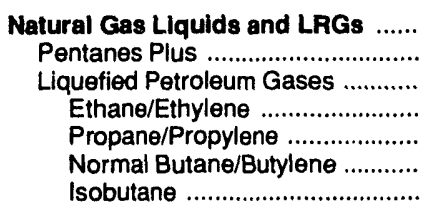 & $\begin{array}{r}298 \\
48 \\
251 \\
89 \\
105 \\
35 \\
22\end{array}$ & $\begin{array}{r}115 \\
115 \\
0 \\
102 \\
17 \\
-3\end{array}$ & $\begin{array}{r}58 \\
1 \\
56 \\
0 \\
46 \\
11 \\
(s)\end{array}$ & $\begin{array}{l}- \\
- \\
- \\
-\end{array}$ & $\begin{array}{r}14 \\
23 \\
-9 \\
-58 \\
17 \\
9 \\
24\end{array}$ & $\begin{array}{r}104 \\
20 \\
85 \\
(s) \\
44 \\
41 \\
-1\end{array}$ & $\begin{array}{l}- \\
- \\
- \\
-\end{array}$ & $\begin{array}{r}103 \\
42 \\
61 \\
0 \\
0 \\
8 \\
52\end{array}$ & $\begin{array}{l}4 \\
0 \\
4 \\
0 \\
3 \\
1 \\
0\end{array}$ & $\begin{array}{r}274 \\
10 \\
265 \\
30 \\
221 \\
22 \\
8\end{array}$ \\
\hline $\begin{array}{l}\text { Other Liquids ............................... } \\
\text { Other Hydrocarbons/Alcohol .......... } \\
\text { Unfinished Oils ............................. } \\
\text { Motor Gasoline Blend. Comp. ....... } \\
\text { Aviation Gasoline Blend. Comp. .... }\end{array}$ & $\begin{array}{l}3 \\
3 \\
- \\
-\end{array}$ & $\begin{array}{l}- \\
- \\
-\end{array}$ & $\begin{array}{l}6 \\
0 \\
0 \\
6 \\
0\end{array}$ & $\begin{array}{l}- \\
- \\
-\end{array}$ & $\begin{array}{l}7 \\
0 \\
6 \\
1 \\
0\end{array}$ & $\begin{array}{r}-57 \\
-1 \\
-65 \\
8 \\
(s)\end{array}$ & $\begin{array}{l}- \\
- \\
-\end{array}$ & $\begin{array}{r}138 \\
3 \\
113 \\
21 \\
(s)\end{array}$ & $\begin{array}{l}0 \\
0 \\
0 \\
0 \\
0\end{array}$ & $\begin{array}{r}-65 \\
0 \\
-43 \\
-22 \\
0\end{array}$ \\
\hline 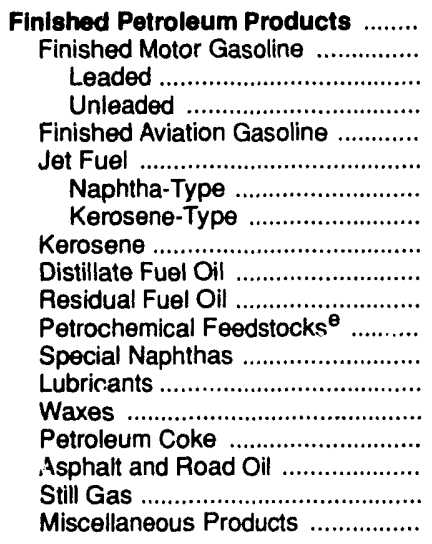 & $\begin{array}{l}- \\
\bar{z} \\
\overline{-} \\
\overline{-} \\
\overline{-} \\
\overline{-} \\
\overline{-} \\
\overline{-} \\
\overline{-}\end{array}$ & $\begin{array}{r}3,374 \\
1,811 \\
12 \\
1,799 \\
4 \\
211 \\
25 \\
186 \\
1 \\
711 \\
79 \\
41 \\
16 \\
23 \\
3 \\
128 \\
194 \\
147 \\
9\end{array}$ & $\begin{array}{r}24 \\
10 \\
0 \\
10 \\
0 \\
1 \\
1 \\
0 \\
0 \\
6 \\
2 \\
(\mathbf{s}) \\
3 \\
1 \\
(\mathrm{~s}) \\
0 \\
1 \\
0 \\
\text { (s) }\end{array}$ & $\begin{array}{l}- \\
- \\
- \\
- \\
- \\
- \\
- \\
- \\
- \\
- \\
- \\
- \\
-\end{array}$ & $\begin{array}{r}738 \\
510 \\
2 \\
507 \\
3 \\
88 \\
(\mathrm{~s}) \\
89 \\
1 \\
144 \\
-25 \\
2 \\
1 \\
7 \\
0 \\
0 \\
7 \\
0 \\
(\mathrm{~s})\end{array}$ & $\begin{array}{r}24 \\
96 \\
-3 \\
99 \\
-1 \\
4 \\
4 \\
-1 \\
-6 \\
-1 \\
1 \\
3 \\
-1 \\
1 \\
(s) \\
-2 \\
-67 \\
0 \\
-2\end{array}$ & $\begin{array}{l}- \\
- \\
\bar{z} \\
\overline{-} \\
\overline{-} \\
\overline{-} \\
\overline{-} \\
- \\
- \\
\overline{-} \\
\overline{-}\end{array}$ & 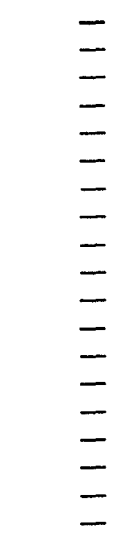 & $\begin{array}{r}24 \\
10 \\
0 \\
10 \\
0 \\
1 \\
(s) \\
1 \\
1 \\
(s) \\
0 \\
0 \\
(s) \\
1 \\
(s) \\
9 \\
2 \\
0 \\
0\end{array}$ & $\begin{array}{r}4,089 \\
2,225 \\
18 \\
2,207 \\
9 \\
295 \\
21 \\
274 \\
6 \\
862 \\
56 \\
40 \\
20 \\
29 \\
3 \\
121 \\
267 \\
147 \\
11\end{array}$ \\
\hline Total & 1,011 & 3,489 & 618 & 34 & 2,651 & 124 & $\mathbf{0}$ & 3,353 & 28 & 4,298 \\
\hline
\end{tabular}

a Represents the PAD District in which the material entered the United States and not necessarily where the crude oil or product is processed and/or consumed.

b Unaccounted for crude oil represents the difference between the supply and disposition of crude oil.

c A negative number indicates a decrease in stocks and a positive number indicates an increase in stocks.

d Products supplied is equal to field production, plus refinery production, plus imports, plus unaccounted for crude oil, plus net receipts, minus stock change, minus crude losses, minus refinery inputs, minus exports.

$\theta$ Includes naphtha less than $401^{\circ} \mathrm{F}$ endpoint and other oils equal to or greater than $401^{\circ} \mathrm{F}$ endpoint.

(s) = Less than 500 barrels per day.

$E=$ Estimated

LRG = Liquefied Refinery Gas.

Note: Totals may not equal sum of components due to independent rounding.

Sources: • Energy Information Administration (EIA) Forms EIA-810, "Monthly Refinery Report," EIA-811, "Monthly Bulk Terminal Report," EIA-812, "Monthly Product Pipeline Report," EIA-813, "Monthly Crude Oil Report," EIA-814, "Monthly Imports Report," EIA-816, "Monthly Natural Gas Liquids Report," and ElA-817, "Monthly Tanker and Barge Movement Feport." - Domestic crude oil production estimates based on historical statistics from State conservation agencies and the Minerals Management Service of the U.S. Department of the Interior. - Export data from the Bureau of the Census and Form ElA-810, "Monthly Refinery Report." 
Table 13. PAD District II-Year-to-Date Dally Average Supply and Disposition of Crude Oil and Petroleum Products, January-August 1991

(Thousand Barrels per Day)

\begin{tabular}{|c|c|c|c|c|c|c|c|c|c|c|}
\hline \multirow[b]{2}{*}{ Commodity } & \multicolumn{5}{|c|}{ Supply } & \multicolumn{5}{|c|}{ Disposition } \\
\hline & $\begin{array}{c}\text { Fleid } \\
\text { Production }\end{array}$ & \begin{tabular}{|c|} 
Piefinery \\
Production
\end{tabular} & $\begin{array}{c}\text { imports by } \\
\text { PAD } \\
\text { Distrlct } \\
\text { of Entry }\end{array}$ & $\begin{array}{c}\text { Unac- } \\
\text { counted } \\
\text { For } \\
\text { Crude Oll } \\
\end{array}$ & $\begin{array}{c}\text { Net } \\
\text { Recelpts }\end{array}$ & $\begin{array}{c}\text { Stock } \\
\text { Change }\end{array}$ & $\begin{array}{c}\text { Crude } \\
\text { Losses }\end{array}$ & $\begin{array}{c}\text { Refinery } \\
\text { Inputs }\end{array}$ & Exports & $\begin{array}{l}\text { Products } \\
\text { Supplied }\end{array}$ \\
\hline 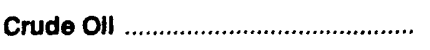 & $E_{730}$ & - & 599 & 13 & 1,722 & 10 & (s) & 3,053 & (s) & 0 \\
\hline 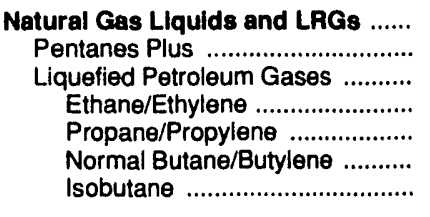 & $\begin{array}{r}312 \\
47 \\
265 \\
94 \\
112 \\
37 \\
23\end{array}$ & $\begin{array}{r}109 \\
109 \\
(s) \\
101 \\
9 \\
-1\end{array}$ & $\begin{array}{r}64 \\
1 \\
62 \\
8 \\
44 \\
9 \\
2\end{array}$ & $\begin{array}{l}- \\
\overline{-} \\
\overline{-} \\
-\end{array}$ & $\begin{array}{r}22 \\
15 \\
6 \\
-38 \\
18 \\
7 \\
19\end{array}$ & $\begin{array}{r}47 \\
5 \\
41 \\
2 \\
21 \\
19 \\
-1\end{array}$ & $\begin{array}{l}- \\
- \\
- \\
-\end{array}$ & $\begin{array}{r}105 \\
33 \\
72 \\
0 \\
0 \\
24 \\
48\end{array}$ & $\begin{array}{l}5 \\
0 \\
5 \\
0 \\
4 \\
1 \\
0\end{array}$ & $\begin{array}{r}349 \\
25 \\
324 \\
62 \\
249 \\
17 \\
-4\end{array}$ \\
\hline $\begin{array}{l}\text { Other Liquids ............................. } \\
\text { Other Hydrocarbons/Alcohol ......... } \\
\text { Unfinished Oils ........................... } \\
\text { Motor Gasoline Blend. Comp. ....... } \\
\text { Aviation Gasoline Blend. Comp. .... }\end{array}$ & $\begin{array}{r}4 \\
- \\
-\end{array}$ & $\begin{array}{l}- \\
- \\
-\end{array}$ & $\begin{array}{l}2 \\
0 \\
0 \\
2 \\
0\end{array}$ & $\begin{array}{l}- \\
- \\
-\end{array}$ & $\begin{array}{r}5 \\
0 \\
6 \\
\text { (s) } \\
0\end{array}$ & $\begin{array}{r}5 \\
(s) \\
6 \\
-1 \\
(s)\end{array}$ & $\begin{array}{l}- \\
- \\
-\end{array}$ & $\begin{array}{r}54 \\
4 \\
20 \\
29 \\
\text { (s) }\end{array}$ & $\begin{array}{l}0 \\
0 \\
0 \\
0 \\
0\end{array}$ & $\begin{array}{r}-47 \\
0 \\
-21 \\
-26 \\
0\end{array}$ \\
\hline 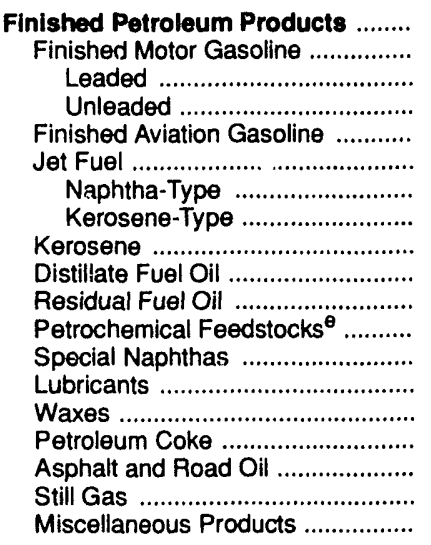 & $\begin{array}{l}- \\
- \\
- \\
z \\
- \\
- \\
- \\
- \\
- \\
-\end{array}$ & $\begin{array}{r}3,233 \\
1,733 \\
17 \\
1,716 \\
3 \\
199 \\
19 \\
179 \\
12 \\
705 \\
76 \\
38 \\
15 \\
23 \\
2 \\
121 \\
158 \\
138 \\
11\end{array}$ & $\begin{array}{r}30 \\
10 \\
0 \\
10 \\
(\mathbf{s}) \\
1 \\
1 \\
0 \\
0 \\
11 \\
3 \\
1 \\
3 \\
1 \\
(\mathbf{s}) \\
0 \\
\text { (s) } \\
0 \\
\text { (s) }\end{array}$ & $\begin{array}{l}- \\
- \\
- \\
- \\
- \\
- \\
- \\
- \\
- \\
- \\
- \\
- \\
- \\
- \\
-\end{array}$ & $\begin{array}{r}608 \\
416 \\
2 \\
414 \\
2 \\
77 \\
2 \\
75 \\
(s) \\
125 \\
-25 \\
1 \\
1 \\
7 \\
0 \\
0 \\
3 \\
0 \\
\text { (s) }\end{array}$ & $\begin{array}{r}34 \\
17 \\
-6 \\
23 \\
(s) \\
-2 \\
1 \\
-2 \\
-1 \\
2 \\
3 \\
(s) \\
-1 \\
(s) \\
(s) \\
3 \\
13 \\
0 \\
(s)\end{array}$ & $\begin{array}{l}- \\
- \\
- \\
- \\
- \\
- \\
- \\
- \\
- \\
- \\
- \\
- \\
- \\
- \\
-\end{array}$ & $\begin{array}{l}- \\
- \\
- \\
- \\
- \\
- \\
- \\
- \\
- \\
- \\
- \\
- \\
- \\
-\end{array}$ & $\begin{array}{r}14 \\
3 \\
(s) \\
3 \\
0 \\
1 \\
(s) \\
1 \\
1 \\
1 \\
1 \\
0 \\
1 \\
1 \\
(s) \\
4 \\
1 \\
0 \\
\text { (s) }\end{array}$ & $\begin{array}{r}3,823 \\
2,138 \\
25 \\
2,113 \\
6 \\
278 \\
22 \\
256 \\
12 \\
840 \\
51 \\
40 \\
18 \\
30 \\
2 \\
113 \\
148 \\
138 \\
11\end{array}$ \\
\hline 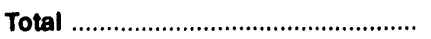 & 1,046 & 3,342 & 695 & 13 & 2,357 & 96 & (8) & 3,212 & 19 & 4,125 \\
\hline
\end{tabular}

a Represents the PAD District in which the material entered the United States and not necessarily where the crude oil or product is processed and/or consumed.

b Unaccounted for crude oil represents the difference between the supply and disposition of crude oil.

c A negative number indicates a decrease in stocks and a positive number indicates an increase in stocks.

d Products supplied is equal to field production, plus refinery production, plus imports, plus unaccounted for crude oil, plus net receipts, minus stock change, minus crude losses, minus refinery inputs, minus exports.

$\theta$ Includes naphtha less than $401^{\circ} \mathrm{F}$ endpoint and other oils equal to or greater than $401^{\circ} \mathrm{F}$ endpoint.

(s) = Less than 500 barrels per day.

$E=$ Estimated.

LRG = Liquefied Refinery Gas.

Note: Totals may not equal sum of components due to independent rounding.

Sources: - Energy Information Administration (EIA) Forms EIA-810, "Monthly Refinery Report," EIA-811, "Monthly Bulk Terminal Report," EIA-812, "isonthly Product Pipeline Report," EIA-813, "Monthly Crude Oil Report," EIA-814, "Monthly Imports Report," EIA-816, "Monthly Natural Gas Liquids Report," ancj EIA-817, "Monthly Tanker and Barge Movem int Report." - Domestic crude oil production estimates based on historical statistics from State conservatinn agencies and the Minerals Management Service of the U.S. Department of the Interior. - Export data from the Bureau of the Census and Form EIA-810, "Monthly Refinery Report." 
Table 14. PAD District II-Supply, Disposition, and Ending Stocks of Crude Oll and Petroleum Products, August 1991 (Thousand Barrels)

\begin{tabular}{|c|c|c|c|c|c|c|c|c|c|c|c|}
\hline \multirow[b]{2}{*}{ Commodity } & \multicolumn{5}{|c|}{ Supply } & \multicolumn{5}{|c|}{ Disposition } & \multirow[b]{2}{*}{$\begin{array}{l}\text { Ending } \\
\text { Stocks }\end{array}$} \\
\hline & $\begin{array}{c}\text { Field } \\
\text { Production }\end{array}$ & $\begin{array}{c}\text { Refinery } \\
\text { Production }\end{array}$ & $\begin{array}{c}\text { Imports by } \\
\text { PAD } \\
\text { District } \\
\text { of Entry }\end{array}$ & $\begin{array}{c}\text { Unac- } \\
\text { counted } \\
\text { For } \\
\text { Crude OII }\end{array}$ & $\begin{array}{c}\text { Net } \\
\text { Recelpts }\end{array}$ & $\begin{array}{c}\text { Stock } \\
\text { Change }\end{array}$ & $\begin{array}{c}\text { Crude } \\
\text { Losses }\end{array}$ & $\begin{array}{c}\text { Refinery } \\
\text { Inputs }\end{array}$ & Exports & $\begin{array}{l}\text { Products } \\
\text { Supplied }^{\mathrm{d}}\end{array}$ & \\
\hline Crude Oll ............................................... & $E_{104,135}$ & - & 137,520 & 1,900 & $-47,225$ & 2,440 & $\mathbf{0}$ & 193,890 & $\mathbf{0}$ & 0 & 738,615 \\
\hline 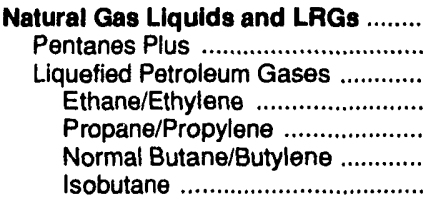 & $\begin{array}{r}33,455 \\
6,333 \\
27,122 \\
11,735 \\
9,436 \\
1,746 \\
4,205\end{array}$ & $\begin{array}{r}9,476 \\
9,476 \\
391 \\
6,861 \\
1,810 \\
414\end{array}$ & $\begin{array}{r}2,112 \\
0 \\
2,112 \\
233 \\
487 \\
831 \\
561\end{array}$ & $\begin{array}{l}- \\
- \\
- \\
-\end{array}$ & $\begin{array}{r}-501 \\
-399 \\
-102 \\
2,764 \\
-2,186 \\
-89 \\
-591\end{array}$ & $\begin{array}{r}1,469 \\
53 \\
1,416 \\
-2,206 \\
-29 \\
2,797 \\
854\end{array}$ & $\begin{array}{l}- \\
- \\
- \\
-\end{array}$ & $\begin{array}{r}6,767 \\
2,863 \\
3,904 \\
0 \\
0 \\
950 \\
2,954\end{array}$ & $\begin{array}{r}339 \\
0 \\
339 \\
0 \\
256 \\
84 \\
0\end{array}$ & $\begin{array}{r}35,967 \\
3,018 \\
32,949 \\
17,329 \\
14,371 \\
467 \\
781\end{array}$ & $\begin{array}{r}69,544 \\
5,631 \\
63,913 \\
12,396 \\
23,360 \\
21,433 \\
6,724\end{array}$ \\
\hline $\begin{array}{l}\text { Other Liquids ............................... } \\
\text { Other Hydrocarbons/Alcohol ........... } \\
\text { Unfinished Oils ............................... } \\
\text { Motor Gasoline Blend. Comp. ......... } \\
\text { Aviation Gasoline Blend. Comp. ..... }\end{array}$ & $\begin{array}{r}1,611 \\
1,611 \\
- \\
-\end{array}$ & $\begin{array}{l}- \\
- \\
-\end{array}$ & $\begin{array}{r}5,946 \\
0 \\
5,945 \\
1 \\
0\end{array}$ & $\begin{array}{c}- \\
- \\
-\end{array}$ & $\begin{array}{r}-487 \\
0 \\
-323 \\
-164 \\
0\end{array}$ & $\begin{array}{r}1,299 \\
104 \\
1,369 \\
-162 \\
-12\end{array}$ & $\begin{array}{l}- \\
- \\
-\end{array}$ & $\begin{array}{r}11,106 \\
1,507 \\
9,215 \\
357 \\
27\end{array}$ & $\begin{array}{l}0 \\
0 \\
0 \\
0 \\
0\end{array}$ & $\begin{array}{r}-5,335 \\
0 \\
-4,962 \\
-358 \\
-15\end{array}$ & $\begin{array}{r}70,407 \\
1,008 \\
53,017 \\
16,350 \\
32\end{array}$ \\
\hline 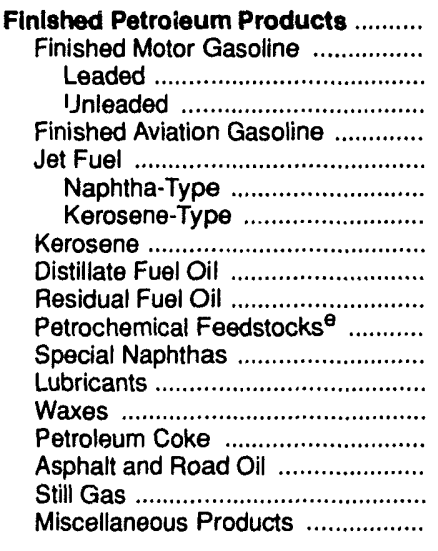 & $\begin{array}{l}- \\
- \\
- \\
- \\
- \\
- \\
- \\
- \\
- \\
- \\
-\end{array}$ & $\begin{array}{r}212,685 \\
98,465 \\
1,049 \\
97,416 \\
425 \\
22,374 \\
2,571 \\
19,803 \\
345 \\
41,201 \\
11,965 \\
11,053 \\
869 \\
2,861 \\
354 \\
7,953 \\
3,856 \\
9,645 \\
1,319\end{array}$ & $\begin{array}{r}6,885 \\
0 \\
0 \\
0 \\
0 \\
248 \\
0 \\
248 \\
0 \\
0 \\
2,717 \\
3,625 \\
111 \\
0 \\
4 \\
0 \\
180 \\
0 \\
0\end{array}$ & $\begin{array}{l}- \\
- \\
- \\
- \\
- \\
- \\
- \\
- \\
- \\
- \\
- \\
- \\
-\end{array}$ & $\begin{array}{r}-94,654 \\
-58,045 \\
-181 \\
-57,864 \\
-241 \\
-13,807 \\
-155 \\
-13,652 \\
-137 \\
-20,913 \\
215 \\
0 \\
-173 \\
-750 \\
0 \\
0 \\
-757 \\
0 \\
-46\end{array}$ & $\begin{array}{r}509 \\
-1,320 \\
-33 \\
-1,287 \\
-383 \\
496 \\
-347 \\
843 \\
-29 \\
1,206 \\
971 \\
-642 \\
-227 \\
-23 \\
-28 \\
100 \\
165 \\
0 \\
223\end{array}$ & $\begin{array}{l}- \\
- \\
- \\
z \\
- \\
- \\
- \\
z \\
- \\
- \\
- \\
-\end{array}$ & $\begin{array}{l}- \\
- \\
- \\
z \\
- \\
- \\
- \\
- \\
- \\
- \\
- \\
-\end{array}$ & $\begin{array}{r}12,433 \\
2,176 \\
163 \\
2,013 \\
0 \\
191 \\
0 \\
191 \\
1 \\
3,293 \\
2,003 \\
0 \\
63 \\
299 \\
25 \\
4,357 \\
24 \\
0 \\
(s)\end{array}$ & $\begin{array}{r}111,974 \\
39,564 \\
738 \\
38,826 \\
567 \\
8,128 \\
2,763 \\
5,365 \\
236 \\
15,789 \\
11,923 \\
15,320 \\
971 \\
1,835 \\
361 \\
3,496 \\
3,090 \\
9,645 \\
1,050\end{array}$ & $\begin{array}{r}127,974 \\
45,008 \\
496 \\
44,512 \\
535 \\
17,855 \\
1,883 \\
15,972 \\
1,138 \\
28,494 \\
15,102 \\
2,538 \\
1,104 \\
6,443 \\
500 \\
3,489 \\
4,473 \\
0 \\
1,295\end{array}$ \\
\hline 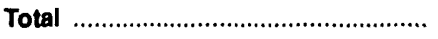 & 139,201 & 222,161 & 152,463 & 1,900 & $-142,867$ & 5,717 & $\mathbf{0}$ & 211,763 & 12,773 & 142,605 & $1,006,540$ \\
\hline
\end{tabular}

a Represents the PAD District in which the material entered the United States and not necessarily where the crude oil or product is processed and/or consumed.

b Unaccounted for crude oil represents the difference between the supply and disposition of crude oil.

c A negative number indicates a decrease in stocks and a positive number indicates an increase in stocks.

d Products supplied is equal to field production, plus refinery production, plus imports, plus unaccounted for crude oil, plus net receipts, minus stock change, minus crude losses, minus refinery inputs, minus exports.

$\theta$ Includes naphtha less than $401^{\circ} \mathrm{F}$ endpoint and other oils equal to or greater than $401^{\circ} \mathrm{F}$ endpoint.

(s) $=$ Less than 500 barrels.

$E=$ Estimated

LRG = Liquefied Refinery Gas.

Note: Totals may not equal sum of components due to independent rounding.

Sources: • Energy Information Administration (EIA) Forms ElA-810, "Monthly Refinery Report," ElA-811, "Monthly Bulk Terminal Report" EIA-812, "Monthly Product Pipeline Report," EIA-813, "Monthly Crude Oil Report," EIA-814, "Monthly imports Report," EIA-816, "Monthly Natural Gas Liquids Report," and EIA-817, "Monthly Tanker and Barge Movement Report." - Domestic crude oil production estimates based on historical statistics from State conservation agencies and the Minerals Management Service of the U.S. Department of the Interior. - Export data from the Bureau of the Census and Form EIA-810, "Monthly Refinery Report." 
Table 15. PAD District III-Year-to-Date Supply, Disposition, and Ending Stocks of Crude Oll and Petroleum Products, January-August 1991 (Thousand Barrels)

\begin{tabular}{|c|c|c|c|c|c|c|c|c|c|c|c|}
\hline \multirow[b]{2}{*}{ Commodity } & \multicolumn{5}{|c|}{ Supply } & \multicolumn{5}{|c|}{ Disposition } & \multirow[b]{2}{*}{$\begin{array}{l}\text { Ending } \\
\text { Stocks }\end{array}$} \\
\hline & \begin{tabular}{|c|} 
Field \\
Production \\
\end{tabular} & $\begin{array}{c}\text { Refinery } \\
\text { Production }\end{array}$ & $\begin{array}{c}\text { Imports by } \\
\text { PAD } \\
\text { District } \\
\text { of Entry } \\
\end{array}$ & $\begin{array}{c}\text { Unac- } \\
\text { counted } \\
\text { For } \\
\text { Crude Oll }\end{array}$ & $\begin{array}{c}\text { Not } \\
\text { Recelpts }\end{array}$ & $\begin{array}{c}\text { Stock } \\
\text { Change }\end{array}$ & $\begin{array}{l}\text { Crude } \\
\text { Losses }\end{array}$ & $\begin{array}{c}\text { Reflnery } \\
\text { Inputs }\end{array}$ & Exports & $\begin{array}{l}\text { Products } \\
\text { Supplled }\end{array}$ & \\
\hline 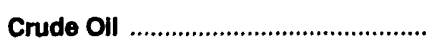 & $E_{822,320}$ & 一 & 910,336 & 41,996 & $-320,999$ & 1,475 & $\mathbf{0}$ & $1,452,278$ & $\mathbf{0}$ & $\mathbf{0}$ & 738,615 \\
\hline 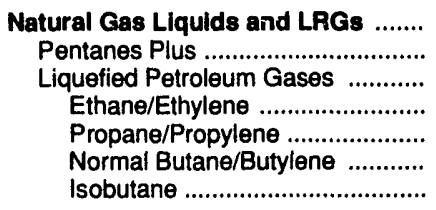 & $\begin{array}{r}263,687 \\
47,315 \\
216,372 \\
94,869 \\
75,130 \\
17,179 \\
29,194\end{array}$ & $\begin{array}{r}72,903 \\
-72,903 \\
3,237 \\
54,428 \\
12,485 \\
2,753\end{array}$ & $\begin{array}{r}11,148 \\
0 \\
11,148 \\
233 \\
5,473 \\
3,554 \\
1,888\end{array}$ & $\begin{array}{l}- \\
- \\
- \\
-\end{array}$ & $\begin{array}{r}-6,271 \\
-1,112 \\
-5,159 \\
16,005 \\
-18,372 \\
627 \\
-3,419\end{array}$ & $\begin{array}{r}9,231 \\
1,869 \\
7,362 \\
-1,833 \\
-1,075 \\
10,255 \\
15\end{array}$ & $\begin{array}{l}- \\
- \\
- \\
-\end{array}$ & $\begin{array}{r}55,185 \\
23,121 \\
32,064 \\
0 \\
0 \\
10,560 \\
21,504\end{array}$ & $\begin{array}{r}5,502 \\
148 \\
5,354 \\
0 \\
3,979 \\
1,374 \\
0\end{array}$ & $\begin{array}{r}271,549 \\
21,065 \\
250,484 \\
116,177 \\
113,755 \\
11,656 \\
8,897\end{array}$ & $\begin{array}{r}69,544 \\
5,631 \\
63,913 \\
12,396 \\
23,360 \\
21,433 \\
6,724\end{array}$ \\
\hline $\begin{array}{l}\text { Other Llquids ................................ } \\
\text { Other Hydrocarbons/Alcohol ........... } \\
\text { Unfinished Oils ............................. } \\
\text { Motor Gasoline Blend. Comp. ......... } \\
\text { Aviation Gasoline Blend. Comp. ..... }\end{array}$ & $\begin{array}{r}12,337 \\
12,337 \\
- \\
-\end{array}$ & $\begin{array}{l}- \\
- \\
-\end{array}$ & $\begin{array}{r}58,349 \\
28 \\
56,739 \\
1,582 \\
0\end{array}$ & $\begin{array}{l}- \\
- \\
-\end{array}$ & $\begin{array}{r}-5,228 \\
0 \\
-2,984 \\
-2,244 \\
0\end{array}$ & $\begin{array}{r}6,559 \\
555 \\
6,672 \\
-632 \\
-36\end{array}$ & $\begin{array}{l}- \\
- \\
-\end{array}$ & $\begin{array}{r}102,127 \\
11,810 \\
86,405 \\
3,863 \\
49\end{array}$ & $\begin{array}{l}0 \\
0 \\
0 \\
0 \\
0\end{array}$ & $\begin{array}{r}-43,228 \\
0 \\
-39,322 \\
-3,893 \\
-13\end{array}$ & $\begin{array}{r}70,407 \\
1,008 \\
53,017 \\
16,350 \\
32\end{array}$ \\
\hline 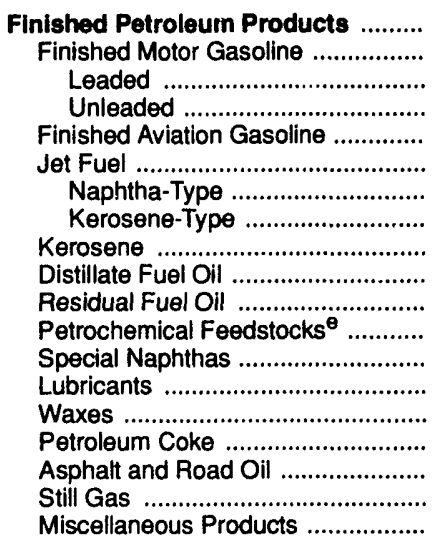 & $\begin{array}{l}- \\
- \\
\overline{-} \\
\overline{-} \\
\overline{-} \\
\overline{-} \\
\overline{-} \\
\overline{-} \\
-\end{array}$ & $\begin{array}{r}1,613,386 \\
743,668 \\
10,674 \\
732,994 \\
3,140 \\
171,324 \\
21,280 \\
150,044 \\
3,912 \\
315,346 \\
91,961 \\
84,925 \\
7,590 \\
23,719 \\
2,614 \\
59,913 \\
24,291 \\
71,162 \\
9,821\end{array}$ & $\begin{array}{r}49,504 \\
756 \\
1 \\
755 \\
0 \\
346 \\
0 \\
346 \\
87 \\
23 \\
13,550 \\
32,887 \\
631 \\
0 \\
22 \\
98 \\
889 \\
0 \\
215\end{array}$ & $\begin{array}{l}- \\
- \\
- \\
- \\
- \\
- \\
- \\
- \\
- \\
- \\
- \\
- \\
-\end{array}$ & $\begin{array}{r}-727,067 \\
-447,309 \\
-892 \\
-446,417 \\
-1,453 \\
-107,060 \\
-3,070 \\
-103,990 \\
-1,697 \\
-158,185 \\
-239 \\
203 \\
-1,570 \\
-5,483 \\
-26 \\
0 \\
-3,789 \\
0 \\
-459\end{array}$ & $\begin{array}{r}-3,224 \\
-4,453 \\
-355 \\
-4,098 \\
-44 \\
144 \\
-362 \\
506 \\
-191 \\
366 \\
719 \\
-262 \\
-702 \\
581 \\
25 \\
-104 \\
605 \\
0 \\
92\end{array}$ & $\begin{array}{l}- \\
- \\
- \\
- \\
- \\
- \\
- \\
- \\
- \\
- \\
- \\
-\end{array}$ & $\begin{array}{l}- \\
- \\
- \\
- \\
- \\
- \\
- \\
- \\
- \\
- \\
-\end{array}$ & $\begin{array}{r}111,298 \\
11,712 \\
1,239 \\
10,473 \\
0 \\
6,657 \\
541 \\
6,116 \\
491 \\
34,358 \\
20,836 \\
0 \\
2,519 \\
2,000 \\
173 \\
32,482 \\
66 \\
0 \\
2\end{array}$ & $\begin{array}{r}827,749 \\
289,856 \\
8,899 \\
280,957 \\
1,731 \\
57,809 \\
18,031 \\
39,778 \\
2,002 \\
122,460 \\
83,717 \\
118,277 \\
4,834 \\
15,655 \\
2,412 \\
27,633 \\
20,720 \\
71,162 \\
9,483\end{array}$ & $\begin{array}{r}127,974 \\
45,008 \\
496 \\
44,512 \\
535 \\
17,855 \\
1,883 \\
15,972 \\
1,138 \\
28,494 \\
15,102 \\
2,538 \\
1,104 \\
6,443 \\
500 \\
3,489 \\
4,473 \\
0 \\
1,295\end{array}$ \\
\hline 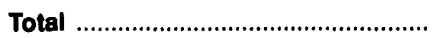 & $1,098,344$ & $1,686,289$ & $1,029,337$ & 41,996 & $-1,059,465$ & 14,041 & $\mathbf{0}$ & $1,609,590$ & 116,800 & $1,056,070$ & $1,006,540$ \\
\hline
\end{tabular}

a Represents the PAD District in which the material entered the United States and not necessarily where the crude oil or product is processed and/or consumed.

b Unaccounted for crude oil represents the difference between the supply and disposition of crude oil.

c A negative number indicates a vecrease in stocks and a positive number indicates an increase in stocks.

d Products supplied is equal to field production, plus refinery production, plus imports, plus unaccounted for crude oil, plus net receipts, minus stock change, minus crude losses, minus refinery inputs, minus exports.

$\theta$ Includes naphtha less than $401^{\circ} \mathrm{F}$ endpoint and other oils equal to or greater than $401^{\circ} \mathrm{F}$ endpoint.

(s) = Less than 500 barrels.

$E=$ Estimated.

LRG = Liquefied Refinery Gas.

Note: Totals may not equal sum of components due to independent rounding.

Sources: - Energy Information Administration (EIA) Forms EIA-810, "Monthly Refinery Report," EIA-811, "Monthly Bulk Terminal Report," EIA-812, "Monthly Product Pipeline Report," EIA-813, "Monthly Crude Oil Report," EIA-814, "Monthly Imports Report," EIA-816, "Monthly Natural Gas Liquids Report," and EIA-817, "Monthly Tanker and Barge Movement Report." - Domestic crude oil production estimates based on historical statistics from State conservation agencies and the Minerals Management Service of the U.S. Department of the Interior. - Export data from the Bureau of the Census and Form EIA-810, "Monthly Refinery Report." 
Table 16. PAD District III-Daily Average Supply and Disposition of Crude Oil and Petroleum Products, August 1991

(Thousand Barrels per Day)

\begin{tabular}{|c|c|c|c|c|c|c|c|c|c|c|}
\hline \multirow[b]{2}{*}{ Commodity } & \multicolumn{5}{|c|}{ Supply } & \multicolumn{5}{|c|}{ Disposition } \\
\hline & $\begin{array}{c}\text { Field } \\
\text { Production }\end{array}$ & $\begin{array}{c}\text { Pettnery } \\
\text { Production }\end{array}$ & $\begin{array}{c}\text { Imports by } \\
\text { PAD } \\
\text { District } \\
\text { of Entry }\end{array}$ & $\begin{array}{c}\text { Unac- } \\
\text { counted } \\
\text { For } \\
\text { Crude Oll }^{\mathrm{b}}\end{array}$ & $\begin{array}{c}\text { Net } \\
\text { Receipts }\end{array}$ & $\begin{array}{c}\text { Stock } \\
\text { Changec }\end{array}$ & $\begin{array}{c}\text { Crude } \\
\text { Losses }\end{array}$ & $\begin{array}{l}\text { Refinery } \\
\text { Inputs }\end{array}$ & Exports & $\begin{array}{l}\text { Products } \\
\text { Supplied }^{d}\end{array}$ \\
\hline 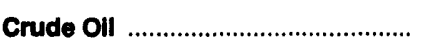 & $E_{3,359}$ & 一 & 4,436 & 61 & $-1,523$ & 79 & 0 & 6,255 & $\mathbf{0}$ & 0 \\
\hline $\begin{array}{l}\text { Natural Gas Liquids and LRGs ...... } \\
\text { Pentanes Plus ............................. } \\
\text { Liquefied Petroleum Gases .......... } \\
\text { Ethane/Ethylene ..................... } \\
\text { Propane/Propylene .................. } \\
\text { Normal Butane/Butylene .......... } \\
\text { Isobutane ................................. }\end{array}$ & $\begin{array}{r}1,079 \\
204 \\
875 \\
379 \\
304 \\
56 \\
136\end{array}$ & $\begin{array}{r}306 \\
306 \\
13 \\
221 \\
58 \\
13\end{array}$ & $\begin{array}{r}68 \\
0 \\
68 \\
8 \\
16 \\
27 \\
18\end{array}$ & $\begin{array}{l}- \\
- \\
- \\
-\end{array}$ & $\begin{array}{r}-16 \\
-13 \\
-3 \\
89 \\
-71 \\
-3 \\
-19\end{array}$ & $\begin{array}{r}47 \\
2 \\
46 \\
-71 \\
-1 \\
90 \\
28\end{array}$ & $\begin{array}{l}- \\
- \\
- \\
-\end{array}$ & $\begin{array}{r}218 \\
92 \\
126 \\
0 \\
0 \\
31 \\
95\end{array}$ & $\begin{array}{r}11 \\
0 \\
11 \\
0 \\
8 \\
3 \\
0\end{array}$ & $\begin{array}{r}1,160 \\
97 \\
1,063 \\
559 \\
464 \\
15 \\
25\end{array}$ \\
\hline $\begin{array}{l}\text { Other Liquids ............................. } \\
\text { Other Hydrocarbons/Alcohol ......... } \\
\text { Unfinished Oils ............................. } \\
\text { Motor Gasoline Blend. Comp. ....... } \\
\text { Aviation Gasoline Blend. Comp. ... }\end{array}$ & $\begin{array}{l}52 \\
52 \\
- \\
-\end{array}$ & $\frac{-}{-}$ & $\begin{array}{r}192 \\
0 \\
192 \\
(s) \\
0\end{array}$ & $\frac{-}{-}$ & $\begin{array}{r}-16 \\
0 \\
-10 \\
-5 \\
0\end{array}$ & $\begin{array}{r}42 \\
3 \\
44 \\
-5 \\
(s)\end{array}$ & $\begin{array}{c}- \\
- \\
-\end{array}$ & $\begin{array}{r}358 \\
49 \\
297 \\
12 \\
1\end{array}$ & $\begin{array}{l}0 \\
0 \\
0 \\
0 \\
0\end{array}$ & $\begin{array}{r}-172 \\
0 \\
-160 \\
-12 \\
(s)\end{array}$ \\
\hline 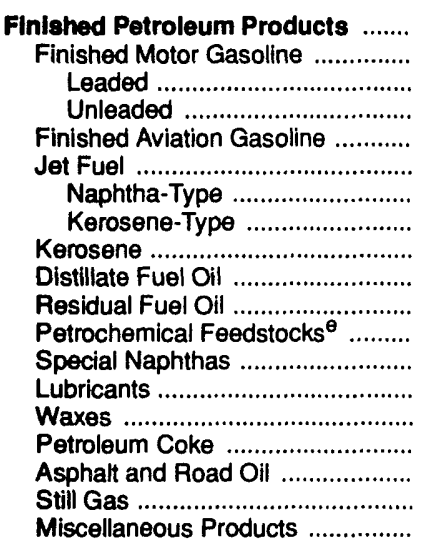 & $\begin{array}{l}- \\
- \\
- \\
- \\
- \\
- \\
- \\
- \\
- \\
- \\
-\end{array}$ & $\begin{array}{r}6,861 \\
3,176 \\
34 \\
3,142 \\
14 \\
722 \\
83 \\
639 \\
11 \\
1,329 \\
386 \\
357 \\
28 \\
92 \\
11 \\
257 \\
124 \\
311 \\
43\end{array}$ & $\begin{array}{r}222 \\
0 \\
0 \\
0 \\
0 \\
8 \\
0 \\
8 \\
0 \\
0 \\
88 \\
117 \\
4 \\
0 \\
(s) \\
0 \\
6 \\
0 \\
0\end{array}$ & $\begin{array}{l}- \\
- \\
- \\
- \\
- \\
- \\
- \\
- \\
- \\
- \\
- \\
- \\
-\end{array}$ & $\begin{array}{r}-3,053 \\
-1,872 \\
-6 \\
-1,867 \\
-8 \\
-445 \\
-5 \\
-440 \\
-4 \\
-675 \\
7 \\
0 \\
-6 \\
-24 \\
0 \\
0 \\
-24 \\
0 \\
-1\end{array}$ & $\begin{array}{r}16 \\
-43 \\
-1 \\
-42 \\
-12 \\
16 \\
-11 \\
27 \\
-1 \\
39 \\
31 \\
-21 \\
-7 \\
-1 \\
-1 \\
3 \\
5 \\
0 \\
7\end{array}$ & $\begin{array}{l}- \\
- \\
- \\
- \\
- \\
- \\
- \\
- \\
- \\
- \\
- \\
- \\
-\end{array}$ & $\begin{array}{l}- \\
- \\
- \\
- \\
- \\
- \\
- \\
- \\
- \\
- \\
- \\
- \\
- \\
-\end{array}$ & $\begin{array}{r}401 \\
70 \\
5 \\
65 \\
0 \\
6 \\
0 \\
6 \\
(s) \\
106 \\
65 \\
0 \\
2 \\
10 \\
1 \\
141 \\
1 \\
0 \\
(s)\end{array}$ & $\begin{array}{r}3,612 \\
1,276 \\
24 \\
1,252 \\
18 \\
262 \\
89 \\
173 \\
8 \\
509 \\
385 \\
494 \\
31 \\
59 \\
12 \\
113 \\
100 \\
311 \\
34\end{array}$ \\
\hline Total & 4,490 & 7,166 & 4,918 & 61 & $-4,609$ & 184 & 0 & 6,831 & 412 & 4,600 \\
\hline
\end{tabular}

a Represents the PAD District in which the material entered the United States and not necessarily where the crude oil or product is processed and/or consumed.

Represents the PAD District in which the material entered the United States and not necessarily where
Unaccounted for crude oil represents the difference between the supply and disposition of crude oil.

c A negative number indicates a decrease in stocks and a positive number indicates an increase in stocks.

d Products supplied is equal to field production, plus refinery production, plus imports, plus unaccounted for crude oil, plus net receipts, minus stock change, minus crude losses, minus refinery inputs, minus exports.

$\theta$ Includes naphtha less than $401^{\circ} \mathrm{F}$ endpoint and other oils equal to or greater than $401^{\circ} \mathrm{F}$ endpoint.

(s) = Less than 500 barrels per day.

$E=$ Estimated.

LRG = Liquefied Refinery Gas

Note: Totals may not equal sum of components due to independent rounding.

Sources: • Energy Information Administration (EIA) Forms ElA-810, "Monthly Refinery Report," ElA-811, "Monthly Bulk Terminal Report," EIA-812, "Monthly Product Pipeline Report," EIA-813, "Monthly Crude Oil Report," ElA-814, "Monthly Imports Report," ElA-816, "Monthly Natural Gas Liquids Report," and EIA-817, "Monthly Tanker and Barge Movement Report." - Domestic crude oll production estimates based on historical statistics from State conservation agencies and the Minerals Management Service of the U.S. Department of the Interior. - Export data from the Bureau of the Census and Form ElA-810, "Monthly Refinery Report." 
Table 17. PAD District III-Year-to-Date Daily Average Supply and Disposition of Crude Oil and Petroleum Products, January-August 1991

(Thousand Barrels per Day)

\begin{tabular}{|c|c|c|c|c|c|c|c|c|c|c|}
\hline \multirow[b]{2}{*}{ Commodity } & \multicolumn{5}{|c|}{ Supply } & \multicolumn{5}{|c|}{ Disposition } \\
\hline & $\begin{array}{c}\text { Fleld } \\
\text { Production }\end{array}$ & $\begin{array}{c}\text { Reflnery } \\
\text { Productlon }\end{array}$ & $\begin{array}{c}\text { Imports by } \\
\text { PAD } \\
\text { District } \\
\text { of Entry }\end{array}$ & $\begin{array}{c}\text { Unac- } \\
\text { counted } \\
\text { For } \\
\text { Crude OII }\end{array}$ & $\begin{array}{c}\text { Net } \\
\text { Recelpts }\end{array}$ & $\begin{array}{c}\text { Stock } \\
\text { Change }\end{array}$ & $\begin{array}{c}\text { Crude } \\
\text { Losses }\end{array}$ & $\begin{array}{c}\text { Refinery } \\
\text { Inputs }\end{array}$ & Exports & $\begin{array}{l}\text { Products } \\
\text { Supplled }^{\mathrm{d}}\end{array}$ \\
\hline 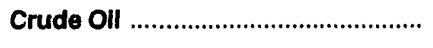 & $E_{3,384}$ & - & 3,746 & 173 & $-1,321$ & 6 & 0 & 5,976 & 0 & $\mathbf{0}$ \\
\hline 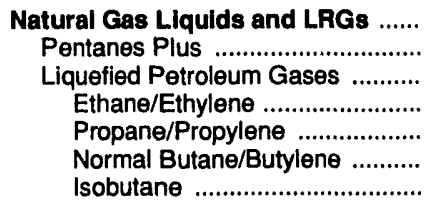 & $\begin{array}{r}1,085 \\
195 \\
890 \\
390 \\
309 \\
71 \\
120\end{array}$ & $\begin{array}{r}300 \\
300 \\
13 \\
224 \\
51 \\
11\end{array}$ & $\begin{array}{r}46 \\
0 \\
46 \\
1 \\
23 \\
15 \\
8\end{array}$ & $\begin{array}{l}- \\
\overline{-} \\
\overline{-}\end{array}$ & $\begin{array}{r}-26 \\
-5 \\
-21 \\
66 \\
-76 \\
3 \\
-14\end{array}$ & $\begin{array}{r}38 \\
8 \\
30 \\
-8 \\
-4 \\
42 \\
(s)\end{array}$ & $\begin{array}{l}- \\
- \\
- \\
-\end{array}$ & $\begin{array}{r}227 \\
95 \\
132 \\
0 \\
0 \\
43 \\
88\end{array}$ & $\begin{array}{r}23 \\
1 \\
22 \\
0 \\
16 \\
6 \\
0\end{array}$ & $\begin{array}{r}1,117 \\
87 \\
1,031 \\
478 \\
468 \\
48 \\
37\end{array}$ \\
\hline $\begin{array}{l}\text { Other Llquilds .................................. } \\
\text { Other Hydrocarbons/Alcohol ......... } \\
\text { Unfinished Oils ............................ } \\
\text { Motor Gasoline Blend. Comp. ....... } \\
\text { Aviation Gasoline Blend. Comp. .... }\end{array}$ & $\begin{array}{l}51 \\
51 \\
- \\
-\end{array}$ & $\begin{array}{l}- \\
- \\
-\end{array}$ & $\begin{array}{r}240 \\
(s) \\
233 \\
7 \\
0\end{array}$ & $\begin{array}{l}- \\
- \\
-\end{array}$ & $\begin{array}{r}-22 \\
0 \\
-12 \\
-9 \\
0\end{array}$ & $\begin{array}{r}27 \\
2 \\
27 \\
-3 \\
(s)\end{array}$ & $\begin{array}{l}- \\
- \\
-\end{array}$ & $\begin{array}{r}420 \\
49 \\
356 \\
16 \\
(\mathrm{~s})\end{array}$ & $\begin{array}{l}0 \\
0 \\
0 \\
0 \\
0\end{array}$ & $\begin{array}{r}-178 \\
0 \\
-162 \\
-16 \\
(5)\end{array}$ \\
\hline 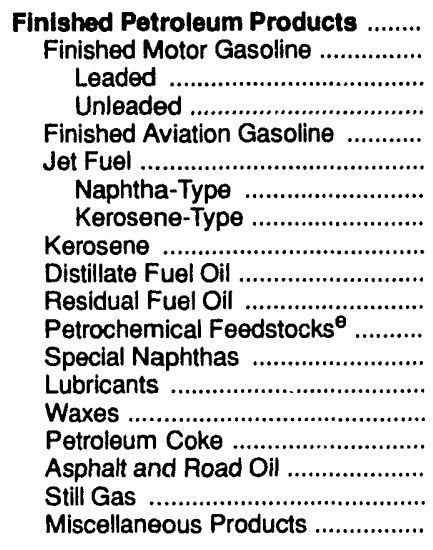 & $\begin{array}{l}- \\
- \\
- \\
- \\
- \\
- \\
- \\
- \\
- \\
- \\
-\end{array}$ & $\begin{array}{r}6,639 \\
3,060 \\
44 \\
3,016 \\
13 \\
705 \\
88 \\
617 \\
16 \\
1,298 \\
378 \\
349 \\
31 \\
98 \\
11 \\
247 \\
100 \\
293 \\
40\end{array}$ & $\begin{array}{r}204 \\
3 \\
(s) \\
3 \\
0 \\
1 \\
0 \\
1 \\
(s) \\
(s) \\
56 \\
135 \\
3 \\
0 \\
(s) \\
(s) \\
4 \\
0 \\
1\end{array}$ & $\begin{array}{l}- \\
- \\
- \\
- \\
- \\
- \\
- \\
- \\
- \\
- \\
- \\
- \\
-\end{array}$ & $\begin{array}{r}-2,992 \\
-1,841 \\
-4 \\
-1,837 \\
-6 \\
-441 \\
-13 \\
-428 \\
-7 \\
-651 \\
-1 \\
1 \\
-6 \\
-23 \\
(s) \\
0 \\
-16 \\
0 \\
-2\end{array}$ & $\begin{array}{r}-13 \\
-18 \\
-1 \\
-17 \\
(s) \\
1 \\
-1 \\
2 \\
-1 \\
2 \\
3 \\
-1 \\
-3 \\
2 \\
(s) \\
(s) \\
2 \\
0 \\
(s)\end{array}$ & $\begin{array}{l}- \\
- \\
- \\
- \\
- \\
- \\
- \\
- \\
- \\
- \\
- \\
- \\
-\end{array}$ & $\begin{array}{l}- \\
- \\
- \\
- \\
- \\
- \\
- \\
- \\
- \\
- \\
- \\
- \\
-\end{array}$ & $\begin{array}{r}458 \\
48 \\
5 \\
43 \\
0 \\
27 \\
2 \\
25 \\
2 \\
141 \\
86 \\
0 \\
10 \\
8 \\
1 \\
134 \\
\text { (s) } \\
0 \\
\text { (s) }\end{array}$ & $\begin{array}{r}3,406 \\
1,193 \\
37 \\
1,156 \\
7 \\
238 \\
74 \\
164 \\
8 \\
504 \\
345 \\
487 \\
20 \\
64 \\
10 \\
114 \\
85 \\
293 \\
39\end{array}$ \\
\hline . & 4,520 & 6,939 & 4,236 & 173 & $-4,360$ & 58 & 0 & 6,624 & 481 & 4,346 \\
\hline
\end{tabular}

a Represents the PAD District in which the material entered the United States and not necessarily where the crude oil or product is processed and/or consumed.

Unaccounted for crude oil represents the difference between the supply and disposition of crude oil.

c A negative number indicates a decrease in stocks and a positive number indicates an increase in stocks.

d Products supplied is equal to field production, plus refinery production, plus imports, plus unaccounted for crude oil, plus net receipts, minus stock change, minus crude losses, minus refinery inputs, minus exports.

$\theta$ Includes naphtha less than $401^{\circ} \mathrm{F}$ endpoint and other oils equal to or greater than $401^{\circ} \mathrm{F}$ endpoint.

(s) = Less than 500 barrels per day.

$E=$ Estimated.

LRG = Liquefied Refinery Gas.

Note: Totals may not equal sum of components due to independent rounding.

Sources: - Energy Information Administration (EIA) Forms EIA-810, "Monthly Refinery Report," EIA-811, "Monthly Bulk Terminal Report," EIA-812, "Monthly Product Pipeline Report," ElA-813, "Monthly Crude Oil Report," ElA-814, "Monthly Imports Report," ElA-816, "Monthly Natural Gas Liquids Report," and EIA-817, "Monthly Tanker and Barge Movement Report." - Domestic crude oil production estimates based on historical statistics from State conservation agencies and the Minerals Management Service of the U.S. Department of the Interior. - Export data from the Bureau of the Census and Form EIA-810, "Monthly Refinery Report." 
Table 18. PAD District IV-Supply, Disposition, and Ending Stocks of Crude Oil and Petroleum Products, August 1991

(Thousand Barrels)

\begin{tabular}{|c|c|c|c|c|c|c|c|c|c|c|c|}
\hline \multirow[b]{2}{*}{ Commodity } & \multicolumn{5}{|c|}{ Supply } & \multicolumn{5}{|c|}{ Disposition } & \multirow[b]{2}{*}{$\begin{array}{l}\text { Ending } \\
\text { Stocks }\end{array}$} \\
\hline & $\begin{array}{c}\text { Fleld } \\
\text { Production }\end{array}$ & $\begin{array}{c}\text { Refinery } \\
\text { Production }\end{array}$ & $\begin{array}{c}\text { Imports by } \\
\text { PAD } \\
\text { District } \\
\text { of Entry }\end{array}$ & $\begin{array}{c}\text { Unac- } \\
\text { coinited } \\
\text { For } \\
\text { Crude Oll }\end{array}$ & $\begin{array}{c}\text { itet } \\
\text { Recelpts }\end{array}$ & $\begin{array}{c}\text { Stock } \\
\text { Changec } \\
\end{array}$ & $\begin{array}{c}\text { Crude } \\
\text { Losses }\end{array}$ & $\begin{array}{c}\text { Refinery } \\
\text { Inputs }\end{array}$ & Exports & $\begin{array}{l}\text { Products } \\
\text { Supplled d }\end{array}$ & \\
\hline 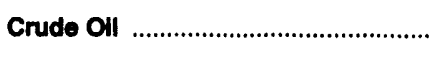 & $E_{14,702}$ & - & 2,561 & 1,545 & $-3,701$ & -268 & 0 & 15,375 & 0 & 0 & 11,487 \\
\hline 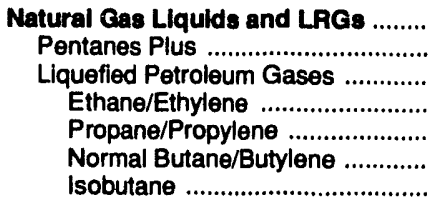 & $\begin{array}{r}3,961 \\
855 \\
3,106 \\
1,091 \\
1,257 \\
534 \\
224\end{array}$ & $\begin{array}{r}294 \\
294 \\
0 \\
248 \\
56 \\
-10\end{array}$ & $\begin{array}{r}307 \\
110 \\
197 \\
0 \\
119 \\
71 \\
7\end{array}$ & $\begin{array}{l}- \\
\overline{-} \\
\overline{-}\end{array}$ & $\begin{array}{r}-2,286 \\
-302 \\
-1,984 \\
-951 \\
-532 \\
-277 \\
-224\end{array}$ & $\begin{array}{r}1 \\
-5 \\
6 \\
0 \\
7 \\
4 \\
-5\end{array}$ & $\begin{array}{l}- \\
- \\
z \\
-\end{array}$ & $\begin{array}{r}629 \\
215 \\
414 \\
0 \\
0 \\
298 \\
116\end{array}$ & $\begin{array}{r}14 \\
0 \\
14 \\
0 \\
0 \\
14 \\
0\end{array}$ & $\begin{array}{r}1,632 \\
453 \\
1,179 \\
140 \\
1,085 \\
68 \\
-114\end{array}$ & $\begin{array}{r}1,244 \\
133 \\
1,111 \\
174 \\
449 \\
350 \\
138\end{array}$ \\
\hline $\begin{array}{l}\text { Other Llquids ............................... } \\
\text { Other Hydrocarbons/Alcohol .......... } \\
\text { Unfinished Oils ............................... } \\
\text { Motor Gasoline Blend. Comp. ......... } \\
\text { Aviation Gasoline Blend. Comp. ..... }\end{array}$ & $\begin{array}{l}17 \\
17 \\
- \\
-\end{array}$ & $\begin{array}{l}- \\
- \\
-\end{array}$ & $\begin{array}{l}0 \\
0 \\
0 \\
0 \\
0\end{array}$ & $\begin{array}{l}- \\
- \\
-\end{array}$ & $\begin{array}{l}0 \\
0 \\
0 \\
0 \\
0\end{array}$ & $\begin{array}{r}-404 \\
11 \\
-154 \\
-261 \\
0\end{array}$ & $\begin{array}{l}\overline{-} \\
\overline{-} \\
-\end{array}$ & $\begin{array}{r}314 \\
6 \\
44 \\
264 \\
0\end{array}$ & $\begin{array}{l}\mathbf{0} \\
0 \\
0 \\
0 \\
0\end{array}$ & $\begin{array}{r}107 \\
0 \\
110 \\
-3 \\
0\end{array}$ & $\begin{array}{r}3,749 \\
85 \\
2,060 \\
1,604 \\
0\end{array}$ \\
\hline 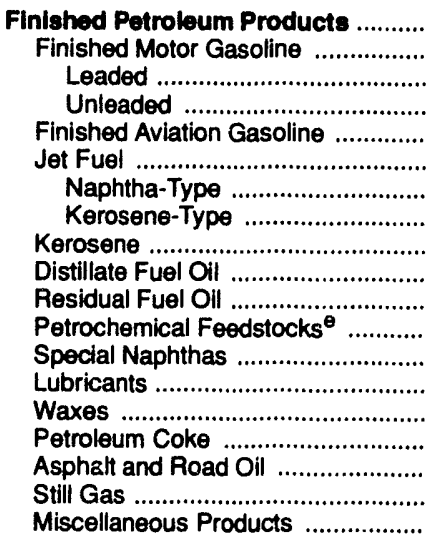 & 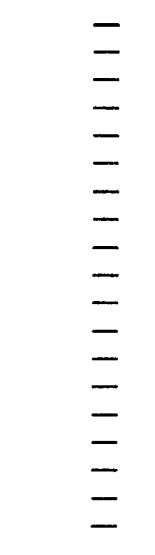 & $\begin{array}{r}16,469 \\
8,220 \\
1,590 \\
6,630 \\
28 \\
1,069 \\
366 \\
703 \\
1 \\
4,313 \\
294 \\
12 \\
0 \\
-1 \\
64 \\
356 \\
1,355 \\
690 \\
68\end{array}$ & $\begin{array}{r}214 \\
62 \\
10 \\
52 \\
0 \\
0 \\
0 \\
0 \\
0 \\
152 \\
0 \\
0 \\
0 \\
0 \\
0 \\
0 \\
0 \\
0 \\
0\end{array}$ & $\begin{array}{l}- \\
- \\
- \\
z \\
- \\
- \\
- \\
- \\
- \\
- \\
- \\
- \\
-\end{array}$ & $\begin{array}{r}60 \\
-34 \\
-307 \\
273 \\
22 \\
392 \\
-155 \\
547 \\
0 \\
-320 \\
0 \\
0 \\
0 \\
0 \\
0 \\
0 \\
0 \\
0 \\
0\end{array}$ & $\begin{array}{r}-1,206 \\
-405 \\
-68 \\
-337 \\
-2 \\
-41 \\
8 \\
-49 \\
-18 \\
-328 \\
11 \\
-4 \\
0 \\
-1 \\
31 \\
19 \\
-472 \\
0 \\
4\end{array}$ & $\begin{array}{l}- \\
- \\
z \\
z \\
z \\
z \\
- \\
z \\
z \\
- \\
- \\
-\end{array}$ & $\begin{array}{l}- \\
- \\
z \\
- \\
- \\
- \\
- \\
- \\
- \\
- \\
- \\
- \\
-\end{array}$ & $\begin{array}{r}5 \\
1 \\
(s) \\
(s) \\
0 \\
0 \\
0 \\
0 \\
0 \\
1 \\
0 \\
0 \\
0 \\
3 \\
0 \\
0 \\
1 \\
0 \\
0\end{array}$ & $\begin{array}{r}17,944 \\
8,652 \\
1,361 \\
7,292 \\
52 \\
1,502 \\
203 \\
1,299 \\
19 \\
4,472 \\
283 \\
16 \\
0 \\
-3 \\
33 \\
337 \\
1,826 \\
690 \\
64\end{array}$ & $\begin{array}{r}10,472 \\
3,582 \\
913 \\
2,669 \\
33 \\
1,016 \\
285 \\
731 \\
66 \\
2,896 \\
550 \\
4 \\
2 \\
7 \\
124 \\
21 \\
2,159 \\
0 \\
12\end{array}$ \\
\hline ..................... & 18,680 & 16,763 & 3,082 & 1,545 & $-5,927$ & $-1,877$ & 0 & 16,318 & 19 & 19,683 & 26,952 \\
\hline
\end{tabular}

a Represents the PAD District in which the material entered the United States and not necessarily where the crude oil oi product is processed and/or consumed.

b Unaccounted for crude oil represents the difference between the supply and disposition of crude oil.

c A negative number indicates a decrease in stocks and a positive number indicates an increase in stocks.

Droducts supplied is equal to field production, plus refinery production, plus imports, plus unaccounted for crude oil, plus net receipts, minus stock change, minus crude losses, minus refinery inputs, minus exports.

$\theta$ Includes naphtha less than $401^{\circ} \mathrm{F}$ endpoint and other oils equal to or greater than $401^{\circ} \mathrm{F}$ endpoint.

(s) = Less than 500 barrels.

$\mathrm{E}=$ Estimated.

LRG = Liquefied Refinery Gas.

Note: Totals may not equal sum of components due to independent rounding.

Sources: - Energy Information Administration (EIA) Forms EIA-810, "Monthly Refinery Report," EIA-811, "Monthly Bulk Terminal Report," EIA-812, "Monthly Product Pipeline Report," EIA-813, "Monthly Crude Oil Report," EIA-814, "Monthly Imports Report," EIA-816, "Monthly Natural Gas Liquids Report," and EIA-817, "Monthly Tanker and Barge Movement Report." - Domestic crude oil production estimates based on historical statistics from State conservation agencies and the Minerals Management Service of the U.S. Department of the Interior. - Export data from the Bureau of the Census and Form ElA-810, "Monthly Retinery Report." 
Table 19. PAD District IV_Year-to-Date Supply, Disposition, and Ending Stocks of Crude Oil and Petroleum Products, January-August 1991 (Thousand Barrels)

\begin{tabular}{|c|c|c|c|c|c|c|c|c|c|c|c|}
\hline \multirow[b]{2}{*}{ Commodity } & \multicolumn{5}{|c|}{ Supply } & \multicolumn{5}{|c|}{ Disposition } & \multirow[b]{2}{*}{$\begin{array}{l}\text { Ending } \\
\text { Stocks }\end{array}$} \\
\hline & \begin{tabular}{|c|} 
Fleld \\
Productlon
\end{tabular} & $\begin{array}{c}\text { Refinery } \\
\text { Production }\end{array}$ & $\begin{array}{c}\text { Imports by } \\
\text { PAD } \\
\text { Distrlct } \\
\text { of Entry }\end{array}$ & $\begin{array}{l}\text { Unac- } \\
\text { counted } \\
\text { For } \\
\text { Crude Oll }\end{array}$ & $\begin{array}{c}\text { Net } \\
\text { Recelpts }\end{array}$ & $\begin{array}{c}\text { Stock } \\
\text { Change }^{c}\end{array}$ & $\begin{array}{l}\text { Crude } \\
\text { Losses }\end{array}$ & $\begin{array}{c}\text { Refinery } \\
\text { Inputs }\end{array}$ & Exports & $\begin{array}{l}\text { Products } \\
\text { Supplled d }\end{array}$ & \\
\hline 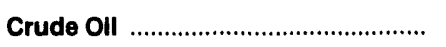 & $E_{117,198}$ & - & 18,341 & 7,445 & $-32,072$ & -442 & 5 & 111,041 & 307 & 0 & 11,487 \\
\hline 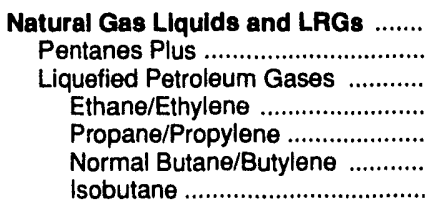 & $\begin{array}{r}31,725 \\
6,456 \\
25,269 \\
8,856 \\
10,325 \\
4,287 \\
1,801\end{array}$ & $\begin{array}{r}1,589 \\
- \\
1,589 \\
0 \\
1,660 \\
32 \\
-103\end{array}$ & $\begin{array}{r}1,854 \\
535 \\
1,319 \\
0 \\
644 \\
552 \\
123\end{array}$ & $\begin{array}{l}- \\
- \\
- \\
-\end{array}$ & $\begin{array}{r}-17,604 \\
-2,642 \\
-14,962 \\
-6,784 \\
-4,175 \\
-2,486 \\
-1,517\end{array}$ & $\begin{array}{r}58 \\
-24 \\
82 \\
0 \\
62 \\
22 \\
-2\end{array}$ & $\begin{array}{l}- \\
- \\
- \\
-\end{array}$ & $\begin{array}{r}4,477 \\
1,422 \\
3,055 \\
0 \\
0 \\
2,149 \\
906\end{array}$ & $\begin{array}{r}99 \\
0 \\
99 \\
0 \\
6 \\
94 \\
0\end{array}$ & $\begin{array}{r}12,930 \\
2,951 \\
9,979 \\
2,072 \\
8,386 \\
120 \\
-600\end{array}$ & $\begin{array}{r}1,244 \\
133 \\
1,111 \\
174 \\
449 \\
350 \\
138\end{array}$ \\
\hline $\begin{array}{l}\text { Other Llquids ................................. } \\
\text { Other Hydrocarbons/Alcohol ........... } \\
\text { Unfinished Oils ............................. } \\
\text { Motor Gasoline Blend. Comp. ......... } \\
\text { Aviation Gasoline Blend. Comp. ..... }\end{array}$ & $\begin{array}{l}181 \\
181 \\
- \\
-\end{array}$ & $\begin{array}{l}- \\
- \\
-\end{array}$ & $\begin{array}{l}0 \\
0 \\
0 \\
0 \\
0\end{array}$ & $\begin{array}{l}- \\
- \\
-\end{array}$ & $\begin{array}{l}0 \\
0 \\
0 \\
0 \\
0\end{array}$ & $\begin{array}{r}-1,056 \\
-24 \\
67 \\
-1,099 \\
0\end{array}$ & $\begin{array}{l}- \\
- \\
-\end{array}$ & $\begin{array}{r}1,035 \\
205 \\
-322 \\
1,152 \\
0\end{array}$ & $\begin{array}{l}0 \\
0 \\
0 \\
0 \\
0\end{array}$ & $\begin{array}{r}202 \\
0 \\
255 \\
-53 \\
0\end{array}$ & $\begin{array}{r}3,749 \\
85 \\
2,060 \\
1,604 \\
0\end{array}$ \\
\hline 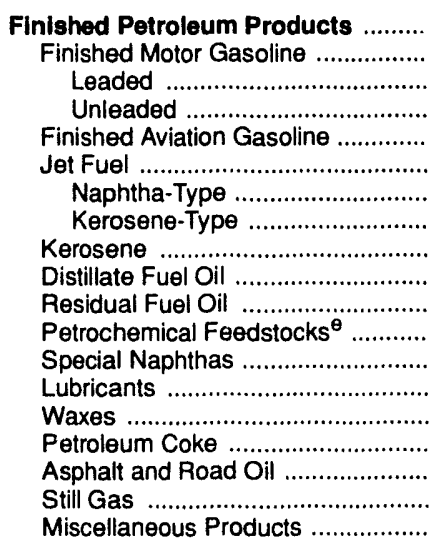 & $\begin{array}{l}- \\
- \\
- \\
z \\
- \\
- \\
z \\
- \\
- \\
-\end{array}$ & $\begin{array}{r}117,781 \\
58,319 \\
10,796 \\
47,523 \\
185 \\
8,408 \\
2,641 \\
5,767 \\
105 \\
31,721 \\
2,453 \\
126 \\
-2 \\
-1 \\
265 \\
2,645 \\
8,166 \\
4,911 \\
480\end{array}$ & $\begin{array}{r}973 \\
311 \\
27 \\
284 \\
0 \\
0 \\
0 \\
0 \\
0 \\
632 \\
30 \\
0 \\
0 \\
0 \\
0 \\
0 \\
0 \\
0 \\
0\end{array}$ & $\begin{array}{l}- \\
- \\
- \\
- \\
- \\
- \\
- \\
- \\
- \\
- \\
- \\
-\end{array}$ & $\begin{array}{r}-3,915 \\
-2,548 \\
-2,673 \\
125 \\
104 \\
2,237 \\
-1,190 \\
3,427 \\
0 \\
-3,708 \\
0 \\
0 \\
0 \\
0 \\
0 \\
0 \\
0 \\
0 \\
0\end{array}$ & $\begin{array}{r}-764 \\
-1,262 \\
-338 \\
-924 \\
-22 \\
-3 \\
-89 \\
86 \\
41 \\
-378 \\
54 \\
-15 \\
-2 \\
-1 \\
-6 \\
19 \\
824 \\
0 \\
-13\end{array}$ & $\begin{array}{l}- \\
- \\
- \\
- \\
- \\
- \\
- \\
- \\
- \\
- \\
- \\
-\end{array}$ & $\begin{array}{l}- \\
- \\
- \\
- \\
- \\
- \\
- \\
- \\
- \\
- \\
- \\
-\end{array}$ & $\begin{array}{r}101 \\
28 \\
1 \\
27 \\
0 \\
0 \\
0 \\
0 \\
0 \\
9 \\
(s) \\
0 \\
1 \\
24 \\
(s) \\
34 \\
5 \\
0 \\
0\end{array}$ & $\begin{array}{r}115,502 \\
57,316 \\
8,487 \\
48,829 \\
311 \\
10,648 \\
1,540 \\
9,108 \\
64 \\
29,014 \\
2,429 \\
141 \\
-1 \\
-24 \\
271 \\
2,592 \\
7,337 \\
4,911 \\
493\end{array}$ & $\begin{array}{r}10,472 \\
3,582 \\
913 \\
2,669 \\
33 \\
1,016 \\
285 \\
731 \\
66 \\
2,896 \\
550 \\
4 \\
2 \\
7 \\
124 \\
21 \\
2,159 \\
0 \\
12\end{array}$ \\
\hline Total & 149,104 & 119,370 & 21,168 & 7,445 & $-53,591$ & $-2,204$ & 5 & 116,553 & 507 & 128,634 & 26,952 \\
\hline
\end{tabular}

a Represents the PAD District in which the material entered the United States and not necessarily where the crude oil or product is processed and/or consumed.

b Unaccounted for crude oil represents the difference between the supply and disposition of crude oil.

c A negative number indicates a decrease in stocks and a positive number indicates an increase in stocks.

d Products supplied is equal to field production, plus refinery production, plus imports, plus unaccounted for crude oil, plus net receipts, minus stock change, minus crude losses, minus refinery inputs, minus exports.

$\theta$ Includes naphtha less than $401^{\circ} \mathrm{F}$ endpoint and other oils equal to or greater than $401^{\circ} \mathrm{F}$ endpoint.

(s) $=$ Less than 500 barrels.

$E=$ Estimated.

LRG = Liquefied Refinery Gas.

Note: Totals may not equal sum of components due to independent rounding.

Sources: - Energy Information Administration (EIA) Forms EIA-810, "Monthly Refinery Report," EIA-811, "Monthly Bulk Terminal Report," EIA-812, "Monthly Product Pipeline Report," EIA-813, "Monthly Crude Oil Report," EIA-814, "Monthly Imports Report," ElA-816, "Monthly Natural Gas Liquids Report," and EIA-817, "Monthly Tanker and Barge Movement Report." - Domestic crude oil production estimates based on historical statistics from State conservation agencies and the Minerals Management Service of the U.S. Department of the Interior. - Export data from the Bureau of the Census and Form EIA-810, "Monthly Refinery Report." 
Table 20. PAD District IV-Daily Average Supply and Disposition of Crude OII and Petroleum Products, August 1991 (Thousand Barrels per Day)

\begin{tabular}{|c|c|c|c|c|c|c|c|c|c|c|}
\hline \multirow[b]{2}{*}{ Commodity } & \multicolumn{5}{|c|}{ Supply } & \multicolumn{5}{|c|}{ Disposition } \\
\hline & $\begin{array}{c}\text { Flold } \\
\text { Production }\end{array}$ & $\begin{array}{c}\text { Refinery } \\
\text { Production }\end{array}$ & $\begin{array}{c}\text { Imports by } \\
\text { PAD } \\
\text { Diatrict } \\
\text { of Entry } \\
\end{array}$ & $\begin{array}{c}\text { Unac- } \\
\text { counted } \\
\text { For } \\
\text { Crude OII }\end{array}$ & $\begin{array}{c}\text { Not } \\
\text { Recelpts }\end{array}$ & $\begin{array}{c}\text { Stock } \\
\text { Change }\end{array}$ & \begin{tabular}{|c|} 
Crude \\
Losses
\end{tabular} & $\begin{array}{c}\text { Rofinery } \\
\text { Inputs }\end{array}$ & Exports & $\begin{array}{l}\text { Products } \\
\text { Suppllod }\end{array}$ \\
\hline 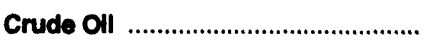 & $E_{474}$ & - & 83 & 50 & -119 & -9 & 0 & 496 & 0 & 0 \\
\hline 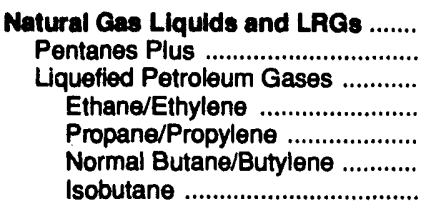 & $\begin{array}{r}128 \\
28 \\
100 \\
35 \\
41 \\
17 \\
7\end{array}$ & $\begin{array}{r}9 \\
9 \\
0 \\
8 \\
2 \\
(\mathbf{s})\end{array}$ & $\begin{array}{r}10 \\
4 \\
6 \\
0 \\
4 \\
2 \\
(s)\end{array}$ & $\begin{array}{l}\bar{z} \\
\bar{z} \\
\bar{z}\end{array}$ & $\begin{array}{r}-74 \\
-10 \\
-64 \\
-31 \\
-17 \\
-9 \\
-7\end{array}$ & $\begin{array}{l}\text { (s) } \\
\text { (s) } \\
\text { (s) } \\
0 \\
\text { (s) } \\
\text { (s) } \\
\text { (s) }\end{array}$ & $\begin{array}{l}\bar{z} \\
\bar{z} \\
\bar{z}\end{array}$ & $\begin{array}{r}20 \\
7 \\
13 \\
0 \\
0 \\
10 \\
4\end{array}$ & $\begin{array}{r}\text { (8) } \\
0 \\
(\mathbf{s}) \\
0 \\
0 \\
(\mathbf{s}) \\
0\end{array}$ & $\begin{array}{r}53 \\
15 \\
38 \\
5 \\
35 \\
2 \\
4\end{array}$ \\
\hline 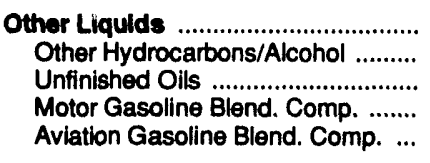 & $\begin{array}{l}1 \\
1 \\
=\end{array}$ & $\begin{array}{l}\bar{z} \\
\bar{z}\end{array}$ & $\begin{array}{l}0 \\
0 \\
0 \\
0 \\
0\end{array}$ & $\begin{array}{l}\bar{z} \\
\bar{z}\end{array}$ & $\begin{array}{l}0 \\
0 \\
0 \\
0 \\
0\end{array}$ & $\begin{array}{r}-13 \\
(s) \\
-5 \\
-8 \\
0\end{array}$ & $\begin{array}{l}\bar{z} \\
\bar{z}\end{array}$ & $\begin{array}{r}10 \\
\text { (s) } \\
1 \\
9 \\
0\end{array}$ & $\begin{array}{l}0 \\
0 \\
0 \\
0 \\
0\end{array}$ & $\begin{array}{r}3 \\
0 \\
4 \\
(\mathbf{s}) \\
0\end{array}$ \\
\hline 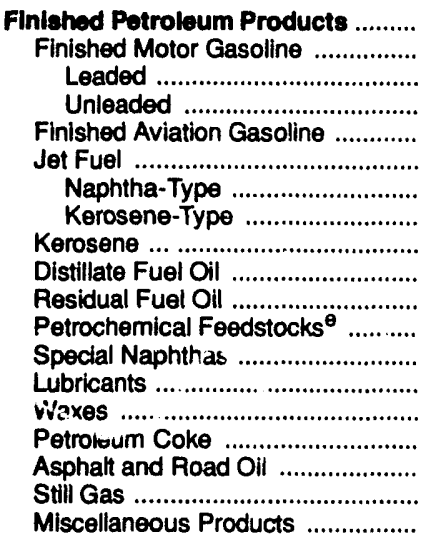 & $\begin{array}{l}\bar{z} \\
\bar{z} \\
\bar{z} \\
\bar{z} \\
\bar{z} \\
\bar{z} \\
\bar{z} \\
=\end{array}$ & $\begin{array}{r}531 \\
265 \\
51 \\
214 \\
1 \\
34 \\
12 \\
23 \\
\text { (s) } \\
139 \\
9 \\
1(\mathrm{~s}) \\
0 \\
(\mathrm{~s}) \\
2 \\
11 \\
44 \\
22 \\
2\end{array}$ & $\begin{array}{r}7 \\
2 \\
\text { (s) } \\
2 \\
0 \\
0 \\
0 \\
0 \\
0 \\
5 \\
0 \\
0 \\
0 \\
0 \\
0 \\
0 \\
0 \\
0 \\
0\end{array}$ & $\begin{array}{l}\bar{z} \\
\bar{z} \\
\bar{z} \\
\bar{z} \\
\bar{z} \\
\bar{z} \\
\overline{-}\end{array}$ & $\begin{array}{r}2 \\
-1 \\
-10 \\
9 \\
1 \\
13 \\
-5 \\
18 \\
0 \\
-10 \\
0 \\
0 \\
0 \\
0 \\
0 \\
0 \\
0 \\
0 \\
0\end{array}$ & $\begin{array}{r}-39 \\
-13 \\
-2 \\
-11 \\
\text { (s) } \\
-1 \\
\text { (s) } \\
-2 \\
-1 \\
-11 \\
\text { (s) } \\
\text { (s) } \\
0 \\
\text { (s) } \\
1 \\
1 \\
-15 \\
0 \\
\text { (s) }\end{array}$ & $\begin{array}{l}\bar{I} \\
\bar{z} \\
\bar{z} \\
\bar{z} \\
\bar{z} \\
\bar{z} \\
\bar{z} \\
\bar{z} \\
\bar{z}\end{array}$ & $\begin{array}{l}\bar{z} \\
\bar{z} \\
\bar{z} \\
\bar{z} \\
\bar{z} \\
\bar{z} \\
\bar{z} \\
\bar{z} \\
\bar{z}\end{array}$ & $\begin{array}{r}\text { (g) } \\
\text { (s) } \\
(\mathbf{s}) \\
(\mathbf{s}) \\
0 \\
0 \\
0 \\
0 \\
0 \\
(\mathbf{s}) \\
0 \\
0 \\
0 \\
(\mathbf{s}) \\
0 \\
0 \\
(\mathbf{s}) \\
0 \\
0\end{array}$ & $\begin{array}{r}579 \\
279 \\
44 \\
235 \\
2 \\
48 \\
7 \\
72 \\
1 \\
1 \\
144 \\
9 \\
1 \\
0 \\
\text { (s) } \\
1 \\
11 \\
59 \\
22 \\
2\end{array}$ \\
\hline Total & 603 & 541 & 99 & 50 & -191 & -61 & 0 & 526 & 1 & 635 \\
\hline
\end{tabular}

a Represents the PAD District in which the material entered the United States and not necessarily where the crude oll or product is processed and/or consumed.

b Unaccounted for crude cil represents the difference between the supply and disposition of crude oil.

c A negative number indicates a decrease in stocks and a positive number indicates an increase in stocks.

d Products supplied is equal to field production, plus refinery production, plus imports, plus unaccounted for crude oil, plus net receipts, minus stock change, minus crude losses, minus refinery inputs, minus exports.

Includes naphtha less than $401^{\circ} \mathrm{F}$ endpoint and other oils equal to or greater than $401^{\circ} \mathrm{F}$ endpoint.

(s) = Less than 500 barrels per day.

$E=$ Estimated.

LRG = Liquefied Refinery Gas.

Note: Totals may not equal sum of components due to independent rounding.

Sources: - Energy Information Administration (EIA) Forms EIA-810, "Monthly Refinery Report," EIA-811, "Monthly Bulk Terminal Report," EIA-812, "Monthly Product Pipeline Report," EIA-813, "Monthly Crude Oil Report," ElA-814, "Monthly Imports Report," EIA-816, "Monthly Natural Gas Liquids Report," and ElA-817, "Monthly Tanker and Barge Movement Report." - Domestic crude oil production estimates based on historical statistics from State consenvation agencies and the Minerals Management Service of the U.S. Department of the Interior. - Export data from the Bureau of the Census and Form EIA-810, "Monthly Refinery Report." 
Table 21. PAD District IV-Year-to-Date Dally Average Supply and Disposition of Crude Oll and Petroleum Products, January-August 1991

(Thousand Barrels per Day)

\begin{tabular}{|c|c|c|c|c|c|c|c|c|c|c|}
\hline \multirow[b]{2}{*}{ Commodity } & \multicolumn{5}{|c|}{ Supply } & \multicolumn{5}{|c|}{ Diepoatilon } \\
\hline & $\begin{array}{c}\text { Filld } \\
\text { Production }\end{array}$ & $\begin{array}{c}\text { Rofinery } \\
\text { Production }\end{array}$ & $\begin{array}{c}\text { Imports by } \\
\text { PAD } \\
\text { Diatrict } \\
\text { of Entry }\end{array}$ & $\begin{array}{c}\text { Unac- } \\
\text { counted } \\
\text { For } \\
\text { Crude OIb }\end{array}$ & $\begin{array}{c}\text { Not } \\
\text { Recelpte }\end{array}$ & $\begin{array}{c}\text { Stock } \\
\text { Changec }\end{array}$ & $\begin{array}{c}\text { Crude } \\
\text { Loseses }\end{array}$ & $\begin{array}{c}\text { Rofinery } \\
\text { Inputs }\end{array}$ & Exports & $\begin{array}{l}\text { Products } \\
\text { Supplled }\end{array}$ \\
\hline 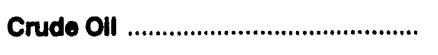 & $E_{482}$ & - & 75 & 31 & -132 & -2 & (b) & 467 & 1 & $\mathbf{0}$ \\
\hline 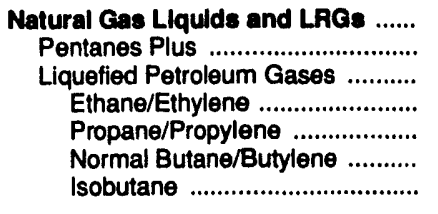 & $\begin{array}{r}131 \\
27 \\
104 \\
36 \\
42 \\
18 \\
7\end{array}$ & $\begin{array}{l}\frac{7}{7} \\
0 \\
7 \\
\text { (s) } \\
\text { (s) }\end{array}$ & $\begin{array}{l}8 \\
2 \\
5 \\
0 \\
3 \\
2 \\
1\end{array}$ & $\begin{array}{l}\bar{z} \\
\bar{z} \\
\bar{z}\end{array}$ & $\begin{array}{r}-72 \\
-11 \\
-62 \\
-28 \\
-17 \\
-10 \\
-6\end{array}$ & $\begin{array}{l}\text { (b) } \\
\text { (s) } \\
\text { (s) } \\
0 \\
\text { (s) } \\
\text { (s) } \\
\text { (s) }\end{array}$ & $\begin{array}{l}\bar{z} \\
\bar{z} \\
\bar{z}\end{array}$ & $\begin{array}{r}18 \\
6 \\
13 \\
0 \\
0 \\
9 \\
4\end{array}$ & $\begin{array}{r}\text { (g) } \\
0 \\
(\mathbf{s}) \\
0 \\
(\mathbf{s}) \\
(\mathbf{s}) \\
0\end{array}$ & $\begin{array}{r}53 \\
12 \\
41 \\
9 \\
35 \\
\text { (s) } \\
-2\end{array}$ \\
\hline 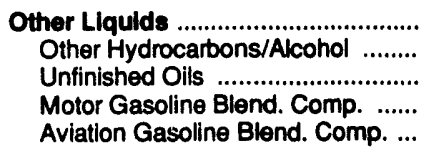 & $\begin{array}{l}1 \\
\frac{1}{2} \\
-\end{array}$ & $\begin{array}{l}\bar{I} \\
\bar{I}\end{array}$ & $\begin{array}{l}0 \\
0 \\
0 \\
0 \\
0\end{array}$ & $\begin{array}{l}\bar{z} \\
\bar{z}\end{array}$ & $\begin{array}{l}0 \\
0 \\
0 \\
0 \\
0\end{array}$ & $\begin{array}{r}-4 \\
(8) \\
(8) \\
5 \\
0\end{array}$ & $\bar{z}$ & $\begin{array}{r}4 \\
1 \\
-1 \\
5 \\
0\end{array}$ & $\begin{array}{l}0 \\
0 \\
0 \\
0 \\
0\end{array}$ & $\begin{array}{r}1 \\
0 \\
1 \\
(s) \\
0\end{array}$ \\
\hline 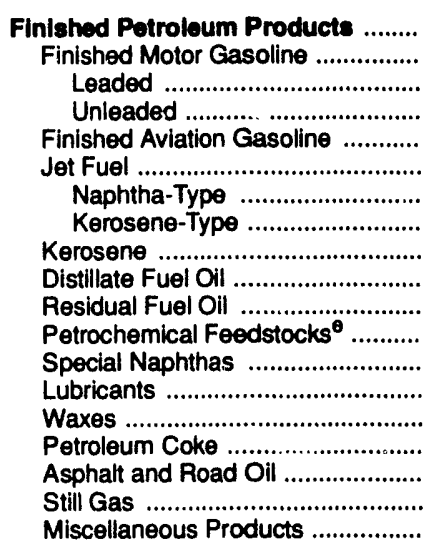 & $\begin{array}{l}\bar{z} \\
\bar{z} \\
\bar{z} \\
\bar{z} \\
\bar{z} \\
\bar{z} \\
\bar{z}\end{array}$ & $\begin{array}{r}485 \\
240 \\
44 \\
196 \\
1 \\
35 \\
11 \\
24 \\
(s) \\
131 \\
10 \\
1 \\
i s) \\
(s) \\
1 \\
11 \\
34 \\
20 \\
2\end{array}$ & $\begin{array}{r}4 \\
1 \\
\text { (s) } \\
1 \\
0 \\
0 \\
0 \\
0 \\
0 \\
3 \\
(\mathbf{s}) \\
0 \\
0 \\
0 \\
0 \\
0 \\
0 \\
0 \\
0\end{array}$ & $\begin{array}{l}= \\
\bar{z} \\
\bar{z} \\
\bar{z} \\
= \\
= \\
\bar{z} \\
=\end{array}$ & $\begin{array}{r}-16 \\
-10 \\
-11 \\
1 \\
(s) \\
9 \\
-5 \\
14 \\
0 \\
-15 \\
0 \\
0 \\
0 \\
0 \\
0 \\
0 \\
0 \\
0 \\
0\end{array}$ & $\begin{array}{r}3 \\
-5 \\
-1 \\
-4 \\
(8) \\
(s) \\
(s) \\
(8) \\
(8) \\
-2 \\
(8) \\
(8) \\
(s) \\
(s) \\
(s) \\
(s) \\
3 \\
0 \\
(8)\end{array}$ & $\begin{array}{l}\bar{z} \\
\bar{z} \\
\bar{z} \\
\bar{z} \\
\bar{z} \\
\bar{z} \\
\bar{z}\end{array}$ & $\begin{array}{l}\bar{z} \\
\bar{z} \\
\bar{z} \\
\bar{z} \\
\bar{z} \\
\bar{z} \\
\bar{z} \\
\bar{z} \\
\bar{z}\end{array}$ & $\begin{array}{r}(\mathbf{s}) \\
(\mathbf{s}) \\
(\mathbf{s}) \\
(\mathbf{s}) \\
0 \\
0 \\
0 \\
0 \\
0 \\
(\mathbf{s}) \\
(\mathbf{s}) \\
0 \\
(\mathrm{~s}) \\
(\mathrm{s}) \\
(\mathrm{s}) \\
(\mathrm{s}) \\
(\mathrm{s}) \\
0 \\
0\end{array}$ & $\begin{array}{r}475 \\
236 \\
35 \\
201 \\
1 \\
44 \\
6 \\
37 \\
(\mathbf{s}) \\
119 \\
10 \\
1 \\
(\mathbf{5}) \\
(\mathbf{5}) \\
1 \\
11 \\
30 \\
20 \\
2\end{array}$ \\
\hline Total & 614 & 491 & 87 & 31 & -221 & $\rightarrow$ & (0) & 480 & 2 & 529 \\
\hline
\end{tabular}

a Represents the PAD District in which the material entered the United States and not necessarily where the crude oil or product is processed and/or consumed.

b Unaccounted for crude oil represents the difference between the supply and disposition of crude oll.

c A negative number indicates a decrease in stocks and a positive number indicates an increase in stocks.

d Products supplied is equal to field production, plus refinery production, plus imports, plus unaccounted for crude oll, plus net receipts, minus stock change, minus crude losses, minus refinery inputs, minus exports.

- Includes naphtha less than $401^{\circ} \mathrm{F}$ endpoint and other oils equal to or greater than $401^{\circ} \mathrm{F}$ endpoint.

(s) = Less than 500 barrels per day.

$E$ = Estimated.

LRG = Liquefied Refinery Gas.

Note: Totals may not equal sum of components due to independent rounding.

Sources: • Energy Information Administration (EIA) Forms EIA-810, "Monthly Refinery Report," EIA-811, "Monthly Bulk Terminal Report," EIA-812, "Monthly Product Pipeline Report," EIA-813, "Monthly Crude Oll Report," EIA-814, "Monthly imports Report," EIA-816, "Monthly Natural Gas Liquids Report," and ElA-817, "Monthly Tanker and Barge Movement Report." - Domestic crude oll production estimates based on historical statistics from State conservation agencies and the Minerals Management Service of the U.S. Department of the Interior. - Export data from the Bureau of the Census and Form ElA-810, "Monthly Refinery Report." 
Table 22. PAD District V-Supply, Disposition, and Ending Stocks of Crude Oll and Petroleum Products, August 1991 (Thousand Barrels)

\begin{tabular}{|c|c|c|c|c|c|c|c|c|c|c|c|}
\hline \multirow[b]{2}{*}{ Commodity } & \multicolumn{5}{|c|}{ Supply } & \multicolumn{5}{|c|}{ Disposition } & \multirow[b]{2}{*}{$\begin{array}{l}\text { Endling } \\
\text { Stocks }\end{array}$} \\
\hline & $\begin{array}{c}\text { Fleld } \\
\text { Production }\end{array}$ & $\begin{array}{c}\text { Refinery } \\
\text { Production }\end{array}$ & $\begin{array}{c}\text { Imports by } \\
\text { PAD } \\
\text { District } \\
\text { of Entry }\end{array}$ & $\begin{array}{c}\text { Unac- } \\
\text { counted } \\
\text { For } \\
\text { Crude OII }\end{array}$ & $\begin{array}{c}\text { Net } \\
\text { Recelpts }\end{array}$ & $\begin{array}{c}\text { Stock } \\
\text { Changec }\end{array}$ & $\begin{array}{c}\text { Crude } \\
\text { Loseses }\end{array}$ & $\begin{array}{c}\text { Rofinery } \\
\text { Inputs }\end{array}$ & Exports & $\begin{array}{l}\text { Products } \\
\text { Supplled }\end{array}$ & \\
\hline 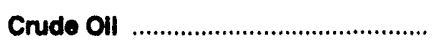 & $E_{83,841}$ & - & 7,755 & -558 & $-7,702$ & 554 & 0 & 80,714 & 1,666 & 402 & 77,116 \\
\hline 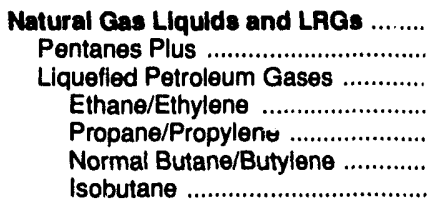 & $\begin{array}{r}2,743 \\
1,499 \\
1,244 \\
1 \\
301 \\
562 \\
380\end{array}$ & $\begin{array}{r}2,324 \\
-324 \\
0 \\
1,227 \\
995 \\
102\end{array}$ & $\begin{array}{r}22 \\
0 \\
22 \\
0 \\
1 \\
10 \\
11\end{array}$ & $\begin{array}{l}- \\
- \\
- \\
-\end{array}$ & $\begin{array}{l}0 \\
0 \\
0 \\
0 \\
0 \\
0 \\
0\end{array}$ & $\begin{array}{r}750 \\
-23 \\
773 \\
0 \\
419 \\
278 \\
76\end{array}$ & $\begin{array}{l}- \\
- \\
- \\
-\end{array}$ & $\begin{array}{r}2,398 \\
1,073 \\
1,325 \\
0 \\
0 \\
722 \\
603\end{array}$ & $\begin{array}{r}37 \\
2 \\
35 \\
0 \\
31 \\
3 \\
0\end{array}$ & $\begin{array}{r}1,804 \\
447 \\
1,457 \\
1 \\
1,079 \\
564 \\
-186\end{array}$ & $\begin{array}{r}4,182 \\
35 \\
4,147 \\
0 \\
1,418 \\
2,216 \\
513\end{array}$ \\
\hline $\begin{array}{l}\text { Other Llquids .................................. } \\
\text { Other Hydrocarbons/Alcohol ........... } \\
\text { Unfinished Oils ................................ } \\
\text { Motor Gasoline Blend. Comp. ......... } \\
\text { Aviation Gasoline Blend. Comp. ..... }\end{array}$ & $\begin{array}{r}593 \\
593 \\
- \\
-\end{array}$ & $\begin{array}{l}- \\
- \\
-\end{array}$ & $\begin{array}{r}261 \\
0 \\
261 \\
0 \\
0\end{array}$ & $\begin{array}{l}- \\
- \\
-\end{array}$ & $\begin{array}{l}0 \\
0 \\
0 \\
0 \\
0\end{array}$ & $\begin{array}{r}-891 \\
-65 \\
-1,198 \\
378 \\
-6\end{array}$ & $\begin{array}{l}- \\
- \\
-\end{array}$ & $\begin{array}{r}2,567 \\
658 \\
1,692 \\
211 \\
6\end{array}$ & $\begin{array}{l}0 \\
0 \\
0 \\
0 \\
0\end{array}$ & $\begin{array}{r}-822 \\
0 \\
-233 \\
-589 \\
0\end{array}$ & $\begin{array}{r}31,869 \\
1,529 \\
22,795 \\
7,542 \\
3\end{array}$ \\
\hline 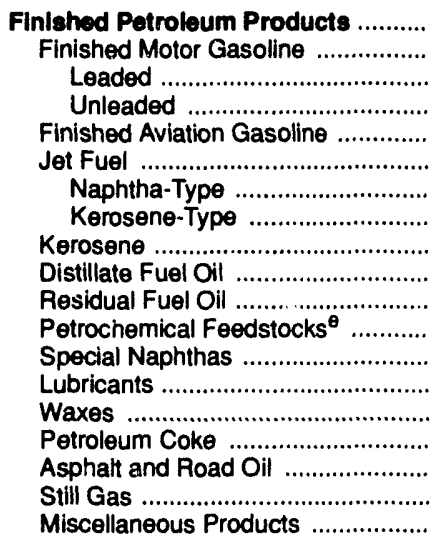 & $\begin{array}{l}- \\
- \\
z \\
z \\
z \\
z \\
z \\
z \\
- \\
- \\
-\end{array}$ & $\begin{array}{r}88,694 \\
39,411 \\
4,738 \\
34,673 \\
197 \\
13,022 \\
1,468 \\
11,554 \\
120 \\
13,060 \\
10,251 \\
380 \\
40 \\
603 \\
50 \\
4,250 \\
2,668 \\
4,494 \\
148\end{array}$ & $\begin{array}{r}2,104 \\
729 \\
0 \\
729 \\
0 \\
6 \\
0 \\
6 \\
0 \\
125 \\
1,141 \\
71 \\
6 \\
0 \\
4 \\
13 \\
9 \\
0 \\
0\end{array}$ & $\begin{array}{l}- \\
- \\
- \\
z \\
z \\
z \\
z \\
z \\
- \\
z \\
z \\
-\end{array}$ & $\begin{array}{r}2,682 \\
1,692 \\
414 \\
1,278 \\
0 \\
481 \\
219 \\
262 \\
0 \\
526 \\
0 \\
0 \\
0 \\
-17 \\
0 \\
0 \\
0 \\
0 \\
0\end{array}$ & $\begin{array}{r}-1,066 \\
-1,013 \\
-595 \\
-418 \\
-52 \\
-153 \\
-201 \\
48 \\
20 \\
-3 \\
503 \\
105 \\
-7 \\
-4 \\
-43 \\
-375 \\
-63 \\
0 \\
19\end{array}$ & $\begin{array}{l}- \\
- \\
- \\
- \\
- \\
- \\
- \\
- \\
- \\
- \\
- \\
- \\
-\end{array}$ & $\begin{array}{l}- \\
- \\
- \\
= \\
- \\
= \\
- \\
- \\
- \\
- \\
- \\
-\end{array}$ & $\begin{array}{r}9,324 \\
505 \\
1 \\
503 \\
0 \\
59 \\
0 \\
59 \\
(s) \\
1,015 \\
4,133 \\
0 \\
3 \\
93 \\
31 \\
3,452 \\
33 \\
0 \\
(s)\end{array}$ & $\begin{array}{r}85,222 \\
42,340 \\
5,746 \\
36,595 \\
249 \\
13,603 \\
1,888 \\
11,715 \\
100 \\
12,699 \\
6,756 \\
346 \\
50 \\
497 \\
66 \\
1,186 \\
2,707 \\
4,494 \\
129\end{array}$ & $\begin{array}{r}54,270 \\
21,014 \\
4,043 \\
16,971 \\
407 \\
7,803 \\
1,551 \\
6,252 \\
54 \\
9,977 \\
8,001 \\
282 \\
48 \\
1,908 \\
138 \\
2,088 \\
2,414 \\
0 \\
136\end{array}$ \\
\hline 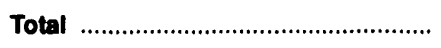 & 87,177 & 91,018 & 10,142 & -558 & $-5,020$ & -653 & $\mathbf{0}$ & 85,679 & 11,027 & 86,706 & 167,437 \\
\hline
\end{tabular}

a Represents the PAD District in which the material entered the United States and not necessarily where the crude oil or product is processed and/or consumed.

b Unaccounted for crude oil represents the difference between the supply and disposition of crude oil.

c A negative number indicates a decrease in stocks and a positive number indicates an increase in stocks.

d Products supplied is equal to field production, plus refinery production, plus imports, plus unaccounted for crude oil, plus net receipts, minus stock change, minus crude losses, minus refinery inputs, minus exports.

Includes naphtha less than $401^{\circ} \mathrm{F}$ endpoint and other oils equal to or greater than $401^{\circ} \mathrm{F}$ endpoint.

(s) $=$ Less than 500 barrels.

$E=$ Estimated.

LRG = Liquefied Refinery Gas.

Note: Totals may not equal sum of components due to independent rounding.

Sources: - Energy Information Administration (EIA) Forms EIA-810, "Monthly Refinery Report," EIA-811, "Monthly Bulk Terminal Report," EIA-812, "Monthly Product Pipeline Report," EIA-813, "Monthly Crude Oil Report," EIA-814, "Monthly Imports Report," ElA-816, "Monthly Natural Gas Liquids Report," and EIA-817, "Monthly Tanker and Barge Movement Report." - Domestic crude oil production estimates based on historical statistics from State conservation agencies and the Minerals Management Service of the U.S. Department of the Interior. - Export data from the Bureau of the Census and Form ElA-810, "Monthly Refinery Report." 
Table 23. PAD District V-Year-to-Date Supply, Disposition, and Ending Stocks of Crude Oll and Petroleum Products, January-August 1991 (Thousand Barrels)

\begin{tabular}{|c|c|c|c|c|c|c|c|c|c|c|c|}
\hline \multirow[b]{2}{*}{ Commodity } & \multicolumn{5}{|c|}{ Supply } & \multicolumn{5}{|c|}{ Disposition } & \multirow[b]{2}{*}{$\begin{array}{l}\text { Ending } \\
\text { Stocks }\end{array}$} \\
\hline & $\begin{array}{c}\text { Field } \\
\text { Production }\end{array}$ & $\begin{array}{c}\text { Refinery } \\
\text { Production }\end{array}$ & $\begin{array}{c}\text { Imports by } \\
\text { PAD } \\
\text { District } \\
\text { of Entry }\end{array}$ & $\begin{array}{c}\text { Unac- } \\
\text { counted } \\
\text { For } \\
\text { Crude oll }\end{array}$ & $\begin{array}{c}\text { Net } \\
\text { Recelpts }\end{array}$ & $\begin{array}{c}\text { Stock } \\
\text { Change }\end{array}$ & $\begin{array}{l}\text { Crude } \\
\text { Losses }\end{array}$ & $\begin{array}{c}\text { Reflnery } \\
\text { Inputs }\end{array}$ & Exports & $\begin{array}{l}\text { Products } \\
\text { Supplied }^{d}\end{array}$ & \\
\hline 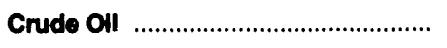 & $E_{673,708}$ & 一 & 47,130 & 3,861 & $-66,068$ & 404 & $\mathbf{5}$ & 626,284 & 27,764 & 4,174 & 77,116 \\
\hline 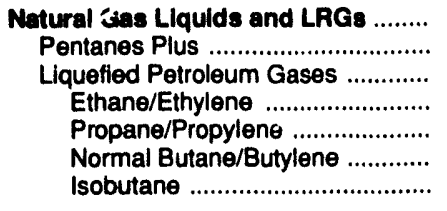 & $\begin{array}{r}22,158 \\
12,353 \\
9,805 \\
16 \\
2,451 \\
5,191 \\
2,147\end{array}$ & $\begin{array}{r}16,702 \\
16,702 \\
101 \\
9,709 \\
6,468 \\
424\end{array}$ & $\begin{array}{r}615 \\
0 \\
615 \\
0 \\
343 \\
73 \\
199\end{array}$ & $\begin{array}{l}- \\
- \\
- \\
-\end{array}$ & $\begin{array}{l}0 \\
0 \\
0 \\
0 \\
0 \\
0 \\
0\end{array}$ & $\begin{array}{r}1,339 \\
-9 \\
1,348 \\
0 \\
592 \\
496 \\
260\end{array}$ & $\begin{array}{l}- \\
- \\
- \\
-\end{array}$ & $\begin{array}{r}18,832 \\
9,093 \\
9,739 \\
0 \\
9 \\
5,844 \\
3,886\end{array}$ & $\begin{array}{r}2,364 \\
16 \\
2,348 \\
0 \\
1,917 \\
431 \\
0\end{array}$ & $\begin{array}{r}16,940 \\
3,253 \\
13,687 \\
117 \\
9,985 \\
4,961 \\
-1,376\end{array}$ & $\begin{array}{r}4,182 \\
35 \\
4,147 \\
0 \\
1,418 \\
2,216 \\
513\end{array}$ \\
\hline $\begin{array}{l}\text { Other Llquids ................................ } \\
\text { Other Hydrocarbons/Alcohol .......... } \\
\text { Unfinished Oils ................................ } \\
\text { Motor Gasoline Blend. Comp. ......... } \\
\text { Aviation Gasoline Blend. Comp. ..... }\end{array}$ & $\begin{array}{r}5,238 \\
5,238 \\
- \\
-\end{array}$ & $\begin{array}{l}- \\
- \\
-\end{array}$ & $\begin{array}{r}2,372 \\
308 \\
1,953 \\
111 \\
0\end{array}$ & $\begin{array}{l}- \\
- \\
-\end{array}$ & $\begin{array}{r}309 \\
0 \\
309 \\
0 \\
0\end{array}$ & $\begin{array}{r}549 \\
1,341 \\
-1,734 \\
-157 \\
1\end{array}$ & $\begin{array}{l}- \\
- \\
-\end{array}$ & $\begin{array}{r}12,293 \\
4,205 \\
7,783 \\
306 \\
-1\end{array}$ & $\begin{array}{l}0 \\
0 \\
0 \\
0 \\
0\end{array}$ & $\begin{array}{r}-3,825 \\
0 \\
-3,787 \\
-38 \\
0\end{array}$ & $\begin{array}{r}31,869 \\
1,529 \\
22,795 \\
7,542 \\
3\end{array}$ \\
\hline 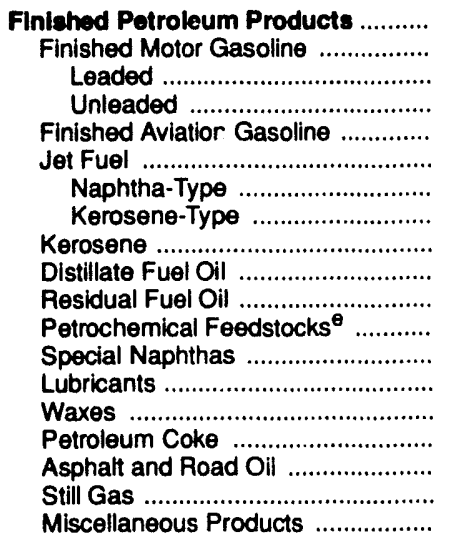 & $\begin{array}{l}- \\
\bar{z} \\
\bar{z} \\
\bar{z} \\
\bar{z} \\
\overline{-} \\
\overline{-} \\
\overline{-} \\
-\end{array}$ & $\begin{array}{r}678,339 \\
300,287 \\
38,060 \\
262,227 \\
1,456 \\
97,868 \\
9,582 \\
88,286 \\
772 \\
102,143 \\
83,886 \\
2,896 \\
2885 \\
5,017 \\
444 \\
33,515 \\
13,728 \\
34,690 \\
1,352\end{array}$ & $\begin{array}{r}8,941 \\
2,463 \\
0 \\
2,463 \\
33 \\
903 \\
18 \\
885 \\
0 \\
699 \\
4,064 \\
234 \\
57 \\
0 \\
15 \\
320 \\
153 \\
0 \\
0\end{array}$ & 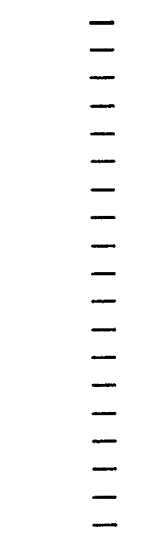 & $\begin{array}{r}24,285 \\
14,764 \\
3,276 \\
11,488 \\
30 \\
4,434 \\
2,157 \\
2,277 \\
0 \\
5,176 \\
0 \\
0 \\
0 \\
-119 \\
0 \\
0 \\
0 \\
0 \\
0\end{array}$ & $\begin{array}{r}-5,070 \\
-2,754 \\
-1,342 \\
-1,412 \\
55 \\
-1,048 \\
-483 \\
-565 \\
-26 \\
-2,510 \\
875 \\
-36 \\
-60 \\
172 \\
-37 \\
50 \\
235 \\
0 \\
14\end{array}$ & $\begin{array}{l}- \\
- \\
- \\
- \\
- \\
- \\
- \\
- \\
- \\
- \\
- \\
-\end{array}$ & $\begin{array}{l}- \\
- \\
- \\
- \\
- \\
- \\
- \\
- \\
- \\
- \\
- \\
- \\
-\end{array}$ & $\begin{array}{r}83,598 \\
7,523 \\
44 \\
7,479 \\
0 \\
3,939 \\
111 \\
3,829 \\
4 \\
12,516 \\
33,243 \\
0 \\
817 \\
715 \\
148 \\
24,502 \\
190 \\
0 \\
1\end{array}$ & $\begin{array}{r}633,037 \\
312,745 \\
42,634 \\
270,111 \\
1,464 \\
100,314 \\
12,129 \\
88,184 \\
794 \\
98,012 \\
53,832 \\
3,166 \\
-415 \\
4,011 \\
348 \\
9,283 \\
13,456 \\
34,690 \\
1,337\end{array}$ & $\begin{array}{r}54,270 \\
21,014 \\
4,043 \\
16,971 \\
407 \\
7,803 \\
1,551 \\
6,252 \\
54 \\
9,977 \\
8,001 \\
282 \\
48 \\
1,908 \\
138 \\
2,088 \\
2,414 \\
0 \\
136\end{array}$ \\
\hline , & 701,104 & 695,041 & 59,058 & 3,861 & $-41,474$ & $-3,876$ & 5 & 657,409 & 113,725 & 650,327 & 167,437 \\
\hline
\end{tabular}

a Represents the PAD District in which the material entered the United States and not necessarily where the crude oil or product is processed and/or consumed.

b Unaccounted for crude oil represents the difference between the supply and disposition of crude oil.

c A negative number indicates a decrease in stocks and a positive number indicates an increase in stocks.

d Products supplied is equal to field production, plus refinery production, plus imports, plus unaccounted for crude oil, plus net receipts, minus stock change, minus crude losses, minus refinery inputs, minus exports.

$\theta$ Includes naphtha less than $401^{\circ} \mathrm{F}$ endpoint and other oils equal to or greater than $401^{\circ} \mathrm{F}$ endpoint.

(s) = Less than 500 barrels.

E = Estimated.

LRG = Liquefied Refinery Gas.

Note: Totals may not equal sum of components due to independent rounding.

Sources: - Energy Information Administration (EIA) Forms EIA-810, "Monthly Refinery Report, EIA-811, "Monthly Bulk Terminal Report," EIA-812, "Monthly Product Pipeline Report," EIA-813, "Monthly Crude Oil Report," EIA-814, "Monthly Imports Report," EIA-816, "Monthly Natural Gas Liquids Report," and EIA-817, "Monthly Tanker and Barge Movement Report." - Domestic rrude oil production estimates based on historical statistics from State conservation agencies and the Minerals Management Service of the U.S. Department of the Interior. - Export data from the Bureau of the Census and Form ElA-810, "Monthly Refinery Report." 
Table 24. PAD District V - Dally Average Supply and Disposition of Crude Oll and Petroleum Products, August 1991

(Thousand Barrels per Day)

\begin{tabular}{|c|c|c|c|c|c|c|c|c|c|c|}
\hline \multirow[b]{2}{*}{ Commodity } & \multicolumn{5}{|c|}{ Supply } & \multicolumn{5}{|c|}{ Disposition } \\
\hline & $\begin{array}{c}\text { Fleld } \\
\text { Production }\end{array}$ & $\begin{array}{c}\text { Refinery } \\
\text { Production }\end{array}$ & $\begin{array}{c}\text { Imports by } \\
\text { PAD } \\
\text { District } \\
\text { of Entry }\end{array}$ & $\begin{array}{c}\text { Unac- } \\
\text { counted } \\
\text { For } \\
\text { Crude Oil }\end{array}$ & $\begin{array}{c}\text { Not } \\
\text { Recelpts }\end{array}$ & $\begin{array}{c}\text { Stock } \\
\text { Change }^{c}\end{array}$ & $\begin{array}{c}\text { Crude } \\
\text { Losses }\end{array}$ & $\begin{array}{c}\text { Refinery } \\
\text { Inputs }\end{array}$ & Exports & $\begin{array}{l}\text { Products } \\
\text { Suppllod }\end{array}$ \\
\hline Crude Oll . & $E_{2,705}$ & - & 250 & -18 & -248 & 18 & 0 & 2,604 & 54 & 13 \\
\hline 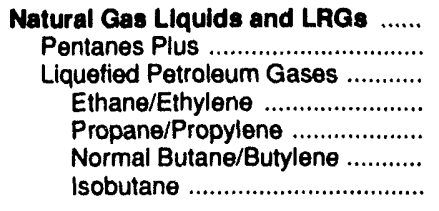 & $\begin{array}{l}88 \\
48 \\
40 \\
\text { (s) } \\
10 \\
18 \\
12\end{array}$ & $\begin{array}{r}75 \\
75 \\
0 \\
40 \\
32 \\
3\end{array}$ & $\begin{array}{r}1 \\
0 \\
1 \\
0 \\
(\mathbf{s}) \\
\text { (s) } \\
\text { (s) }\end{array}$ & $\begin{array}{l}\bar{z} \\
\bar{z} \\
\bar{z}\end{array}$ & $\begin{array}{l}0 \\
0 \\
0 \\
0 \\
0 \\
0 \\
0\end{array}$ & $\begin{array}{r}24 \\
-1 \\
25 \\
0 \\
14 \\
9 \\
2\end{array}$ & $\begin{array}{l}\bar{z} \\
\bar{z} \\
\bar{z}\end{array}$ & $\begin{array}{r}77 \\
35 \\
43 \\
0 \\
0 \\
23 \\
19\end{array}$ & $\begin{array}{r}1 \\
(s) \\
1 \\
0 \\
1 \\
(s) \\
0\end{array}$ & $\begin{array}{l}6 i \\
14 \\
47 \\
(s) \\
35 \\
18 \\
-6\end{array}$ \\
\hline 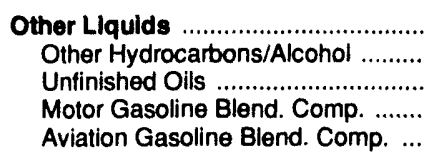 & $\begin{array}{l}19 \\
19 \\
= \\
-\end{array}$ & $\begin{array}{l}\bar{z} \\
\bar{z}\end{array}$ & $\begin{array}{l}8 \\
0 \\
8 \\
0 \\
0\end{array}$ & $\begin{array}{l}\bar{z} \\
\bar{z}\end{array}$ & $\begin{array}{l}0 \\
0 \\
0 \\
0 \\
0\end{array}$ & $\begin{array}{r}-29 \\
-2 \\
-39 \\
12 \\
(s)\end{array}$ & $\begin{array}{l}\bar{z} \\
\bar{z}\end{array}$ & $\begin{array}{r}83 \\
21 \\
55 \\
7 \\
(s)\end{array}$ & $\begin{array}{l}0 \\
0 \\
0 \\
0 \\
0\end{array}$ & $\begin{array}{r}-27 \\
0 \\
-8 \\
-19 \\
0\end{array}$ \\
\hline 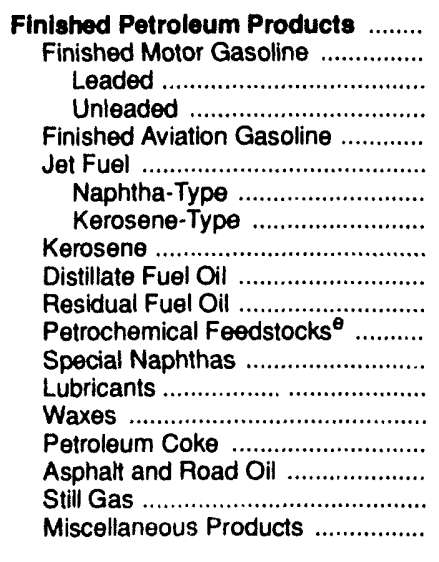 & $\begin{array}{l}= \\
\bar{z} \\
= \\
\bar{z} \\
\bar{z} \\
\bar{z} \\
\bar{z} \\
\bar{z}\end{array}$ & $\begin{array}{r}2,861 \\
1,271 \\
153 \\
1,118 \\
6 \\
420 \\
47 \\
373 \\
4 \\
421 \\
331 \\
12 \\
1 \\
19 \\
2 \\
137 \\
86 \\
145 \\
5\end{array}$ & $\begin{array}{r}68 \\
24 \\
0 \\
24 \\
0 \\
(\mathbf{s}) \\
0 \\
\text { (s) } \\
0 \\
4 \\
37 \\
2 \\
(\mathbf{s}) \\
0 \\
(\mathbf{s}) \\
(\mathrm{s}) \\
(\mathrm{s}) \\
0 \\
0\end{array}$ & $\begin{array}{l}\bar{z} \\
= \\
\bar{z} \\
\bar{z} \\
= \\
\bar{z} \\
= \\
= \\
=\end{array}$ & $\begin{array}{r}87 \\
55 \\
13 \\
41 \\
0 \\
16 \\
7 \\
8 \\
0 \\
0 \\
17 \\
0 \\
0 \\
0 \\
-1 \\
0 \\
0 \\
0 \\
0 \\
0\end{array}$ & $\begin{array}{r}34 \\
33 \\
-19 \\
-13 \\
-2 \\
-5 \\
-6 \\
2 \\
1 \\
(s) \\
16 \\
3 \\
(s) \\
(s) \\
-1 \\
-12 \\
-2 \\
0 \\
1\end{array}$ & $\begin{array}{l}\bar{z} \\
\bar{z} \\
\bar{z} \\
\bar{z} \\
\bar{z} \\
\bar{z} \\
= \\
\bar{z} \\
\bar{z} \\
=\end{array}$ & $\begin{array}{l}= \\
= \\
= \\
= \\
= \\
= \\
= \\
= \\
= \\
= \\
=\end{array}$ & $\begin{array}{r}301 \\
16 \\
(\mathbf{s}) \\
16 \\
0 \\
2 \\
0 \\
2 \\
(\mathbf{s}) \\
33 \\
133 \\
0 \\
(\mathbf{s}) \\
3 \\
1 \\
111 \\
1 \\
0 \\
(\mathrm{~s})\end{array}$ & $\begin{array}{r}2,749 \\
1,366 \\
185 \\
1,180 \\
8 \\
439 \\
61 \\
378 \\
3 \\
410 \\
218 \\
11 \\
2 \\
16 \\
2 \\
38 \\
87 \\
145 \\
4\end{array}$ \\
\hline Total & 2,812 & 2,936 & 327 & -18 & -162 & -21 & 0 & 2,764 & 356 & 2,797 \\
\hline
\end{tabular}

a Represents the PAD District in which the material entered the United States and not necessarily where the crude oil or product is processed and/or consumed.

b Unaccounted for crude oil represents the difference between the supply and disposition of crude oil.

c A negative number indicates a decrease in stocks and a positive number indicates an increase in stocks.

d Products supplied is equal to field production, plus refinery production, plus imports, plus unaccounted for crude oil, plus net receipts, minus stock change, minus crude losses, minus refinery inputs, minus exports.

$\theta$ Includes naphtha less than $401^{\circ} \mathrm{F}$ endpoint and other oils equal to or greater than $401^{\circ} \mathrm{F}$ endpoint.

(s) = Less than 500 barrels per day.

$E=$ Estimated.

LRG = Liquefied Refinery Gas.

Note: Totals may not equal sum of components due to independent rounding.

Sources: - Energy Information Administration (EIA) Forms EIA-810, "Monthly Refinery Report, "EIA-811, "Monthly Bulk Terminal Report," EIA-812, "Monthly Product Pipeline Report," EIA-813, "Monthly Crude Oil Report," EIA-814, "Monthiy Imports Report," EIA-816, "Monthly Natural Gas Liquids Report," and EIA-817, "Monthly Tanker and Barge Movement Report." - Domestic crude oil production estimates based on historical statistics from State conservation agencies and the Minerals Management Service of the U.S. Department of the Interior. • Export data from the Bureau of the Census and Form EIA-810, "Monthly Refinery Report." 
Table 25. PAD District V - Year-to-Date Daily Average Supply and Disposition of Crude Oil and Petroleum Products, January-August 1991

(Thousand Barrels per Day)

\begin{tabular}{|c|c|c|c|c|c|c|c|c|c|c|}
\hline \multirow[b]{2}{*}{ Commodity } & \multicolumn{5}{|c|}{ Supply } & \multicolumn{5}{|c|}{ Disposition } \\
\hline & $\begin{array}{c}\text { Field } \\
\text { Production }\end{array}$ & $\begin{array}{c}\text { Refinery } \\
\text { Production }\end{array}$ & $\begin{array}{c}\text { Imports by } \\
\text { PAD } \\
\text { District } \\
\text { of Entry }\end{array}$ & $\begin{array}{c}\text { Unac- } \\
\text { counted } \\
\text { For } \\
\text { Crude OIt } \\
\end{array}$ & $\begin{array}{c}\text { Net } \\
\text { Recelpts }\end{array}$ & $\begin{array}{c}\text { Stock } \\
\text { Change }\end{array}$ & $\begin{array}{c}\text { Crude } \\
\text { Losses }\end{array}$ & $\begin{array}{c}\text { Refinery } \\
\text { Inputs }\end{array}$ & Exports & $\begin{array}{l}\text { Products } \\
\text { Supplied }^{d}\end{array}$ \\
\hline 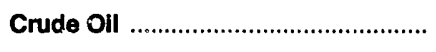 & $\mathrm{E}_{2,772}$ & - & 194 & 16 & -272 & 2 & (s) & 2,577 & 114 & 17 \\
\hline 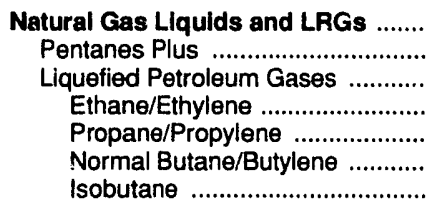 & $\begin{array}{r}91 \\
51 \\
40 \\
(s) \\
10 \\
21 \\
9\end{array}$ & $\begin{array}{r}69 \\
69 \\
(s) \\
40 \\
27 \\
2\end{array}$ & $\begin{array}{r}3 \\
0 \\
3 \\
0 \\
1 \\
\text { (s) } \\
1\end{array}$ & $\begin{array}{l}- \\
- \\
- \\
-\end{array}$ & $\begin{array}{l}0 \\
0 \\
0 \\
0 \\
0 \\
0 \\
0\end{array}$ & $\begin{array}{r}6 \\
(s) \\
6 \\
0 \\
2 \\
2 \\
1\end{array}$ & $\begin{array}{l}- \\
- \\
- \\
-\end{array}$ & $\begin{array}{r}77 \\
37 \\
40 \\
0 \\
(s) \\
24 \\
16\end{array}$ & $\begin{array}{r}10 \\
\text { (s) } \\
10 \\
0 \\
8 \\
2 \\
0\end{array}$ & $\begin{array}{l}70 \\
13 \\
56 \\
(s) \\
41 \\
20 \\
-6\end{array}$ \\
\hline $\begin{array}{l}\text { Other Liquids .............................. } \\
\text { Other Hydrocarbons/Alcohol ......... } \\
\text { Unfinished Oils ............................. } \\
\text { Motor Gasoline Blend. Comp. ....... } \\
\text { Aviation Gasoline Blend. Comp. ..... }\end{array}$ & $\begin{array}{l}22 \\
22 \\
- \\
-\end{array}$ & $\begin{array}{l}- \\
- \\
-\end{array}$ & $\begin{array}{r}10 \\
1 \\
8 \\
(s) \\
0\end{array}$ & $\begin{array}{l}- \\
- \\
-\end{array}$ & $\begin{array}{l}1 \\
0 \\
1 \\
0 \\
0\end{array}$ & $\begin{array}{r}-2 \\
6 \\
-7 \\
-1 \\
\text { (s) }\end{array}$ & $\begin{array}{l}- \\
- \\
-\end{array}$ & $\begin{array}{r}51 \\
17 \\
32 \\
1 \\
\text { (s) }\end{array}$ & $\begin{array}{l}0 \\
0 \\
0 \\
0 \\
0\end{array}$ & $\begin{array}{r}-16 \\
0 \\
-16 \\
(s) \\
0\end{array}$ \\
\hline 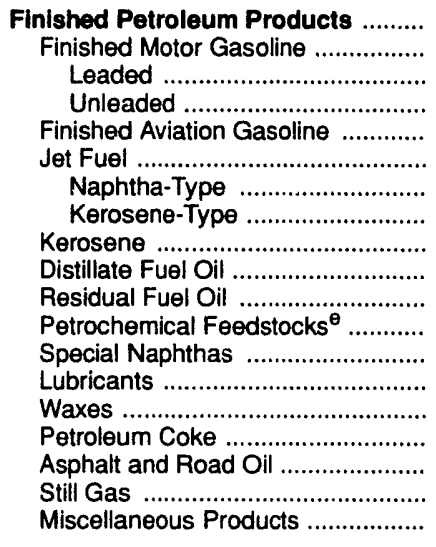 & $\begin{array}{l}- \\
- \\
= \\
z \\
z \\
z \\
z \\
- \\
- \\
- \\
-\end{array}$ & $\begin{array}{r}2,792 \\
1,236 \\
157 \\
1,079 \\
6 \\
403 \\
39 \\
363 \\
3 \\
420 \\
345 \\
12 \\
1 \\
21 \\
2 \\
138 \\
56 \\
143 \\
6\end{array}$ & $\begin{array}{r}37 \\
10 \\
0 \\
10 \\
(s) \\
4 \\
(s) \\
4 \\
0 \\
3 \\
17 \\
1 \\
(s) \\
0 \\
(s) \\
1 \\
1 \\
0 \\
0\end{array}$ & $\begin{array}{l}- \\
- \\
- \\
- \\
- \\
- \\
- \\
- \\
- \\
- \\
- \\
- \\
- \\
-\end{array}$ & $\begin{array}{r}100 \\
61 \\
13 \\
47 \\
(s) \\
18 \\
9 \\
9 \\
0 \\
21 \\
0 \\
0 \\
0 \\
(s) \\
0 \\
0 \\
0 \\
0 \\
0\end{array}$ & $\begin{array}{r}-21 \\
-11 \\
-6 \\
-6 \\
(s) \\
-4 \\
-2 \\
-2 \\
(\mathrm{~s}) \\
-10 \\
4 \\
(\mathrm{~s}) \\
(\mathrm{s}) \\
1 \\
(\mathrm{~s}) \\
(\mathrm{s}) \\
1 \\
0 \\
\text { (s) }\end{array}$ & $\begin{array}{l}- \\
- \\
- \\
- \\
- \\
- \\
- \\
- \\
- \\
- \\
- \\
- \\
- \\
-\end{array}$ & $\begin{array}{l}- \\
- \\
- \\
- \\
- \\
- \\
- \\
- \\
- \\
- \\
- \\
- \\
-\end{array}$ & $\begin{array}{r}344 \\
31 \\
(s) \\
31 \\
0 \\
16 \\
(s) \\
16 \\
(s) \\
52 \\
137 \\
0 \\
3 \\
3 \\
1 \\
101 \\
1 \\
0 \\
(s)\end{array}$ & $\begin{array}{r}2,605 \\
1,287 \\
175 \\
1,112 \\
6 \\
413 \\
50 \\
363 \\
3 \\
403 \\
222 \\
13 \\
-2 \\
17 \\
1 \\
38 \\
55 \\
143 \\
6\end{array}$ \\
\hline Total & 2,885 & 2,860 & 243 & 16 & -171 & -16 & (s) & 2,705 & 468 & 2,676 \\
\hline
\end{tabular}

a Represents the PAD District in which the material entered the United States and no: necessarily where the crude oil or product is processed and/or consumed.

b Unaccounted for crude oil represents the difference between the supply and disposition of crude oil.

c A negative number indicates a ditcrease in stocks and a positive number indicates an increase in stocks.

d Products supplied is equal to field production, plus refinery production, plus imports, plus unaccounted for crude oil, plus net receipts, minus stock change, minus crude losses, minus refinery inputs, minus exports.

$\theta$ Includes naphtha less than $401^{\circ} \mathrm{F}$ endpoint and other oils equal to or greater than $401^{\circ} \mathrm{F}$ endpoint.

(s) = Less than 500 barrels per day.

$E=$ Estimated.

LRG = Liquefied Refinery Gas.

Note: Totals may not equal sum of components due to independent rounding.

Sources: - Energy Information Administration (EIA) Forms EIA-810, "Monthly Refinery Report," EIA-811, "Monthly Bulk Terminal Report," EIA-812, "Monthly Product Pipeline Report," EIA-813, "Monthly Crude Oil Report," EIA-814, "Monthly imports Report," EIA-816, "Monthly Natural Gas Liquids Report," and EIA-817, "Monthly Tanker and Barge Movement Report." - Domestic crude oil production estimates based on historical statistics from State conservation agencies and the Minerals Management Service of the U.S. Department of the Interior. - Export data from the Bureau of the Census and Form ElA-810, "Monthly Refinery Report." 
Table 26. Production of Crude Oll by PAD District and State (Thousand Barrels)

\begin{tabular}{|c|c|c|c|c|}
\hline \multirow[b]{2}{*}{ PAD District and State } & \multicolumn{2}{|c|}{ June 1991} & \multicolumn{2}{|c|}{ January-June 1997} \\
\hline & Total & $\begin{array}{c}\text { Daily } \\
\text { Average }\end{array}$ & Total & $\begin{array}{c}\text { Dally } \\
\text { Average }\end{array}$ \\
\hline 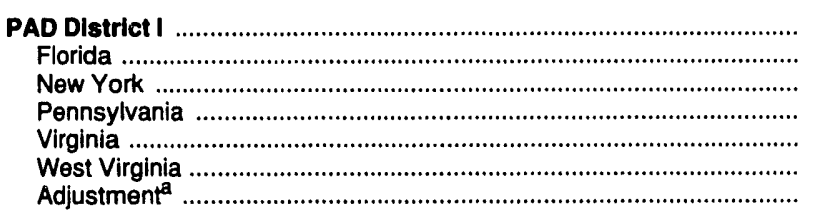 & $\begin{array}{r}E_{630} \\
192 \\
E_{35} \\
E_{204} \\
1 \\
153 \\
45\end{array}$ & $\begin{array}{r}E_{21} \\
6 \\
E_{1} \\
(s) \\
5 \\
1\end{array}$ & $\begin{array}{r}E_{4,614} \\
2,134 \\
E_{1,208} \\
E_{1} \\
995 \\
-26\end{array}$ & $\begin{array}{r}E_{25} \\
12 \\
E_{1} \\
E_{7} \\
(s) \\
5 \\
(s)\end{array}$ \\
\hline $\begin{array}{l}\text { PAD District II } \\
\text { Illinois } \\
\text { Kansana } \\
\text { Kentucky } \\
\text { Michigan } \\
\text { Missouri } \\
\text { Nebraska } \\
\text { Ohio Dakota } \\
\text { Southoma Dakota } \\
\text { Tennesse日 } \\
\text { Adjustment }{ }^{a}\end{array}$ & $\begin{array}{r}E_{21,420} \\
1,480 \\
246 \\
4,603 \\
443 \\
E_{1,491} \\
11 \\
477 \\
2,998 \\
E^{\prime} \\
8,735 \\
135 \\
40 \\
29\end{array}$ & $\begin{array}{r}E_{714} \\
49 \\
8 \\
153 \\
15 \\
E_{50} \\
(s) \\
16 \\
100 \\
E_{25} \\
291 \\
5 \\
1 \\
1\end{array}$ & $\begin{array}{r}E_{133,166} \\
9,375 \\
1,502 \\
28,610 \\
2,652 \\
E_{9,457} \\
70 \\
2,876 \\
18,280 \\
E_{4,596} \\
E_{54,533} \\
829 \\
234 \\
151\end{array}$ & $\begin{array}{r}E_{736} \\
52 \\
8 \\
158 \\
15 \\
E_{52} \\
(s) \\
16 \\
101 \\
E_{25} \\
E_{301} \\
5 \\
1 \\
1\end{array}$ \\
\hline $\begin{array}{l}\text { PAD District III } \\
\text { Alabama } \\
\text { Arkansas }{ }_{1} \\
\text { Louisiana } \\
\text { Mississippi } \\
\text { New Mexico } \\
\text { Texas }{ }^{b} \\
\text { Federal Offshore PAD District III } \\
\text { Adjustment }\end{array}$ & $\begin{array}{r}100,119 \\
1,504 \\
E_{804}^{\prime} \\
E_{11,877} \\
2,222 \\
5,607 \\
54,976 \\
23,307 \\
-178\end{array}$ & $\begin{array}{r}E_{3,337} \\
50 \\
E_{27} \\
E_{396} \\
74 \\
187 \\
1,833 \\
777 \\
-6\end{array}$ & $\begin{array}{r}E_{613,864} \\
9,213 \\
E_{5,100} \\
E_{73,133} \\
13,167 \\
34,589 \\
339,313 \\
136,054 \\
3,295\end{array}$ & $\begin{array}{r}E_{3,392} \\
51 \\
E_{28} \\
E_{404} \\
73 \\
191 \\
1,875 \\
752 \\
18\end{array}$ \\
\hline $\begin{array}{l}\text { PAD District IV } \\
\text { Colorado } \\
\text { Montana } \\
\text { Utah } \\
\text { Wyoming } \\
\text { Adjustment }\end{array}$ & $\begin{array}{r}\mathbf{1 4 , 5 2 0} \\
2,584 \\
1,589 \\
2,015 \\
8,046 \\
287\end{array}$ & $\begin{array}{r}\text { E } 484 \\
86 \\
53 \\
67 \\
268 \\
10\end{array}$ & $\begin{array}{r}E_{87,669} \\
15,130 \\
9,805 \\
12,822 \\
49,696 \\
217\end{array}$ & $\begin{array}{r}E_{484} \\
84 \\
54 \\
71 \\
275 \\
i\end{array}$ \\
\hline $\begin{array}{l}\text { PAD District V } \\
\text { Alaskab } \\
\text { South Alaska } \\
\text { North Slope } \\
\text { Adjustment for Alaskaa } \\
\text { Arizona } \\
\text { Californiab } \\
\text { Fevada } \\
\text { Federal Otjustment excluding Alaska }{ }^{a}\end{array}$ & $\begin{array}{r}E_{81,774} \\
52,701 \\
1,275 \\
51,425 \\
1 \\
10 \\
26,338 \\
277 \\
2,277 \\
171\end{array}$ & $\begin{array}{r}E_{2,726} \\
E_{1,757} \\
43 \\
1,714 \\
(s) \\
(s) \\
878 \\
9 \\
76 \\
6\end{array}$ & $\begin{array}{r}E_{504,822} \\
E_{330,713} \\
7,666 \\
323,044 \\
3 \\
58 \\
158,820 \\
1,898 \\
12,952 \\
381\end{array}$ & $\begin{array}{r}E_{2,789} \\
E_{1,827} \\
42 \\
1,785 \\
(s) \\
(s) \\
877 \\
10 \\
72 \\
2\end{array}$ \\
\hline U.S. Total ${ }^{b}$ & $E_{218,463}$ & $E_{7,282}$ & $E_{1,344,135}$ & $E_{7,426}$ \\
\hline
\end{tabular}

a These adjustments are used to reconcile the national and PAD District level sums of the State data with the independently estimated U.S. and Alaskan figures shown in the Summarv Statistics portion of this issue and with the PAD Dis rict level figures published in a previous issue. Revised data at the State, PAD District, and national levels will be published without adjustments in the Petroleum Supply Annual.

$\mathrm{b}$ Includes the following current month offshore production (thousand barrels): Alaska: State - 4,417; California: State - 1,898; Louisiana: State -

E1,994; Texas: State-165; U.S. Total, including Fedoral offshore - E34,059.

(s) = Less than 500 barrels or less than 500 barrels per day.

$\mathrm{E}=$ Estimated.

Noie: Totals may not equal sum of components due to independent rounding.

Sources: State government agencies, U.S. Department of the Interior, Minerals Management Service and the Conservation Committee of California Oil Producers. 
Table 27. Natural Gas Plant Net Production and Stocks of Petroleum Products by PAD and Refining Districts, August 1991

(Thousand Barrels)

\begin{tabular}{|c|c|c|c|c|c|c|c|c|c|}
\hline \multirow{2}{*}{ Commodity } & \multicolumn{4}{|c|}{ PAD District I } & \multicolumn{5}{|c|}{ PAD District II } \\
\hline & $\begin{array}{c}\text { East } \\
\text { Coast }\end{array}$ & \multicolumn{2}{|c|}{$\begin{array}{l}\text { Appalachlan } \\
\text { No. } 1\end{array}$} & Total & Ind., III., Ky. & \multicolumn{2}{|c|}{$\begin{array}{l}\text { Minn.,W/s., } \\
\text { N. Dak., S. Dak. }\end{array}$} & $\begin{array}{c}\text { Okla., Kans., } \\
\text { Mo. }\end{array}$ & Total \\
\hline \multirow{3}{*}{ 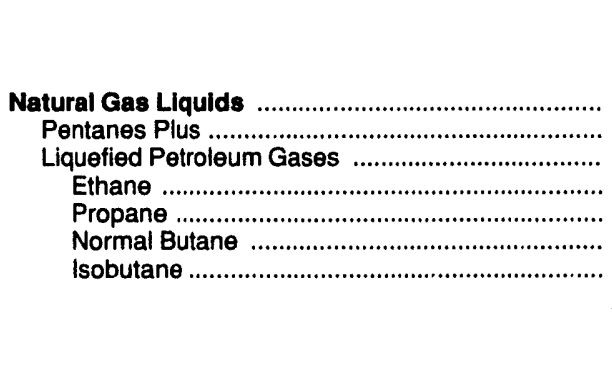 } & \multicolumn{9}{|c|}{ Net Production } \\
\hline & $\begin{array}{r}87 \\
22 \\
65 \\
21 \\
22 \\
17 \\
5\end{array}$ & & & $\begin{array}{r}728 \\
98 \\
630 \\
208 \\
285 \\
98 \\
39\end{array}$ & $\begin{array}{r}622 \\
144 \\
478 \\
68 \\
219 \\
106 \\
85\end{array}$ & & $\begin{array}{r}436 \\
111 \\
325 \\
1 \\
192 \\
128 \\
4\end{array}$ & $\begin{array}{r}8,190 \\
1,219 \\
6,971 \\
2,694 \\
2,833 \\
840 \\
604\end{array}$ & $\begin{array}{r}9,248 \\
1,474 \\
7,774 \\
2,763 \\
3,244 \\
1,074 \\
693\end{array}$ \\
\hline & \multicolumn{9}{|c|}{ Stocks } \\
\hline 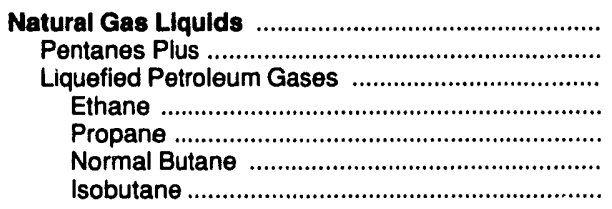 & $\begin{array}{r}161 \\
7 \\
154 \\
0 \\
97 \\
54 \\
3\end{array}$ & & $\begin{array}{l}2 \\
5 \\
7 \\
0 \\
0 \\
3 \\
4\end{array}$ & $\begin{array}{r}193 \\
12 \\
181 \\
0 \\
117 \\
57 \\
7\end{array}$ & $\begin{array}{r}108 \\
20 \\
88 \\
13 \\
42 \\
16 \\
17\end{array}$ & & $\begin{array}{r}41 \\
13 \\
28 \\
0 \\
19 \\
9 \\
0\end{array}$ & $\begin{array}{r}3,005 \\
358 \\
2,647 \\
812 \\
1,017 \\
657 \\
161\end{array}$ & $\begin{array}{r}3,154 \\
391 \\
2,763 \\
825 \\
1,078 \\
682 \\
178\end{array}$ \\
\hline \multirow[b]{2}{*}{ Commodity } & \multicolumn{6}{|c|}{ PAD Dlsitrict III } & $\begin{array}{c}\text { PAD Dist. } \\
\text { IV }\end{array}$ & $\begin{array}{c}\text { PAD Dist. } \\
\text { V }\end{array}$ & \multirow[b]{2}{*}{$\begin{array}{l}\text { U.S. } \\
\text { Total }\end{array}$} \\
\hline & $\begin{array}{l}\text { Texas } \\
\text { Inland }\end{array}$ & $\begin{array}{c}\text { Texas } \\
\text { Gulf } \\
\text { Coast }\end{array}$ & $\begin{array}{l}\text { La. } \\
\text { Gulf } \\
\text { Coast }\end{array}$ & $\begin{array}{l}\text { N. La., } \\
\text { Ark. }\end{array}$ & $\begin{array}{l}\text { Now } \\
\text { Mexico }\end{array}$ & Total & $\begin{array}{c}\text { IV } \\
\text { Rocky Mt. }\end{array}$ & \begin{tabular}{|c|} 
West Coast \\
\end{tabular} & \\
\hline & & & & & Net Product & & & & \\
\hline \multirow[t]{2}{*}{ 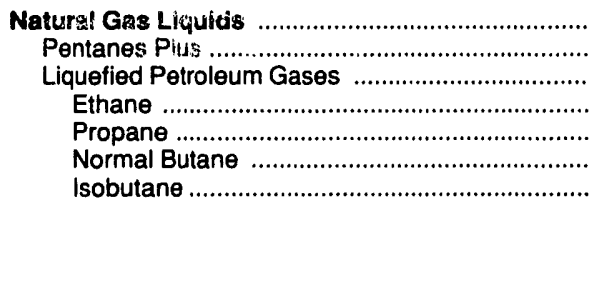 } & $\begin{array}{r}19,082 \\
3,714 \\
15,368 \\
6,432 \\
5,559 \\
2,468 \\
909\end{array}$ & $\begin{array}{r}2,617 \\
586 \\
2,031 \\
1,048 \\
600 \\
-1,876 \\
2,259\end{array}$ & $\begin{array}{r}6,974 \\
1,296 \\
5,678 \\
2,434 \\
1,907 \\
579 \\
758\end{array}$ & $\begin{array}{r}550 \\
153 \\
397 \\
46 \\
174 \\
125 \\
52\end{array}$ & $\begin{array}{r}4,232 \\
584 \\
3,648 \\
1,775 \\
1,196 \\
450 \\
227\end{array}$ & $\begin{array}{r}33,455 \\
6,333 \\
27,122 \\
11,735 \\
9,436 \\
1,746 \\
4,205\end{array}$ & $\begin{array}{r}3,961 \\
855 \\
3,106 \\
1,091 \\
1,257 \\
534 \\
224\end{array}$ & $\begin{array}{r}2,743 \\
1,499 \\
1,244 \\
1 \\
301 \\
562 \\
380\end{array}$ & $\begin{array}{r}\mathbf{5 0 , 1 3 5} \\
10,259 \\
39,876 \\
15,798 \\
14,523 \\
4,014 \\
5,541\end{array}$ \\
\hline & \multicolumn{9}{|c|}{ Stocks } \\
\hline $\begin{array}{l}\text { Natural Gas Llqulds } \\
\text { Pentanes Plus } \\
\text { Liquefied Petroleum Gases } \\
\text { Ethane }\end{array}$ & $\begin{array}{r}846 \\
411 \\
435 \\
47 \\
125 \\
223 \\
40\end{array}$ & $\begin{array}{r}3,507 \\
552 \\
2,955 \\
971 \\
1,034 \\
647 \\
303\end{array}$ & $\begin{array}{r}1,074 \\
138 \\
936 \\
6 \\
376 \\
398 \\
156\end{array}$ & $\begin{array}{r}136 \\
29 \\
107 \\
32 \\
41 \\
28 \\
6\end{array}$ & $\begin{array}{r}114 \\
24 \\
90 \\
18 \\
45 \\
19 \\
8\end{array}$ & $\begin{array}{r}5,677 \\
1,154 \\
4,523 \\
1,074 \\
1,621 \\
1,315 \\
513\end{array}$ & $\begin{array}{r}175 \\
58 \\
117 \\
3 \\
68 \\
35 \\
11\end{array}$ & $\begin{array}{r}156 \\
17 \\
139 \\
0 \\
110 \\
14 \\
15\end{array}$ & $\begin{array}{r}9,355 \\
1,632 \\
7,723 \\
1,902 \\
2,994 \\
2,103 \\
724\end{array}$ \\
\hline
\end{tabular}

Note: Refer to Appendix a for Refining District descriptions.

Source: Energy Information Adriinistration (EIA) Form EIA-816, "Monthly Natural Gas Liquids Report." 
Table 28. Refinery Input of Crude Oll and Petrc'eum Products by PAD and Refining Districts, August 1991

(Thousand Barrels, Except Where Noted)

\begin{tabular}{|c|c|c|c|c|c|c|c|}
\hline \multirow[b]{2}{*}{ Commodity } & \multicolumn{3}{|c|}{ PAD Distict I } & \multicolumn{4}{|c|}{ PAD Dlatrlct II } \\
\hline & $\begin{array}{l}\text { East } \\
\text { Coast }\end{array}$ & $\begin{array}{c}\text { Appalachian } \\
\text { No. } 1\end{array}$ & Total & Ind., III., Ky. & $\begin{array}{l}\text { Minn.,Wis., } \\
\text { N. Dak., S. Dak. }\end{array}$ & $\begin{array}{c}\text { Okla., Kans., } \\
\text { Mo. }\end{array}$ & Total \\
\hline Crude Oil & 37,879 & 3,085 & 40,964 & 63,895 & 10,085 & 22,526 & 96,506 \\
\hline $\begin{array}{l}\text { Natural Gas Llquids } \\
\text { Pentanes Plus } \\
\text { Liquefied Petroleum Gases } \\
\text { Ethane } \\
\text { Propane } \\
\text { Normal Butane } \\
\text { Isobutane }\end{array}$ & $\begin{array}{r}73 \\
14 \\
59 \\
0 \\
0 \\
21 \\
38\end{array}$ & $\begin{array}{l}0 \\
0 \\
0 \\
0 \\
0 \\
0 \\
0\end{array}$ & $\begin{array}{r}73 \\
14 \\
59 \\
0 \\
0 \\
21 \\
38\end{array}$ & $\begin{array}{r}1,608 \\
338 \\
1,270 \\
0 \\
0 \\
136 \\
1,134\end{array}$ & $\begin{array}{r}354 \\
286 \\
68 \\
0 \\
0 \\
1 \\
67\end{array}$ & $\begin{array}{r}1,216 \\
678 \\
538 \\
0 \\
0 \\
125 \\
413\end{array}$ & $\begin{array}{r}3,178 \\
1,302 \\
1,876 \\
0 \\
0 \\
262 \\
1,614\end{array}$ \\
\hline 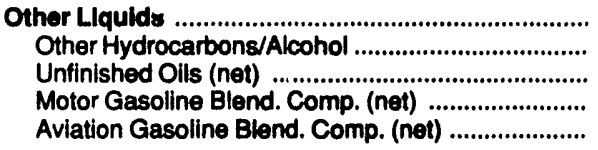 & $\begin{array}{r}7,623 \\
319 \\
5,756 \\
1,548 \\
0\end{array}$ & $\begin{array}{r}242 \\
0 \\
247 \\
-5 \\
0\end{array}$ & $\begin{array}{r}7,865 \\
319 \\
6,003 \\
1,543 \\
0\end{array}$ & $\begin{array}{r}3,389 \\
85 \\
2,619 \\
686 \\
-1\end{array}$ & $\begin{array}{r}64 \\
16 \\
81 \\
-33 \\
0\end{array}$ & $\begin{array}{r}815 \\
2 \\
806 \\
8 \\
-1\end{array}$ & $\begin{array}{r}4,268 \\
103 \\
3,506 \\
661 \\
-2\end{array}$ \\
\hline 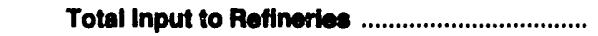 & 45,575 & 3,327 & 48,902 & 68,892 & 10,503 & 24,55i & 103,952 \\
\hline 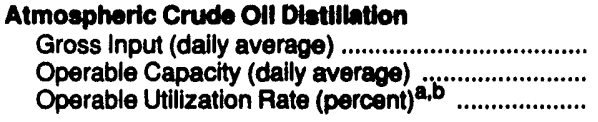 & $\begin{array}{r}1,198 \\
1,388 \\
86.3\end{array}$ & $\begin{array}{r}100 \\
105 \\
95.1\end{array}$ & $\begin{array}{r}1,298 \\
1,493 \\
86.9\end{array}$ & $\begin{array}{r}2,093 \\
2,237 \\
93.6\end{array}$ & $\begin{array}{r}323 \\
358 \\
90.2\end{array}$ & $\begin{array}{r}734 \\
753 \\
97.4\end{array}$ & $\begin{array}{r}3,150 \\
3,348 \\
94.1\end{array}$ \\
\hline 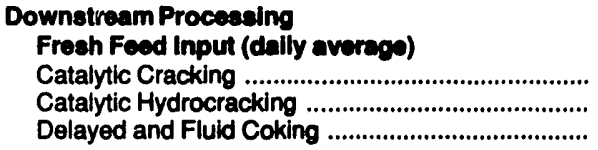 & $\begin{array}{r}527 \\
61 \\
80\end{array}$ & $\begin{array}{r}21 \\
5 \\
0\end{array}$ & $\begin{array}{r}549 \\
66 \\
80\end{array}$ & $\begin{array}{l}827 \\
114 \\
162\end{array}$ & $\begin{array}{r}119 \\
0 \\
56\end{array}$ & $\begin{array}{r}246 \\
5 \\
63\end{array}$ & $\begin{array}{r}1,192 \\
119 \\
281\end{array}$ \\
\hline $\begin{array}{l}\text { Crude Oll Quallties } \\
\text { Sulfur Content, Woighted Average (percint) .......... } \\
\text { API Gravity, Weighted Average (degrees) ............. }\end{array}$ & $\begin{array}{r}1.26 \\
30.05\end{array}$ & $\begin{array}{r}0.87 \\
37.25\end{array}$ & $\begin{array}{r}1.23 \\
30.60\end{array}$ & $\begin{array}{r}1.09 \\
33.36\end{array}$ & $\begin{array}{r}1.69 \\
30.86\end{array}$ & $\begin{array}{r}0.67 \\
35.64\end{array}$ & $\begin{array}{r}1.05 \\
33.63\end{array}$ \\
\hline $\begin{array}{l}\text { Operable Capacity (dally average) } \\
\text { Operating } \\
\text { Idle }\end{array}$ & $\begin{array}{r}1,388 \\
1,340 \\
49\end{array}$ & $\begin{array}{r}105 \\
105 \\
0\end{array}$ & $\begin{array}{r}1,493 \\
1,445 \\
49\end{array}$ & $\begin{array}{r}2,237 \\
2,236 \\
1\end{array}$ & $\begin{array}{r}358 \\
358 \\
0\end{array}$ & $\begin{array}{r}753 \\
753 \\
0\end{array}$ & $\begin{array}{r}3,348 \\
3,347 \\
1\end{array}$ \\
\hline Alaskan Crude Oll Recolpts & o & $\mathbf{0}$ & $\mathbf{0}$ & 491 & $\mathbf{0}$ & 422 & 913 \\
\hline
\end{tabular}


Table 28. Refinery Input of Crude Oil and Petroleum Products by PAD and Refining Districts, August 1991 (Continued) (Thousand Barrels, Except Where Noted)

\begin{tabular}{|c|c|c|c|c|c|c|c|c|c|}
\hline \multirow{3}{*}{ Commodity } & \multicolumn{6}{|c|}{ PAD Dlstrict III } & \multirow{3}{*}{$\begin{array}{c}\text { PAD Dist. } \\
\text { IV } \\
\text { Rocky Mt. }\end{array}$} & \multirow{3}{*}{\begin{tabular}{|c|}
$\begin{array}{c}\text { PAD Dlst. } \\
\text { West Coast }\end{array}$ \\
\end{tabular}} & \multirow[b]{3}{*}{$\begin{array}{l}\text { U.S. } \\
\text { Total }\end{array}$} \\
\hline & \multirow[b]{2}{*}{$\begin{array}{l}\text { Texas } \\
\text { Inland }\end{array}$} & \multirow{2}{*}{$\begin{array}{c}\text { Toxas } \\
\text { Gulf } \\
\text { Coset }\end{array}$} & \multirow{2}{*}{$\begin{array}{l}\text { La. } \\
\text { Gult } \\
\text { Coast }\end{array}$} & \multirow[b]{2}{*}{$\begin{array}{l}\text { N. La., } \\
\text { Ark. }\end{array}$} & \multirow[b]{2}{*}{$\begin{array}{l}\text { New } \\
\text { Mexlco }\end{array}$} & \multirow[b]{2}{*}{ Total } & & & \\
\hline & & & & & & & & & \\
\hline 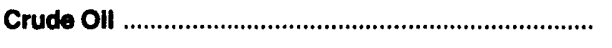 & 16,738 & 93,590 & 75,115 & 6,036 & 2,411 & 193,890 & 15,375 & 80,714 & 427,449 \\
\hline 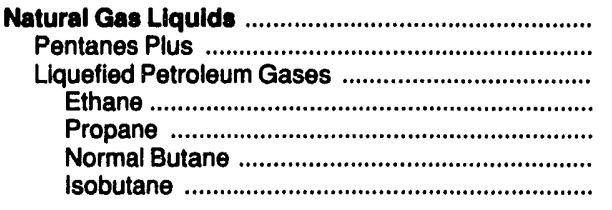 & $\begin{array}{r}1,214 \\
773 \\
441 \\
0 \\
0 \\
97 \\
344\end{array}$ & $\begin{array}{r}2,901 \\
1,390 \\
1,511 \\
0 \\
0 \\
263 \\
1,248\end{array}$ & $\begin{array}{r}2,233 \\
422 \\
1,811 \\
0 \\
0 \\
588 \\
1,223\end{array}$ & $\begin{array}{r}251 \\
157 \\
94 \\
0 \\
0 \\
2 \\
92\end{array}$ & $\begin{array}{r}168 \\
121 \\
47 \\
0 \\
0 \\
0 \\
47\end{array}$ & $\begin{array}{r}6,767 \\
2,863 \\
3,904 \\
0 \\
0 \\
950 \\
2,954\end{array}$ & $\begin{array}{r}629 \\
215 \\
414 \\
0 \\
0 \\
298 \\
116\end{array}$ & $\begin{array}{r}2,388 \\
1,073 \\
1,325 \\
0 \\
0 \\
722 \\
603\end{array}$ & $\begin{array}{r}13,045 \\
5,467 \\
7,578 \\
0 \\
0 \\
2,253 \\
5,325\end{array}$ \\
\hline 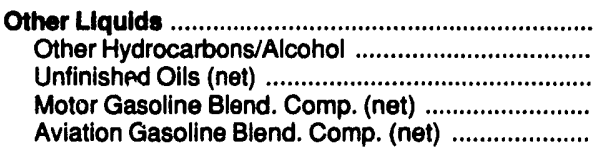 & $\begin{array}{r}276 \\
216 \\
175 \\
-115 \\
0\end{array}$ & $\begin{array}{r}8,773 \\
811 \\
7,506 \\
457 \\
-1\end{array}$ & $\begin{array}{r}1,811 \\
456 \\
1,316 \\
11 \\
28\end{array}$ & $\begin{array}{r}192 \\
13 \\
171 \\
8 \\
0\end{array}$ & $\begin{array}{r}54 \\
11 \\
47 \\
-4 \\
0\end{array}$ & $\begin{array}{r}11,106 \\
1,507 \\
9,215 \\
357 \\
27\end{array}$ & $\begin{array}{r}314 \\
6 \\
44 \\
264 \\
0\end{array}$ & $\begin{array}{r}2,567 \\
658 \\
1,692 \\
211 \\
6\end{array}$ & $\begin{array}{r}26,120 \\
2,593 \\
20,460 \\
3,036 \\
31\end{array}$ \\
\hline 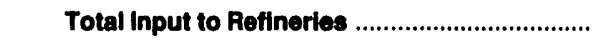 & 18,228 & 105,264 & 79,159 & 6,479 & 2,633 & 211,763 & 16,318 & 85,679 & 466,614 \\
\hline 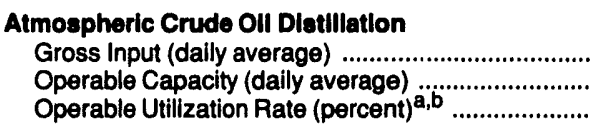 & $\begin{array}{r}544 \\
618 \\
88.1\end{array}$ & $\begin{array}{r}3,037 \\
3,351 \\
90.6\end{array}$ & $\begin{array}{r}2,443 \\
2,965 \\
82.4\end{array}$ & $\begin{array}{r}192 \\
243 \\
78.8\end{array}$ & $\begin{array}{r}78 \\
79 \\
98.7\end{array}$ & $\begin{array}{r}6,294 \\
7,256 \\
86.7\end{array}$ & $\begin{array}{r}505 \\
550 \\
91.8\end{array}$ & $\begin{array}{r}2,744 \\
3,103 \\
88.4\end{array}$ & $\begin{array}{r}13,991 \\
15,751 \\
88.8\end{array}$ \\
\hline \multicolumn{10}{|l|}{$\begin{array}{l}\text { Downstream Processing } \\
\text { Freah Feed Input (daily average) }\end{array}$} \\
\hline 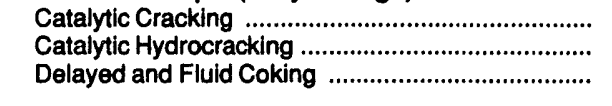 & $\begin{array}{r}196 \\
22 \\
6\end{array}$ & $\begin{array}{r}1,306 \\
218 \\
216\end{array}$ & $\begin{array}{l}781 \\
225 \\
382\end{array}$ & $\begin{array}{r}30 \\
0 \\
13\end{array}$ & $\begin{array}{r}29 \\
0 \\
0\end{array}$ & $\begin{array}{r}2,343 \\
464 \\
618\end{array}$ & $\begin{array}{r}179 \\
8 \\
20\end{array}$ & $\begin{array}{l}726 \\
465 \\
467\end{array}$ & $\begin{array}{l}4,989 \\
1,121 \\
1,466\end{array}$ \\
\hline \multicolumn{10}{|l|}{ Crude Oll Qualtiles } \\
\hline $\begin{array}{l}\text { Sulfur Content, Weighted Average (percent) ......... } \\
\text { API Gravity, Weighted Average (degrees) .............. }\end{array}$ & $\begin{array}{r}0.76 \\
38.25\end{array}$ & $\begin{array}{r}1.08 \\
33.13\end{array}$ & $\begin{array}{r}1.37 \\
30.42\end{array}$ & $\begin{array}{r}1.44 \\
34.35\end{array}$ & $\begin{array}{r}0.81 \\
38.08\end{array}$ & $\begin{array}{r}1.17 \\
32.62\end{array}$ & $\begin{array}{r}1.04 \\
35.11\end{array}$ & $\begin{array}{r}1.18 \\
25.29\end{array}$ & $\begin{array}{r}1.15 \\
31.37\end{array}$ \\
\hline 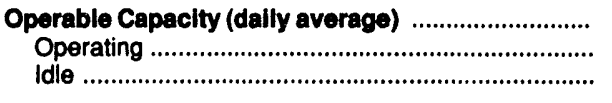 & $\begin{array}{r}618 \\
610 \\
8\end{array}$ & $\begin{array}{r}3,351 \\
3,324 \\
27\end{array}$ & $\begin{array}{r}2,965 \\
2,634 \\
332\end{array}$ & $\begin{array}{r}243 \\
238 \\
6\end{array}$ & $\begin{array}{r}79 \\
79 \\
0\end{array}$ & $\begin{array}{r}7,256 \\
6,884 \\
372\end{array}$ & $\begin{array}{r}\mathbf{5 5 0} \\
\mathbf{5 5 0} \\
0\end{array}$ & $\begin{array}{r}3,103 \\
3,005 \\
99\end{array}$ & $\begin{array}{r}15,751 \\
15,230 \\
521\end{array}$ \\
\hline 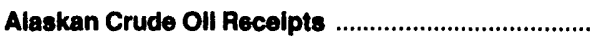 & 4 & 1,458 & 645 & 183 & 0 & 2,290 & 0 & 43,807 & 47,010 \\
\hline
\end{tabular}

a Represents gross input divided by operable capacity.

b See Table H2 in the Highlights Section for additional information concerning utilization rates.

Note: - Totals may not equal sum of components due to independent rounding. - Refer to Appendix A for Refining District descriptions.

Source: Energy Information Administration (EIA) Form ElA-810, "Monthly Refinery Report." 
Table 29. Refinery Net Production of Finished Petroleum Products by PAD and Refining Districts, August 1991 (Thousand Barrels)

\begin{tabular}{|c|c|c|c|c|c|c|c|}
\hline \multirow[b]{2}{*}{ Commodity } & \multicolumn{3}{|c|}{ PAD District I } & \multicolumn{4}{|c|}{ PAD District II } \\
\hline & $\begin{array}{c}\text { East } \\
\text { Cosst }\end{array}$ & $\begin{array}{c}\text { Appalachian } \\
\text { No. } 1\end{array}$ & Total & Ind., III., Ky. & $\begin{array}{l}\text { Minn.,Wls., } \\
\text { N. Dak., } \\
\text { S. Dak. }\end{array}$ & $\begin{array}{c}\text { Okla., Kans., } \\
\text { Mo. }\end{array}$ & Total \\
\hline 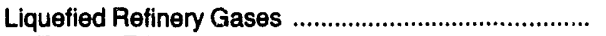 & 1,575 & 49 & 1,624 & 2,438 & 323 & 812 & 3,573 \\
\hline Ethan $\theta /$ Ethylene & 0 & 0 & 0 & 0 & 0 & 0 & 0 \\
\hline Ethane & $W$ & $\mathbf{W}$ & $W$ & W & W & W & $\mathbf{W}$ \\
\hline 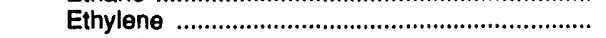 & W & $\ddot{W}$ & W & W & w & W & W \\
\hline 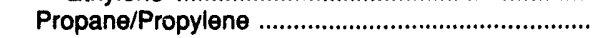 & 1,151 & 35 & 1,186 & 2,243 & 267 & 639 & 3,149 \\
\hline 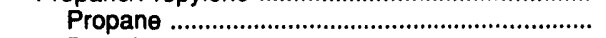 & W & W & $W$ & W & $W$ & W & W \\
\hline 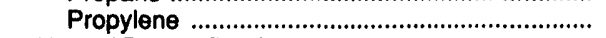 & $W$ & W & W & w & W & w & W \\
\hline 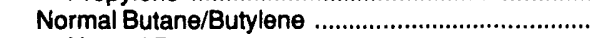 & 438 & 17 & 455 & 284 & 66 & 173 & 523 \\
\hline Normal Butane & W & W & W & W & 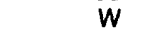 & W & W \\
\hline 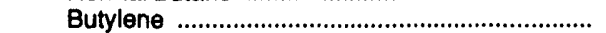 & $W$ & W & $\mathbf{W}$ & W & W & W & $\mathbf{W}$ \\
\hline Isobutane & -14 & -3 & -17 & -89 & -10 & 0 & -99 \\
\hline 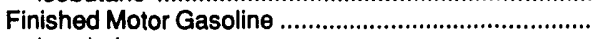 & 21,442 & 1,292 & 22,734 & 37,857 & 5,669 & 12,611 & 56,137 \\
\hline 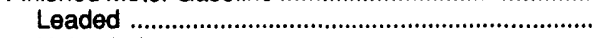 & 397 & 3 & 400 & 121 & 110 & 135 & 366 \\
\hline 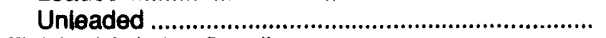 & 21,045 & 1,289 & 22,334 & 37,736 & 5,559 & 12,476 & 55,771 \\
\hline 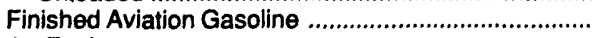 & -4 & 0 & -4 & 89 & 22 & 16 & 127 \\
\hline 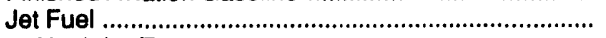 & 3,074 & 1 & 3,075 & 4,589 & 453 & 1,486 & 6,528 \\
\hline 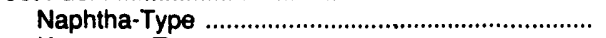 & 97 & 0 & 97 & 472 & -4 & 298 & 766 \\
\hline 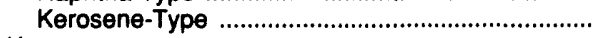 & 2,977 & 1 & 2,978 & 4,117 & 457 & 1,188 & 5,762 \\
\hline 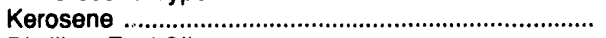 & -62 & 55 & -7 & -64 & 79 & -37 & -22 \\
\hline 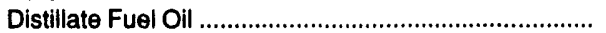 & 10,122 & 1,007 & 11,129 & 13,217 & 2,661 & 6,160 & 22,038 \\
\hline 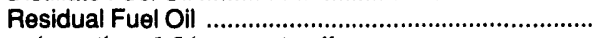 & 3,647 & 57 & 3,704 & 1,970 & 287 & 193 & 2,450 \\
\hline 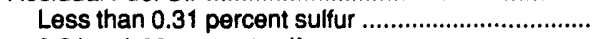 & 955 & 21 & 976 & 70 & 0 & 41 & 111 \\
\hline 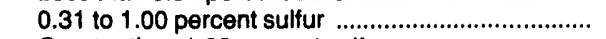 & 2,303 & 0 & 2,303 & 163 & 0 & 55 & 218 \\
\hline 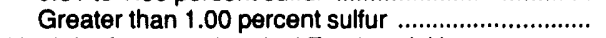 & 389 & 36 & 425 & 1,737 & 287 & 97 & 2,121 \\
\hline Naphtha for Petrochemical Feedstock Use ................. & 407 & 0 & 407 & 568 & 0 & 53 & 621 \\
\hline Other Oils for Petrochemical Feedstock Use .............. & 13 & 0 & 13 & 589 & 0 & 59 & 648 \\
\hline 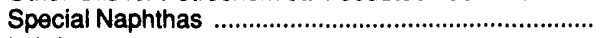 & 54 & 30 & 84 & 227 & 0 & 267 & 494 \\
\hline 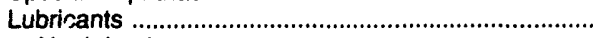 & 194 & 325 & 519 & 405 & 0 & 313 & 718 \\
\hline 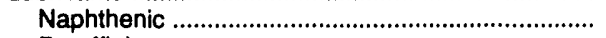 & -1 & 0 & -1 & 0 & 0 & 0 & 0 \\
\hline 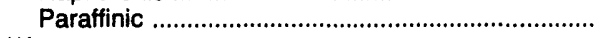 & 195 & 325 & 520 & 405 & 0 & 313 & 718 \\
\hline Waxes & 0 & 74 & 74 & 42 & 0 & 36 & 78 \\
\hline Petroleum Coke & 1,332 & 28 & 1,360 & 2,447 & 590 & 921 & 3,958 \\
\hline 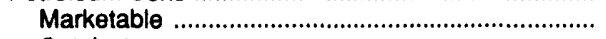 & 508 & 0 & 508 & 1,381 & 423 & 613 & 2,417 \\
\hline 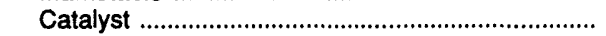 & 824 & 28 & 852 & 1,066 & 167 & 308 & 1,541 \\
\hline 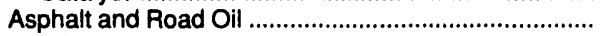 & 3,475 & 269 & 3,744 & 4,247 & 555 & 1,199 & 6,001 \\
\hline Still Gas & 2,016 & 156 & 2,172 & 3,041 & 395 & 1,120 & 4,556 \\
\hline 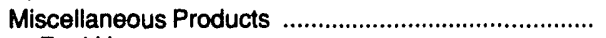 & 288 & 41 & 329 & 199 & 27 & 43 & 269 \\
\hline 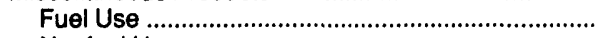 & 0 & 0 & 0 & 0 & 0 & 1 & 1 \\
\hline 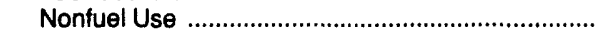 & 288 & 41 & 329 & 199 & 27 & 42 & 268 \\
\hline 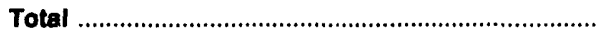 & 47,573 & 3,384 & 50,957 & 71,861 & 11,061 & 25,252 & 108,174 \\
\hline Processing Gain(-) or Loss $(+)^{a}$ & $-1,998$ & -57 & $-2,055$ & $-2,969$ & -558 & -695 & $-4,222$ \\
\hline
\end{tabular}

See footnotes at end of table. 
Table 29. Refinery Net Production of Finished Petroleum Products by PAD and Refining Districts, August 1991 (Continued) (Thousand Barrels)

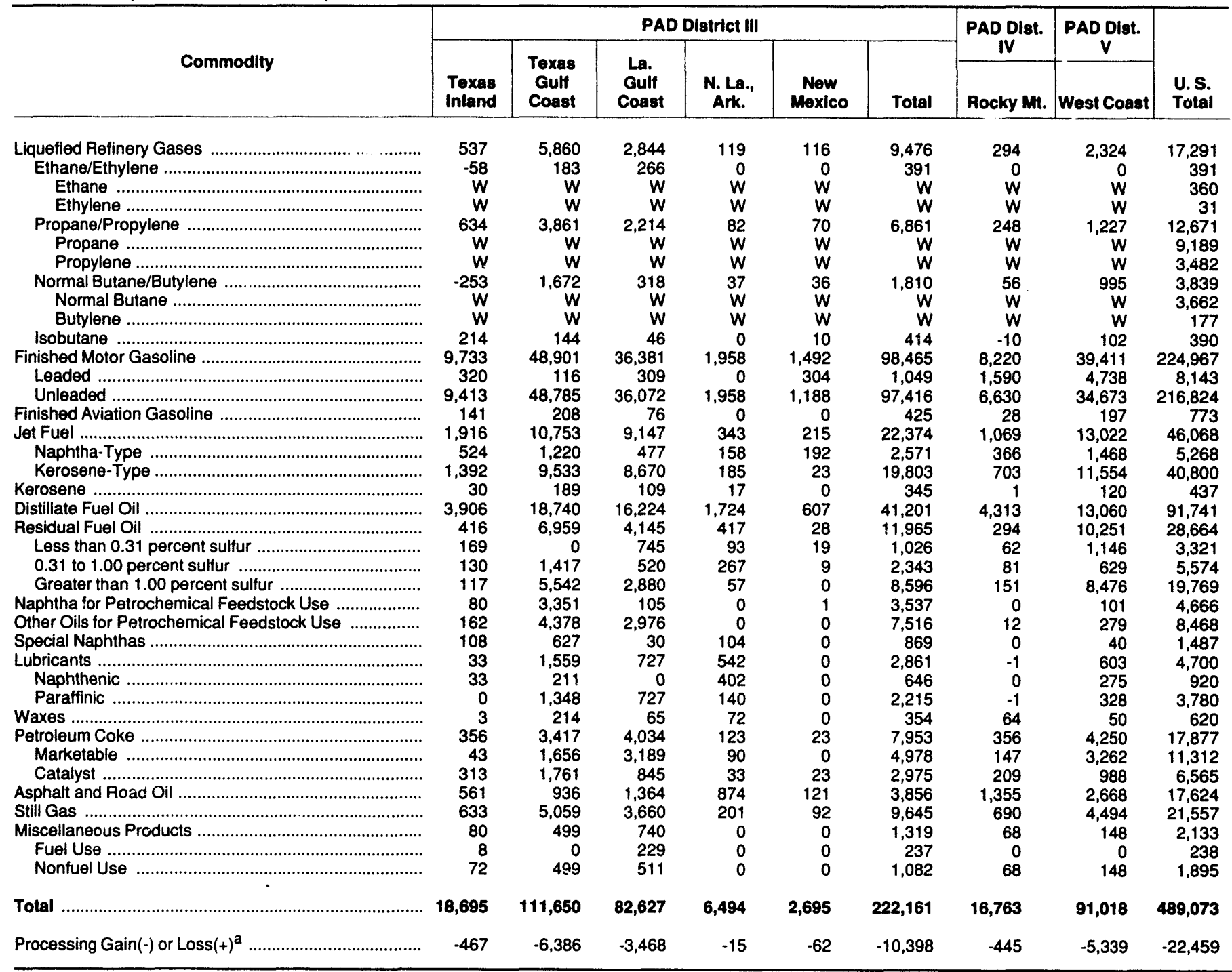

a Represents the arithmetic difference between input and production.

$W=$ Withheld to avoid disclosure of individual company data.

Note: Refer to Appendix A for refining District descriptions.

Source: Energy Information Administration (EIA) Form EIA-810, "Monthly Refinery Report." 
Table 30. Refinery Stocks of Crude Oil and Petroleum Products by PAD and Refining Districts, August 1991 (Thousand Barrels)

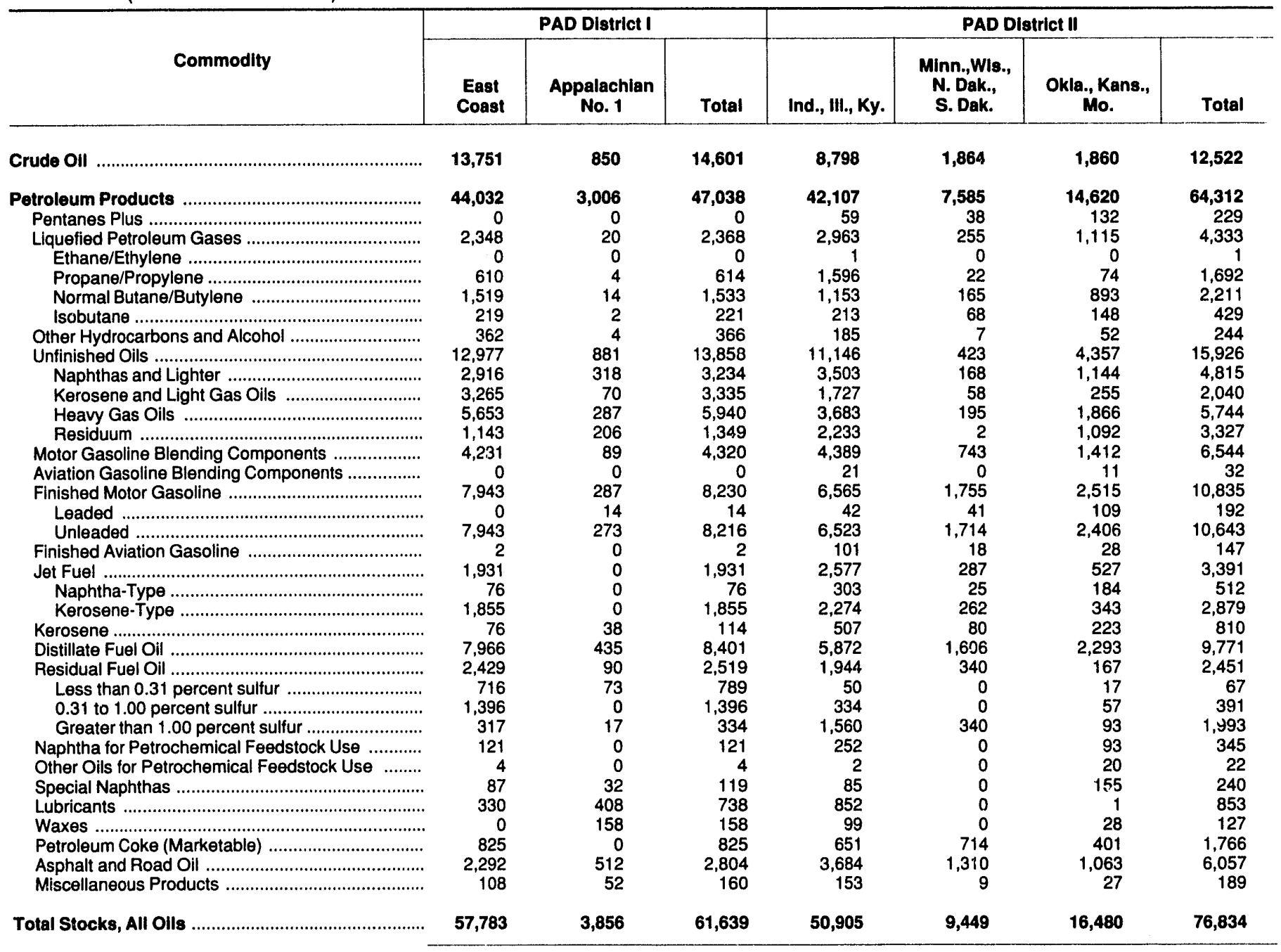

See footnotes at end of table. 
Table 30. Refinery Stocks of Crude Oll and Petroleum Products by PAD and Refining Districts, August 1991 (Continued) (Thousand Barrels)

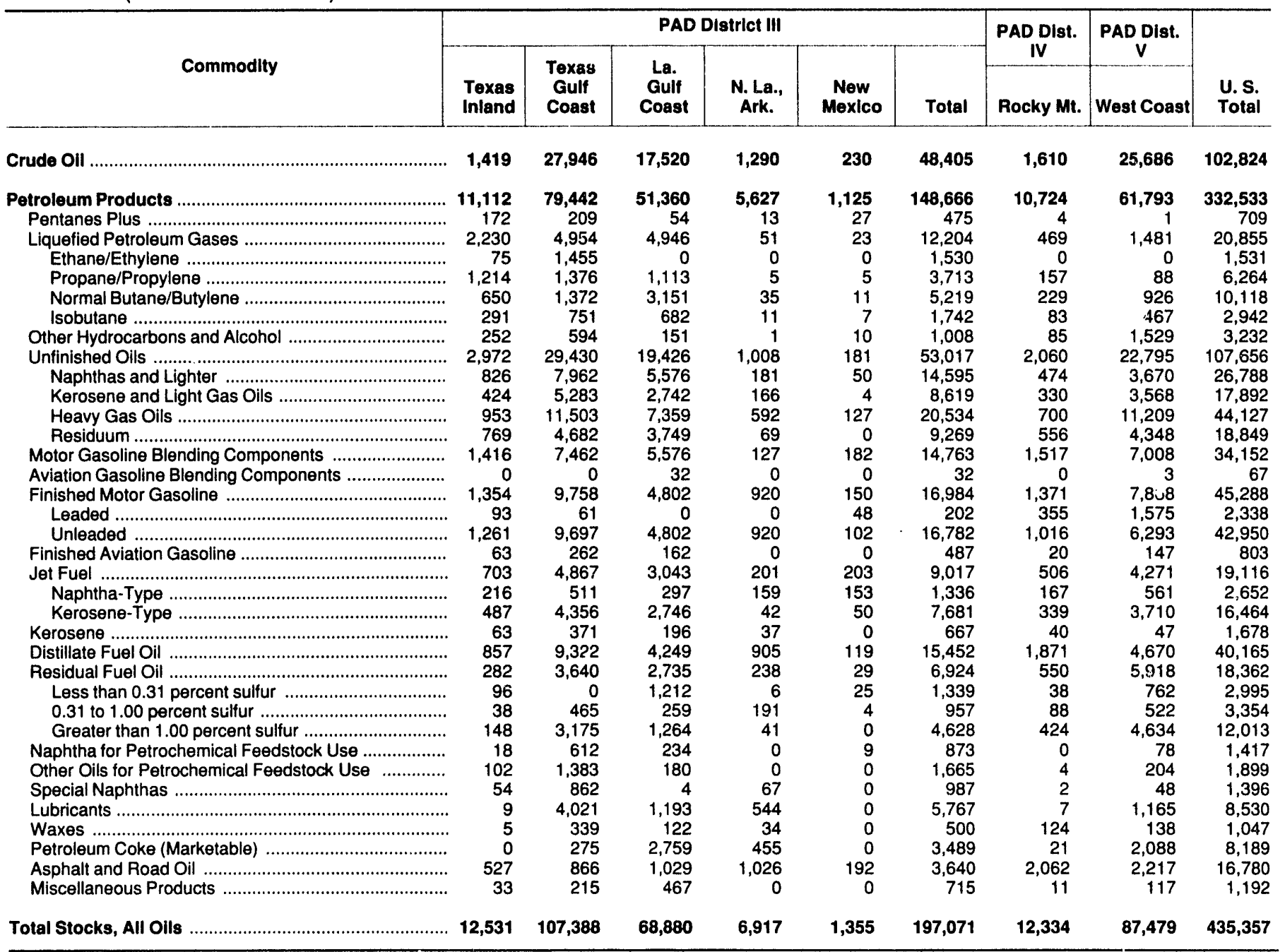

Notes: - Stocks are reported as of the last day of the month. - Refer to Appendix A for Refining District descriptions. Source: Energy Infcrmation Administration (EIA) Form EIA-810, "Monthly Refinery Report." 
Table 31. Percent Refinery Yield of Petroleum Products by PAD and Refining Districts, ${ }^{a}$ August 1991

\begin{tabular}{|c|c|c|c|c|c|c|c|}
\hline \multirow[b]{2}{*}{ Commodity } & \multicolumn{3}{|c|}{ PAD District I } & \multicolumn{4}{|c|}{ PAD District ॥ } \\
\hline & $\begin{array}{c}\text { East } \\
\text { Coast }\end{array}$ & $\begin{array}{c}\text { Appalachian } \\
\text { No. } 1\end{array}$ & Total & Ind., III., Ky. & $\begin{array}{c}\text { Minn.,Wis., } \\
\text { N. Dak., } \\
\text { S. Dak. }\end{array}$ & $\begin{array}{c}\text { Okla., Kans., } \\
\text { Mo. }\end{array}$ & Total \\
\hline 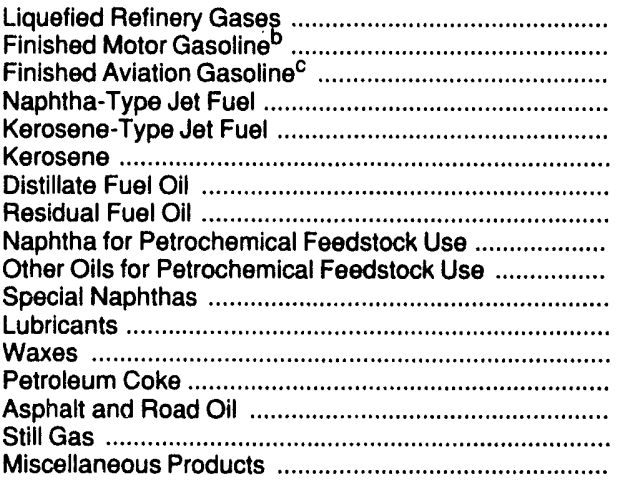 & $\begin{array}{r}3.6 \\
44.7 \\
0.0 \\
0.2 \\
6.8 \\
-0.1 \\
23.2 \\
8.4 \\
0.9 \\
0.0 \\
0.1 \\
0.4 \\
0.0 \\
3.1 \\
8.0 \\
4.6 \\
0.7\end{array}$ & $\begin{array}{r}1.5 \\
38.9 \\
0.0 \\
0.0 \\
0.0 \\
1.7 \\
30.2 \\
1.7 \\
0.0 \\
0.0 \\
0.9 \\
9.8 \\
2.2 \\
0.8 \\
8.1 \\
4.7 \\
1.2\end{array}$ & $\begin{array}{r}3.5 \\
44.3 \\
0.0 \\
0.2 \\
6.3 \\
0.0 \\
23.7 \\
7.9 \\
0.9 \\
0.0 \\
0.2 \\
1.1 \\
0.2 \\
2.9 \\
8.0 \\
4.6 \\
0.7\end{array}$ & $\begin{array}{r}3.7 \\
53.3 \\
0.1 \\
0.7 \\
6.2 \\
-0.1 \\
19.9 \\
3.0 \\
0.9 \\
0.9 \\
0.3 \\
0.6 \\
0.1 \\
3.7 \\
6.4 \\
4.6 \\
0.3\end{array}$ & $\begin{array}{r}3.2 \\
52.4 \\
0.2 \\
0.0 \\
4.5 \\
0.8 \\
26.2 \\
2.8 \\
0.0 \\
0.0 \\
0.0 \\
0.0 \\
0.0 \\
5.8 \\
5.5 \\
3.9 \\
0.3\end{array}$ & $\begin{array}{r}3.5 \\
48.8 \\
0.1 \\
1.3 \\
5.1 \\
-0.2 \\
26.4 \\
0.8 \\
0.2 \\
0.3 \\
1.1 \\
1.3 \\
0.2 \\
3.9 \\
5.1 \\
4.8 \\
0.2\end{array}$ & $\begin{array}{r}3.6 \\
52.2 \\
0.1 \\
0.8 \\
5.8 \\
0.0 \\
22.0 \\
2.4 \\
0.6 \\
0.6 \\
0.5 \\
0.7 \\
0.1 \\
4.0 \\
6.0 \\
4.6 \\
0.3\end{array}$ \\
\hline Processing Gain(-) or Loss $(+)^{d}$ & -4.6 & -1.7 & -4.4 & -4.5 & -5.5 & -3.0 & -4.2 \\
\hline
\end{tabular}

\begin{tabular}{|c|c|c|c|c|c|c|c|c|c|}
\hline \multirow{3}{*}{ Commodity } & \multicolumn{6}{|c|}{ PAD District III } & \multirow{3}{*}{$\begin{array}{c}\begin{array}{c}\text { PAD Dlst. } \\
\text { IV }\end{array} \\
\text { Rocky Mt. }\end{array}$} & \multirow{3}{*}{\begin{tabular}{|c|} 
PAD Dist. \\
\\
West Coast
\end{tabular}} & \multirow[b]{3}{*}{$\begin{array}{l}\text { U. S. } \\
\text { Total }\end{array}$} \\
\hline & \multirow[b]{2}{*}{$\begin{array}{l}\text { Texas } \\
\text { Inland }\end{array}$} & \multirow{2}{*}{$\begin{array}{c}\text { Texas } \\
\text { Gulf } \\
\text { Coast }\end{array}$} & \multirow{2}{*}{$\begin{array}{l}\text { La. } \\
\text { Gulf } \\
\text { Coast }\end{array}$} & \multirow[b]{2}{*}{$\begin{array}{c}\text { N. La., } \\
\text { Ark. }\end{array}$} & \multirow[b]{2}{*}{$\begin{array}{c}\text { New } \\
\text { Mexico }\end{array}$} & \multirow[b]{2}{*}{ Total } & & & \\
\hline & & & & & & & & & \\
\hline 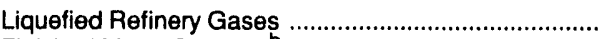 & 3.2 & 5.8 & 3.7 & 1.9 & 4.7 & 4.7 & 1.9 & 2.8 & 3.9 \\
\hline Finished Motor Gasoline & 49.8 & 44.2 & 44.1 & 27.2 & 53.6 & 44.2 & 47.5 & 43.9 & 46.1 \\
\hline 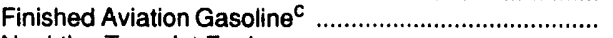 & 0.8 & 0.2 & 0.1 & 0.0 & 0.0 & 0.2 & 0.2 & 0.2 & 0.2 \\
\hline 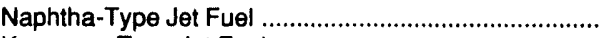 & 3.1 & 1.2 & 0.6 & 2.5 & 7.8 & 1.3 & 2.4 & 1.8 & 1.2 \\
\hline 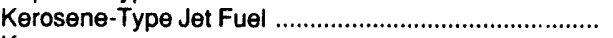 & 8.2 & 9.4 & 11.3 & 3.0 & 0.9 & 9.8 & 4.6 & 14.0 & 9.1 \\
\hline 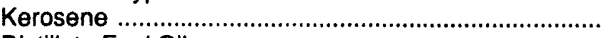 & 0.2 & 0.2 & 0.1 & 0.3 & 0.0 & 0.2 & 0.0 & 0.1 & 0.1 \\
\hline 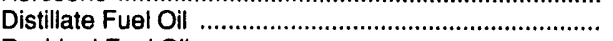 & 23.1 & 18.5 & 21.2 & 27.8 & 24.7 & 20.3 & 28.0 & 15.8 & 20.5 \\
\hline 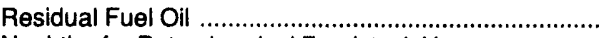 & 2.5 & 6.9 & 5.4 & 6.7 & 1.1 & 5.9 & 1.9 & 12.4 & 6.4 \\
\hline Naphtha for Petrochemical Feedstock Use ................... & 0.5 & 3.3 & 0.1 & 0.0 & 0.0 & 1.7 & 0.0 & 0.1 & 1.0 \\
\hline Other Oils for Petrochemical Feedstock Use ................ & 1.0 & 4.3 & 3.9 & 0.0 & 0.0 & 3.7 & 0.1 & 0.3 & 1.9 \\
\hline 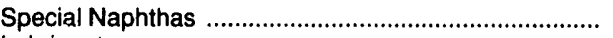 & 0.6 & 0.6 & 0.0 & 1.7 & 0.0 & 0.4 & 0.0 & 0.0 & 0.3 \\
\hline 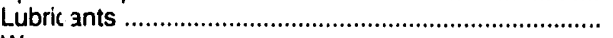 & 0.2 & 1.5 & 1.0 & 8.7 & 0.0 & 1.4 & 0.0 & 0.7 & 1.0 \\
\hline Waxes & 0.0 & 0.2 & 0.1 & 1.2 & 0.0 & 0.2 & 0.4 & 0.1 & 0.1 \\
\hline 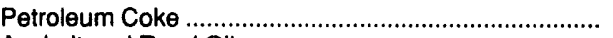 & 2.1 & 3.4 & 5.3 & 2.0 & 0.9 & 3.9 & 2.3 & 5.2 & 4.0 \\
\hline 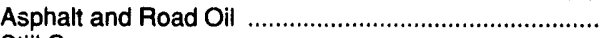 & 3.3 & 0.9 & 1.8 & 14.1 & 4.9 & 1.9 & 8.8 & 3.2 & 3.9 \\
\hline Still Gas & 3.7 & 5.0 & 4.8 & 3.2 & 3.7 & 4.7 & 4.5 & 5.5 & 4.8 \\
\hline 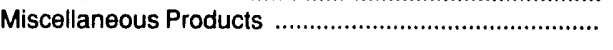 & 0.5 & 0.5 & 1.0 & 0.0 & 0.0 & 0.6 & 0.4 & 0.2 & 0.5 \\
\hline Processing Gain $(\cdot)$ or Loss $(+)^{\text {d }} \ldots \ldots \ldots \ldots \ldots . . . .$. & -2.8 & -6.3 & -4.5 & -0.2 & -2.5 & -5.1 & -2.9 & -6.5 & -5.0 \\
\hline
\end{tabular}

a Based on crude oil input and net reruns of unfinished oils.

b Based on total finished motor gasoline output minus net input of motor gasoline blending components, minus input of natural gas plant liquids, other hydrocarbons and alcohol.

c Based on finished aviation gasoline output minus net input of aviation gasoline blending components.

$d$ Represents the difference between input and productior.

Notes: - Totals may not equal sum of components due to independent rounding. - Refer to Appendix A for Refining District descriptions.

Sources: Calculated from data on Tables 29 and 30. 
Table 32. Imports of Residual Fuel Oll by Sulfur Content and by PAD District and State of Entry, August 1991

(Thousand Barrels)

\begin{tabular}{|c|c|c|c|c|}
\hline \multirow[b]{2}{*}{ PAD District and State of Entry } & \multicolumn{4}{|c|}{ Residual Fuel OII } \\
\hline & $\begin{array}{l}\text { Less than } \\
0.31 \% \\
\text { Sulfur }\end{array}$ & $\begin{array}{l}0.31 \text { to } \\
1.00 \% \\
\text { Sulfur }\end{array}$ & $\begin{array}{l}\text { Greater } \\
\text { than } 1.00 \% \\
\text { Sulfur }\end{array}$ & Total \\
\hline $\begin{array}{l}\text { PAD Distrlct I } \\
\text { Florida } \\
\text { Maine } \\
\text { Maryland ... } \\
\text { New Jerseysetts } \\
\text { New York } \\
\text { North Carolina } \\
\text { Pennsylvania } \\
\text { South Carolina } \\
\text { Vermont } \\
\text { Virginia }\end{array}$ & $\begin{array}{r}1,922 \\
44 \\
0 \\
0 \\
0 \\
1,002 \\
876 \\
0 \\
0 \\
0 \\
0 \\
0\end{array}$ & $\begin{array}{r}3,133 \\
539 \\
230 \\
0 \\
78 \\
989 \\
909 \\
0 \\
388 \\
0 \\
0 \\
0\end{array}$ & $\begin{array}{r}8,638 \\
1,613 \\
698 \\
539 \\
1,851 \\
1,146 \\
1,711 \\
189 \\
60 \\
104 \\
2 \\
725\end{array}$ & $\begin{array}{r}13,693 \\
2,196 \\
928 \\
539 \\
1,929 \\
3,137 \\
3,496 \\
189 \\
448 \\
104 \\
2 \\
725\end{array}$ \\
\hline $\begin{array}{r}\text { PAD District II } \\
\text { Michigan } \\
\text { North Dakota }\end{array}$ & $\begin{array}{r}32 \\
32 \\
0\end{array}$ & $\begin{array}{r}12 \\
0 \\
12\end{array}$ & $\begin{array}{r}27 \\
8 \\
19\end{array}$ & $\begin{array}{l}71 \\
40 \\
31\end{array}$ \\
\hline 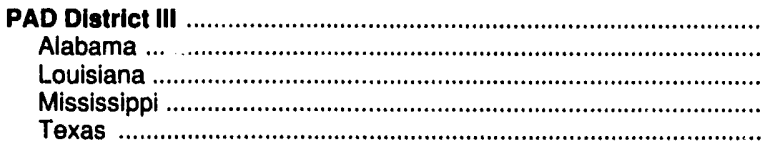 & $\begin{array}{r}630 \\
0 \\
0 \\
0 \\
630\end{array}$ & $\begin{array}{r}331 \\
0 \\
331 \\
0 \\
0\end{array}$ & $\begin{array}{r}1,756 \\
130 \\
373 \\
80 \\
1,173\end{array}$ & $\begin{array}{r}2,717 \\
130 \\
704 \\
80 \\
1,803\end{array}$ \\
\hline PAD Dlstrict V & $\begin{array}{r}205 \\
0 \\
205 \\
0\end{array}$ & $\begin{array}{r}189 \\
189 \\
0 \\
0\end{array}$ & $\begin{array}{r}747 \\
559 \\
0 \\
188\end{array}$ & $\begin{array}{r}1,141 \\
748 \\
205 \\
188\end{array}$ \\
\hline U.S. Total & 2,789 & 3,665 & 11,168 & 17,622 \\
\hline
\end{tabular}

Source: Energy Information Administration (EIA) Form EIA-814, "Monthly Imports Report." 
Table 33. Imports of Crude Oil and Petroleum Products by PAD District, August 1991

(Thousand Barrels)

\begin{tabular}{|c|c|c|c|c|c|c|c|}
\hline \multirow{2}{*}{ Commodity } & \multicolumn{6}{|c|}{ Petroleum Administration for Defense Districts } & \multirow[b]{2}{*}{$\begin{array}{c}\text { Dally } \\
\text { Average }\end{array}$} \\
\hline & 1 & II & III & IV & $\mathbf{v}$ & $\begin{array}{l}\text { U.S. } \\
\text { Total }\end{array}$ & \\
\hline Crude $\mathrm{Oll}^{\mathrm{a}, \mathrm{b}}$ & 42,392 & 39,703 & 114,264 & 2,561 & 7,755 & 206,675 & 6,667 \\
\hline 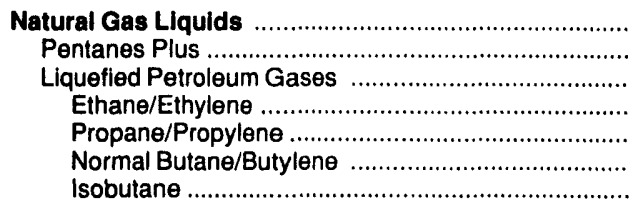 & $\begin{array}{r}181 \\
0 \\
181 \\
0 \\
132 \\
29 \\
20\end{array}$ & $\begin{array}{r}1,783 \\
38 \\
1,745 \\
0 \\
1,414 \\
330 \\
1\end{array}$ & $\begin{array}{r}2,112 \\
0 \\
2,112 \\
233 \\
487 \\
831 \\
561\end{array}$ & $\begin{array}{r}307 \\
110 \\
197 \\
0 \\
119 \\
71 \\
7\end{array}$ & $\begin{array}{r}22 \\
0 \\
22 \\
0 \\
1 \\
10 \\
11\end{array}$ & $\begin{array}{r}4,405 \\
148 \\
4,257 \\
233 \\
2,153 \\
1,271 \\
600\end{array}$ & $\begin{array}{r}142 \\
5 \\
137 \\
8 \\
69 \\
41 \\
19\end{array}$ \\
\hline 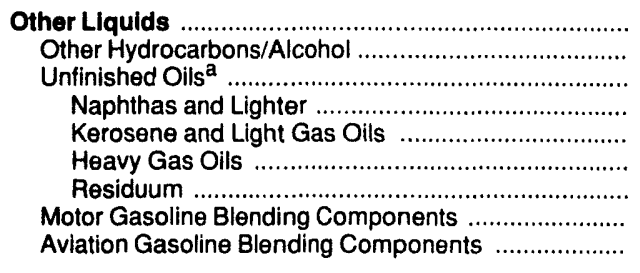 & $\begin{array}{r}7,342 \\
0 \\
6,457 \\
773 \\
0 \\
4,677 \\
1,007 \\
885 \\
0\end{array}$ & $\begin{array}{r}193 \\
0 \\
0 \\
0 \\
0 \\
0 \\
0 \\
193 \\
0\end{array}$ & $\begin{array}{r}5,772 \\
0 \\
5,771 \\
1,323 \\
0 \\
1,979 \\
2,469 \\
1 \\
0\end{array}$ & $\begin{array}{l}0 \\
0 \\
0 \\
0 \\
0 \\
0 \\
0 \\
0 \\
0\end{array}$ & $\begin{array}{r}261 \\
0 \\
261 \\
0 \\
0 \\
0 \\
261 \\
0 \\
0\end{array}$ & $\begin{array}{r}13,568 \\
0 \\
12,489 \\
2,096 \\
0 \\
6,656 \\
3,737 \\
1,079 \\
0\end{array}$ & $\begin{array}{r}438 \\
0 \\
403 \\
68 \\
0 \\
215 \\
121 \\
35 \\
0\end{array}$ \\
\hline 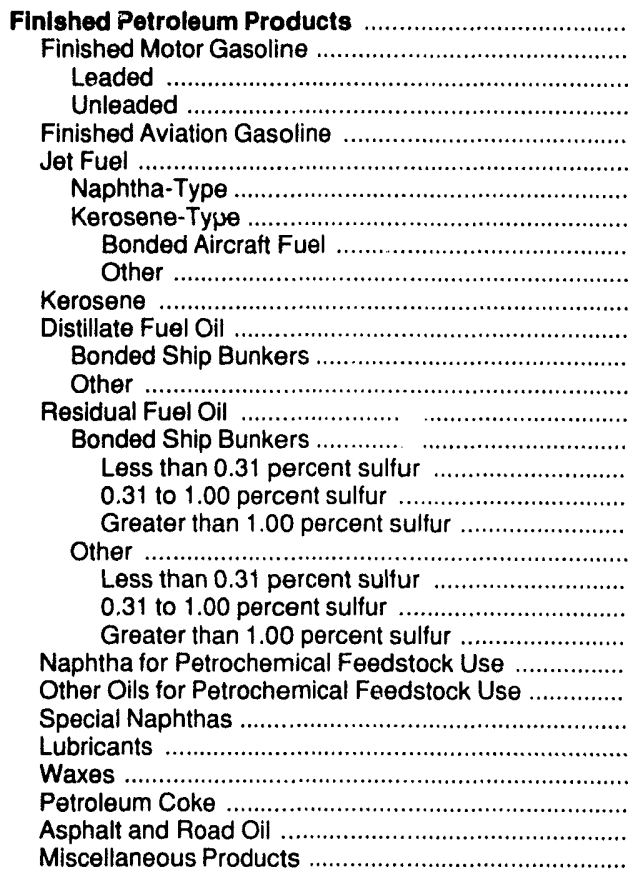 & $\begin{array}{r}32,695 \\
10,855 \\
0 \\
10,855 \\
0 \\
1,938 \\
418 \\
1,520 \\
723 \\
797 \\
21 \\
4,725 \\
0 \\
4,725 \\
13,693 \\
0 \\
0 \\
0 \\
0 \\
13,693 \\
1,922 \\
3,133 \\
8,638 \\
315 \\
0 \\
240 \\
196 \\
13 \\
0 \\
658 \\
41\end{array}$ & $\begin{array}{r}743 \\
302 \\
0 \\
302 \\
0 \\
27 \\
27 \\
0 \\
0 \\
0 \\
0 \\
183 \\
0 \\
183 \\
71 \\
0 \\
0 \\
0 \\
0 \\
71 \\
32 \\
12 \\
27 \\
9 \\
0 \\
82 \\
22 \\
3 \\
0 \\
38 \\
6\end{array}$ & $\begin{array}{r}6,885 \\
0 \\
0 \\
0 \\
0 \\
248 \\
0 \\
248 \\
0 \\
248 \\
0 \\
0 \\
0 \\
0 \\
2,717 \\
0 \\
0 \\
0 \\
0 \\
2,717 \\
630 \\
331 \\
1,756 \\
297 \\
3,328 \\
111 \\
0 \\
4 \\
0 \\
180 \\
0\end{array}$ & $\begin{array}{r}214 \\
62 \\
10 \\
52 \\
0 \\
0 \\
0 \\
0 \\
0 \\
0 \\
0 \\
152 \\
0 \\
152 \\
0 \\
0 \\
0 \\
0 \\
0 \\
0 \\
0 \\
0 \\
0 \\
0 \\
0 \\
0 \\
0 \\
0 \\
0 \\
0 \\
0\end{array}$ & $\begin{array}{r}2,104 \\
729 \\
0 \\
729 \\
0 \\
6 \\
0 \\
6 \\
0 \\
6 \\
0 \\
125 \\
0 \\
125 \\
1,141 \\
0 \\
0 \\
0 \\
0 \\
1,141 \\
205 \\
189 \\
747 \\
71 \\
0 \\
6 \\
0 \\
4 \\
13 \\
9 \\
0\end{array}$ & $\begin{array}{r}42,641 \\
11,948 \\
10 \\
11,938 \\
0 \\
2,219 \\
445 \\
1,774 \\
723 \\
1,051 \\
21 \\
5,185 \\
0 \\
5,185 \\
17,622 \\
0 \\
0 \\
0 \\
0 \\
17,622 \\
2,789 \\
3,665 \\
11,168 \\
692 \\
3,328 \\
439 \\
218 \\
24 \\
13 \\
885 \\
47\end{array}$ & $\begin{array}{r}1,376 \\
385 \\
(s) \\
385 \\
0 \\
72 \\
14 \\
57 \\
23 \\
34 \\
1 \\
167 \\
0 \\
167 \\
568 \\
0 \\
0 \\
0 \\
0 \\
568 \\
90 \\
118 \\
360 \\
22 \\
107 \\
14 \\
7 \\
1 \\
(s) \\
29 \\
2\end{array}$ \\
\hline Total & 82,610 & 42,422 & 129,033 & 3,082 & 10,142 & 267,289 & 8,622 \\
\hline
\end{tabular}


Tatie 34. Year-to-Date Imports of Crude Oll and Petroleum Products by PAD District, January-August 1991

(T!iousand Barrels)

\begin{tabular}{|c|c|c|c|c|c|c|c|}
\hline \multirow{2}{*}{ Commodity } & \multicolumn{6}{|c|}{ Petroleum Administration for Defense Districts } & \multirow{2}{*}{$\begin{array}{c}\text { Daily } \\
\text { Average }\end{array}$} \\
\hline & $\mathbf{I}$ & ॥ & III & IV & $\mathbf{v}$ & Total & \\
\hline 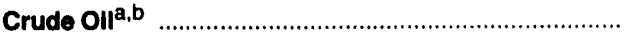 & 300,333 & 273,267 & 782,571 & 18,341 & 47,130 & $1,421,642$ & 5,850 \\
\hline 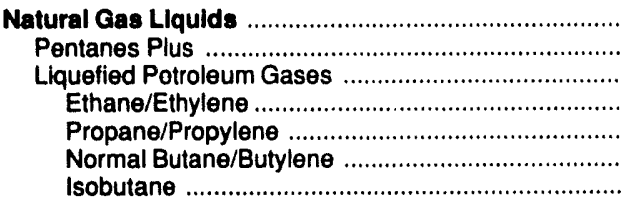 & $\begin{array}{r}4,282 \\
890 \\
3,392 \\
0 \\
3,100 \\
117 \\
175\end{array}$ & $\begin{array}{r}15,468 \\
315 \\
15,153 \\
1,850 \\
10,603 \\
2,209 \\
491\end{array}$ & $\begin{array}{r}11,148 \\
0 \\
11,148 \\
233 \\
5,473 \\
3,554 \\
1,888\end{array}$ & $\begin{array}{r}1,854 \\
535 \\
1,319 \\
0 \\
644 \\
552 \\
123\end{array}$ & $\begin{array}{r}615 \\
0 \\
615 \\
0 \\
343 \\
73 \\
199\end{array}$ & $\begin{array}{r}33,367 \\
1,740 \\
31,627 \\
2,083 \\
20,163 \\
6,505 \\
2,876\end{array}$ & $\begin{array}{r}137 \\
7 \\
130 \\
9 \\
83 \\
27 \\
12\end{array}$ \\
\hline 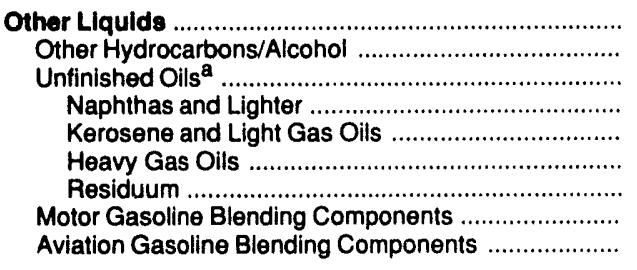 & $\begin{array}{r}44,008 \\
264 \\
35,508 \\
4,237 \\
0 \\
24,626 \\
6,645 \\
8,236 \\
0\end{array}$ & $\begin{array}{r}561 \\
0 \\
0 \\
0 \\
0 \\
0 \\
0 \\
561 \\
0\end{array}$ & $\begin{array}{r}58,175 \\
28 \\
56,565 \\
13,190 \\
0 \\
20,307 \\
23,068 \\
1,582 \\
0\end{array}$ & $\begin{array}{l}0 \\
0 \\
0 \\
0 \\
0 \\
0 \\
0 \\
0 \\
0\end{array}$ & $\begin{array}{r}2,372 \\
308 \\
1,953 \\
410 \\
152 \\
966 \\
425 \\
111 \\
0\end{array}$ & $\begin{array}{r}105,116 \\
600 \\
94,026 \\
17,837 \\
152 \\
45,899 \\
30,138 \\
10,490 \\
0\end{array}$ & $\begin{array}{r}433 \\
2 \\
387 \\
73 \\
1 \\
189 \\
124 \\
43 \\
0\end{array}$ \\
\hline 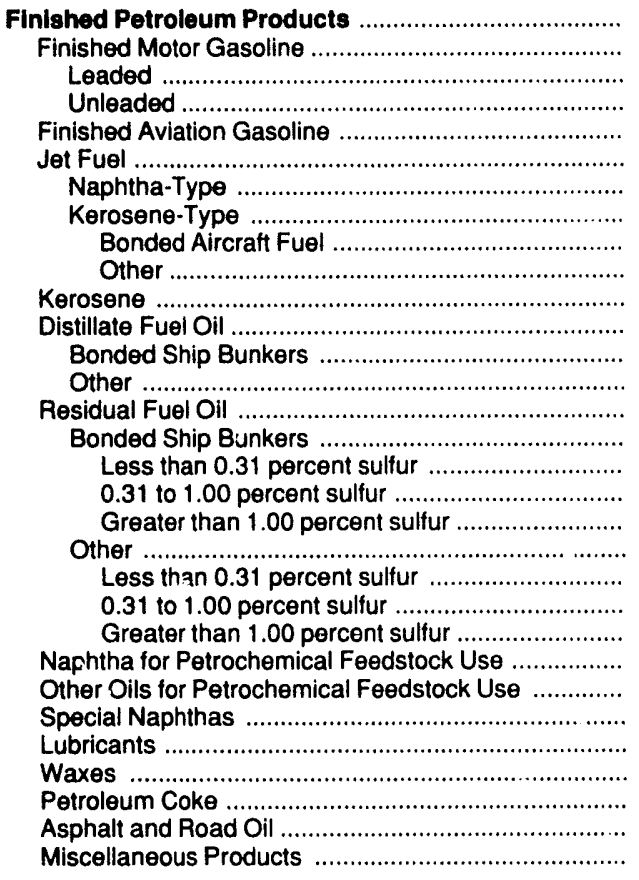 & $\begin{array}{r}223,155 \\
69,204 \\
0 \\
69,204 \\
11 \\
14,879 \\
2,791 \\
12,088 \\
6,910 \\
5,178 \\
976 \\
41,692 \\
116 \\
41,576 \\
86,876 \\
0 \\
0 \\
0 \\
0 \\
86,876 \\
13,022 \\
19,133 \\
54,721 \\
2,096 \\
0 \\
537 \\
1,528 \\
296 \\
0 \\
4,787 \\
273\end{array}$ & $\begin{array}{r}7,385 \\
2,321 \\
0 \\
2,321 \\
11 \\
322 \\
322 \\
0 \\
0 \\
0 \\
0 \\
2,736 \\
0 \\
2.736 \\
649 \\
0 \\
0 \\
0 \\
0 \\
649 \\
150 \\
142 \\
357 \\
239 \\
0 \\
796 \\
158 \\
17 \\
0 \\
90 \\
46\end{array}$ & $\begin{array}{r}\mathbf{4 9 , 5 0 4} \\
756 \\
1 \\
755 \\
0 \\
346 \\
0 \\
346 \\
0 \\
346 \\
87 \\
23 \\
0 \\
23 \\
13,550 \\
0 \\
0 \\
0 \\
0 \\
13,550 \\
2,387 \\
4,653 \\
6,510 \\
3,829 \\
29,058 \\
631 \\
0 \\
22 \\
98 \\
889 \\
215\end{array}$ & $\begin{array}{r}973 \\
311 \\
27 \\
284 \\
0 \\
0 \\
0 \\
0 \\
0 \\
0 \\
0 \\
632 \\
1 \\
631 \\
30 \\
0 \\
0 \\
0 \\
0 \\
30 \\
0 \\
0 \\
30 \\
0 \\
0 \\
0 \\
0 \\
0 \\
0 \\
0 \\
0\end{array}$ & $\begin{array}{r}8,941 \\
2,463 \\
0 \\
2,463 \\
33 \\
903 \\
18 \\
885 \\
776 \\
109 \\
0 \\
699 \\
0 \\
699 \\
4,064 \\
0 \\
0 \\
0 \\
0 \\
4,064 \\
1,327 \\
369 \\
2,368 \\
234 \\
0 \\
57 \\
0 \\
15 \\
320 \\
153 \\
0\end{array}$ & $\begin{array}{r}289,958 \\
75,055 \\
28 \\
75,027 \\
55 \\
16,450 \\
3,131 \\
13,319 \\
7,686 \\
5,633 \\
1,063 \\
45,782 \\
117 \\
45,665 \\
105,169 \\
0 \\
0 \\
0 \\
0 \\
105,169 \\
16,886 \\
24,297 \\
63,986 \\
6,398 \\
29,058 \\
2,021 \\
1,686 \\
350 \\
418 \\
5,919 \\
531\end{array}$ & $\begin{array}{r}1,193 \\
309 \\
(s) \\
309 \\
(s) \\
68 \\
13 \\
55 \\
32 \\
23 \\
4 \\
188 \\
(s) \\
188 \\
433 \\
0 \\
0 \\
0 \\
0 \\
433 \\
69 \\
100 \\
263 \\
26 \\
120 \\
8 \\
7 \\
1 \\
2 \\
24 \\
2\end{array}$ \\
\hline Total & 571,778 & 296,681 & 901,398 & 21,168 & 59,058 & $1,850,083$ & 7,614 \\
\hline
\end{tabular}

${ }^{a}$ Crude oil and unfinished oils are reported by the PAD District in which they are to be processed; all other products are reported by the PAD District of entry. Includes crude oil imported for storage in the Strategic Petroleum Reserve.

(s) = Less than 500 barrels or less than 500 barrels per day.

Note: Totals may not equal sum of components due to independent rounding.

Source: Energy Information Administration (EIA) Form EIA-814, "Monthly Imports Report." 
Table 35. Imports of Crude Oil and Petroleum Products Into the United States by Country of Origin, ${ }^{a}$ August 1991 (Thousand Barrels)

\begin{tabular}{|c|c|c|c|c|c|c|c|c|c|c|}
\hline Country of Origin & $\begin{array}{c}\text { Crude } \\
\text { oulb }\end{array}$ & $\begin{array}{c}\text { Lquefied } \\
\text { Petroleum } \\
\text { Cases }\end{array}$ & $\begin{array}{c}\text { Unfinished } \\
\text { Olls }\end{array}$ & $\begin{array}{c}\text { Gasoline } \\
\text { Blending } \\
\text { Compo- } \\
\text { nonts }\end{array}$ & $\begin{array}{l}\text { Finlahed } \\
\text { Motor } \\
\text { Gasoline }\end{array}$ & Jet Fuel & $\begin{array}{l}\text { Diatllate } \\
\text { Fuel OII }\end{array}$ & $\begin{array}{l}\text { Residual } \\
\text { Fuel Oll }\end{array}$ & Kerosene & $\begin{array}{c}\text { Special } \\
\text { Naphthas }\end{array}$ \\
\hline 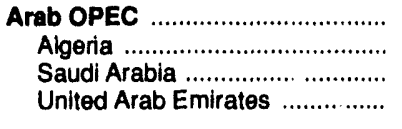 & $\begin{array}{r}61,369 \\
481 \\
60,888 \\
0\end{array}$ & $\begin{array}{r}344 \\
344 \\
0 \\
0\end{array}$ & $\begin{array}{r}1,007 \\
1,007 \\
0 \\
0\end{array}$ & $\begin{array}{l}0 \\
0 \\
0 \\
0\end{array}$ & $\begin{array}{r}1,449 \\
0 \\
1,449 \\
0\end{array}$ & $\begin{array}{r}243 \\
0 \\
243 \\
0\end{array}$ & $\begin{array}{l}0 \\
0 \\
0 \\
0\end{array}$ & $\begin{array}{r}704 \\
475 \\
0 \\
229\end{array}$ & $\begin{array}{l}0 \\
0 \\
0 \\
0\end{array}$ & $\begin{array}{l}0 \\
0 \\
0 \\
0\end{array}$ \\
\hline 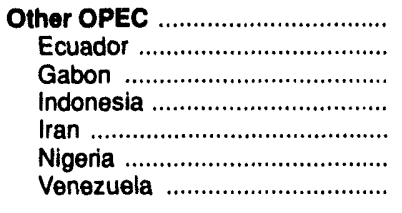 & $\begin{array}{r}60,954 \\
2,869 \\
1,723 \\
2,686 \\
1,484 \\
30,463 \\
21,729\end{array}$ & $\begin{array}{l}0 \\
0 \\
0 \\
0 \\
0 \\
0 \\
0\end{array}$ & $\begin{array}{r}3,390 \\
0 \\
0 \\
0 \\
0 \\
0 \\
3,390\end{array}$ & $\begin{array}{r}180 \\
0 \\
0 \\
0 \\
0 \\
0 \\
180\end{array}$ & $\begin{array}{r}961 \\
0 \\
0 \\
0 \\
0 \\
0 \\
961\end{array}$ & $\begin{array}{r}639 \\
0 \\
0 \\
0 \\
0 \\
0 \\
639\end{array}$ & $\begin{array}{r}2,393 \\
0 \\
0 \\
0 \\
0 \\
0 \\
2,393\end{array}$ & $\begin{array}{r}4,256 \\
593 \\
0 \\
198 \\
0 \\
1,043 \\
2,422\end{array}$ & $\begin{array}{l}0 \\
0 \\
0 \\
0 \\
0 \\
0 \\
0\end{array}$ & $\begin{array}{l}0 \\
0 \\
0 \\
0 \\
0 \\
0 \\
0\end{array}$ \\
\hline 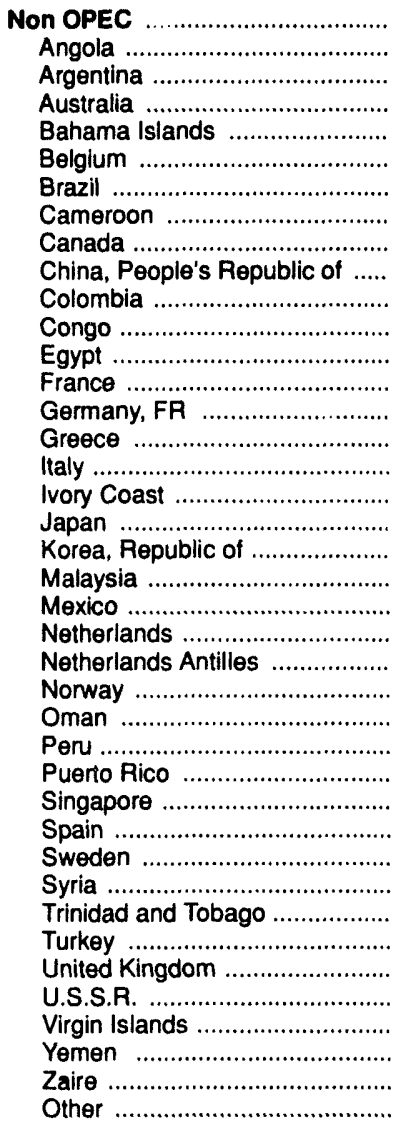 & $\begin{array}{r}84,352 \\
9,242 \\
407 \\
673 \\
0 \\
0 \\
0 \\
2,006 \\
21,282 \\
2,315 \\
5,557 \\
0 \\
700 \\
0 \\
0 \\
0 \\
338 \\
0 \\
0 \\
0 \\
430 \\
24,710 \\
0 \\
0 \\
4,223 \\
0 \\
0 \\
0 \\
0 \\
0 \\
0 \\
592 \\
2,032 \\
0 \\
6,714 \\
717 \\
0 \\
894 \\
1,520 \\
0\end{array}$ & $\begin{array}{r}3,913 \\
0 \\
0 \\
482 \\
0 \\
0 \\
0 \\
0 \\
2,436 \\
0 \\
0 \\
0 \\
0 \\
21 \\
0 \\
0 \\
25 \\
0 \\
6 \\
0 \\
0 \\
929 \\
14 \\
0 \\
0 \\
0 \\
0 \\
0 \\
0 \\
0 \\
0 \\
0 \\
0 \\
0 \\
0 \\
0 \\
0 \\
0 \\
0 \\
0\end{array}$ & $\begin{array}{r}8,092 \\
0 \\
0 \\
0 \\
0 \\
0 \\
0 \\
0 \\
525 \\
0 \\
0 \\
0 \\
0 \\
0 \\
0 \\
0 \\
866 \\
0 \\
0 \\
0 \\
0 \\
210 \\
0 \\
1,144 \\
0 \\
300 \\
0 \\
201 \\
261 \\
932 \\
0 \\
0 \\
0 \\
0 \\
0 \\
1,762 \\
1,570 \\
0 \\
0 \\
321\end{array}$ & $\begin{array}{r}899 \\
0 \\
0 \\
0 \\
0 \\
0 \\
0 \\
0 \\
233 \\
0 \\
0 \\
0 \\
0 \\
238 \\
0 \\
0 \\
0 \\
0 \\
0 \\
0 \\
0 \\
213 \\
85 \\
0 \\
0 \\
0 \\
0 \\
0 \\
0 \\
0 \\
0 \\
0 \\
0 \\
0 \\
0 \\
0 \\
130 \\
0 \\
0 \\
0\end{array}$ & $\begin{array}{r}9,538 \\
0 \\
0 \\
0 \\
0 \\
0 \\
834 \\
0 \\
2,771 \\
305 \\
0 \\
0 \\
0 \\
1,400 \\
195 \\
598 \\
242 \\
0 \\
0 \\
0 \\
0 \\
0 \\
489 \\
417 \\
0 \\
0 \\
0 \\
0 \\
0 \\
551 \\
0 \\
0 \\
0 \\
0 \\
514 \\
0 \\
1,222 \\
0 \\
0 \\
0\end{array}$ & $\begin{array}{r}1,337 \\
0 \\
0 \\
0 \\
0 \\
0 \\
0 \\
0 \\
171 \\
0 \\
0 \\
0 \\
0 \\
0 \\
0 \\
0 \\
0 \\
0 \\
0 \\
0 \\
0 \\
112 \\
0 \\
60 \\
0 \\
0 \\
0 \\
418 \\
0 \\
0 \\
0 \\
0 \\
0 \\
0 \\
0 \\
0 \\
576 \\
0 \\
0 \\
0\end{array}$ & $\begin{array}{r}2,792 \\
0 \\
0 \\
0 \\
0 \\
0 \\
0 \\
0 \\
1,427 \\
0 \\
0 \\
0 \\
0 \\
0 \\
0 \\
0 \\
0 \\
0 \\
0 \\
0 \\
0 \\
0 \\
0 \\
50 \\
0 \\
0 \\
0 \\
0 \\
0 \\
0 \\
0 \\
0 \\
0 \\
0 \\
91 \\
0 \\
1,224 \\
0 \\
0 \\
0\end{array}$ & $\begin{array}{r}12,662 \\
0 \\
0 \\
0 \\
2,410 \\
152 \\
0 \\
0 \\
1,291 \\
0 \\
1,240 \\
194 \\
263 \\
78 \\
230 \\
0 \\
293 \\
180 \\
0 \\
0 \\
0 \\
807 \\
343 \\
1,245 \\
187 \\
0 \\
516 \\
0 \\
7 \\
0 \\
166 \\
0 \\
776 \\
0 \\
559 \\
0 \\
1,725 \\
0 \\
0 \\
0\end{array}$ & $\begin{array}{r}21 \\
0 \\
0 \\
0 \\
0 \\
0 \\
0 \\
0 \\
21 \\
0 \\
0 \\
0 \\
0 \\
0 \\
0 \\
0 \\
0 \\
0 \\
0 \\
0 \\
0 \\
0 \\
0 \\
0 \\
0 \\
0 \\
0 \\
0 \\
0 \\
0 \\
0 \\
0 \\
0 \\
0 \\
0 \\
0 \\
0 \\
0 \\
0 \\
0\end{array}$ & $\begin{array}{r}439 \\
0 \\
0 \\
0 \\
0 \\
0 \\
0 \\
0 \\
213 \\
0 \\
0 \\
0 \\
0 \\
0 \\
0 \\
0 \\
10 \\
0 \\
0 \\
0 \\
0 \\
216 \\
0 \\
0 \\
0 \\
0 \\
0 \\
0 \\
0 \\
0 \\
0 \\
0 \\
0 \\
0 \\
0 \\
0 \\
0 \\
0 \\
0 \\
0\end{array}$ \\
\hline 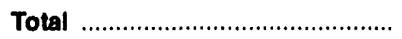 & 206,675 & 4,257 & 12,489 & 1,079 & 11,948 & 2,219 & 5,185 & 17,622 & 21 & 439 \\
\hline
\end{tabular}


Table 35. Imports of Crude Oil and Petroleum Products into the United States by Country of Origin," August 1991 (Continued) (Thousand Barrels)

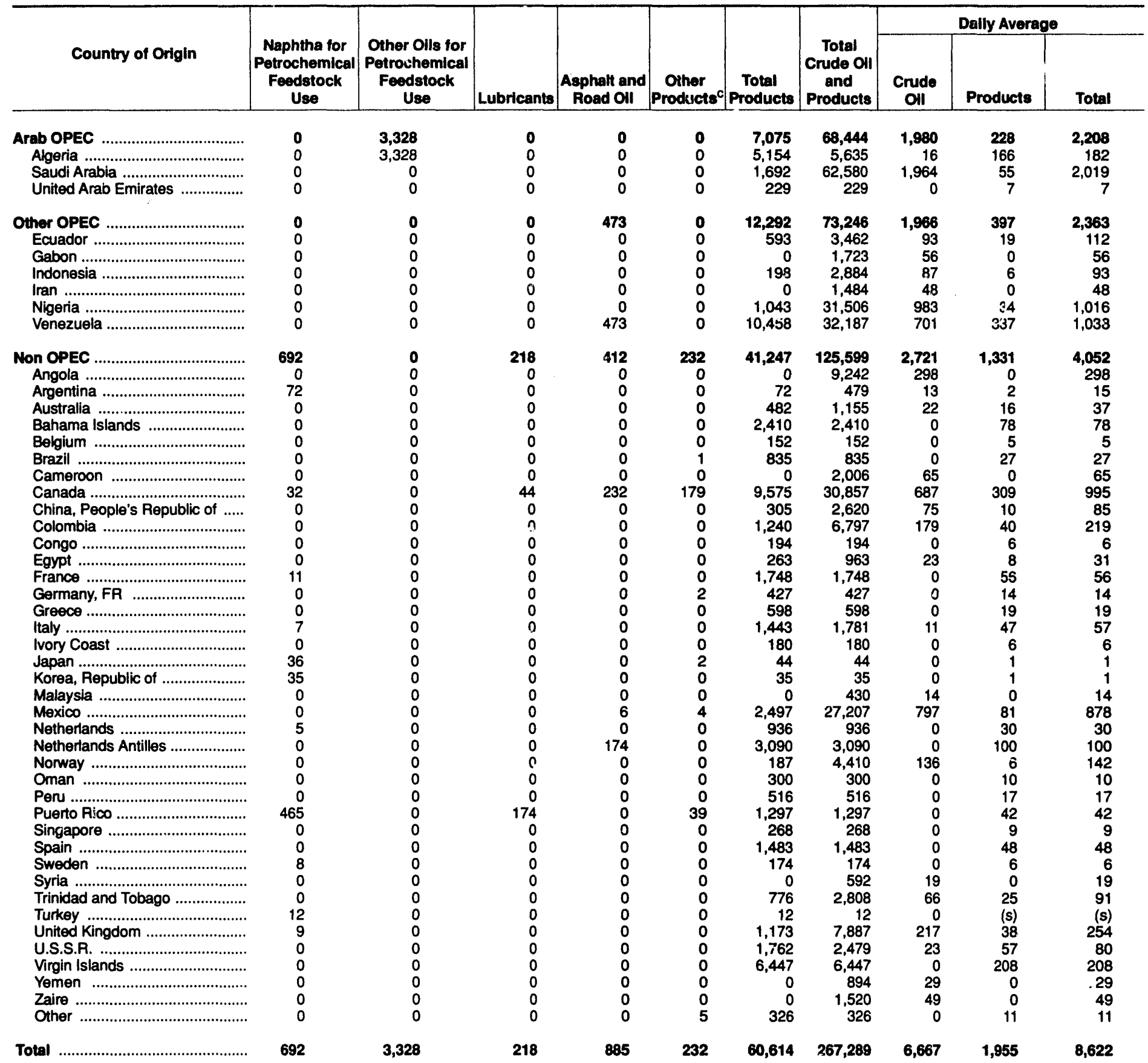

a Crude oil and unfinished oils are reported by the PAD District in which they are to be processed; all other products are reported by the PAD District of entry

b Includes crude oil imported for storage in the Strategic Petroleum Reserve.

c Includes aviation gasoline, aviation gasoline blending components, miscellaneous products, other hydrocarbons and alcohol, pentanes plus, petroleum coke, and waxes.

$(s)=$ Less than 500 barrels or less than 500 barrels per day.

Note: Totals may not equal sum of components due to independent rounding.

Source: Energy Information Administration (EIA) Form EIA-814, "Monthly Imports Report." 
Table 36. PAD District —Imports of Crude Oil and Petroleum Products $b_{3:}$ Country of Origin, ${ }^{a}$ August 1991 (Thousand Barrels)

\begin{tabular}{|c|c|c|c|c|c|c|c|c|c|c|}
\hline Country of Origin & $\begin{array}{c}\text { Crude } \\
\text { Oll }^{b}\end{array}$ & $\begin{array}{c}\text { Liquefiod } \\
\text { Petroleum } \\
\text { Gases }\end{array}$ & $\begin{array}{l}\text { Unfinished } \\
\text { Olls }\end{array}$ & $\begin{array}{c}\text { Gasoline } \\
\text { Blending } \\
\text { Compo- } \\
\text { nents }\end{array}$ & $\begin{array}{l}\text { Finished } \\
\text { Motor } \\
\text { Gasoline }\end{array}$ & Jet Fuel & $\begin{array}{l}\text { Distillate } \\
\text { Fuel Oll }\end{array}$ & $\begin{array}{l}\text { Residual } \\
\text { Fivi Oll }\end{array}$ & Kerosene & $\begin{array}{l}\text { Special } \\
\text { Naphthas }\end{array}$ \\
\hline 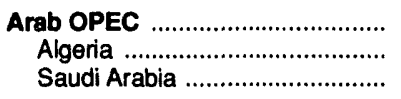 & $\begin{array}{r}8,021 \\
0 \\
8,021\end{array}$ & $\begin{array}{l}0 \\
0 \\
0\end{array}$ & $\begin{array}{r}1,007 \\
1,007 \\
0\end{array}$ & $\begin{array}{l}0 \\
0 \\
0\end{array}$ & $\begin{array}{r}1,449 \\
0 \\
1,449\end{array}$ & $\begin{array}{r}243 \\
0 \\
243\end{array}$ & $\begin{array}{l}\mathbf{0} \\
0 \\
0\end{array}$ & $\begin{array}{r}475 \\
475 \\
0\end{array}$ & $\begin{array}{l}0 \\
0 \\
0\end{array}$ & $\begin{array}{l}0 \\
0 \\
0\end{array}$ \\
\hline 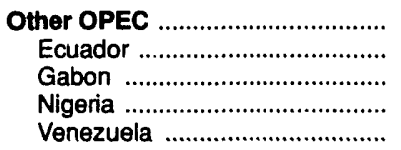 & $\begin{array}{r}20,688 \\
706 \\
190 \\
15,580 \\
4,212\end{array}$ & $\begin{array}{l}0 \\
0 \\
0 \\
0 \\
0\end{array}$ & $\begin{array}{r}844 \\
0 \\
0 \\
0 \\
844\end{array}$ & $\begin{array}{r}180 \\
0 \\
0 \\
0 \\
180\end{array}$ & $\begin{array}{r}961 \\
0 \\
0 \\
0 \\
961\end{array}$ & $\begin{array}{r}639 \\
0 \\
0 \\
0 \\
639\end{array}$ & $\begin{array}{r}2,393 \\
0 \\
0 \\
0 \\
2,393\end{array}$ & $\begin{array}{r}2,179 \\
189 \\
0 \\
706 \\
1,284\end{array}$ & $\begin{array}{l}0 \\
0 \\
0 \\
0 \\
0\end{array}$ & $\begin{array}{l}0 \\
0 \\
0 \\
0 \\
0\end{array}$ \\
\hline 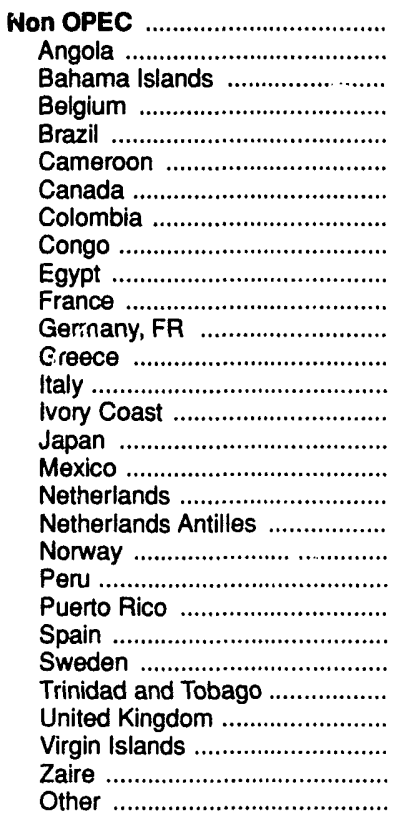 & $\begin{array}{r}13,683 \\
3,819 \\
0 \\
0 \\
0 \\
1,536 \\
2,048 \\
521 \\
0 \\
700 \\
0 \\
0 \\
0 \\
338 \\
0 \\
0 \\
3,378 \\
0 \\
0 \\
0 \\
0 \\
0 \\
0 \\
0 \\
0 \\
994 \\
0 \\
349 \\
0\end{array}$ & $\begin{array}{r}181 \\
0 \\
0 \\
0 \\
0 \\
0 \\
181 \\
0 \\
0 \\
0 \\
0 \\
0 \\
0 \\
0 \\
0 \\
0 \\
0 \\
0 \\
0 \\
0 \\
0 \\
0 \\
0 \\
0 \\
0 \\
0 \\
0 \\
0 \\
0\end{array}$ & $\begin{array}{r}4,606 \\
0 \\
0 \\
0 \\
0 \\
0 \\
0 \\
0 \\
0 \\
0 \\
0 \\
0 \\
0 \\
557 \\
0 \\
0 \\
210 \\
0 \\
815 \\
0 \\
0 \\
201 \\
932 \\
0 \\
0 \\
0 \\
1,570 \\
0 \\
321\end{array}$ & $\begin{array}{r}705 \\
0 \\
0 \\
0 \\
0 \\
0 \\
40 \\
0 \\
0 \\
0 \\
238 \\
0 \\
0 \\
0 \\
0 \\
0 \\
212 \\
85 \\
0 \\
0 \\
0 \\
0 \\
0 \\
0 \\
0 \\
0 \\
130 \\
0 \\
0\end{array}$ & $\begin{array}{r}8,445 \\
0 \\
0 \\
0 \\
834 \\
0 \\
1,983 \\
0 \\
0 \\
0 \\
1,400 \\
195 \\
598 \\
242 \\
0 \\
0 \\
0 \\
489 \\
417 \\
0 \\
0 \\
0 \\
551 \\
0 \\
0 \\
514 \\
1,222 \\
0 \\
0\end{array}$ & $\begin{array}{r}1,056 \\
0 \\
0 \\
0 \\
0 \\
0 \\
138 \\
0 \\
0 \\
0 \\
0 \\
0 \\
0 \\
0 \\
0 \\
0 \\
112 \\
0 \\
60 \\
0 \\
0 \\
418 \\
0 \\
0 \\
0 \\
0 \\
328 \\
0 \\
0\end{array}$ & $\begin{array}{r}2,332 \\
0 \\
0 \\
0 \\
0 \\
0 \\
967 \\
0 \\
0 \\
0 \\
0 \\
0 \\
0 \\
0 \\
0 \\
0 \\
0 \\
0 \\
50 \\
0 \\
0 \\
0 \\
0 \\
0 \\
0 \\
91 \\
1,224 \\
0 \\
0\end{array}$ & $\begin{array}{r}11,039 \\
0 \\
2,280 \\
152 \\
0 \\
0 \\
1,220 \\
1,240 \\
194 \\
263 \\
78 \\
230 \\
0 \\
0 \\
180 \\
0 \\
0 \\
343 \\
1,245 \\
187 \\
516 \\
0 \\
0 \\
166 \\
461 \\
559 \\
1,725 \\
0 \\
0\end{array}$ & $\begin{array}{r}21 \\
0 \\
0 \\
0 \\
0 \\
0 \\
21 \\
0 \\
0 \\
0 \\
0 \\
0 \\
0 \\
0 \\
0 \\
0 \\
0 \\
0 \\
0 \\
0 \\
0 \\
0 \\
0 \\
0 \\
0 \\
0 \\
0 \\
0 \\
0\end{array}$ & $\begin{array}{r}240 \\
0 \\
0 \\
0 \\
0 \\
0 \\
24 \\
0 \\
0 \\
0 \\
0 \\
0 \\
0 \\
0 \\
0 \\
0 \\
216 \\
0 \\
0 \\
0 \\
0 \\
0 \\
0 \\
0 \\
0 \\
0 \\
0 \\
0 \\
0\end{array}$ \\
\hline 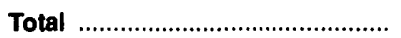 & 42,392 & 181 & 6,457 & 885 & 10,855 & 1,938 & 4,725 & 13,693 & 21 & 240 \\
\hline
\end{tabular}


Table 36. PAD District —Imports of Crude Oil and Petroleum Products by Country of Origin, ${ }^{\text {a }}$ August 1991 (Continued)

(Thousand Barrels)

\begin{tabular}{|c|c|c|c|c|c|c|c|c|c|c|}
\hline \multirow{2}{*}{ Country of Origin } & \multirow{2}{*}{$\begin{array}{c}\text { Naphtha for } \\
\text { Petrochemical } \\
\text { Feedstock } \\
\text { Use }\end{array}$} & \multirow{2}{*}{$\begin{array}{c}\text { Other Olls for } \\
\text { Petrochemical } \\
\text { Feedstock } \\
\text { Use }\end{array}$} & \multirow[b]{2}{*}{ Lubricants } & \multirow[b]{2}{*}{$\begin{array}{c}\text { Asphalt and } \\
\text { Road OII }\end{array}$} & \multirow[b]{2}{*}{$\begin{array}{c}\text { Other } \\
\text { Products }\end{array}$} & \multirow[b]{2}{*}{\begin{tabular}{c|} 
Total \\
Products
\end{tabular}} & \multirow{2}{*}{$\begin{array}{l}\text { Total } \\
\text { Crude OII } \\
\text { and } \\
\text { Products }\end{array}$} & \multicolumn{3}{|c|}{ Dally Average } \\
\hline & & & & & & & & $\begin{array}{c}\text { Crude } \\
\text { Oll }\end{array}$ & Products & Total \\
\hline 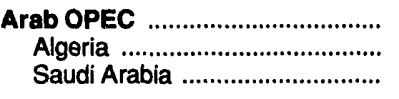 & $\begin{array}{l}0 \\
0 \\
0\end{array}$ & $\begin{array}{l}0 \\
0 \\
0\end{array}$ & $\begin{array}{l}0 \\
0 \\
0\end{array}$ & $\begin{array}{l}0 \\
0 \\
0\end{array}$ & $\begin{array}{l}0 \\
0 \\
0\end{array}$ & $\begin{array}{l}3,174 \\
1,482 \\
1,692\end{array}$ & $\begin{array}{r}11,195 \\
1,482 \\
9,713\end{array}$ & $\begin{array}{r}259 \\
0 \\
259\end{array}$ & $\begin{array}{r}102 \\
48 \\
55\end{array}$ & $\begin{array}{r}361 \\
48 \\
313\end{array}$ \\
\hline 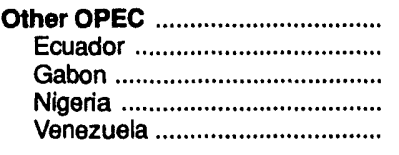 & $\begin{array}{l}0 \\
0 \\
0 \\
0 \\
0\end{array}$ & $\begin{array}{l}0 \\
0 \\
0 \\
0 \\
0\end{array}$ & $\begin{array}{l}0 \\
0 \\
0 \\
0 \\
0\end{array}$ & $\begin{array}{r}473 \\
0 \\
0 \\
0 \\
473\end{array}$ & $\begin{array}{l}0 \\
0 \\
0 \\
0 \\
0\end{array}$ & $\begin{array}{r}7,669 \\
189 \\
0 \\
706 \\
6,774\end{array}$ & $\begin{array}{r}28,357 \\
895 \\
190 \\
16,286 \\
10,986\end{array}$ & $\begin{array}{r}667 \\
23 \\
6 \\
503 \\
136\end{array}$ & $\begin{array}{r}247 \\
6 \\
0 \\
23 \\
219\end{array}$ & $\begin{array}{r}915 \\
29 \\
6 \\
525 \\
354\end{array}$ \\
\hline 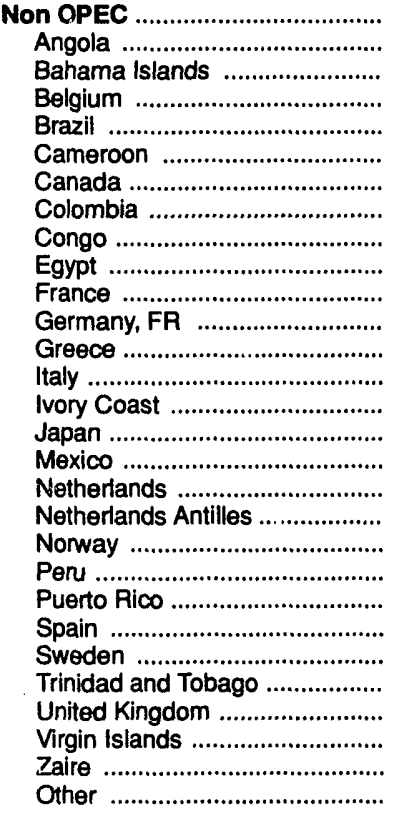 & $\begin{array}{r}315 \\
0 \\
0 \\
0 \\
0 \\
0 \\
4 \\
0 \\
0 \\
0 \\
11 \\
0 \\
0 \\
0 \\
0 \\
0 \\
0 \\
0 \\
0 \\
0 \\
0 \\
300 \\
0 \\
0 \\
0 \\
0 \\
0 \\
0 \\
0\end{array}$ & $\begin{array}{l}0 \\
0 \\
0 \\
0 \\
0 \\
0 \\
0 \\
0 \\
0 \\
0 \\
0 \\
0 \\
0 \\
0 \\
0 \\
0 \\
0 \\
0 \\
0 \\
0 \\
0 \\
0 \\
0 \\
0 \\
0 \\
0 \\
0 \\
0 \\
0\end{array}$ & $\begin{array}{r}196 \\
0 \\
0 \\
0 \\
0 \\
0 \\
22 \\
0 \\
0 \\
0 \\
0 \\
0 \\
0 \\
0 \\
0 \\
0 \\
0 \\
0 \\
0 \\
0 \\
0 \\
174 \\
0 \\
0 \\
0 \\
0 \\
0 \\
0 \\
0\end{array}$ & $\begin{array}{r}185 \\
0 \\
0 \\
0 \\
0 \\
0 \\
185 \\
0 \\
0 \\
0 \\
0 \\
0 \\
0 \\
0 \\
0 \\
0 \\
0 \\
0 \\
0 \\
0 \\
0 \\
0 \\
0 \\
0 \\
0 \\
0 \\
0 \\
0 \\
0\end{array}$ & $\begin{array}{r}54 \\
0 \\
0 \\
0 \\
1 \\
0 \\
9 \\
0 \\
0 \\
0 \\
0 \\
2 \\
0 \\
0 \\
0 \\
2 \\
0 \\
0 \\
0 \\
0 \\
0 \\
39 \\
0 \\
0 \\
0 \\
0 \\
0 \\
0 \\
1\end{array}$ & $\begin{array}{r}29,375 \\
0 \\
2,280 \\
152 \\
835 \\
0 \\
4,794 \\
1,240 \\
194 \\
263 \\
1,727 \\
427 \\
598 \\
799 \\
180 \\
2 \\
750 \\
917 \\
2,587 \\
187 \\
516 \\
1,132 \\
1,483 \\
166 \\
461 \\
1,164 \\
6,199 \\
0 \\
322\end{array}$ & $\begin{array}{r}43,058 \\
3,819 \\
2,280 \\
152 \\
835 \\
1,536 \\
6,842 \\
1,761 \\
194 \\
963 \\
1,727 \\
427 \\
598 \\
1,137 \\
180 \\
2 \\
4,128 \\
917 \\
2,587 \\
187 \\
516 \\
1,132 \\
1,483 \\
166 \\
461 \\
2,158 \\
6,199 \\
349 \\
322\end{array}$ & $\begin{array}{r}441 \\
123 \\
0 \\
0 \\
0 \\
50 \\
66 \\
17 \\
0 \\
23 \\
0 \\
0 \\
0 \\
11 \\
0 \\
0 \\
109 \\
0 \\
0 \\
0 \\
0 \\
0 \\
0 \\
0 \\
0 \\
32 \\
0 \\
11 \\
0\end{array}$ & $\begin{array}{r}948 \\
0 \\
74 \\
5 \\
27 \\
0 \\
155 \\
40 \\
6 \\
8 \\
56 \\
14 \\
19 \\
26 \\
6 \\
(s) \\
24 \\
30 \\
83 \\
6 \\
17 \\
37 \\
48 \\
5 \\
15 \\
38 \\
200 \\
0 \\
10\end{array}$ & $\begin{array}{r}1,389 \\
123 \\
74 \\
5 \\
27 \\
50 \\
221 \\
57 \\
6 \\
31 \\
56 \\
14 \\
19 \\
37 \\
6 \\
(\mathrm{~s}) \\
133 \\
30 \\
83 \\
6 \\
17 \\
37 \\
48 \\
5 \\
15 \\
70 \\
200 \\
11 \\
10\end{array}$ \\
\hline . & 315 & 0 & 196 & 658 & 54 & 40,218 & 82,610 & 1,367 & 1,297 & 2,665 \\
\hline
\end{tabular}

a Crude oil and unfinished oils are reported by the PAD District in which they are to be processed; all other products are reported by the PAD District of entry.

b Includes crude oil imported for storage in the Strategic Petroleum Reserve.

c Includes aviation gasoline, aviation gasoline blending components, miscellaneous products, other hydrocarbons and alcohol, pentanes plus, petroleum coke, and waxes.

(s) = Less than 500 barrels or less than 500 barrels per day.

Note: Totals may not equal sum of components due to independent rounding.

Source: Energy Information Administration (EIA) For.n EIA-814, "Monthly Imports Report." 
Table 37. PAD District II-Imports of Crude Oil and Petroleum Products by Country of Origin, ${ }^{a}$ August 1991 (Thousand Barrels)

\begin{tabular}{|c|c|c|c|c|c|c|c|c|c|c|}
\hline Country of Origin & $\begin{array}{c}\text { Crude } \\
\text { OII }^{b}\end{array}$ & $\begin{array}{c}\text { Lquefied } \\
\text { Petroleum } \\
\text { Gases }\end{array}$ & $\begin{array}{c}\text { Unfinished } \\
\text { Olls }\end{array}$ & $\begin{array}{l}\text { Gasoline } \\
\text { Blending } \\
\text { Compo- } \\
\text { nents }\end{array}$ & $\begin{array}{l}\text { Finished } \\
\text { Motor } \\
\text { Gasoline }\end{array}$ & Jet Fuel & $\begin{array}{l}\text { Distlllate } \\
\text { Fuel Oll }\end{array}$ & $\begin{array}{l}\text { Residual } \\
\text { Fuel Oil }\end{array}$ & Kerosene & $\begin{array}{l}\text { Special } \\
\text { Naphthas }\end{array}$ \\
\hline 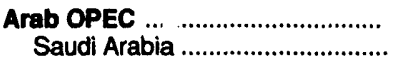 & $\begin{array}{l}4,964 \\
4,964\end{array}$ & $\begin{array}{l}\mathbf{0} \\
\mathbf{0}\end{array}$ & $\begin{array}{l}0 \\
0\end{array}$ & $\begin{array}{l}\mathbf{0} \\
0\end{array}$ & $\begin{array}{l}0 \\
0\end{array}$ & $\begin{array}{l}0 \\
0\end{array}$ & $\begin{array}{l}0 \\
0\end{array}$ & $\begin{array}{l}0 \\
0\end{array}$ & $\begin{array}{l}0 \\
0\end{array}$ & $\begin{array}{l}0 \\
0\end{array}$ \\
\hline 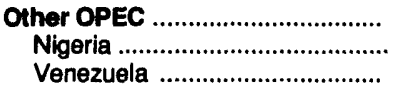 & $\begin{array}{l}8,150 \\
3,521 \\
4,629\end{array}$ & $\begin{array}{l}0 \\
0 \\
0\end{array}$ & $\begin{array}{l}0 \\
0 \\
0\end{array}$ & $\begin{array}{l}0 \\
0 \\
0\end{array}$ & $\begin{array}{l}0 \\
0 \\
0\end{array}$ & $\begin{array}{l}0 \\
0 \\
0\end{array}$ & $\begin{array}{l}0 \\
0 \\
0\end{array}$ & $\begin{array}{l}0 \\
0 \\
0\end{array}$ & $\begin{array}{l}0 \\
0 \\
0\end{array}$ & $\begin{array}{l}0 \\
0 \\
0\end{array}$ \\
\hline 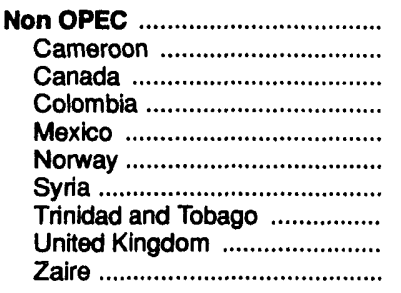 & $\begin{array}{r}26,589 \\
470 \\
16,447 \\
524 \\
4,281 \\
1,047 \\
302 \\
440 \\
2,542 \\
536\end{array}$ & $\begin{array}{r}1,745 \\
0 \\
1,745 \\
0 \\
0 \\
0 \\
0 \\
0 \\
0 \\
0\end{array}$ & $\begin{array}{l}0 \\
0 \\
0 \\
0 \\
0 \\
0 \\
0 \\
0 \\
0 \\
0\end{array}$ & $\begin{array}{r}193 \\
0 \\
193 \\
0 \\
0 \\
0 \\
0 \\
0 \\
0 \\
0\end{array}$ & $\begin{array}{r}302 \\
0 \\
302 \\
0 \\
0 \\
0 \\
0 \\
0 \\
0 \\
0\end{array}$ & $\begin{array}{r}27 \\
0 \\
27 \\
0 \\
0 \\
0 \\
0 \\
0 \\
0 \\
0\end{array}$ & $\begin{array}{r}183 \\
0 \\
183 \\
0 \\
0 \\
0 \\
0 \\
0 \\
0 \\
0\end{array}$ & $\begin{array}{r}71 \\
0 \\
71 \\
0 \\
0 \\
0 \\
0 \\
0 \\
0 \\
0\end{array}$ & $\begin{array}{l}0 \\
0 \\
0 \\
0 \\
0 \\
0 \\
0 \\
0 \\
0 \\
0\end{array}$ & $\begin{array}{r}82 \\
0 \\
82 \\
0 \\
0 \\
0 \\
0 \\
0 \\
0 \\
0\end{array}$ \\
\hline 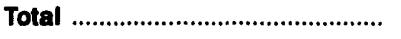 & 39,703 & 1,745 & 0 & 783 & 302 & 27 & 183 & 71 & $\mathbf{0}$ & 82 \\
\hline
\end{tabular}


Table 37. PAD District II-Imports of Crude Oil and Petroleum Products by Country of Origin, ${ }^{a}$ August 1991 (Continued)

(Thousand Barrels)

\begin{tabular}{|c|c|c|c|c|c|c|c|c|c|c|}
\hline \multirow{2}{*}{ Country of Origin } & \multirow{2}{*}{$\begin{array}{l}\text { Naphtha for } \\
\text { Petrochemical } \\
\text { Feedstock } \\
\text { Use }\end{array}$} & \multirow{2}{*}{$\begin{array}{l}\text { Other Olls for } \\
\text { Petrochemical } \\
\text { Feedstock } \\
\text { Use }\end{array}$} & \multirow[b]{2}{*}{ Lubricants } & \multirow[b]{2}{*}{$\begin{array}{l}\text { Asphalt and } \\
\text { Road Oil }\end{array}$} & \multirow[b]{2}{*}{$\begin{array}{c}\text { Other } \\
\text { Products }\end{array}$} & \multirow[b]{2}{*}{ Totrii } & \multirow{2}{*}{$\begin{array}{l}\text { Total } \\
\text { Crude OII } \\
\text { and } \\
\text { Products }\end{array}$} & \multicolumn{3}{|c|}{ Dally Average } \\
\hline & & & & & & & & $\begin{array}{l}\text { Crude } \\
\text { Oll }\end{array}$ & Products & Total \\
\hline Arab OPEC & $\begin{array}{l}0 \\
0\end{array}$ & $\begin{array}{l}0 \\
0\end{array}$ & $\begin{array}{l}0 \\
0\end{array}$ & $\begin{array}{l}0 \\
0\end{array}$ & $\begin{array}{l}0 \\
0\end{array}$ & $\begin{array}{l}0 \\
0\end{array}$ & $\begin{array}{l}4,964 \\
4,964\end{array}$ & $\begin{array}{l}160 \\
160\end{array}$ & $\begin{array}{l}0 \\
0\end{array}$ & $\begin{array}{l}160 \\
160\end{array}$ \\
\hline 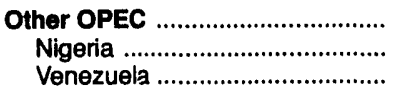 & $\begin{array}{l}0 \\
0 \\
0\end{array}$ & $\begin{array}{l}0 \\
0 \\
0\end{array}$ & $\begin{array}{l}0 \\
0 \\
0\end{array}$ & $\begin{array}{l}0 \\
0 \\
0\end{array}$ & $\begin{array}{l}0 \\
0 \\
0\end{array}$ & $\begin{array}{l}0 \\
0 \\
0\end{array}$ & $\begin{array}{l}8,150 \\
3,521 \\
4,629\end{array}$ & $\begin{array}{l}263 \\
114 \\
149\end{array}$ & $\begin{array}{l}0 \\
0 \\
0\end{array}$ & $\begin{array}{l}263 \\
114 \\
149\end{array}$ \\
\hline 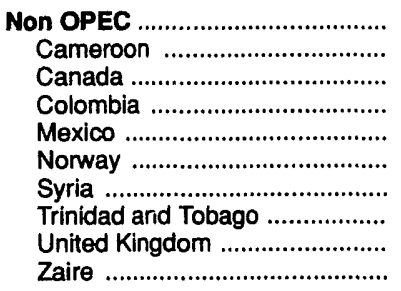 & $\begin{array}{l}9 \\
0 \\
9 \\
0 \\
0 \\
0 \\
0 \\
0 \\
0 \\
0\end{array}$ & $\begin{array}{l}0 \\
0 \\
0 \\
0 \\
0 \\
0 \\
0 \\
0 \\
0 \\
0\end{array}$ & $\begin{array}{r}22 \\
0 \\
22 \\
0 \\
0 \\
0 \\
0 \\
0 \\
0 \\
0\end{array}$ & $\begin{array}{r}38 \\
0 \\
38 \\
0 \\
0 \\
0 \\
0 \\
0 \\
0 \\
0\end{array}$ & $\begin{array}{r}47 \\
0 \\
47 \\
0 \\
0 \\
0 \\
0 \\
0 \\
0 \\
0\end{array}$ & $\begin{array}{r}2,719 \\
0 \\
2,719 \\
0 \\
0 \\
0 \\
0 \\
0 \\
0 \\
0\end{array}$ & $\begin{array}{r}29,308 \\
470 \\
19,166 \\
524 \\
4,281 \\
1,047 \\
302 \\
440 \\
2,542 \\
536\end{array}$ & $\begin{array}{r}858 \\
15 \\
531 \\
17 \\
138 \\
34 \\
10 \\
14 \\
82 \\
17\end{array}$ & $\begin{array}{r}88 \\
0 \\
88 \\
0 \\
0 \\
0 \\
0 \\
0 \\
0 \\
0\end{array}$ & $\begin{array}{r}945 \\
15 \\
618 \\
17 \\
138 \\
34 \\
10 \\
14 \\
82 \\
17\end{array}$ \\
\hline 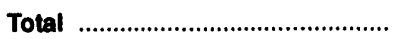 & 9 & 0 & 22 & 38 & 47 & 2,719 & 42,422 & 1,281 & 88 & 1,368 \\
\hline
\end{tabular}

a Crude oil and unfinished oils are reported by the PAD District in which they are to be processed; all other products are reported by the PAD District of entry.

b Includes crude oil imported for storage in the Strategic Petroleum Reserve.

c Includes aviation gasoline, aviation gasoline blending components, miscellaneous products, other hydrocarbons and alcohol, pentanes plus, petroleum coke, and waxes.

$(s)=$ Less than 500 barrels or less than 500 barrels per day.

Note: Totals may not equal sum of components due to independent rounding.

Source: Energy Information Administration (EIA) Form EIA-814, "Monthly Imports Report." 
Table 38. PAD District III-Imports of Crude Oil and Petroleum Products by Country of Origin, ${ }^{a}$ August 1991 (Thousand Barrels)

\begin{tabular}{|c|c|c|c|c|c|c|c|c|c|c|}
\hline Country of Origin & $\begin{array}{c}\text { Crude } \\
\text { Oll }^{b}\end{array}$ & $\begin{array}{c}\text { Liquefied } \\
\text { Petroleum } \\
\text { Gases }\end{array}$ & $\begin{array}{c}\text { Unfinished } \\
\text { Olls }\end{array}$ & $\begin{array}{c}\text { Gasoline } \\
\text { Blending } \\
\text { Compo- } \\
\text { nents }\end{array}$ & $\begin{array}{l}\text { Finished } \\
\text { Motor } \\
\text { Gasoline }\end{array}$ & Jot Fuel & $\begin{array}{l}\text { Distillate } \\
\text { Fuel Oll }\end{array}$ & $\begin{array}{l}\text { Residual } \\
\text { Fuel Oil }\end{array}$ & Kerosene & $\begin{array}{c}\text { Special } \\
\text { Naphthas }\end{array}$ \\
\hline 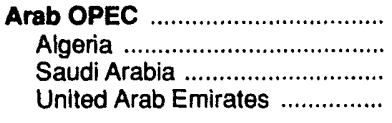 & $\begin{array}{r}47,299 \\
481 \\
46,818 \\
0\end{array}$ & $\begin{array}{r}344 \\
344 \\
0 \\
0\end{array}$ & $\begin{array}{l}0 \\
0 \\
0 \\
0\end{array}$ & $\begin{array}{l}0 \\
0 \\
0 \\
0\end{array}$ & $\begin{array}{l}0 \\
0 \\
0 \\
0\end{array}$ & $\begin{array}{l}0 \\
0 \\
0 \\
0\end{array}$ & $\begin{array}{l}0 \\
0 \\
0 \\
0\end{array}$ & $\begin{array}{r}229 \\
0 \\
0 \\
229\end{array}$ & $\begin{array}{l}0 \\
0 \\
0 \\
0\end{array}$ & $\begin{array}{l}0 \\
0 \\
0 \\
0\end{array}$ \\
\hline 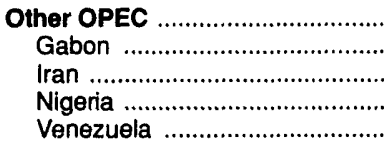 & $\begin{array}{r}26,775 \\
1,533 \\
1,484 \\
11,362 \\
12,396\end{array}$ & $\begin{array}{l}0 \\
0 \\
0 \\
0 \\
0\end{array}$ & $\begin{array}{r}2,546 \\
0 \\
0 \\
0 \\
2,546\end{array}$ & $\begin{array}{l}0 \\
0 \\
0 \\
0 \\
0\end{array}$ & $\begin{array}{l}0 \\
0 \\
0 \\
0 \\
0\end{array}$ & $\begin{array}{l}0 \\
0 \\
0 \\
0 \\
0\end{array}$ & $\begin{array}{l}0 \\
0 \\
0 \\
0 \\
0\end{array}$ & $\begin{array}{r}1,131 \\
0 \\
0 \\
337 \\
794\end{array}$ & $\begin{array}{l}0 \\
0 \\
0 \\
0 \\
0\end{array}$ & $\begin{array}{l}0 \\
0 \\
0 \\
0 \\
0\end{array}$ \\
\hline 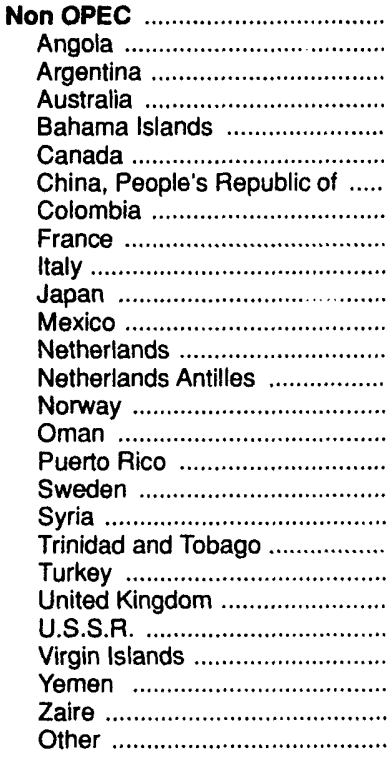 & $\begin{array}{r}40,190 \\
5,423 \\
407 \\
0 \\
0 \\
0 \\
2,315 \\
4,512 \\
0 \\
0 \\
0 \\
17,051 \\
0 \\
0 \\
3,176 \\
0 \\
0 \\
0 \\
290 \\
1,592 \\
0 \\
3,178 \\
717 \\
0 \\
894 \\
635 \\
0\end{array}$ & $\begin{array}{r}1,768 \\
0 \\
0 \\
482 \\
0 \\
291 \\
0 \\
0 \\
21 \\
25 \\
6 \\
929 \\
14 \\
0 \\
0 \\
0 \\
0 \\
0 \\
0 \\
0 \\
0 \\
0 \\
0 \\
0 \\
0 \\
0 \\
0\end{array}$ & $\begin{array}{r}3,225 \\
0 \\
0 \\
0 \\
0 \\
525 \\
0 \\
0 \\
0 \\
309 \\
0 \\
0 \\
0 \\
329 \\
0 \\
300 \\
0 \\
0 \\
0 \\
0 \\
0 \\
0 \\
1,762 \\
0 \\
0 \\
0 \\
0\end{array}$ & $\begin{array}{l}1 \\
0 \\
0 \\
0 \\
0 \\
0 \\
0 \\
0 \\
0 \\
0 \\
0 \\
1 \\
0 \\
0 \\
0 \\
0 \\
0 \\
0 \\
0 \\
0 \\
0 \\
0 \\
0 \\
0 \\
0 \\
0 \\
0\end{array}$ & $\begin{array}{l}0 \\
0 \\
0 \\
0 \\
0 \\
0 \\
0 \\
0 \\
0 \\
0 \\
0 \\
0 \\
0 \\
0 \\
0 \\
0 \\
0 \\
0 \\
0 \\
0 \\
0 \\
0 \\
0 \\
0 \\
0 \\
0 \\
0\end{array}$ & $\begin{array}{r}248 \\
0 \\
0 \\
0 \\
0 \\
0 \\
0 \\
0 \\
0 \\
0 \\
0 \\
0 \\
0 \\
0 \\
0 \\
0 \\
0 \\
0 \\
0 \\
0 \\
0 \\
0 \\
0 \\
248 \\
0 \\
0 \\
0\end{array}$ & $\begin{array}{l}u \\
0 \\
0 \\
0 \\
0 \\
0 \\
0 \\
0 \\
0 \\
0 \\
0 \\
0 \\
0 \\
0 \\
0 \\
0 \\
0 \\
0 \\
0 \\
0 \\
0 \\
0 \\
0 \\
0 \\
0 \\
0 \\
0\end{array}$ & $\begin{array}{r}1,357 \\
0 \\
0 \\
0 \\
130 \\
0 \\
0 \\
0 \\
0 \\
293 \\
0 \\
807 \\
0 \\
0 \\
0 \\
0 \\
0 \\
0 \\
0 \\
127 \\
0 \\
0 \\
0 \\
0 \\
0 \\
0 \\
0\end{array}$ & $\begin{array}{l}0 \\
0 \\
0 \\
0 \\
0 \\
0 \\
0 \\
0 \\
0 \\
0 \\
0 \\
0 \\
0 \\
0 \\
0 \\
0 \\
0 \\
0 \\
0 \\
0 \\
0 \\
0 \\
0 \\
0 \\
0 \\
0 \\
0\end{array}$ & $\begin{array}{r}111 \\
0 \\
0 \\
0 \\
0 \\
101 \\
0 \\
0 \\
0 \\
10 \\
0 \\
0 \\
0 \\
0 \\
0 \\
0 \\
0 \\
0 \\
0 \\
0 \\
0 \\
0 \\
0 \\
0 \\
0 \\
0 \\
0\end{array}$ \\
\hline Total & 114,264 & 2,112 & 5,771 & 1 & 0 & 248 & 0 & 2,717 & $\mathbf{0}$ & 111 \\
\hline
\end{tabular}


Table 38. PAD District II-Imports of Crude Oil and Petroleum Products by Country of Origin, ${ }^{a}$ August 1991 (Continued) (Thousand Barreis)

\begin{tabular}{|c|c|c|c|c|c|c|c|c|c|c|}
\hline \multirow[b]{2}{*}{ Country of Origin } & \multirow[b]{2}{*}{$\begin{array}{c}\text { Naphtha for } \\
\text { Petrochemical } \\
\text { Feedstock } \\
\text { Use }\end{array}$} & \multirow[b]{2}{*}{$\begin{array}{l}\text { Other Qlis for } \\
\text { Petrochemical } \\
\text { Feedstock } \\
\text { Use }\end{array}$} & \multirow[b]{2}{*}{ Lubricants } & \multirow[b]{2}{*}{$\begin{array}{l}\text { Asphalt and } \\
\text { Road OII }\end{array}$} & \multirow[b]{2}{*}{$\begin{array}{c}\text { Other } \\
\text { Products }\end{array}$} & \multirow[b]{2}{*}{$\begin{array}{c}\text { Total } \\
\text { Products }\end{array}$} & \multirow[b]{2}{*}{$\begin{array}{c}\text { Total } \\
\text { Crude OII } \\
\text { and } \\
\text { Products }\end{array}$} & \multicolumn{3}{|c|}{ Daily Average } \\
\hline & & & & & & & & $\begin{array}{c}\text { Crude } \\
\text { Oll }\end{array}$ & Products & Total \\
\hline 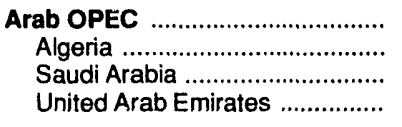 & $\begin{array}{l}0 \\
0 \\
0 \\
0\end{array}$ & $\begin{array}{r}3,328 \\
3,328 \\
0 \\
0\end{array}$ & $\begin{array}{l}0 \\
0 \\
0 \\
0\end{array}$ & $\begin{array}{l}0 \\
0 \\
0 \\
0\end{array}$ & $\begin{array}{l}0 \\
0 \\
0 \\
0\end{array}$ & $\begin{array}{r}3,901 \\
3,672 \\
0 \\
229\end{array}$ & $\begin{array}{r}51,200 \\
4,153 \\
46,818 \\
229\end{array}$ & $\begin{array}{r}1,526 \\
16 \\
1,510 \\
0\end{array}$ & $\begin{array}{r}126 \\
118 \\
0 \\
7\end{array}$ & $\begin{array}{r}1,652 \\
134 \\
1,510 \\
7\end{array}$ \\
\hline 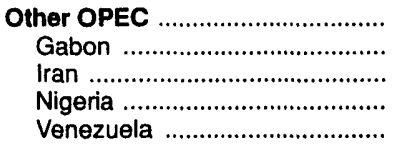 & $\begin{array}{l}0 \\
0 \\
0 \\
0 \\
0\end{array}$ & $\begin{array}{l}0 \\
0 \\
0 \\
0 \\
0\end{array}$ & $\begin{array}{l}0 \\
0 \\
0 \\
0 \\
0\end{array}$ & $\begin{array}{l}0 \\
0 \\
0 \\
0 \\
0\end{array}$ & $\begin{array}{l}0 \\
0 \\
0 \\
0 \\
0\end{array}$ & $\begin{array}{r}3,677 \\
0 \\
0 \\
337 \\
3,340\end{array}$ & $\begin{array}{r}30,452 \\
1,533 \\
1,484 \\
11,699 \\
15,736\end{array}$ & $\begin{array}{r}864 \\
49 \\
48 \\
367 \\
400\end{array}$ & $\begin{array}{r}119 \\
0 \\
0 \\
11 \\
108\end{array}$ & $\begin{array}{r}982 \\
49 \\
48 \\
377 \\
508\end{array}$ \\
\hline 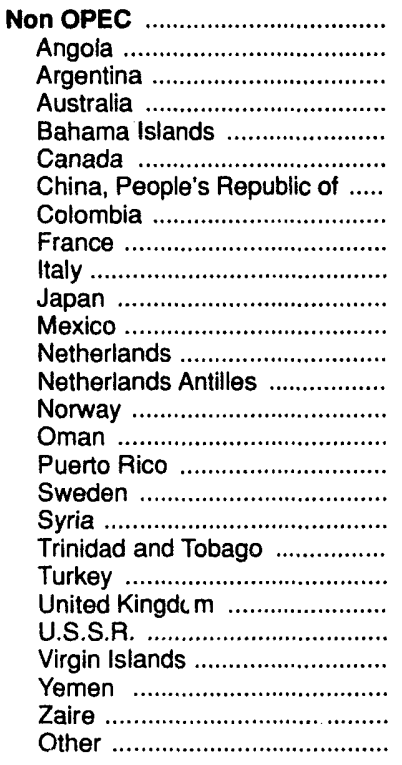 & $\begin{array}{r}297 \\
0 \\
72 \\
0 \\
0 \\
19 \\
0 \\
0 \\
0 \\
7 \\
0 \\
0 \\
5 \\
0 \\
0 \\
0 \\
165 \\
8 \\
0 \\
0 \\
12 \\
9 \\
0 \\
0 \\
0 \\
0 \\
0\end{array}$ & $\begin{array}{l}0 \\
0 \\
0 \\
0 \\
0 \\
0 \\
0 \\
0 \\
0 \\
0 \\
0 \\
0 \\
0 \\
0 \\
0 \\
0 \\
0 \\
0 \\
0 \\
0 \\
0 \\
0 \\
0 \\
0 \\
0 \\
0 \\
0\end{array}$ & $\begin{array}{l}0 \\
0 \\
0 \\
0 \\
0 \\
0 \\
0 \\
0 \\
0 \\
0 \\
0 \\
0 \\
0 \\
0 \\
0 \\
0 \\
0 \\
0 \\
0 \\
0 \\
0 \\
0 \\
0 \\
0 \\
0 \\
0 \\
0\end{array}$ & $\begin{array}{r}180 \\
0 \\
0 \\
0 \\
0 \\
0 \\
0 \\
0 \\
0 \\
0 \\
0 \\
6 \\
0 \\
174 \\
0 \\
0 \\
0 \\
0 \\
0 \\
0 \\
0 \\
0 \\
0 \\
0 \\
0 \\
0 \\
0\end{array}$ & $\begin{array}{l}4 \\
0 \\
0 \\
0 \\
0 \\
0 \\
0 \\
0 \\
0 \\
0 \\
0 \\
0 \\
0 \\
0 \\
0 \\
0 \\
0 \\
0 \\
0 \\
0 \\
0 \\
0 \\
0 \\
0 \\
0 \\
0 \\
4\end{array}$ & $\begin{array}{r}7,191 \\
0 \\
72 \\
482 \\
130 \\
936 \\
0 \\
0 \\
21 \\
644 \\
6 \\
1,743 \\
19 \\
503 \\
0 \\
300 \\
165 \\
8 \\
0 \\
127 \\
12 \\
9 \\
1,762 \\
248 \\
0 \\
0 \\
4\end{array}$ & $\begin{array}{r}47,381 \\
5,423 \\
479 \\
482 \\
130 \\
936 \\
2,315 \\
4,512 \\
21 \\
644 \\
6 \\
18,794 \\
19 \\
503 \\
3,176 \\
300 \\
165 \\
8 \\
290 \\
1,719 \\
12 \\
3,187 \\
2,479 \\
248 \\
894 \\
635 \\
4\end{array}$ & $\begin{array}{r}1,296 \\
175 \\
13 \\
0 \\
0 \\
0 \\
75 \\
146 \\
0 \\
0 \\
0 \\
550 \\
0 \\
0 \\
102 \\
0 \\
0 \\
0 \\
9 \\
51 \\
0 \\
103 \\
23 \\
0 \\
29 \\
20 \\
0\end{array}$ & $\begin{array}{r}232 \\
0 \\
2 \\
16 \\
4 \\
30 \\
0 \\
0 \\
1 \\
21 \\
(s) \\
56 \\
1 \\
16 \\
0 \\
10 \\
5 \\
(s) \\
0 \\
4 \\
(s) \\
(s) \\
57 \\
8 \\
0 \\
0 \\
(s)\end{array}$ & $\begin{array}{r}1,528 \\
175 \\
15 \\
16 \\
4 \\
30 \\
75 \\
146 \\
1 \\
21 \\
(s) \\
606 \\
1 \\
16 \\
102 \\
10 \\
5 \\
(s) \\
9 \\
55 \\
(s) \\
103 \\
80 \\
8 \\
29 \\
20 \\
(s)\end{array}$ \\
\hline Total & 297 & 3,328 & 0 & 180 & 4 & 14,769 & 129,033 & 3,686 & 476 & 4,162 \\
\hline
\end{tabular}

a Crude oil and unfinished oils are reported by the PAD District in which they are to be processed; all other products are reported by the PAD District of entry

b Includes crude oil imported for storage in the Strategic Petroleum Reserve.

c Includes aviation gasoline, aviation gasoline blending components, miscellaneous products, other hydrucarbons and alcohol, pentanes plus, petroleum coke, and waxes.

$(s)=$ l.ess than 500 barrels or less than 500 barrels per day.

Note: Totals may not equal sum of components due to independent rounding.

Source: Energy Information Administration (EIA) FormI EIA-814, "Monthly Imports Report." 

Table 39. PAD Districts IV and V-Imports of Crude Oil and Petroleum Products by Country of Origin,a
August 1991 (Thousand Barrels)

\begin{tabular}{|c|c|c|c|c|c|c|c|c|c|c|}
\hline Country of Origin & $\underset{\text { Oll }^{b}}{\text { Crude }}$ & $\begin{array}{c}\text { Liquefied } \\
\text { Petroleum } \\
\text { Gases }\end{array}$ & $\begin{array}{l}\text { Unfinished } \\
\text { Olls }\end{array}$ & $\begin{array}{c}\text { Gasollne } \\
\text { Blending } \\
\text { Compo- } \\
\text { nents }\end{array}$ & $\begin{array}{l}\text { Flnished } \\
\text { Motor } \\
\text { Gasoline }\end{array}$ & Jet Fuel & $\begin{array}{l}\text { Distillate } \\
\text { Fuel OIl }\end{array}$ & $\begin{array}{l}\text { Residual } \\
\text { Fuel Oll }\end{array}$ & Kerosene & $\begin{array}{c}\text { Special } \\
\text { Naphthas }\end{array}$ \\
\hline
\end{tabular}

PAD District IV

\begin{tabular}{|c|c|c|c|c|c|c|c|c|c|c|}
\hline $\begin{array}{r}\text { Non OPEC } \\
\text { Canada }\end{array}$ & $\begin{array}{l}2,561 \\
2,561\end{array}$ & $\begin{array}{l}197 \\
197\end{array}$ & $\begin{array}{l}0 \\
0\end{array}$ & $\begin{array}{l}0 \\
0\end{array}$ & $\begin{array}{l}62 \\
62\end{array}$ & $\begin{array}{l}0 \\
0\end{array}$ & $\begin{array}{l}152 \\
152\end{array}$ & $\begin{array}{l}0 \\
0\end{array}$ & $\begin{array}{l}0 \\
0\end{array}$ & $\begin{array}{l}0 \\
0\end{array}$ \\
\hline Total & 2,561 & 197 & $\mathbf{0}$ & $\mathbf{0}$ & 62 & 0 & 152 & 0 & 0 & \\
\hline
\end{tabular}

PAD District V

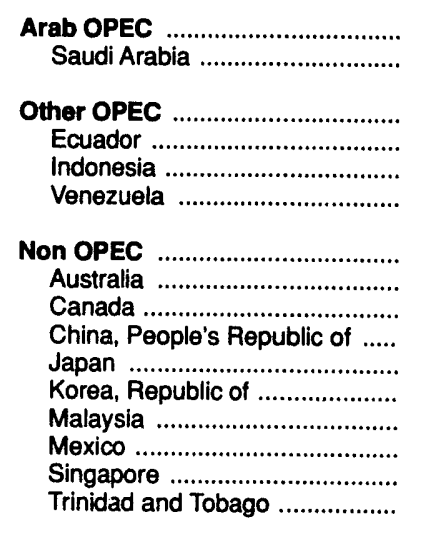

Total

\begin{tabular}{|c|c|}
\hline $\begin{array}{l}1,085 \\
1,085\end{array}$ & $\begin{array}{l}0 \\
0\end{array}$ \\
\hline $\begin{array}{r}5,341 \\
2,163 \\
2,686 \\
492\end{array}$ & $\begin{array}{l}0 \\
0 \\
0 \\
0\end{array}$ \\
\hline $\begin{array}{r}1,329 \\
673 \\
226 \\
0 \\
0 \\
0 \\
430 \\
0 \\
0 \\
0\end{array}$ & $\begin{array}{r}22 \\
0 \\
22 \\
0 \\
0 \\
0 \\
0 \\
0 \\
0 \\
0\end{array}$ \\
\hline 7,755 & 22 \\
\hline
\end{tabular}

$\begin{array}{rll}0 & 0 \\ 0 & 0 & \\ 0 & 0 & \\ 0 & 0 & \\ 0 & 0 & \\ 0 & 0 & \\ 261 & 0 & \\ 0 & 0 & 729 \\ 0 & 0 & 424 \\ 0 & 0 & 30 \\ 0 & 0 & \\ 0 & 0 & \\ 0 & 0 & \\ 0 & 0 & \\ 261 & 0 & \\ 0 & 0 & \\ 261 & 0 & 729\end{array}$

$\begin{array}{rr}0 & 0 \\ 0 & 0 \\ 0 & 0 \\ 0 & 0 \\ 0 & 0 \\ 0 & 0 \\ 729 & 6 \\ 0 & 0 \\ 424 & 6 \\ 305 & 0 \\ 0 & 0 \\ 0 & 0 \\ 0 & 0 \\ 0 & 0 \\ 0 & 0 \\ 0 & 0 \\ 729 & 6\end{array}$

0
0
0
0
0
0
6
0
6
0
0
0
0
0
0
0
6

0
0
0
0
0
0

125
0
125
0
0
0
0
0
0
0

0
0
946
404
198
344

195
0
0
0
0
0
0
0
7
188
1,141


Table 39. PAD Districts IV and V_Imports of Crude Oil and Petroleum Products by Country of Origin, ${ }^{a}$ August 1991 (Continued) (Thousand Barrels)

\begin{tabular}{|c|c|c|c|c|c|c|c|c|c|c|}
\hline \multirow[b]{2}{*}{ Country of Origin } & \multirow[b]{2}{*}{$\begin{array}{c}\text { Naphtha for } \\
\text { Petrochemical } \\
\text { Feedstock } \\
\text { Use }\end{array}$} & \multirow[b]{2}{*}{$\begin{array}{l}\text { Other Olls for } \\
\text { Petrochemical } \\
\text { Feedstock } \\
\text { Use }\end{array}$} & \multirow[b]{2}{*}{ Lubricants } & \multirow[b]{2}{*}{$\begin{array}{l}\text { Asphalt and } \\
\text { Road OII }\end{array}$} & \multirow[b]{2}{*}{$\begin{array}{c}\text { Other } \\
\text { Products }\end{array}$} & \multirow[b]{2}{*}{$\begin{array}{c}\text { Total } \\
\text { Products }\end{array}$} & \multirow[b]{2}{*}{$\begin{array}{c}\text { Total } \\
\text { Crude OII } \\
\text { and } \\
\text { Products }\end{array}$} & \multicolumn{3}{|c|}{ Dally Average } \\
\hline & & & & & & & & $\begin{array}{c}\text { Crude } \\
\text { Oll }\end{array}$ & Products & Total \\
\hline
\end{tabular}

PAD District iv

\begin{tabular}{|c|c|c|c|c|c|c|c|c|c|c|}
\hline Non OPEC & $\begin{array}{l}\mathbf{0} \\
0\end{array}$ & $\begin{array}{l}\mathbf{0} \\
0\end{array}$ & $\begin{array}{l}0 \\
0\end{array}$ & $\begin{array}{l}0 \\
0\end{array}$ & $\begin{array}{l}110 \\
110\end{array}$ & $\begin{array}{l}\mathbf{5 2 1} \\
\mathbf{5 2 1}\end{array}$ & $\begin{array}{l}3,082 \\
3,082\end{array}$ & $\begin{array}{l}83 \\
83\end{array}$ & $\begin{array}{l}17 \\
17\end{array}$ & $\begin{array}{l}99 \\
99\end{array}$ \\
\hline Total & $\mathbf{0}$ & $\mathbf{0}$ & $\mathbf{0}$ & $\mathbf{0}$ & 110 & 521 & 3,082 & 83 & 17 & 99 \\
\hline
\end{tabular}

PAD District V

\begin{tabular}{|c|c|c|c|c|c|c|c|c|c|c|}
\hline 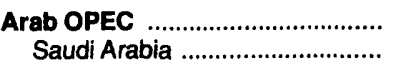 & $\begin{array}{l}0 \\
0\end{array}$ & $\begin{array}{l}0 \\
0\end{array}$ & $\begin{array}{l}0 \\
0\end{array}$ & $\begin{array}{l}0 \\
0\end{array}$ & $\begin{array}{l}0 \\
0\end{array}$ & $\begin{array}{l}0 \\
0\end{array}$ & $\begin{array}{l}1,085 \\
1,085\end{array}$ & $\begin{array}{l}35 \\
35\end{array}$ & $\begin{array}{l}0 \\
0\end{array}$ & $\begin{array}{l}35 \\
35\end{array}$ \\
\hline 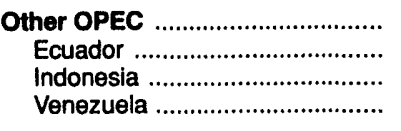 & $\begin{array}{l}0 \\
0 \\
0 \\
0\end{array}$ & $\begin{array}{l}0 \\
0 \\
0 \\
0\end{array}$ & $\begin{array}{l}0 \\
0 \\
0 \\
0\end{array}$ & $\begin{array}{l}0 \\
0 \\
0 \\
0\end{array}$ & $\begin{array}{l}0 \\
0 \\
0 \\
0\end{array}$ & $\begin{array}{l}946 \\
404 \\
198 \\
344\end{array}$ & $\begin{array}{r}6,287 \\
2,567 \\
2,884 \\
836\end{array}$ & $\begin{array}{r}172 \\
70 \\
87 \\
16\end{array}$ & $\begin{array}{r}31 \\
13 \\
6 \\
11\end{array}$ & $\begin{array}{r}203 \\
83 \\
93 \\
27\end{array}$ \\
\hline 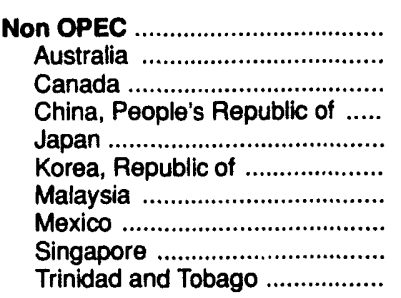 & $\begin{array}{r}71 \\
0 \\
0 \\
0 \\
36 \\
35 \\
0 \\
0 \\
0 \\
0\end{array}$ & $\begin{array}{l}0 \\
0 \\
0 \\
0 \\
0 \\
0 \\
0 \\
0 \\
0 \\
0\end{array}$ & $\begin{array}{l}0 \\
0 \\
0 \\
0 \\
0 \\
0 \\
0 \\
0 \\
0 \\
0\end{array}$ & $\begin{array}{l}9 \\
0 \\
9 \\
0 \\
0 \\
0 \\
0 \\
0 \\
0 \\
0\end{array}$ & $\begin{array}{r}17 \\
0 \\
13 \\
0 \\
0 \\
0 \\
0 \\
4 \\
0 \\
0\end{array}$ & $\begin{array}{r}1,441 \\
0 \\
605 \\
305 \\
36 \\
35 \\
0 \\
4 \\
268 \\
188\end{array}$ & $\begin{array}{r}2,770 \\
673 \\
831 \\
305 \\
36 \\
35 \\
430 \\
4 \\
268 \\
188\end{array}$ & $\begin{array}{r}43 \\
22 \\
7 \\
0 \\
0 \\
0 \\
14 \\
0 \\
0 \\
0\end{array}$ & $\begin{array}{r}46 \\
0 \\
20 \\
10 \\
1 \\
1 \\
0 \\
(s) \\
9 \\
6\end{array}$ & $\begin{array}{r}89 \\
22 \\
27 \\
10 \\
1 \\
1 \\
14 \\
(s) \\
9 \\
6\end{array}$ \\
\hline Total & 71 & 0 & $\mathbf{0}$ & 9 & 17 & 2,387 & 10,142 & 250 & 77 & 327 \\
\hline
\end{tabular}

a Crude oil and unfinished oils are reported by the PAD District in which they are to be processed; all other products are reported by the PAD District of entry.

b Includes crude oil importeri for storage in the Strategic Petroleum Reserve.

c Includes aviation gasoline, aviation gasoline blending components, miscellaneous products, other hydrocarbons and alcohol, pentanes plus, petroleum coke, and waxes.

$(s)=$ Less than 500 barrels or less than 500 barrels per day.

Note: Totals may not equal sum of components due to independent rounding.

Source: Energy Information Administration (EIA) Form EIA-814, "Monthly Imports Report." 
Table 40. Year-to-Date Imports of Crude Oil and Petroleum Products into the United States by Country of Origin, ${ }^{a}$ January-August 1991 (Thousand Barrels)

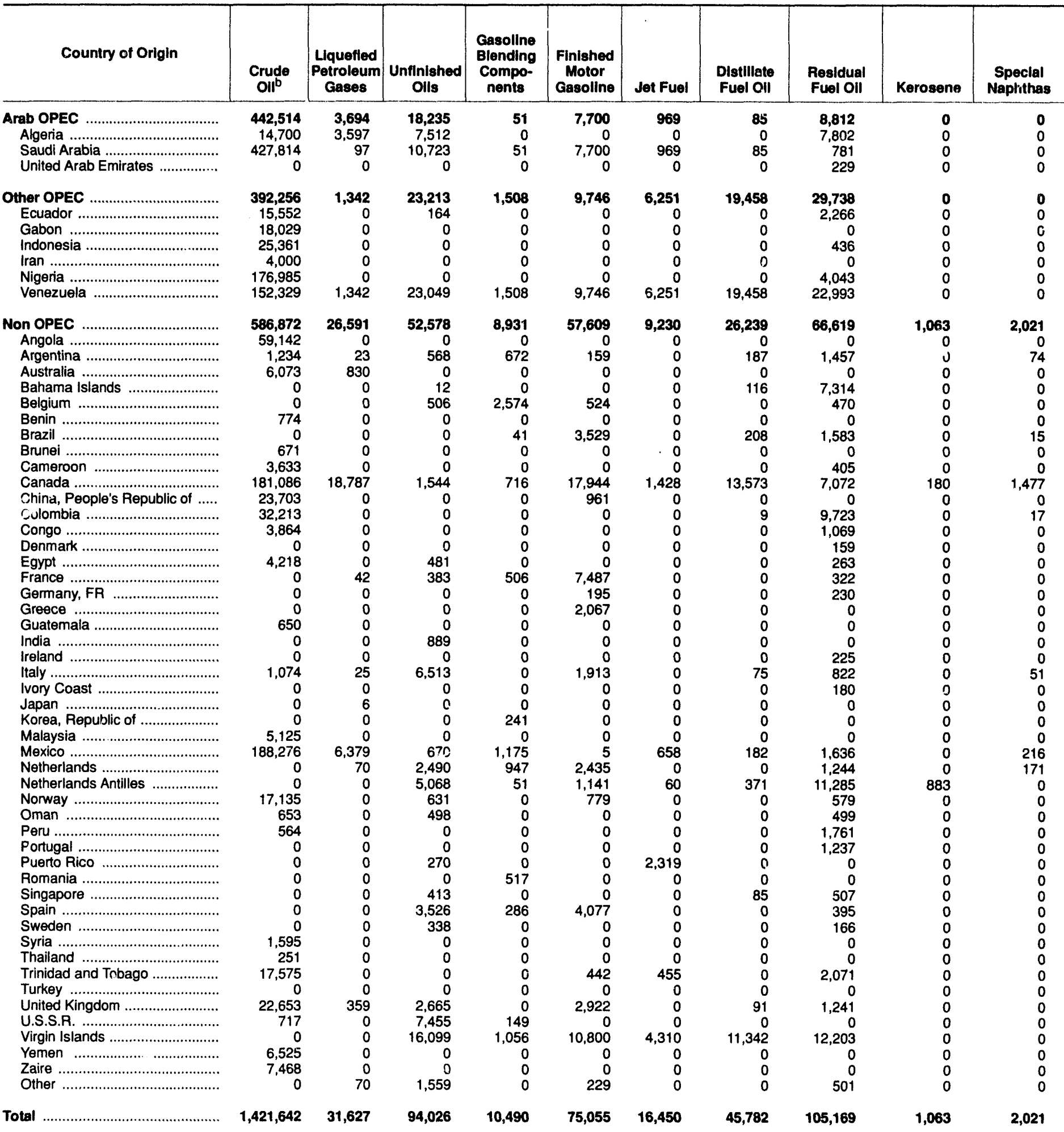

See footnotes at end of table. 
Table 40. Year-to-Date Imports of Crude Oil and Petroleum Products into the United States by Country of Origin, January-August 1991 (Continued) (Thousand Barrels)

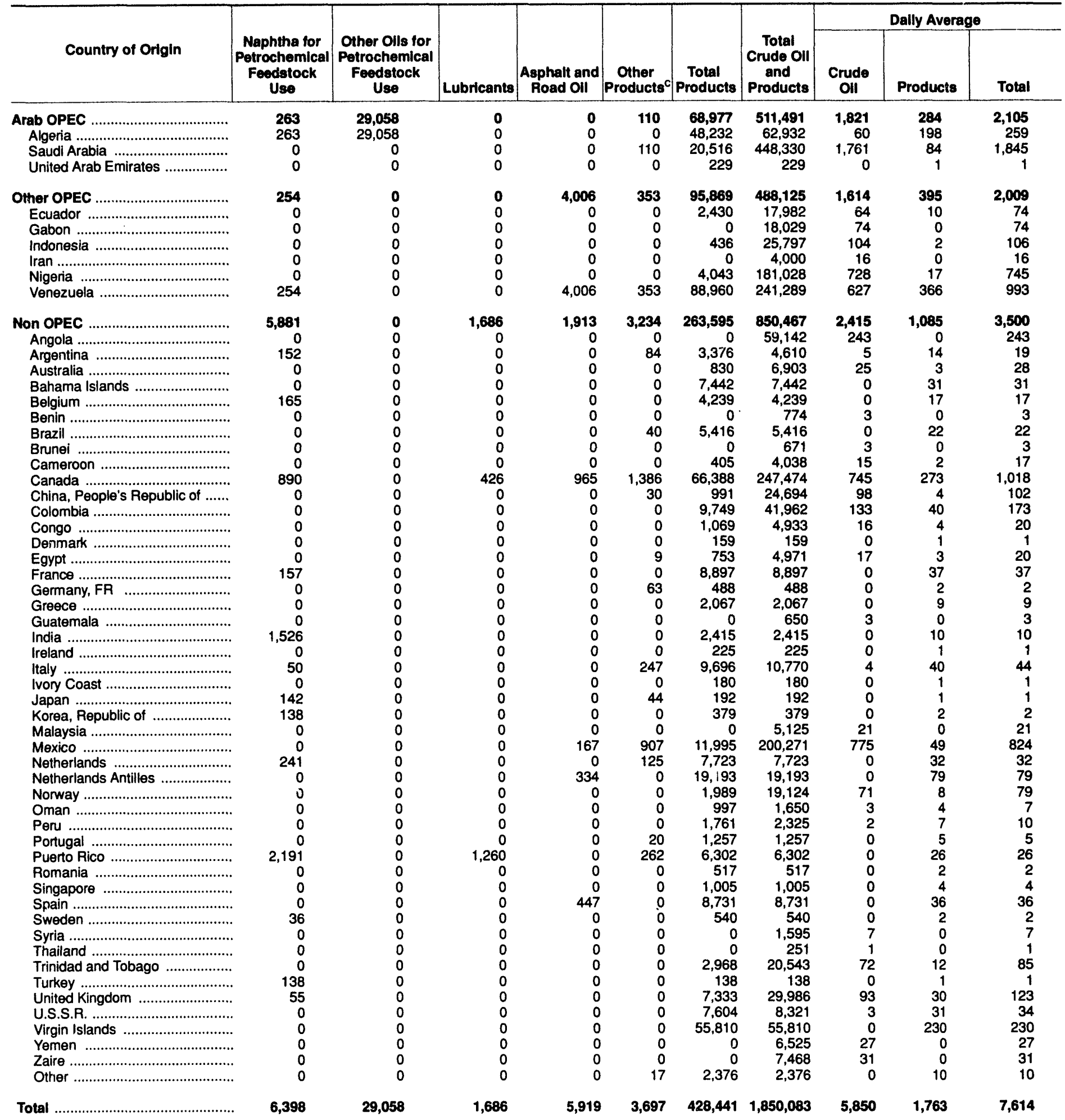

a Crude oil and unfinished oils are reported by the PAD District in which they are to be processed; all other products are reported by the PAD District of entry.

b Includes crude oil imported for storage in the Strategic Petroleum Reserve.

c Includes aviation gasoline, aviation gasoline blending components, miscellaneous products, other hydrocarbons and alcohol, pentanes plus, petroleum coke, and waxes.

(s) $=$ Less than 500 barrels or less than 500 barrels per day.

Note: Totals may not equal sum of components due to independent rounding.

Source: Energy Information Administration (EIA) Form EIA-814, "Monthly Imports Report." 
Table 41. PAD District —Year-to-Date Imports of Crude Oil and Petroleum Products by Country of Origin, ${ }^{a}$ January-August 1991 (Th,ousand Barrels)

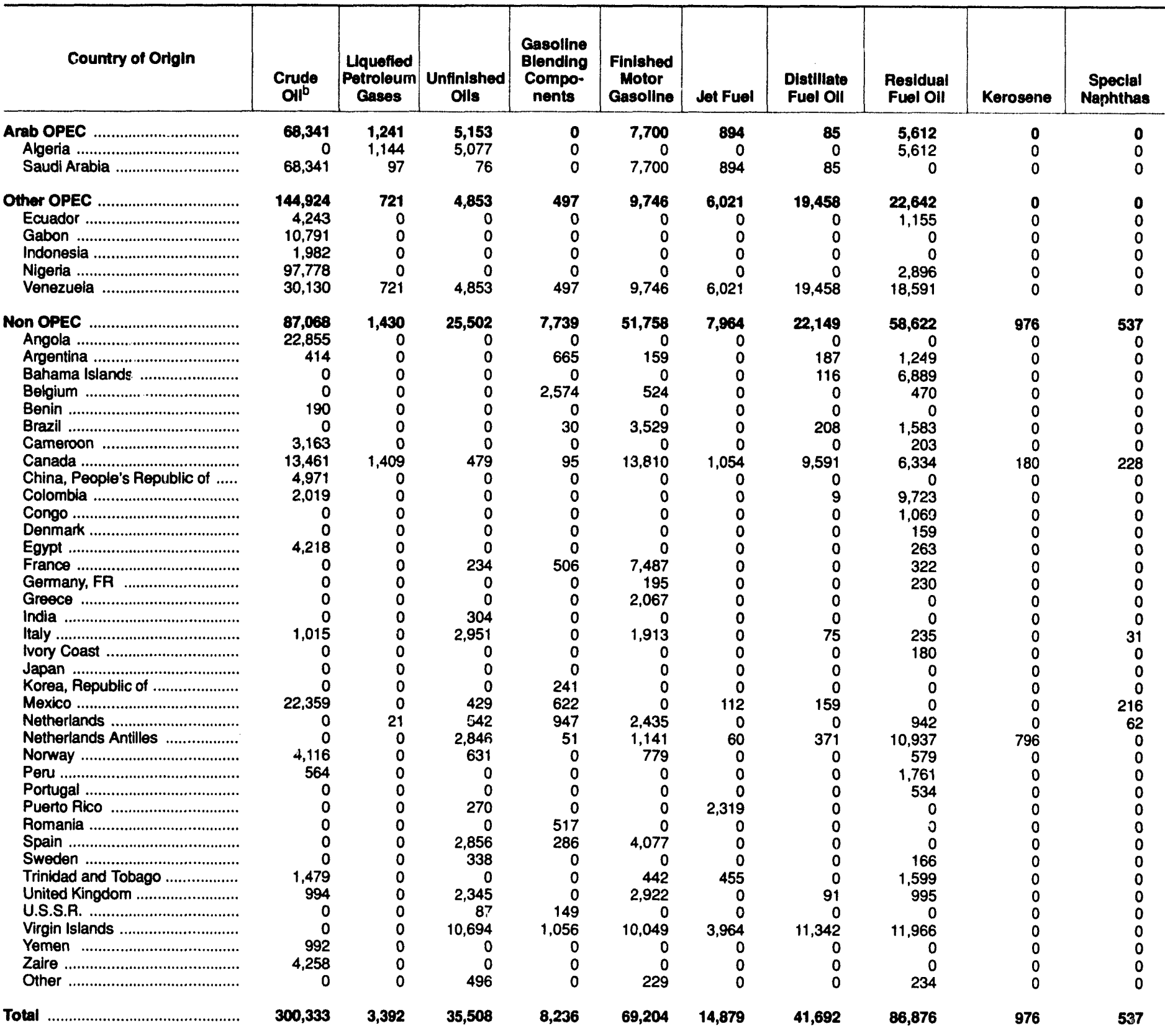

See footnotes at end of table. 
Table 41. PAD District $\vdash$ Year-to-Date Imports of Crude Oil and Petroleum Products by Country of Origin, ${ }^{a}$ January-August 1991 (Continued) (Thousand Barrels)

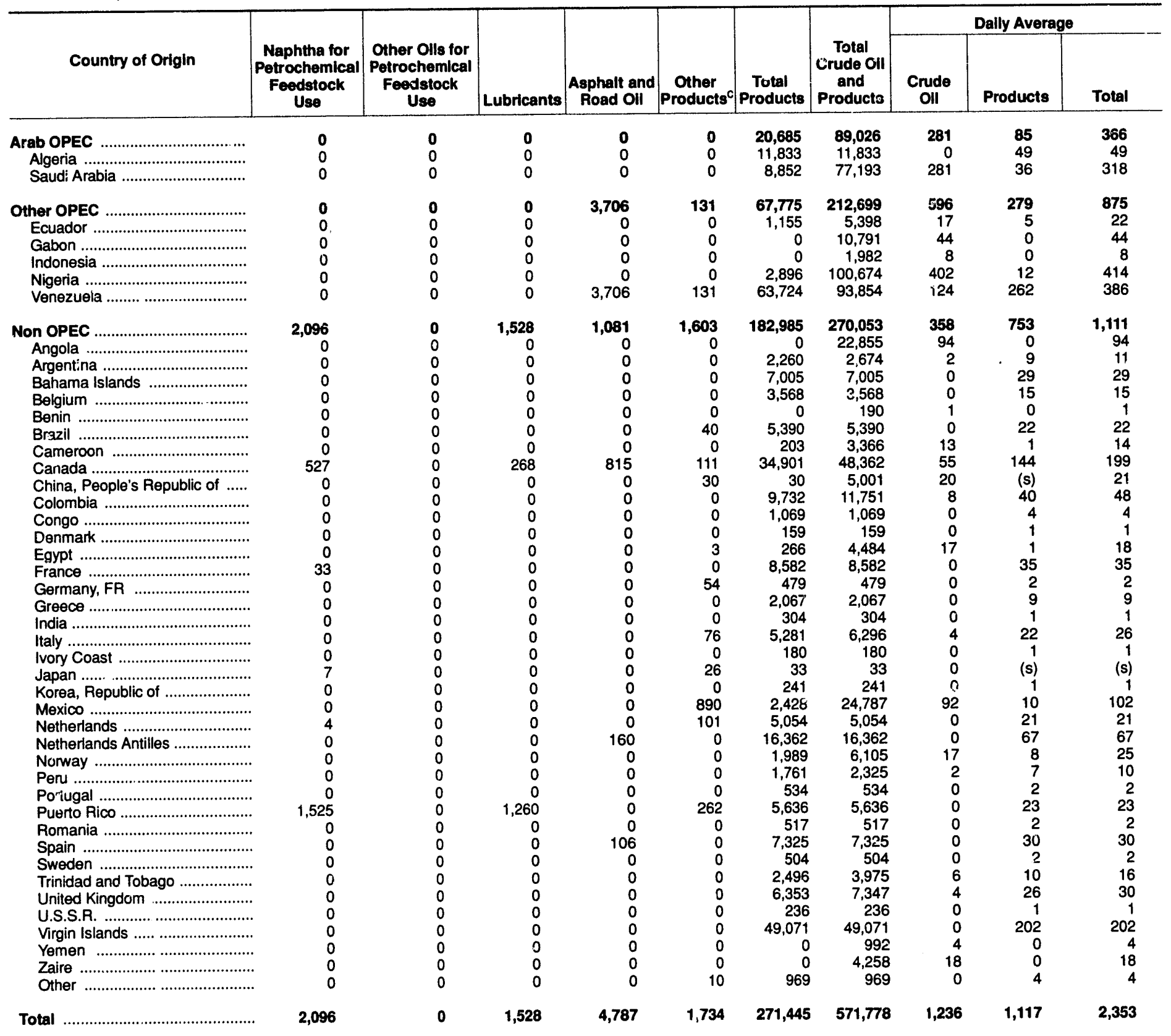

\footnotetext{
a Crude oil and unfinished oils are ; sported by the PAD District in which they are to be processed; all other products are reported by the PAD District of entry.

b Includes crude oil imported for storage in the Strategic Petroleum Reserve.

c includes aviation gasoline, aviation gasoline blending components, miscellaneous products, other hydrocarbons and alcohol, pentanes plus, petroleum coke, and waxes.

(s) = Less than 500 barrels or less than 500 barrels per day.

Note: Totals may not equal sum of components due to independent rounding.

Source: Energy Information Administration (EIA) Form EIA-814, "Monthly Imports Report."
} 
Table 42. PAD District II-Year-to-Date Imports of Crude Oil and Petroleum Products by Country of Origin, ${ }^{a}$ January-August 1991 (Thousand Barrels)

\begin{tabular}{|c|c|c|c|c|c|c|c|c|c|c|}
\hline Country of Origin & $\begin{array}{c}\text { Crude } \\
\text { Oll }^{\mathrm{b}}\end{array}$ & $\begin{array}{c}\text { Liquefied } \\
\text { Petroleum } \\
\text { Gases }\end{array}$ & $\begin{array}{l}\text { Unfinished } \\
\text { Oils }\end{array}$ & $\begin{array}{c}\text { Gasoline } \\
\text { Blending } \\
\text { Compo- } \\
\text { nents }\end{array}$ & $\begin{array}{l}\text { Finished } \\
\text { Motor } \\
\text { Gasoline }\end{array}$ & Jet Fuel & $\begin{array}{l}\text { Distillate } \\
\text { Fuel Oll }\end{array}$ & $\begin{array}{l}\text { Residual } \\
\text { Fuel OII }\end{array}$ & Kerosene & $\begin{array}{l}\text { Special } \\
\text { Naphthas }\end{array}$ \\
\hline 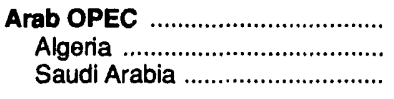 & $\begin{array}{r}41,581 \\
1,180 \\
40,401\end{array}$ & $\begin{array}{l}0 \\
0 \\
0\end{array}$ & $\begin{array}{l}0 \\
0 \\
0\end{array}$ & $\begin{array}{l}0 \\
0 \\
0\end{array}$ & $\begin{array}{l}\mathbf{0} \\
0 \\
0\end{array}$ & $\begin{array}{l}0 \\
0 \\
0\end{array}$ & $\begin{array}{l}\mathbf{0} \\
0 \\
0\end{array}$ & $\begin{array}{l}0 \\
0 \\
0\end{array}$ & $\begin{array}{l}\mathbf{0} \\
0 \\
0\end{array}$ & $\begin{array}{l}0 \\
0 \\
0\end{array}$ \\
\hline 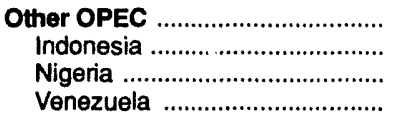 & $\begin{array}{r}39,082 \\
541 \\
12,287 \\
26,254\end{array}$ & $\begin{array}{l}0 \\
0 \\
0 \\
0\end{array}$ & $\begin{array}{l}0 \\
0 \\
0 \\
0\end{array}$ & $\begin{array}{l}0 \\
0 \\
0 \\
0\end{array}$ & $\begin{array}{l}0 \\
0 \\
0 \\
0\end{array}$ & $\begin{array}{l}\mathbf{0} \\
0 \\
0 \\
0\end{array}$ & $\begin{array}{l}0 \\
0 \\
0 \\
0\end{array}$ & $\begin{array}{l}0 \\
0 \\
0 \\
0\end{array}$ & $\begin{array}{l}0 \\
0 \\
0 \\
0\end{array}$ & $\begin{array}{l}0 \\
0 \\
0 \\
0\end{array}$ \\
\hline 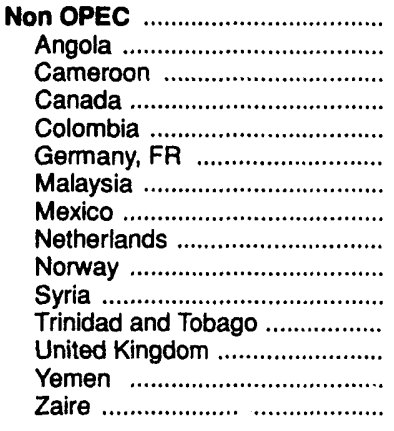 & $\begin{array}{r}192,604 \\
2,867 \\
470 \\
145,502 \\
3,225 \\
0 \\
523 \\
23,863 \\
0 \\
3,281 \\
302 \\
5,373 \\
4,966 \\
1,696 \\
536\end{array}$ & $\begin{array}{r}15,153 \\
0 \\
0 \\
15,153 \\
0 \\
0 \\
0 \\
0 \\
0 \\
0 \\
0 \\
0 \\
0 \\
0 \\
0\end{array}$ & $\begin{array}{l}0 \\
0 \\
0 \\
0 \\
0 \\
0 \\
0 \\
0 \\
0 \\
0 \\
0 \\
0 \\
0 \\
0 \\
0\end{array}$ & $\begin{array}{r}561 \\
0 \\
0 \\
561 \\
0 \\
0 \\
0 \\
0 \\
0 \\
0 \\
0 \\
0 \\
0 \\
0 \\
0\end{array}$ & $\begin{array}{r}2,321 \\
0 \\
0 \\
2,321 \\
0 \\
0 \\
0 \\
0 \\
0 \\
0 \\
0 \\
0 \\
0 \\
0 \\
0\end{array}$ & $\begin{array}{r}322 \\
0 \\
0 \\
322 \\
0 \\
0 \\
0 \\
0 \\
0 \\
0 \\
0 \\
0 \\
0 \\
0 \\
0\end{array}$ & $\begin{array}{r}2,736 \\
0 \\
0 \\
2,736 \\
0 \\
0 \\
0 \\
0 \\
0 \\
0 \\
0 \\
0 \\
0 \\
0 \\
0\end{array}$ & $\begin{array}{r}649 \\
0 \\
0 \\
649 \\
0 \\
0 \\
0 \\
0 \\
0 \\
0 \\
0 \\
0 \\
0 \\
0 \\
0\end{array}$ & $\begin{array}{l}0 \\
0 \\
0 \\
0 \\
0 \\
0 \\
0 \\
0 \\
0 \\
0 \\
0 \\
0 \\
0 \\
0 \\
0\end{array}$ & $\begin{array}{r}796 \\
0 \\
0 \\
796 \\
0 \\
0 \\
0 \\
0 \\
0 \\
0 \\
0 \\
0 \\
0 \\
0 \\
0\end{array}$ \\
\hline 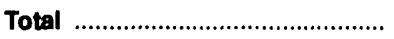 & 273,267 & 15,153 & 0 & 561 & 2,321 & 322 & 2,736 & 649 & $\mathbf{0}$ & 796 \\
\hline
\end{tabular}

See footnotes at end of table. 
Table 42. PAD District II-Year-to-Date Imports of Crude Oil and Petroleum Products by Country of Origin, January-August 1991 (Continued) (Thousand Barrels)

\begin{tabular}{|c|c|c|c|c|c|c|c|c|c|c|}
\hline \multirow{2}{*}{ Country of Origin } & \multirow{2}{*}{$\begin{array}{c}\text { Naphtha for } \\
\text { Petrochemical } \\
\text { Feedstock } \\
\text { Use }\end{array}$} & \multirow{2}{*}{$\begin{array}{l}\text { Other Olls for } \\
\text { Petrochemical } \\
\text { Fee /stock } \\
\text { Jse }\end{array}$} & \multirow[b]{2}{*}{ Lubricants } & \multirow[b]{2}{*}{$\begin{array}{c}\text { Asphalt and } \\
\text { Road Oll }\end{array}$} & \multirow[b]{2}{*}{$\begin{array}{c}\text { Other } \\
\text { Products }\end{array}$} & \multirow[b]{2}{*}{$\begin{array}{c}\text { Total } \\
\text { Products }\end{array}$} & \multirow{2}{*}{$\begin{array}{c}\text { Total } \\
\text { Crude Oil } \\
\text { and } \\
\text { Products }\end{array}$} & \multicolumn{3}{|c|}{ Dally Average } \\
\hline & & & & & & & & $\begin{array}{c}\text { Crude } \\
\text { Oll }\end{array}$ & Products & Total \\
\hline 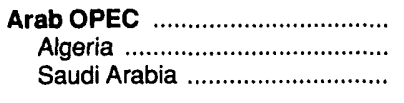 & $\begin{array}{l}0 \\
0 \\
0\end{array}$ & $\begin{array}{l}0 \\
0 \\
0\end{array}$ & $\begin{array}{l}0 \\
0 \\
0\end{array}$ & $\begin{array}{l}0 \\
0 \\
0\end{array}$ & $\begin{array}{l}0 \\
0 \\
0\end{array}$ & $\begin{array}{l}0 \\
0 \\
0\end{array}$ & $\begin{array}{r}41,581 \\
1,180 \\
40,401\end{array}$ & $\begin{array}{r}171 \\
5 \\
166\end{array}$ & $\begin{array}{l}0 \\
0 \\
0\end{array}$ & $\begin{array}{r}171 \\
5 \\
166\end{array}$ \\
\hline 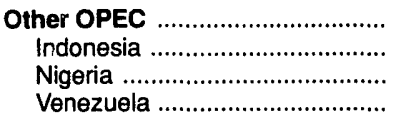 & $\begin{array}{l}0 \\
0 \\
0 \\
0\end{array}$ & $\begin{array}{l}0 \\
0 \\
? \\
0\end{array}$ & $\begin{array}{l}0 \\
0 \\
0 \\
0\end{array}$ & $\begin{array}{l}0 \\
0 \\
0 \\
0\end{array}$ & $\begin{array}{l}0 \\
0 \\
0 \\
0\end{array}$ & $\begin{array}{l}0 \\
0 \\
0 \\
0\end{array}$ & $\begin{array}{r}39,082 \\
541 \\
12,287 \\
26,254\end{array}$ & $\begin{array}{r}161 \\
2 \\
51 \\
108\end{array}$ & $\begin{array}{l}0 \\
0 \\
0 \\
0\end{array}$ & $\begin{array}{r}161 \\
2 \\
51 \\
108\end{array}$ \\
\hline 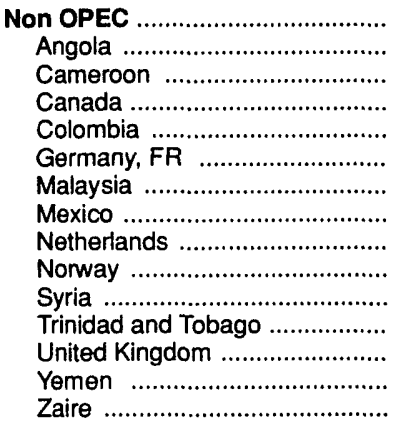 & $\begin{array}{r}239 \\
0 \\
0 \\
216 \\
0 \\
0 \\
0 \\
0 \\
23 \\
0 \\
0 \\
0 \\
0 \\
0 \\
0\end{array}$ & $\begin{array}{l}0 \\
0 \\
0 \\
0 \\
0 \\
0 \\
0 \\
0 \\
0 \\
0 \\
0 \\
0 \\
0 \\
0 \\
0\end{array}$ & $\begin{array}{r}158 \\
0 \\
0 \\
158 \\
0 \\
0 \\
0 \\
0 \\
0 \\
0 \\
0 \\
0 \\
0 \\
0 \\
0\end{array}$ & $\begin{array}{r}90 \\
0 \\
0 \\
90 \\
0 \\
0 \\
0 \\
0 \\
0 \\
0 \\
0 \\
0 \\
0 \\
0 \\
0\end{array}$ & $\begin{array}{r}389 \\
0 \\
0 \\
387 \\
0 \\
2 \\
0 \\
0 \\
0 \\
0 \\
0 \\
0 \\
0 \\
0 \\
0\end{array}$ & $\begin{array}{r}23,414 \\
0 \\
0 \\
23,389 \\
0 \\
2 \\
0 \\
0 \\
23 \\
0 \\
0 \\
0 \\
0 \\
0 \\
0\end{array}$ & $\begin{array}{r}216,018 \\
2,867 \\
470 \\
168,891 \\
3,225 \\
2 \\
523 \\
23,863 \\
23 \\
3,281 \\
302 \\
5,373 \\
4,966 \\
1,696 \\
536\end{array}$ & $\begin{array}{r}793 \\
12 \\
2 \\
599 \\
13 \\
0 \\
2 \\
2 \\
98 \\
0 \\
14 \\
1 \\
22 \\
20 \\
7 \\
2\end{array}$ & $\begin{array}{r}96 \\
0 \\
0 \\
96 \\
0 \\
(s) \\
0 \\
0 \\
(s) \\
0 \\
0 \\
0 \\
0 \\
0 \\
0\end{array}$ & $\begin{array}{r}889 \\
12 \\
2 \\
695 \\
13 \\
(s) \\
2 \\
98 \\
(s) \\
14 \\
1 \\
22 \\
20 \\
7 \\
2\end{array}$ \\
\hline 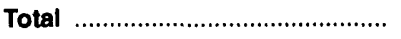 & 239 & $\mathbf{0}$ & 158 & 90 & 389 & 23,414 & 296,681 & 1,125 & 96 & 1,221 \\
\hline
\end{tabular}

a Crude oil and unfinished oils are reported by the PAD District in which they are to be processed; all other products are reported by the PAD District of eniry.

Includes crude oil imported tor storage in the Strategic Petroleum Reserve.

c Includes aviation gasoline, aviation gasoline blending components, miscellaneous products, other hydrocarbons and alcohol, pentanes plus, petroleum coke, and waxes.

(s) = Less than 500 barrels or less than 500 barrels per day.

Note: Totals may not equal sum of components due to independent rounding.

Source: Energy Information Administration (EIA) Form EIA-814, "Monthly Imports Report." 
Table 43. PAD District II-Year-to-Date Imports of Crude Oll and Petroleum Products by Country of Origin, ${ }^{a}$ January-August 1991 (Thousand Barrels)

\begin{tabular}{|c|c|c|c|c|c|c|c|c|c|c|}
\hline Country of Origin & $\begin{array}{c}\text { Crude } \\
\text { OII }^{b}\end{array}$ & $\begin{array}{c}\text { Liquefied } \\
\text { Petroleum } \\
\text { Gases }\end{array}$ & $\begin{array}{c}\text { Unfinished } \\
\text { Olls }\end{array}$ & $\begin{array}{l}\text { Gasoline } \\
\text { Blending } \\
\text { Compo- } \\
\text { nents }\end{array}$ & $\begin{array}{l}\text { Finished } \\
\text { Motor } \\
\text { Gasoline }\end{array}$ & Jet Fuel & $\begin{array}{l}\text { Distlllate } \\
\text { Fuel Oil }\end{array}$ & $\begin{array}{l}\text { Residual } \\
\text { Fuel Oll }\end{array}$ & Kerosene & $\begin{array}{c}\text { Spocial } \\
\text { Naphthas }\end{array}$ \\
\hline 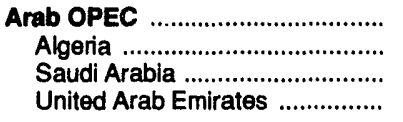 & $\begin{array}{r}328,660 \\
13,520 \\
315,140 \\
0\end{array}$ & $\begin{array}{r}2,453 \\
2,453 \\
0 \\
0\end{array}$ & $\begin{array}{r}13,082 \\
2,435 \\
10,647 \\
0\end{array}$ & $\begin{array}{l}0 \\
0 \\
0 \\
0\end{array}$ & $\begin{array}{l}0 \\
0 \\
0 \\
0\end{array}$ & $\begin{array}{l}0 \\
0 \\
0 \\
0\end{array}$ & $\begin{array}{l}0 \\
0 \\
0 \\
0\end{array}$ & $\begin{array}{r}3,200 \\
2,190 \\
781 \\
229\end{array}$ & $\begin{array}{l}0 \\
0 \\
0 \\
0\end{array}$ & $\begin{array}{l}0 \\
0 \\
0 \\
0\end{array}$ \\
\hline 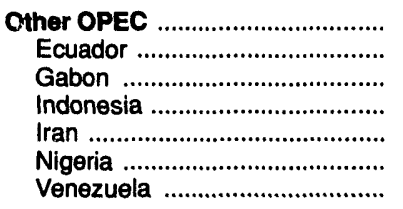 & $\begin{array}{r}180,450 \\
6,243 \\
7,238 \\
2,332 \\
4,000 \\
66,920 \\
93,717\end{array}$ & $\begin{array}{r}621 \\
0 \\
0 \\
0 \\
0 \\
0 \\
621\end{array}$ & $\begin{array}{r}17,943 \\
0 \\
0 \\
0 \\
0 \\
0 \\
17,943\end{array}$ & $\begin{array}{r}1,011 \\
0 \\
0 \\
0 \\
0 \\
0 \\
1,011\end{array}$ & $\begin{array}{l}0 \\
0 \\
0 \\
0 \\
0 \\
0 \\
0\end{array}$ & $\begin{array}{l}0 \\
0 \\
0 \\
0 \\
0 \\
0 \\
0\end{array}$ & $\begin{array}{l}0 \\
0 \\
0 \\
0 \\
0 \\
0 \\
0\end{array}$ & $\begin{array}{r}4,600 \\
0 \\
0 \\
0 \\
0 \\
1,147 \\
3,453\end{array}$ & $\begin{array}{l}0 \\
0 \\
0 \\
0 \\
0 \\
0 \\
0\end{array}$ & $\begin{array}{l}0 \\
0 \\
0 \\
0 \\
0 \\
0 \\
0\end{array}$ \\
\hline 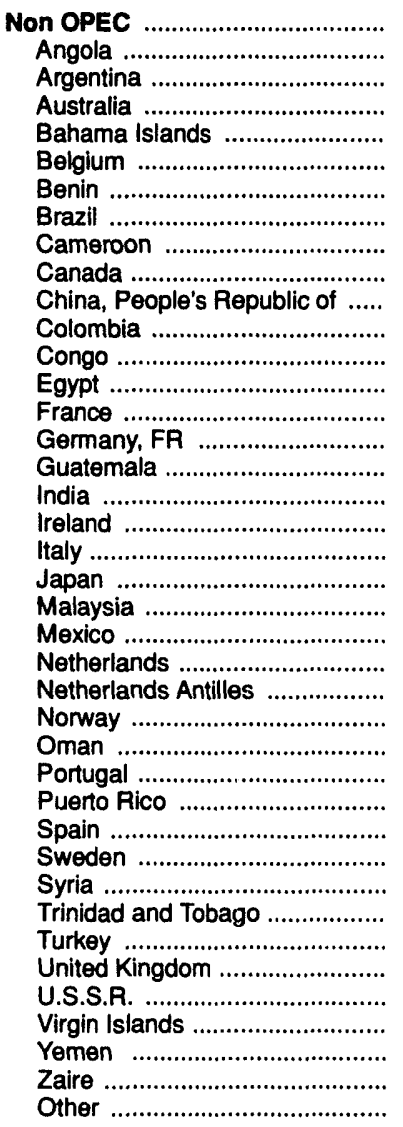 & $\begin{array}{r}273,461 \\
33,420 \\
820 \\
438 \\
0 \\
0 \\
584 \\
0 \\
0 \\
1,729 \\
16,653 \\
26,969 \\
3,864 \\
0 \\
0 \\
0 \\
650 \\
0 \\
0 \\
59 \\
0 \\
1,043 \\
141,440 \\
0 \\
0 \\
9,738 \\
496 \\
0 \\
0 \\
0 \\
0 \\
1,293 \\
10,723 \\
0 \\
16,693 \\
717 \\
0 \\
3,837 \\
2,295 \\
0\end{array}$ & $\begin{array}{r}8,074 \\
0 \\
23 \\
830 \\
0 \\
0 \\
0 \\
0 \\
0 \\
291 \\
0 \\
0 \\
0 \\
0 \\
42 \\
0 \\
0 \\
0 \\
0 \\
25 \\
6 \\
0 \\
6,379 \\
49 \\
0 \\
0 \\
0 \\
0 \\
0 \\
0 \\
0 \\
0 \\
0 \\
0 \\
359 \\
0 \\
0 \\
0 \\
0 \\
70\end{array}$ & $\begin{array}{r}25,540 \\
0 \\
568 \\
0 \\
12 \\
506 \\
0 \\
0 \\
0 \\
979 \\
0 \\
0 \\
0 \\
481 \\
149 \\
0 \\
0 \\
545 \\
0 \\
3,562 \\
0 \\
0 \\
241 \\
1,948 \\
1,581 \\
0 \\
498 \\
0 \\
0 \\
274 \\
0 \\
0 \\
0 \\
0 \\
320 \\
7,368 \\
5,405 \\
0 \\
0 \\
1,063\end{array}$ & $\begin{array}{r}571 \\
0 \\
7 \\
0 \\
0 \\
0 \\
0 \\
11 \\
0 \\
0 \\
0 \\
0 \\
0 \\
0 \\
0 \\
0 \\
0 \\
0 \\
0 \\
0 \\
0 \\
0 \\
553 \\
0 \\
0 \\
0 \\
0 \\
0 \\
0 \\
0 \\
0 \\
0 \\
0 \\
0 \\
0 \\
0 \\
0 \\
0 \\
0 \\
0\end{array}$ & $\begin{array}{r}756 \\
0 \\
0 \\
0 \\
0 \\
0 \\
0 \\
0 \\
0 \\
0 \\
0 \\
0 \\
0 \\
0 \\
0 \\
0 \\
0 \\
0 \\
0 \\
0 \\
0 \\
0 \\
5 \\
0 \\
0 \\
0 \\
0 \\
0 \\
0 \\
0 \\
0 \\
0 \\
0 \\
0 \\
0 \\
0 \\
751 \\
0 \\
0 \\
0\end{array}$ & $\begin{array}{r}346 \\
0 \\
0 \\
0 \\
0 \\
0 \\
0 \\
0 \\
0 \\
0 \\
0 \\
0 \\
0 \\
0 \\
0 \\
0 \\
0 \\
0 \\
0 \\
0 \\
0 \\
0 \\
0 \\
0 \\
0 \\
0 \\
0 \\
0 \\
0 \\
0 \\
0 \\
0 \\
0 \\
0 \\
0 \\
0 \\
346 \\
0 \\
0 \\
0\end{array}$ & $\begin{array}{r}23 \\
0 \\
0 \\
0 \\
0 \\
0 \\
0 \\
0 \\
0 \\
0 \\
0 \\
0 \\
0 \\
0 \\
0 \\
0 \\
0 \\
0 \\
0 \\
0 \\
0 \\
0 \\
23 \\
0 \\
0 \\
0 \\
0 \\
0 \\
0 \\
0 \\
0 \\
0 \\
0 \\
0 \\
0 \\
0 \\
0 \\
0 \\
0 \\
0\end{array}$ & $\begin{array}{r}5,750 \\
0 \\
0 \\
0 \\
425 \\
0 \\
0 \\
0 \\
202 \\
0 \\
0 \\
0 \\
0 \\
0 \\
0 \\
0 \\
0 \\
0 \\
225 \\
587 \\
0 \\
0 \\
1,636 \\
302 \\
0 \\
0 \\
499 \\
703 \\
0 \\
395 \\
0 \\
0 \\
284 \\
0 \\
246 \\
0 \\
237 \\
0 \\
0 \\
9\end{array}$ & $\begin{array}{r}87 \\
0 \\
0 \\
0 \\
0 \\
0 \\
0 \\
0 \\
0 \\
0 \\
0 \\
0 \\
0 \\
0 \\
0 \\
0 \\
0 \\
0 \\
0 \\
0 \\
0 \\
0 \\
0 \\
0 \\
87 \\
0 \\
0 \\
0 \\
0 \\
0 \\
0 \\
0 \\
0 \\
0 \\
0 \\
0 \\
0 \\
0 \\
0 \\
0 \\
0 \\
0\end{array}$ & $\begin{array}{r}631 \\
0 \\
74 \\
0 \\
0 \\
0 \\
0 \\
15 \\
0 \\
396 \\
0 \\
17 \\
0 \\
0 \\
0 \\
0 \\
0 \\
0 \\
0 \\
20 \\
0 \\
0 \\
0 \\
109 \\
0 \\
0 \\
0 \\
0 \\
0 \\
0 \\
0 \\
0 \\
0 \\
0 \\
0 \\
0 \\
0 \\
0 \\
0 \\
0\end{array}$ \\
\hline 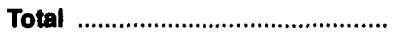 & 782,571 & 11,148 & 56,565 & 1,582 & 756 & 346 & 23 & 13,550 & 87 & 631 \\
\hline
\end{tabular}


Table 43. PAD District II-Year-to-Date Imports of Crude Oil and Petroleum Products by Country of Origin, ${ }^{a}$ January-August 1991 (Continued) (Thousand Barrels)

\begin{tabular}{|c|c|c|c|c|c|c|c|c|c|c|}
\hline \multirow{2}{*}{ Country of Origin } & \multirow{2}{*}{$\begin{array}{c}\text { Naphtha for } \\
\text { Petrochemical } \\
\text { Feedstock } \\
\text { Use }\end{array}$} & \multirow{2}{*}{$\begin{array}{c}\text { Other Olls for } \\
\text { Petrochemical } \\
\text { Feedstock } \\
\text { Use }\end{array}$} & \multirow[b]{2}{*}{ Lubricants } & \multirow[b]{2}{*}{$\begin{array}{c}\text { Asphalt and } \\
\text { Road OII }\end{array}$} & \multirow[b]{2}{*}{$\begin{array}{c}\text { Other } \\
\text { Products }\end{array}$} & \multirow[b]{2}{*}{$\begin{array}{c}\text { Total } \\
\text { Products }\end{array}$} & \multirow{2}{*}{$\begin{array}{c}\text { Total } \\
\text { Crude OII } \\
\text { and } \\
\text { Products }\end{array}$} & \multicolumn{3}{|c|}{ Dally Average } \\
\hline & & & & & & & & $\begin{array}{c}\text { Crude } \\
\text { OII }\end{array}$ & Products & Total \\
\hline 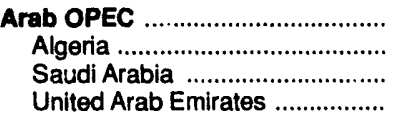 & $\begin{array}{r}263 \\
263 \\
0 \\
0\end{array}$ & $\begin{array}{r}29,058 \\
29,058 \\
0 \\
0\end{array}$ & $\begin{array}{l}0 \\
0 \\
0 \\
0\end{array}$ & $\begin{array}{l}0 \\
0 \\
0 \\
0\end{array}$ & $\begin{array}{l}0 \\
0 \\
0 \\
0\end{array}$ & $\begin{array}{r}48,056 \\
36,399 \\
11,428 \\
229\end{array}$ & $\begin{array}{r}376,716 \\
49,919 \\
326,568 \\
229\end{array}$ & $\begin{array}{r}1,353 \\
56 \\
1,297 \\
0\end{array}$ & $\begin{array}{r}198 \\
150 \\
47 \\
1\end{array}$ & $\begin{array}{r}1,550 \\
205 \\
1,344 \\
1\end{array}$ \\
\hline 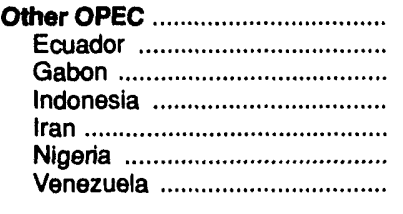 & $\begin{array}{r}254 \\
0 \\
0 \\
0 \\
0 \\
0 \\
254\end{array}$ & $\begin{array}{l}0 \\
0 \\
0 \\
0 \\
0 \\
0 \\
0\end{array}$ & $\begin{array}{l}0 \\
0 \\
0 \\
0 \\
0 \\
0 \\
0\end{array}$ & $\begin{array}{r}300 \\
0 \\
0 \\
0 \\
0 \\
0 \\
300\end{array}$ & $\begin{array}{r}24 \\
0 \\
0 \\
0 \\
0 \\
0 \\
24\end{array}$ & $\begin{array}{r}24,753 \\
0 \\
0 \\
0 \\
0 \\
1,147 \\
23,606\end{array}$ & $\begin{array}{r}205,203 \\
6,243 \\
7,238 \\
2,332 \\
4,000 \\
68,067 \\
117,323\end{array}$ & $\begin{array}{r}743 \\
26 \\
30 \\
10 \\
16 \\
275 \\
386\end{array}$ & $\begin{array}{r}102 \\
0 \\
0 \\
0 \\
0 \\
5 \\
97\end{array}$ & $\begin{array}{r}844 \\
26 \\
30 \\
10 \\
16 \\
280 \\
483\end{array}$ \\
\hline 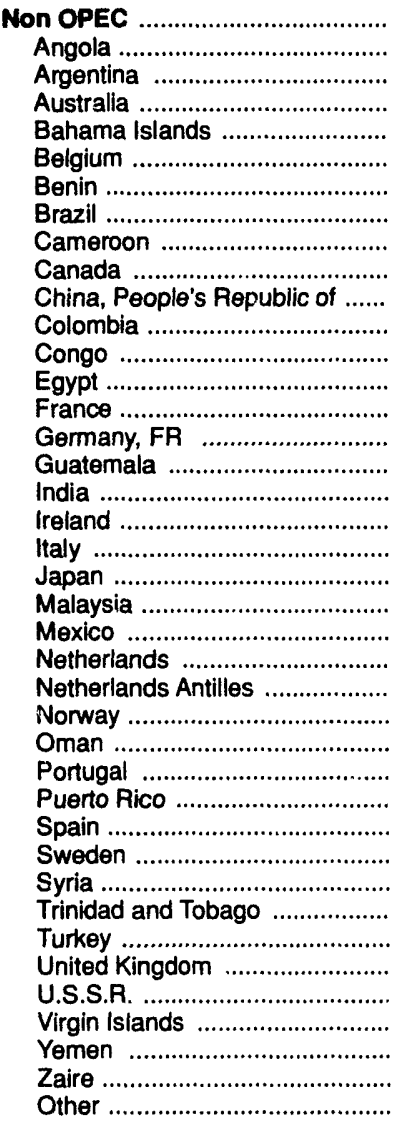 & $\begin{array}{r}3,312 \\
0 \\
152 \\
0 \\
0 \\
165 \\
0 \\
0 \\
0 \\
147 \\
0 \\
0 \\
0 \\
0 \\
124 \\
0 \\
0 \\
1,526 \\
0 \\
50 \\
39 \\
0 \\
0 \\
214 \\
0 \\
0 \\
0 \\
0 \\
666 \\
0 \\
36 \\
0 \\
0 \\
138 \\
55 \\
0 \\
0 \\
0 \\
0 \\
0\end{array}$ & $\begin{array}{l}0 \\
0 \\
0 \\
0 \\
0 \\
0 \\
0 \\
0 \\
0 \\
0 \\
0 \\
0 \\
0 \\
0 \\
0 \\
0 \\
0 \\
0 \\
0 \\
0 \\
0 \\
0 \\
0 \\
0 \\
0 \\
0 \\
0 \\
0 \\
0 \\
0 \\
0 \\
0 \\
0 \\
0 \\
0 \\
0 \\
0 \\
0 \\
0 \\
0\end{array}$ & $\begin{array}{l}0 \\
0 \\
0 \\
0 \\
0 \\
0 \\
0 \\
0 \\
0 \\
0 \\
0 \\
0 \\
0 \\
0 \\
0 \\
0 \\
0 \\
0 \\
0 \\
0 \\
0 \\
0 \\
0 \\
0 \\
0 \\
0 \\
0 \\
0 \\
0 \\
0 \\
0 \\
0 \\
0 \\
0 \\
0 \\
0 \\
0 \\
0 \\
0 \\
0\end{array}$ & $\begin{array}{r}589 \\
0 \\
0 \\
0 \\
0 \\
0 \\
0 \\
0 \\
0 \\
0 \\
0 \\
0 \\
0 \\
0 \\
0 \\
0 \\
0 \\
0 \\
0 \\
0 \\
0 \\
0 \\
74 \\
0 \\
174 \\
0 \\
0 \\
0 \\
0 \\
341 \\
0 \\
0 \\
0 \\
0 \\
0 \\
0 \\
0 \\
0 \\
0 \\
0\end{array}$ & $\begin{array}{r}339 \\
0 \\
84 \\
0 \\
0 \\
0 \\
0 \\
0 \\
0 \\
0 \\
0 \\
0 \\
0 \\
6 \\
0 \\
7 \\
0 \\
0 \\
0 \\
171 \\
18 \\
0 \\
2 \\
24 \\
0 \\
0 \\
0 \\
20 \\
0 \\
0 \\
0 \\
0 \\
0 \\
0 \\
0 \\
0 \\
0 \\
0 \\
0 \\
7\end{array}$ & $\begin{array}{r}46,018 \\
0 \\
908 \\
830 \\
437 \\
671 \\
0 \\
26 \\
202 \\
1,813 \\
0 \\
17 \\
0 \\
487 \\
315 \\
7 \\
0 \\
2,111 \\
225 \\
4,415 \\
63 \\
0 \\
8,913 \\
2,646 \\
1,842 \\
0 \\
997 \\
723 \\
666 \\
1,010 \\
36 \\
0 \\
284 \\
138 \\
980 \\
7,368 \\
6,739 \\
0 \\
0 \\
1,149\end{array}$ & $\begin{array}{r}319,479 \\
33,420 \\
1,728 \\
1,268 \\
437 \\
671 \\
584 \\
26 \\
202 \\
3,542 \\
16,653 \\
26,986 \\
3,864 \\
487 \\
315 \\
7 \\
650 \\
2,111 \\
225 \\
4,474 \\
63 \\
1,043 \\
150,353 \\
2,646 \\
1,842 \\
9,738 \\
1,493 \\
723 \\
666 \\
1,010 \\
36 \\
1,293 \\
11,007 \\
138 \\
17,673 \\
8,085 \\
6,739 \\
3,837 \\
2,295 \\
1,149\end{array}$ & $\begin{array}{r}1,125 \\
138 \\
3 \\
2 \\
0 \\
0 \\
2 \\
0 \\
0 \\
7 \\
69 \\
111 \\
16 \\
0 \\
0 \\
0 \\
3 \\
0 \\
0 \\
(5) \\
0 \\
4 \\
582 \\
0 \\
0 \\
40 \\
2 \\
0 \\
0 \\
0 \\
0 \\
5 \\
44 \\
0 \\
69 \\
3 \\
0 \\
16 \\
9 \\
0\end{array}$ & $\begin{array}{r}189 \\
0 \\
4 \\
3 \\
2 \\
3 \\
0 \\
(s) \\
1 \\
7 \\
0 \\
3(s) \\
0 \\
2 \\
1 \\
(s) \\
0 \\
9 \\
1 \\
18 \\
(s) \\
0 \\
37 \\
11 \\
8 \\
0 \\
4 \\
3 \\
3\end{array}$ & $\begin{array}{r}1,315 \\
138 \\
7 \\
5 \\
2 \\
3 \\
2 \\
(s) \\
1 \\
15 \\
69 \\
111 \\
16 \\
2 \\
1 \\
(s) \\
3 \\
9 \\
1 \\
18 \\
(s) \\
4 \\
619 \\
11 \\
8 \\
40 \\
6 \\
3 \\
3 \\
4 \\
(s) \\
5 \\
45 \\
1 \\
73 \\
33 \\
28 \\
16 \\
9 \\
5\end{array}$ \\
\hline Total . & 3,829 & 29,058 & 0 & 889 & 363 & 118,827 & 901,398 & 3,220 & 489 & 3,709 \\
\hline
\end{tabular}

a Crude oil and unfinished oils are reported by the PAD District in which they are to be processed; all other products are reported by the PAD District of entry.

Includes crude oil imported for storage in the Strategic Petroleum Reserve.

$c$ Includes aviation gasoline, aviation gasoline blending components, miscellaneous products, other hydrocarbons and alcohol, pentanes plus, petroleum coke, and waxes.

(s) = Less than 500 barrels or less than 500 barrels per day.

Note: Totals may not equal sum of components due to independent rounding.

Source: Energy Information Administration (EIA) Form EIA-814, "Monthly Imports Report." 
Table 44. PAD Districts IV and V-Year-to-Date Imports of Crude OIl and Petroleum Products by Country of Origin., January-August 1991 (Tholisand Barrels)

\begin{tabular}{|c|c|c|c|c|c|c|c|c|c|c|}
\hline Country of Origln & $\begin{array}{c}\text { Crude } \\
\text { Ollb }^{b}\end{array}$ & $\begin{array}{c}\text { Llquefied } \\
\text { Potroleum } \\
\text { Cases }\end{array}$ & $\begin{array}{c}\text { Unfinished } \\
\text { Olls }\end{array}$ & $\begin{array}{c}\text { Gasoline } \\
\text { Blending } \\
\text { Compo- } \\
\text { nents }\end{array}$ & $\begin{array}{l}\text { Finished } \\
\text { Motor } \\
\text { Gasoline }\end{array}$ & Jet Fuel & $\begin{array}{l}\text { Distillate } \\
\text { Fuel Oll }\end{array}$ & $\begin{array}{l}\text { Residual } \\
\text { Fuel Oll }\end{array}$ & Kerosene & $\begin{array}{l}\text { Special } \\
\text { Naphthas }\end{array}$ \\
\hline
\end{tabular}

PAD District IV

Non OPEC

Total

$\begin{array}{ll}18,341 & 1,319 \\ 18,341 & 1,319\end{array}$

$18,341 \quad 1,319$

0
0
0

311
311
311

632
632
632

30
30

$\mathbf{0}$
0

0

Total

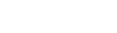

0

832

30

0

PAD District V

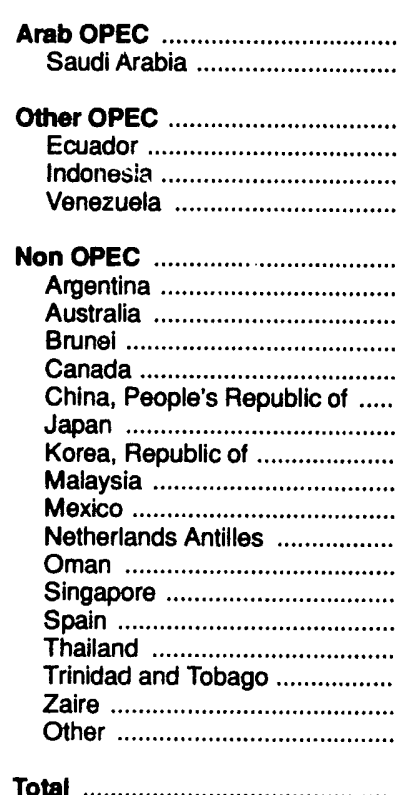

Total

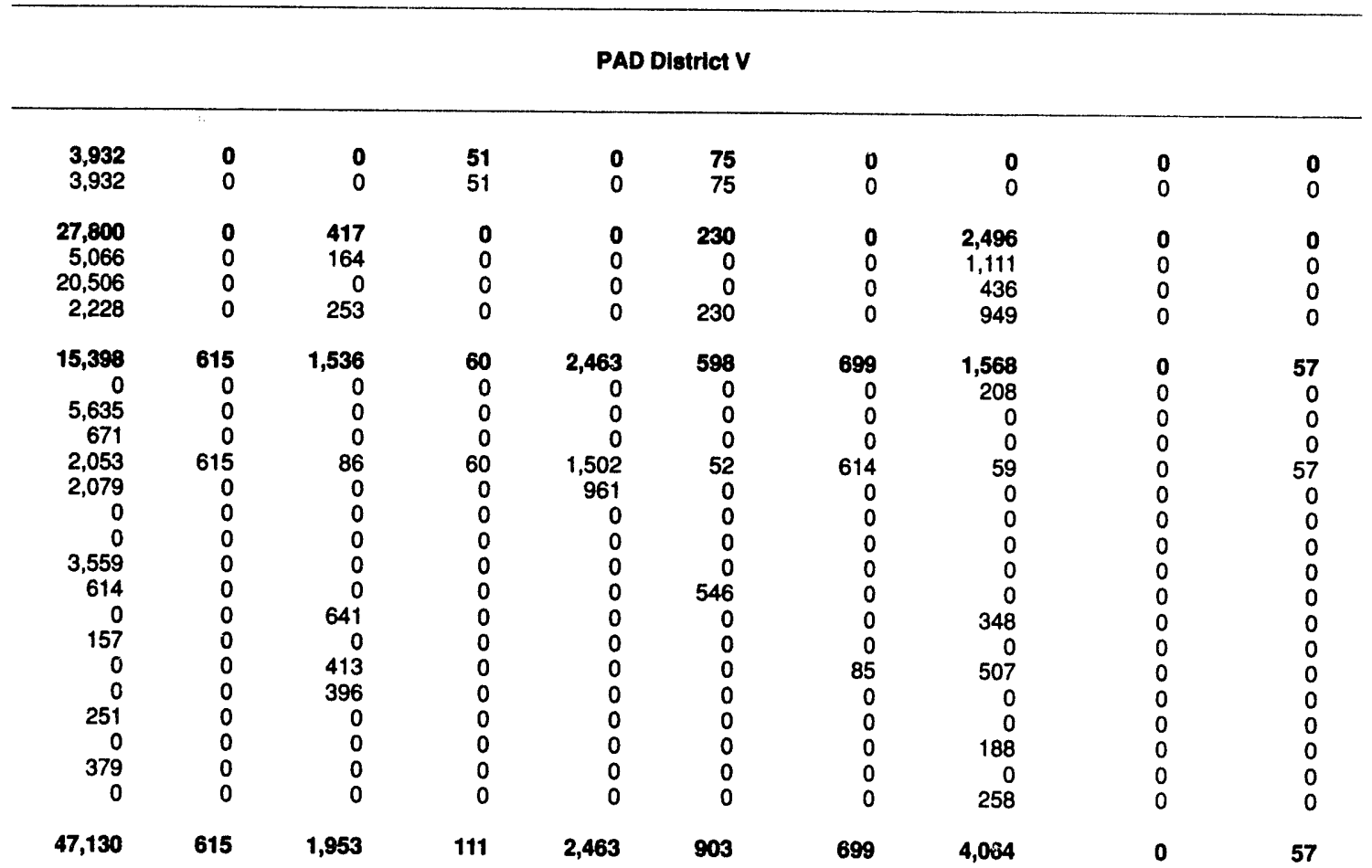

See footnotes at end of table. 
Table 44. PAD Districts IV and V-Year-to-Date Imports of Crude Oil and Petroleum Products by Country of Origin, ${ }^{a}$ January-August 1991 (Continued) (Thousand Barrels)

\begin{tabular}{|c|c|c|c|c|c|c|c|c|c|c|}
\hline \multirow[b]{2}{*}{ Country of Origin } & \multirow[b]{2}{*}{$\begin{array}{l}\text { Naphtha for } \\
\text { Petrochemical } \\
\text { Feedstock } \\
\text { Use }\end{array}$} & \multirow[b]{2}{*}{$\begin{array}{c}\text { Other Olls for } \\
\text { Petrochemical } \\
\text { Feedstock } \\
\text { Use }\end{array}$} & \multirow[b]{2}{*}{ Lubricants } & \multirow[b]{2}{*}{$\begin{array}{c}\text { Asphalt and } \\
\text { Road OII }\end{array}$} & \multirow[b]{2}{*}{$\begin{array}{c}\text { Other } \\
\text { Products }\end{array}$} & \multirow[b]{2}{*}{$\begin{array}{c}\text { Total } \\
\text { Products }\end{array}$} & \multirow[b]{2}{*}{$\begin{array}{c}\text { Total } \\
\text { Crude OII } \\
\text { and } \\
\text { Products }\end{array}$} & \multicolumn{3}{|c|}{ Dally Average } \\
\hline & & & & & & & & $\begin{array}{c}\text { Crude } \\
\text { Oll }\end{array}$ & Products & Total \\
\hline
\end{tabular}

PAD District IV

\begin{tabular}{|c|c|c|c|c|c|c|c|c|c|c|}
\hline $\begin{array}{l}\text { Non OPEC } \\
\text { Canada }\end{array}$ & $\begin{array}{l}0 \\
0\end{array}$ & $\begin{array}{l}0 \\
0\end{array}$ & $\begin{array}{l}0 \\
0\end{array}$ & $\begin{array}{l}0 \\
0\end{array}$ & $\begin{array}{l}\mathbf{5 3 5} \\
\mathbf{5 3 5}\end{array}$ & $\begin{array}{l}2,827 \\
2,827\end{array}$ & $\begin{array}{l}21,168 \\
21,168\end{array}$ & $\begin{array}{l}75 \\
75\end{array}$ & $\begin{array}{l}12 \\
12\end{array}$ & $\begin{array}{l}87 \\
87\end{array}$ \\
\hline ..................... & 0 & 0 & 0 & 0 & 535 & 2,827 & 21,168 & 75 & 12 & 87 \\
\hline
\end{tabular}

PAD District V

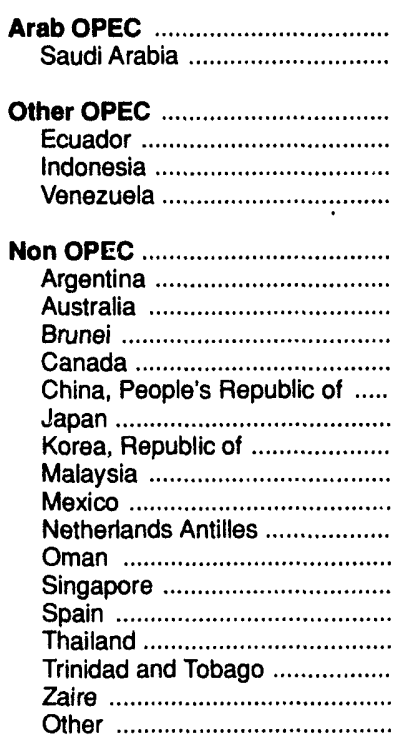

Total

\begin{tabular}{|c|c|c|}
\hline $\begin{array}{l}0 \\
0\end{array}$ & $\begin{array}{l}0 \\
0\end{array}$ & $\begin{array}{l}0 \\
0\end{array}$ \\
\hline $\begin{array}{l}\mathbf{0} \\
0 \\
0 \\
0\end{array}$ & $\begin{array}{l}0 \\
0 \\
0 \\
0\end{array}$ & $\begin{array}{l}0 \\
0 \\
0 \\
0\end{array}$ \\
\hline $\begin{array}{r}234 \\
0 \\
0 \\
0 \\
0 \\
0 \\
96 \\
138 \\
0 \\
0 \\
0 \\
0 \\
0 \\
0 \\
0 \\
0 \\
0 \\
0\end{array}$ & $\begin{array}{l}0 \\
0 \\
0 \\
0 \\
0 \\
0 \\
0 \\
0 \\
0 \\
0 \\
0 \\
0 \\
0 \\
0 \\
0 \\
0 \\
0 \\
0\end{array}$ & $\begin{array}{l}0 \\
0 \\
0 \\
0 \\
0 \\
0 \\
0 \\
0 \\
0 \\
0 \\
0 \\
0 \\
0 \\
0 \\
0 \\
0 \\
0 \\
0\end{array}$ \\
\hline
\end{tabular}

$\begin{array}{rr}0 & 1 \\ 0 & 1 \\ 0 & 1 \\ 0 & \\ 0 & \\ 0 & \\ 153 & \\ 0 & \\ 0 & \\ 0 & \\ 60 & \\ 0 & \\ 0 & \\ 0 & \\ 0 & \\ 93 & \\ 0 & \\ 0 & \\ 0 & \\ 0 & \\ 0 & \\ 0 & \\ 0 & \\ 0 & \\ & \end{array}$

$\begin{array}{rrr}110 & 236 & 4,168 \\ 110 & 236 & 4,168 \\ 198 & 3,341 & 31,141 \\ 0 & 1,275 & 6,34 \\ 0 & 436 & 20,94 \\ 198 & 1,630 & 3,85 \\ 368 & 8,351 & 23,749 \\ 0 & 208 & 20 \\ 0 & 0 & 5,635 \\ 0 & 0 & 671 \\ 353 & 3,458 & 5,511 \\ 0 & 961 & 3,040 \\ 0 & 96 & 96 \\ 0 & 138 & 138 \\ 0 & 0 & 3,559 \\ 15 & 654 & 1,268 \\ 0 & 989 & 989 \\ 0 & 0 & 157 \\ 0 & 1,005 & 1,005 \\ 0 & 396 & 396 \\ 0 & 0 & 251 \\ 0 & 188 & 188 \\ 0 & 0 & 379 \\ 0 & 258 & 258 \\ & & \\ 676 & 11,928 & 59,058\end{array}$

4,168

4,168

16
16

1

153
31,141

6,341

20,942

3,858

3,749
208

5,635

671

5,511

3,040

96

138
3,559

1,268

989

157
1,005

396

251

188

258

59,058
114

21
84

14

5
2
7

128

26

26
86
16

$63-34$

$\begin{array}{lll}63 & 34 & 98\end{array}$

$\begin{array}{rrr}0 & 1 & 1 \\ 23 & 0 & 23\end{array}$

23

8
9

9

0
15

15
3

194

\footnotetext{
a Crude oil and unfinished oils are reported by the PAD District in which they are to be processed; all other products are reported by the PAD District of entry.

Includes crude oil imported for storage in the Strategic Petroleum Reserve.

c Includes aviation gasoline, aviation gasoline blending components, miscellaneous products, other hydrocarbons and alcohol, pentanes plus, petroleum coke, and waxes.

(s) = Less than 500 barrels or less than 500 barrels per day.

Nota: Totals may not equal sum of components due to independent rounding.

Source: Energy Information Administration (EIA) Form EIA-814, "Monthly Imports Report."
} 
Table 45. Exports of Crude Oll and Petroleum Products by PAD District, August 1991

(Thousand Barrels)

\begin{tabular}{|c|c|c|c|c|c|c|c|}
\hline \multirow{2}{*}{ Commodity } & \multicolumn{6}{|c|}{ Petroloum Administratlon for Defense Districts } & \multirow[b]{2}{*}{$\begin{array}{c}\text { Dally } \\
\text { Average }\end{array}$} \\
\hline & 1 & II & III & IV & v & U.S. & \\
\hline Crude OII ${ }^{\mathrm{a}}$ & 0 & 32 & 0 & 0 & 1,666 & 1,699 & 55 \\
\hline 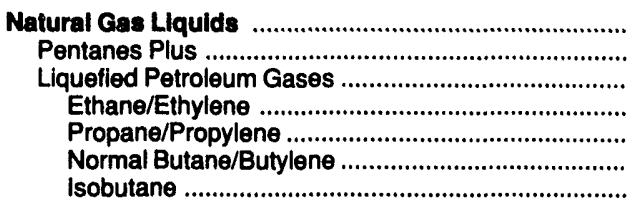 & $\begin{array}{r}61 \\
0 \\
61 \\
0 \\
31 \\
31 \\
0\end{array}$ & $\begin{array}{r}110 \\
0 \\
110 \\
0 \\
92 \\
18 \\
0\end{array}$ & $\begin{array}{r}339 \\
0 \\
339 \\
0 \\
256 \\
84 \\
0\end{array}$ & $\begin{array}{r}14 \\
0 \\
14 \\
0 \\
0 \\
14 \\
0\end{array}$ & $\begin{array}{r}37 \\
2 \\
35 \\
0 \\
31 \\
3 \\
0\end{array}$ & $\begin{array}{r}561 \\
2 \\
559 \\
0 \\
410 \\
149 \\
0\end{array}$ & $\begin{array}{r}18 \\
(s) \\
18 \\
0 \\
13 \\
5 \\
0\end{array}$ \\
\hline 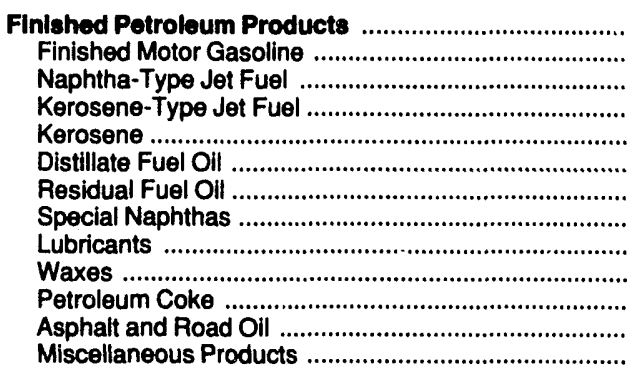 & $\begin{array}{r}1,197 \\
55 \\
(s) \\
40 \\
1 \\
160 \\
553 \\
26 \\
166 \\
8 \\
144 \\
30 \\
13\end{array}$ & $\begin{array}{r}738 \\
303 \\
(s) \\
35 \\
16 \\
10 \\
0 \\
2 \\
32 \\
8 \\
269 \\
61 \\
0\end{array}$ & $\begin{array}{r}12,433 \\
2,176 \\
0 \\
191 \\
1 \\
3,293 \\
2,003 \\
63 \\
299 \\
25 \\
4,357 \\
24 \\
(s)\end{array}$ & $\begin{array}{l}5 \\
1 \\
0 \\
0 \\
0 \\
1 \\
0 \\
0 \\
3 \\
0 \\
0 \\
1 \\
0\end{array}$ & $\begin{array}{r}9,324 \\
505 \\
0 \\
59 \\
(s) \\
1,015 \\
4,133 \\
3 \\
93 \\
31 \\
3,452 \\
33 \\
(s)\end{array}$ & $\begin{array}{r}23,698 \\
3,039 \\
1 \\
326 \\
18 \\
4,479 \\
6,689 \\
94 \\
594 \\
73 \\
8,221 \\
149 \\
13\end{array}$ & $\begin{array}{r}764 \\
98 \\
(s) \\
11 \\
1 \\
144 \\
216 \\
3 \\
19 \\
2 \\
265 \\
5 \\
(s)\end{array}$ \\
\hline Total & 1,258 & 880 & 12.773 & 19 & 11,027 & 25,957 & 837 \\
\hline
\end{tabular}

a Crude oil exports are restricted to: (1) crude oil derived from fields under the State waters of Alaska's Cook Inlet; (2) certain domestically produced crude oil destined for Canada; and (3) shipments to U.S. territories.

(s) = Less than 500 barrels or less than 500 barrels per day.

Note: Totals may not equal sum of components due to independent rounding.

Sources: Energy Information Administration (EIA) Form EIA-810, "Monthly Refinery Report" and the U.S. Bureau of the Census. 
Table 46. Year-to-Date Exports of Crude Oil and Petroleum Products by PAD District, January-August 1991

(Thousand Barrels)

\begin{tabular}{|c|c|c|c|c|c|c|c|}
\hline \multirow{2}{*}{ Commodity } & \multicolumn{6}{|c|}{ Potroleum Adminlstration for Defense Distrlcts } & \multirow[b]{2}{*}{$\begin{array}{c}\text { Dally } \\
\text { Average }\end{array}$} \\
\hline & 1 & II & III & IV & $\mathbf{V}$ & $\begin{array}{l}\text { U.S. } \\
\text { Total }\end{array}$ & \\
\hline 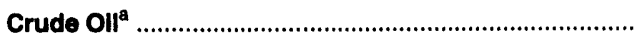 & 272 & 51 & 0 & 307 & 27,764 & 28,394 & 117 \\
\hline 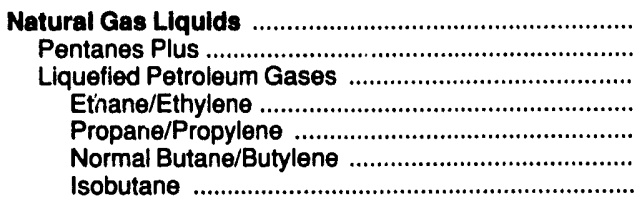 & $\begin{array}{r}715 \\
12 \\
703 \\
0 \\
465 \\
238 \\
0\end{array}$ & $\begin{array}{r}1,260 \\
0 \\
1,260 \\
0 \\
988 \\
272 \\
0\end{array}$ & $\begin{array}{r}5,502 \\
148 \\
5,354 \\
0 \\
3,979 \\
1,374 \\
0\end{array}$ & $\begin{array}{r}99 \\
0 \\
99 \\
0 \\
6 \\
94 \\
0\end{array}$ & $\begin{array}{r}2,364 \\
16 \\
2,348 \\
0 \\
1,917 \\
431 \\
0\end{array}$ & $\begin{array}{r}9,940 \\
176 \\
9,763 \\
0 \\
7,355 \\
2,408 \\
0\end{array}$ & $\begin{array}{r}41 \\
1 \\
40 \\
0 \\
30 \\
10 \\
0\end{array}$ \\
\hline $\begin{array}{l}\text { Finished Potroleum Products } \\
\text { Finished Motor Gasoline } \\
\text { Naphtha-Type Jet Fuel } \\
\text { Kerosene-Type Jet Fuel } \\
\text { Kerosene } \\
\text { Distillate Fuel Oil } \\
\text { Residual Fuel Oil } \\
\text { Special Naphthas } \\
\text { Wubricants } \\
\text { Petros } \\
\text { Asphaum Coke and Road Oil . . } \\
\text { Miscellaneous Products .......... }\end{array}$ & $\begin{array}{r}11,255 \\
694 \\
15 \\
976 \\
472 \\
3,167 \\
2,634 \\
430 \\
1,346 \\
69 \\
1,268 \\
132 \\
53\end{array}$ & $\begin{array}{r}3,383 \\
670 \\
1 \\
296 \\
123 \\
173 \\
226 \\
288 \\
225 \\
39 \\
1,078 \\
264 \\
(s)\end{array}$ & $\begin{array}{r}111,298 \\
11,712 \\
541 \\
6,116 \\
491 \\
34,358 \\
20,836 \\
2,519 \\
2,000 \\
173 \\
32,482 \\
66 \\
2\end{array}$ & $\begin{array}{r}101 \\
28 \\
0 \\
0 \\
0 \\
9 \\
(s) \\
1 \\
24 \\
(5) \\
34 \\
5 \\
0\end{array}$ & $\begin{array}{r}83,598 \\
7,523 \\
111 \\
3,829 \\
4 \\
12,516 \\
33,243 \\
817 \\
715 \\
148 \\
24,502 \\
190 \\
1\end{array}$ & $\begin{array}{r}209,635 \\
20,627 \\
667 \\
11,217 \\
1,091 \\
50,223 \\
56,939 \\
4,055 \\
4,311 \\
429 \\
59,364 \\
657 \\
56\end{array}$ & $\begin{array}{r}863 \\
85 \\
3 \\
46 \\
4 \\
207 \\
234 \\
17 \\
18 \\
2 \\
244 \\
3 \\
(s)\end{array}$ \\
\hline Total & 12,242 & 4,695 & 116,800 & 507 & 113,725 & 247,969 & 1,020 \\
\hline
\end{tabular}

a Crude oil exports are restricted to: (1) crude oil derived from fields under the State waters of Alaska's Cook Inlet; (2) certain domestically produced crude oil destined for Canada; and (3) shipments to U.S. territories.

(s) = Less than 500 barrels or less than 500 barrels per day.

Note: Totals may not equal sum of components due to independent rounding.

Sources: Energy Information Administration (EIA) Form EIA-810, "Monthly Refinery Report" and the U.S. Bureau of the Census. 
Table 47. Exports of Crude Oll and Petroleum Products by Destination, August 1991 (Thousand Barrels)

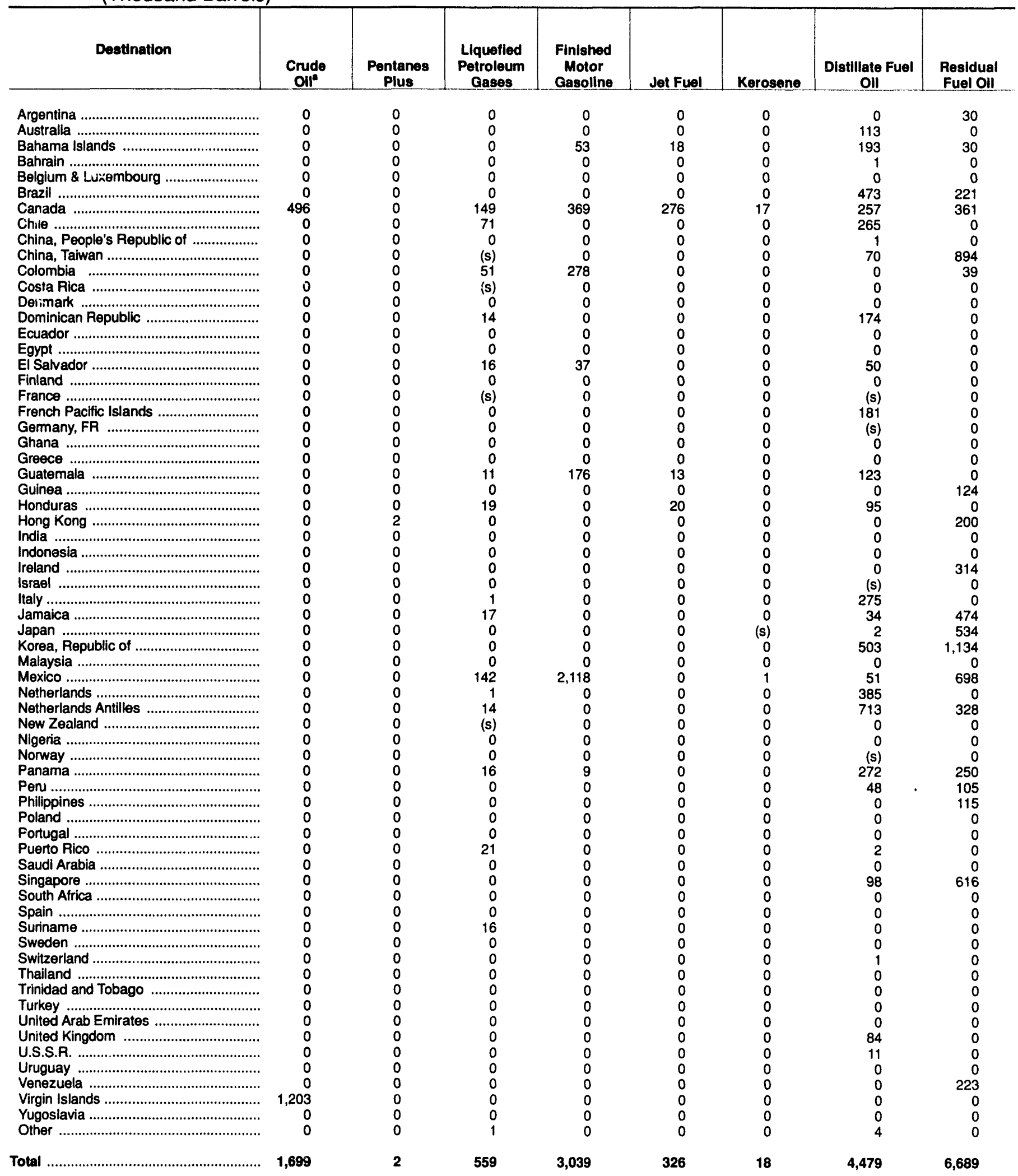

See footnotes at end of table. 
Table 47. Exports of Crude Oil and Petroleum Products by Destination, August 1991 (Continued) (Thcusand Barrels)

\begin{tabular}{|c|c|c|c|c|c|c|c|c|}
\hline \multirow{2}{*}{ Destination } & \multirow[b]{2}{*}{$\begin{array}{c}\text { Special } \\
\text { Nephthas }\end{array}$} & \multirow[b]{2}{*}{ Lubricants } & \multirow[b]{2}{*}{ W'axes } & \multirow[b]{2}{*}{$\begin{array}{c}\text { Petroleum } \\
\text { Coke }\end{array}$} & \multirow[b]{2}{*}{$\begin{array}{c}\text { Asphalt } \\
\text { and Road } \\
\text { Oil }\end{array}$} & \multirow[b]{2}{*}{$\begin{array}{c}\text { Miscellaneous } \\
\text { Products } \\
\end{array}$} & \multicolumn{2}{|c|}{ Crude Oll and Products } \\
\hline & & & & & & & Total & $\begin{array}{c}\text { Daily. } \\
\text { Average }\end{array}$ \\
\hline Argentina & 0 & 1 & (s) & 0 & 0 & (s) & 31 & 1 \\
\hline 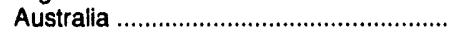 & 1 & 1 & 1 & 224 & (s) & (s) & 340 & 11 \\
\hline 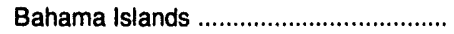 & 0 & 5 & 0 & 0 & (s) & 0 & 299 & 10 \\
\hline 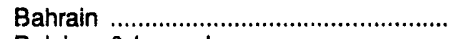 & 0 & 0 & 0 & 64 & 0 & 0 & 64 & 2 \\
\hline Belgium \& Luxembourg ........................... & 20 & 15 & (s) & $1,1,28$ & (s) & 0 & 1,164 & 38 \\
\hline 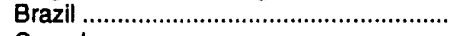 & 0 & 3 & (s) & 3 & (s) & 0 & 699 & 23 \\
\hline 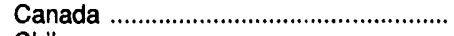 & 3 & 101 & 15 & 366 & 93 & 1 & 2,504 & 81 \\
\hline Chile & 0 & 30 & (s) & 0 & 0 & 3 & 369 & 12 \\
\hline China, People's Republic of ...................... & 0 & (s) & 0 & 0 & 0 & (s) & 1 & (s) \\
\hline 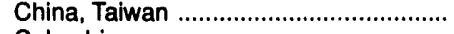 & (s) & 25 & 1 & (s) & 1 & (s) & 991 & 32 \\
\hline 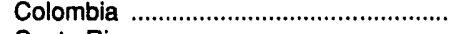 & (s) & 3 & (s) & 0 & 0 & (s) & 371 & 12 \\
\hline 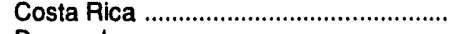 & (s) & 6 & (s) & 0 & 0 & (s) & 7 & (s) \\
\hline 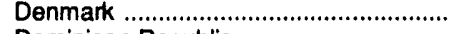 & 0 & (s) & (s) & 0 & 0 & 0 & (s) & (s) \\
\hline Dominican Republic .................................... & 1 & 42 & (s) & 0 & (s) & (s) & 231 & 7 \\
\hline 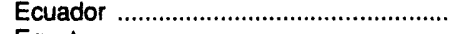 & (s) & 2 & 0 & 0 & 0 & 0 & 2 & (s) \\
\hline Egypt & 0 & 1 & (s) & 0 & (s) & 0 & 1 & (s) \\
\hline 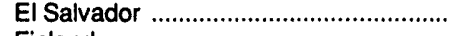 & (s) & 22 & 0 & 0 & 0 & 0 & $12 b$ & 4 \\
\hline 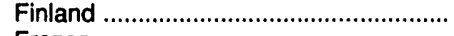 & 0 & 3 & (s) & 319 & 0 & 0 & 322 & 10 \\
\hline France & 0 & 2 & 1 & 464 & 1 & 0 & 468 & 15 \\
\hline French Pacific Islands ........................... & 0 & 0 & 0 & 0 & 0 & 0 & 181 & 6 \\
\hline 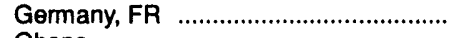 & 3 & 2 & 1 & 24 & 6 & (s) & 37 & 1 \\
\hline Ghana & 0 & (s) & 0 & 50 & 0 & 0 & 50 & 2 \\
\hline Greece & 0 & 1 & 0 & 140 & 0 & 0 & 141 & 5 \\
\hline 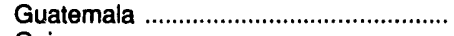 & 1 & 6 & (s) & 0 & 19 & (s) & 350 & 11 \\
\hline Guinea & 0 & 0 & 0 & 0 & 0 & 0 & 124 & 4 \\
\hline 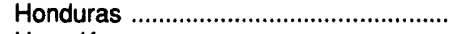 & 0 & 3 & (s) & 0 & 0 & 0 & 137 & 4 \\
\hline 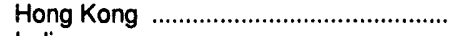 & (s) & 2 & (s) & 0 & 0 & (s) & 204 & 7 \\
\hline India & 0 & (s) & 1 & 0 & (s) & 0 & 2 & (s) \\
\hline 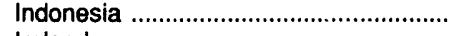 & 0 & 2 & (s) & 0 & 0 & 1 & 3 & (s) \\
\hline 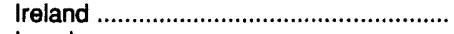 & 0 & 0 & 0 & 0 & 0 & 0 & 314 & 10 \\
\hline Israel & 0 & (s) & (s) & 89 & 0 & 0 & 89 & 3 \\
\hline Italy & 0 & (s) & 1 & 1,489 & 0 & 0 & 1,766 & 57 \\
\hline 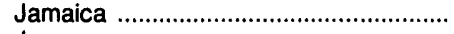 & (s) & 1 & (s) & 0 & 0 & (s) & 526 & 17 \\
\hline 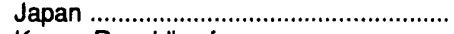 & (s) & 22 & 4 & 2,385 & 1 & 3 & 2,951 & 95 \\
\hline 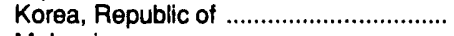 & 1 & 9 & (s) & (s) & (s) & (s) & 1,648 & 53 \\
\hline Malaysia & 0 & (s) & 1 & 0 & 0 & (s) & 2 & (s) \\
\hline Mexico & 2 & 153 & 27 & 39 & 23 & (s) & 3,252 & 105 \\
\hline 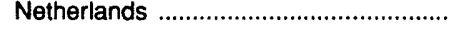 & 4 & 2 & (s) & 922 & (s) & 0 & 1,314 & 42 \\
\hline Netherlands Antilles ............................... & 0 & 3 & 0 & 0 & 0 & 0 & 1,057 & 34 \\
\hline New Zealand ............................................ & 0 & 2 & (s) & 0 & 0 & (s) & 3 & (s) \\
\hline 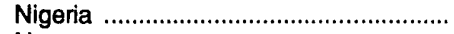 & (s) & 1 & 0 & 0 & (s) & 1 & 2 & (s) \\
\hline 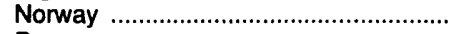 & (s) & (s) & (s) & 0 & 0 & 0 & 1 & (s) \\
\hline 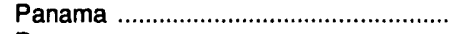 & (s) & 3 & (s) & 0 & (s) & 0 & 551 & 18 \\
\hline Pers & (s) & 2 & (s) & 0 & 0 & (s) & 156 & 5 \\
\hline Philippines ............................................... & 0 & 1 & (s) & 0 & (s) & (s) & 116 & 4 \\
\hline 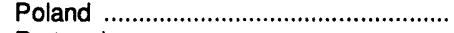 & 0 & 1 & 0 & 0 & 0 & 0 & 1 & (s) \\
\hline 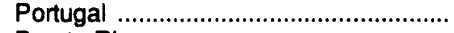 & 0 & (s) & 0 & 0 & 0 & 0 & (s) & (s) \\
\hline 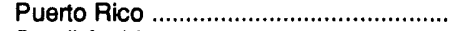 & 51 & 15 & 1 & 0 & (s) & (s) & 90 & 3 \\
\hline Saudi Arabia ................................................ & (s) & 2 & 0 & (s) & 0 & 0 & 2 & (s) \\
\hline 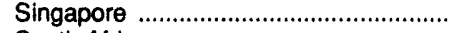 & 2 & 8 & (s) & 0 & 1 & 0 & 724 & 23 \\
\hline 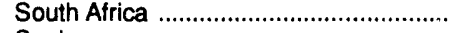 & 0 & (s) & (s) & 0 & (s) & 0 & 1 & (s) \\
\hline 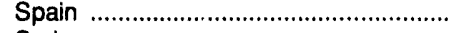 & (s) & (s) & 8 & 453 & 0 & 0 & 462 & 15 \\
\hline Suriname & 0 & 1 & 0 & 0 & 0 & 0 & 17 & 1 \\
\hline 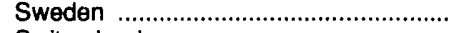 & 0 & 1 & 0 & 0 & 0 & (s) & 1 & (s) \\
\hline 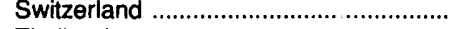 & 0 & (s) & 0 & 0 & 0 & 0 & 1 & (s) \\
\hline 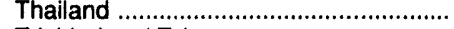 & 0 & 2 & (s) & is) & 0 & (s) & 3 & (s) \\
\hline 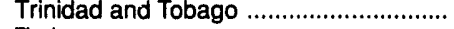 & 0 & (s) & 0 & (s) & 0 & (s) & 1 & (s) \\
\hline 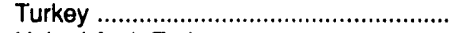 & 0 & 1 & (s) & 0 & 0 & 0 & 1 & (s) \\
\hline United Arab Emirates .............................. & (s) & 24 & 0 & 58 & 0 & 0 & 82 & 3 \\
\hline United Kingdom ......................................... & 0 & 1 & 1 & 2 & (s) & (s) & 89 & 3 \\
\hline 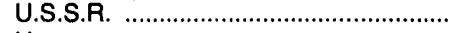 & 0 & 37 & 0 & 0 & 0 & 0 & 47 & 2 \\
\hline 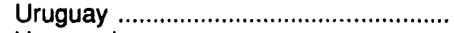 & 0 & 2 & 0 & 0 & 0 & 0 & 2 & (s) \\
\hline 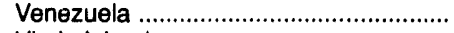 & 0 & 1 & 6 & 1 & 1 & (s) & 231 & 7 \\
\hline 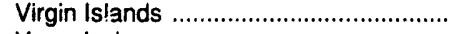 & 0 & (s) & 0 & 0 & 0 & 0 & 1,203 & 39 \\
\hline Yugoslavia .............................................. & 0 & (s) & 0 & 0 & 0 & 0 & (s) & (s) \\
\hline Other & 3 & 22 & (s) & 0 & (s) & (s) & 31 & 1 \\
\hline Total & 94 & 594 & 73 & 8,221 & 149 & 13 & 25,957 & 837 \\
\hline
\end{tabular}

a Crude oil exports are restricted to: (1) crude oil derived from fields under the State waters of Alaska's Cook Inlet; (2) certain domestically produced crude oil destined for Canada; and (3) shipments to U.S. territories.

(s) = Less than 500 barrels or less than 500 barrels per day.

Note: Totals may not equal sum of components due to independent rounding.

Sources: Energy Information Administration (EIA) Form EIA-810, "Monthly Refinery Report" and the U.S. Bureau of the Census. 
Table 48. Year-to-Date Exports of Crude Oll and Petroleum Products by Destination, January-August 1991 (Thousand Barrels)

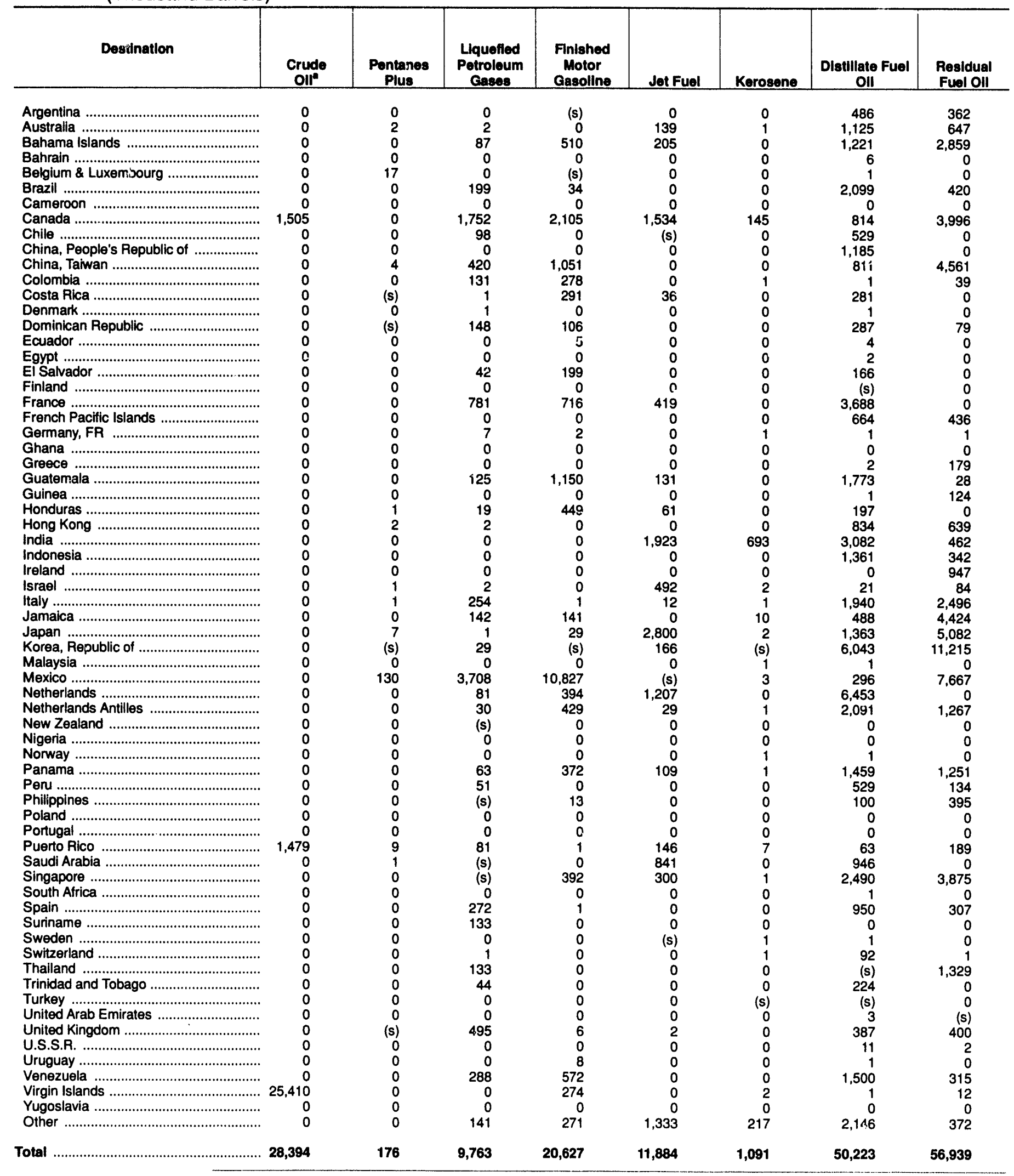

See footnotes at end of table. 
Table 48. Year-to-Date Exports of Crude Oll and Petroleum Products by Destination, January-August 1991 (Continued) (Thousand Barrels)

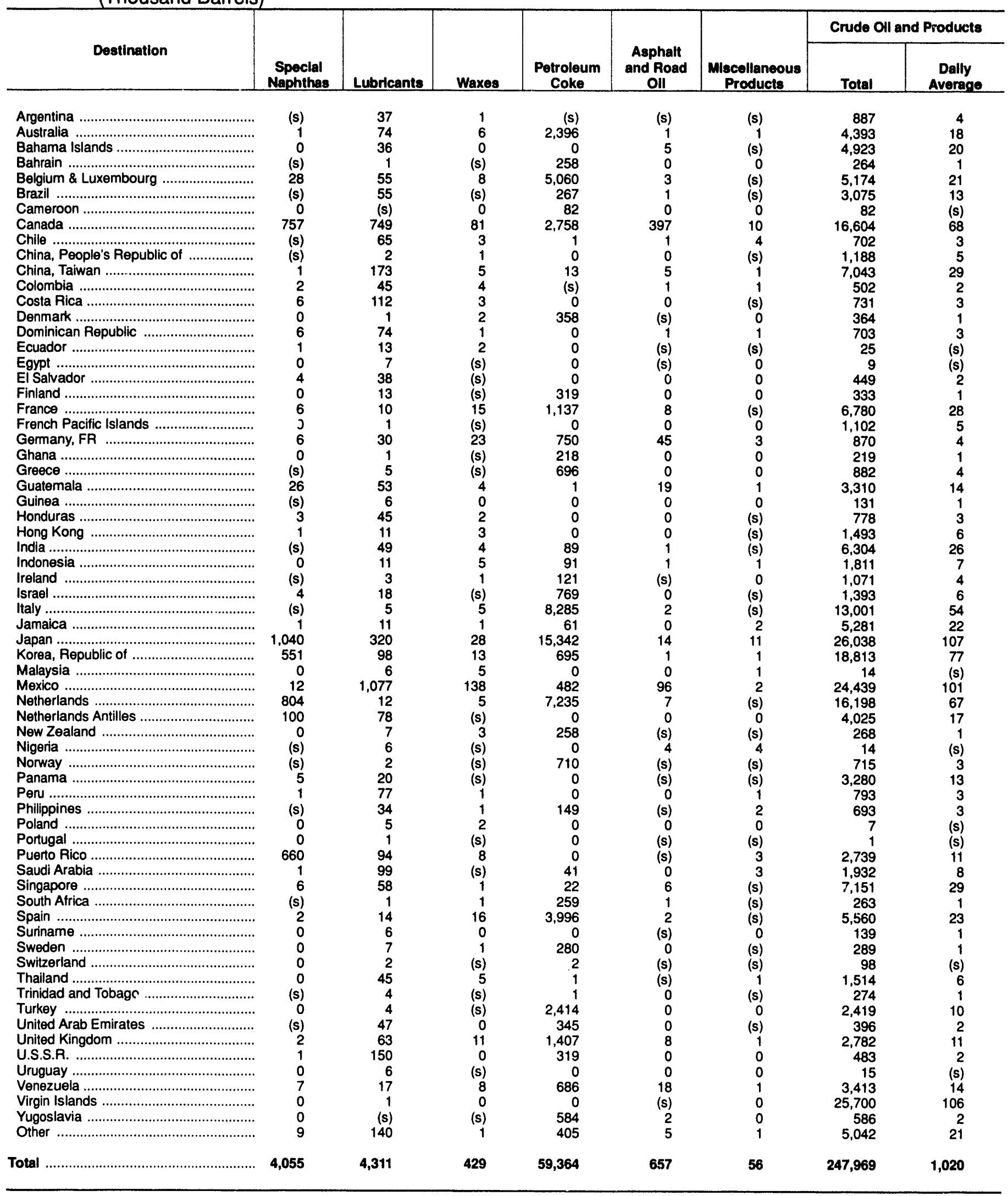

a Crude oil exports are restricted to: (1) crude oil derived from fields under the State waters of Alaska's Cook Inlet; (2) certain domestically produced crude oil destined for Canada; and (3) shipments to U.S. territories.

(s) = Less than 500 barrels or less than 500 barrels per day.

Note: Totals may not equal sum of components due to independent rounding.

Sources: Energy Information Administration (EIA) Form EIA-810, "Monthly Refinery Report" and the U.S. Bureau of the Census. 
Table 49. Net Imports of Crude Oil and Petroleum Products into the United States by Country, August 1991

(Thousand Barrels per Day)

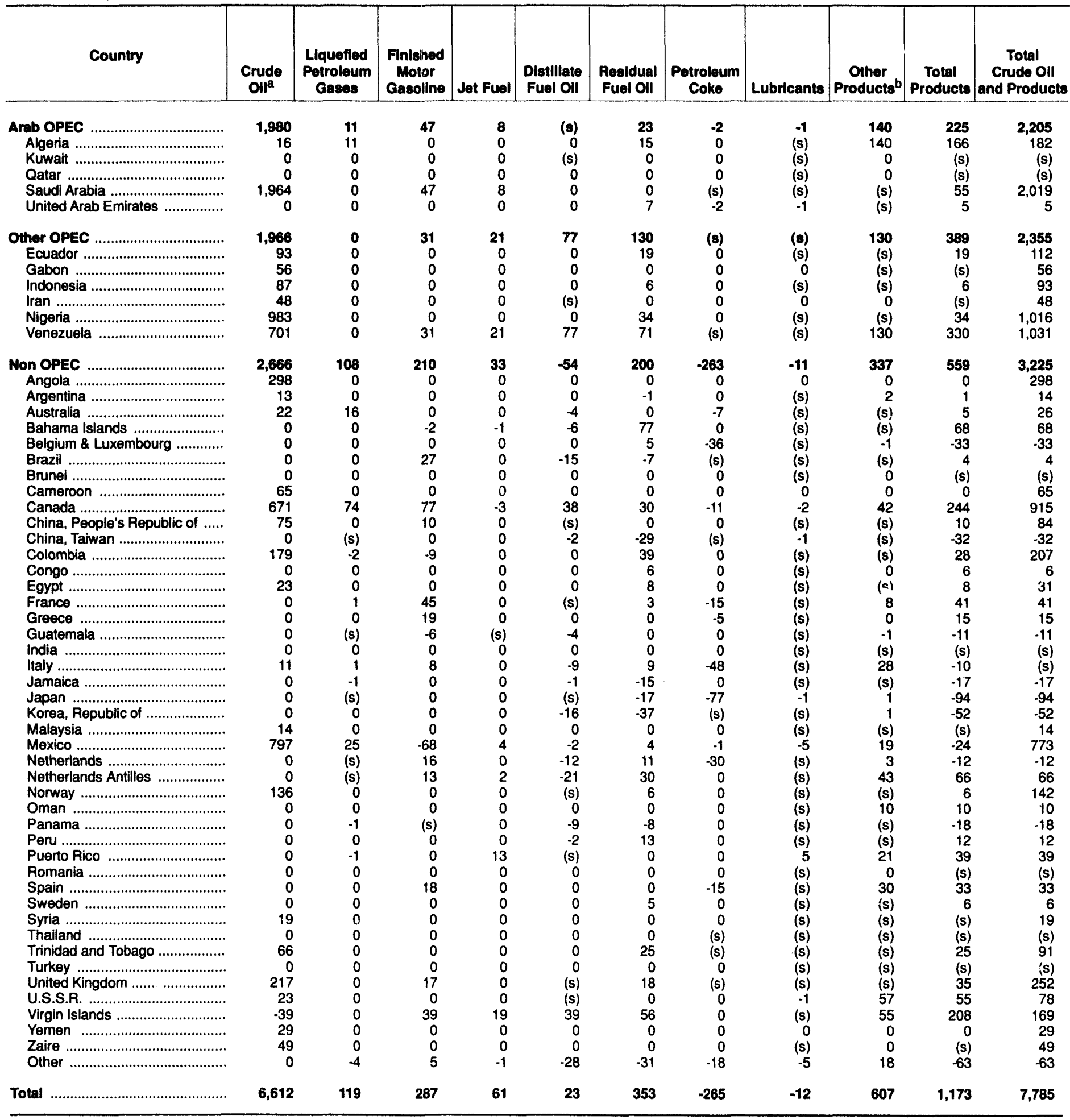

a Includes crude oil imported for storage in the Strategic Petroleum Reserve.

b Includes asphalt and road oll, aviation gasoline, aviation gasoline blending components, kerosene, miscellaneous products, motor gasoline blending components, naphtha for petrochemical feedstock use, other hydrocarbons and alcohol, other oils for petrochemical feedstock use, pentanes plus, special naphthas, unfinished oils, and waxes.

$(s)=$ Less than 500 barrels per day.

Note: Totals may not equal sum of components due to independent rounding.

Sources: Energy Information Administration (EIA) Forms EIA-810, "Monthly Refinery Report," EIA-814, "Mcnthly Imports Report" and the U.S. Bureau of the Census. 
Table 50. Year-to-Date Net Imports of Crude Oil and Petroleum Products into the United States by Country, January-August 1991

(Thousand Barrels per Day)

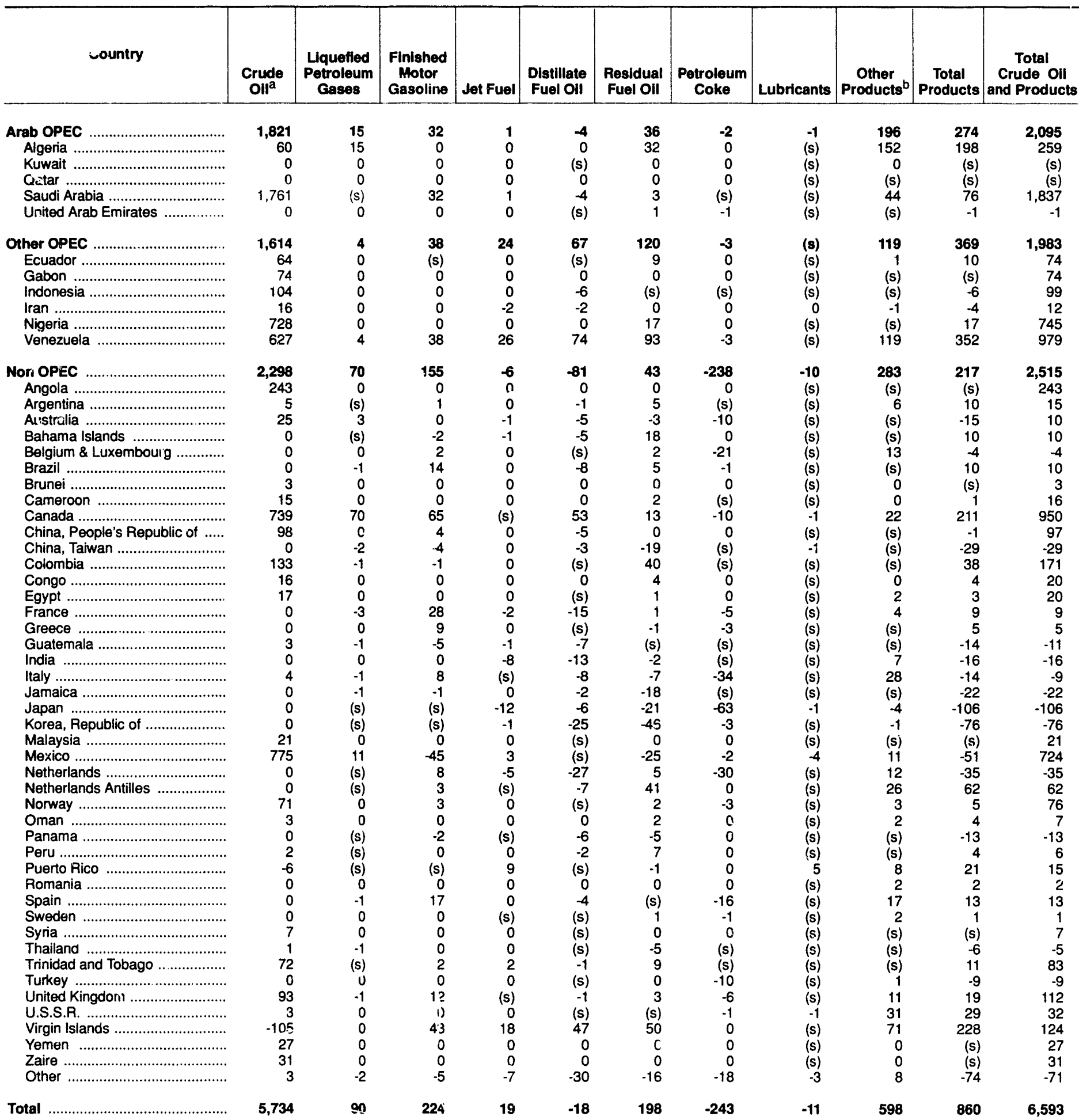

a Includes crude oil imported for storage in the Strategic Petroleum Reserve.

b Includes asphalt and road oil, aviation gasoline, aviation gasoline blending compcnents, kerosene, miscellaneous products, motor gasoline blending components, naphtha for petrochemical feedstock use, other hydrocarbons and alcohol, other ois for petrochemical feedstock use, pentanes plus, special naphthas, unfinished oils, and waxes.

(s) = Less than 500 barrels per day.

Note: Toials may not equal sum of components due to independent rounding.

Sources: Energy Information Administration (EIA) Forms EIA-810, "Monthly Refinery Report," EIA-814, "Monthly Imports Report" and the U.S. Bureau of the Census. 
Table 51. Stocks of Crude Oil and Petroleum Products by PAD District, August 1991 (Thousand Barrels)

\begin{tabular}{|c|c|c|c|c|c|c|}
\hline \multirow{2}{*}{ Commodity } & \multicolumn{5}{|c|}{ Petroleum Administration for Defense Districts } & \multirow{2}{*}{$\begin{array}{l}\text { U. S. } \\
\text { Total }\end{array}$} \\
\hline & $\mathbf{I}$ & II & III & IV & $\mathbf{v}$ & \\
\hline 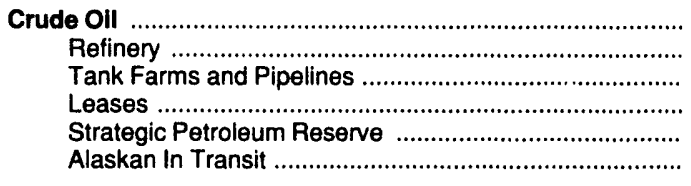 & $\begin{array}{r}15,711 \\
14,601 \\
1,091 \\
19 \\
0 \\
0\end{array}$ & $\begin{array}{r}70,916 \\
12,522 \\
57,053 \\
1,341 \\
0 \\
0\end{array}$ & $\begin{array}{r}738,615 \\
48,405 \\
106,072 \\
15,635 \\
568,503 \\
0\end{array}$ & $\begin{array}{r}11,487 \\
1,610 \\
8,895 \\
982 \\
0 \\
0\end{array}$ & $\begin{array}{r}77,116 \\
25,686 \\
35,918 \\
1,106 \\
0 \\
14,406\end{array}$ & $\begin{array}{r}913,845 \\
102,824 \\
209,029 \\
19,083 \\
568,503 \\
14,406\end{array}$ \\
\hline 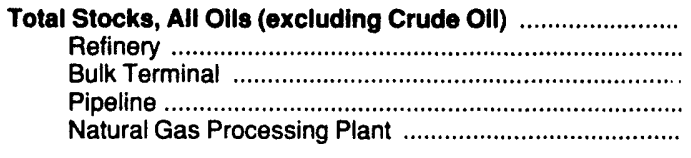 & $\begin{array}{r}173,077 \\
47,038 \\
100,250 \\
25,596 \\
193\end{array}$ & $\begin{array}{r}184,349 \\
64,312 \\
78,990 \\
37,893 \\
3,154\end{array}$ & $\begin{array}{r}267,925 \\
148,666 \\
74,816 \\
38,766 \\
5,677\end{array}$ & $\begin{array}{r}15,465 \\
10,724 \\
2,520 \\
2,046 \\
175\end{array}$ & $\begin{array}{r}90,321 \\
61,793 \\
22,655 \\
5,717 \\
156\end{array}$ & $\begin{array}{r}731,137 \\
332,533 \\
279,231 \\
110,018 \\
9,355\end{array}$ \\
\hline 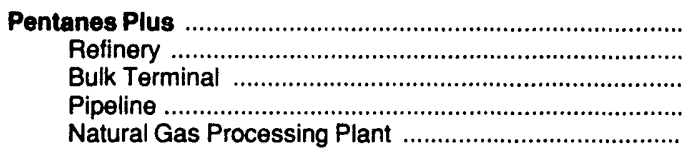 & $\begin{array}{r}30 \\
0 \\
18 \\
0 \\
12\end{array}$ & $\begin{array}{r}3,464 \\
229 \\
1,289 \\
1,555 \\
391\end{array}$ & $\begin{array}{r}5,631 \\
475 \\
3,100 \\
902 \\
1,154\end{array}$ & $\begin{array}{r}133 \\
4 \\
0 \\
71 \\
58\end{array}$ & $\begin{array}{r}35 \\
1 \\
17 \\
0 \\
17\end{array}$ & $\begin{array}{r}9,293 \\
709 \\
4,424 \\
2,528 \\
1,632\end{array}$ \\
\hline 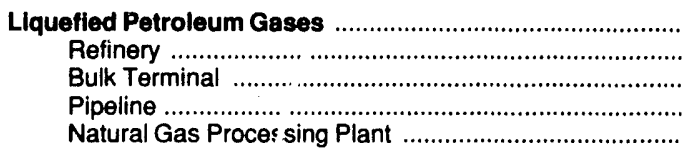 & $\begin{array}{r}6,022 \\
2,368 \\
1,837 \\
1,636 \\
181\end{array}$ & $\begin{array}{r}41,182 \\
4,333 \\
27,432 \\
6,654 \\
2,763\end{array}$ & $\begin{array}{r}63,913 \\
12,204 \\
41,123 \\
6,063 \\
4,523\end{array}$ & $\begin{array}{r}1,111 \\
469 \\
84 \\
441 \\
117\end{array}$ & $\begin{array}{r}4,147 \\
1,481 \\
2,527 \\
0 \\
139\end{array}$ & $\begin{array}{r}116,375 \\
20,855 \\
73,003 \\
14,794 \\
7,723\end{array}$ \\
\hline 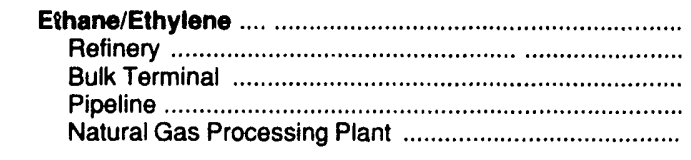 & $\begin{array}{l}2 \\
0 \\
2 \\
0 \\
0\end{array}$ & $\begin{array}{r}6,059 \\
1 \\
3,974 \\
1,259 \\
825\end{array}$ & $\begin{array}{r}12,396 \\
1,530 \\
7,388 \\
2,404 \\
1,074\end{array}$ & $\begin{array}{r}174 \\
0 \\
0 \\
171 \\
3\end{array}$ & $\begin{array}{l}0 \\
0 \\
0 \\
0 \\
0\end{array}$ & $\begin{array}{r}18,631 \\
1,531 \\
11,364 \\
3,834 \\
1,902\end{array}$ \\
\hline 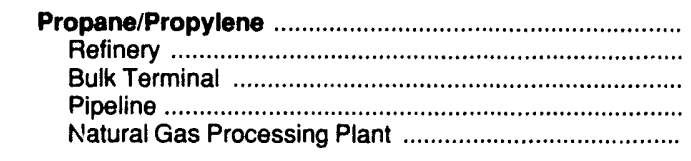 & $\begin{array}{r}3,276 \\
614 \\
914 \\
1,631 \\
117\end{array}$ & $\begin{array}{r}23,048 \\
1,692 \\
17,166 \\
3,112 \\
1,078\end{array}$ & $\begin{array}{r}23,360 \\
3,713 \\
15,671 \\
2,355 \\
1,621\end{array}$ & $\begin{array}{r}449 \\
157 \\
83 \\
141 \\
68\end{array}$ & $\begin{array}{r}1,418 \\
88 \\
1,220 \\
0 \\
110\end{array}$ & $\begin{array}{r}\mathbf{5 1 , 5 5 1} \\
6,264 \\
35,054 \\
7,239 \\
2,994\end{array}$ \\
\hline 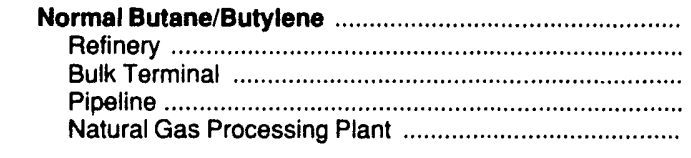 & $\begin{array}{r}2,513 \\
1,533 \\
918 \\
5 \\
57\end{array}$ & $\begin{array}{r}9,749 \\
2,211 \\
5,159 \\
1,697 \\
682\end{array}$ & $\begin{array}{r}21,433 \\
5,219 \\
14,204 \\
695 \\
1,315\end{array}$ & $\begin{array}{r}350 \\
229 \\
1 \\
85 \\
35\end{array}$ & $\begin{array}{r}2,216 \\
926 \\
1,276 \\
0 \\
14\end{array}$ & $\begin{array}{r}36,261 \\
10,118 \\
21,558 \\
2,482 \\
2,103\end{array}$ \\
\hline 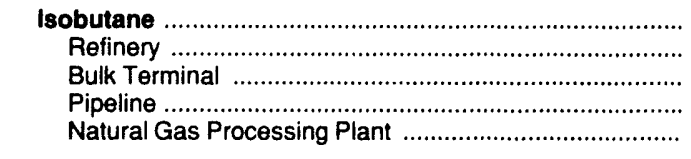 & $\begin{array}{r}231 \\
221 \\
3 \\
0 \\
7\end{array}$ & $\begin{array}{r}2,326 \\
429 \\
1,133 \\
586 \\
178\end{array}$ & $\begin{array}{r}6,724 \\
1,742 \\
3,860 \\
609 \\
513\end{array}$ & $\begin{array}{r}138 \\
83 \\
0 \\
44 \\
11\end{array}$ & $\begin{array}{r}513 \\
467 \\
31 \\
0 \\
15\end{array}$ & $\begin{array}{r}9,932 \\
2,942 \\
5,027 \\
1,239 \\
724\end{array}$ \\
\hline $\begin{array}{l}\text { Other Hydrocarbons/Alcohol } \\
\text { Refinery }\end{array}$ & $\begin{array}{l}366 \\
366\end{array}$ & $\begin{array}{l}244 \\
244\end{array}$ & $\begin{array}{l}1,008 \\
1,008\end{array}$ & $\begin{array}{l}85 \\
85\end{array}$ & $\begin{array}{l}1,529 \\
1,529\end{array}$ & $\begin{array}{l}3,232 \\
3,232\end{array}$ \\
\hline $\begin{array}{l}\text { Unfinished Olis } \\
\text { Refinery }\end{array}$ & 13,858 & 15,926 & 53,017 & 2,060 & 22,795 & 107,656 \\
\hline 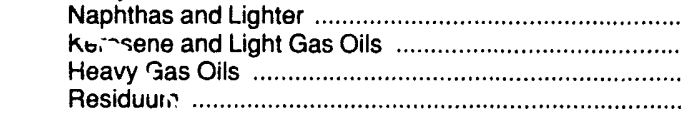 & $\begin{array}{l}3,234 \\
3,335 \\
5,940 \\
1,349\end{array}$ & $\begin{array}{l}4,815 \\
2,040 \\
5,744 \\
3,327\end{array}$ & $\begin{array}{r}14,595 \\
8,619 \\
20,534 \\
9,269\end{array}$ & $\begin{array}{l}474 \\
330 \\
700 \\
556\end{array}$ & $\begin{array}{r}3,670 \\
3,568 \\
11,209 \\
4,348\end{array}$ & $\begin{array}{l}26,788 \\
17,892 \\
44,127 \\
18,849\end{array}$ \\
\hline 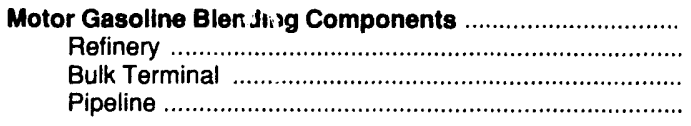 & $\begin{array}{r}5,119 \\
4,320 \\
689 \\
110\end{array}$ & $\begin{array}{r}7,448 \\
6,544 \\
648 \\
256\end{array}$ & $\begin{array}{r}16,350 \\
14,763 \\
1,440 \\
147\end{array}$ & $\begin{array}{r}1,604 \\
1,517 \\
87 \\
0\end{array}$ & $\begin{array}{r}7,542 \\
7,008 \\
16 \\
518\end{array}$ & $\begin{array}{r}38,063 \\
34,152 \\
2,880 \\
1,031\end{array}$ \\
\hline
\end{tabular}

See footnotes at end of table. 
Table 51. Stocks of Crude Oil and Petroleum Products by PAD District, August 1991 (Continued) (Thousand Barrels)

\begin{tabular}{|c|c|c|c|c|c|c|}
\hline \multirow{2}{*}{ Commodity } & \multicolumn{5}{|c|}{ Petroleum Administration for Defense Dlstricts } & \multirow{2}{*}{$\begin{array}{l}\text { U.S. } \\
\text { Total }\end{array}$} \\
\hline & $\mathbf{I}$ & ॥ & III & IV & $\mathbf{v}$ & \\
\hline 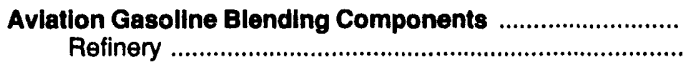 & $\begin{array}{l}0 \\
0\end{array}$ & $\begin{array}{l}32 \\
32\end{array}$ & 32 & $\begin{array}{l}0 \\
0\end{array}$ & $\begin{array}{l}3 \\
3\end{array}$ & $\begin{array}{l}67 \\
67\end{array}$ \\
\hline 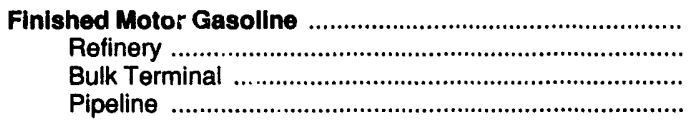 & $\begin{array}{r}49,317 \\
8,230 \\
27,330 \\
13,757\end{array}$ & $\begin{array}{l}\mathbf{5 2 , 1 6 5} \\
10,835 \\
24,673 \\
16,657\end{array}$ & $\begin{array}{l}45,008 \\
16,984 \\
10,455 \\
17,569\end{array}$ & $\begin{array}{r}3,582 \\
1,371 \\
1,275 \\
936\end{array}$ & $\begin{array}{r}21,014 \\
7,868 \\
10,324 \\
2,822\end{array}$ & $\begin{array}{r}171,086 \\
45,288 \\
74,057 \\
51,741\end{array}$ \\
\hline 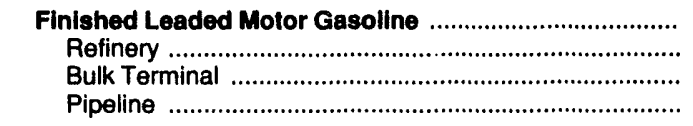 & $\begin{array}{r}106 \\
14 \\
92 \\
0\end{array}$ & $\begin{array}{l}926 \\
192 \\
486 \\
248\end{array}$ & $\begin{array}{l}496 \\
202 \\
130 \\
164\end{array}$ & $\begin{array}{l}913 \\
355 \\
348 \\
210\end{array}$ & $\begin{array}{r}4,043 \\
1,575 \\
2,231 \\
237\end{array}$ & $\begin{array}{r}6,484 \\
2,338 \\
3,287 \\
859\end{array}$ \\
\hline 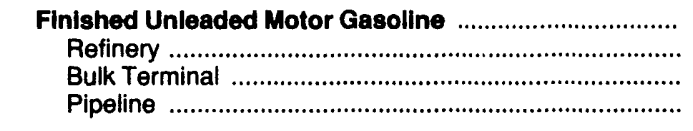 & $\begin{array}{r}49,211 \\
8,216 \\
27,238 \\
13,757\end{array}$ & $\begin{array}{l}51,239 \\
10,643 \\
24,187 \\
16,409\end{array}$ & $\begin{array}{l}\mathbf{4 4 , 5 1 2} \\
16,782 \\
10,325 \\
17,405\end{array}$ & $\begin{array}{r}2,669 \\
1,016 \\
927 \\
726\end{array}$ & $\begin{array}{r}16,971 \\
6,293 \\
8,093 \\
2,585\end{array}$ & $\begin{array}{r}164,602 \\
42,950 \\
70,770 \\
50,882\end{array}$ \\
\hline 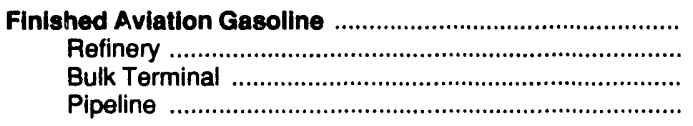 & $\begin{array}{r}212 \\
2 \\
210 \\
0\end{array}$ & $\begin{array}{r}483 \\
147 \\
322 \\
14\end{array}$ & $\begin{array}{r}535 \\
487 \\
48 \\
0\end{array}$ & $\begin{array}{r}33 \\
20 \\
13 \\
0\end{array}$ & $\begin{array}{r}407 \\
147 \\
260 \\
0\end{array}$ & $\begin{array}{r}1,670 \\
803 \\
853 \\
14\end{array}$ \\
\hline 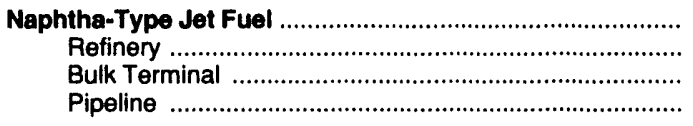 & $\begin{array}{r}461 \\
76 \\
216 \\
169\end{array}$ & $\begin{array}{r}1,106 \\
512 \\
255 \\
339\end{array}$ & $\begin{array}{r}1,883 \\
1,336 \\
189 \\
358\end{array}$ & $\begin{array}{r}285 \\
167 \\
0 \\
118\end{array}$ & $\begin{array}{r}1,551 \\
561 \\
563 \\
427\end{array}$ & $\begin{array}{l}5,286 \\
2,652 \\
1,223 \\
1,411\end{array}$ \\
\hline 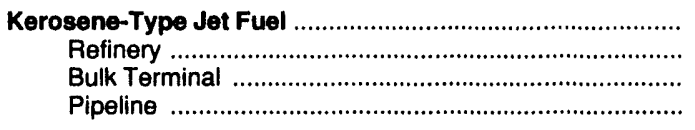 & $\begin{array}{r}10,281 \\
1,855 \\
4,618 \\
3,808\end{array}$ & $\begin{array}{l}9,191 \\
2,879 \\
3,186 \\
3,126\end{array}$ & $\begin{array}{r}15,972 \\
7,681 \\
2,542 \\
5,749\end{array}$ & $\begin{array}{l}731 \\
339 \\
256 \\
136\end{array}$ & $\begin{array}{r}6,252 \\
3,710 \\
1,723 \\
819\end{array}$ & $\begin{array}{l}42,427 \\
16,464 \\
12,325 \\
13,638\end{array}$ \\
\hline 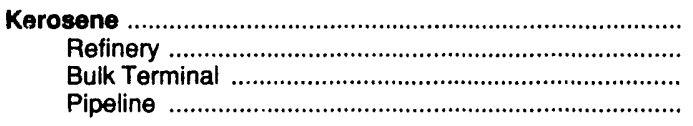 & $\begin{array}{r}2,243 \\
114 \\
2,046 \\
83\end{array}$ & $\begin{array}{r}1,435 \\
810 \\
484 \\
141\end{array}$ & $\begin{array}{r}1,138 \\
667 \\
302 \\
169\end{array}$ & $\begin{array}{r}66 \\
40 \\
26 \\
0\end{array}$ & $\begin{array}{r}54 \\
47 \\
2 \\
5\end{array}$ & $\begin{array}{r}4,936 \\
1,678 \\
2,860 \\
398\end{array}$ \\
\hline 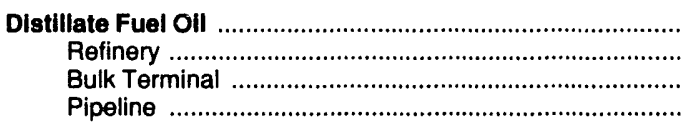 & $\begin{array}{r}56,050 \\
8,401 \\
41,616 \\
6,033\end{array}$ & $\begin{array}{r}33,133 \\
9,771 \\
14,272 \\
9,090\end{array}$ & $\begin{array}{r}28,494 \\
15,452 \\
5,248 \\
7,794\end{array}$ & $\begin{array}{r}2,896 \\
1,871 \\
681 \\
344\end{array}$ & $\begin{array}{r}9,977 \\
4,670 \\
4,352 \\
955\end{array}$ & $\begin{array}{r}130,550 \\
40,165 \\
66,169 \\
24,216\end{array}$ \\
\hline 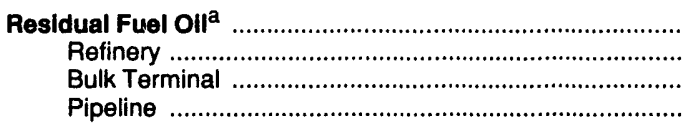 & $\begin{array}{r}18,018 \\
2,519 \\
15,499 \\
0\end{array}$ & $\begin{array}{r}3,924 \\
2,451 \\
1,473 \\
0\end{array}$ & $\begin{array}{r}15,102 \\
6,924 \\
8,178 \\
0\end{array}$ & $\begin{array}{r}550 \\
550 \\
0 \\
0\end{array}$ & $\begin{array}{r}8,001 \\
5,918 \\
1,912 \\
171\end{array}$ & $\begin{array}{r}45,595 \\
18,362 \\
27,062 \\
171\end{array}$ \\
\hline 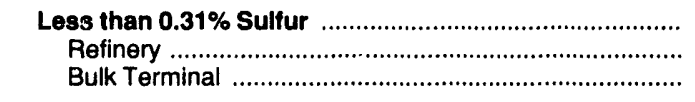 & $\begin{array}{r}4,381 \\
789 \\
3,592\end{array}$ & $\begin{array}{r}561 \\
67 \\
494\end{array}$ & $\begin{array}{r}1,588 \\
1,339 \\
249\end{array}$ & $\begin{array}{r}38 \\
38 \\
0\end{array}$ & $\begin{array}{r}763 \\
762 \\
1\end{array}$ & $\begin{array}{l}7,331 \\
2,995 \\
4,336\end{array}$ \\
\hline 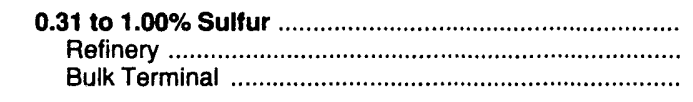 & $\begin{array}{l}6,424 \\
1,396 \\
5,028\end{array}$ & $\begin{array}{l}737 \\
391 \\
346\end{array}$ & $\begin{array}{r}4,616 \\
957 \\
3,659\end{array}$ & $\begin{array}{r}88 \\
88 \\
0\end{array}$ & $\begin{array}{l}641 \\
522 \\
119\end{array}$ & $\begin{array}{r}12,506 \\
3,354 \\
9,152\end{array}$ \\
\hline 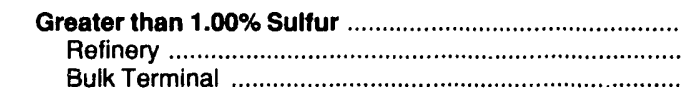 & $\begin{array}{r}7,213 \\
334 \\
6,879\end{array}$ & $\begin{array}{r}2,626 \\
1,993 \\
633\end{array}$ & $\begin{array}{l}8,898 \\
4,628 \\
4,270\end{array}$ & $\begin{array}{r}424 \\
424 \\
0\end{array}$ & $\begin{array}{l}6,426 \\
4,634 \\
1,792\end{array}$ & $\begin{array}{l}25,587 \\
12,013 \\
13,574\end{array}$ \\
\hline 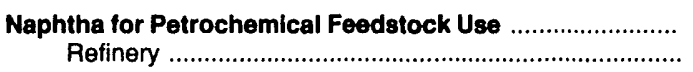 & $\begin{array}{l}121 \\
121\end{array}$ & $\begin{array}{l}345 \\
345\end{array}$ & $\begin{array}{l}873 \\
873\end{array}$ & $\begin{array}{l}0 \\
0\end{array}$ & $\begin{array}{l}78 \\
78\end{array}$ & $\begin{array}{l}1,417 \\
1,417\end{array}$ \\
\hline
\end{tabular}

See footnotes at end of table. 
Table 51. Stocks of Crude Oil and Petroleum Products by PAD District, August 1991 (Continued) (Thousand Barrels)

\begin{tabular}{|c|c|c|c|c|c|c|}
\hline \multirow{2}{*}{ Commodity } & \multicolumn{5}{|c|}{ Petroleum Adminlstration for Defense Districts } & \multirow{2}{*}{$\begin{array}{l}\text { U. S. } \\
\text { Total }\end{array}$} \\
\hline & $\mathbf{I}$ & \| & III & IV & $\mathbf{v}$ & \\
\hline 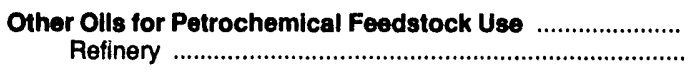 & 4 & $\begin{array}{l}22 \\
22\end{array}$ & $\begin{array}{l}1,665 \\
1,665\end{array}$ & 4 & $\begin{array}{l}204 \\
204\end{array}$ & $\begin{array}{l}1,899 \\
1,899\end{array}$ \\
\hline 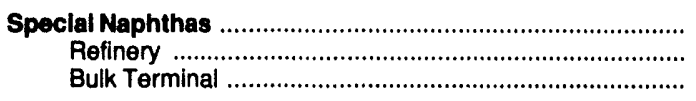 & $\begin{array}{l}604 \\
119 \\
485\end{array}$ & $\begin{array}{l}362 \\
240 \\
122\end{array}$ & $\begin{array}{r}1,104 \\
987 \\
117\end{array}$ & $\begin{array}{l}2 \\
2 \\
0\end{array}$ & $\begin{array}{r}48 \\
48 \\
0\end{array}$ & $\begin{array}{r}2,120 \\
1,396 \\
724\end{array}$ \\
\hline 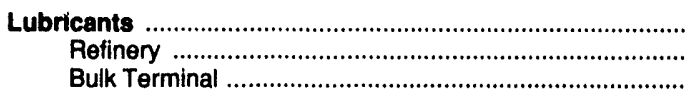 & $\begin{array}{r}2,509 \\
738 \\
1,771\end{array}$ & $\begin{array}{r}1,806 \\
853 \\
953\end{array}$ & $\begin{array}{r}6,443 \\
5,767 \\
676\end{array}$ & $\begin{array}{l}7 \\
7 \\
0\end{array}$ & $\begin{array}{r}1,908 \\
1,165 \\
743\end{array}$ & $\begin{array}{r}12,673 \\
8,530 \\
4,143\end{array}$ \\
\hline 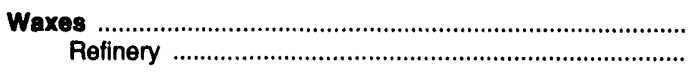 & $\begin{array}{l}158 \\
158\end{array}$ & $\begin{array}{l}127 \\
127\end{array}$ & $\begin{array}{l}500 \\
500\end{array}$ & $\begin{array}{l}124 \\
124\end{array}$ & $\begin{array}{l}138 \\
138\end{array}$ & $\begin{array}{l}1,047 \\
1,047\end{array}$ \\
\hline $\begin{array}{l}\text { Petroleum Coke } \\
\text { Refinery }\end{array}$ & $\begin{array}{l}825 \\
825\end{array}$ & $\begin{array}{l}1,766 \\
1,766\end{array}$ & $\begin{array}{l}3,489 \\
3,489\end{array}$ & $\begin{array}{l}21 \\
21\end{array}$ & $\begin{array}{l}2,088 \\
2,088\end{array}$ & $\begin{array}{l}8,189 \\
8,189\end{array}$ \\
\hline $\begin{array}{l}\text { Asphalt and Road Oll } \\
\text { Refinery } \\
\text { Bulk Terminal }\end{array}$ & $\begin{array}{l}5,933 \\
2,804 \\
3,129\end{array}$ & $\begin{array}{l}9,923 \\
6,057 \\
3,866\end{array}$ & $\begin{array}{r}4,473 \\
3,640 \\
833\end{array}$ & $\begin{array}{r}2,159 \\
2,062 \\
97\end{array}$ & $\begin{array}{r}2,414 \\
2,217 \\
197\end{array}$ & $\begin{array}{r}24,902 \\
16,780 \\
8,122\end{array}$ \\
\hline 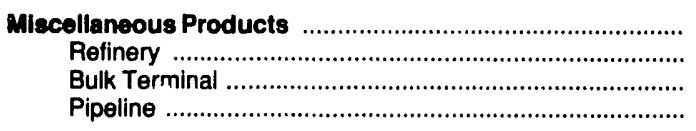 & $\begin{array}{r}946 \\
160 \\
786 \\
0\end{array}$ & $\begin{array}{r}265 \\
189 \\
15 \\
61\end{array}$ & $\begin{array}{r}1,295 \\
715 \\
565 \\
15\end{array}$ & $\begin{array}{r}12 \\
11 \\
1 \\
0\end{array}$ & $\begin{array}{r}136 \\
117 \\
19 \\
0\end{array}$ & $\begin{array}{r}2,654 \\
1,192 \\
1,386 \\
76\end{array}$ \\
\hline 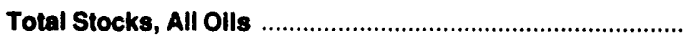 & 188,788 & 255,265 & $1,006,540$ & 26,952 & 167,437 & $1,644,982$ \\
\hline
\end{tabular}

a Sulfur content not available for stocks held by pipelines.

Note: Stocks are reported as of the last day of the month.

Sources: Energy Information Administration (EIA) Forms EIA-810, "Monthly Refinery Report," EIA-811, "Monthly Bulk Terminal Report," EIA-812, "Monthly Product Pipeline Report," EIA-813, "Monthly Crude Oil Report," and EIA-816, "Monthly Natural Gas Liquids Report." 
Table 52. Refinery, Bulk Terminal, and Natural Gas Plant Stocks of Selected Petroleum Products by PAD District and State, August 1991 (Thousand Barrels)

\begin{tabular}{|c|c|c|c|c|c|c|}
\hline PAD District and State & $\begin{array}{l}\text { Leaded Motor } \\
\text { Gasoline }\end{array}$ & $\begin{array}{c}\text { Unleaded Motor } \\
\text { Gasoline }\end{array}$ & Kerosene & $\begin{array}{c}\text { Distllate Fuel } \\
\text { Oll }\end{array}$ & Residual Fuel & $\begin{array}{l}\text { Propane/ } \\
\text { Propylene }\end{array}$ \\
\hline 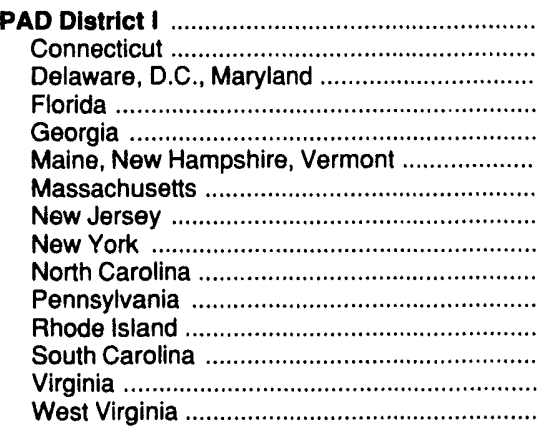 & $\begin{array}{r}106 \\
0 \\
71 \\
0 \\
0 \\
0 \\
0 \\
1 \\
2 \\
2 \\
2 \\
0 \\
0 \\
14 \\
14\end{array}$ & $\begin{array}{r}35,454 \\
1,168 \\
2,310 \\
5,346 \\
2,568 \\
830 \\
1,428 \\
7,633 \\
3,108 \\
1,929 \\
4,638 \\
490 \\
1,272 \\
2,584 \\
150\end{array}$ & $\begin{array}{r}2,160 \\
33 \\
85 \\
156 \\
79 \\
155 \\
126 \\
208 \\
411 \\
151 \\
496 \\
W \\
99 \\
108 \\
W\end{array}$ & $\begin{array}{r}50,017 \\
3,200 \\
5,100 \\
1,975 \\
1,206 \\
2,866 \\
2,365 \\
13,985 \\
9,326 \\
1,373 \\
4,153 \\
1,418 \\
574 \\
2,368 \\
108\end{array}$ & $\begin{array}{r}18,018 \\
219 \\
3,231 \\
1,209 \\
224 \\
757 \\
901 \\
5,931 \\
3,142 \\
292 \\
1,101 \\
W \\
W \\
537 \\
W\end{array}$ & $\begin{array}{r}1,645 \\
W \\
W \\
165 \\
W \\
W \\
W \\
W \\
W \\
W \\
W \\
W \\
W \\
W \\
W\end{array}$ \\
\hline 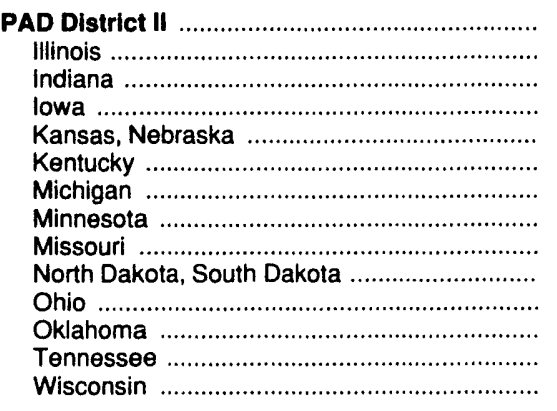 & $\begin{array}{r}678 \\
112 \\
176 \\
2 \\
72 \\
9 \\
53 \\
88 \\
7 \\
43 \\
4 \\
110 \\
0 \\
2\end{array}$ & $\begin{array}{r}34,830 \\
7,155 \\
4,445 \\
1,661 \\
2,435 \\
1,291 \\
3,720 \\
1,817 \\
1,361 \\
678 \\
4,074 \\
1,979 \\
2,142 \\
2,072\end{array}$ & $\begin{array}{r}1,294 \\
198 \\
107 \\
W \\
9 \\
73 \\
145 \\
W \\
W \\
W \\
411 \\
W \\
57 \\
W\end{array}$ & $\begin{array}{r}24,043 \\
4,803 \\
3,491 \\
1,287 \\
1,946 \\
742 \\
2,126 \\
1,528 \\
745 \\
870 \\
2,335 \\
1,334 \\
875 \\
1,961\end{array}$ & $\begin{array}{r}3,924 \\
1,519 \\
545 \\
W \\
37 \\
W \\
155 \\
319 \\
W \\
W \\
336 \\
336 \\
207 \\
119\end{array}$ & $\begin{array}{r}19,936 \\
956 \\
W \\
W \\
13,631 \\
W \\
2,043 \\
W \\
W \\
W \\
W \\
1,127 \\
W \\
W\end{array}$ \\
\hline $\begin{array}{l}\text { PAD District III } \\
\text { Alabama } \\
\text { Arkansas } \\
\text { Louisiana } \\
\text { Mississippi } \\
\text { New Mexico } \\
\text { Texas }\end{array}$ & $\begin{array}{r}332 \\
0 \\
0 \\
0 \\
0 \\
108 \\
224\end{array}$ & $\begin{array}{r}27,107 \\
1,400 \\
857 \\
4,943 \\
2,578 \\
363 \\
16,966\end{array}$ & $\begin{array}{r}969 \\
45 \\
W \\
242 \\
11 \\
W \\
651\end{array}$ & $\begin{array}{r}20,700 \\
844 \\
476 \\
4,292 \\
1,533 \\
202 \\
13,353\end{array}$ & $\begin{array}{r}15,102 \\
634 \\
W \\
6,121 \\
W \\
29 \\
8,120\end{array}$ & $\begin{array}{r}21,005 \\
49 \\
W \\
2,953 \\
1,458 \\
W \\
16,442\end{array}$ \\
\hline 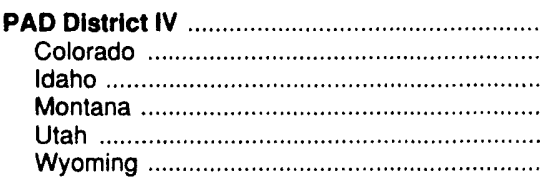 & $\begin{array}{r}703 \\
73 \\
119 \\
279 \\
121 \\
111\end{array}$ & $\begin{array}{r}1,943 \\
551 \\
184 \\
507 \\
259 \\
442\end{array}$ & $\begin{array}{l}66 \\
W \\
W \\
W \\
W \\
W\end{array}$ & $\begin{array}{r}2,552 \\
409 \\
129 \\
837 \\
416 \\
761\end{array}$ & $\begin{array}{r}550 \\
W \\
W \\
47 \\
131 \\
W\end{array}$ & $\begin{array}{r}308 \\
W \\
W \\
23 \\
197 \\
47\end{array}$ \\
\hline 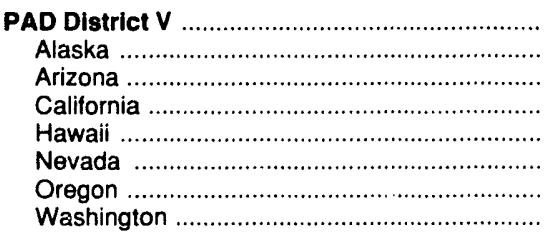 & $\begin{array}{r}3,806 \\
140 \\
238 \\
1,995 \\
33 \\
95 \\
284 \\
1,021\end{array}$ & $\begin{array}{r}14,386 \\
524 \\
466 \\
9,506 \\
654 \\
239 \\
1,058 \\
1,939\end{array}$ & $\begin{array}{l}49 \\
W \\
W \\
47 \\
W \\
W \\
W \\
W\end{array}$ & $\begin{array}{r}9,022 \\
662 \\
234 \\
5,385 \\
334 \\
99 \\
726 \\
1,582\end{array}$ & $\begin{array}{r}7,830 \\
W \\
W \\
5,113 \\
W \\
W \\
121 \\
1,332\end{array}$ & $\begin{array}{r}1,418 \\
W \\
W \\
189 \\
W \\
W \\
W \\
27\end{array}$ \\
\hline 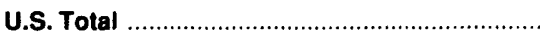 & 5,625 & 113,720 & 4,538 & 106,334 & 45,424 & 44,312 \\
\hline
\end{tabular}

$W=$ Withheld to avoid disclosure of individual company data.

Notes: - Stocks are reported as of the last day of the month. - Totals may not equal sum of components due to independent rounding.

Sources: Energy Information Administration (EIA) Forms EIA-810, "Monthly Refinery Report," EIA-811, "Monthly Bulk Terminal Report," and EIA-816, "Monthly Natural Gas Liquids Raport." 
Table 53. Movements of Crude Oll and Petroleum Products by Pipeline, Tanker, and Barge Between PAD Districts, August 1991

(Thousand Barrels)

\begin{tabular}{|c|c|c|c|c|c|c|c|c|c|}
\hline \multirow{2}{*}{ Commodity } & \multicolumn{3}{|c|}{ From I to } & \multicolumn{4}{|c|}{ From II to } & \multicolumn{2}{|c|}{ From III to } \\
\hline & II & III & $\mathbf{v}$ & 1 & III & IV & $\mathbf{v}$ & 1 & $\|$ \\
\hline 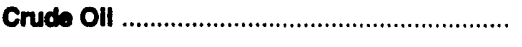 & 129 & 0 & 0 & 96 & 2,330 & 531 & 0 & 0 & 58,957 \\
\hline Potroloum Products & 7,626 & 71 & 0 & 3,443 & 5,856 & 2,131 & 0 & 75,933 & 25,461 \\
\hline Pentanes Plus ................................................ & & 0 & 0 & & 152 & 1 & 0 & 0 & 741 \\
\hline Liquefied Petroleum Gases ............................... & 0 & 0 & 0 & 493 & 3,574 & 37 & 0 & 1,868 & 3,085 \\
\hline 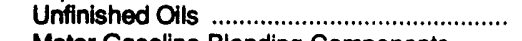 & 29 & 0 & 0 & 28 & 0 & 0 & 0 & 152 & 171 \\
\hline Motor Gasoline Blending Components ........ & 30 & 0 & 0 & 0 & 0 & 0 & 0 & 164 & 0 \\
\hline Finished Motor Gasoline ................................... & 5,258 & 0 & 0 & 1,516 & 940 & 1,258 & 0 & 44,373 & 13,682 \\
\hline 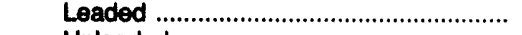 & 0 & 0 & 0 & 0 & 0 & 0 & 0 & 0 & 2 \\
\hline 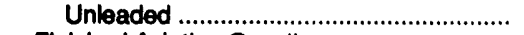 & 5,298 & 0 & 0 & 1,516 & $940^{\circ}$ & 1,258 & 0 & 44,373 & 13,680 \\
\hline Finished Aviation Gasoline ........................... & 0 & 0 & 0 & 0 & 0 & 22 & 0 & 117 & 124 \\
\hline Jet Fuel & 302 & 0 & 0 & 267 & 220 & 600 & 0 & 10,233 & 3,463 \\
\hline 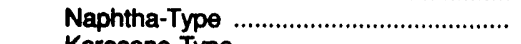 & 0 & 0 & 0 & 0 & 74 & 0 & 0 & 99 & 10 \\
\hline 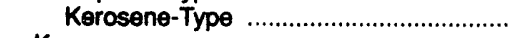 & 302 & 0 & 0 & 267 & 146 & 600 & 0 & 10,134 & 3,453 \\
\hline Kerosene & 20 & 0 & 0 & 8 & 0 & 0 & 0 & 128 & 9 \\
\hline 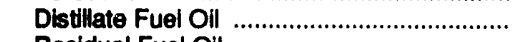 & 1,889 & 0 & 0 & 728 & 297 & 213 & 0 & 17,399 & 3,413 \\
\hline 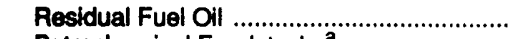 & 0 & 0 & 0 & 101 & 662 & 0 & 0 & 447 & 0 \\
\hline 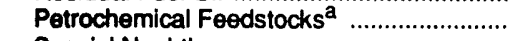 & 58 & 0 & 0 & 0 & 0 & 0 & 0 & 0 & 0 \\
\hline 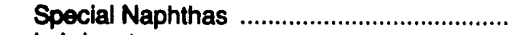 & 0 & 0 & 0 & 0 & 0 & 0 & 0 & 140 & 33 \\
\hline 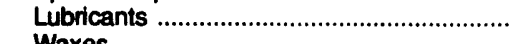 & 0 & 18 & 0 & 119 & 0 & 0 & 0 & 442 & 343 \\
\hline Waxes & 0 & 0 & 0 & 0 & 0 & 0 & 0 & 0 & 0 \\
\hline 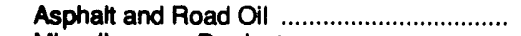 & 0 & 53 & 0 & 183 & 0 & 0 & 0 & 413 & 397 \\
\hline 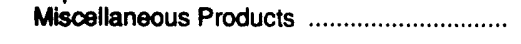 & 0 & 0 & 0 & 0 & 11 & 0 & 0 & 57 & 0 \\
\hline Total & 7,755 & 71 & $\mathbf{0}$ & 3,539 & 8,186 & 2,662 & 0 & 75,933 & 84,418 \\
\hline
\end{tabular}

\begin{tabular}{|c|c|c|c|c|c|c|c|c|c|}
\hline \multirow{2}{*}{ Commodity } & \multicolumn{2}{|c|}{ From III to } & \multicolumn{3}{|c|}{ From IV to } & \multicolumn{4}{|c|}{ From V to } \\
\hline & IV & $\mathbf{v}$ & " & III & $\mathbf{v}$ & 1 & $\|$ & III & IV \\
\hline Crudb Oll ............... & 0 & $\mathbf{0}$ & 2,532 & 1,700 & $\mathbf{0}$ & 0 & 0 & 7,702 & 0 \\
\hline 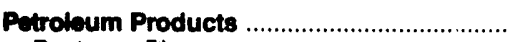 & 0 & 1,685 & 1,850 & 1,467 & 1,040 & 0 & $\mathbf{0}$ & 43 & 0 \\
\hline 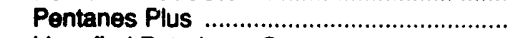 & 0 & 0 & 113 & 190 & 0 & 0 & 0 & 0 & 0 \\
\hline 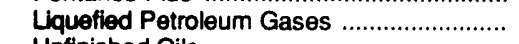 & 0 & 0 & 744 & 1,277 & 0 & 0 & 0 & 0 & 0 \\
\hline 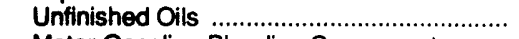 & 0 & 0 & 0 & 0 & 0 & 0 & 0 & 0 & 0 \\
\hline Motor Gasoline Blending Components ........ & 0 & 0 & 0 & 0 & 0 & 0 & 0 & 0 & 0 \\
\hline 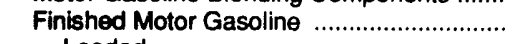 & 0 & 930 & 530 & 0 & 762 & 0 & 0 & 0 & 0 \\
\hline 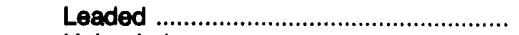 & 0 & 179 & 72 & 0 & 235 & 0 & 0 & 0 & 0 \\
\hline 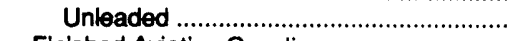 & 0 & 751 & 458 & 0 & 527 & 0 & 0 & 0 & 0 \\
\hline Finished Aviation Gasoline ................................ & 0 & 0 & 0 & 0 & 0 & 0 & 0 & 0 & 0 \\
\hline 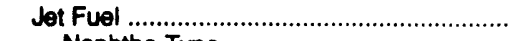 & 0 & 331 & 58 & 0 & 150 & 0 & 0 & 0 & 0 \\
\hline 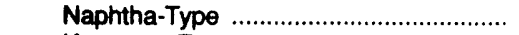 & 0 & 120 & 56 & 0 & 99 & 0 & 0 & 0 & 0 \\
\hline 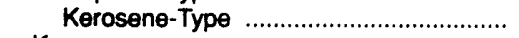 & 0 & 211 & 2 & 0 & 51 & 0 & 0 & 0 & 0 \\
\hline Kerosene & 0 & 0 & 0 & 0 & 0 & 0 & 0 & 0 & 0 \\
\hline 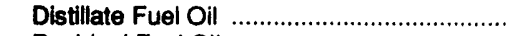 & 0 & 398 & 405 & 0 & 128 & 0 & 0 & 0 & 0 \\
\hline 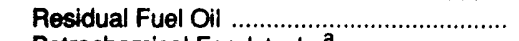 & 0 & 0 & 0 & 0 & 0 & 0 & 0 & 0 & 0 \\
\hline Petrochemical Feedstocks ${ }^{\mathrm{a}}$ & 0 & 0 & 0 & 0 & 0 & 0 & 0 & 0 & 0 \\
\hline 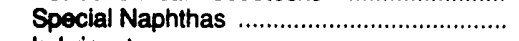 & 0 & 0 & 0 & 0 & 0 & 0 & 0 & 0 & 0 \\
\hline 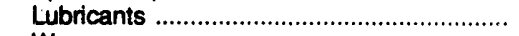 & 0 & 26 & 0 & 0 & 0 & 0 & 0 & 43 & 0 \\
\hline 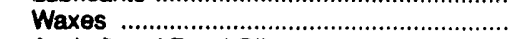 & 0 & 0 & 0 & 0 & 0 & 0 & 0 & 0 & 0 \\
\hline 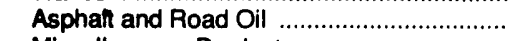 & 0 & 0 & 0 & 0 & 0 & 0 & 0 & 0 & 0 \\
\hline 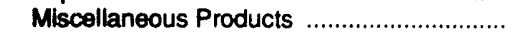 & 0 & 0 & 0 & 0 & 0 & 0 & 0 & 0 & 0 \\
\hline (1) & $\mathbf{0}$ & 1,685 & 4,382 & 3,167 & 1,040 & $\mathbf{0}$ & 0 & 7,745 & 0 \\
\hline
\end{tabular}

a Includes naphtha less than $401^{\circ} \mathrm{F}$ endpoint and other oils equal to or greater than $401^{\circ} \mathrm{F}$ endpoint

Sources: Energy Information Administration (EIA) Forms EIA-812, "Monthly Product Pipeline Report," EIA-813, "Monthly Crude Oil Report," and EIA-817, "Monthly Tanker and Barge Movement Report." 
Table 54. Movements of Crude Oil and Petroleum Products by Pipeline Between PAD Districts, August 1991 (Thousand Barrels)

\begin{tabular}{|c|c|c|c|c|c|c|c|}
\hline \multirow{2}{*}{ Commodity } & \multicolumn{2}{|c|}{ From I to } & \multicolumn{3}{|c|}{ From II to } & \multicolumn{2}{|c|}{ From III to } \\
\hline & II & III & $\mathbf{I}$ & III & IV & $\mathbf{I}$ & II \\
\hline 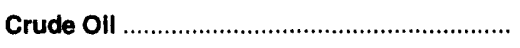 & 104 & $\mathbf{0}$ & $\mathbf{0}$ & 2,330 & 531 & 0 & 58,857 \\
\hline 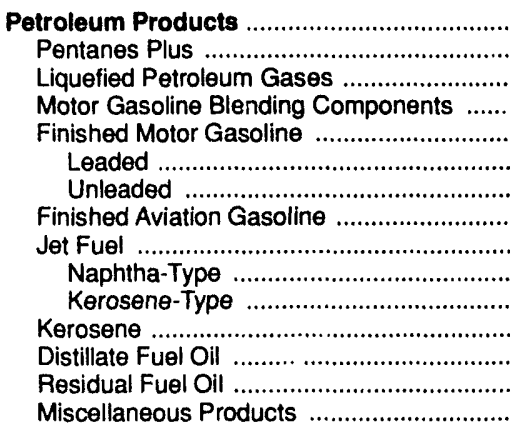 & $\begin{array}{r}7,531 \\
0 \\
0 \\
30 \\
5,290 \\
0 \\
5,290 \\
0 \\
302 \\
0 \\
302 \\
20 \\
1,889 \\
0 \\
0\end{array}$ & $\begin{array}{l}0 \\
0 \\
0 \\
0 \\
0 \\
0 \\
0 \\
0 \\
0 \\
0 \\
0 \\
0 \\
0 \\
0 \\
0\end{array}$ & $\begin{array}{r}1,781 \\
0 \\
493 \\
0 \\
800 \\
0 \\
800 \\
0 \\
167 \\
0 \\
167 \\
0 \\
321 \\
0 \\
0\end{array}$ & $\begin{array}{r}5,194 \\
152 \\
3,574 \\
0 \\
940 \\
0 \\
940 \\
0 \\
220 \\
74 \\
146 \\
0 \\
297 \\
0 \\
11\end{array}$ & $\begin{array}{r}2,131 \\
1 \\
37 \\
0 \\
1,258 \\
0 \\
1,258 \\
22 \\
600 \\
0 \\
600 \\
0 \\
213 \\
0 \\
0\end{array}$ & $\begin{array}{r}63,484 \\
0 \\
1,682 \\
164 \\
37,450 \\
0 \\
37,450 \\
0 \\
8,402 \\
99 \\
8,303 \\
128 \\
15,658 \\
0 \\
0\end{array}$ & $\begin{array}{r}22,287 \\
741 \\
3,085 \\
0 \\
12,348 \\
2 \\
12,346 \\
108 \\
3,150 \\
10 \\
3,140 \\
0 \\
2,855 \\
0 \\
0\end{array}$ \\
\hline Total & 7,635 & 0 & 1,781 & 7,524 & 2,662 & 63,484 & 81,244 \\
\hline
\end{tabular}

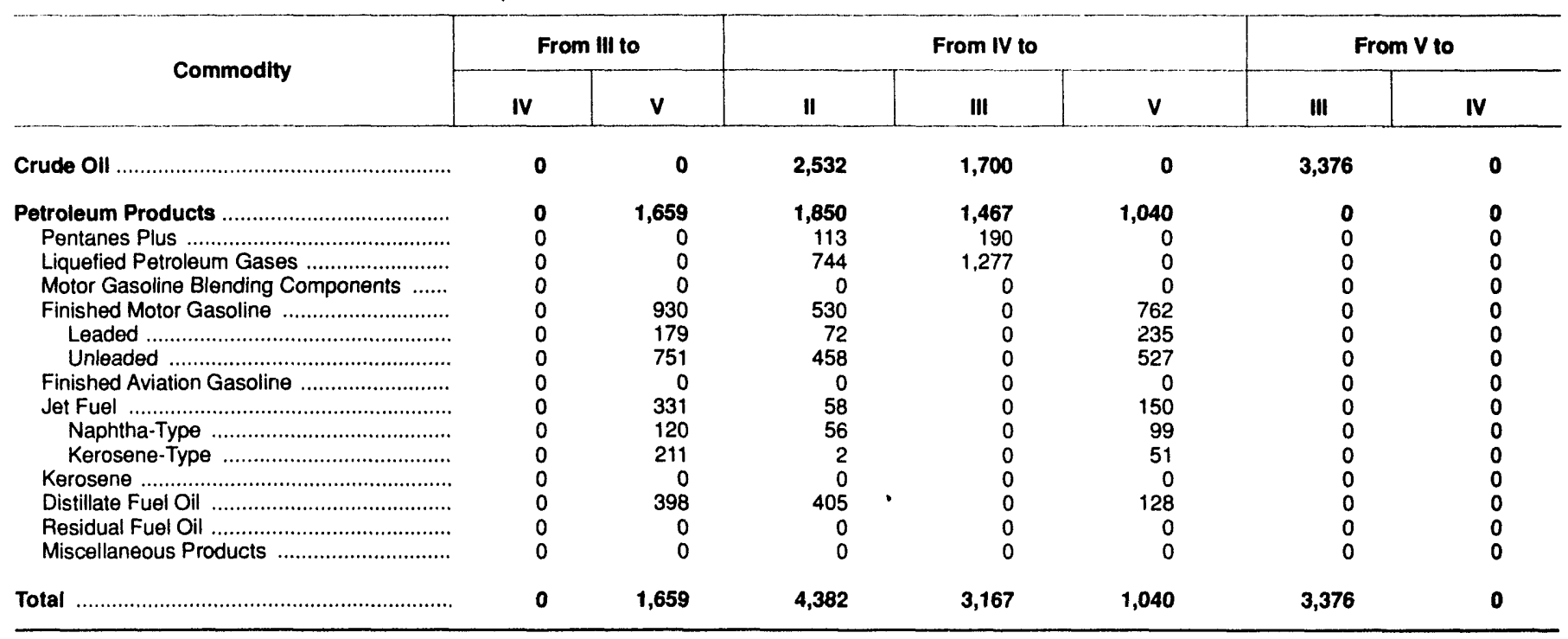

Sources: Energy Information Administration (EIA) Forms EIA-812, "Monthly Product Pipeline Repon," and EIA-813, Monthly Crude Oil Report." 
Table 55. Movements of Crude Oll and Petroleum Products by Tanker and Barge Between PAD Districts, August 1991

(Thousand Barrels)

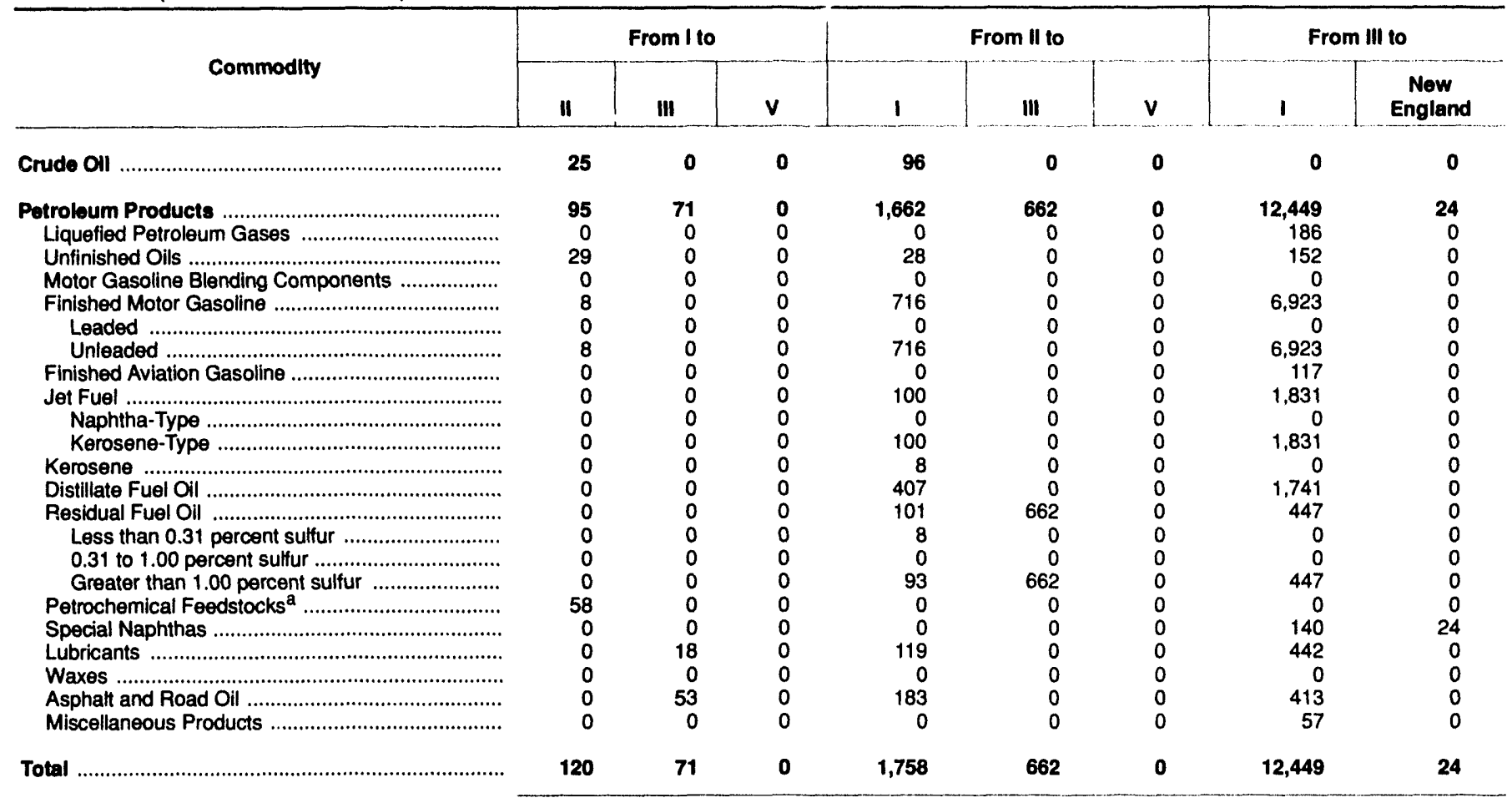

\begin{tabular}{|c|c|c|c|c|c|c|c|}
\hline \multirow{2}{*}{ Commodity } & \multicolumn{4}{|c|}{ From III to } & \multicolumn{3}{|c|}{ From $V$ to } \\
\hline & $\begin{array}{l}\text { Central } \\
\text { Atlantlc }\end{array}$ & $\begin{array}{l}\text { Lower } \\
\text { Atlantlc }\end{array}$ & $\|$ & $\mathbf{v}$ & $\mathbf{I}$ & II & III \\
\hline 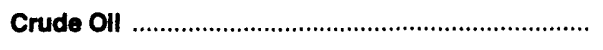 & $\mathbf{0}$ & 0 & 0 & 0 & $\mathbf{0}$ & 0 & 4,326 \\
\hline 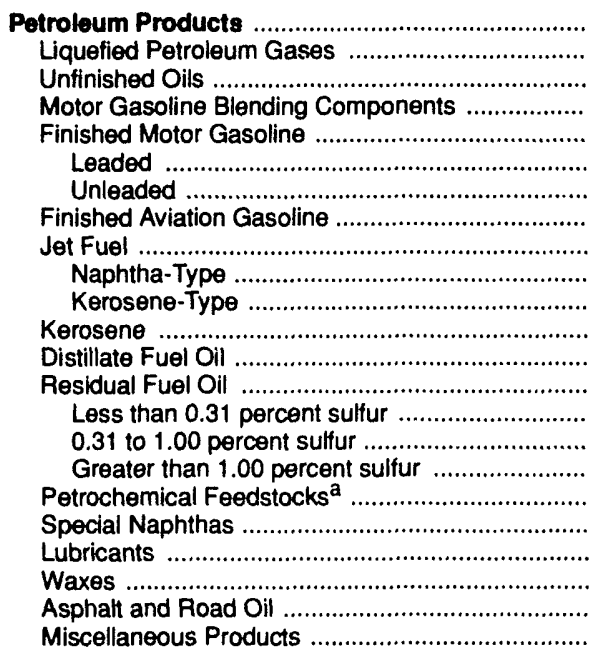 & $\begin{array}{r}1,335 \\
0 \\
12 \\
0 \\
524 \\
0 \\
524 \\
30 \\
157 \\
0 \\
157 \\
0 \\
232 \\
0 \\
0 \\
0 \\
0 \\
0 \\
24 \\
299 \\
0 \\
0 \\
57\end{array}$ & $\begin{array}{r}11,090 \\
186 \\
140 \\
0 \\
6,399 \\
0 \\
6,399 \\
87 \\
1,674 \\
0 \\
1,674 \\
0 \\
1,509 \\
447 \\
0 \\
0 \\
447 \\
0 \\
92 \\
143 \\
0 \\
413 \\
0\end{array}$ & $\begin{array}{r}3,174 \\
0 \\
171 \\
0 \\
1,334 \\
0 \\
1,334 \\
16 \\
313 \\
0 \\
313 \\
9 \\
558 \\
0 \\
0 \\
0 \\
0 \\
0 \\
33 \\
343 \\
0 \\
397 \\
0\end{array}$ & $\begin{array}{r}26 \\
0 \\
0 \\
0 \\
0 \\
0 \\
0 \\
0 \\
0 \\
0 \\
0 \\
0 \\
0 \\
0 \\
0 \\
0 \\
0 \\
0 \\
0 \\
26 \\
0 \\
0 \\
0\end{array}$ & $\begin{array}{l}0 \\
0 \\
0 \\
0 \\
0 \\
0 \\
0 \\
0 \\
0 \\
0 \\
0 \\
0 \\
0 \\
0 \\
0 \\
0 \\
0 \\
0 \\
0 \\
0 \\
0 \\
0 \\
0\end{array}$ & $\begin{array}{l}0 \\
0 \\
0 \\
0 \\
0 \\
0 \\
0 \\
0 \\
0 \\
0 \\
0 \\
0 \\
0 \\
0 \\
0 \\
0 \\
0 \\
0 \\
0 \\
0 \\
0 \\
0 \\
0\end{array}$ & $\begin{array}{r}43 \\
0 \\
0 \\
0 \\
0 \\
0 \\
0 \\
0 \\
0 \\
0 \\
0 \\
0 \\
0 \\
0 \\
0 \\
0 \\
0 \\
0 \\
0 \\
43 \\
0 \\
0 \\
0\end{array}$ \\
\hline Total & 1,335 & 11,090 & 3,174 & 26 & 0 & 0 & 4,369 \\
\hline
\end{tabular}

a Includes naphtha less than $401^{\circ} \mathrm{F}$ endpoint and other oils equal to or greater than $401^{\circ} \mathrm{F}$ endpoint.

Sources: Energy Information Administration (EIA) Forms EIA-812, "Monthly Product Pipeline Report" and EIA-813, "Monthly Crude Oil Report." 
Table 56. Net Movements of Crude Oll and Petroleum Products by Pipeline, Tanker, and Barge Between PAD Districts, August 1991

(Thousand Barrels)

\begin{tabular}{|c|c|c|c|c|c|c|}
\hline \multirow{2}{*}{ Commodity } & \multicolumn{3}{|c|}{ PAD District I } & \multicolumn{3}{|c|}{ PAD District II } \\
\hline & Recelpts & Shipments & Not Recelpts & Recelpts & Shipments & Net Recelpts \\
\hline 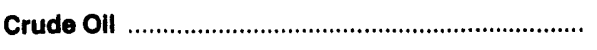 & 98 & 129 & -33 & 61,618 & 2,957 & 58,661 \\
\hline 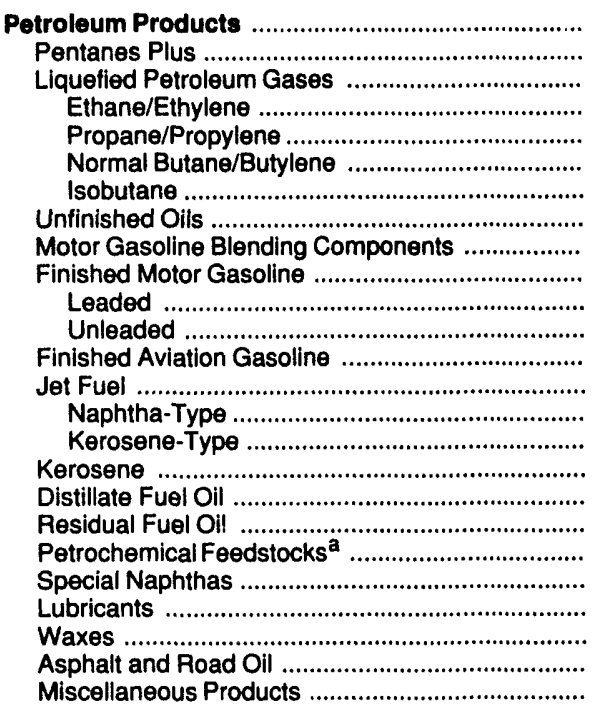 & $\begin{array}{r}79,376 \\
0 \\
2,361 \\
0 \\
2,200 \\
82 \\
79 \\
180 \\
164 \\
45,889 \\
0 \\
45,889 \\
117 \\
10,500 \\
99 \\
10,401 \\
136 \\
18,127 \\
548 \\
0 \\
140 \\
561 \\
0 \\
596 \\
57\end{array}$ & $\begin{array}{r}7,697 \\
0 \\
0 \\
0 \\
0 \\
0 \\
0 \\
29 \\
30 \\
5,298 \\
0 \\
5,298 \\
0 \\
302 \\
0 \\
302 \\
20 \\
1,889 \\
0 \\
58 \\
0 \\
18 \\
0 \\
53 \\
0\end{array}$ & $\begin{array}{r}71,679 \\
0 \\
2,361 \\
0 \\
2,200 \\
82 \\
79 \\
151 \\
134 \\
40,591 \\
0 \\
40,591 \\
117 \\
10,198 \\
99 \\
10,099 \\
116 \\
16,238 \\
548 \\
-58 \\
140 \\
543 \\
0 \\
543 \\
57\end{array}$ & $\begin{array}{r}34,937 \\
854 \\
3,829 \\
496 \\
1,755 \\
692 \\
886 \\
200 \\
30 \\
19,510 \\
74 \\
19,436 \\
124 \\
3,823 \\
66 \\
3,757 \\
29 \\
5,707 \\
0 \\
58 \\
33 \\
343 \\
0 \\
397 \\
0\end{array}$ & $\begin{array}{r}11,430 \\
153 \\
4,104 \\
2,309 \\
1,237 \\
408 \\
150 \\
28 \\
0 \\
3,714 \\
0 \\
3,714 \\
22 \\
1,087 \\
74 \\
1,013 \\
8 \\
1,238 \\
763 \\
0 \\
0 \\
119 \\
0 \\
183 \\
11\end{array}$ & $\begin{array}{r}23,507 \\
701 \\
-275 \\
-1,813 \\
518 \\
284 \\
736 \\
172 \\
30 \\
15,796 \\
74 \\
15,722 \\
102 \\
2,736 \\
-8 \\
2,744 \\
21 \\
4,469 \\
-763 \\
58 \\
33 \\
224 \\
0 \\
214 \\
-11\end{array}$ \\
\hline Total & 79,472 & 7,826 & 71,646 & 96,555 & 14,387 & 82,168 \\
\hline
\end{tabular}

\begin{tabular}{|c|c|c|c|c|c|c|c|c|c|}
\hline \multirow{2}{*}{ Commodity } & \multicolumn{3}{|c|}{ PAD District III } & \multicolumn{3}{|c|}{ PAD District IV } & \multicolumn{3}{|c|}{ PAD District V } \\
\hline & Recelpts & Shlpments & $\begin{array}{c}\text { Not } \\
\text { Recelpts }\end{array}$ & Recelpte & Shipments & $\begin{array}{c}\text { Net } \\
\text { Recelpts }\end{array}$ & Recelpts & Shipments & $\begin{array}{c}\text { Net } \\
\text { Receipts }\end{array}$ \\
\hline 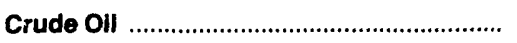 & 11,732 & 58,957 & $-47,225$ & 531 & 4,232 & $-3,701$ & $\mathbf{0}$ & 7,702 & $-7,702$ \\
\hline 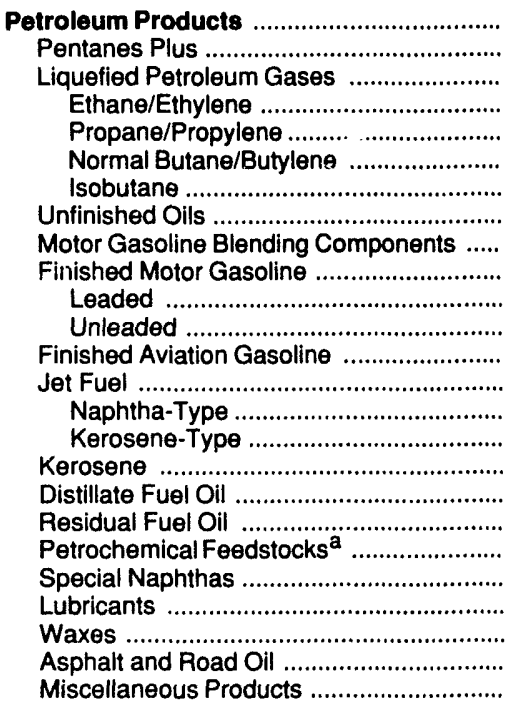 & $\begin{array}{r}7,437 \\
342 \\
4,851 \\
3,009 \\
1,208 \\
455 \\
179 \\
0 \\
0 \\
940 \\
0 \\
940 \\
0 \\
220 \\
74 \\
146 \\
0 \\
297 \\
662 \\
0 \\
0 \\
61 \\
0 \\
53\end{array}$ & $\begin{array}{r}103,079 \\
741 \\
4,953 \\
245 \\
3,394 \\
544 \\
770 \\
323 \\
164 \\
58,985 \\
181 \\
58,804 \\
241 \\
14,027 \\
229 \\
13,798 \\
137 \\
21,210 \\
447 \\
0 \\
173 \\
811 \\
0 \\
810 \\
57\end{array}$ & $\begin{array}{r}-95,642 \\
-399 \\
-102 \\
2,764 \\
-2,186 \\
-89 \\
-591 \\
-323 \\
-164 \\
-58,045 \\
-181 \\
-57,864 \\
-241 \\
-13,807 \\
-155 \\
-13,652 \\
-137 \\
-20,913 \\
215 \\
0 \\
-173 \\
-750 \\
0 \\
-757 \\
-46\end{array}$ & $\begin{array}{r}2,131 \\
1 \\
37 \\
0 \\
36 \\
1 \\
0 \\
0 \\
0 \\
1,258 \\
0 \\
1,258 \\
22 \\
600 \\
0 \\
600 \\
0 \\
213 \\
0 \\
0 \\
0 \\
0 \\
0 \\
0 \\
0\end{array}$ & $\begin{array}{r}4,357 \\
303 \\
2,021 \\
951 \\
568 \\
278 \\
224 \\
0 \\
0 \\
1,292 \\
307 \\
985 \\
0 \\
208 \\
155 \\
53 \\
0 \\
533 \\
0 \\
0 \\
0 \\
0 \\
0 \\
0 \\
0\end{array}$ & $\begin{array}{r}-2,226 \\
-302 \\
-1,984 \\
-951 \\
-532 \\
-277 \\
-224 \\
0 \\
0 \\
-34 \\
-307 \\
273 \\
22 \\
392 \\
-155 \\
547 \\
0 \\
-320 \\
0 \\
0 \\
0 \\
0 \\
0 \\
0 \\
0\end{array}$ & $\begin{array}{r}2,725 \\
0 \\
0 \\
0 \\
0 \\
0 \\
0 \\
0 \\
0 \\
1,692 \\
414 \\
1,278 \\
0 \\
481 \\
219 \\
262 \\
0 \\
526 \\
0 \\
0 \\
0 \\
26 \\
0 \\
0 \\
0\end{array}$ & $\begin{array}{r}43 \\
0 \\
0 \\
0 \\
0 \\
0 \\
0 \\
0 \\
0 \\
0 \\
0 \\
0 \\
0 \\
0 \\
0 \\
0 \\
0 \\
0 \\
0 \\
0 \\
0 \\
43 \\
0 \\
0 \\
0\end{array}$ & $\begin{array}{r}2,682 \\
0 \\
0 \\
0 \\
0 \\
0 \\
0 \\
0 \\
0 \\
1,692 \\
414 \\
1,278 \\
0 \\
481 \\
219 \\
262 \\
0 \\
526 \\
0 \\
0 \\
0 \\
-17 \\
0 \\
0 \\
0\end{array}$ \\
\hline 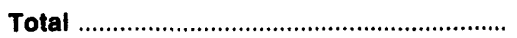 & 19,169 & 162,036 & $-142,867$ & 2,662 & 8,589 & $-5,927$ & 2,725 & $\mathbf{7 , 7 4 5}$ & $-5,020$ \\
\hline
\end{tabular}

a Includes naphtha less than $401^{\circ} \mathrm{F}$ endpoint and other oils equal to or greater than $401^{\circ} \mathrm{F}$ endpoint.

Sources: Energy Information Administration (EIA) Forms EIA-812, "Monthly Product Pipeline Report," EIA-813, "Monthly Crude Oil Report," and EIA-817, "Monthly Tanker and Barge Movement Report." 


\section{Appendix A}

\section{District Descriptions and Maps}

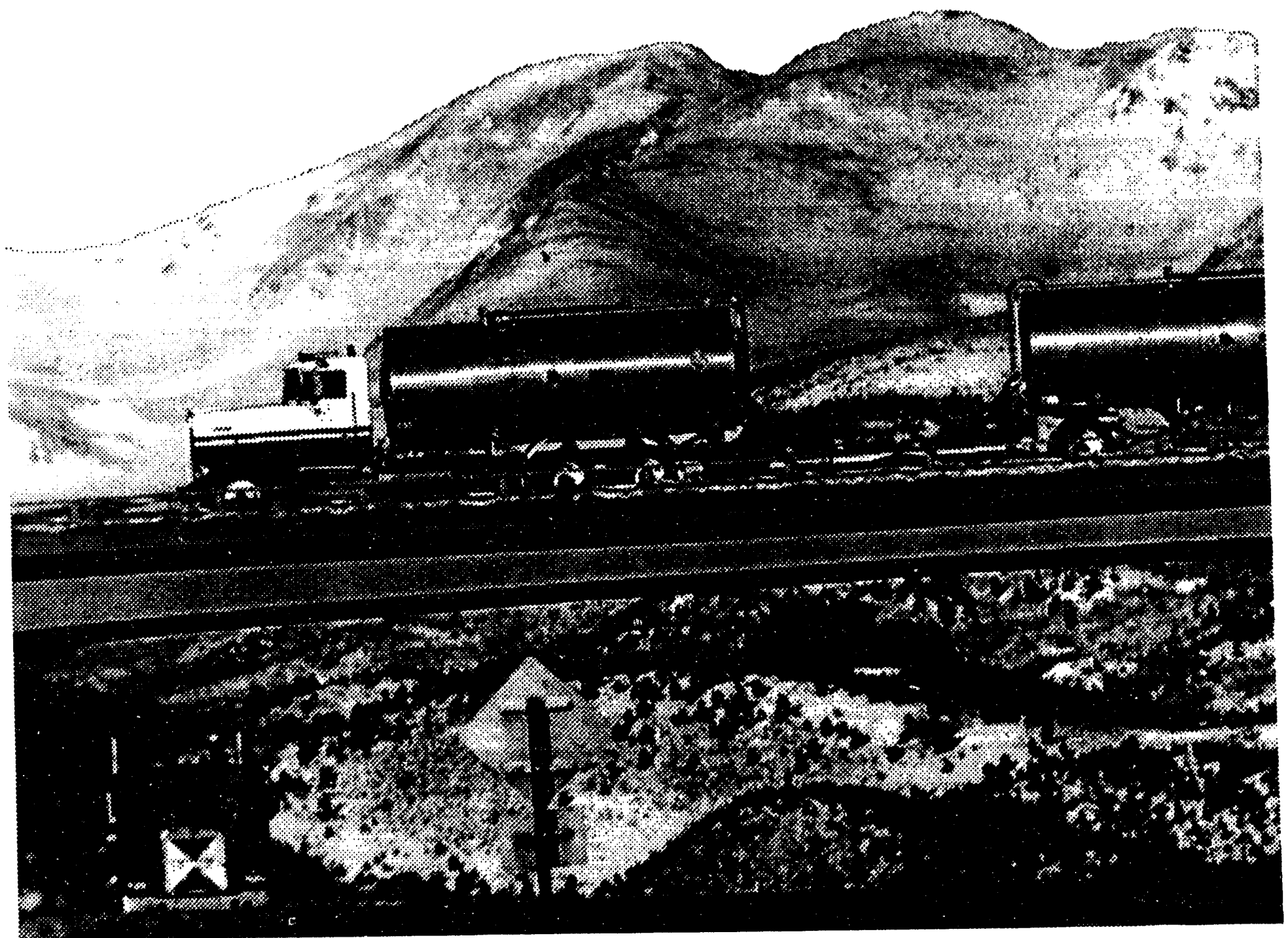




\section{District Descriptions and Maps}

The following are the Refining Districts which make up the Petroleum Administration for Defense (PAD) Districts.

\section{PAD District I}

East Coast: District of Columbia and the States of Maine, New Hampshire, Vermont, Massachusetts, Rhode Island, Connecticut, New Jersey, Delaware, Maryland, Virginia, North Carolina, South Carolina, Georgia, Florida, and the following counties of the State of New York: Cayuga, Tompkins, Chemung, and all counties east and north thereof. Also the following counties in the State of Pennsylvania: Bradford, Sullivan, Columbia, Montour, Northumberland, Dauphin, York, and all counties east thereof.

Appalachian No. 1: The State of West Virginia and those parts of the States of Pennsylvania and New York not included in the East Coast District.

\section{Sub-PAD District I}

New England: The States of Connecticut, Maine, Massachusetts, New Hampshire, Rhode Island and Vermont.

Central Atlantic: The District of Columbia and the States of Delaware, Maryland, New Jersey, New York, and Pennsylvania.

Lower Atlantic: The States of Florida, Georgia, North Carolina, South Carolina, Virginia and West Virginia.

\section{PAD District II}

Indiana-Illinois-Kentucky: The States of Indiana, Illinois, Kentucky, Tennessee, Michigan, and Ohio.

Minnesota-Wisconsin-North and South Dakota: The States of Minnesota, Wisconsin, North Dakota, and South Dakota.
Oklahoma-Kansas-Missouri: The States of Oklahoma, Kansas, Missouri, Nebraska, and Iowa.

\section{PAD District III}

Texas Inland: The State of Texas except the Texas Gulf Coast District.

Texas Gulf Coast: The following counties of the State of Texas: Newton, Orange, Jefferson, Jasper, Tyler, Hardin, Liberty, Chambers, Polk, San Jacinto, Montgomery, Harris, Galveston, Waller, Fort Bend, Brazoria, Wharton, Matagorda, Jackson, Victoria, Calhoun, Refugio, Aransas, San Patricio, Nueces, Kleberg, Kenedy, Willacy, and Cameron.

Louisiana Gulf Coast: The following parishes of the State of Louisiana: Vernon, Rapides, Avoyelles, Pointe Coupee, West Feliciana, East Feliciana, Saint Helena, Tangipahoa, Washington, and all parishes south thereof. Also the following counties of the State of Mississippi: Pearl River, Stone, George, Hancock, Harrison, and Jackson. Also the following counties of the State of Alabama: Mobile and Baldwin.

North Louisiana-Arkansas: The State of Arkansas and those parts of the States of Louisiana, Mississippi, and Alabama not included in the Louisiana Gulf Coast District.

New Mexico: The State of New Mexico.

\section{PAD District IV}

Rocky Mountain: The States of Montana, Idaho, Wyoming, Utah, and Colorado.

\section{PAD District V}

West Coast: The States of Washington, Oregon, California, Nevada, Arizona, Alaska, and Hawaii. 


\section{Petroleum Administration for Defense (PAD) Districts}

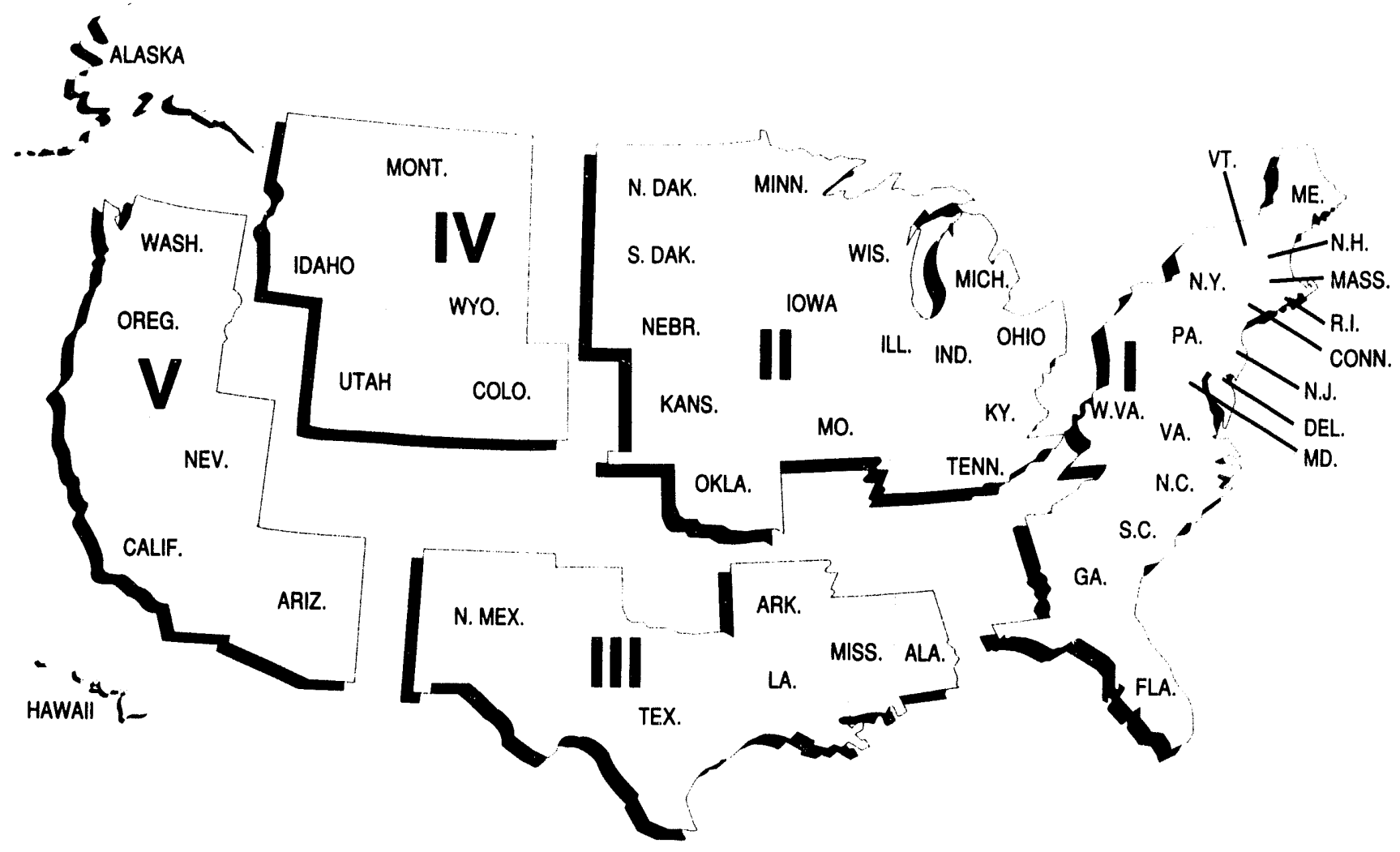

\section{Refining Districts}

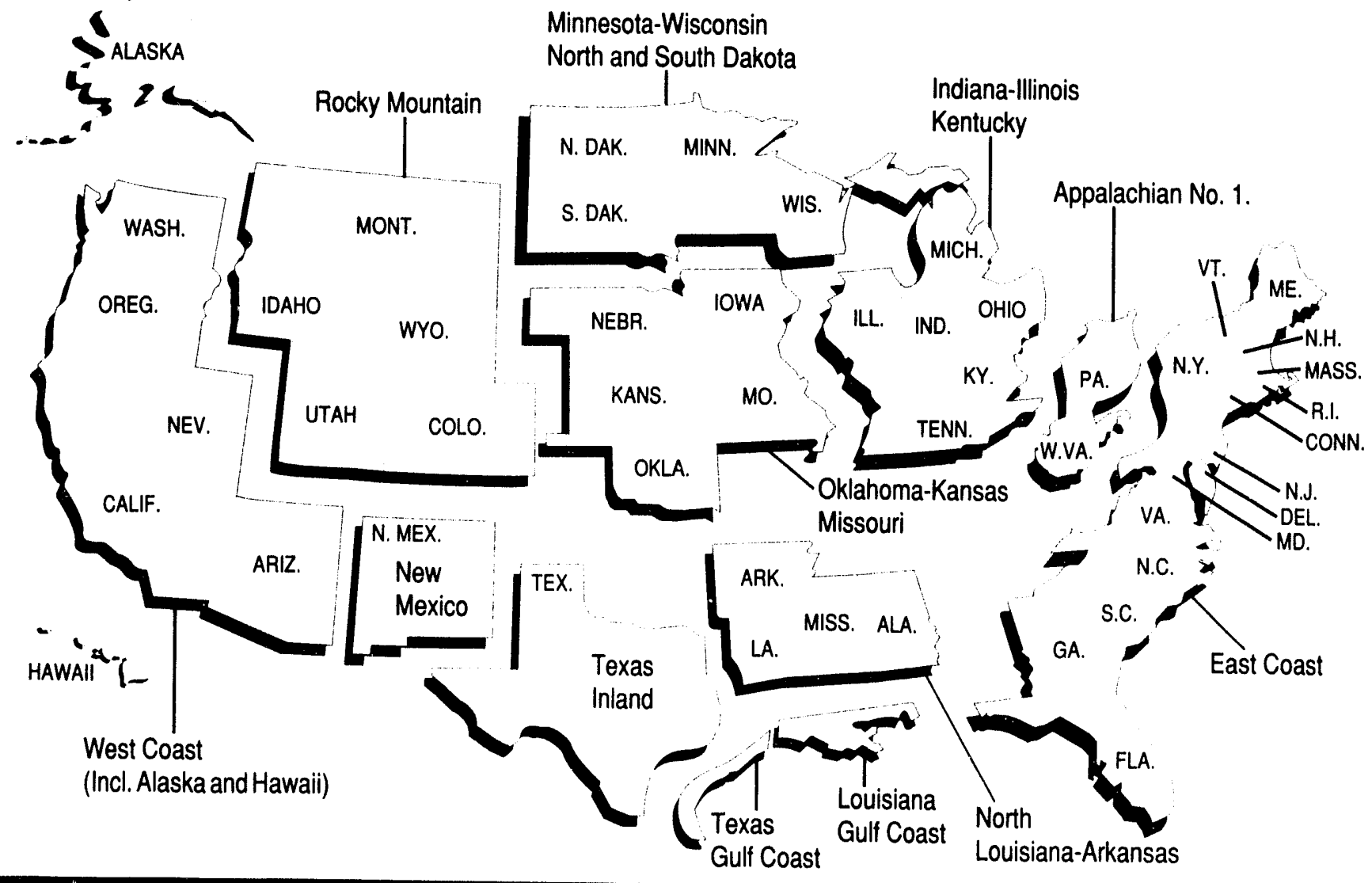




\section{Appendix B}

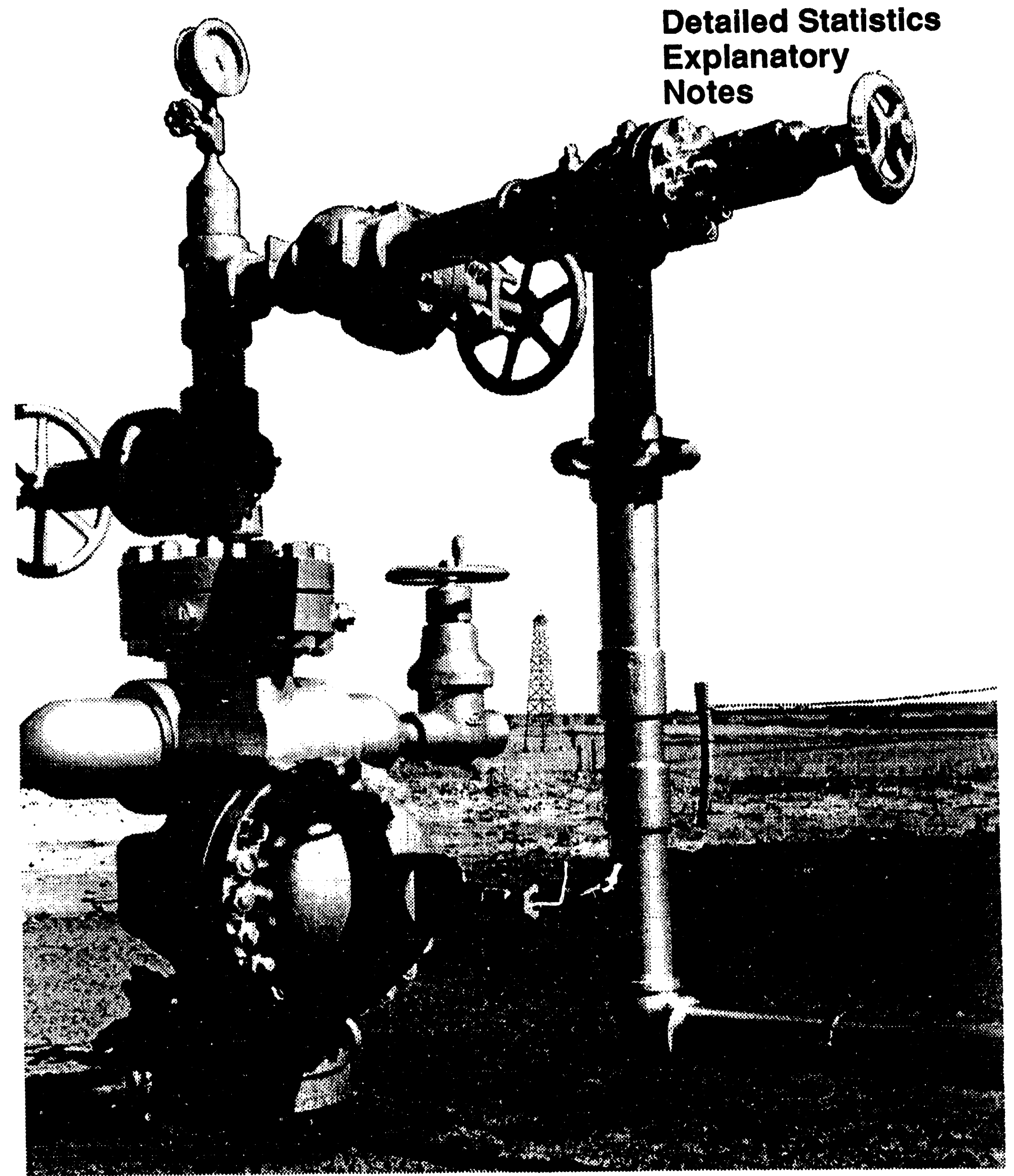

The cluster of pipes and valves that control the flow of oil at the mouth of an oil well is what oilmen call a "Christmas Tree." 


\section{Detailed Statistics Explanatory Notes}

The following Explanatory Notes are provided to assist in understanding and interpreting the data presented in this publication.

- Note 1. Petroleum Supply Reporting System

- Note 2. Monthly Petroleum Supply Reporting System

- Note 3. Technical Notes for Detailed Statistics Tables

- Note 4. Domestic Crude Oil Production

- Note 5. Export Data

- Note 6. Quality Control and Data Revision

- Note 7. Frames Maintenance

- Note 8. 1981 Changes in the Petroleum Supply Reporting System

- Note 9. 1983 Changes in the Petroleum Supply Reporting System

- Note 10. 1984 Changes in the Petroleum Supply Reporting System

- Note 11. 1985 Changes in the Petroleum Supply Reporting System

- Note 12. 1986 Changes in the Petroleum Supply Reporting System

- Note 13. 1987 Changes in the Petroleum Supply Reporting System

- Note 14. 1989 Changes in the Petroleum Supply Reporting System

- Note 15. 1990 Changes in the Petroleum Supply Reporting System

- Note 16. 1991 Changes in the Petroleum Supply Reporting System

\section{Note 1. Petroleum Supply Reporting System}

The Petroleum Supply Reporting System (PSRS) represents a family of data collection survey forms, data processing systems, and publication systems that have been consolidated to achieve comparability and consistency throughout. The survey forms that comprise the PSRS are:

\begin{tabular}{|ll|}
\hline Form & \\
Number & Name \\
EIA-800 & "Weekly Refinery Report" \\
EIA-801 & "Weekly Bulk Terminal Report" \\
EIA-802 & "Weekly Product Pipeline Report" \\
EIA-803 & "Weekly Crude Oil Stocks Report" \\
EIA-804 & "Weekly Imports Report" \\
EIA-810 & "Monthly Refinery Report" \\
EIA-811 & "Monthly Bulk Terminal Report" \\
EIA-812 & "Monthly Product Pipeline Report" \\
EIA-813 & "Monthly Crude Oil Report" \\
EIA-814 & "Monthly Imports Report" \\
EIA-816 & "Monthly Natural Gas Liquids Report" \\
EIA-817 & "Monthly Tanker and Barge Movement \\
& Report" \\
EIA-820 & "Annual Refinery Report" \\
&
\end{tabular}

Forms EIA-800 through 804 comprise the Weekly Petroleum Supply Reporting System (WPSRS). A sample of all petroleum companies report weekly data to the Energy Information Administration (EIA) on crude oil and petroleum product stocks, refinery inputs and production, and crude oil and petroleum product imports. The sample of companies that report weekly is selected from the universe of companies that report on the comparable monthly surveys. Data collected from the WPSRS are used to develop estimates of the most current monthly quantities in the Summary Statistics section of the Petroleum Supply Monthly (PSM) and which appear in the Weekly Petroleum Status Report.

Forms EIA-810 through 814,816 , and 817 comprise the Monthly Petroleum Supply Reporting System (MPSRS). These surveys are used to collect detailed refinery and natural gas plant operations data; refinery, bulk terminal, natural gas plant, and pipeline stocks data; crude oil and petroleum product imports data; and data on movements of petroleum products and crude oil between Petroleum Administration for Defense Districts. A description of the MPSRS forms follows in Explanatory Note 2.

Data from these surveys are published in preliminary form in the PSM. They are published in final form in the Summary Statistics and the Detailed Statistics sections of the Petroleum Supply Annual (PSA), Volumes 1 and 2. 
Summary information on the revision error between preliminary and final data is found in the feature article in the PSM entitled, "Timeliness and Accuracy of Petroleum Supply Data." The last article was published in the April 1990 issue and dealt with the years 1985 through 1989. Subsequent updates to this article will be published in the April issue of this pislication.

The Form EIA-820, "Annual Refinery Report" is used to collect data on refinery fuel use and consumption of steam and electricity, refinery receipts of crude oil by method of transportation, and refinery operable and storage capacity. This survey is the primary source of data in the Refinery Capacity section of the PSA, Volume 1 .

\section{Note 2. Monthly Petroleum Supply Reporting System}

The Monthly Petroleum Supply Reporting System (MPSRS) was implemented in January 1983 as the result of an extensive effort by the Energy Information Administration (EIA) to integrate the collection and processing of petroleum supply data that had been collected on other survey forms for many years. The collection of monthly petroleum supply statistics began as early as 1918 when the U.S. Bureau of Mines began collecting data on refinery operations, crude oil stocks and movements. The collection systems were further expanded in 1925 to include natural gas plant liquids production and storage, imports of crude oil and petroleum products and storage and movement of petroleum products in 1959, and tanker and barge movements of crude oil and petroleum products in 1964. Since their inception, each survey has undergone numerous changes, but the MPSRS was the first effort to make them all consistent and comparable.

The forms that comprise the MPSRS are:

$\begin{array}{ll}\text { Form } & \\ \text { Number } & \text { Name } \\ \text { EIA-810 } & \text { "Monthly Refinery Repoit" } \\ \text { EIA-811 } & \text { "Monthly Bulk Terminal Report" } \\ \text { EIA-812 } & \text { "Monthly Product Pipeline Report" } \\ \text { EIA-813 } & \text { "Monthly Crude Oil Report" } \\ \text { EIA-814 } & \text { "Monthly Imports Report" } \\ \text { EIA }-816 & \text { "Monthly Natural Gas Liquids Report" } \\ \text { EIA-817 } & \text { "Monthly Tanker and Barge Movement } \\ & \text { Report" }\end{array}$

\section{Respondent Frame}

Form EIA-810, “Monthly Refinery Report" - Operators of all operating and idle petroleum refineries and blending plants located in the 50 States, the District of Columbia, Puerto Rico, the Virgin Islands, Guam and other U.S. possessions. Approximately 240 respondents report on the Form EIA-810.

Form EIA-811, "Monthly Bulk Terminal Report" - Every bulk terminal operating company located in the 50 States, the District of Columbia, Puerto Rico, the Virgin Islands, and other U.S. possessions. A bulk terminal is primarily used for storage and/or marketing of petroleum products and has a total bulk storage capacity of 50,000 barrels or more, and/or receives petroleum products by tanker, barge, or pipeline. Bulk terminal facilities associated with a product pipeline are included. Approximately 350 respondents report on the Form EIA -811 .

Form EIA-812, "Monthly Product Pipeline Report" - All product pipeline companies that carry peiroleum products (including interstate, intrastate, and intracompany pipelines) in the 50 States and the District of Columbia. Approximately 80 respondents report on the Form EIA812.

Form EIA-813, "Monthly Crude Oil Report" - All companies which carry or store 1,000 barrels or more of crude oil. Included in this survey are gathering and trunk pipeline companies (including interstate, intrastate, and intracompany pipelines), crude oil producers, terminal operators, storers of crude oil (except refineries), and companies transporting Alaskan crude oil by water in the 50 States and the District of Columbia. Approximately 170 respordents report on the Form EIA-813.

Form EIA-814, "Monthly Imports Report" - All companies, including subsidiary or affiliated companies, that import crude oil or petroleum products (1) into the 50 States and the District of Columbia, (2) into Puerto Rico, the Virgin Islands and other U.S. possessions (Guam, Midway Islands, Wake Island, American Samoa, and Northern Mariana Islands), and (3) from Puerto Rico, the Virgin Islands and other U.S. nossessions into the 50 States and the District of Colurnbia. Imports into Foreign Trade Zones located in the 50 Statej and the District of Columbia are considered imporits into the 50 States and the District of Columbia and must be reported. A report is required only if there has been an import during the month unless the importer has been selected as part of a sample to report every month regardless of activity. Approximately 860 respondents report on the Form EIA-814.

Form EIA-816, "Monthly Natural Gas Liquids Report" Operators of all facilities that extract liquid hydrocarbons from a natural gas stream (natural gas processing plant) and/or separate a liquid hydrocarbon stream into its component products (fractionator). Approximately 800 respondents report on the Form EIA-816.

Form EIA-817, "Monthly Tanker and Barge Movement Report" - All companies that have custody of crude oil or 
petroleum products transported by tanker or barge between Petroleum Administration for Defense (PAD) Districts or between the Panama Canal and the United States. For purposes of this report, custody is defined as physical possession of crude oil or petroleum products on a company-owned tanker or barge. Also, companies which lease vessels or contract for the movement of crude oil or petroleum products on a tanker or barge between PAD Districts or between the Panama Canal and the United States are considered to have custody. Approximately 35 respondents report on the Form EIA-817.

\section{Description of Survey Forms}

The Form EIA-810, "Monthly Refinery Report," is used to collect data on refinery input and capacity, sulfur content and APl gravity of crude oil, and data on supply (beginning stocks, receipts, and production) and disposition (inputs, shipments, fuel use and losses, and ending stocks) of crude oil and refined products.

The Form EIA-811, "Monthly Bulk Terminal Report," is used to collect data on end-of-month stock levels of finished petroleum products by State in the custody of the bulk terminal company regardless of ownership. Leased tankage at other facilities is excluded. All domestic and foreign stocks held at bulk terminals and in-transit thereto, except those in-transit by pipeline are included. Petroleum products in-transit by pipeline are reported by pipeline operators on Form EIA-812, "Monthly Product Pipeline Report."

The Form ElA-812, "Monthly Product Pipeline Report," is used to collect data on end-of-month stock levels and movements of petroleum products transported by pipeline. Intermediate movements for pipeline systems operating in more than two PAD Districts are included.

The Form ElA-813, "Monthly Crude Oil Report," is used to collect data on end-of-month stocks of crude oil held at pipeline and tank farms (associated with the pipelines) and terminals operated by the reporting company. Also, crude oil consumed by pipelines and on leases as pump fuel, boiler fuel, etc., is reported. Data are reported on a PAD District basis.

Total Alaskan crude oil stocks in-transit by water (including stocks held at transshipment terminals between Alaska and the continental United States) to the 50 States, the District of Columbia, Puerto Rico, and the Virgin Islands are also reported by the transporting company having custody of the stocks.

Inter-PAD District movements of crude oil by pipeline are collected by the shipping and receiving PAD District. Intermediate movements for pipeline systems operating in more than two PAD Districts are not included.
The Form EIA-814, "Monthly Imports Report," is used to collect data on imports of crude oil and petroleum products (1) into the 50 States and the District of Columbia, (2) into Puerto Rico, the Virgin Islands, and other U.S. possessions (Guam, Midway Islands, Wake Island, American Samoa, and Northern Mariana Islands), and (3) from Puerto Rico, the Virgin Islands, and other U.S. possessions into the 50 States and the District of Columbia. Imports into Foreign Trade Zones located in the $\mathbf{5 0}$ States and the District of Columbia are considered impoits into the 50 States and the District of Columbia.

The type of commodity, port of entry, country of origin, quantity (thousand barrels), sulfur percent by weight, API gravity, and name and location of the processing or storage facility are reported. Sulfur percent by weight is requested for crude oil, crude oil burned as fuel, and residual fuel oil only. API gravity is requested for crude oil only. The name and location of the processing or storage facility is requested for crude oil, unfinished oils, other hydrocarbons/alcohol, and blending components only.

The Form EIA-816, "Monthly Natural Gas Liquids Report," is used to collect data on the operations of natural gas processing plants and fractionators. Beginning and end-of-month stocks, receipts, inputs, production, shipments, and plant fuel use and losses during tis month are collected from operators of natural gas processing plants. End-of-month stocks are collected from fractionators.

The Form EIA-817, "Monthly Tanker and Barge Movement Report," is used to collect data on the movements of crude oil and petroleum products between PAD Districts. Data are reported by shipping and receiving PAD District and sub-PAD District. Shipments to and from the Panama Canal are also included if the shipment was delivered to the Canal.

\section{Collection Methods}

Survey forms for the MPSRS can be submitted by mail, facsimile, or electronic transmission. Completed forms are required to be postmarked by the 20th calendar day following the end of the report month. Receipt of the reports are monitored using an automated respondent mailing list. Telephone follow-up calls are made to nonrespondents prior to the publication deadline.

\section{Response Rate}

The response rate is generally 98 to 100 perc ${ }^{\circ}$... Chronic nonrespondents and late filing resmondents are contacted in writing and reminded of their requirement to report. Companies that file late or fail to file are subject to criminal fines, civil penalties, and other sanctions as provided 
by Section 13(i) of the Federal Energy Administration (FEA) Act.

\section{Data Imputation}

Imputation is performed for companies that fail to file Forms EIA-810 through 813 and 816 . For such companies, previous monthly values are used for current values. The ending stock value of the previous month is used as the value for beginning and ending stocks for the current month. Data for nonrespondents on the Forms EIA-814 and 817 are not imputed because these data series, by respondent, are highly variable.

\section{Confidentiality}

The information contained on Forms EIA-810 through 813,816 and 817 are kept confidential and not disclosed to the public to the extent that they satisfy the criteria for exemption under the Freedom of Information Act (FOIA), 5 U.S.C. 552, the Department of Energy (DOE) regulations, 10 C.F.R. 1004.11, implementing the FOIA, and the Trade Secrets Act, 18 U.S.C. 1905. The information contained on Form EIA-814 are not considered confidential and historically has not been treated as such.

Upon receipt of a request for this information under the FOIA, the DOE shall make a final determination whether the information is exempt from disclosure in accordance with the procedures and criteria provided in the regulations. To assist us in this determination, respondents should demonstrate to the DOE that, for example, their information contains trade secrets or commercial or financial information whose release would be likely to cause substantial harm to their company's competitive position. A letter accompanying the submission that explains (on an element-by-element basis) the reasons why the information would be likely to cause the respondent substantial competitive harm if released to the public would aid in this determination. A new justification does not need to be provided each time information is submitted on the form, if the company has previously submitted a justification for that information and the justification has not changed.

The information contained on the EIA-810 through 813, 816 and 817 may be made available in response to an order of a Court of competent jurisdiction, or, upon request, to another component of the DOE, another Federal agency for official use, to any Committee of Congress, the General Accounting Office, or other Congressional agencies authorized by law to receive such information.

The data collected on Forms EIA-810 through 814, 816, and 817 appear in EIA publications such as Petroleum
Supply Monthly (PSM), Monthly Energy Review, Petroleum Supply Annual (PSA), and the Annual Energy Review.

Data on the breakdown between liquefied refinery gases and olefins is suppressed on PSM Table 29, "Refinery Net Production of Finished Petroleum Products by PAD and Refining Districts" and the corresponding PSA table to avoid disclosure of company identifiable data.

Data on PSM Table 52, "Refinery, Bulk Terminal, and Natural Gas Plant Stocks of Selected Petroleum Products by State" and the corresponding PSA table are subject to statistical nondisclosure procedures. Statistics representing data aggregated from less than three companies or aggregated data representing 60 percent or more of a single company's data are suppressed.

With the exception of Tables 29 and 52 in the PSM (and corresponding PSA tables), the tables are not subject to statistical nondisclosure procedures. Thus, there may be some table cells which are based on data from only one or two respondents, or which are dominated by data from one or two large respondents. In these cases, it may be possible for a knowledgeable user of the data to make inferences about the data reported by a specific respondent. Company specific data are also provided to other DOE offices for the purpose of examining operations in the context of emergency response planning and actual emergencies.

\section{Note 3. Technical Notes for Detailed Statistics Tables}

The detailed statistics tables in the Petroleum Supply Monthly (PSM) provide complete supply and demand information for the cl.rent year. The tables are organized to locate National and Petroleum Administration for Defense (PAD) District summary data at the front followed by tables on crude oil and petroleum product production, import/export data, stocks information, and lastly, data on crude oil and petroleum product movements. To assist in the interpretation of these tables, the following technical notes are provided. Column and row headings are defined in the Glossary.

\section{Supply}

Field Production - Field production is the sum of crude oil production, natural gas plant liquids production, and other liquids.

Crude oil production is an estimate based on data received from State conservation agencies and the Mineral 
Management Service of the U.S. Department of the Interior. Refer to Explanatory Note 4 for further details.

Field production of natural gas plant liquids is and published on a net basis (i.e., production minus inputs) in this column.

Other liquids field production is calculated by adding the stock change to the refinery inputs.

Negative production will occur when the amount of a product produced during the month is less than the amount of that same product that is reprocessed (input) or reclassified to become another product during the same month.

Refinery Production - Published production of these products equal refinery production minus refinery input. Refinery production of other hydrocarbons, hydrogen and alcohol, unfinished oils, and motor and aviation gasoline blending components appear on a net basis under refinery input. Negative refinery production will occur when the amount of a product produced during the month is less than the amount of that same product that is reprocessed (input) or reclassified to become another product during the same month.

Unaccounted for Crude Oil - This column is a balancing item for crude oil. This data element represents the difference between crude oil supply and disposition. Crude oil supply is the sum of field production and imports. Crude oil disposition is the sum of stock change, losses, refinery inputs, exports, and products supplied. A positive result indicates that refiners and exporters reported use of more crude oil than was reported to have been available to them. (This occurs, for example, when imports are undercounted due to late reporting or other problems). A negative result indicates that more crude oil was reported to have been supplied to refiners and exporters than they reported to have used.

\section{Disposition}

Stock Change - This column is calculated as the difference between the Ending Stocks column of this table and the Ending Stocks column of this table in the prior month's publication. A negative number indicates a decrease in stocks and a positive number indicates an increase in stocks.

Crude Losses - The volume of crude oil reported by petroleum refineries as being lost in their operations. These losses are due to spills, contamination, fires, etc., as opposed to refining processing losses or gains.

Refinery Inputs - Refinery inputs of crude oil and intermediate materials (unfinished oils, gasoline blending components, other hydrocarbons and alcohol, liquefied petroleum gases, and pentanes plus) that are processed at refineries to produce finished petroleum products.

Crude oil inputs represents total crude oil (domestic and foreign) input to atmospheric crude oil distillation units and other refinery processing units (i.e., catalytic cracking units, cokers).

Inputs of natural gas liquids are natural gas liquids received from natural gas plants for blending and processing. Published inputs of natural gas liquids are reported on a gross basis.

Inputs of unfinished oils, motor and aviation gasoline blending components, and other hydrocarbons and alcohol are published on a net basis (i.e., refinery input minus refinery production).

Inputs of finished petroleum products are published on a net basis (i.e., refinery production minus refinery inputs) and displayed under the refinery production column.

Exports - Exports include crude oil shipments from the 50 States to Puerto Rico, and the Virgin Islands.

Products Supplied - Products supplied is equal to field production, plus refinery production, plus imports, plus unaccounted for crude oil, (plus net receipts on a PAD District basis), minus stock change, minus crude losses, minus refinery inputs, minus exports.

Products supplied indicates those quantities of petroleum products supplied for domestic consumption. Occasionally, the result for a product is negative because total disposition of the product exceeds total supply. Negative product supplied may occur for a number of reasons: (1) product reclassification has not been reported; (2) data were misreported or reported late; (3) in the case of calculations on a PAD District basis, the figure for net receipts was inaccurate because the coverage of interdistrict movements was incomplete; and (4) products such as gasoline blending components and unfinished oils have entered the primary supply channels with their production not having been reported, e.g., streams returned to refineries from petrochemical plants.

Product supplied for crude oil is the sum of crude oil burned on leases and by pipelines as fuel. Prior to January 1983, crude oil burned on leases and by pipelines as fuel were reported as either distillate or residual fuel oil and were included in product supplied for these products.

\section{Yields}

The refinery yield of finished motor gasoline is calculated by subtracting the inputs of pentanes plus, liquefied 
petroleum gases, other hydrocarbons/alcohol and motor gasoline blending components from the production of finished motor gasoline before dividing by the sum of crude oil input and unfinished oils input (net).

The refinery yield of finished aviation gasoline is calculated by subtracting the inputs of aviation gasoline blending components from the production of finished aviation gasoline before dividing by the sum of crude oil input and unfinished oils input (net).

Refinery yields for all products (except finished motor gasoline and finished aviation gasoline) are calculated by dividing the production for each product by the sum of crude oil input and unfinished oils input (net) reported in the U.S. total.

\section{Stocks}

Primary stocks of petroleum products do not include either secondary stocks held by dealers and jobbers or tertiary stocks held by consumers.

\section{Movements}

Movements of crude oil by pipeline between PAD Districts include trunk pipeline companies (interstate, intrastate, and intracompany pipelines). Intermediate movements for crude oil pipeline systems operating in more than two PAD Districts are not included.

Movements of petroleum products by pipeline between PAD Districts include trunk pipeline companies (interstate, intrastate and intracompany pipelines). Intermediate movements for product pipeline systems operating in more than two PAD Districts are included. For example, a shipment originating in PAD District 3, passing through PAD District 2 to PAD District 1, is reported as a movement from PAD District 3 to PAD District 2 and also from PAD District 2 to PAD District 1.

Waterborne movements of crude oil and petroleum products between PAD Districts include all shipments of crude oil or petroleum. ıducts for which the transporter has custody at the time of shipment. Custody is defined as physical possession of crude oil or petroleum products on a company-owned tanker and barge.

\section{Note 4. Domestic Crude Oil Production}

The Energy Information Administration (EIA) collects monthly crude oil production data on an ongoing basis. Data on crude oil production for States are reported to the EIA by State government agencies. Data on crude oil production for Federal offshore areas are reported to the
EIA by the Minerals Management Service of the U.S. Department of the Interior and the Conservation Committee of California Oil Producers.

Currently, all except four crude oil producing States (Michigan, New York, Ohio, and Pennsylvania) report production on a monthly basis. These four States report crude oil production on an annual basis. Estimates of monthly crude oil production for these four States are made by the ElA using data reported on Form EIA-182, "Domestic Crude Oil First Purchase Report." After the end of each calendar year, the monthly crude oil production estimates are updated using annu:i i reports from various State agencies, the Minerals Management Service, and the Conservation Committee of California Oil Producers. The final estimate is published in the Petroleum Supply Annual (PSA).

Table 26 of this publication provides estimates of crude oil production in the latest month for which most State production data are available. There is a time lag of approximately 4 months between the end of the production month and the time when most monthly State crude oil production data become available.

In order to present more timely crude oil production estimates, the EIA prepares a weekly crude oil production estimate, which is used in the Weekly Petroleum Status Report. At the end of the production month, these weekly estimates are aggregated into an original estimate of monthly crude oil pruduction. Approximately 45 days later, this original estimate is replaced by State-level interim estimates. The State-level interim estimates are based on: (a) data reported by the State (e.g., production data for Alaska are typically reported to the EIA before the interim estimate is made); (b) first purchase data reported on Form EIA-182, "Domestic Crude Oil First Purchase Report;" (c) exponential or hyperbolic curve fitted projections based on recent State data; or (d) constant level projections based on the average production rate during a recent time period.

Table $\mathrm{B} 1$ is intended to provide further insight into the EIA's estimates of monthly U.S. crude oil production. It shows: (a) how the aggregate of reported State data evolves over a period of 18 months; (b) the number of producing States that have not reported production for a given month within that period; and (c) various EIA estimates of monthly crude oil production within that period:

- The original estimate is a monthly aggregate of the weekly crude oil production estimates published in the Weekly Petroleum Status Report. This original monthly estimate is used in the Petroleum Supply Monthly (PSM) Tables S1 and S2 until replaced by the interim estimate. 
Table B1. U.S. Crude Oila Production Estimates and Reported States ${ }^{b}$ Data by Month (Thousand Barrels per Day)

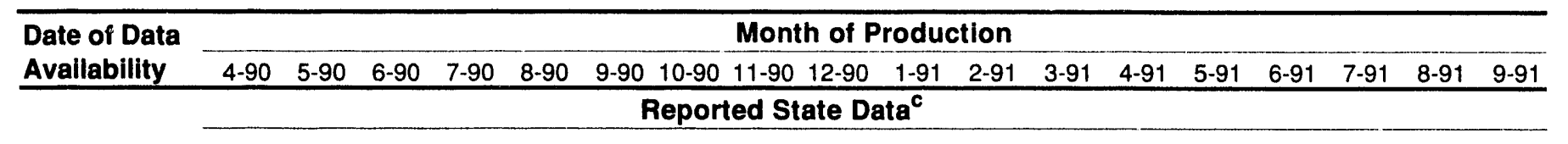

\begin{tabular}{|c|c|c|c|c|c|c|c|c|c|c|c|c|c|c|c|c|c|c|}
\hline $6-14-90$ & 1977 & 0 & & & & & & & & & & & & & & & & \\
\hline $7-14-90$ & 4705 & 1841 & 0 & & & & & & & & & & & & & & & \\
\hline $8-14-90$ & 6742 & 4444 & 1672 & 0 & & & & & & & & & & & & & & \\
\hline $9-14-90$ & 6831 & 6701 & 3919 & 1757 & 0 & & & & & & & & & & & & & \\
\hline $10-14-90$ & 7264 & 6753 & 6530 & 4291 & 1758 & 0 & & & & & & & & & & & & \\
\hline $11-14-90$ & 7279 & 7177 & 6553 & 6560 & 4226 & 1787 & 0 & & & & & & & & & & & \\
\hline $12-14-90$ & 7299 & 7211 & 6969 & 6629 & 6727 & 4607 & 1963 & 0 & & & & & & & & & & \\
\hline $1-14-91$ & 7299 & 7194 & 6971 & 7031 & 6737 & 6644 & 2482 & 1763 & 0 & & & & & & & & & \\
\hline $2-14-91$ & 7309 & 7205 & 6982 & 7052 & 7161 & 6712 & 6987 & 4494 & 1919 & 0 & & & & & & & & \\
\hline 3-14-91 & 7309 & 720.5 & 6984 & 7054 & 7161 & 7124 & 7010 & 6841 & 4648 & 1935 & 0 & & & & & & & \\
\hline $4-14-91$ & 7397 & 7314 & 7071 & 7138 & 7251 & 7190 & 7508 & 6947 & 6880 & 4642 & 1930 & 0 & & & & & & \\
\hline $5-14-91$ & 7405 & 7323 & 7081 & 7156 & 7267 & 7212 & 7536 & 7395 & 7311 & 6848 & 2379 & 1961 & 0 & & & & & \\
\hline $6-14-91$ & 7409 & 7327 & 7088 & 7168 & 7272 & 7218 & 7541 & 7405 & 7352 & 6926 & 6712 & 4400 & 1823 & 0 & & & & \\
\hline $7-14-91$ & 7409 & 7327 & 7086 & 7161 & 7271 & 7217 & 7540 & 7404 & 7351 & 7335 & 7033 & 6893 & 2720 & 1786 & 0 & & & \\
\hline $8-14-91$ & 7415 & 7337 & 7122 & 7202 & 7315 & 7260 & 7582 & 7451 & 7397 & 7356 & 7486 & 6995 & 6907 & 2387 & 1822 & 0 & & \\
\hline $9-14-91$ & 7418 & 7340 & 7123 & 7207 & 7319 & 7262 & 7581 & 7452 & 7398 & 7363 & 7493 & 7429 & 6947 & 6826 & 2693 & 1848 & 0 & \\
\hline \multirow[t]{2}{*}{$10-14-91$} & 7418 & 7340 & 7123 & 7207 & 7318 & 7262 & 7581 & 7452 & 7398 & 7365 & 7496 & 7412 & 7368 & 6860 & 6765 & 2563 & 1797 & 0 \\
\hline & \multicolumn{18}{|c|}{ Producing States Without Reported Monthly Production ${ }^{d}$} \\
\hline \multirow[t]{4}{*}{$10-14-91$} & 0 & 0 & 0 & 0 & 0 & 0 & 0 & 0 & 0 & 5 & 5 & 5 & 5 & 6 & 6 & 17 & 29 & 33 \\
\hline & \multicolumn{18}{|c|}{ Month of Production } \\
\hline & $4-90$ & $5-90$ & $6-90$ & $7-90$ & $8-90$ & $9-90$ & $10-90$ & $11-90$ & $12-90$ & $1-91$ & $2-91$ & 3-91 & 4-91 & $5-91$ & $6-91$ & $7-91$ & $8-91$ & $9-91$ \\
\hline & \multicolumn{18}{|c|}{ Production Estimates } \\
\hline Original ${ }^{\theta} \ldots \ldots \ldots \ldots$ & 7310 & 7241 & 6981 & 7130 & 6971 & 6991 & 7261 & 7187 & 7375 & 7411 & 7427 & 7392 & 7339 & 7310 & 7350 & 7360 & 7251 & 7301 \\
\hline Interim ${ }^{\prime} \ldots \ldots \ldots \ldots . . . . .$. & 7331 & 7259 & 7076 & 7144 & 7215 & 7167 & 7454 & 7308 & 7282 & 7418 & 7548 & 7481 & 7467 & 7368 & 7282 & 7326 & 7272 & \\
\hline \multicolumn{19}{|l|}{ Form EIA-182 } \\
\hline Initial ............. & 7316 & 7220 & 7013 & 7116 & 7274 & 7146 & 7495 & 7333 & 7227 & 7332 & 7587 & 7482 & 7445 & 7402 & 7192 & 7219 & 7186 & \\
\hline Revised......... & 7317 & 7223 & 7022 & 7112 & 7282 & 7147 & 7491 & 7349 & 7210 & 7345 & 7590 & 7468 & 7431 & 7396 & 7213 & 7235 & & \\
\hline Fina $^{9} \ldots \ldots \ldots \ldots$ & 7407 & 7328 & 7106 & 7173 & 7287 & 7224 & 7542 & 7387 & 7338 & & & & & & & & & \\
\hline
\end{tabular}

\footnotetext{
a Includes lease condensate.

b Includes Federal offshore areas, Gulf of Mexico (PADD III) and Pacific (PADD V), as two separate reporting entities.

c Includes EIA prorated monthly production in 1990 (annual average of 90 thousand barrels per day) for four States (Michigan, New York, Ohio, and Pennsylvania) for which only annual State data are available.

Michigan, New York, and Ohio are counted as having monthly reported data in 1990 after their annual reports were received. These data are first reported as of 4-14-91. Pennsylvania is counted as having monthly reported data in 1990 after its annual report was received. These data are first reported as of 5-14-91.

* Original estimates, through October 1990, were made on the first of each month. As of November 1990, original estimates are weighted averages based on the weekly estimates published in the Weekly Petroleum Status Report.

Interim estimates were made 44 days after the end of the production month.

9 Published in the Petroleum Supply Annual 1990, DOE/EIA 0340(90/2).
} 
- The interim estimate is used in the PSM Tables 1 through 25 , and in Tables $S 1$ and $S 2$ until replaced by the final estimate.

- The initial estimate based upon first purchase data collected on the Form EIA-182 is used as an estimation tool in generating the interim estimate. The initial volume represents the best estimate available 40 days after the end of the production month and includes imputation for nonresponse and possible reporting errors. The revised volume is the best estimate available about 70 days after the production month and includes imputation as needed. A final revision is published concurrent with publication of Form EIA182 price data in the Petroleum Marketing Annual.

- The final estimate is published in the PSA.

\section{Note 5. Export Data}

Each month the Energy Information Administration (EIA) receives magnetic tapes of aggregated export statistics from the U.S. Bureau of the Census (EM-522 and EM594).

Census export statistics used in the Petroleum Supply Monthly reflect both government and nongovernment exports of domestic and foreign merchandise from the United States (the 50 States and the District of Columbia) to foreign countries and U.S. possessions, without regard to whether or not the exportation involves a commercial transaction. The following types of transactions are excluded from the statistics:

(1) Merchandise shipped in transit through the United States from one foreign country to another, when documented as such with U.S. Customs.

(2) Bunker fuels and other supplies and equipment for use on departing vessels, planes, or other carriers engaged in foreign trade.

\section{Source of Export Information}

The official U.S. export statistics are compiled by the U.S. Bureau of the Census. Exporters are required to file export documents with U.S. Customs officials (Customs Form 7525).

\section{Country and Area of Destination}

The country of destination is defined as the country of ultimate destination or the country where the goods are to be consumed, further processed, or manufactured, as known to the shipper at the time of exportation. If the shipper does not know the country of ultimate destination, the shipment is credited to the last country to which the shipper knows that the merchandise will be shipped in the same form as it was when exported.

\section{Note 6. Quality Control and Data Revision}

\section{Quality Control}

The Energy Information Administration (EIA) monitors the supply and disposition of crude oil, petroleum products, and natural gas liquids in the United States. Through a tracking system, the EIA provides insight into the activities of primary operators and distributors in the petroleum industry. The tracking system, known as the Petroleum Supply Reporting System (PSRS), consists of production, inputs, imports, inventories, movements, and other petroleum-related data collected on weekly, monthly, and annual surveys.

Survey forms are periodically reviewed for completeness, meaningfulness, and clarity. Modifications are made, when needed, to maintain efficient measure of the intended data items and to track product movement accurately throughout the industry. Through this process, the EIA can maintain consistency among forms, minimize respondent burden, and eliminate ambiguity.

In any survey, nonresponse can be a major concern because the effects can cause serious bias in survey results. Nonresponse occurs whenever requested information is not obtained from all units in a survey. The PSRS surveys have a very high response rate. In general, response rates average above 95 percent for the weekly survey and above 98 percent for monthly surveys. Whenever survey responses are not received in time to be included in published statistics, the data are imputed. Although imputing for missing data may not eliminate the total error associated with nonresponse, it can serve to reduce the error. The data reported in the previous month are used as imputed values for missing data for all surveys except the Forms EIA-814, "Monthly Imports Report," and EIA-817, "Monthly Tanker and Barge Movement Report." There is no imputation procedure for these surveys because these data series, by respondent, are highly variable.

Response error is the major factor affecting the accuracy of PSRS data. Response, or reporting error, is the difference between the true value and the value reported on a survey form. Response error can occur for any number of reasons. For example, figures may be entered incorrectly when written on forms by the respondent, or errors may result from the misunderstanding of survey form instructions or definitions. Response error can also occur from the use of preliminary data when final data are not 
available. This can result in differences between published preliminary and final data. To help detect and minimize probable reporting errors, automated editing procedures are used to check current data for consistency with past data, as well as for internal consistency (e.g., totals equal to the sums of the parts), and to flag those data elements that fail edit criteria.

Errors can also be introduced during data processing. For example, while creating computer data files, key errors can occur in transcribing or coding the data; or information can be entered into the wrong cell. Using well designed edit criteria which examine orders of magnitude, cell position, and historical reporting patterns, many of these errors can be identified and corrected.

A principal objective of PSRS surveys is to provide a timely and accurate picture of petroleum industry activities. As part of this objective, a comparison of the data collected on the PSRS with other similar data series from sources outside of the Petroleum Supply Division is performed each year. The results of this data comparison are published in the Petroleum Supply Monthly (PSM) feature article, "Comparison of Independent Statistics on Petroleum Supply" and in subsequent explanatory notes.

\section{Resubmissions}

Resubmissions are any changes to the originally submitted data that were either requested by the EIA or initiated by the respondent. Resubmissions are compared with the original submission and processed at the time of receipt. The Resubmission Tracking System (RTS) is run after resubmissions have been processed for the month. The RTS enables the user to study major products and data series to see how company resubmissions impact published data on a month by month basis. During the processing year, a summary of the effect of these resubmissions to major series is provided in Appendix $C$.

\section{Late Response}

Respondents who fail to respond within the prescribed time limit (25th day following the end of the report month) become nonrespondents for that particular report period and are contacted by phone to obtain the current month's data. Respondents who are chronically late (i.e., 3 consecutive months) are notified by EIA either by letter or telephone.

\section{Nonresponse}

Follow-up action is taken when a company fails to respond adequately to data requests from the EIA. Pre- liminary attempts to gather delinquent reports are made by phone. Noncompliance form letters are sent to those companies that have not submitted reports and have not responded to data requests by phone.

\section{Note 7. Frames Maintenance}

The Petroleum Supply Division (PSD) maintains complete lists of respondents to its monthly surveys. Each survey has a list of companies and facilities required to submit petroleum activity data. This list is known as the survey frame. Frame maintenance procedures are used to monitor the status of petroleum companies and facilities currently contained in each survey frame as well as to identify new members to be added to the frame. As a result, all known petroleun supply organizations falling "within the definition of "Who Must Submit" participate in the survey.

The activities for frames maintenance are conducted within three time frames: monthly, annually, and triennially. Monthly frames maintenance procedures focus on examining several frequently published industry periodicals that report changes in status (births, deaths, sales, and acquisitions) of petroleum facilities producing, transporting, importing, and/or storing crude oil and petroleum products. These sources are augmented by articles in newspapers, letters from respondents indicating changes in status, and information received from survey systems operated by other offices. Survey managers review these sources to monitor changes in company operations and to develop lists of potential respondents. These activities assure coverage of the reporting universe and maintain accurate facility information on addresses and ownership. Annual frames maintenance focuses on reevaluating the "must submit" companies filing the Form EIA-814.

To supplement monthly and annual frames maintenance activities and to provide more comprehensive coverage, the PSD conducts a comprehensive triennial frames investigation. These triennial evaluations result in the reassessinent and recompilation of the complete frame for each survey.

In January 1975, 198:, 1983, and 1984 numerous respondents were added to bulk terminal and pipeline surveys affecting subsequent stocks reported and stock change calculations. Table B2 displays the end-of-year stocks, in million barrels using the expanded coverage (new basis). 


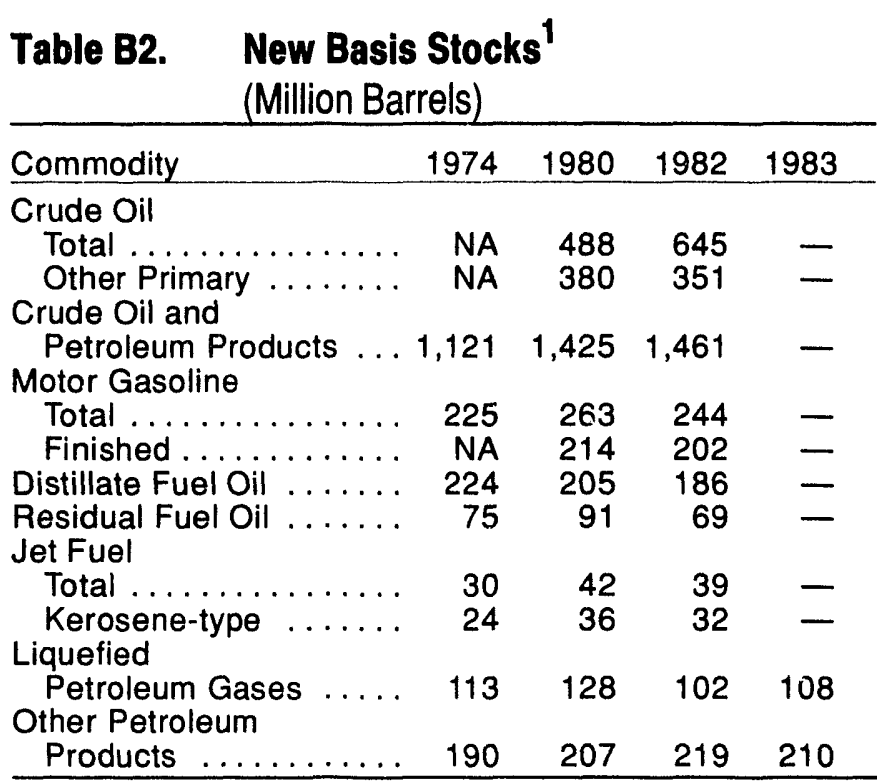

1 Stocks as of December 31. survey forms. Second, a large amount of gasoline was being produced away from refineries at "downstream blending stations" to take advantage of provisions in regulations governing the amount of lead that could be added. These blending stations were not reporting gasoline production to the EIA until the data system was changed in January 1981.

Quantitative estimates of the magnitude of the difference in EIA's gasoline product supplied data in 1979 and 1980 have been made by the EIA and the American Petroleum Institute (API). Table B3 provides 1979 and 1980 data as published in the Petroleum Statement, Annual, as well as EIA and API estimates of "recast" motor gasoline product supplied.

Table B3. Finished Motor Gasoline Product Supplied

(Thousand Barrels per Day)

\begin{tabular}{ccccc}
\hline & $\begin{array}{c}\text { EIA } \\
\text { Reported }\end{array}$ & $\begin{array}{c}\text { API } \\
\text { Recast }\end{array}$ & $\begin{array}{c}\text { EIA } \\
\text { Recast }\end{array}$ & FHWA $^{\mathrm{a}}$ \\
\hline $1979 \ldots \ldots$ & 7,034 & 7,302 & $7,183-7,347$ & 7,258 \\
$1980 \ldots \ldots$ & 6,579 & 6,882 & $6,806-6,889$ & 6,792 \\
\hline
\end{tabular}

a FHWA gasoline statistics based on data from Federal Highway Administration, Estimate of Total Gasoline Use, Table MF-21A published October 1980 and September 1981. Aviation gasoline (Table MF-24) has been subtracted from FHWA product supplied quantities to make data comparable.

The EIA recast estimates were based upon preliminary monthly information in the Monthly Petroleum Statement. The ranges displayed in the EIA column reflect uncertainty in the estimates. Also shown are the FHWA motor gasoline sales statistics for those years.

\section{Distlllate and Residual Fuel OII}

magnitudes of differences in the major data series are described below to form a basis for comparing 1979 , 1980 , and 1981 data.

\section{Motor Gasoline}

Prior to 1979, the EIA product-supplied series for motor gasoline was consistently about 2 percent lower than the Federal Highway Administration (FHWA) gasoline sales data series, which is derived from State tax receipts. The difference increased to about 3 percent in 1979 and 1980. There were two primary causes for this growing difference. First, refinery operations, particularly the flows of unfinished oils and the redesignation of some finished products, were not being accurately described on the EIA
Distillate and residual fuel oil refinery production statistics through 1980 were adjusted to account for an imbalance between unfinished oil supply and disposition. The reported quantities of refinery inputs of unfinished oils typically exceed the available supply of unfinished oils. It has been assumed that this occurs when distillate and residual fuel oils produced by a refinery are shipped to another refinery, where it is treated as unfinished oil. This oil is then reprocessed rather than used or sold as distillate or residual fuel oil.

For many years (including 1980), the difference between unfinished oil disposition and supply was subtracted from 
distillate and residual fuel oil production to adjust for this discrepancy. Two-thirds of the difference was applied to distillate fuel oil, and one-third to residual fuel oil.

Beginning in January 1981, this adjustment was discontinued because there was not sufficient empirical evidence to support it. Table B4 presents distillate and residual fuel oil refinery production in 1979 and 1980 as published (adjusted) and on the same basis as 1981 statistics (unadjusted) to permit comparison.

Table B4. Distillate and Residual Fuel Oil
Production and Product Supplied
(Thousand Barrels per Day)

Adjusted distillate and residual fuel oil product supplied volumes differ from the unadjusted volumes by the same amounts as the adjusted and unadjusted production volumes.

\section{Total Petroleum Products}

The imbalance between the supply and disposition of unfinished oils and gasoline blending components is included with other products (line 35) in Table 1. These imbalances are reported as negative product supplied in Table 2 . Since these changes only involve redistribution of the volumes of finished motor gasoline, distillate and residual fuel oil, gasoline blending components, and unfinished oils, the total volume of petroleum products supplied remains unaffected by them.

\section{Alaskan In-Transit Stocks}

Stocks of Alaskan crude oil in-transit were included for the first time in January 1981. The major impact of this change is on the reporting of stock change calculations. Using the expanded coverage (new basis), 1980 end-ofyear crude oil stocks would have been 488 million barrels for Total and 380 million barrels for Other Primary.

\section{Note 9. 1983 Changes in the Petroleum Supply Reporting System}

January 1983 marked the implementation of recent changes in the collection, processing and availability of the Energy Information Administration's (EIA) petroleum supply data. Survey forms and definitions were made consistent; frames for bulk terminals, petroleum product pipelines and crude oil stock holders were updated, and the survey processing system was redesigned and incorporated into the new Petroleum Supply Reporting System (PSRS).

\section{Changes in Data Collection}

Changes in data collection can be grouped into five categories. Some were made to improve consistency, others to classify activity more precisely, and others to combine or eliminate information elements or to reduce the frequency of reporting in recognition of the trade-off between data value and reporting burden. The changes are itemized below.

- Motor gasoline was divided into three standard categories (finished leaded motor gasoline, finished unleaded motor gasoline and motor gasoline blending components).

- Aviation gasoline blending components were added to Form EIA-817.

- Crude oil burned as fuel on leases and by pipelines is reported as a single item on Form EIA-813. Previously it was reported as distillate or residual fuel oil consumption.

- Number 4 Fuel Oil is now included with distillate fuel oil.

- Gasohol was eliminated as a separate category and is now reported as either "finished leaded motor gasoline" or "finished unleaded motor gasoline."

- Waterborne movements of petrochemical feedstocks are now divided into naphtha-less than 400 degrees end-point and other-oils equal to or greater than 400 degrees end-point on Form EIA-817.

- Data aggregation for Petroleum Administration for Defense District (PADD) I was divided into three subdistricts on Forms EIA-812 and 817.

- Detailed categories of Gross Input to Crude Oil Distillation Units were eliminated, and only Total Gross Inputs is collected on Form EIA-810. 
- Waterborne movements of crude oil and petroleum products between PADD's, on Form EIA-817, no longer reflect shipping and receiving States.

- Reporting of production and stocks of Number 4 Fuel Oil by sulfur levels were eliminated from Forms EIA$810,811,812$, and 817 .

- Crude oil stocks are collected at PADD levels rather than State levels on Form EIA-813.

- Shipments from natural gas processing plants no longer reflect destination by facility type on Form EIA-816.

- The four categories for unfinished oils were reduced to two on Form EIA-810.

- The five categories for sulfur content of residual fuel oil were reduced to three on Forms EIA-810, 811, and 817.

- Normal Butane and Other Butanes were combined into a single category on Forms EIA-810, 811, and 816.

- Three subcategories of lubricating oils (bright stock, neutral, and other) were combined into a single category on the Form EIA-810.

- Three subcategories of waxes (microcrystalline, crystalline-fully refined, and crystalline-other) were combined into a single category on the Form EIA-810.

- Asphalt and Road Oil were combined into a single category on Forms EIA-810 and 811.

- Plant fuel use and Losses were combined on Form EIA-816.

- Natural Gasoline and Isopentane were combined on Form EIA-816.

\section{Note 10. 1984 Changes in the Petroleum Supply Reporting System}

In January 1984, a number of changes in the reporting of natural gas liquids (NGL) were implemented. The modified system reflects supply and disposition of NGL on a component, rather than a product, basis.

From 1979 to 1983, the Energy Information Administration (EIA) collected and reported information on the supply and disposition of nine NGL products. Beginning with January 1984, NGL supply and disposition data were reported for 5 components to be consistent with record keeping practices used by the industry. Table B5 shows the product category under the new and old basis.

\section{Table B5. Product Basis vs. Component Basis Reporting}

\begin{tabular}{|c|c|c|c|c|c|}
\hline \multirow[b]{2}{*}{$\begin{array}{l}\text { 1979-1983 } \\
\text { Product Basis }\end{array}$} & \multicolumn{5}{|c|}{$\begin{array}{l}1984 \text { Component } \\
\text { Basis }\end{array}$} \\
\hline & 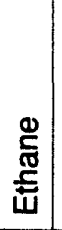 & 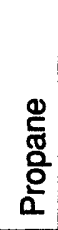 & 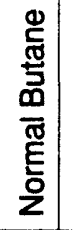 & 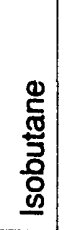 & 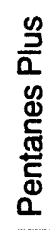 \\
\hline Ethane & $\bullet$ & & & & \\
\hline Ethane-Propane Mixtures & - & $\cdot$ & & & \\
\hline Propane & & $\cdot$ & & & \\
\hline Butane-Propane Mixtures & & $\cdot$ & $\cdot$ & & \\
\hline Butane & & & $\cdot$ & & \\
\hline Isobutane & & & & $\cdot$ & \\
\hline Unfractionated Stream & - & $\cdot$ & $\cdot$ & $\cdot$ & $\cdot$ \\
\hline Natural Gasoline and Isopentane & & & & & $\cdot$ \\
\hline Plant Condensate & & & & & - \\
\hline
\end{tabular}

Four Petroleum Supply Reporting System surveys were modified beginning in January 1984 . They were:
EIA-810
EIA-811
EIA-812
EIA-816

\author{
"Monthly Refinery Report" \\ "Monthly Bulk Terminal Report" \\ "Monthly Product Pipeline Report" \\ "Monthly Natural Gas Liquids Report"
}

This change affected stocks reported and stock change calculations. Under the new basis, end-of-year 1983 stocks would have been 108 million barrels for Liquefied Petroleum Gases and 248 million barrels for Other Petroleum Products.

A fifth survey, Form EIA-814, "Monthly Imports Report" (formerly Form ERA-60), was not modified. Therefore, to allocate imports and exports of mixed NGL streams to individual component parts, the EIA developed a statistical algorithm.

Imports

The imports algorithm was based on information gathered from the larger importers of NGL, who were asked to provide component analysis of the products they imported during the first 6 months of 1983 . The percentages shown 


\begin{tabular}{|c|c|c|c|c|c|}
\hline \multirow{2}{*}{ Product } & \multicolumn{5}{|c|}{ EIA Component Slate } \\
\hline & Ethane & Propane & Normal Butane & Isobutane & Pentanes Plus \\
\hline \multicolumn{6}{|l|}{ Import Product } \\
\hline Natural Gasoline and Isopentane (EIA-814) . . . & - & - & - & - & 100 \\
\hline Plant Condensate (EIA-814) . . . . . . . . . . & - & 一 & - & - & 100 \\
\hline Ethane $(\mathrm{IM}-145) \ldots \ldots \ldots \ldots \ldots \ldots$ & 100 & - & - & - & 一 \\
\hline Propane $(\mathrm{IM}-145) \ldots \ldots \ldots \ldots \ldots$ & - & 100 & - & - & - \\
\hline Butane $(I M-145) \ldots \ldots \ldots \ldots \ldots \ldots$ & - & - & 65 & 35 & - \\
\hline Butane-Propane Mixtures (IM-145) $\ldots \ldots \ldots \ldots$ & - & 40 & 35 & 20 & 5 \\
\hline Ethane-Propane Mixtures (IM-145) $\ldots \ldots \ldots$ & 60 & 40 & - & - & - \\
\hline \multicolumn{6}{|l|}{ Export Product } \\
\hline Ethane (All PAD Districts) $\ldots \ldots \ldots \ldots \ldots \ldots$ & 100 & - & - & - & - \\
\hline Propane (All PAD Districts) . . . . . . . . . . . . . & - & 100 & - & - & - \\
\hline Butane (All PAD Districts) . . . . . . . . . . . . & - & - & 100 & - & - \\
\hline \multicolumn{6}{|l|}{ Mixed Streams } \\
\hline PAD Districts I, IV, V . . . . . . . . . . . & - & 40 & 60 & - & - \\
\hline PAD District $\| \ldots \ldots \ldots \ldots \ldots \ldots \ldots$ & 30 & 25 & 15 & 15 & 15 \\
\hline PAD District III $\ldots \ldots \ldots \ldots \ldots \ldots \ldots$ & - & 80 & 20 & - & 一 \\
\hline
\end{tabular}

in Table B6 are derived from the weighted averages of the data provided by the importers.

\section{Exports}

The exports algorithm was based on information gathered from the larger exporters of NGL, who were asked to provide component analysis of the products they exported during 1983. The percentages shown in Table B6 are derived from the weighted averages of the data provided by the exporters. It was necessary to derive percentages by Petroleum Administration for Defense District of exportation, due to the wide variation of components included in the mixed streams.

\section{Note 11. 1985 Changes in the Petroleum Supply Reporting System}

Beginning in January 1985, inter-Petroleum Administration for Defense (PAD) District pipeline movements of crude oil were included in the crude oil supply balance at the PAD District level but did not affect National level statistics. As a result of including these movements, Net Receipts of crude oil and Unaccounted for Crude Oil at the PAD District level changed significantly. Also affected were crude oil imports and unfinished oil imports at the PAD District level which are provided by PAD District of Entry (Tables 6-10) and by PAD District of Processing (Tables 16-19).
The tables in the Petroleum Supply Monthly that were changed due to the inclusion of inter-PAD District pipeline movements of crude oil are the following:

- Tables 6 through 10, "PAD Districts I to V, Supply and Disposition of Crude Oil and Petroleum Products."

- Effective January 1985, crude oil imports and unfinished oil imports in Tables 4 through 8 were reported at the PAD District of Entry rather than at the PAD District of Processing. Net Receipts now include movements by pipeline as well as by tanker and barge.

- Table 26, "Movements of Crude Oil and Petroleum Products by Pipeline, Tanker, and Barge Between PAD Districts."

- The crude oil line includes movements by pipeline as well as by tanker and barge.

- Table 27, "Movements of Crude Oil and Petroleum Products by Pipeline Between PAD Districts."

- A line was added to report crude oil movements.

- Table 29, "Net Movements of Crude Oil and Petroleum Products by Pipeline, Tanker, and Barge Between PAD Districts."

- The crude oil line includes movements by pipeline as well as by tanker and barge. 
Note 12. 1986 Changes in the Petroleum Supply Reporting System

Beginning in January 1986, several changes to the Petroleum Supply Reporting System (PSRS) went into effect. These changes affected the frame of operators of petroleum facilities required to complete the monthly surveys in the PSRS and resulted in some changes to the tables presented in the Petroleum Supply Monthly (PSM).

\section{Changes in Survey Frames}

As a result of frames maintenance activities, 39 respondents were added to the monthly survey frames: 2 motor gasoline blenders, 30 bulk terminal operators, 3 pipeline operators, 3 crude oil stock holders, and 1 tanker and barge operator. Table B7 shows the impact of the data reported by the new respondents on published data for production and stocks of major petroleum products.

Also, beginning in January 1986, a major petroleum company consolidated production and stocks reporting for some of its facilities. Data previously reported separately on Form EIA-811, "Monthly Bulk Terminal Report," and on Form EIA-816, "Monthly Natural Gas Liquids Report" for two facilities were combined with data reported for two refineries on Form EIA-810, "Monthly Refinery Report." The primary impact of this reporting change is on Table 24, "Stocks of Crude Oil and Petroleum Products by PAD District," which showed a decrease in natural gas liquids (NGL) stocks at bulk terminals and natural gas processing plants, and an increase in NGL stocks at refineries.

\section{Changes in Data Collection}

- The unit of measure used on Form EIA-814, "Monthly Imports Report," has been changed from barrels to thousands of barrels.

- Unfinished oil imports data, previously reported as one product on the Form EIA-814, are now reported separately unde' four classifications. These classification are:

Naphthas and lighter

Kerosene and light gas oils

Heavy gas oils

Residuum

- The number of categories for reporting natural gas liquids and liquefied petroleum gases data on Form EIA-814 was reduced from 19 to 5 by eliminating the requirement to separately identify categories for further processing, petrochemical use, and fuel use.

- The requirements to report the type of processing facility and the applicable section of the oil import regulations were eliminated for the Form EIA-814.

- The requirement to report data for imports of crude oil, unfinished oils, and finished products on separate schedules of the Form EIA-814 was eliminated.

- The requirement to report two end-use categories, petrochemical use and other use, for still gas and liquefied refinery gases, was eliminated on Form EIA810, "Monthly Refinery Report."

Table B7. Impact of New Respondents to December 1985 PSM Data

\begin{tabular}{|c|c|c|c|c|}
\hline \multirow[b]{2}{*}{ Product } & \multicolumn{2}{|c|}{$\begin{array}{l}\text { Refinery Production } \\
\text { (thousand barrels per day) }\end{array}$} & \multicolumn{2}{|c|}{$\begin{array}{c}\text { Stocks }^{a} \\
\text { (thousand barrels) }\end{array}$} \\
\hline & $\begin{array}{c}\text { Reported } \\
\text { by New } \\
\text { Respondents }\end{array}$ & $\begin{array}{l}\text { Published } \\
\text { U.S. Total }\end{array}$ & $\begin{array}{c}\text { Reported } \\
\text { by New } \\
\text { Responderits }\end{array}$ & $\begin{array}{l}\text { Published } \\
\text { U.S. Total }\end{array}$ \\
\hline Leaded Gasoline & 1.3 & 2,326 & 224 & 81,379 \\
\hline Unleaded Gasoline & 0.6 & 4,323 & 276 & 108,422 \\
\hline Distillate Fuel Oil . . & 0 & 3,174 & 1,217 & 143,911 \\
\hline Residual Fuel Oil . & 0 & 1,055 & 1,747 & 50,671 \\
\hline NGLs \& LRGs & 0 & 393 & 409 & 80,898 \\
\hline Other Products & 0 & 3,302 & 1,413 & 239,158 \\
\hline Crude Oil (excl. SPR) & - & - & 2,314 & 318,695 \\
\hline
\end{tabular}

a Stocks as of December 31, 1985. 
- Form EIA-815, "Monthly Shipments from Puertc Rico to the United States Report," was discontinued. The data previously reported on this form are now reported on Form EIA-814.

\section{Changes in Publication Tables}

Several changes were also made to tables in the PSM either as a direct result of changes in reporting requirements or to improve the usefulness of the publication. These changes were:

- Table 13, "Refinery Input of Crude Oil and Petroleum Products by PAD District."

- Alaskan crude oil receipts were shown separately.

- Table 14, "Refinery Production of Petroleum Products by PAD District."

- The breakout between "petrochemical feedstock use" and "other use" were no longer shown separately for still gas or for liquefied refinery gases.

- Tables 16 and 17, "Imports of Crude Oil and Petroleum Products by PAD District."

- Imports of unfinished oils were separated into four categories: naphthas and lighter, kerosene and light gas oils, heavy gas oils, and residuum.

- Tables 18 and 19, "Imports of Crude Oil and Petroleum Products by Source."

- Countries formerly included in the categories "Other Western Hemisphere" and "Other Eastern Hemisphere" were shown individually.

- Table 24, "Stocks of Crude Oil and Petroleum Products by PAD District."

- The breakout between "petrochemical feedstock use" and "other use" for each liquefied petroleum gas was eliminated.

\section{Note 13. 1987 Changes in the Petroleum Supply Reporting System}

Several changes to the Petroleum Supply Reporting System (PSRS) went into effect at the beginning of January 1987. These changes were made as part of the Energy Information Administration's (EIA's) continuing effort to provide pertinent, timely, and consistent energy information.

\section{Changes In Data Collection}

Fresh feed input to catalytic cracking units, hydrocracking units, and cokers were added to the Form EIA-810, "Monthly Refinery Report."

\section{Changes in Publication Tables}

- The "Appalachian No. 2" Refining District was combined with the "Indiana, Illinois, Kentucky," Refining District. This affected Petroleum Supply Monthly (PSM) Tables 12 through 15, 24, 30, and 31 .

- Fresh feed inputs to catalytic cracking units, hydrocracking units, and cokers were added to Table 13, "Refinery Input of Crude Oil and Petroleum Products by PAD District."

\section{Clarlfication}

In 1986, several refineries and terminals in the United States applied for Foreign Trade Zone (FTZ) status and applications from three refineries were approved. Consequently, during 1986, some refineries with FTZ status were treated as if they were within the United States while the Hawaiian FTZ was considered outside.

Effective with the January 1987 data. all FTZ facilities located within the 50 United States are considered domestic entities and are included in PSM statistics. The principal differences in the PSM data series as a result of adding the Hawaiian FTZ was an approximate 1-percent increase in crude imports and a 3 -percent decrease in product imports.

\section{Note 14. 1989 Changes in the Petroleum Supply Reporting System}

Several changes to the Petroleum Supply Reporting System (PSRS) went into effect at the beginning of January 1989. These changes were made to reduce respondent burden, to fulfill user requests for additional data, and to improve accuracy and consistency in reporting. To reflect these changes and to improve the usefulness of the Petroleum Supply Monthly (PSM) publication, the following changes were made in January 1989 and subsequently reflected in the Petroleum Supply Annual (PSA).

\section{Changes in Data Collection}

- Data on inputs and production of naphthenic and paraffinic lubricants were added to the Form EIA-810, "Monthly Refinery Report." 
- Separate lines for the collection of inputs and production of olefins (ethylene, propylene, and butylene)were added to Form EIA-810, "Monthly Refinery Report."

- The collection of data on the movement of Liquefied Petroleum Gases (LPGs) and Liquefied Refinery Gases (LRGs) on a component basis were added to the Forms EIA-812, "Monthly Product Pipeline Report," and the EIA-817, "Monthly Tanker and Barge Movement Report."

- Bonded imports of jet fuel and fuel oils and imports of LPGs previously published from data provided by the U.S. Bureau of the Census were discontinued. Data are now published from the data reported on Form EIA814, "Monthly Imports Report."

- Exports of butane/propane and ethane/propane mixtures were split in a ratio of 60 percent for the butane and ethane portions and 40 percent for the propane portion.

- The reporting of products other than Natural Gas Liquids (NGLs) by natural gas processing plants was eliminated on Form EIA-816, "Monthly Natural Gas Liquids Report."

- Fractionators were required to report only end-ofmonth stocks of NGLs on Form EIA-816, "Monthly Natural Gas Liquids Report."

\section{Changes in Nitural Gas Liquids and Crude Oil Statistics}

Beginning with the January 1989 issue of the PSM, adjustments were being made to refinery inputs and product supplied of NGLs and refinery inputs of crude oil to account for refiner misreporting. Substantial volumes of NGLs are produced at natural gas processing plants in Alaska and injected into the crude oil moving in the Trans Alaska Pipeline System (TAPS). Refiners receiving any crude oil commingled with NGLs are instructed to report the NGL portion of that stream separately from the crude oil portion. This has not been done for Alaskan crude oil because refiners are unable to identify these volumes for accounting purposes. As a result, the i $\mathrm{NGL}$ production in Alaska has been credited directly toward product supplied and also toward product supplied from refinery production when the refiner processes the crude oil-NGL mixture. In addition, the reporting of the commingled stream as crude oil by the refiner has overstated crude oil inputs and resulted in an increase in unaccounted for cride oil equal to the volume of NGL in the crude oil.

To offset this reporting error, an adjustment was made to refinery input in all Petroleum Administration for Defense (PAD) Districts receiving Alaskan crude oil. The adjustment reduces the crude oil inputs and increases the NGL inputs by an equal amo'nt. Each PAD District adjustment is a portion of the known Alaskan NGL production that is proportional to the PAD District's share of Alaskan crude oil received at all refineries in the United States. The greatest impact occurs in PAD District $V$ for butane and pentanes plus.

The reporting problem began in 1987 and has grown as injections of NGLs into the TAPS have increased. Data for 1988 was revised to account for the adjustment in the PSA published in May 1989. Revisions for 1987 data are not planned.

\section{Changes in Publication Tables}

- Year-to-Date tables on Supply and Disposition by PAD District (Tables 7, 9, 11, 13, and 15) were added.

- "Stock Withdrawal" was renamed "Stock Change" and was moved from Supply to Disposition in Tables 2 through 15. A negative number indicates a decrease in stocks and a positive number indicates an increase in stocks.

- A jet fuel total line was added to Tables $2-15,19,20$, $23,24,43-46$.

- PAD District Supply and Disposition tables (Tables 6 through 15) now display liquefied petroleum gases on a component basis.

- Tables showing net imports by country for the current month and year-to-date (Tables 39 and 40) were added.

- Table numbers were changed as a result of data additions and table reorganization. Table B8 is provided to show the old to new table numbers for the detailed statistics tables.

- Table 17, "Natural Gas Plant Net Production and Stocks of Petroleum Products by PAD and Refining District."

- Stocks at natural gas processing plants by Refining District previously published in Table 24 was included with net production of petroleum products at natural gas plants.

- The reporting of products other than natural gas liquids by natural gas processing plants was eliminated.

- Table 19, "Net R finery Production of Finished Petroleum Products by PAD and Refining District."

- Net production of olefins (ethylene, propylene, and butylene) was added. 
Table B8. Conversion Table for 1989 PSM

\begin{tabular}{|c|c|c|c|c|c|c|c|c|c|c|c|}
\hline \multicolumn{12}{|c|}{ Table Numbers } \\
\hline Old & New & Old & New & Old & New & Old & New & Old & New & Old & New \\
\hline 1 & 1 & NA & 9 & 12,24 & 17 & 18,33 & 25 & 19 & 33 & 24,31 & 4 \\
\hline 2 & 2 & 8 & 10 & 13 & 18 & 18,33 & 26 & 19 & 34 & 25 & 42 \\
\hline 3 & 3 & NA & 11 & 14,30 & 19 & 18,33 & 27 & 20 & 35 & 26 & 43 \\
\hline 4 & 4 & 9 & 12 & 24,31 & 20 & 18,33 & 28 & 21 & 36 & 27 & 44 \\
\hline 5 & 5 & NA & 13 & 15 & 21 & 18,33 & 29 & 22 & 37 & 28,32 & 45 \\
\hline 6 & 6 & 10 & 14 & 34 & 22 & 19 & 30 & 23 & 38 & 29 & 46 \\
\hline NA & 7 & NA & 15 & 16 & 23 & 19 & 31 & NA & 39 & & \\
\hline 7 & 8 & 11 & 16 & 17 & 24 & 19 & 32 & NA & 40 & & \\
\hline
\end{tabular}

NA $=$ Not Applicable

- Net production of naphthenic and paraffinic lubricants was added.

- Net production of residual fuel oil by percent sulfur, previously published as Table 30 , was added.

- Table 20, "Refinery Stocks of Crude Oil and Petroleum Products by PAD and Refining District."

- Stocks at refineries by Refining District were added from Table 24 .

- Stocks of residual fuel oil by percent sulfur content, previously published as Table 31, were added.

- Tables 25 through 34, "Imports of Crude Oil and Petroleum Products by Country of Origin."

- Data previously included in the "Other Products" category were displayed separately for naphthas for petrochemical feedstock use, other oils for petrochemical feedstock use, lubricants, and asphalt and road oil.

- Sulfur content categories for residual fuel oil, previously published as Table 33 , were added.

- Tables 37 and 38, "Exports of Crude Oil and Petroleum Products by Destination."

- Data for exports by destination previously included in the "Other Products" category were displayed separately for pentanes plus, kerosene, naphthas for petrochemical feedstock use, and other oils for petrochemical feedstock use.

- Table 41, "Stocks of Crude Oil and Petroleum Products by PAD District."
- Refining District data were eliminated. Refinery stocks and natural gas processing plant stocks by Refining District were added to Tables 17 and 20, respectively.

- Sulfur content categories for residual fuel oil, previously published as Table 31 , were added.

\section{Note 15. 1990 Changes in the Petroleum Supply Reporting System}

Beginning with the May 1990 issue of the Petroleum Supply Monthly (PSM), stocks of propane/propylene were added to Table 42, "Refinery, Bulk Terminal, and Natural Gas Plant Stocks of Selected Petroleum Products by State." This change will be subsequently reflected in the Petroleum Supply Annual(PSA).

\section{Note 16. 1991 Changes in the Petroleum Supply Reporting System}

Several changes have been made to the Petroleum Supply Reporting System effective with the March issue of the Petroleum Supply Monthly (PSM). These changes were made to provide additional data and to improve the usefulness of the publication.

\section{Changes in Publication Tables}

\section{Summary StatisticsTables}

- A new table has been added to show jet fuel supply and disposition.

- Table S8, "Other Petroleum Products Supply and Disposition" has been redesignated as Table S9. Jet fuel 
data is no longer included. Historical data have been revised to exclude jet fuel.

- Table S3, "Crude Oil and Petroleum Product Imports" has been expanded to display all Organization of Petroleum Exporting Countries (OPEC) and additional Non-OPEC countries. A separate column for crude oil imports has also been added for each country.

- Time periods have been included in table titles.

\section{Figures}

- Annual graphs have been eliminated.

- Time periods have been included in figure titles.

- Sources are provided for each figure.

- Bar graphs used to display end-of-month stocks have been replaced with line graphs.

\section{Sources}

The sources and explanatory notes for this section have been updated and are now located at the end of the Summary Statistics section.

\section{Detailed Statistics Tables}

- Table 1, "U.S. Petroleum Balance"
- A line has been added to display jet fuel as a separate category for Total Products Supplied and Total Stocks (lines 34 and 44, respectively).

- PAD District Supply and Disposition Tables

- A year-to-date table in thousand barrels and a current month table in thousand barrels per day have been added for each PAD District.

- Imports of Crude Oil and Petroleum Products by PAD District

- Residual fuel oil sulfur categories have been added.

- Imports of Crude Oil and Petroleum Products by Country of Origin

- Residual fuel oil sulfur categories by country of origin have been eliminated. These categories are now reported on a PAD District basis.

- Separate daily average columns have been added for crude oil and petroleum products.

- Table numbers have been changed as a result of table additions. Table B9 is provided to show the old to new table numbers for the detailed statistics tables.

Table B9. Conversion Table for 1991 PSM

\begin{tabular}{|c|c|c|c|c|c|c|c|c|c|c|c|}
\hline \multicolumn{12}{|c|}{ Table Numbers } \\
\hline Old & New & Old & New & Old & New & Old & New & Old & New & Old & New \\
\hline 1 & 1 & $N$ & 11 & 13 & 21 & 21 & 31 & 31 & 41 & 41 & 51 \\
\hline 2 & 2 & iv & 12 & 14 & 22 & 22 & 32 & 32 & 42 & 42 & 52 \\
\hline 3 & 3 & 9 & 13 & $N$ & 23 & 23 & 33 & 33 & 43 & 43 & 53 \\
\hline 4 & 4 & 10 & 14 & $N$ & 24 & 24 & 34 & 34 & 44 & 44 & 54 \\
\hline 5 & 5 & $N$ & 15 & 15 & 25 & 25 & 35 & 35 & 45 & 45 & 55 \\
\hline 6 & 6 & $N$ & 16 & 16 & 26 & 26 & 36 & 36 & 46 & 46 & 56 \\
\hline $\mathrm{N}$ & 7 & 11 & 17 & 17 & 27 & 27 & 37 & 37 & 47 & & \\
\hline$N$ & 8 & 12 & 18 & 18 & 28 & 28 & 38 & 38 & 48 & & \\
\hline 7 & 9 & $N$ & 19 & 19 & 29 & 29 & 39 & 39 & 49 & & \\
\hline 8 & 10 & $N$ & 20 & 20 & 30 & 30 & 40 & 40 & 50 & & \\
\hline
\end{tabular}

$\mathrm{N}=$ New Table 


\section{Appendix C}

This table contains information on revisions to published statistics caused by resubmission of respondent survey forms. The table shows the published value in the Petroleum Supply Monthly (PSM) and the cumulative difference resulting from resubmissions for the major product series. The official published petroleum supply statistics are not changed to reflect revisions until publication of the Petroleum Supply Annual (PSA), except in cases of catastrophic error.

This table is provided as a service to analysts who need to know the latest available statistics. It should be used with caution because resubmissions are received on an irregular basis and the impact on published data can change from month to month. In some cases, the pattern of revision caused by resubmissions during the year is a poor indicator of final statistics that will be published in the PSA.

\section{Impact of \\ Resubmissions \\ on Major Series, 1991}

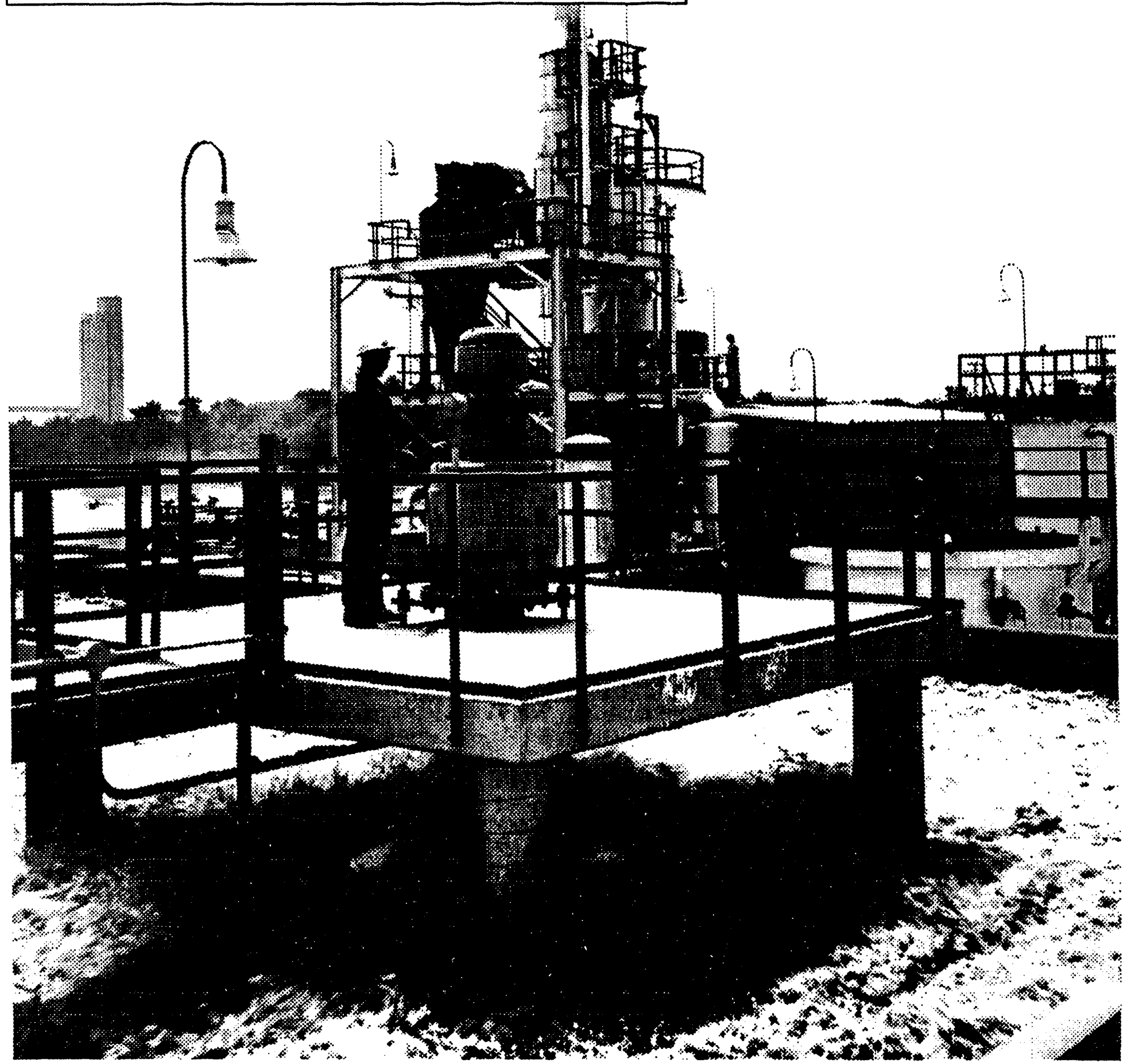

Surface aerators are used at U.S. petroleum refineries to help prevent water pollution. These aerators speed up the oxidation process by beating air into water. 
Table C1. Impact of Resubmissions on Major Series, 1991

(Thousand Barrels per Day, Except Where Noted)

\begin{tabular}{|c|c|c|c|c|c|c|c|c|c|c|c|c|c|}
\hline \multirow[b]{2}{*}{ Product } & \multicolumn{2}{|c|}{ January } & \multicolumn{2}{|c|}{ February } & \multicolumn{2}{|c|}{ March } & \multicolumn{2}{|c|}{ April } & \multicolumn{2}{|c|}{ May } & \multicolumn{2}{|c|}{ June } & $\begin{array}{l}\text { Year to } \\
\text { Date }\end{array}$ \\
\hline & $\begin{array}{l}\text { PSM } \\
\text { Value }\end{array}$ & $\begin{array}{l}\text { Differ- } \\
\text { ence }\end{array}$ & $\begin{array}{l}\text { PSM } \\
\text { Value }\end{array}$ & $\begin{array}{l}\text { Differ- } \\
\text { ence }\end{array}$ & $\begin{array}{l}\text { PSM } \\
\text { Value }\end{array}$ & $\begin{array}{l}\text { Differ- } \\
\text { ence }\end{array}$ & $\begin{array}{l}\text { PSM } \\
\text { Value }\end{array}$ & $\begin{array}{l}\text { Differ. } \\
\text { ence }\end{array}$ & $\begin{array}{l}\text { PSM } \\
\text { Value }\end{array}$ & $\begin{array}{l}\text { Differ. } \\
\text { ence }\end{array}$ & $\begin{array}{l}\text { PSM } \\
\text { Value }\end{array}$ & $\begin{array}{l}\text { Differ- } \\
\text { ence }\end{array}$ & $\begin{array}{c}\text { Average } \\
\text { Difference }\end{array}$ \\
\hline Inputs & 13,921 & 17 & 14,078 & -5 & 13,898 & 5 & 14,050 & 3 & 14,674 & 4 & 15,256 & 1 & 4 \\
\hline ...................... & 12,727 & 2 & 13,052 & -9 & 12,832 & 4 & 13,037 & 0 & 13,533 & 4 & 13,915 & 0 & (s) \\
\hline Pentanes Plus .......................... & 187 & 0 & 171 & 0 & 169 & 0 & 162 & 0 & 166 & 0 & 173 & 0 & 0 \\
\hline 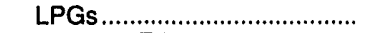 & 359 & 7 & 304 & 4 & 234 & 4 & 224 & 3 & 221 & 9 & 238 & -1 & 4 \\
\hline Ethane/Ethylene ................... & 0 & 0 & 0 & 0 & 0 & 0 & 0 & 0 & 0 & 0 & 0 & 0 & 0 \\
\hline Propane/Propylene............... & 0 & 0 & (s) & 0 & 0 & 0 & (s) & 0 & (s) & 0 & (s) & 0 & 0 \\
\hline Normal Butane/Butylene..... & 230 & 7 & 166 & 4 & 88 & 2 & 60 & 0 & 58 & 1 & 67 & -1 & 2 \\
\hline 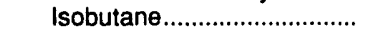 & 129 & (s) & 138 & (s) & 146 & 1 & 164 & 3 & 163 & 8 & 171 & (s) & 2 \\
\hline Other Hydrocarbons................ & 83 & 2 & 84 & 2 & 75 & (s) & 78 & 0 & 78 & 0 & 77 & 0 & 1 \\
\hline Unfinished Oils ....................... & 480 & 11 & 444 & 1 & 422 & -1 & 399 & -2 & 671 & 1 & 806 & (s) & 2 \\
\hline Motor Gas. Blend. Comp ....... & 84 & -6 & 22 & -2 & 164 & -3 & 151 & 2 & 6 & -9 & 48 & 1 & -3 \\
\hline Aviation Gas. Blend. Comp... & 1 & 0 & 1 & 0 & 1 & 0 & 1 & 0 & (s) & 0 & -2 & 0 & 0 \\
\hline 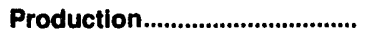 & 16,344 & 21 & 16,549 & 11 & 16,273 & 12 & 16,380 & 1 & 17,086 & 21 & 17,623 & 3 & 12 \\
\hline Pentanes Plus .......................... & 305 & 3 & 316 & 3 & 316 & 3 & 322 & (s) & 325 & (s) & 326 & 1 & 2 \\
\hline 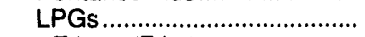 & 1,716 & 25 & 1,829 & 7 & 1,887 & 8 & 1,881 & 5 & 1,924 & 6 & 1,894 & -1 & $\overline{8}$ \\
\hline Ethane/Ethylene .................. & 540 & (s) & 571 & -2 & 564 & 1 & 547 & -2 & 540 & (s) & 532 & (s) & -1 \\
\hline Propane/Propylene................ & 905 & 5 & 916 & 1 & 900 & 1 & 889 & 2 & 910 & 3 & 894 & -1 & 2 \\
\hline Normal Butane/Butylene..... & 127 & 15 & 185 & 2 & 261 & 1 & 285 & 2 & 290 & -3 & 292 & -4 & 2 \\
\hline 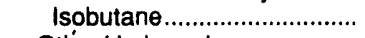 & 145 & 5 & 157 & 6 & 162 & 5 & 160 & 4 & 184 & 5 & 177 & 4 & 5 \\
\hline Othiei Hydrocarbons............... & 82 & -7 & 96 & 2 & 73 & 1 & 82 & -5 & 101 & 17 & 78 & 0 & 1 \\
\hline Finished Motor Gasoline ....... & 6,629 & (s) & 6,573 & (s) & 6,642 & 1 & 6,742 & 0 & 7,063 & (s) & 7,351 & 0 & (s) \\
\hline 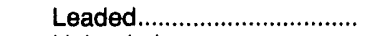 & 286 & -1 & 235 & (s) & 238 & (s) & 263 & 0 & 275 & (s) & 288 & 0 & (s) \\
\hline 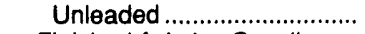 & 6,343 & 1 & 6,338 & (s) & 6,404 & 1 & 6,478 & 0 & 6,788 & (s) & 7,063 & 0 & (s) \\
\hline Finished Aviation Gasoline.... & 20 & 0 & 19 & 0 & 16 & 0 & 18 & 0 & 27 & 0 & 28 & 0 & 0 \\
\hline 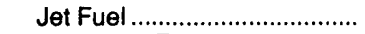 & 1,508 & 1 & 1,548 & (s) & 1,299 & (s) & 1,286 & 0 & 1,365 & 1 & 1,473 & 0 & 1 \\
\hline Naphtha-Type Jet ................ & 155 & 0 & 164 & (s) & 142 & 0 & 151 & 0 & 176 & 0 & 173 & 0 & 0 \\
\hline Kerosene-Type Jet ............... & 1,353 & 1 & 1,384 & (s) & 1,157 & (s) & 1,135 & 0 & 1,190 & 1 & 1,300 & 0 & 1 \\
\hline 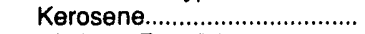 & 79 & (s) & 62 & (s) & 22 & 0 & 35 & 0 & 25 & 0 & 25 & 0 & (s) \\
\hline Distillate Fuel Oil ..................... & 2,851 & -2 & 2,867 & (s) & 2,862 & 1 & 2,822 & 0 & 2,924 & 1 & 2,940 & 0 & 0 \\
\hline Residual Fuel Oil.................... & 1,000 & 1 & 1,049 & 1 & 997 & -3 & 915 & 0 & 926 & 3 & 933 & 0 & (s) \\
\hline Naphtha Pet. Feedstock ........ & 151 & -2 & 148 & 1 & 133 & 0 & 138 & (s) & 134 & -2 & 161 & 4 & 0 \\
\hline Other Oils Pet. Feedstock..... & 270 & (s) & 241 & (s) & 231 & 1 & 242 & (s) & 257 & (s) & 305 & (s) & (s) \\
\hline Special Naphthas................... & 50 & 0 & 54 & (s) & 48 & 1 & 67 & -1 & 50 & (s) & 48 & 0 & 0 \\
\hline 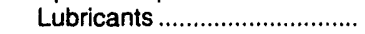 & 167 & 0 & 160 & 0 & 162 & 0 & 152 & 0 & 160 & -2 & 165 & (s) & (s) \\
\hline 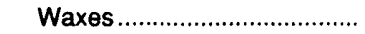 & 17 & 0 & 17 & 0 & 18 & 0 & 16 & 0 & 20 & 0 & 21 & 0 & 0 \\
\hline Petroleum Coke ....................... & 567 & (s) & 546 & 0 & 528 & -2 & 551 & 0 & 569 & (s) & 567 & 0 & (s) \\
\hline Asphalt and Road Oil ............ & 249 & 0 & 336 & -4 & 366 & 0 & 404 & 0 & 473 & 0 & 531 & 0 & -1 \\
\hline 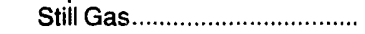 & 606 & 2 & 615 & 2 & 600 & 2 & 646 & 1 & 672 & -2 & 710 & 0 & 1 \\
\hline Miscellaneous Products ........ & 77 & 0 & 73 & -2 & 71 & 0 & 61 & 0 & 72 & 0 & 66 & 0 & (s) \\
\hline 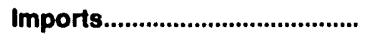 & 7,066 & 19 & 6,844 & 20 & 6,550 & 92 & 7,374 & 44 & 8,496 & 27 & 8,177 & 81 & 47 \\
\hline 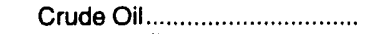 & 5,303 & -6 & 5,498 & 4 & 5,129 & 68 & 5,523 & 22 & 6,387 & -8 & 6,317 & 49 & 22 \\
\hline Pentanes Plus ........................... & 3 & (s) & 11 & (s) & 9 & (s) & 9 & (s) & 5 & 0 & 11 & (s) & (s) \\
\hline 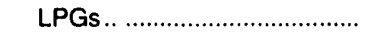 & 137 & 7 & 119 & 5 & 81 & 5 & 149 & 3 & 127 & 1 & 143 & 5 & 4 \\
\hline Ethr:, 1 /Ethylene ..................... & 10 & 0 & 12 & 0 & 10 & 0 & 10 & 0 & 10 & 0 & 10 & 0 & 0 \\
\hline Propane/Propylene............. & 97 & 4 & 88 & 2 & 54 & 1 & 99 & 1 & 89 & (s) & 78 & 2 & 2 \\
\hline Normal Butane/Butylene..... & 22 & 2 & 15 & 2 & 9 & 2 & 29 & (s) & 20 & (s) & 35 & 2 & 1 \\
\hline 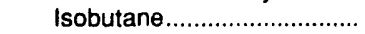 & 8 & 1 & 6 & 2 & 8 & 2 & 11 & 2 & 9 & (s) & 20 & 1 & 1 \\
\hline Other Hydrocarbons............... & 0 & 6 & 0 & 0 & 3 & 6 & 3 & 0 & 8 & 0 & 2 & 0 & 2 \\
\hline Unfinished Oils ....................... & 451 & 6 & 308 & 0 & 280 & 7 & 342 & 6 & 499 & 20 & $28 \overline{5}$ & 8 & 8 \\
\hline Motor Gas.Blend.Comp ......... & 57 & 0 & 37 & 0 & 45 & 0 & 60 & 0 & 48 & 0 & 37 & 0 & 0 \\
\hline Aviation Gas. Blend. Comp... & 0 & 0 & 0 & 0 & 0 & 0 & 0 & 0 & 0 & 0 & 0 & 0 & 0 \\
\hline Finished Motor Gasoline ........ & 227 & 1 & 106 & 9 & 235 & 2 & 371 & 10 & 528 & 1 & 371 & -4 & 3 \\
\hline 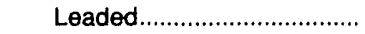 & (s) & 0 & (s) & 0 & (s) & 1 & (s) & 0 & 0 & 0 & (s) & 1 & (s) \\
\hline 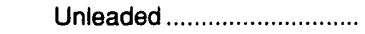 & 227 & 1 & 106 & 9 & 235 & 2 & 371 & 10 & 528 & 1 & 371 & -5 & 3 \\
\hline Finished Aviation Gasoline.... & (s) & 0 & (s) & 0 & (s) & 0 & (s) & 0 & (s) & 0 & 1 & 0 & 0 \\
\hline 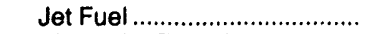 & 67 & 0 & 44 & 0 & 65 & 2 & 73 & 0 & 87 & 5 & 64 & 5 & 2 \\
\hline Naphtha-Type Jet ................ & 20 & 0 & 15 & 0 & 12 & 0 & 13 & 0 & 15 & 0 & 7 & 0 & 0 \\
\hline Kerosene-Type Jet ............. & 47 & 0 & 29 & 0 & 52 & 2 & 61 & 0 & 73 & 5 & 57 & 5 & 2 \\
\hline 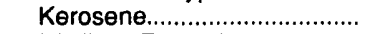 & 9 & 0 & 2 & 0 & 1 & 0 & 4 & 0 & 10 & 0 & 6 & 0 & 0 \\
\hline Distillate Fuel Oil ................... & 190 & 2 & 138 & 1 & 205 & (s) & 258 & 1 & 185 & 3 & 209 & 5 & 2 \\
\hline Residual Fuel Oil.................... & 422 & 3 & 384 & (s) & 331 & 1 & 416 & 0 & 420 & 5 & 499 & 13 & 4 \\
\hline Naphtha Pet. Feedstock ........ & 20 & (s) & 14 & 0 & 9 & 0 & 32 & 0 & 34 & 0 & 43 & 0 & (s) \\
\hline Other Oils Pet. Feedstock..... & 150 & 0 & 142 & 0 & 113 & 0 & 101 & 0 & 113 & 0 & 135 & 0 & 0 \\
\hline Special Naphthas.................. & 6 & (s) & 9 & (s) & 13 & (s) & 5 & (s) & 7 & (s) & 9 & 0 & (s) \\
\hline Lubricants ................................ & 7 & (s) & 2 & 0 & 5 & (s) & 6 & 0 & 10 & (s) & 6 & 0 & (s) \\
\hline 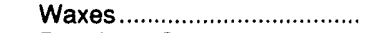 & 1 & 0 & 4 & 0 & 1 & 0 & 2 & 0 & 1 & 0 & 1 & 0 & 0 \\
\hline Petroleum Coke ..................... & 1 & 0 & 4 & 0 & 2 & 0 & 1 & 0 & 2 & 0 & 2 & 0 & 0 \\
\hline Asphalt and Road Oil ............ & 14 & (s) & 23 & (s) & 19 & (s) & 16 & 0 & 20 & (s) & 35 & 0 & (s) \\
\hline Miscellaneous Products ......... & 1 & (s) & (s) & 0 & 4 & 0 & 1 & 0 & 6 & (s) & 1 & 0 & (s) \\
\hline
\end{tabular}

(s) = Less than 500 barrels per day

Note: - Volumes indicate cumulative changes resulting from resubmissions received for that month as of the date of this publication. - Totals may not equal sum of componenis ciue io indepencient rounding. 
Table C1. Impact of Resubmissions on Major Series, 1991

(Thousand Barrels per Day, Except Where Noted)

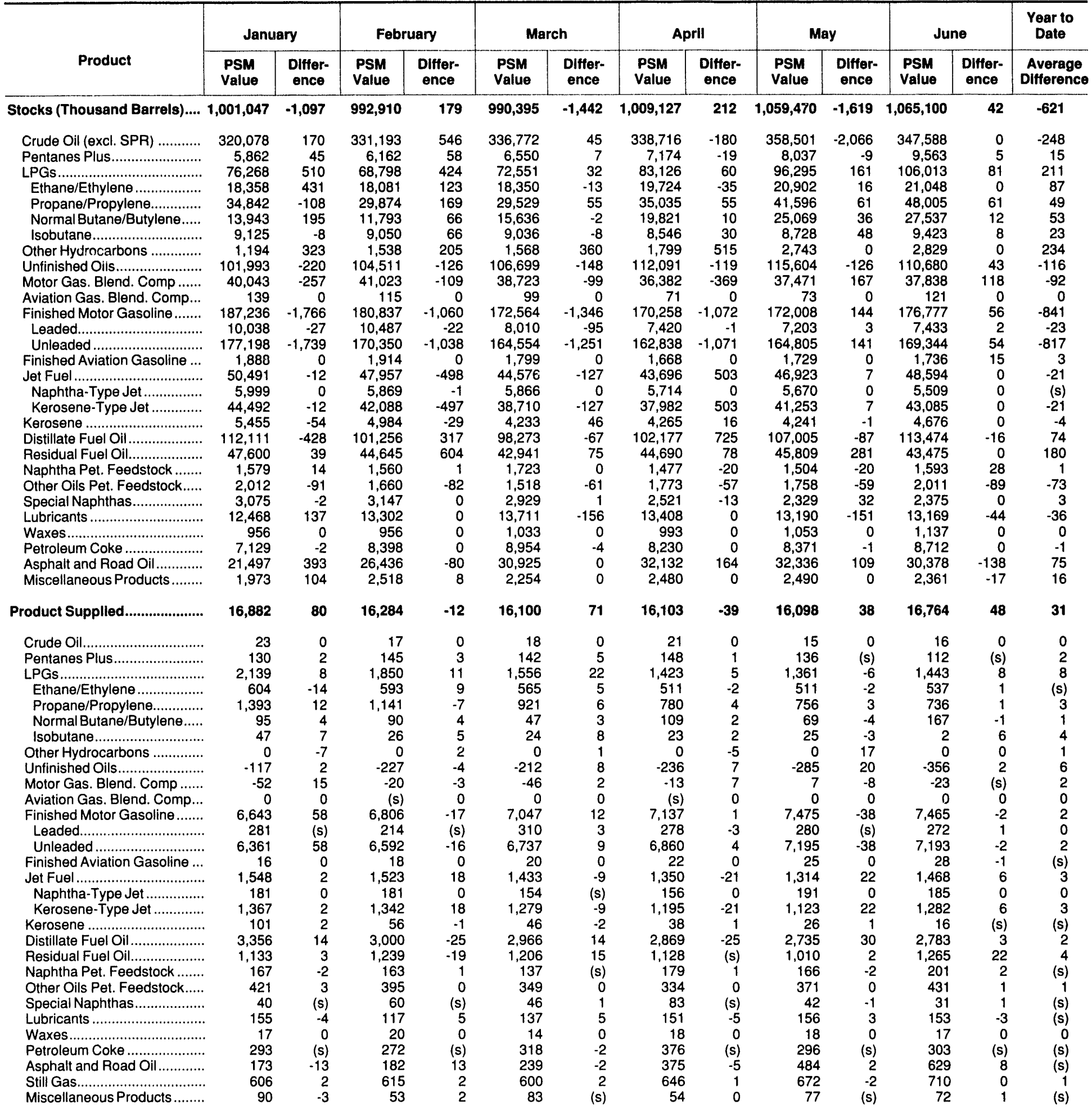

(s) = Less than 500 barrels per day

Note: - Volumes indicate cumulative changes resulting from resubmissions received for that month as of the date of this publication. - Totals may not equal sum of comporients due to independent rounding. 


\section{Glossary}

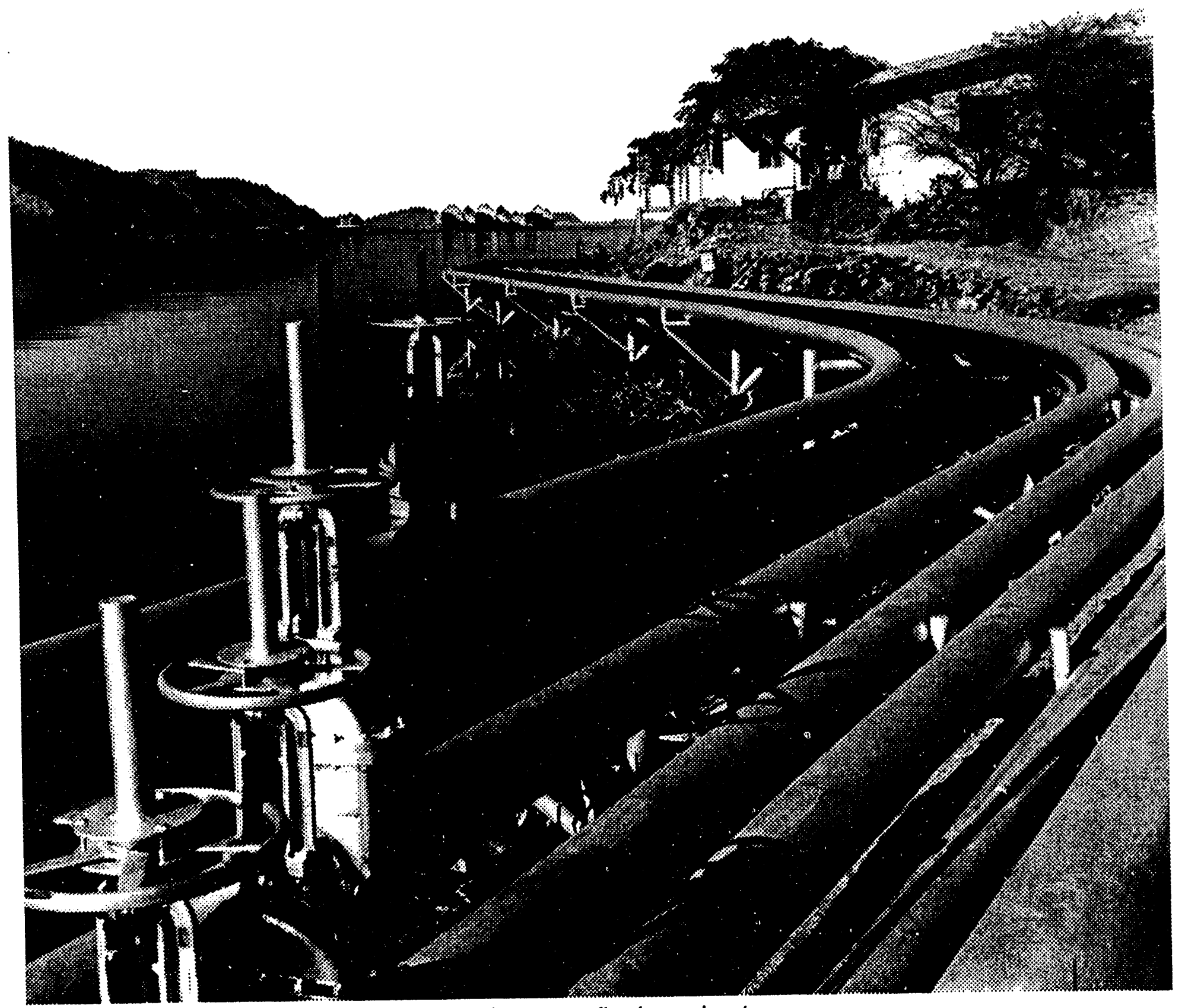

Pipelines carry crude oil and petroleum products between refineries and ports. 


\section{Definitions of Petroleum Products and Other Terms}

Alcohol. The family name of a group of organic chemical compounds composed of carbon, hydrogen, and oxygen. The series of molecules vary in chain length and are composed of a hydrocarbon plus a hydroxyl group; $\mathrm{CH}_{3-}$ $\left(\mathrm{CH}_{2}\right)$ n-OH (e.g., methanol, ethanol, and tertiary butyl alcohol (TBA)).

Alkylate. The product of an alkylation reaction. It usually refers to the high octane product from alkylation units. This alkylate is used in blending high octane gasoline.

Alkylation. A refining process for chemically combining isobutane with olefin hydrocarbons (e.g., propylene, butylene) through the control of temperature and pressure in the presence of an acid catalyst, usually sulfuric acid or hydrofluoric acid. The product alkylate, an isoparaffin, has high octane value and is blended with motor and aviation gasoline to improve the antiknock value of the fuel.

API Gravity. An arbitrary scale expressing the gravity or density of liquid petroleum products. The measuring scale is calibrated in terms of degrees API; it is calculated as follows:

$$
\text { Degrees API }=\frac{141.5}{s p . g r .60^{\circ} \mathrm{F} / 60^{\circ} \mathrm{F}}-131.5
$$

Aromatics. Hydrocarbons characterized by unsaturated ring structures of carbon atoms. Commercial petroleum aromatics are benzene, toluene, and xylene (BTX).

Asphalt. A dark-brown-to-black cement-like material containing bitumens as the predominant constituents, obtained by petroleum processing. The definition includes crude asphalt as well as the following finished products: cements, fluxes, the asphalt content of emulsions (exclusive of water), and petroleum distillates blended with asphalt to make cutback asphalts. The conversion factor for asphalt is 5.5 barrels per short ton.

ASTM. The acronym for the American Society for Testing and Materials.

Atmospheric Crude Oil Distillation. The refining process of separating crude oil components at atmospheric pressure by heating to temperatures of about $600^{\circ}$ to $750^{\circ}$ $F$ (depending on the nature of the crude oil and desired products) and subsequent condensing of the fractions by cooling.
Aviation Gasoline (Finished). All special grades of gasoline for use in aviation reciprocating engines, as given in ASTM Specification D910 and Military Specification MIL-G-5572. Excludes blending components which will be used in blending or compounding into finished aviation gasoline.

Aviation Gasoline Blending Components. Naphthas and aromatics which will be used for blending or compounding into finished aviation gasoline (e.g., straight-run gasoline, alkylate, reformate, benzene, toluene, and xylene). Excludes oxygenates (alcohols, ethers), butane, and pentanes plus. Oxygenates are reported as other hydrocarbons, hydrogen, and alcohol.

Barrel. A volumetric unit of measure for crude oil and petroleum products equivalent to 42 U.S. gallons. This measure is used in most statistical reports. Factors for converting petroleum coke, asphalt, still gas and wax to barrels are given in the definitions of these products.

Barrels Per Calendar Day. The maximum number of barrels of input that can be processed during a 24-hour period after making allowances for the following limitations:

the capability of downstream facilities to absorb the output of crude oil processing facilities of a given refinery. No reduction is made when a planned distribution of intermediate streams through other than downstream facilities is part of a refinery's normal operation;

the types and grades of inputs to be processed;

the types and grades of products expected to be manufactured;

the environmental constraints associated with refinery operations;

the reduction of capacity for scheduled downtime such as routine inspection, mechanical problems, maintenance, repairs, and turnaround; and

the reduction of capacity for unscheduled downtime such as mechanical problems, repairs, and slowdowns.

Barrels Per Stream Day. The amount a unit can process running at full capacity under optimal crude oil and product slate conditions.

Benzene $\left(\mathrm{C}_{6} \mathrm{H}_{6}\right)$. One of the aromatic compounds, commonly referred to as BTXs, and a basic building block of 
the petrochemical industry. It is primarily manufactured through catalytic reforming processes, steel milling coking production and olefin operations. It is found in motor gasoline and is used as a solvent, and in organic synthesis.

Blending Plant. A facility which has no refining capability but is capable of producing finished motor gasoline through mechanical blending.

Bonded Petroleum Imports. Petroleum imported and entered into Customs bonded storage. These imports are not included in the import statistics until they are: (1) withdrawn from storage free of duty for use as fuel for vessels and aircraft engaged in international trade; or (2) withdrawn from storage with duty paid for domestic use.

BTX. The acronym for the commercial petroleum aromatics benzene, toluene, and xylene. See individual categories for definitions.

Bulk Terminal. A facility used primarily for the storage and/or marketing of petroleum products which has a total bulk storage capacity of 50,000 barrels or more and/or receives petroleum products by tanker, barge, or pipeline.

Butane $\left(\mathrm{C}_{4} \mathrm{H}_{10}\right)$. A normally gaseous straight-chain or branch-chain hydrocarbon extracted from natural gas or refinery gas streams. It includes isobutane and normal butane and is designated in ASTM Specification D1835 and Gas Processors Association Specifications for commercial butane.

Isobutane $\left(\mathrm{C}_{4} \mathrm{H}_{10}\right)$. A normally gaseous branch-chain hydrocarbon. It is a colorless paraffinic gas that boils at a temperature of $10.9^{\circ} \mathrm{F}$. It is extracted from natural gas or refinery gas streams.

Normal Butane ( $\left.\mathrm{C}_{4} \mathrm{H}_{10}\right)$. A normally gaseous straightchain hydrocarbon. It is a colorless paraffinic gas that boils at a temperature of $31.1^{\circ} \mathrm{F}$. It is extracted from natural gas or refinery gas streams.

Butylene $\left(\mathrm{C}_{4} \mathrm{H}_{8}\right)$. An olefinic hydrocarbon recovered from refinery processes.

Catalytic Cracking. The refining process of breaking down the larger, heavier, and more complex hydrocarbon molecules into simpler and lighter molecules. Catalytic cracking is accomplished by the use of a catalytic agent and is an effective process for increasing the yield of gasoline from crude oil. Catalytic cracking processes fresh feeds and recycled feeds.

Fresh Feeds. Crude oil or petroleum distillates which are being fed to processing units for the first time.
Recycled Feeds. Feeds that are continuously fed back for additional processing.

Catalytic Hydrocracking. A refining process that uses hydrogen and catalysts with relatively low temperatures and high pressures for converting middle boiling or residual material to high-octane gasoline, reformer charge stock, jet fuel and/or high grade fuel oil. The process uses one or more catalysts, depending upon product output, and can handle high sulfur feedstocks without prior desulfurization.

Catalytic Hydrotreating. A refining process for treating petroleum fractions from atmospheric or vacuum distillation units (e.g., naphthas, middle distillates, reformer feeds, residual fuel oil, and heavy gas oil) and other petroleum (e.g., cat cracked naphtha, coker naphtha, gas oil, etc.) in the presence of catalysts and substantial quantities of hydrogen. Hydrotreating includes desulfurization, removal of substances (e.g., nitrogen compounds) that deactivate catalysts, conversion of olefins to paraffins to reduce gum formation in gasoline, and other processes to upgrade the quality of the fractions.

Catalytic Reforming. A refining process using controlled heat and pressure with catalysts to rearrange certain hydrocarbon molecules, thereby converting paraffinic and naphthenic type hydrocarbons (e.g., low-octane gasoline boiling range fractions) into petrochemical feedstocks and higher octane stocks suitable for blending into finished gasoline. Catalytic reforming is reported in two categories. They are:

Low Pressure. A processing unit operating at less than 225 pounds per square inch gauge (PSIG) measured at the outlet separator.

High Pressure. A processing unit operating at either equal to or greater than 225 pounds per square inch gauge (PSIG) measured at the outlet separator.

Charge Capacity. The input (feed) capacity of the refinery processing facilities.

Coal. A generic term applied to carbonaceous rocks that were formed by the partial or complete dccomposition of vegetation. These stratified carbonaceous rocks are either solid or brittle and are highly combustible. Includes lignite, bituminous coal, and anthracite which conform to ASTM Specification D388.

Crude Oil (Including Lease Condensate). A mixture of hydrocarbons that exists in liquid phase in underground reservoirs and remains liquid at atmospheric pressure after passing through surface-separating facilities. Included are lease condensate and liquid hydrocarbons produced from tar sands, gilsonite, and oil shale. Drip 
gases are also included, but topped crude oil (residual oil) and other unfinished oils are excluded. Liquids produced at natural gas processing plants and mixed with crude oil are likewise excluded where identifiable. Crude oil is considered as either domestic or foreign, according to the following:

Domestic. Crude oil produced in the United States or from its "outer continental shelf" as defined in 43 USC 1331 .

Foreign. Crude oil produced outside the United States. Imported Athabasca hydrocarbons are included.

Crude Oil, Refinery Receipts. Receipts of domestic and foreign crude oil at a refinery. Includes all crude oil in transit except crude oil in transit by pipeline. Foreign crude oil is reported as a receipt only after entry through customs. Crude oil of foreign origin held in bonded storage is excluded.

Crude Oil Losses. Represents the volume of crude oil reported by petroleum refineries as being lost in their operations. These losses are due to spills, contamination, fires, etc. as opposed to refinery processing losses.

Crude Oil Production. The volume of crude oil produced from oil reservoirs during given periods of time. The amount of such production for a given period is measured as volumes delivered from lease storage tanks (i.e., the point of custody transfer) to pipelines, trucks, or other media for transport to refineries or terminals with adjustments for (1) net differences between opening and closing lease inventories, and (2) basic sediment and water $(B S \& W)$.

Crude Oil Qualities. Refers to two properties of crude oil, the sulfur content and API gravity, which affect processing complexity and product characteristics.

Crude Oil Used Directly. Represents the amount of crude oil consumed as fuel by crude oil pipelines and on crude oil leases.

Delayed Coking. A process by which heavier crude oil fractions can be thermally decomposed under conditions of elevated temperatures and pressure to produce a mixture of lighter oils and petroleum coke. The light oils can be processed further in other refinery units to meet product specifications. The coke can be used either as a fuel or in other applications such as the manufacturing of steel or aluminum.

Disposition. The components of petroleum disposition are stock change, crude oil losses, refinery inputs, exports, and prolucts supplied for domestic consumption.
Distillate Fuel Oil. A general classification for one of the petroleum fractions produced in conventional distillation operations. It is used primarily for space heating, on-andoff-highway diesel engine fuel including railroad engine fuel and fuel for agricultural machinery, and electric power generation. Included are products known as No. 1, No. 2, and No. 4 fuel oils; No. 1, No. 2, and No. 4 diesel fuels.

No. 1 Fuel Oil. A light distillate fuel oil intended for use in vaporizing pot-type burners. ASTM Specification D396 specifies for this grade maximum distillation temperatures of $400^{\circ} \mathrm{F}$ at the 10 -percent recovery point and $550^{\circ} \mathrm{F}$ at the 90 -percent point, and kinematic viscosities between 1.4 and 2.2 centistokes at $100^{\circ} \mathrm{F}$.

No. 2 Fuel Oil. A distillate fuel oil for use in atomizingtype burners for domestic heating or for moderate capacity commercial-industrial burner units. ASTM Specification D396 designates minimum and maximum distillation temperatures at the 90 -percent recovery point of $540^{\circ}$ and $640^{\circ} \mathrm{F}$, and kinematic viscosities between 2.0 and 3.6 centistokes at $100^{\circ} \mathrm{F}$.

No. 1 and No. 2 Diesel Fuel Oils. Distillate fuel oils used in compression-ignition engines, as designated in the ASTM Specification D975:

No. 1-D. A volatile distillate fuel oil with a maximum distillation temperature of $550^{\circ} \mathrm{F}$ at the 90percent recovery point for use in high-speed diesel engines generally operated under variations in speed and load. Includes type C-B diesel fuel used for city buses and similar operations. Properties are defined in ASTM Specification D975.

No. 2-D. A gas oil type distillate of lower volatility with minimum and maximum distillation temperatures at the 90 -percent recovery point of $540^{\circ}$ and $640^{\circ} \mathrm{F}$ for use in high-speed diesel engines generally operated under uniform speed and load conditions. Includes Type R-R diesel fuel used for railroad locomotive engines, and Type $T-T$ for diesel-engine trucks. Properties are defined in ASTM Specification D975.

No. 4 Fuel Oil. A fuel oil for commercial burner installations not equipped with preheating facilities. It is used extensively in industrial plants. This grade is a blend of distillate fuel oil and residual fuel oil stocks that conforms to ASTM Specification D396 or Federal Specification VV-F-815C; with minimum and maximum kinematic viscosities between 5.8 and 26.4 centistokes at $100^{\circ} \mathrm{F}$. Also included is No. 4-D, a fuel oil for low and medium-speed diesel engines that conforms to ASTM Specification D975. 
Electricity (Purchased). Electricity purchased for refinery operations that is not produced within the refinery complex.

Ending Stocks. Primary stocks of crude oil and petroleum products held in storage as of 12 midnight on the last day of the month. Primary stocks include crude oil or petroleum products held in storage at (or in) leases, refineries, natural gas processing plants, pipelines, tank farms, and bulk terminals that can store at least 50,000 barrels of petroleum products or that can receive petroleum products by tanker, barge, or pipeline. Crude oil that is in-transit by water from Alaska, or that is stored on Federal leases or in the Strategic Petroleum Reserve is included. Primary Stocks exclude stocks of foreign origin that are held in bonded warehouse storage.

Ethane $\left(\mathrm{C}_{2} \mathrm{H}_{6}\right)$. A normally gaseous straight-chain hydrocarbon. It is a colorless paraffinic gas that boils at a temperature of $-127.48^{\circ} \mathrm{F}$. It is extracted from natural gas and refinery gas streams.

Ether. A generic term applied to a group of organic chemical compounds composed of carbon, hydrogen, and oxygen, characterized by an oxygen atom attached to two carbon atoms (e.g., methyl tertiary butyl ether).

Ethylene $\left(\mathrm{C}_{2} \mathrm{H}_{4}\right)$. An olefinic hydrocarbon recovered from refinery processes or petrochemical processes.

Exports. Shipments of goods from the 50 States and the District of Columbia to foreign countries, Puerto Rico, the Virgin Islands, and other U.S. possessions and territories.

Field Production. Represents crude oil production on leases, natural gas liquids production at natural gas processing plants, and new supply of other hydrocarbons and alcohol.

Flexicoking. A thermal cracking process which converts heavy hydrocarbons such as crude oil, tar sands bitumen, and distillation residues into light hydrocarbons. Feedstocks can be any pumpable hydrocarbons including those containing high concentrations of sulfur and metals.

Fluid Coking. A thermal cracking process utilizing the fluidized-solids technique to remove carbon (coke) for continuous conversion of heavy, low-grade oils into lighter products.

Fresh Feed Input. Represents input of material (crude oil, unfinished oils, natural gas liquids, other hydrocarbons and alcohol or finished products) to processing units at a refinery that is being processed (input) into a particular unit for the first time.

Examples:
(1) Unfinished oils coming out of a crude oil distillation unit which are input into a catalytic cracking unit arc considered fresh feed to the catalytic cracking unit.

(2) Unfinished oils coming out of a catalytic cracking unit being looped back into the same catalytic cracking unit to be reprocessed are not considered fresh feed.

Fuels Solvent Deasphalting. A refining process for removing asphalt compounds from petroleum fractions, such as reduced crude oil. The recovered stream from this process is used to produce fuel products.

Gas Oil. A liquid petroleum distillate having a viscosity intermediate between that of kerosene and lubricating oil. It derives its name from having originally been used in the manufacture of illuminating gas. It is now used to produce distillate fuel oils and gasoline.

Gasohol. A blend of finished motor gasoline (leaded or unleaded) and alcohol (generally ethanol but sometimes methanol), limited to 10 percent volume of alcohol. Gasohol is included in finished leaded and unleaded motor gasoline.

Gasoline Blending Components. Naphthas which will be used for blending or compounding into finished aviation or motor gasoline (e.g., straight-run gasoline, alkylate, and reformate). Excludes oxygenates (alcohols, ethers), butane, and pentanes plus.

Gross Input to Atmospheric Crude Oil Distillation Units. Total input to atmospheric crude oil distillation units. Includes all crude oil, lease condensate, natural gas plant liquids, unfinished oils, liquefied refinery gases, slop oils, and other liquid hydrocarbons (such as shale oil, tar sands oils, gilsonite, etc.).

Heavy Gas Oil. Petroleum distillates with an approximate boiling range from $651^{\circ}$ to $1000^{\circ} \mathrm{F}$.

Hydrogen. The lightest of all gases, occurring chiefly in combination with oxygen in water; also in acids, bases, alcohols, petroleum, and other hydrocarbons.

Idle Capacity. The component of operable capacity that is not in operation and not under active repair, but capable of being placed in operation within 30 days; and capacity not in operation but under active repair that can be completed within 90 days.

Imported Crude Oil Burned As Fuel. The amount of foreign crude oil burned as a fuel oil, usually as residual fuel oil, without being processed as such. Imported crude oil burned as fuel includes lease condensate and liquid 
hydrocarbons produced from tar sand oil, gilsonite, and shale oil.

Imports. Receipts of goods into the 50 States and the District of Columbia from foreign countries, Puerto Rico, the Virgin Islands, and other U.S. possessions and territories.

Isobutane. See Butane.

Isohexane $\left(\mathrm{C}_{6} \mathrm{H}_{14}\right)$. A saturated branch-chain hydrocarbon. It is a colorless liquid that boils at a temperature of $156.2^{\circ} \mathrm{F}$.

Isomerization. A refining process which alters the fundamental arrangement of atoms in the molecule without adding or removing anything from the original material. Used to convert normal butane into isobutane $\left(\mathrm{C}_{4}\right)$, an alkylation process feedstock, and normal pentane and hexane into isopentane $\left(\mathrm{C}_{5}\right)$ and isohexane $\left(\mathrm{C}_{6}\right)$, highoctane gasoline components.

\section{Isopentane. See Natural Gasoline and Isopentane.}

Kerosene. A petroleum distillate that has a maximum distillation temperature of $401^{\circ} \mathrm{F}$ at the 10 -percent recovery point, a final boiling point of $572^{\circ} \mathrm{F}$, and a minimum flash point of $100^{\circ} \mathrm{F}$. Included are the two grades designated in ASTM D3699: No. 1-K and No. 2-K, and all grades of kerosene called range or stove oil. Kerosene is used in space heaters, cook stoves, and water heaters and is suitable for use as an illuminant when burned in wick lamps.

Kerosene-Type Jet Fuel. A quality kerosene product with a maximum distillation temperature of $400^{\circ} \mathrm{F}$ at the 10 percent recovery point and a final maximum boiling point of $572^{\circ} \mathrm{F}$. The fuel is designated in ASTM Specification D1655 and Military Specification MIL-T-5624L (Grades JP-5 and JP-8). A relatively low-freezing point distillate of the kerosene type used primarily for commercial turbojet and turboprop aircraft engines.

Lease Condensate. A natural gas liquid recovered from gas well gas (associated and non-associated) in lease separators or natural gas field facilities. Lease condensate consists primarily of pentanes and heavier hydrocarbons.

Light Gas Oils. Liquid petroleum distillates heavier than naphtha, with an approximate boiling range from $401^{\circ}$ to $650^{\circ} \mathrm{F}$.

Liquefied Petroleum Gases (LPG). Ethane, ethylene, propane, propylene, normal butane, butylene, and isobutane produced at refineries or natural gas processing plants, including plants that fractionate raw natural gas plant liquids.

Liquefied Refinery Gases (LRG). Liquefied petroleum gases fractionated from refinery or still gases. Through compression and/or refrigeration, they are retained in the liquid stat.. The reported categories are ethane/ethylene, propane/propylene, normal butane butylene, and isobutane. Excludes still gas.

Lubricants. A substance used to reduce friction between bearing surfaces or as process materials either incorporated into other materials used as processing aids in the manufacturing of other products, or as carriers of other materials. Petroleum lubricants may be produced either from distillates or residues. Other substances may be added to impart or improve certain required properties. Do not include byproducts of lubricating oil refining such as aromatic extracts derived from solvent extraction or tars derived from deasphalting. "Lubricants" includes all grades of lubricating oils from spindle oil to cylinder oil and those used in greases. Reporting categories include:

Paraffinic. Includes all grades of bright stock and neutrals with a Viscosity Index $>75$.

Naphthenic. Includes all lubricating oil base stocks with a Viscosity Index $<75$.

Note: The criterion for categorizing the lubricants is based solely on the Viscosity Index of the stocks and is independent of crude sources and type of processing used to produce the oils.

Exceptions: Lubricating oil base stocks that have been historically classified as naphthenic or paraffinic by a refiner may continue to be so categorized irrespective of the Viscosity Index criterion.

Example:

(1) Unextracted pariffinic oils that would not meet the Viscosity Index test.

Middle Distillates. A general classification that includes distillate fuel oil and kerosene.

Miscellaneous Products. Includes all finished products not classified elsewhere (e.g., petrolatum, lube refining byproducts (aromatic extracts and tars), absorption oils, ram-jet fuel, petroleum rocket fuels, synthetic natural gas feedstocks, and specialty oils).

Motor Gasoline (Finished). A complex mixture of relatively volatile hydrocarbons, with or without small quantities of additives, that has been blended to form a fuel suitable for use in spark-ignition engines. Motor 
gasoline, as given in ASTM Specification D439 or Federal Specification VV-G-1690B, includes a range in distillation temperatures from $122^{\circ}$ to $158^{\circ} \mathrm{F}$ at the 10 -percent recovery point and from $365^{\circ}$ to $374^{\circ} \mathrm{F}$ at the 90 -percent recovery point. The Reid Vapor Pressure ranges from 9 to 15 psi. "Motor gasoline" includes finished leaded gasoline, finished unleaded gasoline, and gasohol. Blendstock is excluded until blending has been completed. Alcohol that is to be used in the blending of gasohol is also excluded.

Finished Leaded Gasoline. Contains more than 0.05 gram of lead per gallon or more than 0.005 gram of phosphorus per gallon. Premium and regular grades are included, depending on the octane rating. Includes leaded gasohol. Blendstock is excluded until blending has been completed. Alcohol that is to be used in the blending of gasohol is also excluded.

Finished Unleaded Gasoline. Contains not more than 0.05 gram of lead per gallon and not more than 0.005 gram of phosphorus per gallon. Premium and regular grades are included, depending on the octane rating. Includes unleaded gasohol. Blendstock is excluded until blending has been completed. Alcohol that is to be used in the blending of gasohol is also excluded.

Gasohol. A blend of finished motor gasoline (leaded or unleaded) and alcohol (generally ethanol but sometimes methanol), limited to 10 percent by volume of alcohol.

Motor Gasoline Blending Components. Naphthas which will be used for blending or compounding into finished motor gasoline (e.g. straight-run gasoline, alkylate, reformate, benzene, toluene, and xylene). Excludes oxygenates (alcohols, ethers), butane, and pentanes plus. Oxygenates are reported as other hydrocarbons, hydrogens, and alcohol.

Naphtha. A generic term applied to a petroleum fraction with an approximate boiling range between $122^{\circ}$ and $400^{\circ}$ F.

Naphtha Less Than $401^{\circ} \mathrm{F}$. See Petrochemical Feedstocks.

Naphtha-Type Jet Fuel. A fuel in the heavy naphtha boiling range. ASTM Specification D1655 specifies for this fuel maximum distillation temperatures of $290^{\circ} \mathrm{F}$ at the 20 -percent recovery point and $470^{\circ} \mathrm{F}$ at the 90 -percent point, meeting Military Specification MIL-T-5624L (Grade JP-4). JP-4 is used for turbojet and turboprop aircraft engines, primarily by the military. Excludes ram-jet and petroleum rocket fuels.

Natural Gas. A mixture of hydrocarbons and small quantities of various nonhydrocarbons existing in the gaseous phase or in solution with crude oil in underground reservoirs.

Natural Gas Field Facility. A field facility designed to process natural gas produced from more than one lease for the purpose of recovering condensate from a stream of natural gas; however, some field facilities are designed to recover propane, normal butane, pentanes plus, etc., and to control the quality of natural gas to be marketed.

Natural Gas Plant Liquids. Natural gas liquids recovered from natural gas in gas processing plants, and in some situations, from natural gas field facilities. Natural gas liquids extracted by fractionators are also included. These liquids are defined according to the published specifications of the Gas Processors Association and the American Society for Testing and Materials and are classified as follows: ethane, propane, normal butane, isobutane, pentanes plus, and other products from natural gas processing plants (i.e., products meeting the standards for finished petroleum products produced at natural gas processing plants, such as finished motor gasoline, finished aviation gasoline, special naphthas, kerosene, distillate fuel oil, and miscellaneous products).

Natural Gas Processing Plant. A gas processing plant is a facility designed (1) to achieve the recovery of natural gas liquids from the stream of natural gas :vhich may or may not have been processed through lease separators and field facilities, and (2) to control the quality of the natural gas to be marketed. Cycling plants are classified as gas processing plants.

Natural Gasoline and Isopentane. A mixture of hydrocarbons, mostly pentanes and heavier, extracted from natural gas, that meets vapor pressure, end-point, and other specifications for natural gasoline set by the Gas Processors Association. Includes isopentane which is a saturated branch-chain hydrocarbon, $\left(\mathrm{C}_{5} \mathrm{H}_{12}\right)$, obtained by fractionation of natural gasoline or isomerization of normal pentane.

Net Receipts. The difference between total movements into and total movements out of each PAD District by pipeline, tanker, and barge.

Normal Butane. See Butane.

OPEC. The acronym for the Organization of Petroleum Exporting Countries, that have organized for the purpose of negotiating with oil companies on matters of oil production, prices and future concession rights. Current members are Algeria, Ecuador, Gabon, Indonesia, Iran, Iraq, Kuwait, Libya, Nigeria, Qatar, Saudi Arabia, United Arab Emirates, and Venezuela. The Neutral Zone between Kuwait and Saudi Arabia is considered part of OPEC. 
Operable Capacity. The amount of capacity that, at the beginning of the period, is in operation; not in operation and not under active repair, but capable of being placed in operation within 30 days; or not in operation but under active repair that can be completed within 90 days. Operable capacity is the sum of the operating and idle capacity and is measured in barrels per calendar day or barrels per stream day.

Operable Utilization Rate. Represents the utilization of the atmospheric crude oil distillation units. The rate is calculated by dividing the gross input to these units by the operable refining capacity of the units.

Operating Capacity. The component of operable capacity that is in operation at the beginning of the period.

Other Hydrocarbons. Materials received by a refinery and consumed as a raw material. Includes hydrogen, coal tar derivatives, gilsonite, oxygenates, and natural gas received by the refinery for reforming into hydrogen. Natuial gas to be used as fuel is excluded.

Other Oils Equal To or Greater Than $401^{\circ} \mathrm{F}$. See Petrochemical Feedstocks.

Oxygenates. Oxygenates include both alcohols and ethers used as octane boosting additives for gasoline (e.g. methyl tertiary butyl ether).

Pentanes Plus. A mixtl'te of hydrocarbons. mostly pentanes and heavier, extracted from natural gas. Includes isopentane, natural gasoline, and plant condensate.

Petrochemical Feedstocks. Chemical feedstocks derived from petroleum principally for the manufacture of chemicals, synthetic rubber, and a variety of plastics. The categories reported are "Naphtha Less Than $401^{\circ} \mathrm{F}$ " and "Other Oils Equal To or Greater Than $401^{\circ}$ F."

Naphtha Less Than $401^{\circ} \mathrm{F}$. A naphtha with a boiling range of less than $401^{\circ} \mathrm{F}$ that is intended for use as a petrochemical feedstock.

Other Oils Equal To or Greater Than $401^{\circ} \mathrm{F}$. Oils with a boiling range equal to or greater than $401^{\circ} \mathrm{F}$ that are intended for use as a petrochemical feedstock.

Petroleum Administration for Defense (PAD) Districts. Geographic aggregations of the 50 States and the District of Columbia into five districts by the Petroleum Administration for Defense in 1950. These districts were originally instituted for economic and geographic reasons as Petroleum Administration for War (PAW) Districts, which was established in 1942.
Petroleum Coke. A residue, the final product of the condensation process in cracking. This product is reported as marketable coke or catalyst coke. The conversion factor is 5 barrels per short ton.

Marketable Coke. Those grades of coke produced in delayed or fluid cokers which may be recovered as relatively pure carbon. This "green" coke may be sold as is or further purified by calcining.

Catalyst Coke. In many catalytic operations (e.g., catalytic cracking) carbon is deposited on the catalyst, thus deactivating the catalyst. The catalyst is reactivated by burning off the carbon, which is used as a fuel in the refining process. This carbon or coke is not recoverable in a concentrated form.

Petroleum Products. Petroleum products are obtained from the processing of crude oil (including lease condensate), natural gas, and other hydrocarbon compounds. Petroleum products include unfinished oils, liquefied petroleum gases, pentanes plus, aviation gasoline, motor gasoline, naphtha-type jet fuel, kerosene-type jet fuel, kerosene, distillate fuel oil, residual fuel oil, petrochemical feedstocks, special naphthas, lubricants, waxes, petroleum coke, asphalt, road oil, still gas, and miscellaneous products.

Pipeline. Crude oil and product pipelines used to transport crude oil and petroleum products respectively, (including interstate, intrastate, and intracompany pipelines) within the 50 States and the District of Columbia.

Plant Condensate. One of the natural gas liquids, mostly pentanes and heavier hydrocarbons, recovered and separated as liquids at gas inlet separators or scrubbers in processing plants.

Processing Gain. The volumetric amount by which total output is greater than input for a given period of time. This difference is due to the processing of crude oil into products which, in total, have a lower specific gravity than the crude oil processed.

Processing Loss. The volumetric amount by which total refinery output is less than input for a given period of time. This difference is due to the processing of crude oil into products which, in total, have a higher specific gravity than the crude oil processed.

Product Supplied, Crude Oil. Crude oil burned on leases and by pipelines as fuel.

Production Capacity. The amount of product that can be produced from processing facilities. 
Products Supplied. Approximately represents consumption of petroleum products because it measures the disappearance of these products from primary sources, i.e., refineries, natural gas processing plants, blending plants, pipelines, and bulk terminals. In general, product supplied of each product in any given period is computed as follows: field production, plus refinery production, plus imports, plus unaccounted for crude oil, (plus net receipts when calculated on a PAD District basis), minus stock change, minus crude oil losses, minus refinery inputs, minus exports.

Propane $\left(\mathrm{C}_{3} \mathrm{H}_{8}\right)$. A normally gaseous straight-chain hydrocarbon. It is a colorless paraffinic gas that boils at a trmperature of $-43.67^{\circ} \mathrm{F}$. It is extracted from natural gas or refinery gas streams. It includes all products designated in ASTM Specification D1835 and Gas Processors Association Specifications for commercial propane and HD-5 propane.

Propylene $\left(\mathrm{C}_{3} \mathrm{H}_{6}\right)$. An olefinic hydrocarbon recovered frcl.. refinery processes or petrochemical processes.

Refinery. An installation that manufactures finished petroleum products from crude oil, unfinished oil ${ }^{-}$. natural gas liquids, other hydrocarbons, and alcohol.

Refinery Input, Crude Oil. Total crude oil (domestic plus foreign) input to crude oil distillation units and other refinery processing units (cokers, etc.).

Refinery Input, Total. The raw materials and intermediate materials processed at refineries to produce finished petroleum products. They include crude oil, products of natural gas processing plant: unfinished oils, other hydrocarbons and alcohol, motor gasoline and aviation gasoline blending components and finished petroleum products.

Refinery Production. Petroleum products produced at a refinery or blending plant. Published production of these products equals refinery production minus refinery input. Negative production will occur when the amount of a product produced during the month is less than the amount of that same product that is reprocessed (input) or reclassified to become another product during the same month. Refinery production of unfinished oils, and motor and aviation gasoline blending components appear on a net basis under refinery input.

Refinery Yield. Refinery yield (expressed as a percentage) represents the percent of finished product produced from input of crude oil and net input of unfinished oils. It is calculated by dividing the sum of crude oil and net unfinished input into the individual net production of finished products. Before calculating the yield for finished motor gasoline, the input of natural gas liquids, other hydrocarbons and alcohol, and net input of motor gasoline blending components must be subtracted from the nei production of finished motor gasoline. Before calculating the yield for finished aviation gasoline, input of aviation gasolire blending components must be subtracted from the net production of finished aviation gasoline.

Residual Fuel Oil. The heavier oils that remain after the distillate fuel oils and lighter hydrocarbons are distilled away in refinery operations and that conform to ASTM Specifications D396 and 975. Included are No. 5, a residual fuel oil of medium viscosity; Navy Special, for use in steam-powered vessels in government service and in shore power plants; No. 6, which includes Bunker C fuel oil, and is used for commercial and industrial heating, electricity generation and to power ships. Imports of residual fuel oil include imported crude oil burned as fuel.

Residuum. Residue from crude oil after distilling off all out ihe heaviest components, with a boiling range greater than $1000^{\circ} \mathrm{F}$.

Road Oil. Any heavy petroleum oil, including residual asphaltic oil used as a dust pallative and surface treatment on roads and highways. It is generally produced in six grades from 0 , the most liquid, to 5 , the most viscous.

Shell Storage Capacity. The design capacity of a petroleum storage tank which is always greater than or equal to working storage capacity.

Special Naphthas. All finished products within the naphtha boiling range that are used as paint thinners, cleaners, or solvents. These products are refined to a specified flash point. Special naphthas include all commercial hexane and cleaning solvents conforming to ASTM Specification D1836 and D484, respectively. Naphthas to be blended or marketed as motor gasoline or aviation gasoline, or that are to be used as petrochemical and synthetic natural gas (SNG) feedstocks are excluded.

Steam (Purchased). Steam, purchased for use by a refinery, that was not generated from within the refinery complex.

Still Gas (Refinery Gas). Any form or mixture of gases produced in refineries by distillation, cracking, reforming, and other processes. The principal constituents are methane, ethane, ethylene, normal butane, butylene, propane, propylene, etc. Still gas is used as a refinery fuel and a petrochemical feedstock. The conversion factor is 6.000 million BTU's per fuel oil equivalent barrel.

Stock Change. The difference between stocks at the beginining of the nounth and siuchs at the enu of the month. 
A negative number indicates a decrease in stocks and a positive number indicates an increase in stocks.

Strategic Petroleum Reserve (SPR). Petroleum stocks maintained by the Federal Government for use during periods of major supply interruption.

Sulfur. A nonmetallic element of lemon-yellow color, sometimes known as "brimstone".

Supply. The components of petroleum supply are field production, refinery production, imports, and net receipts when calculated on a PAD District basis.

Tank Farm. An installation used by gathering and trunk pipeline companies, crude oil producers, and terminal operators (except refineries) to store crude oil.

Tanker and Barge. Vessels that transport crude oil or petroleum products. In this publication, data are reported for movements between PAD Distritts; from a PAD District to the Panama Canal; or from the Panama Canal to a PAD District.

Thermal Cracking. A refining process in which heat and pressure are used to break down, rearrange, or combine hydrocarbon molecules. Thermal cracking includes gas oil, visbreaking, fluid coking, delayed coking, and other therma: cracking processes (e.g., flexicoking). See individual categories for definition.

Toluene $\left(\mathrm{C}_{6} \mathrm{H}_{5} \mathrm{CH}_{3}\right)$. One of the aromatic compounds, commonly referred to as BTXs, similar to benzene but less volatile. It is primarily manufactured through catalytic reforming processes, steel mill coking production and olefin plant operations. It is used as a motor gasoline high-octane blending compound, as a solvent and in organic synthesis.

Unaccounted for Crude Oil. Represents the arithmetic difference between the calculated supply and the calculated disposition of crude oil. The ca lculated supply is the sum of crude oil production plus imports minus changes in crude oil stocks. The calculated disposition of crude oil is the sum of crude oil input to refineries, crude oil exports, crude oil burned as fuel, and crude oil losses.

Unfinished Oils. Includes all oils requiring further processing, except those requiring only mechanical blending. Includes naphthas and lighter oils, kerosene and light gas oils, heavy gas oils, and residuum. See individual categories for definition.

Unfractionaled Streams. Mixtures of unsegregated natural gas liquid components excluding those in plant condensate. This product is extracted from natural gas.
United States. The United States is defined as the $\mathbf{5 0}$ States and the District of Columbia.

Vacuum Distillation. Distillation under reduced pressure (less the atmospheric) which lowers the boiling temperature of the liquid being distilled. This technique with its relatively low temperatures prevents cracking or decomposition of the charge stock.

Visbreaking. A thermal cracking process in which heavy atmospheric or vacuum-still bottoms are cracked at moderate temperatures to increase production of distillate products and reduce viscosity of the distillation residues.

Wax. A solid or semi-solid material derived from petroleum distillates or residues by such treatments as chilling, precipitating with a solvent, or de-oiling. It is light-colored, more-or-less translucent crystalline mass, slightly greasy to the touch, consisting of a mixture of solid hydrocarbons in which the paraffin series predominates. Includes all marketable wax whether crude scale or fully refined. The three grades included are microcrystalline, crystalline-fully refined, and crystalline-other. The conversion factor is 280 pounds per 42 U.S. gallons per barrel.

Microcrystalline Wax. Wax extracted from certain petroleum residues having a finer and less apparent crystalline structure than paraffin wax and having the following physical characteristics: Penetration at $77^{\circ} \mathrm{F}$ (D1321)-60 maximum. Viscosity at $210^{\circ} \mathrm{F}$ in Saybolt Universal Seconds (SUS). (D88)-60 SUS (10.22 centistokes) minimum to 150 SUS ( 31.8 centistokes) maximum. Oil content (D721)-5 percent minimum.

Crystalline-Fully Refined Wax: A light-colored paraffin wax having the following characteristics: Viscosity at $210^{\circ} \mathrm{F}$ (D88)-59.9 SUS (10.18 centistokes) maximum. Oil content (D721)-0.5 percent maximum. Other +20 color, Saybolt minimum.

Crystalline-Other Wax. A paraffin wax having the following characteristics: Viscosity at $210^{\circ} \mathrm{F}(\mathrm{D} 88)-59.9$ SUS (10.18 centistokes) maximum. Oil content (D721)0.51 percent minimum to 15 percent maximum.

Working Storage Capacity. The difference in volume between the maximum safe fill capacity and the quantity below which pump suction is ineffective (bottoms).

Xylene $\left(\mathrm{C}_{6} \mathrm{H}_{4}\left(\mathrm{CH}_{3}\right)_{2}\right)$. One of the aromatic compounds commonly referred to as BTXs. It is primarily manufactured through catalytic reforming processes, steel mill coking production and olefin plant operations. It is used as a motor gasoline high-octane blending component, as a solvent and in organic synthesis. 


\section{Your Entrée to Federal Statistics!}

\section{CENSUS CATALOG AND GUIDE: 1991}

\section{Helps you select from all the products}

Every Census Bureau product issued mid-1988-90:

Reports Microfiche Computer tapes CD-ROM

Maps Floppy disks Online access

Key statistical publications from other Federal Egencies

Features facts about each product

Topics Areas Dates Prices

\section{Makes finding the right product easy}

Extensive overview chapter Title index Series index Detailed subject index Guides to each statistical subject

\section{Identifies sources of assistance}

1,400 State Data Center organizations

200 Census Bureau specialists

1,500 depository libraries

Other Federal statistical agencies

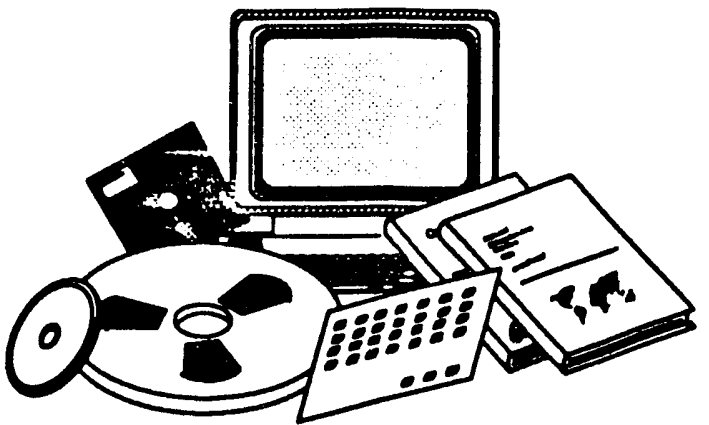

5 other directory lists

$\star 6059$

Yes, please send me:

\section{Superintendent of Documents Publication Order Form} coples of Census (:atalog and Gulde: 1991 at \$15, S/N 003-024-07271-8.

1. The total cost of my order is $\$$ . (international customers please add 25\%.) All prices include regular domestic postage and handling and are good through 1/92. After this date, please call Order and Information Desk at 202-783-3238 to verify prices.

\section{Contents}

General and Reference

Agriculture

Business

Construction and Housing

Foreign Trade

Geography

Governments

International

Manufacturing and Mineral Industries

Population

Transportation

1990 Census Products (NEWI)

Sources of Assistance

Factfinder Guides
2. Please Type or Print

(Company or personal name)

(Additional address/attention line)

(Street address)

(City, State, ZIP Code)

(Daytime phone including area code)
3. Please Choose Method of Payment:

Charge your order. It's easy!

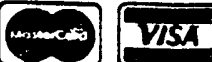

Mall To: Superintendent of Documents, Government Printing Office, Washington, DC 20402-9325 (Charged orders may be sent by FAX. The number is 202-275-0019.) 

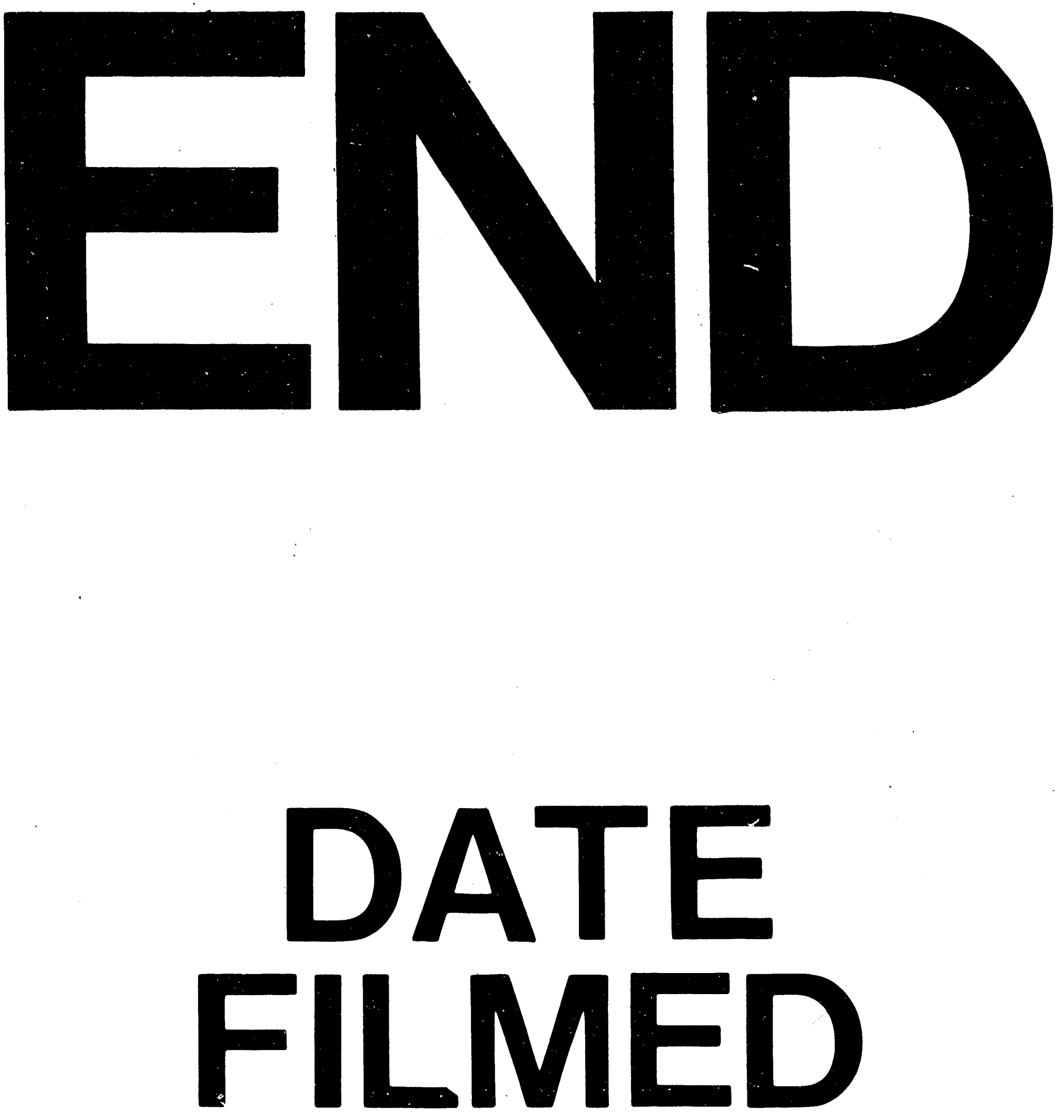

I

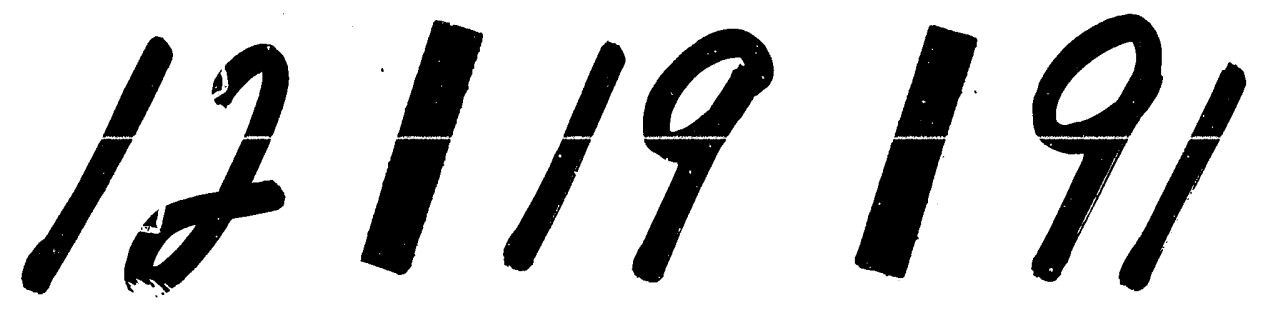


